UNIVERSIDADE DE SÃO PAULO

FACULDADE DE FILOSOFIA, LETRAS E CIÊNCIAS HUMANAS

SUELEN ROSA PELISSARO

O sertão na transversal do tempo: a territorialização na Serra do Cabral

(VERSÃO CORRIGIDA) 
SUELEN ROSA PELISSARO

\section{O sertão na transversal do tempo: a territorialização na Serra do Cabral}

(VERSÃO CORRIGIDA)

Tese apresentada à Faculdade de Filosofia, Letras e Ciências Humanas da Universidade de São Paulo para a obtenção do título de Doutora em Geografia Humana.

Orientador: Heinz Dieter Heidemann 
Autorizo a reprodução e divulgação total ou parcial deste trabalho, por qualquer meio convencional ou eletrônico, para fins de estudo e pesquisa, desde que citada a fonte.

Catalogação na Publicação

Serviço de Biblioteca e Documentação

Faculdade de Filosofia, Letras e Ciências Humanas da Universidade de São Paulo

territorialização na Serra do Cabral / Suelen Rosa

Pelissaro ; orientador Heinz Dieter Heidemann. - São

Paulo, 2021 .

$416 \mathrm{f}$.

Tese (Doutorado) - Faculdade de Filosofia, Letras e Ciências Humanas da Universidade de São Paulo. Departamento de Geografia. Área de concentração: Geografia Humana.

1. sertão. 2. território. 3. garimpo. 4. pecuária. 5. modernização. I. Heidemann, Heinz Dieter, orient. II. Título. 


\section{Ifflch}

\section{ENTREGA DO EXEMPLAR CORRIGIDO DA DISSERTACÃO/TESE}

Nome do (a) aluno (a): ___ Suelen Rosa Pelissaro

Data da defesa: $10 / \ldots 08 / 2021$

Nome do Prof. (a) orientador (a): Heinz Dieter Heidemann

Nos termos da legislação vigente, declaro ESTAR CIENTE do conteúdo deste EXEMPLAR CORRIGIDO elaborado em atenção às sugestões dos membros da comissão Julgadora na sessão de defesa do trabalho, manifestando-me plenamente favorável ao seu encaminhamento e publicação no Portal Digital de Teses da USP.

São Paulo, $30 / 08 / 2021$

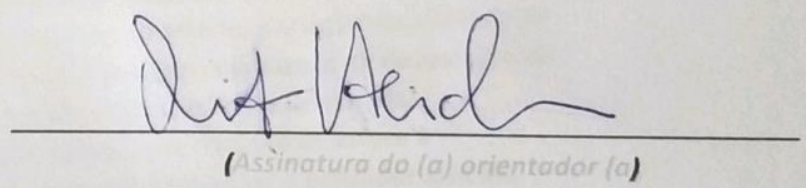


PELISSARO, Suelen Rosa. O sertão na transversal do tempo: a territorialização na Serra do Cabral. Orientador: Heinz Dieter Heidemann. 2021. 416 f. Tese (Doutorado em Geografia Humana) - Faculdade de Filosofia, Letras e Ciências Humanas, Universidade de São Paulo, São Paulo, 2021.

Aprovada em: $\underline{10 / 08 / 2021}$

Banca Examinadora

Prof. Dr. Carlos de Almeida Toledo

Instituição: Universidade de São Paulo (USP)

Julgamento: aprovada

Prof. Dr. Helion Póvoa Neto

Instituição: Universidade Federal do Rio de Janeiro (UFRJ)

Julgamento: aprovada

Prof. Dr. Vicente Eudes Lemos Alves

Instituição: Universidade Estadual de Campinas (Unicamp)

Julgamento: aprovada 
Às duas mulheres da minha vida: Suely, cor do chão daquela Serra, e Bárbara, com quem partilho as mesmas raízes. 


\section{AGRADECIMENTOS}

Este trabalho é o resultado de muita gente envolvida. Pudera eu não citar nomes para não cometer a injustiça de esquecer alguém! Mas não posso deixar de mencionar a minha gratidão àqueles que tornaram possível realizar esta tese.

Ao Heinz Dieter Heidemann, meu amigo desde 2007 e professor orientador, que mais uma vez me estendeu a mão para atravessar este momento de aprendizado. O sertão nos aproximou ainda mais ao longo do tempo e do céu estrelado do Morro da Garça. Posso dizer que Dieter me leu como pessoa antes de mim mesma e talvez já soubesse uma década antes que estudar este assunto me proporcionaria um mergulho para além da Ciência, a ponto de remexer muito o meu eu. Nenhuma palavra aqui dará conta da minha gratidão, do meu amor e da minha admiração por essa pessoa tão generosa e linda. Obrigada por me nortear nesta travessia, Nhô Dito!

Ao tio Pedro Leite da Silva, que me acompanhou e com quem organizei os meus campos e entrevistas sobre esses sertões sem tamanho. Sem a sua guia pela Serra do Cabral, abrindo caminhos na mata e portas de casas de garimpeiros, coletores e vaqueiros, indo e vindo nas catas abandonadas, nos municípios e povoados em Pirapora, Barra do Guaicuí, Grão Mogol, Jequitaí, Buenópolis, Joaquim Felício, Bocaiúva, Francisco Dumont e Buriti Grande, esta pesquisa não seria possível. Reviramos o que pudemos na Serra, conhecendo cavaleiros marginais lavados em ribeirão e voos pássaros, mas também lidando com as cores mórbidas e os homens sórdidos, sempre sentindo que podíamos ir mais longe. Seu velho desejo de resgatar a musicalidade local deu melodia à tese.

À minha tia Nagma Rosa da Silva, por me acomodar na pensão Santa Terezinha, em Francisco Dumont, e por me inserir nas procissões de santos e anjos todo mês de julho. À minha tia Eliane Leite Rosa, parceira em todas as minhas viagens nestes cinco anos, me dando todo o suporte e me ensinando como ser tia, novidade feliz que me aconteceu no meio do caminho. Ao meu primo Carlos Eduardo da Silva Lira, Du, que me acompanhou em Montes Claros pela biblioteca e pelos laboratórios da Unimontes, além dos acervos municipais e dos campos na Serra, e com quem descobri o trabalho de Simeão Pires.

Aos meus pais, porque sou quem sou por causa e apesar deles. Minha mãe, que providenciou carinhosamente todo o apoio no ambiente privado para que eu pudesse me dedicar à pesquisa, volta e meia interessada em saber o que eu andava escrevendo sobre a sua terra, curiosidade partilhada por meu pai, que de alguma forma adotou afetivamente a Serra do Cabral como sua terra também. À Bárbara Pelissaro, minha irmã, que mesmo com um oceano nos 
distanciando e as urgências da maternidade, mais uma vez se dispôs a ler, revisar e comentar tudo o que escrevo. A ela sempre confio os meus esboços.

Neste momento, me lembro da companhia saudosa do Gordon, parceiro amável, silencioso e compreensivo em quase duas décadas de vida. Nele, encontrei muitas vezes o sentido da frase que nos adverte de que "felicidade se acha é em horinhas de descuido".

Ao pessoal do Labur (Caio Esquioga, Luciana Niro, Ariel Machado, Juliana Guilherme, Felipe Borges, Artur Attarian, Cecília Vecina, Ana Silvia, Viviane Alves, Mariana Cavalcanti, Evellyn Nogueira, Cassio Boechat e tantos outros que participaram nos momentos em que passei pela leitura do "colapso", do valor-dissociação e afins), que sempre me recebeu na solidariedade de discutir os textos, dividindo angústias e sacadas, indicando obras e respeitando minhas longas ausências. Ao Luccas Couto e à Laís Oliveira, porque além da companhia nos grupos, partilharam comigo longas reflexões sobre o dissociado no Grande sertão: veredas. Ao Allan Campos, primeiro leitor do meu projeto e uma fonte de sugestões para pensar.

Ao Erick Kluck, amigo desde a graduação, e ao Carlos de Almeida Toledo, pelos apontamentos de profunda importância que fizeram no meu exame de qualificação, os quais nortearam a segunda fase da pesquisa, me advertindo sobre os não ditos dos mapas e outros documentos. Ao Carlão, mais uma vez, por ter me aceito no estágio do PAE no momento delicado de tempo de escrita e, posteriormente, aberto o meu pensamento sobre o olhar crítico às ideias de formação do país na leitura e discussão dos textos em mais um grupo de estudos e de amparo. Ao Helion Póvoa Neto, que no feliz encontro em Morro da Garça, intermediado pelo Dieter, me sugeriu farta bibliografia preliminar para pesquisar os garimpos.

À Lílian Martins e ao Rodrigo Bonicenha, amigos que abriram uma brecha em seus momentos de ócio para uma leitura do que eu vinha rascunhando. À Ana Paula Salviatti, pelo ensinamento bem-humorado de Economia e por me disponibilizar leituras importantes sobre marxismo e questões ambientais. À Jéssica Menegatti, por me apresentar sua dissertação sobre a crítica do valor-dissociação, transpondo a frieza do mundo virtual. Ao Davi Moreira, pela caminhada conjunta, que junto a mim e à minha irmã, saiu da Escola Estadual Professor Carlos Pezzolo, na periferia de São Bernardo do Campo, nutrindo origens e sonhos semelhantes, conhecendo os mesmos caminhos difíceis e fascinantes de estudar e de chegar à universidade, sobretudo a pública. Muitas coisas aconteceram no mundo e em nossas vidas da virada de século pra cá. Dessa mesma escola, também vieram minhas primeiras influências para a escolha profissional, e por isso sou grata a Ricardo Caparroz e a Roseli e Teófila, professoras de Geografia cujos sobrenomes se apagaram em minha memória, mas permaneceu a inspiração. 
Em 2002, a Universidade de São Paulo me acolhia. Em quase duas décadas ininterruptas de aprendizado, com dores e delícias, também sou muito grata à instituição e a quem a faz ser o que é.

À Adriana Cirelli e ao Eduardo Justiniano, pela confecção dos mapas. Ao José Luís de Oliveira, pelos socorros técnicos. Ao Rubens Campos e ao Jucier Assis, pelas trocas amigas entremeadas por sugestões de leituras. À Cíntia Maciel, que graças ao seu ofício de psicóloga me instigou a elaborar o sentido desse tema de pesquisa para a minha vida. Aos amigos de dentro e de fora do trabalho, por atravessarem fraternalmente meus caminhos nos momentos oportunos, por acreditarem em uma educação para além da mobilização dócil do trabalho e por se solidarizaram nas adversidades do meu cotidiano: Wagner Negreiros, Clenes Louzeiro, Joceley Souza, Alessandra Garcia, William dos Santos, Celso Borzani (em memória), Thiago Takemori, Gabriela Moura, Cauê Nogueira, Bianca Tomassi, Cecília Ferreira, Léo, Dani, Heitor e Pedro Pequini, Carlos Eduardo Souza, Roberto Mora, Célio Padial, Caio e Fátima Dellabarba e Gil Oliveira. Aos meus alunos, sempre.

Também quero agradecer a Alex Prates, professor de História que me apresentou o trabalho de Ivana Parrela e me conduziu ao Fórum de Bocaiúva, indicando os inventários com os quais trabalhei. À Márcia Alckmin, do Arquivo Público Mineiro, pela solicitude e imensa simpatia com que me recebeu em Belo Horizonte por mais de uma semana, auxiliando nas procuras e sugerindo mais fontes. Ao Guilherme Dumont, que em Francisco Dumont me abriu o casarão de Sócrates Dumont, seu finado tio, para uma prosa atenta aos livros, fotos e documentos herdados e, depois, em Belo Horizonte, para um almoço e um passeio em Santa Tereza - já que ambos somos fãs do Clube da Esquina. Ao Gê de Dolabela, que se prontificou em me enviar documentos e imagens que registram o distrito de Engenheiro Dolabela. Ao Dirceu Ribeiro dos Santos, por me aproximar de Geraldinho e outros garimpeiros em Jequitaí.

Em Francisco Dumont, não posso me esquecer da ajuda do pessoal da Casa da Cultura Ercília Rosa, que me apresentou tudo o que vem documentando; de Marta Bruzinga, pela foto de minha mãe menina na procissão do Império do Divino de 1964; de Madson Fernando, vulgo Qué Pão, e Lula Lopes, funcionários da prefeitura de Francisco Dumont, que por vezes cederam a camioneta e o Fiat Uno para pegarmos as estradas pedregosas da Serra. De Alex Brown, biólogo a serviço da barragem, que disponibilizou o Eia/Rima do Projeto Hidroagrícola Jequitaí, negado pelo Pedroso, responsável pela assistência social dessa empreitada. De Paolo Lages, engenheiro agrônomo do mesmo projeto, que abriu as portas do escritório para apresentar o trabalho que vinha fazendo. De Genésio Fonseca, por se dispor amigavelmente a me levar na sua Belina de guerra aos cultivos de eucalipto, às cachoeiras da Serra do Cabral e 
ao povoado de Santo Antônio. De Zé Carlos Calixto, Boi, por me levar às lapas pintadas e ao garimpo do Barreirinho. De João Batista Rabelo, que me guiou pelo povoado do Carrapato e pelas ruínas dos casarões dos majores da Guarda Nacional. De José Alves Pinto, Parceiro, por me acompanhar no garimpo do Licuri, me presenteando toda vez com sua vivência de garimpeiro, sua voz, seu violão tocado num abraço e suas pinhas de cristal com ramalhetes de sempre-viva e pencas de coco catolé.

Como não podia deixar de ser, meu agradecimento imensurável e emocionado também àqueles que, sem me conhecer, mas tendo convivido com meus avós e por amizade a eles, confiaram em me receber em suas casas para narrar um pouco de suas vidas. Este trabalho também é de vocês! Tino, Lúcio, Dê, Walmir, Joaquim Pontaria (em memória), Zé, Geraldo e Joaquina Telheiro (em memória), Neco, Dermeval, Lica de Zé Peão, Maria Facão (em memória), Celião, Jota, Maria Eunice (em memória), Ifigênia, Dodô, Antônio de Clara, Geraldinho (em memória), Lilo, Manoel Lopes, Vanja (em memória), Maria Zélia, Betão, Antônio da Serra, João da Serra (em memória), Besouro, Biloca (em memória), Paulo Lopes (em memória), Benjamin, Gercino, Duca, Pixico (em memória), Judite, João de Judite, Messias Preto, Ítalo, Chula, Nem de Bico, Valdomiro, Fulô, Teotônio...

Teotônio da Silva, o garimpeiro da terceira margem. Do nosso passeio com Dieter e Pedro no inverno de julho de 2015 pelas ruas do Buriti Grande, surgiu o tema desta pesquisa. Como gostaria que tivesse visto o que fiz e que antes que sua memória fenecesse pudesse ter passado para o papel a partitura da valsa "Jequitá'", que só ele sabia de cabeça. De clarinetista encantador, tornou-se encantado meses antes de eu concluir este estudo. De onde estiver, espero que saiba que tentei transformar essa matéria vertente em um texto para reflexão. A qualidade disto aqui nunca chegará aos pés de qualquer improviso musical seu.

Por fim, meu agradecimento à Coordenação de Aperfeiçoamento de Pessoal de Nível Superior (Capes), que a partir de janeiro de 2018, concedeu a bolsa de pós-graduação para levar adiante o que ora apresento.

O que muito lhes agradeço é a sua fineza de atenção! 
Ela canta, pobre ceifeira, Julgando-se feliz talvez; Canta, e ceifa, e a sua voz, cheia

De alegre e anónima viuvez,

Ondula como um canto de ave No ar limpo como um limiar, E há curvas no enredo suave Do som que ela tem a cantar.

Ouvi-la alegra e entristece, Na sua voz há o campo e a lida, E canta como se tivesse Mais razões para cantar que a vida.

Ah, canta, canta sem razão! $O$ que em mim sente está pensando.

Derrama no meu coração A tua incerta voz ondeando!

Ah, poder ser tu, sendo eu! Ter a tua alegre inconsciência, E a consciência disso! Ó céu! Ó campo! Ó canção! A ciência

Pesa tanto e a vida é tão breve! Entrai por mim dentro! Tornai Minha alma a vossa sombra leve!

Depois, levando-me, passai!

Fernando Pessoa, 1942 
Viajamos juntos quatro dias, quase trinta léguas, bom tempo beirando o Riachão e enxergando à mão esquerda os vultos da Serra-do-Cabral.

João Guimarães Rosa, 1986 


\section{RESUMO}

PELISSARO, Suelen Rosa. O sertão na transversal do tempo: a territorialização na Serra do Cabral. Orientador: Heinz Dieter Heidemann. 2021. 416 f. Tese (Doutorado em Geografia Humana) - Faculdade de Filosofia, Letras e Ciências Humanas, Universidade de São Paulo, São Paulo, 2021.

Pressupondo a conexão entre sertão e território, a tese aborda o processo de povoamento da Serra do Cabral a partir da imposição da sociabilidade moderna ocidental, incutida ao longo da conformação do capitalismo no seu movimento de vir a ser a relação social mundial por excelência até a contemporaneidade. Retomando a historiografia de ocupação dos sertões nortemineiros pela pecuária bovina extensiva e pelo garimpo de diamantes, a Serra do Cabral é concebida como parte do encadeamento moderno de territorialização do capital nos momentos colonial e de país independente. No decurso da expansão do sistema produtor de mercadorias sobre os espaços apropriados, as formas particulares de produção originaram relações sociais intrínsecas àquela realidade, muitas vezes em embate na contradição em processo do próprio capital. Assim, a Serra do Cabral, enquanto sertão, tem seus arcaísmos reinventados a partir de poderes e interesses específicos, sem deixar de gerar valor. Com a centralização do Estado e a nitidez nos movimentos de autonomização dos fatores de produção - em especial terra, trabalho e capital -, o planejamento descobre a Serra como integrante regional da Sudene, vista como receptáculo das políticas autoritárias no ensejo de transformação das forças produtivas e de estímulo à superacumulação. A decadência econômica das atividades históricas matrizes da ocupação, sobretudo o garimpo, não impede a sua realização clandestina por sujeitos expropriados, que complementam seus ganhos com a coleta de frutos do mato. Relegadas as economias de pecuária e garimpo, ganha vulto a silvicultura, alterando não apenas as relações de produção, já concordes com o desenvolvimentismo das siderúrgicas e de toda a industrialização dependente, como também a existência dos sertanejos, expelidos da realização econômica e condenados à descartabilidade como consequência da pura valorização do valor. Estando os fatores cindidos e transformados em mercadoria, dificultando a reprodução social dos homens e mulheres que vivem nos municípios, roças e povoados da Serra, a toada ecológica soa como o cântico da salvação no devaneio do fracasso da modernização, repondo os movimentos de territorialização do valor-dissociação.

Palavras-chave: Sertão. Território. Garimpo. Pecuária. Modernização. 


\begin{abstract}
PELISSARO, Suelen Rosa. Sertão in the cross of time: the territorialization in Serra do Cabral. Orientador: Heinz Dieter Heidemann. 2021. 416 f. Tese (Doutorado em Geografia Humana) - Faculdade de Filosofia, Letras e Ciências Humanas, Universidade de São Paulo, São Paulo, 2021.

Assuming the connection between sertão and territory, in this study we approach the process of settlement on Serra do Cabral from the imposition of modern Western sociability, instilled along the conformation of capitalism in its movement of turning out to be the global social relationship par excellence until contemporary. Summarizing the historiography of occupation of northern-mineiro sertões by the extensive cattle ranching and diamond mining, Serra do Cabral is conceived as part of the modern process of territorialization of capital in colonial and independent country moments. In the course of the expansion of the commodity-producing system over the appropriated spaces, the particular forms of production have originated social relations intrinsic to that reality, often clashed with the contradiction in the process of capital itself. Thus, Serra do Cabral, as a sertão, has its archaisms reinvented from specific powers and interests, while generating value. With the centralization of the State and the sharpness in the processes of automation of production factors - especially land, labor and capital -, the planning discovers the Serra as a regional member of the Sudene, seen as receptacle of authoritarian policies at the time of transformation of productive forces and stimulus to over accumulation. The economic decay of the historical activities of the occupation, especially the mining, does not prevent its clandestine realization by expropriated subjects, who complement their gains with the collection of fruits of the bush. Relegated the savings of livestock and mining, gains great the forestry, changing not only the production relations, already agree with the develop mentalism of steel mills and all dependent industrialization, as well as the existence of sertanejos, expelled from economic achievement and condemned to discard ability as a consequence of the pure valorization of the value, which since its beginnings of territorialization, also produces its dissociation. Being the factors split and transformed into merchandise, hindering the social reproduction of men and women living in the municipalities, swiddens and villages of the Serra, the ecological tune sounds like the canticle of salvation in the daydream of the collapse of modernization, replacing the territorialization movements of the value-dissociation.
\end{abstract}

Keywords: Sertão. Territory. Mining. Livestock. Modernization. 


\section{APRESENTAÇÃO}

“Quando vou p'ra dar batalha, convido meu coração” (ROSA, 1986, p. 101). Fazer pesquisa no Brasil nunca foi fácil, sobretudo de 2016 para cá, ano do meu ingresso no doutorado. Foi uma batalha dentro de um modelo social no qual estudar tem se tornado cada vez mais uma ilusão de mobilidade e uma exigência vã que, se tomada por suas contradições, também pode fazer alguma diferença rio adentro. Se o desafio está no fazer pesquisa e sobreviver para além dela, o coração não só tem permissão para lutar ao lado, como também para cumprir o papel do afeto com o assunto a se dedicar.

Afirmo de antemão que, como toda pesquisa, a minha não é imparcial. Por trás de cada frase construída há relações humanas nas suas complexidades. E por não ser neutra me ponho a pensar enquanto o meu lugar dentro de uma instituição que, sabe-se, se enquadra com maestria na racionalidade do mundo moderno e suas demandas crescentes por produtividade. Como bacharela em Geografia, tento lidar criticamente com o conhecimento ufanista do status científico da área, que se vale da posição de "verdade" para auxiliar os poderes públicos mancomunados com o capital, na pretensão de passar o rolo compressor sobre os indivíduos via planejamento territorial.

Sendo assim, o produto destes cinco anos, cumpridas as formalidades exigidas pela universidade, está neste volume. Tentei fazer Ciência, aquela forma de conhecimento que carrega as suas ideologias, as camuflando ou não. Mas também tentei dar sentido ao que investi emoção nesse tempo todo, cuidando para não cair no individualismo metodológico, apesar de por vezes me identificar com Pan Apolek na transposição da gente real para as obras que criou - advertindo a distância criativa que nos separa e a minha incapacidade em fundar uma nova heresia ${ }^{1}$.

Muito do material chegou em minhas mãos pela casa dos meus avós, a primeira pensão do município de Francisco Dumont, cujos fundos foram erguidos sobre uma cata de diamante. Lá, foi onde passei as férias de infância e adolescência, vendo chegar e sair gente - cada sujeito com uma história, tal qual essas estalagens e pousos esquecidos de beira de caminho. Tropeiros, mascates, bandas de música e seus crooners, fazendeiros a negócio, os primeiros motoristas da Viação Transnorte, foras da lei, gente sem rumo... Enfim, a "mistura de gente de toda condição", como Antonil (2007) descreveu os sertanejos do século XVIII.

\footnotetext{
${ }^{1}$ Referência a "Pan Apolek", de Isaac Bábel (2006), conto ficcional no qual a personagem que dá título ao texto pinta os ícones sacros das igrejas de Novograd-Volynsk com os rostos dos pobres aldeões do entorno, "canonizando em vida" os profanos e comprando briga com os beatos da Igreja.
} 
Trago à baila o debate autonomista do regionalismo mineiro, que o fiz só sabendo depois de que algumas das reuniões de Alfredo Dolabela Filho e suas confabulações sobre criar um novo estado aconteciam na salinha de visita da casa de meu avô. Ao tratar das festas tradicionais com suas contradições e papeis de classe e de cor, a minha mãe, menina da cor do chão da Serra, é quem aparece de dama de honra da imperatriz numa das fotografias da procissão do império do Divino. Falo do trabalho das mulheres e me inspiro na imagem que crio da minha avó cantando pelas picadas enquanto buscava lenha no mato para cozinhar para os 11 filhos ou em seu silêncio ao bordar as toalhas para o relicário da sala.

Quando abordo pela mão da historiografia a formação das fazendas, imagino meu avô aos 12 anos acompanhando os vaqueiros como cozinheiro de tropa. Ao me envolver nos detalhes das técnicas de faiscação na Serra, sou conduzida pelas memórias de meu primo-avô Teotônio, garimpeiro de diamante e, ao meu ver, o melhor clarinetista do mundo, com seu dom hipnótico ao tocar as valsas do retinto Mestre Lôro na clarineta herdada de seu genitor. Teotônio, neto de Joana Rosa Silva, bugra pega no laço por Pedro Bispo Borém, com quem teve sua mãe, Pedrelina, bastarda, que se casou com o músico e garimpeiro Manoel Tibúrcio, seu pai. Pai que tocava para os peixes no rio e que por pouco não terminou seus dias no Hospital Colônia de Barbacena, por pura vingança de Zé Borém, mandatário do povoado, por seu filho contestar o preço imposto para a venda de diamante achado. Povoado condenado por um padre que, ofendido por Chico Leão, padrinho e pai adotivo de minha avó, jogou praga no lugar após o fazendeiro entrar com seu cavalo na igreja, querendo tirar desforra por ter sua outra filha repreendida pelo decote que usava na missa. De praça agitada na Serra do Cabral, tornou-se um lugarejo quase fantasma.

Eu me dedico à interpretação dos inventários e lido com os antepassados de minha avó, Teresa Borém, então entendendo o mantra entoado por Teotônio em minha memória de adolescente: “A história dos Borém, se torcer, sai sangue”. Já nonagenário, o mal de Alzheimer atravessou seus relembramentos, exceto das melodias das valsas que sabia de coração, transmitidas no solfejo alinhado aos dedos. Meses antes de eu depositar esse esboço de reflexão sobre a Serra, Teotônio mediu o mundo, esquipou por tantas serras, pulando de estrela em estrela, até a terceira margem do rio.

No momento em que toco no assunto do poder dos coronéis, lembro os queixumes e mágoas de minha mãe por ter que fugir para o ABC Paulista em 1977, junto de meus tios e avós, dado que seu pai, Pedro Rosa, fora ameaçado de morte pelo fazendeiro Sócrates Dumont, tocaiado dia e noite pelo soldado Noé. Fundar o diretório municipal do Movimento Democrático Brasileiro (MDB) naquela ocasião, acreditando que com um punhado de 
companheiros quebraria o mandonismo local, foi a ilusão de um sertanejo pobre, neto de ciganos unidos a bugres e pretos, que sempre sonhou em ser doutor, deslumbrado pelos ternos dos magistrados e seus vocabulários prolixos. Na cidade grande do desencontro, minha mãe encontrou meu pai, migrante do norte do Paraná, cujos avós atravessaram o Atlântico para oferecer braços baratos à lavoura que tombava a mata e branquear a população. Descendente da migração forçada que ele também teve que realizar, meu pai estava errante nas ruas da urbe à procura de emprego, conquistado na linha de produção das automobilísticas de nossa industrialização retardatária e emprestada.

Tal qual Riobaldo, que se entendeu homem ao se olhar na lâmina da água, me vi no desafio de me redescobrir como pessoa ao remexer nos caminhos daqueles que deram em mim. Apesar de nem sempre ser bem-vinda no mato que cortava a minha pele na estiagem picadas adentro, cresceu o desejo de pesquisar ao me encontrar com emas, guarás e maritacas nas caminhadas na Serra, bem como ao ter a companhia de Parceiro durante os campos - amigo de meu avô, garimpeiro de diamante, coletor de sempre-vivas e seresteiro místico -, ao acompanhar Teotônio, quando então conseguia caminhar pelas ruas ainda de terra do Buriti Grande, anunciando a cada casa centenária em ruína onde havia escola, padaria e casa de baile, e ao andar com meu tio Pedro, que abriu o meu caminho para cada prosa com os moradores que ele tanto conhece, das redondezas de Francisco Dumont ao Lar São Vicente de Paulo, asilo de Bocaiúva.

O som das águas, o som das valsas: o mato na sua solidão e a festa na comunhão, ambos compondo as minhas lembranças. Ver a coroação de Nossa Senhora da Conceição, me vestir de anjo para participar da procissão, construir enfeites da Festa do Divino, ajudar a fazer a farofa para recepcionar os foliões de Reis, observar décadas antes minha avó colher as roseiras para a oferta da missa, despertar nas madrugadas para ver a banda tocar a Alvorada e disputar com os primos a beirada do fogão a lenha ainda quente nas longas noites julinas, quando meus avós e tios se reuniam na cozinha para arrastar o tempo com os causos de suas vidas, indo na contramão de uma sociedade historicida.

Conforme tecia a tese e no esforço de entender os sentimentos de meus parentes, me perguntava: teriam passado os meus entes por uma desterritorialização com a violência do coronel decadente, concorde com os abusos dos militares que os forçaram à mobilidade pósabertura regional, nos conformes do planejamento autoritário?

Quase todos os meus tios retornaram à Serra, negando a força externa de arrancá-los de lá. Na fusão de tristeza, saudade e necessidade, eles fizeram ali o seu lugar. A urbe não os deslumbrou; talvez os tenha expulsado também. E eu, cá nessa mancha urbana, tive o meu 
umbigo enterrado na Serra pelas superstições de minha mãe, onde jazem meus avós e quem veio antes. De forma teluriana, porém não acrítica, estou ligada à Serra do Cabral, e com esta tese fui revolver suas grotas simbolicamente em busca de um sentido para além do que estudo, na tentativa de me entender para além de sujeito em um mundo que torna todos objetos, ainda mais descartáveis.

Recorri aos trabalhos de campo de 2016 para cá, tentando retirar essa crosta gélida do termo técnico, usado para a empiria classificar a vida dos outros, que se tornam fragmentos transformados em objeto de pesquisa, que eu tentei não objetificar em nome de um volume que analisou uma relação particular nas suas duras conexões e ilusões com o universal - e que inevitavelmente pode guardar poeira na prateleira.

Com isso, eu, pesquisadora, não escapo à condição de sujeito sujeitado que, ao propor discutir a territorialização da Serra do Cabral na transversal do tempo, também estou territorializando via Ciência o meu tema de pesquisa: vou aos campos para produzir conhecimento dentro dos invólucros institucionais, na pretensão de fazer crítica autonomizada, com trabalho complexo e bolsa do governo federal. Não me saiu da cabeça a frase final do professor Carlos Toledo no exame de qualificação, em setembro de 2018: "Estudar é desejo". É o meu desejo transformado em necessidade, dado que sou sujeitada ao mundo moderno e à razão do cotidiano. É a necessidade já supérflua à atual mobilidade do trabalho. Mas é também o meu desejo partido da subjetividade, de me entender por meio daquilo que estudei, vulnerável aos escorregões ontológicos. É esse desejo fruto agora consciente de uma estudante imersa no capitalismo de crise, cujo neoliberalismo e pós-modernidade impõem a individualização e a flexibilização ao degradado sujeito abstrato burguês, minando qualquer pretensão libidinal de vida. Na contramão das transformações das raízes em resíduos, esta tese se desdobrou em pulsão e conflitos, dado que "Uma coisa é pôr ideias arranjadas, outra é lidar com país de pessoas, de carne e sangue, de mil-e-tantas misérias..." (ROSA, 1986, p. 8).

Apesar da frieza e do distanciamento que o fazer científico impõe, me esforcei em captar vida e sensibilidade nos meus entrevistados, forçando romper a barreira sujeito-objeto. E me reconheci neles, pois eu também sou fruto dessa Serra.

Pena que o mais sensível de todo esse tempo vivido não tenha ido para as páginas seguintes. Ao me deparar tantas vezes com o sentido negativo de ocupação dos sertões, me perguntei sobre o motivo de fazer este estudo. É como se devesse lapidar uma narrativa que tinha que se converter em texto acadêmico, remexendo memórias alheias e minhas, das lembranças de cruzar a Rodovia Fernão Dias e a BR-040 ainda não duplicadas para passar as férias na morada dos meus avós maternos e tios, quando a fartura ainda tinha outro significado. 
Casas, ruas e personagens sobre os quais guardo em muito a mesma sensação de Manuel Bandeira ao evocar a sua Recife ${ }^{2}$.

O meu apreço pelas questões concernentes ao território data ainda da graduação. Utilizando outro método - no caso, a Geografia Histórica -, estudei em iniciação científica e no trabalho de conclusão de curso, a formação do Estado brasileiro no recorte temporal da independência e no limite espacial da capitania do Grão-Pará. Como supõem alguns, o sertão também já me rondava, apesar de ser um norte mais boreal. Nos momentos finais daquela pesquisa, conheci o professor Dieter como aluna matriculada em Trabalho de Campo, desafiada a ler "O recado do Morro" e a palmilhar aquele sertão mais uma vez - mas não seria mais uma vez, pois era uma outra travessia.

Em seguida, ingressei no mestrado, sob a orientação do "alemão-rana" e iniciei minha curiosidade pelo sertão a partir da relação entre os laços familiares e a literatura de Guimarães Rosa. Conforme lia seus livros, fui descobrindo que Zé Bebelo e Diadorim nasceram na Serra do Cabral, o primeiro tendo fazenda no Riachão, avistável da estrada que liga Francisco Dumont a Jequitaí, e o segundo, com seu berço em Lassance. Também o rio Jequitaí, principal curso d'água que desemboca no São Francisco, era a terra de seu Joãozinho Bem-Bem, jagunço valente daquelas bandas.

Em 2015, visitei Dieter em sua casa em Morro da Garça, que dista, em média, 200 a 250 quilômetros da Serra do Cabral. Junto ao seu amigo de infância Phillip e ao filho Gugu, subimos o Morro para ver nascer o sol, ouvimos música, assistimos o filme Mutum e conversamos. Eu os convidei para conhecer a terra de minha mãe, e para lá seguimos. Era mês de julho, minha tia Nagma organizava a procissão de Nossa Senhora da Conceição e meu tio Pedro reanimava a banda de música por meio de ensaios persistentes. Para ajudá-los na empreitada, meu primo Teotônio se prontificava com sua clarineta de ébano centenária, dedos e fôlego a postos - era sua última vez por lá.

Decidimos levar Dieter ao povoado do Buriti Grande, onde minha avó e Teotônio nasceram. Ao caminharmos pelas ruas de capim guiados pelas lembranças do meu primo, surgiu a ideia de fazer esta pesquisa. Desde então, é ao que tenho dividido as minhas atenções, traçando um caminho de aprendizado constante pela oportunidade que Dieter tem me proporcionado. As relações e as paisagens para as quais eu olhava sem muito pensar, a partir de então cutucavam a minha atenção, muito porque aprendi, pelo olhar do meu amigo e professor, a buscar enxergar além das aparências.

\footnotetext{
2 “[...] A casa de meu avô... / Nunca pensei que ela acabasse! / Tudo lá parecia impregnado de eternidade / Recife... / Meu avô morto. / Recife morto, Recife bom, Recife brasileiro / como a casa de meu avô" (BANDEIRA, 1993).
} 
É por tudo o que foi exposto que justifico o tratamento que dou à Serra do Cabral. Ela não é uma simples elevação de quartzito, mas uma relação social, dadas as sociabilidades que fomentam o seu povoamento e as suas histórias, baseadas na pecuária e no garimpo - que, com as transformações do tempo, dividiram o território com outras produções. Esses são os dois casos que produzem o objeto de estudo, sendo o primeiro precursor do segundo e, a partir da descoberta mineral, ambos caminhando juntos.

Como toda conexão histórica é feita por homens e mulheres e o capital é uma relação social, a territorialização também é a dessas ligações, por isso o texto contempla os relatos de sertanejos já inseridos na forma da mercadoria. Sendo seus momentos ressignificados ou não durante a maneira de contar, são importantes quanto à sensibilidade do vivido neste território em particular. Todos os entrevistados desta pesquisa são também autores do texto ora apresentado, e eu, a única responsável pelas lacunas e incoerências que ele apresenta, a intermediária mercurial dessas vozes, espero que a transmissão das narrativas chegue intacta para (talvez) mandar um recado.

Trato a Serra do Cabral como uma territorialização pela sociabilidade moderna. A sua realização é a de mercadorias já constituídas no processo de valor-dissociação, apresentada em alguns momentos como formas não especificamente capitalistas, porque os fatores de produção e o Estado ainda não haviam se cindido. Esses momentos fazem parte da historicidade, sendo a Serra, portanto, coetaneamente resultado e movimento históricos; a partir do século XVII, já havia ali alguma geração de valor, cuja dinâmica se utiliza dessas formas para territorializar o espaço estudado. A particularidade de suas relações sociais forjou a região, delineada pelo Estado autonomizado a partir do contexto pós-1930, quando as regiões foram alvos de políticas modernizadoras em nome de um discurso nacional. Para entender esse enredo, convido à leitura do texto.

A Serra do Cabral foi pensada a partir do processo de expansão territorial na formação do capitalismo, de maneira a colocar em diálogo as particularidades que o movimento de totalização do capital engendra. Para realizar esta análise, ancorei-me na fórmula trinitária apresentada por Karl Marx (2003), portadora dos fatores de produção fiandeiros da nova relação social imposta, como chave interpretativa dos vínculos sociais modernos. Esses têm os seus momentos de autonomização despertados na cadência das mudanças nas forças produtivas e formas de acumulação, mais interessantes de compreensão se olhados a partir da crítica do 
valor-cisão. Na busca do seu entendimento, a leitura de alguns trabalhos de pesquisadores que integram o Grupo de $\operatorname{Sexta}^{3}$ foi essencial para ladrilhar o caminho que fiz, mesmo não sendo partícipe do mesmo.

Assim como as relações capitalistas, esse decurso da autonomização do Estado e dos fatores de produção não se dá do dia para a noite, mais se assemelhando a uma trama em que mãos pretensamente onipresentes vão tecendo. Para compor essa malha, introduzi a maioria dos capítulos com trechos de composições de três discos (dois deles lançados no mesmo ano). Dois de Elomar Figueira Melo ${ }^{4}$ e um do Clube da Esquina ${ }^{5}$, no intuito de cruzar o sertão e a cidade, tendo em vista que as letras de Elomar, sertanejo letrado e moderno, retomam um lugar único que une o erudito e o popular (RIBEIRO, 2014), na sua particularidade sobrecarregada ao narrar histórias de quando as sociabilidades refratárias à imposição da mercadoria coexistiam com mais cor, porém atentas às mudanças impostas pela nova relação ${ }^{6}$.

Já o Clube da Esquina ${ }^{7}$, influenciado pelas linhagens musicais estrangeiras e toda a reviravolta que ocorria na música brasileira, traz uma melancolia urbana, fruto de um desenvolvimentismo militar autoritário que busca derrotar a capacidade inventiva e, com a metropolização, quer devastar o sertão, que existe na sua forma mais independente da sociabilidade moderna por meio das lembranças que as letras narram, transmitindo saudade (AB'SÁBER, 2019). Assim, o Clube da Esquina é mencionado como alegoria do urbano que penetra nos Gerais, enquanto Elomar é aludido como representação dos Gerais que persistem apesar da urbanização. A exceção ficou por conta da cantiga setecentista "Baiano do boi", de compositor anônimo (a pensar quem está por trás do anonimato...).

Recorrendo à arte, também costurei o texto com passagens da obra Grande sertão: veredas, por vezes recorrendo a outros textos de João Guimarães Rosa e ao diário de Alice Dayrell, pensando a ficção como uma estratégia de representação ${ }^{8}$. Quanto ao último, foi escrito por uma menina que registrou em seus diários suas vivências na Diamantina do século XIX,

\footnotetext{
${ }^{3}$ Grupo do Laboratório de Geografia Urbana (Labur) do Departamento de Geografia da Universidade de São Paulo (USP), cujas discussões partem dos textos de Robert Kurz, do grupo Krisis e afins, se reunindo há mais de duas décadas em torno da crítica do valor-dissociação.

${ }^{4}$ Das barrancas do Rio Gavião (1972) e Na quadrada das águas perdidas (1978).

${ }^{5}$ Clube da Esquina (1972).

${ }^{6}$ Nascido em Vitória da Conquista em 1937, Elomar é um cantor e compositor, cuja obra é marcada pelo encontro das trovas medievais com o imaginário rural dos sertões. É um típico sertanejo letrado, filho de fazendeiros, enviado à Salvador para realizar os estudos em arquitetura. Após receber o diploma, retorna à terra natal, realizando trabalhos técnicos na região (inclusive para o governo), onde vive ainda hoje. Sua trajetória comprova o quanto a literatura roseana, que permeou este trabalho, é forte alegoria da realidade.

${ }^{7}$ Movimento musical surgido do ponto de encontro entre as ruas Divinópolis e Paraisópolis, no bairro de Santa Tereza, em Belo Horizonte (MG). Composto por uma maioria de jovens músicos mineiros, nasceu no ambiente urbano particular da capital do estado, no contexto de uma modernização violenta puxada pela ditadura militar.

${ }^{8}$ Definição emprestada do professor e historiador Júlio Pimentel Pinto (ENTREVISTA..., 2020).
} 
deixando captar nas impressões pueris a abolição do escravismo, a permanência das relações de compadrio e agregação, o racismo, a decadência da mineração de diamante, a proclamação da República e a participação das mulheres naquela sociedade já em vias de metropolização, assentada sobre a Serra do Espinhaço.

A tese também foi temperada esporadicamente com outras obras literárias, como a epopeia Os Sertões, de Euclides da Cunha, e Onda verde, de Monteiro Lobato. O livro-registro da campanha de Canudos serviu para ilustrar algumas reflexões sobre a modernidade trágica imposta ao país a partir do incômodo republicano em fundar uma nação composta de opostos binários, representados entre litoral e sertão, enquanto os textos reunidos do criador de Emília e sua turma, num posicionamento mais sério, registra no papel suas impressões positivas sobre a terra e a modernização.

A escolha da obra-prima roseana, por sua vez, se deu porque, concordando em parte com as reflexões de Carlo Ginzburg (2000), um autor é alguém capaz de nos tornar conscientes de certas dimensões da realidade, pois a leitura ficcional nos descortina toda uma gama de possibilidades humanas, apesar da advertência de que história e ficção são gêneros distintos que apresentam desafios um ao outro. Na pista dada pelo historiador, a ficção pode ser interpretada como um olhar ao revés e uma imaginação moral acerca do tempo, dado que por trás do enredo, há um escritor que é filho de sua época.

O romance, narrado pelas lembranças de um velho barraqueiro ex-jagunço e letrado de nome Riobaldo, aborda esse processo: cabras que brigam em nome de coronéis que disputam a parceria com o Estado. Entre eles, Zé Bebelo, que de dentro do conflito quer acabar com o sertão. A obra coloca, em seu nome e no seu desejo de ser deputado, o Estado no interior do território na querela de ser construído, a ser "muito nacional" e unificado, apagando as diferenças e os dualismos. No meio do romance, a ascensão do jagunço Riobaldo Tatarana a chefe Urutu Branco via pacto com o Diabo, momento mágico em que o Demônio faz a mediação para o alcance do poder. Daí a pensar no que Riobaldo se torna e se o sertão acaba, se resiste ou se se adapta.

Sendo a ficção uma esfera em que o mágico é uma possibilidade despudorada de realização, justifico o recurso à literatura a partir da explicação de Michael Taussig (2010) sobre o místico nas sociedades não totalmente submissas à forma social capitalista. Para o antropólogo, que estudou o aparecimento do Diabo em comunidades camponesas e mineiras da América do Sul conforme a sociabilidade da mercadoria se impunha, o Cão só era evocado por sujeitos expropriados nos momentos agonizantes e no intuito de, via negociação, alcançar ascensão social pela venda da alma. O Diabo, portanto, era uma figura moderna entre essas 
comunidades, desembarcada no continente junto ao elemento colonizador. Esse evento mágico também é encenado ficcionalmente por Riobaldo, apontando que a penetração do mundo do mercado nem sempre destrói o conteúdo místico das comunidades a ele submetidas; antes, fornece alavancas críticas com as quais avaliamos e entendemos as suposições sacrossantas e inconscientes que são construídas e emergem dos nossos moldes sociais.

No meio dos enredos, o teor sensível completa as narrativas duras, como se fosse a chave para desconfiar da aspereza do espaço abordado por meio da beleza na relação complexa entre Riobaldo e Diadorim. Nas suas verossimilhanças, ficção e realidade formam duas redações cheias de dúvidas 9 .

No primeiro capítulo, "Fuá na Serra do Cabral”, cujo título alude a uma composição do grupo pernambucano Mestre Ambrósio, apresento a Serra desde o primeiro campo realizado, em dezembro de 2016, até o último, em julho de 2019. Pelo subitem “A esses muito sertões, com gentinha pobrejando", trago o que encontrei na Serra nos últimos anos, delimitando-a espacialmente e mostrando dados que a caracterizam quantitativamente. Procuro introduzir como as situações encontradas revelam as contradições e o colapso agonizante do sistema produtor de mercadorias, dando o primeiro passo na trilha teórico-metodológica escolhida para lidar com o assunto. No segundo subitem, "Contar e fazer balancê", exponho a importância da memória como registro pessoal das metamorfoses que as paisagens e as vidas na Serra têm passado, de maneira a evocar a vivência pretérita, com todas as suas incongruências, para entender o presente. Dessa forma, pretendi direcionar o texto para a regressão no processo territorializante da Serra, que começa no conteúdo seguinte. ${ }^{10}$

\footnotetext{
${ }^{9}$ Não há a pretensão aqui de defender a ideia de que Grande sertão: veredas possui todas as condições de integrar as obras que debatem a nossa "formação" social, até porque muitos trabalhos já fazem bem essa análise. Porém, ao se levar em conta o universo do escritor, suas leituras e sua rede de relações, é sedutor pensar assim. Seja entendendo o julgamento de Zé Bebelo como metáfora da proclamação da República, seja interpretando a convalescença de Riobaldo na fazenda Barbarana como alegoria do pacto de conciliação das classes dominantes que o Estado Novo protagonizava, João Guimarães Rosa parecia tentar decifrar o país ou mesmo propor a sua refundação, oferecendo uma linguagem nova em que mistura o erudito e o popular. Funcionário do governo na medicina e na diplomacia, leitor de Oliveira Viana, amigo de Getúlio Vargas, amante da Geografia e sertanejo, Rosa foi homem de seu tempo também preso aos limites da forma social. Contemporâneo das transformações que o nacional-desenvolvimentismo e a modernização conservadora e retardatária engendraram, parece não ter conseguido o propósito de refundar a sociedade pela ficção (se é que é possível interpretar sua obra assim): o jagunço tornado fazendeiro pós-pacto termina seus dias assentado na beira do rio sem consumar o amor vivido nos tempos de guerra, conformado com o mundo monótono real, desencantado depois de integrar as camadas dominantes, cada vez mais racionalizadas e desdenhosas do místico. O ex-jagunço só se mostra cheio de vida apenas quando narra as lembranças do passado, como se transmitisse a mensagem ao leitor de que a modernização profana o futuro com as ruínas do passado.

${ }^{10} \mathrm{O}$ título desse capítulo faz um trocadilho com o nome da canção Fuá na casa de Cabral, do grupo pernambucano Mestre Ambrósio, que brinca com os desencontros do descobrimento do Brasil, enquanto os dois subitens foram colhidos de falas de Riobaldo no Grande sertão: veredas (ROSA, 1986).
} 
No segundo capítulo, "No rastro do boi, no mapa das minas", apresento o mapeamento da Serra. Os dez dias de estada no APM, em Belo Horizonte, renderam o material cartográfico apresentado, além da consulta dos Registros de Terras de 1855 e das notícias e reflexões presentes no anuário do arquivo, cobrindo as duas primeiras décadas do século $\mathrm{XX}$. Na cartografia, busquei representações que registrassem a Serra desde as primeiras incursões pelos caminhos do gado, datadas já do século XVII. Como a Serra do Cabral não foi nitidamente mapeada e nomeada até o século XX, rastreei o registro da área a partir do rio Jequitaí, principal curso d'água daqueles limites territoriais, presente em todos os mapas consultados.

O objetivo de um capítulo para o mapeamento histórico é compreender que cartografar também é uma forma de territorializar o espaço apropriado. Porém, a ausência de informações sobre a Serra se converteu em outra maneira de ler e interpretar esse vácuo. Foi preciso lidar de outras formas com o material em mãos, acompanhando a evolução dos registros e os interesses por trás deles para dar seguimento à pesquisa.

Apesar de a territorialização na Serra do Cabral ter se dado com os vaqueiros e os garimpeiros se relacionando, foi melhor dividir as partes para mera organização do texto. $\mathrm{O}$ terceiro capítulo, "Boi: mercadoria que devora os homens", cujo título é inspirado em expressão de Jacques Lambert contida na sua obra clássica, Os dois Brasis, é dedicado à pecuária, lhe apresentando como o momento que abre os caminhos sertanejos para a entrada da nova relação social, discutindo se a itinerância dos bandeirantes tornados boiadeiros era ou não livre das rédeas reinóis, apesar de se configurar então como economia subsidiária.

Para que a empresa colonial evolvesse, a violência cumpriu papel crucial, por isso o item "O sertanejo é antes de tudo um índio" é apresentado a seguir ${ }^{11}$. As andanças na Serra desde a adolescência já chamavam a atenção para as muitas pinturas nas lapas, compreendidas como forma de registro de povos que foram exterminados fisicamente ou, ao serem agregados nas fazendas, diluídos no sangue das gerações que, submissas ou não, prosseguiram a ocupação. Intenta-se, com esse ponto, mencionar o processo de imposição das relações capitalistas em formação para compreender a dose de barbárie perpetrada em nome da catequização e civilização.

No item "Toda coisa que pode ser roubada ou apropriada, pode ser mercadoria: a terra e o trabalho" 12 , discuto a formação das fazendas dentro do contexto de Brasil imperial e o

\footnotetext{
${ }^{11} \mathrm{O}$ título é uma resposta de Carlos Estevão de Oliveira à célebre frase de Euclides da Cunha - “O sertanejo é, antes de tudo, um forte" (CUNHA, 1905, p. 114) -, escolhido para me referir aos povos originários como os primeiros sertanejos, destacando tanto a sua resistência quanto a sua integração frente à violência colonial.

12 Título inspirado no volume I d'O capital (MARX, 2013).
} 
decreto da Lei de Terras. Terra e trabalho, fatores de produção essenciais para a reprodução capitalista, necessitavam ser autonomizados dentro da urgência do país recém-fundado em acompanhar o novo padrão de reprodução social vigente após a Revolução Industrial. O recurso teórico à colonização sistemática permitiu desvendar não só os mecanismos de grilagem de terras, como também o cativeiro da força de trabalho e a personificação dos donos, caricatas no coronelismo em formação.

Em "Os fatores de produção nos documentos e os seus não ditos", fiz uma análise dos inventários encontrados no Fórum de Bocaiúva em 2017, com a ajuda do professor Alex Prates, historiador no município. Os documentos abrangem de 1823 a 1925, todos pertencentes à família de minha avó materna, Teresa Borém. A princípio, recorri aos inventários para simples comparação entre os nomes das fazendas e córregos plotados na cartografia setecentista e oitocentista e os constantes no livro do Registro de Terras de 1855, também consultado no APM

No entanto, suas páginas esgarçadas pela má conservação revelaram maiores possibilidades de interpretação: a naturalização da apropriação das terras e a certificação de que a pecuária extensiva era o forte econômico regional naquele momento, levando a uma especialização do produto. A maneira como o patrimônio é elencado traduz a transformação da riqueza na passagem do escravismo para a abolição. Novamente, o não dito dos documentos levantou à curiosidade por não ter encontrado nenhum registro de garimpo em suas laudas, mesmo sabendo que a família lidava com o ramo. Além disso, a posse de escravos permitiu pensar o cativeiro norte-mineiro em períodos de decadência econômica, a relação entre escravismo e capitalismo, a racialização nos documentos, o dilema das famílias, entre outras possibilidades.

No item “'O passado era mesmo passado' na 'terra bonita onde mora a maleita': a região sob a bênção do coronel"13 , o século XX é o marco temporal das transformações territoriais no sertão norte-mineiro. Deslumbrados com a promessa de progresso conduzida pela linha do trem e pelas estradas a serem abertas, os memorialistas pesquisados nos anuários estatísticos do APM das três primeiras décadas do século discutiam como o sertão tinha potencial de crescimento, dadas as condições naturais dos pastos. Ao mesmo tempo, localizavam no sertanejo os impasses a essa evolução.

A "terra da maleita" aparecia nos Novecentos como a face abjeta de um Brasil dividido em dois, o fardo que os centros urbanos banhados pelo Atlântico Sul teriam que carregar a

\footnotetext{
${ }^{13}$ Título inspirado na leitura do conto roseano "Sarapalha" (ROSA, 2006).
} 
contragosto. Em resposta, nota-se o embrião de um discurso regionalista, que discuti mais a fundo no desenrolar da tese.

Os intelectuais da época criticavam o sertão mirando seus habitantes, fechando os olhos para a condição de agregados em que muitos sertanejos viviam naquele momento pós-abolição. A sua expropriação era assunto não abordado pela documentação oficial, cujas relações só foram possíveis de desvelo a partir do recurso à literatura ficcional e aos relatos de alguns entrevistados.

No subcapítulo “'Botando pontes, baseando fábricas, estreando mil escolas': o projeto de progresso para o sertão e a Serra"14, apresento os intelectuais e os governos pré-1930 se dedicando à modernização mineira. O regionalismo enquanto ideologia tem maior nitidez, mas ainda não se consolidou como ideologia. A entrada de acadêmicos no governo mineiro dava o tom de como seriam os momentos seguintes, em Minas Gerais e no Brasil, sem romper com o poder dos coronéis latifundiários.

“'Uns, aboiavam sem bois': o trabalho nas fazendas na Serra"15 é o momento da tese em que mais me valho do que ouvi sobre vaqueiros e agregados em quase cinco anos de pesquisa. Procurei apresentar a mobilidade do trabalho desses homens livres pobres enquanto agregados de fazenda, submissos a relações de favor em que o pagamento pelo trabalho não era realizado em dinheiro. Nesse item, abordo a transição do Estado brasileiro a partir de 1930 e como a autonomização dos fatores de produção chegaram à Serra décadas depois, alterando as relações de agregação nas fazendas e introduzindo o trabalho assalariado.

Dentro dessa conexão, compus o subitem "Lica de Zé Peão, Maria de Bruno Facão, Vange de Manoel Lopes e Ifigênia de Dodô: dois dedos de prosa sobre família, trabalho, cor e dissociação-valor", em que trato da presença das mulheres nesse contexto a partir da observação de que em todas as entrevistas, nas casas que me foram abertas, os homens é que recebiam para a conversa, enquanto as mulheres se escondiam nas cozinhas ou nos quintais. Esse comportamento me instigou a observar o papel feminino dentro de relações marcadas pelo patriarcado, na tentativa de compreender não só a divisão laboral, bem como as atividades dissociadas e as incongruências em suas visões de mundo, presentes também nas vozes masculinas. Sendo ou não as mulheres que dão a última palavra no sertão, quis apresentar o feminino na pecuária, na intenção de retornar à questão de gênero páginas adiante.

\footnotetext{
${ }^{14} \mathrm{O}$ título se refere à fala do personagem roseano Zé Bebelo, de Grande sertão: veredas (ROSA, 1986).

${ }^{15} \mathrm{O}$ nome do item saiu das observações de Riobaldo sobre seus companheiros jagunços enquanto livres pobres (ROSA, 1986).
} 
Fecho o capítulo sobre a criação de gado com o item "'O sertão que estremece debaixo da gente': o dissociado entre a realidade e a ficção"16, oferecendo uma possível interpretação de Grande sertão: veredas a partir da teoria que pautou principalmente o item anterior. Localizado praticamente no meio da tese, esse texto estende seus tentáculos sobre a ficção e a ciência vislumbrando entender a literatura como mais uma ferramenta de interpretação do Brasil no seu processo contraditório de territorialização. Ao abordar o sertão como um espaço apropriado pelo valor, o dissociado que o co-constitui estremece debaixo das aparentes formas de produção, havendo nas memórias e reflexões das personagens oportunidades de captar essa existência oculta.

No quarto capítulo, "O garimpo de diamante, 'a mais preciosa das inutilidades", ${ }^{17}$, abro a parcela da pesquisa que aborda o garimpo desse mineral. Dividindo com o boi a proeminência econômica na Serra do Cabral e com a atividade ali introduzida pelo menos um século depois das fazendas de gado, ambas as formas de produção de riqueza caminharam juntas e territorializaram as relações.

No item "Saídas e bandeiras e as descobertas: de bandeirante a garimpeiro e os vadios"18 abordo a discussão acerca do início das prospecções minerais na capitania de Minas Gerais, com destaque para os sertões. Recorri aos relatos de memorialistas dos Oitocentos e de viajantes dos Novecentos para buscar informações sobre o norte mineiro e as formas de garimpar. Sem um consenso historiográfico preciso sobre o início da exploração, tive a impressão de que o debate inconcluso se repete para o caso dos garimpos abandonados na Serra, onde fiz os primeiros campos.

O garimpeiro carregou consigo as pechas de vadio, insubmisso, entre tantos rótulos pejorativos associados à sua constante mobilidade por um espaço inserido nas novas relações de produção, porém indômito à ordem colonial. Atravessado o século XIX, novos memorialistas vêm a classificá-lo na chave da gênese da liberdade sertaneja, tecendo ideologias de um Brasil recém-independente. Se, por um lado, recorri aos viajantes para entender como era organizada a extração de vulto no seu auge e na presença de escravos, por outro, dentro da sua famigerada decadência - o que não significou desaparecimento -, esse sujeito, cativo ou livre, configurou a faiscação como um dos recursos à sua reprodução social, não restringindo sua sobrevivência a apenas essa atividade.

\footnotetext{
${ }^{16}$ Ao pensar sobre como seria se tivesse se casado com Nhorinhá, Riobaldo reflete: “O sertão não chama ninguém às claras; mais, porém, se esconde e acena. Mas o sertão de repente se estremece, debaixo da gente..." (ROSA, 1986, p. 461).

${ }^{17}$ Título cuja frase remete à conclusão do mineralogista Gorceix (1977) sobre a cobiçada pedra.

18 Aludo à composição "Saídas e Bandeiras", do Clube da Esquina.
} 
No item seguinte, “'Esses bateavam faisqueiras': apurando e resumindo na Serra"19, esmiucei a experiência dos campos pelos garimpos abandonados e refleti sobre os garimpeiros ouvidos, na grande maioria já idosos e apartados do serviço. Busquei compreender, tanto dos garimpeiros quanto das leituras de viajantes e técnicos, as formas possíveis de executar esse mister, bem como a divisão do trabalho nas lavras, e encaminhei esse texto para a discutível decadência da extração, quando a grande empresa deu lugar à faiscação em todo o norte de Minas Gerais - sem abandonar o fato de que esta sempre andou junto à exploração de grande vulto.

Para revolver a realidade na Serra do Cabral, compus o subitem "Os diamantes do barão retinto por uma narrativa outsider" para personificar quem ousou dar um caráter empresarial inovador na exploração do diamante nas margens do rio Jequitaí. Busquei examinar a trajetória do barão de Jequitaí como exemplo de fazendeiro de gado e coronel com patente da Guarda Nacional, que também se atreveu à empresa mineradora. A partir da narrativa nada neutra do memorialista montes-clarense Simeão Pires, quem conta essa história, discuto suas intenções de dar conhecimento à existência desse indivíduo na história regional.

No ponto seguinte, "Os garimpeiros na travessia da modernização", verso sobre a Serra do Cabral e o norte mineiro, em geral no debutar do século XX e a situação do garimpo, reduzido à faiscação. Com a decadência da economia do diamante, apresento a situação dos municípios e das pequenas ocupações da Serra a partir da consulta aos anuários do APM e a contribuição deste trabalho na consolidação de núcleos de povoamento, ofuscado pela especialização regional pecuária.

A partir das prosas em "Ouvindo os garimpeiros", proponho que o garimpo na condição de pobreza era apenas mais uma forma de sobrevivência dos homens e mulheres expropriados, que, em tempos ruins, estavam mobilizados para a coleta de frutos no mato, o serviço de roçar mangas e a lavoura de subsistência, diferentemente da situação dos agregados de fazenda, que raramente bateavam as areias e os cascalhos. Aproveito para apresentar o distrito de Dolabela, onde muita gente sem sucesso no garimpo foi cortar e moer cana para a família Matarazzo. Pelo livro do falecido Gumercindo Amaral, primo de meu avô Pedro Alcântara da Silva, discuto os tímidos vislumbres de modernização dos coronéis locais. Dividido entre autobiografia e poesias, recorri ao seu relato de morador de Dolabela, garimpeiro experiente e migrante não apenas atrás de novas catas, mas também das infraestruturas de tratamento da doença do fogoselvagem. Conforme habita a cidade grande, surge o desejo de documentar o vivido, exposto

\footnotetext{
${ }^{19}$ Com esse título, me reporto à observação do jagunço Riobaldo sobre os garimpeiros encontrados durante a sua epopeia (ROSA, 1986).
} 
também nas poesias que retratam a riqueza natural da Serra, as lembranças nem sempre romantizadas da vida em comunidade e a testemunha de um caso de grilagem de terra.

Termino o capítulo com o item "'Feito promessa para cumprir quando ficasse bom': as festas religiosas na Serra e suas sociabilidades" ${ }^{20}$. O objetivo aqui é mostrar como as festas locais são momentos de observação das relações sociais pautadas pela mercadoria e a interação dos diferentes estratos sociais nos ambientes públicos e de visibilidade social. Recorri aos acervos da Casa de Cultura Ercília Rosa, de Francisco Dumont, e a documentos pessoais de famílias locais.

No quinto capítulo, "Do sertão ao cerrado: o Estado maquinal e sua absorção pelo capital”, faço a passagem temporal para o Brasil pós-1930, quando os fatores de produção são explicitamente autonomizados pelos poderes estatais de forma a viabilizar a maior acumulação de capital. Com isso, vale tudo: o Estado revela a sua forma de ser com base na grilagem de terras (subliminarmente juridificada).

No item "O Estado Novo e o embrião do novo Estado: a região aparecendo", mostro o momento em que a região norte de Minas Gerais aparece como especializada na criação de gado, mas, ao mesmo tempo, atrasada do ponto de vista do pensamento dualista. Procuro dar um aporte teórico para auxiliar na compreensão das mudanças impostas à região como um todo, tendo como horizonte os projetos desenvolvimentistas encadeados por Getúlio Vargas, só chegados ao norte mineiro a partir da subida de Juscelino Kubitschek ao poder e da inclusão da região à abrangência da Sudene.

Com isso, no item "O desafino do 'presidente bossa nova' ao tocar a região", me debruço sobre a composição de tecnocratas e intelectuais nos cargos públicos para gestar o país. Busco nas discussões teóricas do nacional-desenvolvimentismo da época as justificativas para a intervenção estatal no sertão, as quais produziram discursos e ideologias condizentes ao dualismo e ao contexto de Guerra Fria.

Ele abre caminho para o item "Na mão do norte, onde 'a cara do chão é minha mais': o regionalismo norte-mineiro" 21 , em que apresento as origens do sentimento baianeiro e, posteriormente, norte mineiro, que fundaram o projeto autonomista. A região seria percebida pelas suas classes dirigentes a partir do planejamento estatal, com o dualismo permitindo aos próprios sertanejos se enxergarem dentro do desenvolvimento.

\footnotetext{
${ }^{20}$ Título inspirado na lembrança de Riobaldo ainda pequeno cumprindo promessa no rio São Francisco (ROSA, 1986).

${ }^{21}$ Expressão usada por Zé Bebelo em Grande sertão: veredas, sinalizando conhecer bem as bandas do norte de Minas Gerais, durante uma conversa com os jagunços na tentativa de convencê-los a prosseguir no ataque ao Hermógenes e ao Ricardão, por vingança a Medeiro Vaz (ROSA, 1986).
} 
Em “"A Serra que eu não conheço mais': o reflorestamento", a partir da observação de um morador antigo que não reconhece mais a Serra por onde andou, abordo a chegada das reflorestadoras durante a ditadura militar. Por meio dos entrevistados, tanto os trabalhadores da silvicultura quanto os encarregados dessas fazendas, discuto como o planejamento, escancaradamente autoritário, penetra a Serra alterando as relações de agregação e expulsando os posseiros. Busco as incongruências nas falas dos entrevistados no tocante a como percebem a modernização em suas vidas, momento em que a grilagem é adensada, as fazendas de gado se modernizam ou são vendidas para carvoejamento e a população agregada é finalmente mobilizada territorialmente para o trabalho assalariado, sinalizando a abertura regional.

Em “'Se essa Serra fosse minha...': sem pedrinhas de brilhantes”, retomo a discussão do garimpo dentro do contexto de expansão da silvicultura e da apropriação das veredas e chapadas, vedando aos faiscadores o livre acesso às terras. A querela ambiental começa a aparecer neste momento, tanto ligada ao garimpo quanto ao eucalipto, apesar de ainda não ter provocado qualquer comoção social.

No item "O desenvolvimento e o regionalismo que viraram carvão", retorno ao derrotado debate autonomista do norte mineiro, desnudando os seus defensores. Aqui, o discurso modernizador contraditoriamente não apetece as classes norte-mineiras dominantes, que não se sentiram compensadas pela integração da região à Sudene. O dualismo aparece como a causa maior da sensação de pobreza e atraso, arregimentando em defesa do projeto intelectuais, políticos e donos de posses. Não só as elites regionais se insatisfizeram com os projetos, como o próprio nacional-desenvolvimentismo chegou ao esgotamento.

Em "'Re-luzir perfeito o norte?",22, encerro o quinto capítulo apresentando as novas relações de trabalho na Serra. Os entrevistados, tanto os presentes no momento de chegada das empresas, quanto os que hoje nelas trabalham, dão o tom. Nesse momento, denuncio a descartabilidade dos trabalhadores conforme as formas de acumulação se transformam.

No título do sexto e último capítulo, "O sertão fora e dentro do lugar da modernização" ${ }^{23}$, abro passagem para discutir a Serra dentro das contradições da modernização. Se antes o planejamento olhava para o sertão identificando sua pobreza natural e técnica, os planos no século XXI passam a enxergá-lo como um espaço cheio de potencialidades econômicas, carente apenas de técnica e pessoal capacitado. Nele, analiso o Projeto Hidroagrícola Jequitaí como grande empreendimento estatal afim de atrair capital privado para a Serra. O entusiasmo dos tecnocratas ouvidos está no desenvolvimento social daquele sertão,

\footnotetext{
${ }^{22}$ Título inspirado em Zé Bebelo e sua ânsia de modernizar o sertão, porém aqui como uma pergunta desconfiada.

${ }^{23}$ O nome é uma brincadeira com o famigerado texto "As ideias fora do lugar" (SCHWARCZ, 1992).
} 
com a promessa de prosperidade para os moradores. Retomo brevemente o velho anseio da construção da barragem no rio Jequitaí, que, até os últimos anos, não passava de juramento político para os moradores mais antigos. Conforme confronto os relatórios técnicos com toda a bagagem de entrevistas, pesquisas de campo e leituras, detecto lacunas dentro de um programa contraditório de modernização retardatária.

Como preocupação inédita naquela região, o plano da barragem traz a questão ambiental, assunto final da tese, transportando para os dias de hoje os problemas causados desde a chegada das reflorestadoras. No item "Progredimos e desaparecemos: o messianismo do discurso ecológico" 24 , abordo o progresso como nada mais do que pura barbárie. Com isso, trago a esperança dos moradores de Francisco Dumont na solução ambiental como forma de salvá-los de um colapso já sentido cotidianamente, porém ainda não plenamente ou criticamente interpretado. A abrangência do meio ambiente por um capitalismo ecológico seria um alvo para a crítica, sem, no entanto, me propor a apresentar saídas.

Termino com as considerações finais, questionando qual o porvir da Serra do Cabral e deixando algumas perguntas. Com isso, interrompo o estudo dedicado a pensar e entender a Serra do Cabral, tomando para mim toda a responsabilidade referente às lacunas teóricas e metodológicas, às insensibilidades e ao insuficiente esforço de dobrar a qualidade do que apresento. Conforta-me saber que a dinâmica do território é o que me permite ir adiante na interpretação do assunto, interminável e imprevisível.

\footnotetext{
${ }^{24} \mathrm{O}$ título uma menção à frase de Euclides da Cunha na reflexão melancólica após o crime de Canudos, escrita em Os sertões: "Ou progredimos ou desaparecemos" (CUNHA, 1905, p. 70).
} 


\section{LISTA DE FIGURAS}

Figura 1 - Célio e Jota à porta da casa da família Facão (à esq.), nas proximidades do cemitério municipal (à dir.)

Figura 2 - Feira com produtores locais em Francisco Dumont 33

Figura 3 - Sempre-vivas colhidas na Serra do Cabral, guardadas em lapa e à espera do caminhão

Figura 4 - José, garimpeiro de diamante clandestino em Jequitaí (à esq.) e ferramentas de garimpo guardadas por seu Joaquim Pontaria em Francisco Dumont (à dir.)

Figura 5 - Exemplo de pintura em lapa na Serra do Cabral 72

Figura 6 - Rancho de coletores de sempre-viva na Serra do Cabral, 1970. 107

Figura 7 - Homens do mutirão para a construção da estrada de Conceição do Barreiro (sem data).

Figura 8 - Pais de Sócrates Dumont, recém-casados (sem data)

Figura 9 - Ata da abertura da escola para meninos, Barreiros, 1927

Figura 10 - Muros de pedra ao longo da Serra do Cabral, Francisco Dumont

Figura 11 - Vista do garimpo do Barreirinho com o município de Francisco Dumont ao fundo

Figura 12 - Achados no solo do garimpo do Barreirinho.

Figura 13 - Cascalho acumulado do garimpo do Barreirinho com a vegetação do cerrado regenerada devido ao abandono do local.

Figura 14 - Vestígio de casa no garimpo do Barreirinho

Figura 15 - Ferramentas de garimpo encontradas no subsolo do garimpo do Barreirinho

Figura 16 - Barão de Jequitaí (sem data)

Figura 17 - Escombros de uma das casas de fazenda do barão, povoado do Carrapato

Figura 18 - Usina de açúcar em Engenheiro Dolabela, início da década de 1950

Figura 19 - Casarão centenário da família Dumont 208

Figura 20 - Capa da Ata de reunião de fundação do Diretório Municipal da União Democrática Nacional - UDN, Francisco Dumont, 1966 
Figura 21 - Festa do Divino Espírito Santo e Nossa Senhora da Conceição, Francisco Dumont, 1950

Figura 22 - Festa do Divino Espírito Santo e Nossa Senhora da Conceição, Francisco Dumont, 1960

Figura 23 - Folia de Reis organizada pela família Prado, Francisco Dumont (sem data)

Figura 24 - Trecho de partitura de dobrado composto por Mestre Lôro para a Banda de Música de Francisco Dumont, 1946

Figura 25 - Centro do povoado de Conceição do Barreiro, atual município de Francisco Dumont, com carroças circulando e extinta birosca (mercearia) do Boresca, início do século XX

Figura 26 - O que restou do trecho da ferrovia que atravessava o distrito de Dolabela

Figura 27 - O que restou da biblioteca de Sócrates Dumont 253

Figura 28 - Inauguração da linha de ônibus da Viação Tolentino (atual Viação Transnorte), Francisco Dumont, 1968

Figura 29 - Derrubada do cerrado na Serra do Cabral e produção de carvão com madeira nativa carregada por bois, década de 1970 .

Figura 30 - As transformações no município de Francisco Dumont: o centro e a periferia, o espaço e o tempo

Figura 31 - Anotações de venda de terras de Sócrates Dumont, maio de 1992. .268

Figura 32 - Título de eleitor de 1958, onde se reconhece o garimpo como profissão.....271

Figura 33 - Frente e verso de uma das carteiras de registro de garimpeiro de Geraldinho, Jequitaí, 1977.

Figura 34 - Restos de uma usina de açúcar abandonada, hoje assentamento de reforma agrária, Engenheiro Dolabela, 2018

Figura 35 - Córrego do Barreiro, com o antigo chiqueiro e moinho de fubá, onde muitas mulheres iam lavar roupa, 1970.

Figura 36 - Grua em cultivo da Plantar e fornos de carvão na Serra 296

Figura 37 - Vereda de Santo Antônio morrendo na Serra do Cabral 314

Figura 38 - Amostra de produtos colhidos na Serra do Cabral e galpão de armazenamento da coleta, Francisco Dumont, 2017

Figura 39 - K3 Millenium na colheita de café na Ecoagrícola 


\section{LISTA DE MAPAS}

Mapa 1 - Serra do Cabral com seus municípios, formas de uso do solo e circulação

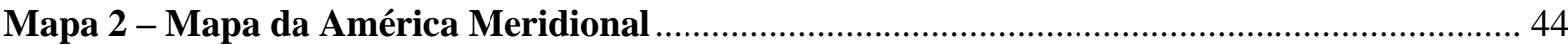

Mapa 3 - Mapa da Capitania de Minas Gerais com a Divisa de suas Comarcas.......................... 46

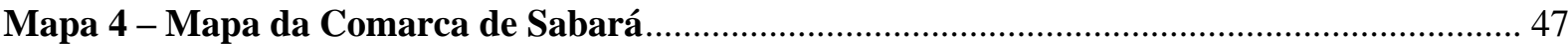

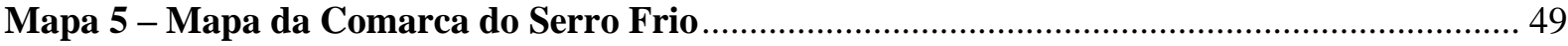

Mapa 6 - Mappa Topografico e Idrografico da Capitania de Minas Geraes ................................. 50

Mapa 7 - Planta Geral da Capitania de Minas Gerais ….................................................................... 51

Mapa 8 - Carta Geographica da Capitania de Minas Geraes …………..................................... 52

Mapa 9 - Theil der neuen Karte der Capitania von Minas Geraes............................................. 53

Mapa 10 - Carta Chorographica da Provincia de Minas Geraes .................................................... 54

Mapa 11 - Provincia de Minas Geraes segundo o projeto de nova divisão do Império ............... 55

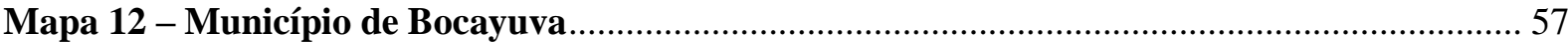

Mapa 13 - Mapa do Estado de Minas Gerais - Município de Bocaiúva .......................................... 58

Mapa 14 - Caminhos da cidade da Bahia para as minas do rio das Velhas ................................. 63

Mapa 15 - Croqui do projeto da barragem de Jequitaí - Codevasf, julho de 1981 …................ 301

Mapa 16 - Mapa do Parque Estadual da Serra do Cabral (limites em azul) .............................. 322

Mapa 17 - Cobertura do solo e formas atuais de seu uso na Serra do Cabral (2021) ................ 332 


\section{LISTA DE SIGLAS}

AHE

AHU

Amamn

ANA

Aneel

APA

APM

Arena

$\mathrm{BN}$

BNDES

BuRec

CAIs

Capes

Cepal

CHE

CMN

Codeno

Codevasf

Conviver

Copasa

CVSF

DNPM

EIA/Rima

Emater
Arquivo Histórico do Exército

Arquivo Histórico Ultramarino

Associação dos Municípios da Área Mineira do Nordeste

Agência Nacional de Águas

Agência Nacional de Energia Elétrica

Áreas de Proteção Ambiental

Arquivo Público Mineiro

Aliança Renovadora Nacional

Biblioteca Nacional

Banco Nacional de Desenvolvimento Econômico e Social

Bureau of Reclamation

Complexos Agroindustriais

Coordenação de Aperfeiçoamento de Pessoal de Nível Superior

Comissão Econômica para a América Latina

Cartografia Histórica do Exército

Conselho Monetário Nacional

Conselho de Desenvolvimento do Nordeste

Companhia de Desenvolvimento dos Vales do São Francisco e do Parnaíba

Programa de Desenvolvimento Integrado e Sustentável do Semi-Árido

Companhia de Saneamento de Minas Gerais

Companhia Vale do São Francisco

Departamento Nacional de Produção Mineral

Estudo de Impacto Ambiental/Relatório de Impacto Ambiental

Empresa de Assistência Técnica e Extensão Rural 


\begin{tabular}{|c|c|}
\hline Embrapa & Empresa Brasileira de Pesquisa Agropecuária \\
\hline Engetel & Engenharia e Telecomunicações Ltda. \\
\hline Esalq & Escola Superior de Agricultura Luiz de Queiroz \\
\hline FAG & Fundação de Assistência aos Garimpeiros \\
\hline Finam & Fundo de Investimentos da Amazônia \\
\hline Fiset & Fundo de Investimentos Setoriais \\
\hline FMI & Fundo Monetário Internacional \\
\hline FPM & Fundo de Participação dos Municípios \\
\hline Funm-Unimontes & $\begin{array}{l}\text { Fundação Norte Mineira de Ensino Superior da Universidade Estadual } \\
\text { de Montes Claros }\end{array}$ \\
\hline GEF & Global Environment Facility / Fundo Global para o Meio Ambiente \\
\hline GTDN & Grupo de Trabalho do Desenvolvimento do Nordeste \\
\hline IBGE & Instituto Brasileiro de Geografia e Estatística \\
\hline Ibra & Instituto Brasileiro de Reforma Agrária \\
\hline IEF & Instituto Estadual de Florestas \\
\hline ICMS & Imposto sobre Circulação de Mercadorias \\
\hline Igam & Instituto Mineiro de Gestão de Águas \\
\hline IHGMC & Instituto Histórico e Geográfico Montes Claros \\
\hline Ipea & Instituto de Pesquisa Econômica Aplicada \\
\hline IPN & Instituto de Pesquisa e Memória Pretos Novos \\
\hline I PND & I Plano Nacional de Desenvolvimento \\
\hline IPT & Instituto de Pesquisas Tecnológicas \\
\hline Iseb & Instituto Superior de Estudos Brasileiros \\
\hline ISS & Imposto Sobre Serviços \\
\hline ITBI & Imposto sobre Transmissão de Bens Imóveis \\
\hline
\end{tabular}


Juscelino Kubitscheck

Labur

Laboratório de Geografia Urbana

MDB

Movimento Democrático Brasileiro

MEC

Ministério da Educação e Cultura

MIT

Massachusetts Institute of Technology

MME

Ministério de Minas e Energia

Novacap

Companhia Urbanizadora da Nova Capital do Brasil

ONG

Organização Não Governamental

PAC

Programa de Aceleração do Crescimento

PAEG

Programa de Ação Econômica do Governo

PCB

Partido Comunista Brasileiro

Planoroeste

Plano Integrado de Desenvolvimento do Nordeste Mineiro

Planvasf

Plano Diretor para o Desenvolvimento do Vale do São Francisco

PND

Plano Nacional de Desenvolvimento

Polocentro

Programa de Desenvolvimento dos Cerrados

PPI

Projeto Piloto de Irrigação

PPP

Parcerias Público-Privadas

Proceder

Programa de Cooperação Nipo-Brasileiro para o Desenvolvimento dos Cerrados

Promover

Programa de Promoção e Inserção Econômica de Sub-Regiões

Pronaf

Projeto PNUD/BRA/98/012

Rima

Relatório de Impacto ao Meio Ambiente

$\mathrm{RMNe}$

Região Mineira do Nordeste

Ruralminas

Fundação Rural Mineira Colonização e Desenvolvimento Agrário

Scai

Serra do Cabral Agroindústria

SFN

Sistema Financeiro Nacional 
SNCR

Sudam

Sudene

Sumoc

SUS

Suvale

TTG

UFRJ

Usaid

USP
Sistema Nacional de Crédito Rural

Superintendência do Desenvolvimento da Amazônia

Superintendência do Desenvolvimento do Nordeste

Superintendência da Moeda e do Crédito

Sistema Único de Saúde

Superintendência do Vale do São Francisco

TTG Brasil Investimentos Florestais Ltda.

Universidade Federal do Rio de Janeiro

United States Agency for International Development

Universidade de São Paulo 


\section{SUMÁRIO}

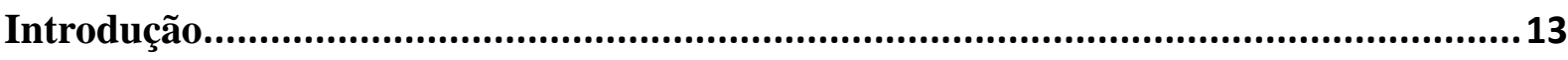

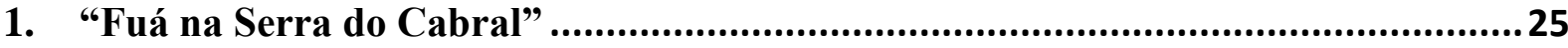

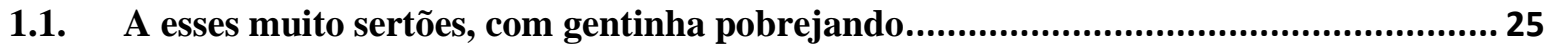

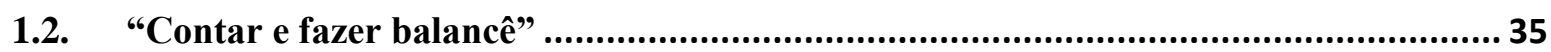

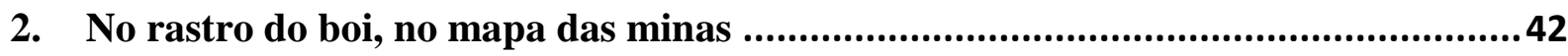

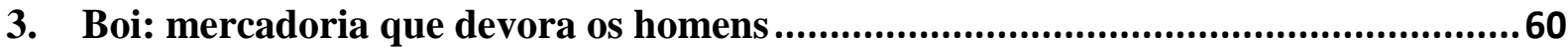

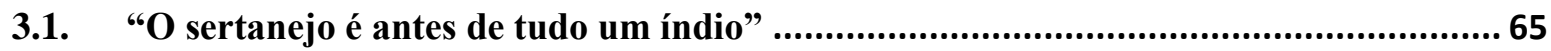

3.2. Toda coisa que pode ser roubada ou apropriada pode ser mercadoria: a terra e o

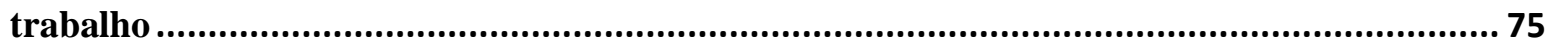

3.3. Os fatores de produção nos documentos e os seus não ditos ...................................... 83

3.4. "O passado era mesmo passado" na "terra bonita onde mora a maleita": a região sob a

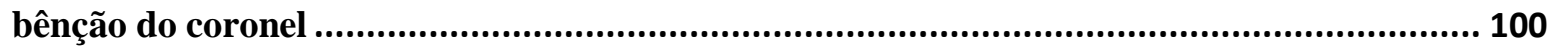

3.5. "Botando pontes, baseando fábricas, estreando mil escolas": o projeto de progresso

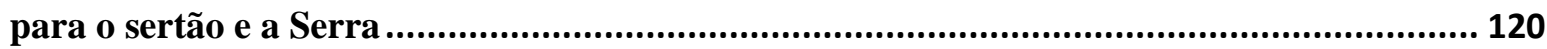

3.5.1. "Uns, aboiavam sem bois": o trabalho nas fazendas na Serra .................................... 127

3.5.2. Lica de Zé Peão, Maria de Bruno Facão, Vanja de Manoel Lopes e Ifigênia de Dodô:

dois dedos de prosa sobre família, trabalho, cor e valor-dissociação.......................................... 134

3.5.3. "O sertão que estremece debaixo da gente": o dissociado entre a realidade e a ficção148

4. O garimpo de diamante, "a mais preciosa das inutilidades" ...............................152

4.1. Saídas e bandeiras e as descobertas: de bandeirante a garimpeiro e os vadios .......... 153

4.2. "Esses bateavam faisqueiras": apurando e resumindo na Serra ............................... 170

4.2.1. Os diamantes do barão retinto por uma narrativa outsider ........................................ 180

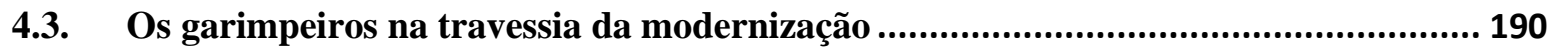

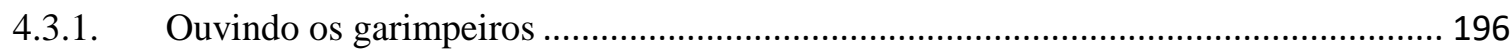

4.4. "Feito promessa para cumprir quando ficasse bom": as festas religiosas na Serra e

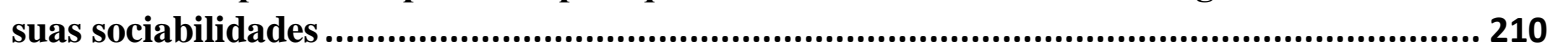

5. Do sertão ao cerrado: o Estado maquinal e sua absorção pelo capital...................... 220

5.1. O Estado Novo e o embrião do novo Estado: a região aparecendo ............................. 223

5.2. O desafino do "presidente bossa nova" ao tocar a região ........................................ 236

5.3. Na mão do norte, onde "a cara do chão é minha mais": o regionalismo norte-mineiro 246

5.4. “A Serra que eu não conheço mais": o reflorestamento ......................................... 254

5.5. Se essa Serra fosse minha...: sem pedrinhas de brilhantes........................................ 270

5.6. O desenvolvimentismo e o regionalismo que viraram carvão .................................... 277

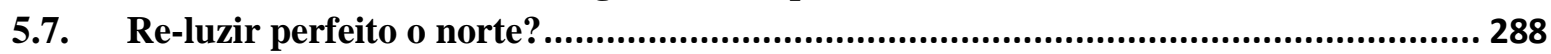

6. O sertão fora e dentro do lugar na modernização ............................................300

6.1. Progredimos e desaparecemos: o messianismo do discurso ecológico......................... 314

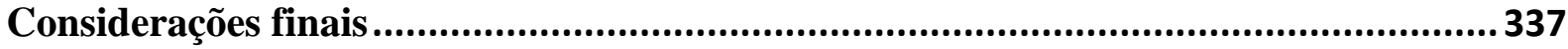

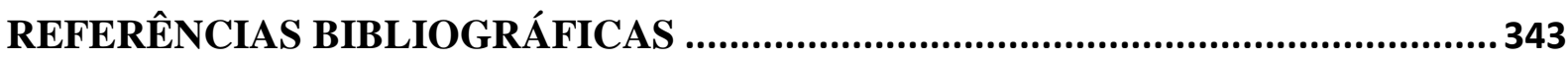

ANEXO A - INVENTÁRIO DE JOÃO DE ALMEIDA BORÉM, 1851 ....................... 363

ANEXO B - INVENTÁRIO DE FRANCISCO DE ALMEIDA BORÉM, 1863........... 366 
ANEXO C - INVENTÁRIO DE HERCULANO ALMEIDA BORÉM, 1893 374 ANEXO D - ENTREVISTADOS.. 


\title{
Introdução
}

\begin{abstract}
Sendo isto. Ao doido, doideiras digo. Mas o senhor é homem sobrevindo, sensato, fiel como papel, o senhor me ouve, pensa e repensa, e rediz, então me ajuda. Assim,

é como conto. Antes conto as coisas que formaram passado para mim com mais pertença. Vou lhe falar. Lhe falo do sertão. Do que não sei. Um grande sertão! Não sei. Ninguém ainda não sabe. Só umas raríssimas pessoas - e só essas poucas veredas, veredazinhas. $O$ que muito lhe agradeço é a sua fineza de atenção.
\end{abstract}

João Guimarães Rosa, 1986

Primícias do século XVIII: Rafael Bluteau explica em seu Vocabulário portuguez e latino que "sertão" significa "região apartada do mar, \& por todas as partes metida entre terras" (BLUTEAU, 1712, p. 613 apud RODRIGUES, 2014, p. 66). No debutar da centúria seguinte, o termo aparecia no dicionário francês Larousse como nome dado, no Brasil, a certas partes do território de algumas províncias pouco povoadas ou incultas, delimitando-o geograficamente: os "ermos do São Francisco, na Província de Minas Gerais. Os raros habitantes destes desertos são chamados sertanejos" (FONSECA, 2011, p. 53, grifos do autor).

Posteriormente a este glossário, o naturalista francês Auguste de Saint-Hilaire afirma que o sertão "não designa uma divisão política de território; não indica senão uma espécie de divisão vaga e convencional determinada pela natureza particular do território" (SAINTHILAIRE, 1938, p. 247-248), marcado pela escassez de população. Para ele, o sertão compreenderia, nas Minas Gerais, à bacia do rio São Francisco e dos seus afluentes, abrangendo metade do território da província e extrapolando seus limites ${ }^{25}$.

Momentos mais tarde, ano de 1867, em sua epopeia de descer de canoa o rio São Francisco desde Sabará até o oceano Atlântico, Richard Burton ouviu pelo caminho que "sertão" significava terras distantes dos povoados de mineradores e onde não há minerações. Após passar por Curvelo, notando a solidão para além desse povoamento, intuiu que o sertão começaria ali, podendo ser mais do que lugares ausentes de garimpeiros, mas desertos de tudo (BURTON, 1977).

\footnotetext{
25 “[O sertão] não designa uma divisão política de território; não indica senão uma espécie de divisão vaga e convencional determinada pela natureza particular do território e, principalmente, pela escassez de população. O Sertão compreende, nas Minas, a bacia do São Francisco e dos seus afluentes, e se estende desde a cadeia que continua a Serra da Mantiqueira ou, pelo menos quase a partir dessa cadeia até os limites ocidentais da província. Abarca, ao sul, uma pequena parte da comarca do Rio das Mortes, a leste, uma imensa porção das comarcas de Sabará e do Serro do Frio, e finalmente, a oeste, toda a comarca de Paracatu situada ao ocidente do São Francisco. Essa imensa região constitui assim cerca de metade da Província de Minas Gerais, e se estende aproximadamente, desde os $13^{\circ}$ até os $21^{\circ}$ de latitude; mas não se deve pensar que o sertão se restrinja à Província de Minas Gerais; prolonga-se pelas da Bahia e Pernambuco, e a Província de Goiás." (SAINT-HILAIRE, 1975, p. 307 apud RODRIGUES, 2014, p. 66).
} 
A Serra do Cabral, situada no norte de Minas Gerais e a poucas centenas de quilômetros para além de Corinto e Curvelo, pontilhada de ocupações fundadas por vaqueiros e garimpeiros e banhada pelo rio Jequitaí, um afluente do São Francisco, é parte do mosaico de sertões que integra o vasto interior do Brasil. Portanto, estudá-la requer pensar e repensar o sertão de maneira a entendê-lo criticamente, e não narrar mais uma apologia mística desse território fetichizado. Seria ele um atributo natural? Se for, então não teria história? Ele é espacialmente delimitável? Se é o espaço indomável e desconhecido, onde a natureza se sobrepõe ao homem, por que então é nomeado e classificado? Se é integrante do campo simbólico, como explicar as gerações que vivem nele? A partir dessa premissa, como lidar com o sertanejo? Se tem sertanejo, não teria história? Logo, continua sendo sertão? Sertão é um só? Desde quando o sertão existe?

Pela superfície do planeta, encontra-se uma grande variedade de ambientes físicos e bióticos, muitos dos quais modificados pela ação humana ao longo do tempo. Essas mudanças na produção dos espaços dão à história a sua parcela de capacidade para explicar as distinções entre as formas de organização social de cada área. A diversidade dessas ações produziu não apenas narrativas, mas uma paisagem geográfica variada, em que diferenças socioculturais se enraizaram profundamente.

Naturalizar a palavra "sertão", referindo-se a ela como nada mais que um espaço físico delimitado, é desconsiderar sua gênese e a alta carga de valores simbólicos a ela associada: é não levar em conta o sertão como espaço apropriado pelo avanço do capitalismo mundial, do qual tanto o Brasil quanto as suas próprias regiões são parte, nem considerar as contradições presentes e as composições na esfera psicossocial de quem vive nele. Todo espaço nomeado, por menores que sejam as intervenções, já sugere uma apropriação inicial, adentrando no imaginário social como existente, como um horizonte a ser alcançado ou uma fronteira a ser transposta.

Feita essa afirmação, esclarece-se que a ótica escolhida para tratar o sertão é aquela que não o considera mera obra da natureza, como também não se limita a pensá-lo apenas na sua dimensão subjetiva individual a partir do imaginário.

Cunhado pelos portugueses na baixa Idade Média, quando já visitavam a franja litorânea africana com os interesses prematuros do mercado, o termo "sertão" tem versões sortidas quanto à sua origem. Podia se referir tanto às áreas distantes da costa quanto à corruptela de desertão, na adaptação imaginária europeia para os desertos do Antigo Testamento. Concebido como terreno de provações, vida errante e desprendimento, era tido tanto como o lugar do maravilhoso quanto das tentações satânicas, mesclando realidades materiais e espirituais, o geográfico e o 
simbólico, o imaginário e o econômico e o social e o ideológico ${ }^{26}$. Assim, a palavra já nasce portando seu duplo sentido.

Da mesma circunstância de criação do termo "sertão" nasceria outro conterrâneo seu, o "fetiche", uma crioulização da palavra portuguesa "feitiço" 27 , usada para designar os rituais das sociedades do Golfo do Benin, testemunhados pelos ibéricos durante suas entradas no continente africano entre os séculos XV e XVI, nos quais os objetos eram adorados e, por isso, adquiriam poderes sobrenaturais.

Assim como o sertão, o fetiche só vai aparecer nos dicionários europeus no século XVIII, tendo em Charles De Brosses (1760) a definição pioneira. Para ele, o fetichismo seria a forma mais elementar de religião, dado que coisas eram adoradas ao acaso. No esforço de comparar as religiões africanas às egípcias antigas, o intelectual e político esclarecido justificava com isso que os povos africanos detinham as formas de religião e sociedade mais simples e selvagens. Para Hegel, o fetichismo era a prova de que esses povos moravam não apenas no passado, mas fora da história, irrecuperáveis para o processo dialético da razão que guia a história, sendo sequer humanos (SANSI, 2008).

Diante de um mesmo berço contextual, propõe-se pensar que ambas as palavras são criações europeias prenhes de modernidade. A transição do mundo medieval para o moderno tem no desenvolvimento do capitalismo o seu ponto fulcral, e suas relações teriam como característica marcante a contradição em processo. Sertão é um espaço nomeado por homens que transpunham a costa da Guiné para buscar mercadorias - incluindo humanos para escravizar na América, que, por sua vez, produziriam para o comércio europeu ${ }^{28}$. Fetichismo é um termo ocidental moderno usado para nomear as religiões julgadas bárbaras, praticadas por essa gente tornada mercadoria nos territórios que os portugueses acessavam, inclusive os sertões da outra margem atlântica.

\footnotetext{
${ }^{26}$ PELISSARO (2011); LE GOFF (1994).

27 "Os termos feitiço e feitiçaria aparecem no português medieval num contexto legal [...]. A feitiçaria nasce portanto como um discurso de acusação. Como um discurso de acusação. [...] Pietz analisou a etimologia de 'feitiço' em conexão ao Latim 'factitius', fictício, também na origem dos termos artifício e artificial; o feitiço é uma coisa feita (o oposto de uma coisa natural), uma coisa falsa, um engano; como sabemos, feitiço também tem o significado de enfeite, artifício de sedução (objeto que pode 'obter a graça' dos outros).” (SANSI, 2008, p. 128).

${ }^{28}$ Não só europeus, como também os súditos da América portuguesa dos Setecentos, sobretudo os miscigenados que, mobilizados pela miséria da capitania de São Paulo, penetraram sertões d'além mar:
} 
Passado o tempo e desenvolvidas as forças produtivas do capitalismo, Karl Marx (2013) daria ao fetiche mais um significado: a capacidade sensível-suprassensível das coisas que, transformadas em mercadorias, ocultam o trabalho do qual elas resultam, originando a forma social que pauta a produção dos espaços, inclusive dos sertões integrados ao que os portugueses chamariam de Novo Mundo. Assim, ambos os termos têm historicidade, e as relações que estabelecem ou das quais fazem parte foram naturalizadas na construção colonial do outro lado do Atlântico.

Atravessando a origem moderna dos termos em questão, pressupõe-se que sertão é palavra porosa entre a forma categorial moderna e outras concepções, o que quer dizer que é uma criação imbuída de todas as contradições possíveis que as relações capitalistas carregam, sendo, dentro da colonização portuguesa e seu sentido, como também dentro da colonização sistemática de país independente, um território dialeticamente fetichizado. ${ }^{29}$

O sertão esteve na mira do Antigo Sistema Colonial, do Império e da República. Urgia, desde o sentido da colonização, ocupar e dominar esses espaços. Se esse sentido é o da submissão à nova sociabilidade, que tem nos países da Europa ocidental o seu centro, supõe-se que o Brasil nasce integrado à modernidade na medida em que, desde os seus primeiros passos, a mediação que se estabelece é, gradualmente, a da forma mercadoria. Para realizá-la, era preciso tomar esses espaços daquilo e daqueles que dificultavam tal feito. Daquilo porque a natureza se coloca como obstáculo, na incongruência de também portar os recursos desejados. Daqueles, porque já havia gente habitando suas veredas, campos e chapadas. Era preciso tornálo território, ocultando o fato de que, antes da imposição dessa forma, esses espaços já eram territórios de outros povos e outras relações, alheias à do capital em formação.

O ímpeto de dominação do sertão tem sua explicação na oposição entre Sociedade e Natureza promovida pela lógica do valor. O capitalismo em formação cindiu violentamente a unicidade que compõe a teia da vida, colocando o homem, enquanto depositário histórico da objetificação valorativa, como representante da Sociedade. Esta, por sua vez, deveria dominar e submeter a Natureza, apartada do corpo social e disposta como riqueza barata e disponível à produção de mercadorias. Assim, no evolver da colonização, o sertão foi concebido como mero ambiente natural desistoricizado.

\footnotetext{
${ }^{29}$ Até certo ponto, trabalha-se com uma forma mais condizente com aquela de Caio Prado Júnior em Formação do Brasil contemporâneo, para quem o país é uma formação moderna que abriga diferentes temporalidades coetâneas. Porém, enquanto para o autor muitas dessas temporalidades não podem ser consideradas capitalistas, entende-se aqui que a coexistência das contradições entre as formas modernas e "não modernas" são parte da imposição da forma da mercadoria nesse território, originando relações que interligam modos entendidos como díspares.
} 
Sertão e fetiche andam juntos desde a colonização do Brasil, contribuindo para moldar a complexa e conflituosa territorialização brasileira e, quiçá, alhures ${ }^{30}$. A construção de uma sociabilidade fetichista só foi possível a partir da "assim chamada acumulação primitiva", por meio da qual se impôs a violência do capital. Territorializar, como se pretende mostrar, é um esforço de apropriação dos espaços pelas relações de poder, que mobilizam gente e cabedais, enquanto depredam o meio dominado e submetem seus habitantes desconsiderando sua excepcionalidade ecológica com um fim único: a valorização do valor. Isso inclui desconsiderar o conteúdo e as formas de organização anteriores e coevas desses espaços, promovendo conflitos na coação de outras sociabilidades à da mercadoria.

Isso significa que no sertão a territorialização se processa no objetivo de produzir mercadorias, criando riqueza abstrata possível apenas pela imposição do trabalho como fenômeno histórico moderno de diferenciação social de exploração. Ele impõe fins não essencialmente ligados às necessidades diretas dos que são empurrados para o processo produtivo, se embrenhando nas comunidades e, tornados seus sujeitos juridicamente livres, os obrigando à comparação abstrata do esforço diferenciado, assim contaminando pela subjetivação toda a realidade social. Tem-se, como resultado, a submissão à qualificação moderna não só das relações sociais, mas também da consciência, o que inclui toda a carga de negatividade resultante do desenvolvimento das forças produtivas.

Se o sistema de mercado exige uma nova lhaneza, é inaceitável tratar o sertão descartando os sertanejos. Por mais que se tenha a mercadoria como centro de análise, é impossível a sua existência sem sujeitos sujeitados à sua lógica. O capitalismo como relação social coage pela violência, seja econômica, seja extraeconômica, expandindo territorialmente, expropriando e mobilizando gente, o que não se faz sem conflitos. Esses embates, se abordados criticamente - no cuidado de não se deixar seduzir pelo essencialismo -, contam a história do território a partir dos vencidos e supérfluos da periferia que a totalização produz.

Colocado isso, propõe-se pensar o sertão a partir da negatividade, porque é uma criação presa à forma categorial moderna, posto que é apropriação espacial onde se implanta essa nova relação com base na categoria trabalho. Ao se deduzir isso, torna-se impossível concordar com

\footnotetext{
${ }^{30}$ Os sertões da África e da América portuguesa, que em tempos geológicos imemoriais já estiveram unidos, se encontravam atravessados pelo rio Atlântico. Crê-se que foram unidos novamente, por pontes de sangue. Sujeitos diversos compuseram a territorialização desses sertões, compulsória e (pretensamente) livremente, tangidos pelas modernas relações da violência extraeconômica. Mas naqueles espaços apropriados, também eles deram vida aos mistérios de suas cosmovisões, unidas das duas margens atlânticas, ressignificando sobrevivências e fincando raízes híbridas entre mundos diferentes que não podem ser compreendidos como meros resíduos.
} 
a ideia de que ele seja apenas qualificativo dos lugares ou que não seja materialidade ${ }^{31}$. Dar ao sertão a pecha de ideologia geográfica é uma função que favorece as personificações do poder e as engrenagens da modernização, considerando-se que um dos traços fundamentais da ideologia consiste em tomar as ideias como independentes da realidade histórica e social (CHAUÍ, 2004). A ideologia desistoriciza, enquanto o sertão não é transistórico.

Também não se quer partir de uma concepção ontológica em que o sertão seja puro imaginário existente por meio de interações ${ }^{32}$, sem considerar as condições materiais fetichistas alienadas que criam suas diversas representações, todas elas em maior ou menor grau presas à forma social que se apropriou desse território. Se o sertão "está movimentante a todo-tempo" (ROSA, 1986, p. 456), ele é uma contradição em processo, representa palavra que se metamorfoseia conforme a relação mercadológica se desenvolve, submetendo os demais tipos de conexões sociais à sua conformação. ${ }^{33}$

O viés fenomenológico, que busca nos sertanejos uma ontologia poética absorta da territorialização, vem de encontro a uma concepção acrítica de região como arcabouço da originalidade do que seria o fantasma do povo brasileiro. O sertão proposto, sendo território dominado pela economia subsidiária da criação de gado somada à expansão dos garimpeiros mobilizados, se conformaria de fins do século XVIII em diante como região, onde formas particulares de produção e reprodução se desenvolvem. A região seria, conforme Maria Odila Leite da Silva Dias captou em sua leitura de Formação do Brasil contemporâneo, a grande herança colonial deixada, onde flagra-se que nem mesmo o pensamento marxista de Caio Prado Júnior escapou do desejo de suprimir as desigualdades regionais como "impasse do inorgânico"

\footnotetext{
31 “O sertão não se constitui, portanto, como uma materialidade criada pelos grupos sociais em suas relações com os lugares terrestres. Ao contrário, a invisibilidade da presença humana é muitas vezes levantada como 'vazios demográficos' ou 'terras desocupadas'. [...] Não se trata de um resultado de processos da natureza na modelagem de uma porção da superfície terrestre (como um ecossistema, um bioma, ou um compartimento geomorfológico), e nem do resultado de processos sociais na criação de um espaço produzido pela sociedade." (MORAES, 2002, p. 12).

32 "Na adoção do conceito de representação, abriu-se uma via de estudos, pela inclusão do imaginário no trato dos objetos geográficos. O imaginário nos permite, afirma BAILLY (1992), pela carga simbólica, ligar o homem e o espaço em sua plenitude, fazendo com que o espaço se inteligível em todas as dimensões. Ele é, portanto, um meio de interrogar o real, confrontando-o com outras possibilidades, de agir sobre o mesmo para fazê-lo parecer ficção. Os homens não agem em função do real mas em razão da imagem que fazem dele, já bem nos disse CLAVAL (1991). [...] Entendo que o sertão/espaço não existe em si mesmo, mas unicamente através de um conjunto de efeitos ou de interações que ele engendra." (ALMEIDA, 1998, p. 34).

${ }^{33}$ Em artigo no qual coteja as abordagens do sertão na literatura ficcional com A divina comédia, Fernando Cristóvão argumenta que, objetivado pela região mediterrânea pastoril onde a criação de gado estabilizou as populações "adaptadas ao meio", unindo em comum distintas sub-regiões do país, se deve entendê-lo genericamente como "uma região do interior, de criação de gado, desértica, mais ou menos estacionada num passado que se recorda como santuário ou reserva das tradições ancestrais, repositório venerado da linguagem e costumes antigos" (CRISTÓVÃO, 1994, p. 45), corroborando o viés ideológico no qual o sertão até pode ser concebido como território, porém estático.
} 
na composição de um país moderno (DIAS, 1989). Um inorgânico que não se encaixa no desejo de formar a nação.

Essa gente, fruto do "caldeamento étnico" (DIAS, 1989, p. 395) e da maior mobilidade pelos territórios relativamente escapos do grande domínio da plantation, é que comporia a massa de pobres a desenvolver formas particulares de territorializar os modos de produção imersos na modernidade, no contato exclusivo com as camadas dominantes locais. Tidos como "inorgânicos", "livres pobres", “desclassificados" e "sem razão de ser”, compunham a massa de vadios de quem Antonil já se queixava em Cultura e opulência do Brasil, com a qual o Estado recém-independente teria que lidar na tarefa de construir o seu território sob organizações a partir de então nacionais. Salpicados pelo vasto interior da Colônia, regionalizaram a produção à maneira da imposição do capital em cada território, onde as diferenças materiais e sociais confluíam com o meio geográfico e se colocavam então os ditames de dominação sob a condição de independente em um cenário internacional imperialista.

Nesse contexto, tem-se em mente que o sertanejo não pode ser considerado um apartado das relações modernas. Composto por capiaus e tantos rotulados de vadios na geração do valor, ele foi, ao longo da literatura ficcional e científica, o bárbaro andejo sem rumo, impregnado ora de selvageria, ora de melancolia inexplicável, ou o outro no qual não se reconhece igualdade. Onde se cobrem os reflexos, se elimina o diferente: Narciso acha feio o que não é espelho. Assim, é o sujeito febril, analfabeto, quase inumano à espera da redenção do deus dinheiro e de suas promessas de inclusão no mundo já em crise. Ele integra às avessas o sistema produtor de mercadorias em todos os momentos em que este se impôs, nem sempre na forma tipicamente capitalista, mas, mais ou menos, relacionado a esse mundo abstrato.

Movimentante a todo-tempo, o sertão é dialético por existir enquanto realidade espacial do dissociado, oriundo das relações com a natureza e entre os indivíduos expelidos da categoria trabalho, que o talhe social moderno criou. Se é admitido como mera ideologia geográfica, pode ser interpretado como ilusão necessária à dominação, abstrata e inversa, produto da experiência imediata desinteressada de sua concretude.

Essa aparência social invertida que a ideologia promove é do gosto dos discursos oficiais. A característica cambiante do sertão conta que, graças a esse viés, ele já foi porção distante do litoral, lugar desconhecido, morada da barbárie, vão e vazio, para além da fronteira $^{34}$, domínio do semiárido, região atrasada, refúgio da tradição, entre tantas

\footnotetext{
${ }^{34}$ Essa é mais uma acepção da palavra "sertão": a transposição da fronteira, para onde o capital se expande; é uma área de terra livre, para onde avança a colonização e o ímpeto do desenvolvimento disposto a "alcançar a
} 
qualificações sobre espaços que existem e são cartografados, cabendo pensar quem é que cartografa e escreve sobre o território e por que o faz. Há uma plêiade de documentos que cobrem da América portuguesa aos dias atuais que repetem os estereótipos negativos sobre o sertão ao sabor das personificações do poder, clamando pela necessidade de organizar a ocupação útil e a modernização desses territórios. As propostas e as análises são muitas, e paira sobre todas elas a ideia de espaço vazio e natural, indo do anônimo Roteiro do Maranhão a Goiaz pela Capitania do Piahui, passando pelo Marquês de Queluz, José Bonifácio, Oliveira Viana, Caio Prado Júnior e Monteiro Lobato, por exemplo, até chegar a governos que institucionalizam a presença dos técnicos e seus projetos de modernização desenvolvimentista, de Getúlio Vargas, JK e militares, aos governantes da neodemocracia e boa parte da intelligentsia que circundava os governos.

Tomada a decisão de rotulá-lo como um hiato espacial, a razão dualista tomou assento oficial no pensamento a partir da década de 1950. Urgindo ao Estado ações que garantissem o lugar do Brasil no grande mercado mundial, teóricos se puseram em marcha a dividir o país em duas faces aparentemente desconexas. O dualismo prometia solucionar o embaraço ao apresentar o sertão como uma folha em branco, pronta para receber do doutor da cidade praiana a tinta que escreveria o seu futuro prometido. Se não tem história, não tem gente, nem tem produção do espaço. Ele é inventado ideologicamente como um oco, à espera desses mesmos doutores para criar o território produtivo. É a ação de ser do Estado sob a promessa de desenvolvimento.

O viés ideológico produziu documentos fiéis como o papel (ROSA, 1986), que são registros oficiais dos vencedores na história, com sua percepção intencional e limitada dos objetos. Por serem oficiais, ganham o status de confiabilidade. De tanto repetirem que o sertão é um vazio, se acreditou nisso. Até geógrafos acreditam - inclusive, muitos se empenharam nos projetos que atravessaram a segunda metade do século $\mathrm{XX}$, tentando resolver a questão, inebriados pelo contexto de Estado edificador do capitalismo moderno na periferia, que a personificação de Getúlio Vargas apenas inaugurava. Enquanto uns, presos à cientificização que a modernização impõe, ainda creem na imagem de "país em construção", denunciando que os ideais mais profundos do desenvolvimentismo ainda jazem em suas convicções, outros preferem insistir na via ontológica e positivada do trabalho para buscar a poesia no sertão, recusando desfazer a neblina que encobre a territorialização e todas as contradições dela

complexidade da vida urbana", concepção presente em intelectuais como Sérgio Buarque de Holanda (1994), bastante influenciada por Frederick Jackson Turner (2004) - respeitadas as particularidades da trajetória de expansão de fronteira estadunidense. 
oriundas $^{35}$, como se o sensível brotasse sozinho, independentemente das relações sociais e seu sentido ali impostas.

O desenvolvimentismo insinua a existência de regiões que devem ser incorporadas ao moderno sistema produtor de mercadorias, alimentando com isso a ideologia de "país em formação", num constante vir a ser. Isso significa tomar o sertão como um espaço vazio a ser incorporado $^{36}$ a cada reordenamento das forças produtivas e processos de acumulação, repetindo o ímpeto de territorialização sobre um espaço onde o futuro já chegou e as relações modernas o constituem desde a expansão dos currais.

Posto isso, junta-se à preocupação com as palavras "sertão" e "fetiche" uma terceira, “formação". Enquanto periferia - que, apesar da diacronia das esferas econômica, política e psicossocial, se dinamiza na mesma frequência dos centros do sistema produtor de mercadorias -, o Brasil, por ser alvo das constantes adequações do território à engenharia do valor, foi concebido como um espaço nacional sujeitado às demandas do capitalismo mundial e suas novas configurações. Essa condição lhe impõe um movimento sempre reposto de modernização para a superação da não-simultaneidade externa e interna do capitalismo, quase nunca conseguida (ALVES, 2006).

Esse movimento de restituição da modernização é uma constante re-territorialização para o capital, normatizado nos planos de funcionalidade e otimização dos espaços para a produção, porém, dentro de um limite temporal, revestido de um verniz civilizatório. $\mathrm{O}$ momento de execução do nacionalismo desenvolvimentista, por exemplo, propunha arrancar a provincianização do país, maquinando o amalgamento das regiões num só corpo territorial, com vias a finalmente fundar a nação a partir do encontro único do universo rural com as dianteiras arrojadas da cidade. Porém, "com a distância do tempo e a ampliação de perspectiva" (SCHWARZ, 1999, p. 157), deixou-se transparecer o débil pacto conciliatório das camadas

\footnotetext{
${ }^{35}$ Pressupõe-se, dentro do teorema da crítica do valor-dissociação a ser apresentado, que Diadorim representa o dissociado que se traveste de masculino para realizar a vingança da morte do pai, figura masculina de poder e de mercado no sertão. Várias são as passagens de Grande sertão: veredas em que esse jagunço manifesta as características típicas do feminino, atreladas ao afeto e ao cuidado, mescladas com a virilidade cobrada dentro do bando todo o tempo. No combate de vingança contra Ricardão e Hermógenes e na tentativa de acabar com os conchavos políticos locais diante do desejo de governo no sertão, Diadorim é morto, só revelando ser mulher quando já estava sem vida. Com isso, fica a impressão de que o dissociado, presente na formação regional, existe como contradição da modernidade, mas, ao mesmo tempo, é negada a sua existência, sendo constantemente anulada. Tal interpretação se vale também do contexto em que o escritor viveu: funcionário do primeiro Governo Vargas, leitor de Oliveira Viana e imerso nos pensamentos que discutiam os caminhos a serem tomados pelo país. 36 "O sertão se repõe, assim, como uma espécie de pecado original do berço colonial de nossa formação, sofrendo requalificações a cada época e recebendo atribuições e qualificações próprias aos interesses em pauta a cada onda de ajustes dos espaços periféricos. $\mathrm{Na}$ atualidade, a perspectiva da globalização poderia identificá-lo com os lugares não integrados às redes de fluxos internacionais ou como os depositários do patrimônio natural e da biodiversidade do planeta." (MORAES, 2002, p. 20).
} 
dominantes, que, em flerte com o horizonte moderno dos países centrais, ladrilharam a industrialização retardatária da periferia, enquanto se reapropriaram dos espaços interiores, crentes no seu vazio à espera dos equipamentos que integrassem e sustentassem as longínquas plantas industriais que dariam ao Brasil o seu lugar no concerto das nações.

Entre esses espaços visados, está o sertão genérico. Dado que a simultaneidade negativa de qualquer sociedade que foi colonial acaba distorcidamente compreendida pelos limites sociais sujeitados ao valor como território onde o capitalismo não foi implantado de fato, a sociedade moderna vislumbrada não se formou, e essa aparência de atraso precisa ser superada para o futuro se realizar. Na esteira da competição internacional, busca-se a partir da centralização do Estado planejar o território nacional de forma a dar um destino equalizado às suas distintas regiões. Seja na interpretação dualista de dois brasis que não se encontram e sabotam o futuro promissor, seja no olhar à esquerda - no qual esse "inorgânico", desestabilizado com a sua retirada brutal para a substituição dos desmandos de régua e compasso não pode se constituir força de trabalho livre que transformará o país -, há, em todos esses discursos, o consenso positivo de que é preciso modernizar o Brasil.

Essa interpretação ilustrada de tempo histórico como linear, propositora de refundação do país quando ele estiver pronto sob a ótica ilusória da mercadoria, persegue uma ideia de progresso que nega os limites internos da lógica do valor, buscando ofuscar os contrassensos sociais que comprovam que esse futuro já chegou. Falido o nacional-desenvolvimentismo e sabotado o seu pacto diante da chegada da microeletrônica, a fantasia de integração social encara a fragmentação dos seus sujeitos e a impossibilidade de juntar seus cacos, como se isso fosse alguma vez possível dentro do sistema social do mercado. Onde o valor e sua dissociação se impõem, não há qualquer possibilidade de integrar uma sociedade incompatível com uma modernização que se propõe segmentadora.

Com isso, a ideia de formação, tão eloquente nas gerações preocupadas com a identidade nacional e a equiparação do país aos centros desenvolvidos, precisa ser superada. "Formação" não é, além de um vocábulo polido que positiva a modernização retardatária, um incômodo que aparece toda vez que não se realiza a tarefa de historicizar a modernização para se entender que dentro do mundo em que se vive já não há lugar para ninguém. No esforço de não se deixar seduzir pelo lirismo do fetiche e das falsas promessas de futuro, é que se intitula este estudo de "territorialização" da Serra do Cabral, utilizando-se "formação" no decorrer do texto diferentemente do que a locução propôs ao longo do tempo. Como toda palavra, "sertão" e "modernização" precisam constantemente ser historicizados e compreendidos na sua negatividade. 
Recorrendo tanto aos documentos e obras ficcionais quanto à discussão teórica e os campos, pressupõe-se então que o sertão é uma apropriação moderna incumbida de produzir mercadoria e, por isso, nunca estática. Ele resguarda uma historicidade particular porque não é possível se desvencilhar da excepcionalidade paisagística que apresenta. Aproveitados os atributos naturais diferentemente ali localizados, passou-se a confeccionar determinados produtos acompanhados de todos os recursos de que historicamente se valeu a produção: escravismo, violência, expropriação etc.

A imposição de rédeas frouxas às coxias da economia de exportação produziu não somente um território envolvido na sociabilidade moderna, mas também um conteúdo sensível, por vezes arredio, à imposição da violência do mercado. A coexistência indissociável dessa contradição traduz cada sertão como um território sui generis - porque, claro, sertão deve ser tratado no plural, para além de "uma questão de opiniães" (ROSA, 1986, p. 1), como prenuncia Riobaldo, na contramão da homogeneização tecnocrata que o Estado inovador propõe ${ }^{37}$. Essa diferença geográfica particular pode ser abrangida, mas não subjugada inteiramente pelo peso homogeneizador da circulação do capital (HARVEY, 2006).

Assim, o sertão é, pelo olhar do poder econômico - e o político a ele submisso -, um espaço concebido, planejado no gabinete por tecnocratas e autoridades, estrangeiros de seus campos e veredas. Eles arquitetam o seu desaparecimento para inventar um novo território, mais fetichizado e especializado, e a regionalização é assim concebida. Nesse processo, o espaço de vivência daqueles que historicamente o produziram é condenado à destruição para a criação de simulacros que, nos seus devaneios, abrigariam um dia as paisagens do centro, do moderno e do civilizado.

O sertão mais uma vez é um poço de contradições. É bárbaro e desconhecido, mas é nomeado; é um vazio, mas se planeja sobre esse oco, o afirmando na prática enquanto o nega na teoria. Tudo para depois ele ser suprimido pelas exigências do capital: o tempo tem que diluir sua solidez. Para os poderes políticos e econômicos, ele existe e não existe. Para os arautos da dominação, ele é no presente o arcaico sobre o qual se projeta o futuro da sociabilidade moderna. No delírio de negar o que está aí, escolhe-se enxergar às avessas. Encare-se o sertão pelo que ele é - "Quem muito se evita, se convive" (ROSA, 1986, p. 2), já sobreavisava um sertanejo letrado.

Para que se sustente a necessidade de construir "nonada", esse "nonada" precisa existir primeiro, inclusive na sua concretude física, biótica e social também - ou seja, só é possível

\footnotetext{
${ }^{37}$ A elaboração em torno de uma ideia única de sertão, associada à seca e à pobreza, foi dada na construção da República, tendo Os Sertões de Euclides da Cunha contribuição inquestionável.
} 
negar o que se conhece, o que se diz e se contradiz. O que não é igual ao modelo esclarecido de mundo precisa ser adestrado para se encaixar. Por isso, sertões e sertanejos seguem empurrados na violência econômica e extraeconômica ao se tornarem urbanizados, civilizados, anexos da metrópole.

No entanto, esse espaço de provações, feito e fator da economia fetichista, se adapta, irrompe. O capital é uma antítese entre expansivo e destrutivo: quanto mais desenvolve suas forças produtivas, mais precisa se expandir, necessitando expelir o trabalho vivo diante das ferramentas tecnológicas e, nesse seu decurso, lidar com as crises e a autodestruição. Enquanto precisar avançar e reterritorializar para prosseguir a sua acumulação, o sertão existirá, bem como seus sertanejos. Ele repetidamente será reinventado para ser destruído; os sertanejos serão amiúde forjados no fetiche para serem domados. Enquanto existir o capital, o sertão existe. “Cidade acaba com o sertão. Acaba?” (ROSA, 1986, p. 144).

É preciso escovar a história a contrapelo, sem grandes presunções, reconhecendo a pesquisa nas suas incongruências, a territorialização que ela própria promove, a arrogância da Ciência, a fragmentação do próprio pesquisador no mundo...

Eis, assim, a Serra do Cabral. Sertão de veredas, chapadas, mulheres, homens, velhos, crianças, doidos, casas, plantations, estradas, máquinas, caminhões, bateias, selas e visões de mundo cruzadas que agregam e convulsionam, fecundando contradições e sociabilidades. Um mosaico de modernização: onde a cristaleira do céu disputa irradiar luz com os postes, onde alguém brinca de roda enquanto o toca-discos entoa flash-backs. Na escadaria da porta da igreja, Pedro e amigos ouviam juntos no rádio de pilha o chiado engolindo as performances internacionais do primeiro Rock in Rio, lá pelos anos 1980. Décadas antes, seu pai, Pedro Rosa, ouvia pela rádio em Barreiro as notícias de sua filha Terezinha, pequena sertaneja à espera de tratamento moderno pelos corredores no Hospital das Clínicas de São Paulo. Hoje, via wi-fi 2G, seus netos e bisnetos ouvem pelos corredores da pensão Santa Terezinha o último hit de Kpop, por onde anos antes circulavam confabulações regionalistas. Sertanejos estiveram e estão conectados ao mundo, são elementos da realidade categorial fetichista.

Tolere, isto também é o sertão. 


\title{
1. "Fuá na Serra do Cabral"
}

\author{
Mensageiro natural de coisas naturais \\ Quando eu falava dessas cores mórbidas \\ Quando eu falava desses homens sórdidos \\ Quando eu falava desse temporal \\ Você não escutou \\ Você não quer acreditar \\ Mas isso é tão normal
}

Lô Borges e Fernando Brant, 1972

Se "o sertão é do tamanho do mundo", mas também "é dentro da gente" (ROSA, 1986, p. 60, 270), ao buscar a totalidade no particular, faz-se necessário construir as últimas impressões guardadas da Serra do Cabral para entender a racionalidade do mundo da mercadoria e todos os seus desdobramentos - na vida, na produção, na reprodução, na cultura e nas demais esferas - pela negatividade.

\subsection{A esses muito sertões, com gentinha pobrejando}

Julho de 2019, derradeiro campo pela Serra do Cabral. Enquanto se ouvia as experiências de Mauro Rodrigues de Oliveira, conhecido como Besouro, 69 anos (2019), um dos primeiros trabalhadores no reflorestamento e hoje aposentado, tocava uma música dos Guns $N^{\prime}$ Roses no rádio de pilha de sua casa, localizada na periferia de Francisco Dumont. Como as moradias do bairro são, na maioria, de parede pré-fabricada, o som atravessava os cômodos, chegando à porta da rua, rente à calçada, onde todos se encontravam. Besouro é modernizado até nos gostos musicais.

Dias depois, após três anos da primeira conversa, nova visita foi feita a Joaquim Marques Crispim, chamado de Joaquim Pontaria, 89 anos (2019). O ex-garimpeiro estava morando numa casinha nos fundos da parte alta da cidade, seu quarto dava para os escombros de um velho muro de adobe. Joaquim mostrou seu rádio de pilha, dos objetos de diversão mais caros a qualquer garimpeiro, bradando da porta: "Esse presidente cachorro nosso, eu posso tá velho e não ter estudo, mas sei muito bem o que ele anda fazendo, querendo matar pobre!". Disse que todo cair da tarde liga seu rádio para ter notícia do mundo.

Janeiro do mesmo ano, mais uma escuta a José Juvenal de Souza, Jota, 65 anos (2019), morador no bairro Vila Nova. Sua casa repete a arquitetura e os materiais da residência de Besouro, porém, sua narrativa não partilha completamente das mesmas semelhanças. À procura 
por trabalho para pagar a conta de luz, Jota estava aceitando qualquer serviço: capina de quintal, plantio, o que aparecesse. "Faz três meses que tô na escuridão", disse.

Quando perguntado sobre onde nasceu, disse que na fazenda de Sócrates Dumont. Lá, viveu até os 39 anos, trabalhando desde os cinco para ajudar a família numerosa, que era agregada na fazenda. Por isso, não estudou. Entrando nos 40 anos de idade, o fazendeiro deu aos seus pais uma casa na antiga periferia da cidade, quitando todos os compromissos de uma vida. Daí a mobilização para outros trabalhos que não fossem plantar capim e fazer cerca: "Trabalhei com eucalipto. (...) Tava ruim de serviço, fui garimpar diamante, fiquei ano e meio, Fábio Bruzinga pagava uma miséria. (...) Garimpei cristal na Serra também”.

A casa está endereçada nas proximidades do cemitério municipal que, quando construído, estava distante do povoamento. Isso sugere que o município cresceu horizontalmente, surgindo as periferias que não existiam até a década de 1970.

\section{Figura 1 - Célio e Jota à porta da casa da família Facão (à esq.), nas proximidades do cemitério municipal (à dir.)}

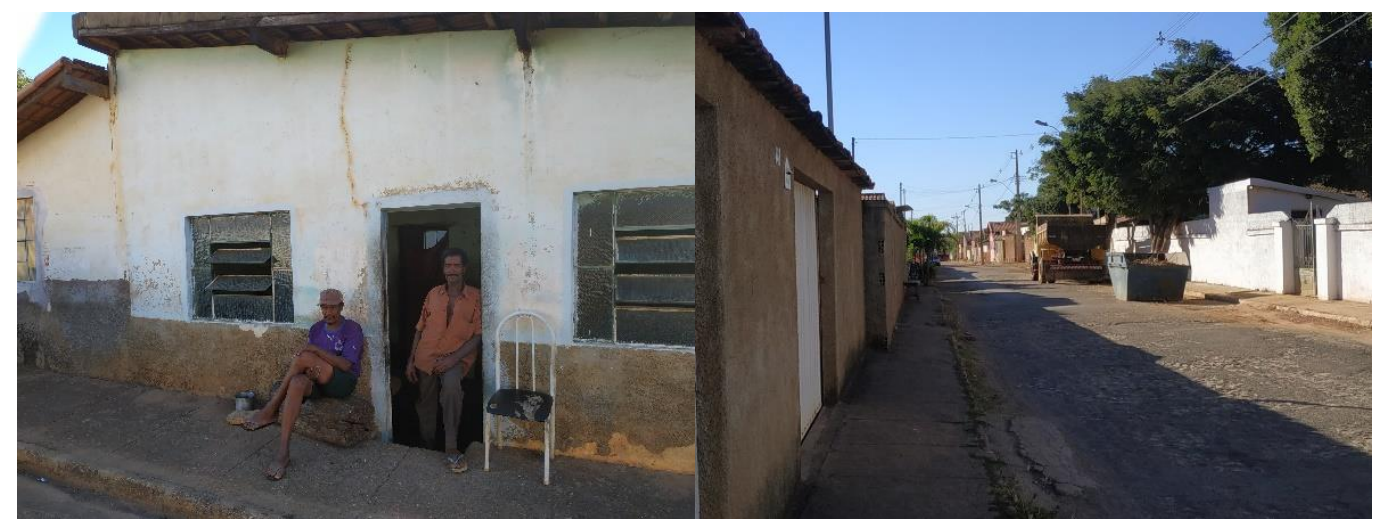

Fonte: arquivo pessoal, janeiro de 2019.

Enquanto Jota narrava como era o serviço de faiscar, seu irmão mais novo, Célio Pereira de Souza, se aproximou contando: "Faz uma semana que enterraram Pedrão, o barranco caiu nele. Tava garimpando escondido na Serra e sobrou só o braço pra fora. Ficou cinco dias até ser achado. Deixou mulher e menino pequeno". Conforme a entrevista tomou ares de prosa de calçada, Célio, entregue por dias à bebida, enfatizou: “A vida nossa é sofrimento demais". O teor da conversa só mudou após Jota receber a notícia de que pela primeira vez na vida tiraria seu RG e, com isso, ficaria mais fácil solicitar o Bolsa Família.

Um ano antes, nas andanças pelo povoado do Carrapato, à procura dos escombros do casarão de um tal major Domingos (da Guarda Nacional), conheceu-se Gercino Rabelo Fonseca, 60 anos (2018). Nascido na Água Fria, parte da Serra do Cabral, passou a vida na 
lavoura. "Planto feijão, crio porco, tudo sem máquina, só no braço. Moro sozinho. (...) Roço manga, cuido de gado pros ôtro.” Quando perguntado se esses serviços lhe rendem pagamento, ele sorri e gesticula com as mãos grandes, calejadas da enxada, estocando a terra vermelha nas unhas: “Aiaiá, ninguém paga não". Daí a pergunta sobre como ele consegue as coisas que não cultiva ou cria, bem como a sua relação com o dinheiro: "O que não tenho compro a crédito na cidade. Se sobra do que planto, vendo; quase não dá. Graças ao Bolsa Família posso pagar a luz! Antes vivia no escuro, tomava banho de rio".

Julho de 2015, um ano antes do início desta pesquisa, na pensão Santa Terezinha, Clarice Medeiros, 36 anos (2015), se organizava no horário dos serviços de faxina da casa para poder aproveitar a Festa de Nossa Senhora da Conceição e do Divino Espírito Santo, cuja festeira, Nagma da Silva, era também sua contratante, responsável pela pensão. Trabalhando ali há mais de dez anos e recebendo menos de um salário mínimo, foi o que Clarice encontrou no município após sua família ter de deixar a fazenda Aliança, de Sócrates Dumont, onde sua mãe vivia de agregada e onde ela nasceu e trabalhou desde os 14 anos. A propriedade estava com grandes parcelas à venda nos anos 1990, e era preciso retirar de suas dependências os moradores de favor para que chegassem os novos donos e as novas relações de trabalho.

Todos esses homens e mulheres apresentados têm muitos traços em comum: dois deles são a expropriação e a exploração, caricatos daqueles que vivem nas cidades. Receberem uma casa nos limites do município após serem dispensados pelos latifundiários ou serem posseiros confinados em pequenos pedaços de terra, os tornam disponíveis para vender sua força de trabalho em troca de um mínimo necessário para comprar comida, pagar uma conta ou mesmo alimentar um vício, indicativo de angústias e sofrimentos sentidos, porém não bem processados.

O mal-estar de Célio e a revolta de Joaquim Pontaria partem do lugar em que cada indivíduo está inserido no seu universo: são, hoje, seres dispensáveis ao atual processo de produção e, como tal, padecem. O trabalho, entendido como categoria histórica moderna que oculta as atividades concretas com a finalidade impositiva do valor, produz um mundo de abstração real e sem outro sentido que não seja o de alimentar essa conexão. Conforme o imperativo do valor criou uma narrativa ontológica do trabalho, a sociedade moderna foi disciplinada a não só aceitá-la, como também a perecer com a trajetória de excreção de braços do processo produtivo, implicando em sofrimento psíquico e miséria social.

O trabalho é, assim, a categoria radical que induz ao mal-estar melancólico entre os expropriados e explorados. Sua igualdade forçada para a troca no mercado retira o sentido das atividades essenciais à reprodução da vida, consideradas dissociadas porque conducentes apenas à satisfação das necessidades dos sujeitos abstratos. Embora massificados, esses 
indivíduos devem, dentro da condição de sujeitos livres, competir já na posição de perdedores, buscando onde for possível algum serviço que renda ao menos o que comer. Ao se acreditar coletivamente nessa ordem metafísica imposta pelo fetiche, inconscientemente permite-se que ela domine a prática social, e, conforme Célio exclamou sem muito explicar, ela é de sofrimento esmagador. Moldados historicamente a essa finalidade, os sujeitos não conseguem questionar a vida além desse sistema.

Nesse invólucro moderno, a riqueza abstrata do valor é o trabalho, é o tempo de atividade humana fragmentada e coagulada. A crise da fragmentação pelo desenvolvimento das forças produtivas que não mais necessitam do esforço individual é a crise do valor, que agora se tornou visível (LION; MELO, 2016). Foi isso que levou o jovem pai de família a garimpar ilegalmente, Célio a recorrer ao álcool, entre tantos exemplos tropeçados nos campos. Se o trabalho surge como diferenciação social e exploração que determinam fins não diretamente conectados às necessidades diretas dos que se empenham no processo produtivo, nasce um incômodo incompreendido da própria descartabilidade. Enquanto isso, as instituições modernas criadas por essa mesma forma social calculam projetos futuros, também elas presas à realidade categorial - confortavelmente ou não, pois o capital é amoral.

Em julho de 2019, foi possível visitar a sede do Projeto Hidroagrícola Jequitaí, em Francisco Dumont, na oportunidade de conversar com representantes do serviço de assistência social: Paolo Lages Sequenzia, engenheiro agrônomo, e Jéssica Augusta Alves de Mello, advogada responsável pelas indenizações sobre as terras atingidas pela barragem do rio Jequitaí.

O projeto era um anseio desde a década de 1950. Nos anos 1970, junto à Companhia de Desenvolvimento dos Vales do São Francisco e do Parnaíba (Codevasf), fez-se um esboço da obra, mas esta não saiu do papel. Desta vez, dando continuidade aos tempos do Programa de Aceleração do Crescimento (PAC), as obras foram iniciadas nos anos 2000, e o projeto foi expandindo: não será apenas uma barragem com vias à agricultura de irrigação, mas duas, sendo a segunda responsável pelo abastecimento elétrico de parte do norte mineiro. A primeira, implodindo as proximidades do Tombador, já estava em andamento.

Muito solícito, Paolo convidou a entrar no escritório e apresentou o jardim, onde faz experiências com plantas. Explicou os esforços do projeto junto à Empresa Brasileira de Pesquisa Agropecuária (Embrapa) para trazer para os pequenos agricultores da Serra do Cabral as técnicas da agroecologia e novas espécies, muito úteis, como capim-elefante, moringa (uma árvore africana cuja farinha, segundo ele, tem a mesma quantidade de proteína que a carne bovina), uma espécie de mosca, “já muito usada na Tailândia”, que decompõe matéria orgânica e cujas pupas também são ricas em proteína etc. Um discurso científico aprofundado e 
aparentemente muito bem intencionado, ressaltando a capacidade regional de desenvolvimento, aumento de produtividade e redução da pobreza.

Para o agrônomo, a população é, no geral, muito pobre tecnicamente, estando nas mãos da barragem e todo o seu suporte a possibilidade de corrigir o problema da pobreza econômica e tecnológica. Quanto aos fazendeiros de gado, Paolo salienta que também não se valiam dos conhecimentos no trato do solo, mas não fazem parte do alvo do programa por terem condições financeiras de acesso a novas formas de manejo.

Lembrar o esforço do cientista agrônomo contratado pelo Governo Federal e parear seu trabalho ao que se lê no Estudo de Impacto Ambiental e Relatório de Impacto ao Meio Ambiente (EIA/Rima) do Projeto Hidroagrícola Jequitaí, induz à reflexão sobre os reais motivos desse projeto a ser cravado na Serra: de um lado, fixar a população no território, prometendo mobilizá-la para o trabalho; de outro, movimentar capital fictício sob a justificativa de levar progresso à região. Ver um empreendimento de grande vulto para a região instiga a perguntar qual a racionalidade por trás.

Paolo enfatizou que a barragem é talvez a única na América Latina projetada com um cinturão de corredores ecológicos no seu entorno, cujo objetivo oficial é conservar a vegetação local, composta de cerrado com manchas de caatinga. Quando perguntado sobre a preocupação acerca das pessoas que sobrevivem da coleta de artigos no mato, respondeu que os posseiros também integrariam o grupo de pequenos agricultores a receber orientação sobre agroecologia. Mas Paolo não entendeu: a pergunta visava a população que não tem acesso à terra, constituída de famílias que há gerações sobrevivem catando flores e frutos do mato. Explicada a intenção da pergunta, reconheceu que o projeto não integra as famílias extrativistas.

Entre os excluídos dos cuidados do projeto, se encontram pessoas como Édio Geraldo Prado, conhecido como Nem de Bico, 65 anos (2020). De família nascida na Serra do Cabral, tomou dos antepassados a ocupação de colher sempre-viva e garimpar cristal, pois "não tinha trabalho, todo mundo dependia da Serra". Atualmente aposentado, se orgulha de ter sobrevivido das flores e das pedras, mas lamenta que hoje as reflorestadoras dos donos "de fora" proíbam a entrada nas terras para a colheita da flor, que vai de abril a junho. "Hoje, ainda tem umas 30 pessoas aqui em Francisco Dumont que vive disso. Da parte de Joaquim Felício é que tem muita gente que panha. Na época de pai e mãe, uns 30 anos atrás, era um monte de família.” À revelia dos grandes projetos, há, portanto, quem sobreviva disso.

No momento em que Paolo emudeceu sobre os extrativistas, Jéssica chegou à sede. Como o assunto fluía para a questão do acesso à terra, ela contou que $80 \%$ das famílias já tinham sido indenizadas pela barragem, restando os $20 \%$ que não possuíam o registro de suas 
terras, num problema crescente por conta dos numerosos herdeiros e envolvidos. Também comentou que encontrou muita gente cujas propriedades foram doações da família Dumont. Perguntada se houve alguma desconfiança de grilagem, ela titubeou: "Se houve, foi há mais de 200 anos". Será?

É consenso que a região é economicamente pobre e sobrevive do trabalho direto com a terra. De acordo com os dados referentes ao Censo de 2010 do sistema Cidades, do Instituto Brasileiro de Geografia e Estatística (IBGE), só o município de Francisco Dumont teria pouco menos de 5 mil habitantes, estando apenas 540 pessoas ocupadas com o trabalho formal. Quase a metade da população sobrevive com meio salário-mínimo, e muitas pessoas dependem dos programas sociais do Governo Federal, como o Bolsa Família. Em 2015, boa parte da receita do município teve origem externa, o que indica que o cultivo de eucalipto pertencente às empresas de fora da região ainda é a maior fonte de renda. Dados muito semelhantes se repetem em outros municípios da Serra do Cabral, como Jequitaí, Joaquim Felício e Buenópolis ${ }^{38}$.

Do ponto de vista fisiográfico, a Serra do Cabral localiza-se no médio vale sanfranciscano, na margem direita do rio São Francisco, entre as bacias dos rios das Velhas e Jequitaí, dos quais é divisora de águas. Ela está inserida no complexo do Espinhaço, que atua como divisor entre as bacias do São Francisco e a dos rios que correm diretamente para o Atlântico. Sua cobertura vegetal é de cerrado com manchas de caatinga e possui grande quantidade de nascentes e cursos d'água, uma verdadeira caixa d'água para o entorno.

Essa abundância de água em meio a uma área com baixos índices pluviométricos foi, segundo o mito fundador local, o motivo da lendária Ana Bonfim, vulgo Ana das Caveiras ${ }^{39}$, ter se arranchado nas margens do córrego Sassafrás em meados do século XIX, após descer da Bahia em busca de catas de diamante. Disputando essa narrativa, outra mulher, de nome Agda, zanzando pelos sertões vinda de Grão Mogol, também arranchada à margem do córrego que recebeu seu nome - que, por sua vez, deságua no do Barreiro ${ }^{40}$, na Serra do Cabral -, teria encontrado ali o alúvio e o alívio da miséria com as pedras que procurava. Duas mulheres pobres se movendo na dianteira das descobertas, descidas dos sertões mais ao norte, como metáfora de uma realidade regional: o sexo frágil já mobilizava para além do universo privado muito antes

\footnotetext{
${ }^{38}$ De acordo com o site IBGE Cidades para o Censo de 2010, o conjunto de municípios presentes na Serra do Cabral abriga pouco mais de 92 mil habitantes. São eles: Joaquim Felício (4.305), Várzea da Palma (38.329), Buenópolis (10.291), Francisco Dumont (4.867), Engenheiro Navarro (7.125), Jequitaí (8.010), Lassance (6.490), Augusto de Lima (4.960) e Claro dos Poções (7.781), com habitantes distribuídos entre as zonas rural e urbana. ${ }^{39} \mathrm{O}$ apelido pejorativo viria do fato de Ana consumir a cabeça do boi, a carne mais barata, e carregar a carcaça até seu rancho.

${ }^{40}$ Córrego que deu o segundo nome ao atual município de Francisco Dumont, então distrito de Conceição do Barreiro, antes chamado Vargem Mimosa. Pelos nomes, intui-se a apropriação dos atributos naturais do lugar para a pecuária, dado que se encontrava "o sal, gratuito, nas baixadas salobras dos barreiros" (CUNHA, 1905, p. 96).
} 
do Ocidente discorrer sobre o pós-fordismo e o ingresso feminino no mercado de trabalho. Estaria aí, nessas duas estórias, a origem quimérica do povoamento da Serra do Cabral.

Enveredando-se pela lenda ou vasculhando com os rigores que a academia exige, fato é que a Serra do Cabral teve a sua ocupação estimulada pelas relações sociais modernas demandadas pela mercadoria - caso se queira abstrair as ocupações anteriores, referentes às etnias que deixaram suas marcas nos rochedos. Além disso, as mulheres expropriadas estão presentes desde o início do estabelecimento dessa nova relação.

Se terra, trabalho e capital só se tornam capitalismo quando postos em conexão, a Serra do Cabral é mais do que um planalto de quartzito erodido por veredas, é uma relação social. Como a constituição do capital é não simultânea e suas categorias não aparecem desde já desdobradas em todos os lugares e momentos históricos em que a sociabilidade moderna se impõe, entende-se a Serra como parte do território do capital em constituição no Brasil em seus elos com o mundo, buscando desfiar o novelo de seu processo de produção.

Captar as metamorfoses sertanejas requer pensar sobre o que David Harvey (2006) chama de "geografia histórica do capitalismo", na busca da relação do fragmento com o mundo e vice-versa. O processo de globalização depende cada vez mais dos recursos tecnológicos que assegurem a circulação do capital para a geração de lucro. A sobrevivência desse modelo depende, para a sua fluidez, da criação de infraestruturas sociais e físicas que sustentam seu circuito, representadas nos sistemas legal, financeiro, educacional e da administração pública, além dos sistemas ambientais não naturais, urbanos e de transportes, de forma que reproduzam a vida cotidiana que dá sustento à circulação.

A partir daí, passa-se a entender o conjunto de interesses que vem transformando a paisagem da Serra do Cabral e seus acessos: a barragem como alternativa de aplicação dos capitais excedentes, via famigerado capital fictício, com promessa de mobilidade da força de trabalho ali excedente; a privatização das estradas, com o compromisso de modernizá-las para garantir a circulação dos futuros artigos a serem produzidos nos vindouros sistemas de irrigação, com a consultoria dos técnicos do Estado dada aos sertanejos, tomados como sedentos por conhecimento pragmático para a produtividade.

O sertão é então tomado como uma inconveniência a ser superada para a otimização do tempo de circulação dos produtos que virão a ser produzidos, cujo fazer requer controlar o trabalho excedente para produzir lucro. Para que o espaço dê passagem à fluidez do tempo, é preciso planejá-lo, de forma que ali se instalem configurações fixas e imóveis que permitam o propósito, adequando a região pobre ao desenvolvimento das forças produtivas, pois o avanço do moderno sistema produtor de mercadorias depende da expansão ininterrupta do valor das 
coisas confeccionadas, alinhado à ideologia do crescimento, independentemente das consequências ambiental, social ou geopolítica e até mesmo dos antecedentes de ocupação e reprodução.

\section{Mapa 1 - Serra do Cabral com seus municípios, formas de uso do solo e circulação}
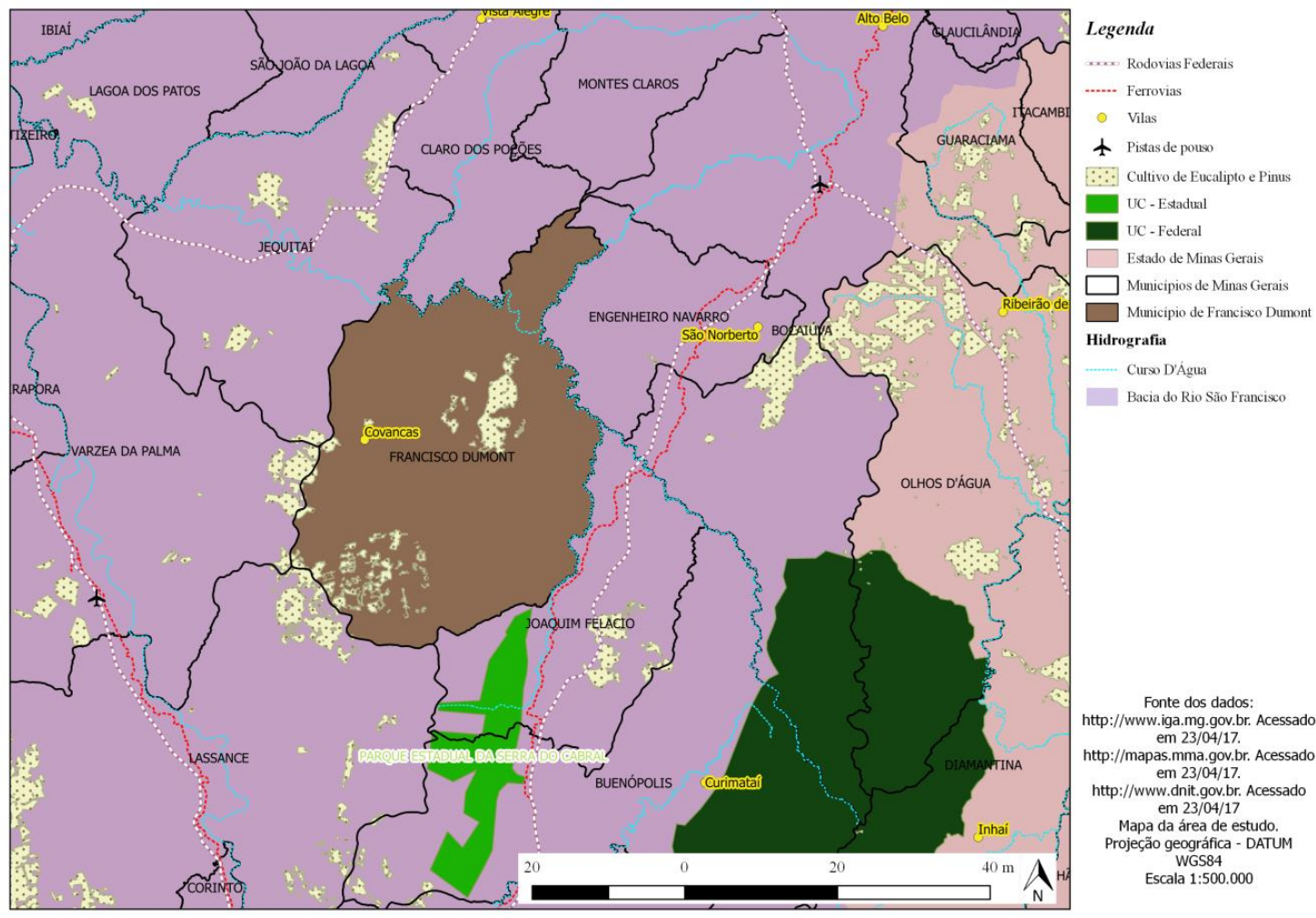

Fonte: Adriana Cirelli, 2016 (elaborado para este estudo).

Nesse sentido, a paisagem se transforma, e, com ela, as relações de produção. O capital se reorganiza ao fincar suas bases no sistema financeiro, estendendo seus tentáculos de controle espacial sobre as regiões consideradas até então arredias à sua organização. Todo esse movimento tende a abalar a coerência estruturada do território, podendo enfatizar a divisão internacional do trabalho no lugar da divisão localmente integrada - como se democratizar as categorias do capital resolvesse o problema do colapso da modernização.

O capitalismo é uma contradição em processo. Dominar o espaço implica produzir esse espaço - dentro de uma relação cuja realidade social é categorial e em que ele, fragmentado em regiões concebidas como desiguais em sua negatividade, se torna o alvo ideal para as ações da produção abstrata de valor e sua finalidade única. Isso significa também elaborar representações dinâmicas de como essa contradição se manifesta por meio das transformações históricogeográficas - e nisso, o papel dos cientistas e técnicos é de grande relevo. 
Em nome dos técnicos, que também redigem relatórios ambientais na boa intenção da sustentabilidade, hoje o garimpo de diamante, um dos pilares da ocupação na região, está proibido. No entanto, clandestina e solitariamente, ele persiste nos cantos mais escondidos da Serra. O garimpo de cristais, corrente, é um tabu menor a ser discutido, realizado com a permissão dos donos locais das terras e a porcentagem a depender do proprietário. $\mathrm{O}$ gado ainda é criado, mas cada vez mais disputa os pastos com a silvicultura, além de encarar a concorrência com as novas regiões da pecuária de corte, como o Triângulo Mineiro e as criações exportadoras do Centro-Oeste. Em poucos anos, vão chegando cultivos homogêneos de café e banana, destinados à sobremesa dos países do centro. A soja já é um horizonte possível.

Quanto mais as terras são ocupadas, mais chega gente da zona rural para compor os limites urbanos de Francisco Dumont, Jequitaí, Buenópolis e cidades do entorno. Também chega gente mais jovem que se arriscou nas grandes metrópoles, mas ao voltar à terra natal, sem o sucesso do emprego, se avizinha nos bairros periféricos, ampliando os cômodos das casas. Assentamentos rurais próximos vão movimentando o comércio, demandando produtos que têm que vir de longe. Os perímetros urbanos vão crescendo e, sem acesso à terra para consumir o que se planta, cria ou colhe, resta à grande parte da força de trabalho ativa tentar o emprego nas fazendas silvicultoras ou nas carvoeiras, para que com o salário se adquira os alimentos, celulares e outros itens.

\section{Figura 2 - Feira com produtores locais em Francisco Dumont}

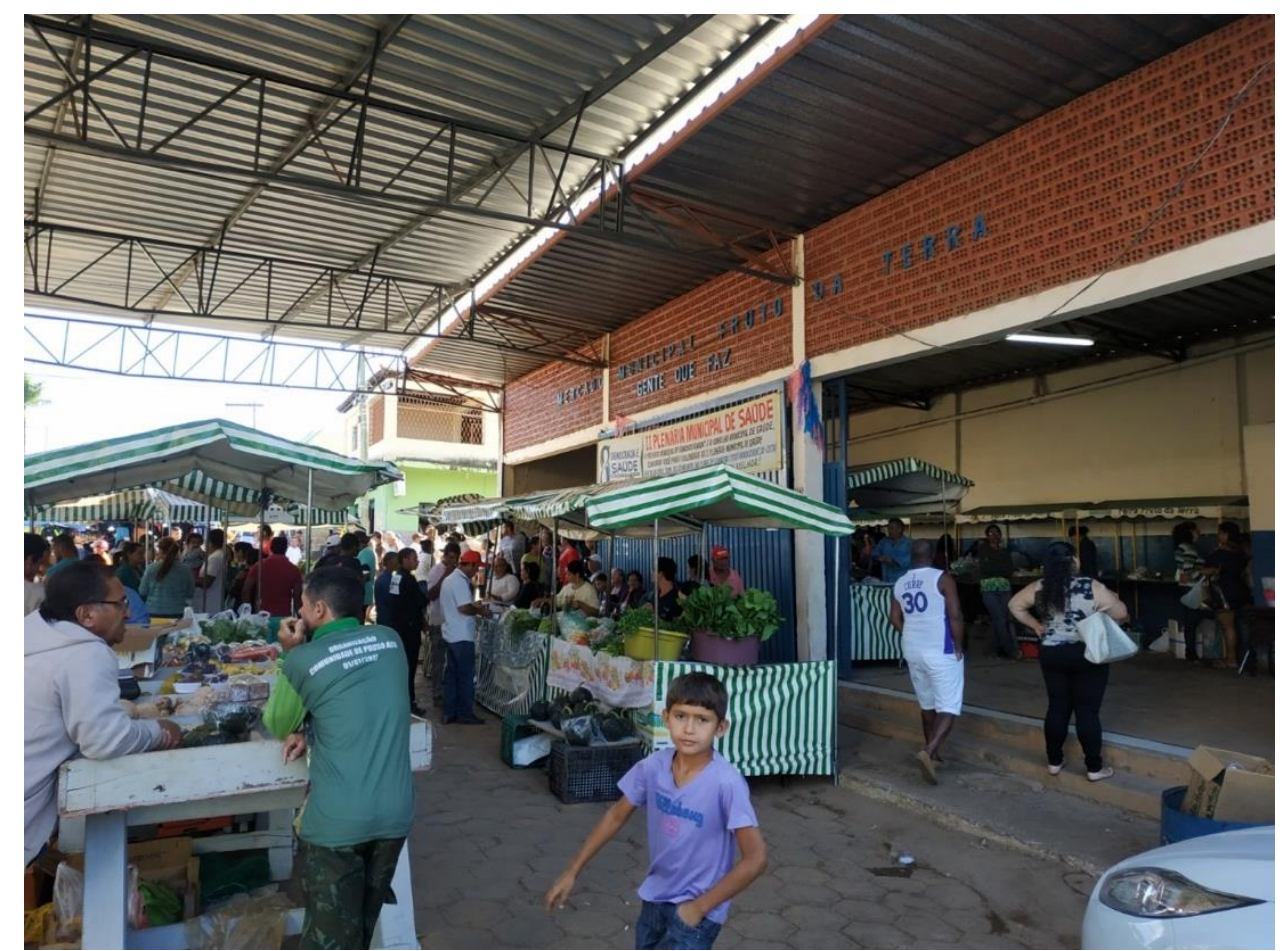

Fonte: acervo pessoal, 2017. 
O que se observa no movimento dessas pequenas cidades é um arremedo de urbanização sertão adentro, cujo processo vem de antes. Os códigos metropolitanos parecem se difundir em espaços muito além dos limites das regiões metropolitanas oficialmente delimitadas, tendo como marco inicial os projetos implantados pelo Estado ainda no Governo Militar. O Projeto Hidroagrícola Jequitaí, guardadas as suas particularidades, não deixa de ser uma extensão desse movimento, incluindo um programa de gestão territorial urbano-rural com a preocupação de intensificar fluxos de pessoas, mercadorias e capitais. Sua meta inclui ampliar a oferta de serviços e a maior utilização de tecnologias de informação e comunicação, tendo nos investimentos da esfera pública uma ponte para a expansão das áreas centrais, articuladas à reprodução do capital financeiro. Esse processo de metropolização da Serra do Cabral não se dá sem a negatividade: o trabalho continua não passando de mero juramento, já decifrado por aqueles que passaram suas vidas esperando o asfalto na estrada e a barragem chegarem.

A barragem veio após décadas de promessa. Quando as reflorestadoras chegaram, a ilusão de benesses foi a mesma; situação parecida se deu com a anexação do norte mineiro pela Superintendência do Desenvolvimento do Nordeste (Sudene) nos anos 1960. Se o moderno já se faz nas relações da Serra do Cabral, por que ainda há quem garimpe clandestinamente, se arriscando a perder a vida, como Pedrão?

José Alves Pinto, conhecido como Parceiro, 80 anos (2017), após uma vida inteira garimpando diamantes e colhendo sempre-viva, conquistou um pequeno pedaço de terra às margens do Jequitaí só depois dos 70 anos de idade. "Lá, planto roça, crio galinha", passando dias a se esquecer do mundo. Porém, ainda sobe a Serra para colher flores e garimpar cristal, produtos que vende à família Prado e a atravessadores ${ }^{41}$. Por que Parceiro, mesmo tendo conquistado o seu pedaço de chão, plantando e criando, ainda precisa colher sempre-viva e garimpar cristal?

\footnotetext{
${ }^{41}$ No primeiro semestre de 2021, o quilograma colhido da flor custava $\mathrm{R} \$ 5,00$.
} 


\section{Figura 3 - Sempre-vivas colhidas na Serra do Cabral, guardadas em lapa e à espera do caminhão}

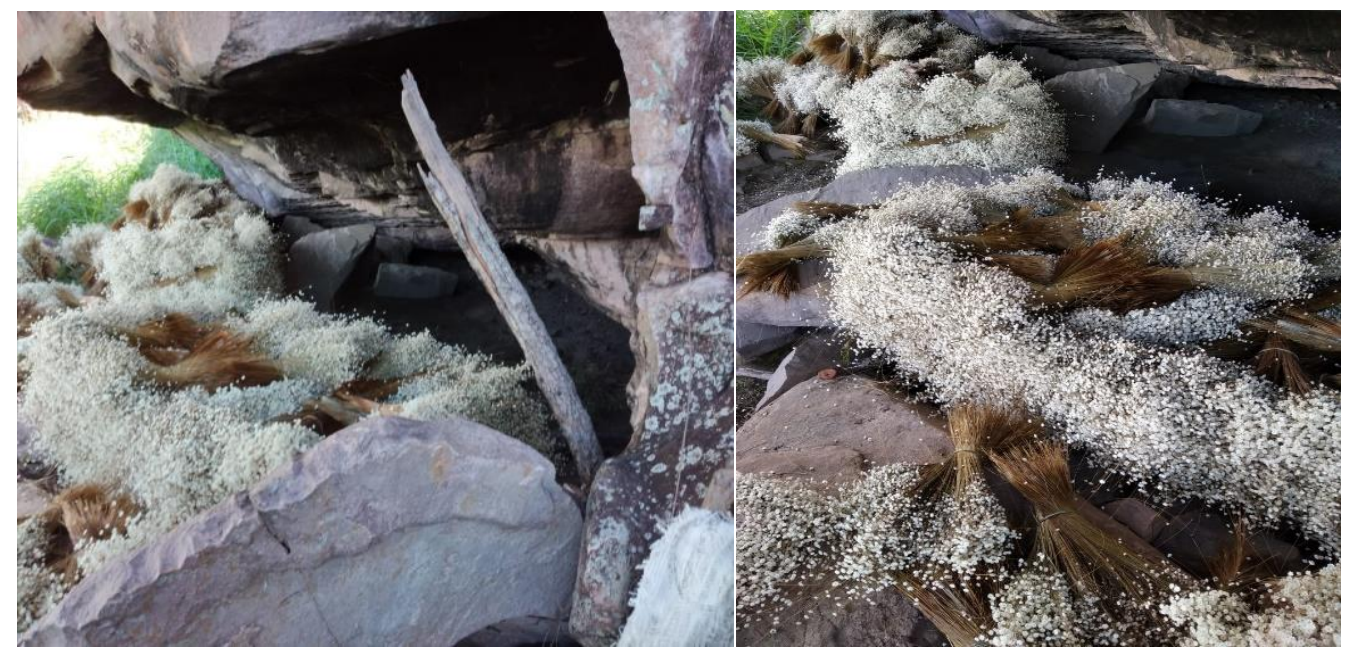

Fonte: acervo de Pedro Leite da Silva, abril de 2020.

Esse dinamismo da sociabilidade moderna engendra seus antagonismos e suas crises. Produz-se o espaço para depois destruí-lo: para que não haja desvalorização e se perpetue a superacumulação, as regiões precisam ser desgarradas de sua ancestralidade e abertas como novas áreas de desenvolvimento, dadas as demandas oriundas do progresso tecnológico e da racionalidade do mercado. Não apenas capitais são desvalorizados e destruídos; eles arrastam consigo os trabalhadores, cravando a morte, a devastação e a destruição, seja no centro desse modelo, seja nas periferias. As contradições internas do capitalismo se expressam mediante a formação e reformação incessantes das paisagens geográficas (HARVEY, 2006), entre elas, a sertaneja. Mas como o seu dinamismo tem como característica naturalizar tudo, expropriando os lugares de sua própria história, é preciso garimpar nas experiências dos sobreviventes a historicidade, advertindo-se de antemão que eles, enquanto frutos de um mundo agonizante, também produzirão suas incongruências. Todo sujeito fala e pensa por meio das categorias que dominam a sua particularidade empírica, expressando a sua individualidade socialmente determinada.

\section{2. "Contar e fazer balancê"}

A Serra não é um amontoado acidental de nomes, animais e coisas, mas uma organização social complexa, que também não é estática, por mais que os discursos oficiais insistam em seu contrário (LEFEBVRE, 1978). Ela é provida de passado, e é preciso escovar a sua história a contrapelo, como propôs Walter Benjamin (1994) em seus conceitos sobre a História. O método regressivo-progressivo se faz ferramenta importante porque os documentos 
analisados e a literatura consultada convidam a uma interpretação de conjunto dos problemas pretéritos que levaram às condições encontradas no presente. Muito do passado se desdobra na contemporaneidade: vários garimpeiros do norte de Minas, por exemplo, ainda se valem das técnicas coloniais africanas de faiscar pelas grotas do norte de Minas, reproduzindo até alguns hábitos alimentares.

\section{Figura 4 - José, garimpeiro de diamante clandestino em Jequitaí (à esq.) e ferramentas de garimpo guardadas por seu Joaquim Pontaria em Francisco Dumont (à dir.)}

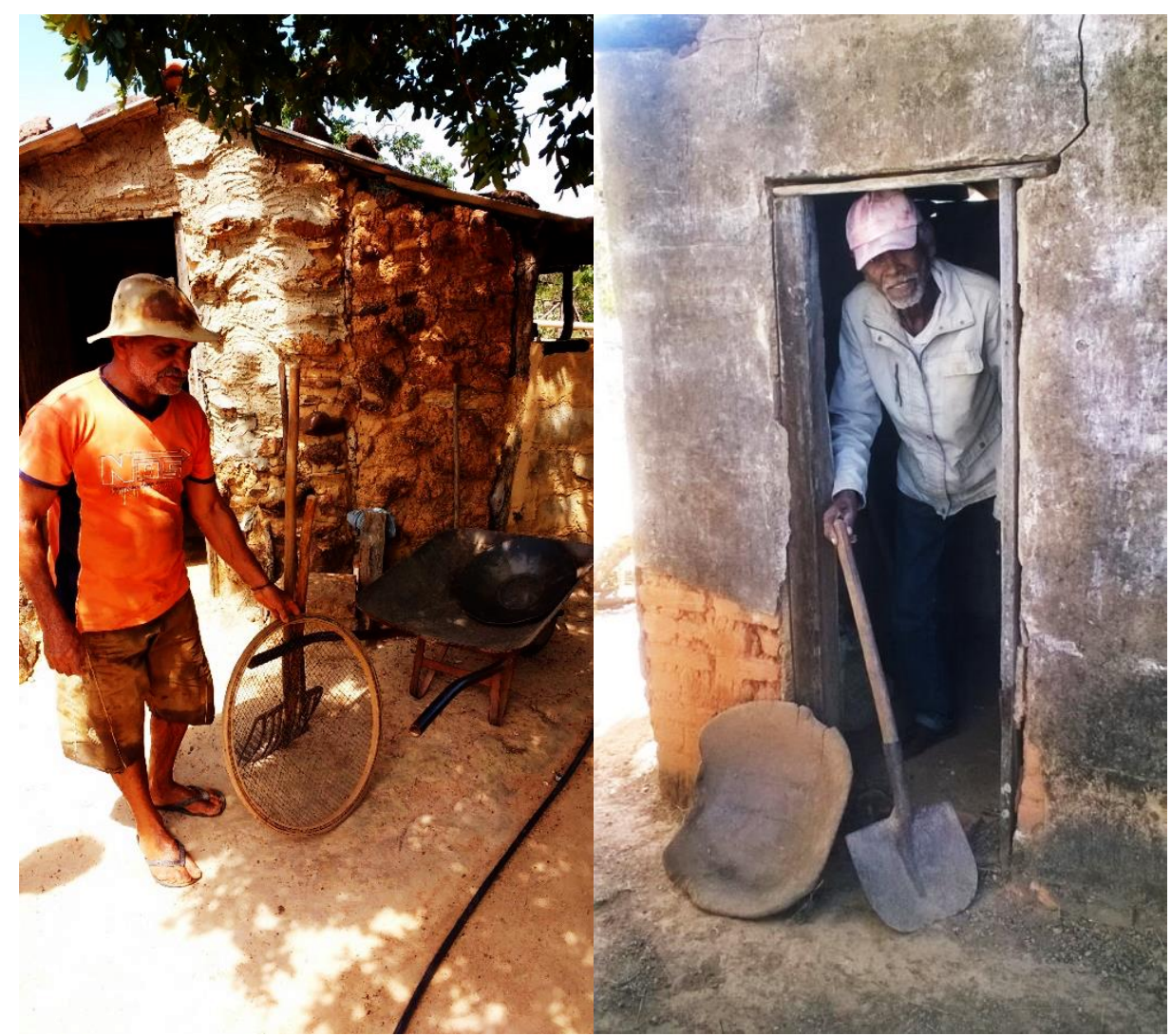

Fonte: acervo pessoal, janeiro de 2017 e julho de 2019.

Essa relação não quer somente repisar o que de outrora permanece. Ela vai no rastro da modernização, buscando também o que mudou e, por isso, confrontando os relatos de hoje com os registros de ontem. Entender o sentido da mudança requer resgatar sua historicidade, tendo de sobreaviso que essas relações rurais não se enquadram nos exemplos lefebvrianos da transição feudal do camponês europeu para o trabalhador assalariado (rural ou urbano), nem a introdução pura e simples dos modelos culturais citadinos degradados na sociabilidade rural, como no caso americano (LEFEBVRE, 1978). Aqui, o camponês, seja ele posseiro ou agregado, surgiu sob o cabresto das relações modernas da mercadoria e, justamente por ser o capital uma contradição dinâmica, permitiu que relações refratárias a ele coexistissem com o mercado e suas abstrações, de alguma forma se conectando com ele. Foram os sertanejos forjados nessa 
conexão, dentro da formação do capitalismo europeu e nacional que revelaram a gênese dessa antinomia.

Portanto, sabendo-se de antemão que os dados são números que podem abstrair as relações sociais e sua historicidade, teve-se como cuidado primeiro a escuta dos moradores mais velhos. Como a preocupação inicial era o surgimento do garimpo e o auge e a queda do povoamento, os pioneiros na atividade foram os primeiros ouvidos durante os campos.

A experiência de vida - melhor, de sobrevida - desses homens e mulheres foi fornecida pela narração do que passaram. Em "O narrador. Considerações sobre a obra de Nikolai Leskov", Walter Benjamin (1994) distingue a preferência pelo romance no lugar da narração dentro dos encadeamentos que levam as sociedades à modernização. Para ele, “'Quem viaja, tem muito que contar'”, referindo-se à experiência de homens que partem para longe e voltam sortidos de histórias. "Mas também escutamos com prazer o homem que ganhou honestamente sua vida sem sair do seu país e que conhece suas histórias e tradições”, ressalta (BENJAMIN, 1994, p. 198-199). No entanto, o filósofo nota que apesar de terem viajado enormes distâncias entre as duas grandes guerras mundiais, os combatentes voltavam mudos do campo de batalha, não mais ricos, mas mais pobres de experiência comunicável. Para ele, isso se explica porque nunca houve experiências mais radicalmente desmoralizadas que a estratégica pela guerra de trincheiras, a econômica pela inflação, a do corpo pela guerra de material e a ética pelos governantes (BENJAMIN, 1994).

Com isso, a narrativa, ligada à experiência, à oralidade e à coletividade, tem cedido lugar ao gênero que encontrou na burguesia ascendente os elementos favoráveis ao seu florescimento: o romance, concebido como produto do indivíduo isolado, anunciando "a profunda perplexidade de quem a vive" (BENJAMIN, 1994, p. 201).

Costurou-se esta pesquisa com João Guimarães Rosa - passagens do romance Grande sertão: veredas (1986) e alguns de seus contos -, na pretensão de mostrar as indecifráveis contradições encontradas. As obras literárias não narram apenas histórias, mas constroem uma certa tipificação da realidade social apresentada, manifesta sobretudo no segundo plano da descrição literária, nas personagens secundárias, designadas muitas vezes por sua função social. As personagens são construções teóricas que ajudam a ordenar os fatos, elaborar imagens sintéticas e penetrar nas divisões e ligações estruturais da sociedade analisada. Como aponta Bronislaw Geremek (1995, p. 16), “As obras literárias permitem confrontar essas construções históricas com o quadro que funcionava na consciência social da época examinada". Por mais que as imagens sociais venham ricas em estereótipos, não se pode negar que surgem do concreto da realidade que inspira o escritor, também inserido em seu tempo e seu espaço. 
O nó da obra-prima roseana está em juntar romance e experiência, sem os conselhos da sabedoria de quem conta, ao mesmo tempo em que é pleno de perplexidade do vivido, em uma mescla de tom romanesco com notas de diário. É romance e também é viagem pelo sertão; é romance e existe narrador e ouvinte. Tem a bruta batalha e convida-se o coração. A luta por vezes remete poeticamente ao romance de cavalaria medieval, mas elabora as disputas territoriais de fazendeiros coronéis e o Estado, ambos modernos. O narrador é o sertanejo, personagem regional que povoa os estereótipos negativos da formação brasileira, mas é letrado, sendo a instrução uma metáfora de acesso ao universal. Assim é o sertão, que é o mundo na sua acepção espacial, mas, ao mesmo tempo, é dentro do ser, com sua complexa carga simbólica. E é também o capital no seu contrassenso, que se expande anunciando a sua crise, autonomizando seus fatores e impondo agruras aos homens provisórios, sujeitos reduzidos à mera forma física.

Grande sertão: veredas é, sem esgotar as definições, uma narrativa na sua oralidade, contando as memórias de um ex-jagunço velho tornado fazendeiro materializadas no papel e endereçadas aos letrados dos centros urbanos. Posicionando o escritor no contexto de escrita, o romance foi publicado em 1956, no auge de um projeto nacional-desenvolvimentista que ainda assombra o país. O papel de feitor que o Estado assume, organizando os (assim chamados pelo mercado) recursos humanos para realizar a modernização retardatária, transformou sertanejos em indivíduos solventes ao mercado, os mobilizando para tal. Assim, Rosa, que também era funcionário do Governo pelo Itamaraty, viu o avanço para o oeste do território, disposto mais uma vez na história a destituir o sertão. Se ele, enquanto indivíduo, concordava ou não com a marcha modernizadora ou se construía uma proposta de leitura de formação do país, são hipóteses. Importa, junto a tantas possibilidades de interpretá-lo, dar relevo às lembranças das metamorfoses do sertão conotadas por seus personagens, tantas vezes cruzadas com as narrativas de vivências dos sujeitos reais da Serra do Cabral.

Cruzando o lúdico e o experienciado, toda narração parte de uma memória, que condensa em si o tempo vivido e produz a sua história. ${ }^{42}$ É sabido que a história oficial, apesar das revisões críticas da história social, enfatiza o lado vencedor, colonizador, dos donos do poder, ou mesmo o registro dos documentos, dado que estes são considerados provas materiais. Com isso, há um desdém a outros relatos, advindos da memória coletiva. Este requer tempo: o

\footnotetext{
${ }^{42}$ Apesar de a história se fundamentar sobre um saber universal aceitável, para a memória a presença do passado no presente é fundamental para a legitimação de certos saberes ou hierarquizações e para articular as narrativas do passado vivido à percepção do presente pretendido. Tal discussão está aprofundada em História e memória, de Jacques Le Goff.
} 
tempo da memória é social, não apenas porque é o calendário do trabalho e da festa, do evento político e do fato insólito, mas também porque repercute no modo de lembrar, e lembrar é reconstruir a partir do hoje as experiências do passado, o que inclui ressignificar ${ }^{43}$. $\mathrm{O}$ ex-jagunço Riobaldo reconhece as dificuldades de manusear as lembranças:

Contar é muito dificultoso. Não pelos anos que já passaram. Mas pela astúcia que têm certas coisas passadas de fazer balancê, de se remexerem dos lugares. A lembrança da vida da gente se guarda em trechos diversos; uns com outros acho que nem se misturam. O que eu falei foi exato? Foi. Mas teria sido? Agora acho que nem não. São tantas horas de pessoas, tantas coisas em tantos tempos, tudo miúdo recruzado. Tem horas antigas que ficaram muito mais perto da gente do que outras de recente data (ROSA, 1986, p. 172).

Se a história considerada vencedora é a da modernização e esta inclui a violência concreta e abstrata no seu processo, emudecer outras experiências integra os seus atos truculentos. Ao apresentar o livro Memória e sociedade: lembrança de velho, de Ecléa Bosi, Marilena Chauí afirma que a sociedade capitalista impede a lembrança, desarmando o velho ao mobilizar mecanismos pelos quais oprime a velhice, destrói os apoios da memória e substitui a lembrança pela história oficial celebrativa (BOSI, 1979). Apesar de não se partilhar da perspectiva ontológica do trabalho presente na arguição de Chauí para o livro de Bosi, a memória do que se considera trabalho foi o fio condutor das lembranças dos sertanejos ouvidos. Eles compuseram a primeira fonte de informações sobre as metamorfoses do sertão vivenciadas por eles.

Esses sertanejos não voltaram de batalhas, como exemplifica Benjamin (1994) na passagem da modernidade em "O narrador", aludindo à brutalidade da Primeira Guerra Mundial. Porém, não deixaram de viver os sofrimentos da expropriação, bem como guardam consigo as narrativas de seus antepassados, transmitidas oralmente e no trabalho, cujos ofícios foram majoritariamente herdados. Em suas histórias, há memórias de territorialização, sem que assim a interpretem. Os homens fazem a sua própria história, mas não de livre e espontânea

\footnotetext{
43 “A memória-hábito adquire-se pelo esforço da atenção e pela repetição de gestos ou palavras. Ela é - embora Bergson não se ocupe explicitamente desse fator - um processo que se dá pelas exigências da socialização. Tratase de um exercício que, retomado até a fixação, transforma-se em um hábito, em um serviço para a vida cotidiana. Graças à memória-hábito, sabemos 'de cor' os movimentos que exigem, por exemplo, o comer segundo as regras da etiqueta, o escrever, o falar uma língua estrangeira, o dirigir um automóvel, o costurar, o escrever a máquina, etc. A memória-hábito faz parte de todo o nosso adestramento cultural.

No outro extremo, a lembrança pura, quando se atualiza na imagem-lembrança, traz à tona da consciência um momento único, singular, não repetido, irreversível, da vida. Daí, também, o caráter não mecânico, mas evocativo, do seu aparecimento por via da memória. Sonho e poesia são, tantas vezes, feitos dessa matéria que estaria latente nas zonas profundas do psiquismo, a que Bergson não hesitará em dar o nome de 'inconsciente'. A imagemlembrança tem data certa: refere-se a uma situação definida, individualizada, ao passo que a memória-hábito já se incorporou às práticas do dia-a-dia. A memória-hábito parece fazer um só todo com a percepção do presente" (BOSI, 1979, p. 11).
} 
vontade, pois não escolhem as circunstâncias sob as quais ela é feita. Estas lhes foram transmitidas assim como se encontram (MARX, 2011). Com isso, consolida-se a premissa de que o conteúdo do narrado acumula a própria vivência e a vivência de quem veio antes, todos de alguma maneira presos à forma social.

No entanto, se para Benjamin o encanto de narrar é quebrado pela invasão das relações modernas na vida corrente ${ }^{44}$, a contradição entre os ouvidos na Serra parte da ideia de que esses sujeitos já eram crias do mundo moderno. Eles puderam narrar porque, apesar do sofrimento impetrado pela violência da moeda e justamente por isso já mobilizados para o trabalho, andaram por terras distantes, volveram o sertão, palmilharam a Serra e construíram mentalmente as paisagens dos lugares vividos.

A maioria dos garimpeiros entrevistados, iludidos na autonomia de sua escolha, estava se mobilizando inclusive espacialmente em busca dos diamantes. A mobilidade é uma forma de deslocamento que dificulta a lembrança, já que nada em algum lugar tende a permanecer no capitalismo. Ela é, portanto, espoliada dos sujeitos oprimidos economicamente, pois a sua condição desde a juventude é a mobilidade do trabalho. Se a lembrança é uma imagem construída pelos materiais que estão, agora, à nossa disposição, como retomá-la se a modernização é o tempo inteiro destrutiva? Daí o cuidado: a lembrança dos entrevistados pode ser traiçoeira - assim como o Estado, na sua forma contraditória de ser, o foi com a historicidade sertaneja.

Com isso, foi preciso ir ao sertão adotando a postura de Riobaldo - que nada sabe, mas que desconfia de muita coisa - e considerar que mesmo na absorção de discursos hegemônicos ou contraditórios é possível vasculhar na sobrevivência dos relatos as concepções de mundo. Tudo até certo ponto, porque no mundo de sujeitos sujeitados, existe uma grande dificuldade em se fazer a própria história. As condições herdadas encontradas nos campos denotam essa sujeição, com vias a reproduzir uma vida subordinada a relações sociais pautadas por diversas formas de sofrimento e brutalidade, cujos poderes lhes são alheios.

Mas não se valeu só de garimpeiros anciãos, e a sujeição esteve presente em todos os envolvidos na pesquisa - até mesmo em quem a produziu: os poucos vaqueiros que ainda vivem, as mulheres que trabalharam nas fazendas e na reprodução familiar e os mais jovens também, já descartados de um sistema produtor de mercadorias que excreta mais e mais o trabalho das relações de produção. Dentro do possível, ouviu-se os técnicos do Estado e as

\footnotetext{
44 “(...) Na realidade, esse processo, que expulsa gradualmente a narrativa da esfera do discurso vivo e ao mesmo tempo dá uma nova beleza ao que está desaparecendo, tem se desenvolvido concomitantemente com toda uma evolução secular das forças produtivas” (BENJAMIN, 1994, p. 201).
} 
personificações de poder locais, sempre mais difíceis de se encontrar, porque os donos do poder há muito tempo são absentistas.

Da parte dos burocratas, notou-se uma ênfase na concepção da Serra e do norte de Minas como uma região pobre, carente, abandonada, atrasada; era preciso modernizar, tirar as pessoas da penúria e do sofrimento, inseri-las no mundo globalizado. A modernização pautou as falas tanto dos atuais representantes da tecnocracia, quanto das pretéritas. Antônio Viriato Neto, conhecido como Antônio da Serra, gerente da Santa Maria Floresta, salientou vaidoso que apenas após a empresa reflorestadora chegar a Francisco Dumont é que passou a existir posto de saúde, estrada e correio. Antes, só havia a delegacia - o que não deixa de ser sugestivo: os crimes passam a ser mediados pela justiça autonomizada.

Hoje, segundo dados do IBGE Cidades sobre o Censo de 2010, o município de Francisco Dumont possui seis estabelecimentos do Sistema Único de Saúde (SUS), quatro escolas de Ensino Fundamental e uma de Ensino Médio, esgotamento sanitário parcial, pequena urbanização de vias públicas, rede elétrica nas zonas urbana e rural, um correio que também funciona como agência do Banco do Brasil, uma delegacia e uma casa de cultura.

Muitos dos entrevistados mais velhos apontaram várias melhorias: até o fim dos anos 1960, a água para o banho e os afazeres domésticos era buscada nos córregos; até a década de 1970, a luz era a motor e funcionava até às 22 horas; até meados da mesma década, cabia às mulheres buscar lenha no mato; atendimento médico mais próximo com profissional, só indo a cavalo até Granjas Reunidas, fazenda adquirida pelos Matarazzo. Porém, a rusticidade da vida no passado se encontrava com a abundância da natureza e os laços de solidariedade, apesar do sofrimento e da violência concomitantes àquela organização social. Para alguns, a tranquilidade não existe mais, nem mesmo a paisagem que guardaram da Serra, espaço da busca de lazer e de recursos para sobreviver. Com os tempos de outrora romantizados por alguns, sobretudo através das falas das figuras masculinas, os sertanejos ouvidos têm seus rostos voltados para o passado, para onde não querem ou não podem voltar, até porque são impelidos irresistivelmente para o futuro, ameaçado de não poder ser semeado pelo presente.

O sertão mudou muito. Desde a chegada da moderna forma social, ele é encarado como um eterno porvir - porque isso também é a economia da mercadoria, um porvir no escuro alimentado na comparação com outros territórios e costurado por cima das pessoas, como toda tentativa de equivalência geral. É preciso, então, voltar ao passado para entender por que o presente ameaça não cerzir o futuro. 


\title{
2. No rastro do boi, no mapa das minas
}

\author{
Lá dentro no fundo do sertão \\ Tem uma estrada de areia de ouro \\ Por onde andaram \\ Outrora senhores-de-engenho \\ $E$ de muitas riquezas \\ Escravos e senhoras \\ Naquelas terras imensas \\ De Nosso Senhor
}

Elomar Figueira de Melo, 1972

Todo mapa é uma representação parcial do real, um instrumento de compreensão do mundo e do espaço transmitido a um suporte material - cabe advertir que o real também pode ser parcial. Historicamente, é fruto de realidades específicas e carrega traços do momento em que foi produzido. Uma das formas de estudar a formação e a consolidação de qualquer território é rastrear os mapas que o localizam e dão informações a seu respeito, pois se o espaço está exposto no papel, tem-se um indício da sua existência por meio da estreita relação entre o real e o representado. Consideradas documentos estratégicos e até secretos, sobretudo quando se trata de mapeamento de potenciais recursos, as cartas revelam os espaços apropriados, suas formas de ocupação, fronteiras e mesmo o imaginário. São registros de percepção do território.

Se os mapas testemunham os espaços apropriados, são documentos de cultura para a narrativa dominante, por isso denotam o real pela ótica do conquistador. Apropriar e dominar fazem parte do projeto colonizador e são tidos, pela voz dos vencedores, como atos civilizadores. Na Europa do século XIX, de acordo com Maristela Svampa (1994), a ideia de civilização se baseava no modelo europeu ocidental de desenvolvimento econômico, político e social, numa concepção linear de desenvolvimento histórico na qual tudo o que não se encaixava a ele estava fadado à barbárie. Para ela, a ideia de progresso, embutida na de civilização, não só encontrará suas fontes no desenvolvimento da ciência moderna, mas também no surgimento do nacionalismo e na luta pela liberdade política e religiosa, condensando assim a crença no perfeccionismo humano (e, com ele, a confiança em que as leis e as instituições podiam moldar o caráter dos homens) e na unidade do gênero humano, expressa na ideia da cooperação entre os homens, cuja tradução será a solidariedade econômica e, ainda mais, o dogma da divisão internacional do trabalho. Tudo isso, claro, válido para o universo europeu, de contornos muito bem delimitados.

A cartografia produzida pela ótica do colonizador é um documento de cultura e um registro do seu projeto de civilização sobre o chamado Novo Mundo, o outro a ser domado de 
acordo com interesses específicos. Ao tomar a ideia de civilização, todo documento de cultura é um documento de barbárie (BENJAMIN, 1994), pois sobre o papel registra-se o avanço territorial, seja dos portugueses, seja dos brasileiros, sobre o meio natural e os chamados povos bárbaros e insubmissos à expansão da lógica da mercadoria. Com isso, abre-se caminho também para questionar os documentos na sua veracidade, considerando-se o silêncio dos vencidos ou as informações que venham a ocultar propositadamente e os interesses e as intenções vinculados àqueles que os confeccionavam.

O requinte da cartografia espelha o processo de dominação territorial em curso, bem como a sua legitimação, que tinha como motor expansionista os mitos de riquezas escondidas no interior desconhecido. $\mathrm{O}$ acervo cartográfico quinhentista era deficiente quanto às informações espaciais, sendo as entradas nos sertões movidas pelas necessidades "do estômago ou da imaginação" (MARX, 2013, vol. 1, p. 113), o mote para a confecção de cartas dos territórios conquistados. O Lacus Eupana ${ }^{45}$, também chamado Vupabuçu, já aparecia na carta de Mercator, de 1607.

O mito do Sabarabuçu - serra resplandecente de ouro com crista de esmeraldas - moveu expedições oficiais até as cabeceiras do rio São Francisco, no sertão baiano, compostas por astrônomos, gente de Castela entendida na cartografia e práticos em mineração. Os malogros só contribuíram para alimentar as fantasias míticas de riqueza, que prosseguiram atrás da Lagoa Dourada, imaginada também nas proximidades do mesmo rio, o mais trafegado já no século XVI (PÓVOA NETO, 1998). Apesar das expedições e seus aparatos, a cartografia dos Quinhentos e Seiscentos apenas esboçava os territórios recém-conquistados, característica que mudaria gradualmente a partir da centúria seguinte.

Encontrar cartas históricas que registram a Serra do Cabral não é tarefa fácil desde há muito: na "Chorographia Mineira" do Annuario de Minas Geraes de 1918, por exemplo, já atesta seu autor ${ }^{46}$, preocupado em levantar informações sobre o estado, que na sua contemporaneidade "Não possúe ainda o Estado uma carta sufficientemente exacta de seo territorio, o que é uma lacuna deploravel” (SENNA, 1918, p. 325). Tal dificuldade é, na

\footnotetext{
${ }^{45}$ Esse nome aparece nos mapas europeus pela primeira vez na cartografia portuguesa, com o mapa de Bartolomeu Velho em 1561. Lacus Eupana é uma forma latinizada de Paraupava. A palavra Paraupava é decomposta em "parau-pava". "Para" foi traduzido com facilidade para "Lacus", e "upava" não encontrou uma tradução correta por apresentar diversos significados. Tendo sido conservada "upava", se deu "Eupana" por corruptela (ANDRADE; BATISTI, 2011, p. 308).

46 Nelson Coelho de Senna (1987-1952) nasceu no Serro e exerceu as funções de parlamentar, advogado, publicitário e professor universitário, vindo a falecer em Belo Horizonte. Em 1906, deu início à publicação do Anuário de Minas Gerais, com destaque para a sua colaboração como correspondente do Arquivo Público Mineiro (APM, 2014). O inventário da coleção Nelson Coelho de Senna, de considerável importância para este estudo, encontra-se disponível no APM.
} 
verdade, estendida a todo o vasto interior da colônia, pelo menos até o fim do século XVII: diferentemente dos navegantes lusos, que cartografaram detalhadamente a costa, os exploradores das entradas ao interior não registraram as suas conquistas em mapas, ou não há conhecimento de qualquer documento cartográfico que tenha sobrevivido desde então, conforme atesta Friedrich Renger (2007b) ${ }^{47}$.

Buscou-se materiais que pudessem dar pistas sobre quando a Serra do Cabral, território de difícil acesso, já estava na mira das autoridades de governo ou já era por elas conhecida, como os mapas coloniais, imperiais ou republicanos. O rio Jequitaí, seu principal curso d'água, tem sua primeira aparição em 1688, no Mapa da América Meridional, de Vincenzo Maria Coronelli, com a alcunha de Geta Caig.

\section{Mapa 2 - Mapa da América Meridional}

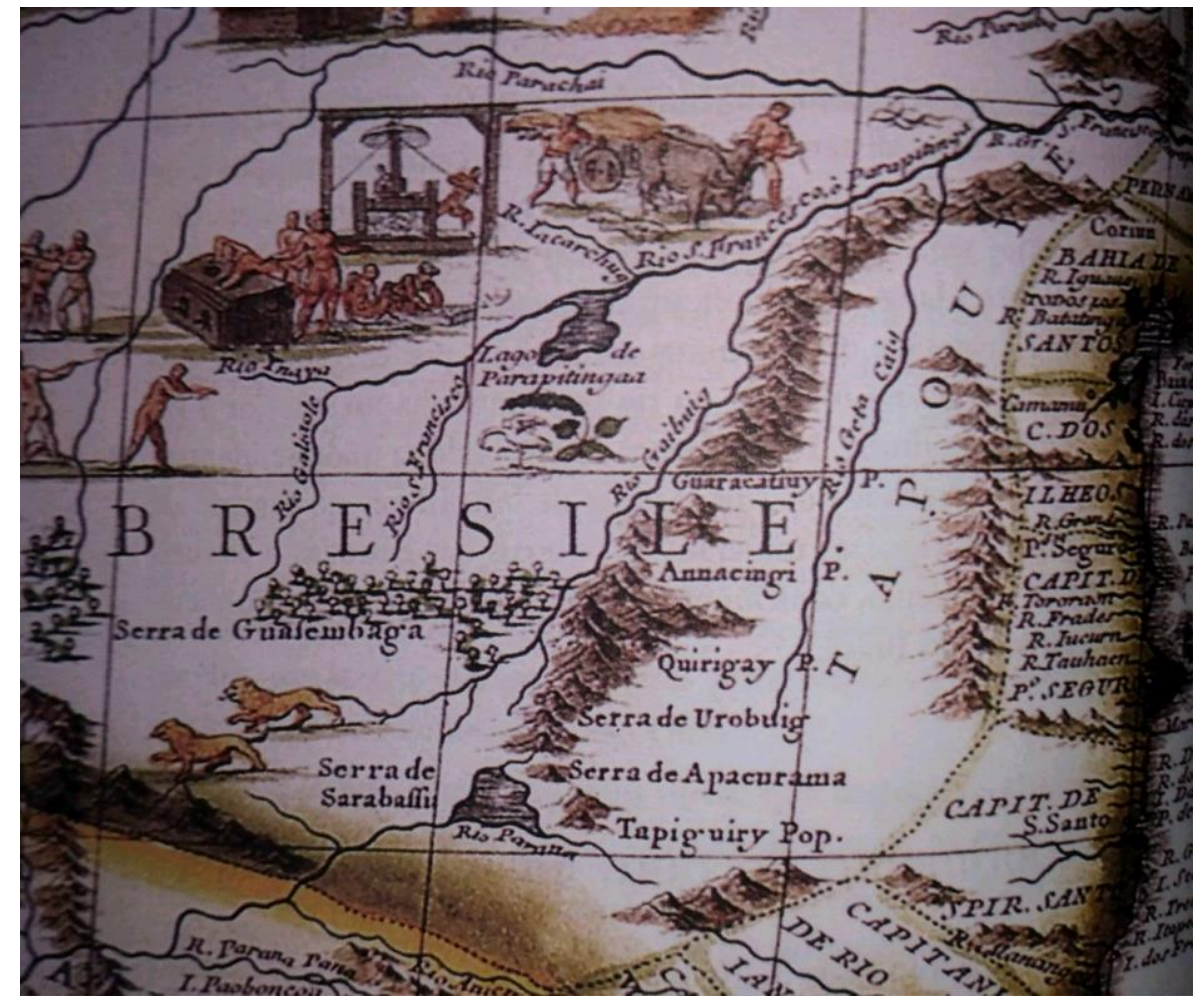

Fonte: Renger (2007b, p. 110).

Sobre este mapa,

O rio São Francisco (ou Parapitinga) aparece bastante distorcido e muito deslocado para noroeste. Na sua margem direita, constam dois afluentes com os nomes Geta Caig e Gaibug (Jequitaí e Guaicuí ou rio das Velhas). [...] Nota-se uma predominância da nomenclatura indígena no interior, ao contrário do litoral, onde prevalece a toponímia religiosa portuguesa [...] (RENGER, 2007b, p. 110-111).

\footnotetext{
${ }^{47}$ Nem mesmo o trabalho minucioso de Alan Viggiano (2007), disposto a encontrar todos os lugares citados em Grande sertão: veredas, cita a Serra do Cabral, mas apenas o rio Jequitaí.
} 
A partir desse mapa, Orville Derby, geógrafo e geólogo estadunidense chegado ao Brasil em 1870, afirma que o vale do Jequitaí representava papel importante na viação primitiva do sertão do vale do São Francisco, porque dava acesso mais fácil ao grande rio a partir da seção da Serra do Espinhaço, cruzada por antiga estrada indígena, já sendo frequentado por europeus antes mesmo do rio das Velhas, até então conhecido como Guaicuí (DERBY, [1899-1900], 1901 apud CARRARA, 2007).

Outro mapa importante é o confeccionado por Jacobo Cocleo, de 1710. Nele, localizamse as recém-descobertas minas e os caminhos abertos na época, tais como o do Mestre de Campo Matias Cardoso, que saía de São Paulo até o curso superior do rio São Francisco, e o Caminho Novo do Gado, que acompanha o rio das Velhas pelo lado esquerdo, cruza o rio São Francisco e daí leva, em grande curva por Goiás, até o Piauí - na época, um grande centro de criação de gado. Na altura do rio Paraúna, que se bifurca, inicia o Caminho de João Glz. [Gonçalves] do Prado, que vai pelo espigão da Serra do Espinhaço até o rio das Contas, de onde desce pelo rio Paraguaçu para a Bahia (Caminho da Bahia). Este caminho partia da região de Curvelo (Morro da Garça) e encurtava a viagem para a capitania baiana (RENGER, 2007b). Infelizmente, esse mapa não foi encontrado nos arquivos.

Entre 2015 e 2019, levantou-se documentação cartográfica que permitisse dialogar com o objeto do trabalho, associado aos campos. Algumas fontes foram de grande importância: o conjunto de mapas de 1778 de José Joaquim da Rocha, pertencente ao acervo do Arquivo Público Mineiro (APM), além de outros documentos encontrados no mesmo local, e o acervo do Arquivo Histórico do Exército do Rio de Janeiro (AHE-RJ).

A primeira delas é o conjunto de mapas em anexo na corografia de José Joaquim da Rocha, engenheiro militar e memorialista de origem portuguesa que viveu na capitania e, na ambição de galgar postos e títulos, elaborou mapas e textos corográficos para os governadores no fim do século XVIII (FURTADO, 2009). A primeira carta, o Mapa da Capitania de Minas Gerais com a Divisa de suas Comarcas - 1778, registra o rio Jequitaí, tributário à direita do rio São Francisco, que margeia a Serra do Cabral e é o curso d'água regional mais importante, acompanhado por um caminho que parece começar nas imediações da ocupação de Araçuaí, com pontos de pouso no Arraial do Bonfim e nas fazendas Santa Engrácia e São Lamberto, seguindo, após o encontro com o São Francisco, para Extrema, sentido Paracatu, acompanhando a partir daí o Velho Chico. O registro desse caminho, já existente no fim do século XVIII, revela uma provável região de passagem para o gado. 


\section{Mapa 3 - Mapa da Capitania de Minas Gerais com a Divisa de suas Comarcas}

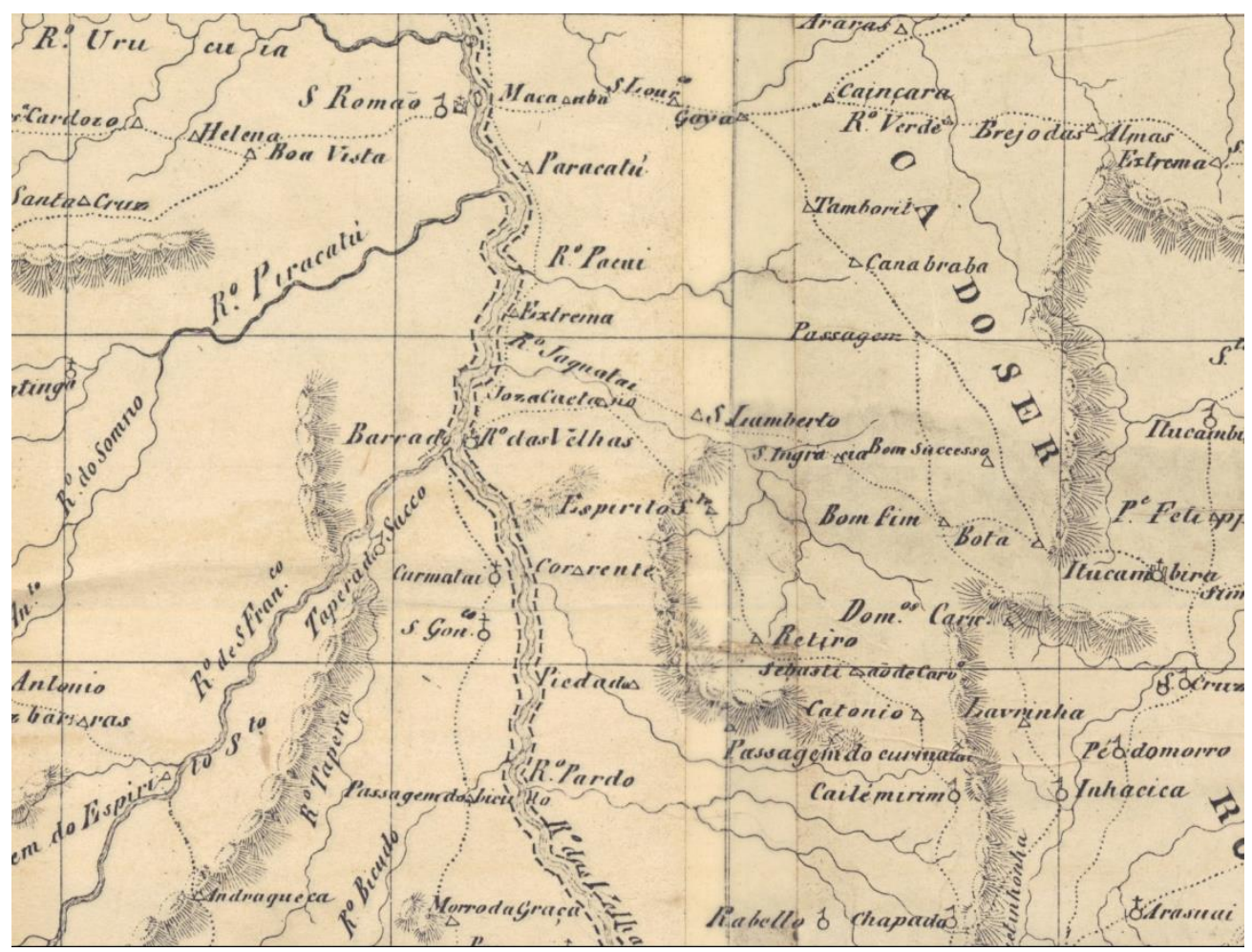

Fonte: AHE, 2018.

É importante estabelecer a relação entre as fazendas de gado e a mineração, apresentada por Capistrano de Abreu (1998). Para o autor, as bandeiras enquanto empresa fundante da capitania de Minas Gerais teriam no sertão o seu palco privilegiado, pois a ocupação da porção ao norte dessa região pelos vaqueiros ainda no século XVII aparece como pré-condição para as futuras descobertas minerais, já que a criação de gado abria caminho para o povoamento. Em correspondência enviada ao governador-geral D. João de Lencastro em 1705, o capitão-mor Pedro Taques de Almeida escreveu sobre os bois e as fazendas na bacia sanfranciscana:

Pelo dito rio ou pelo seu caminho lhe entram os gados de que se sustenta o grande povo que está nas minas, de tal sorte que de nem uma outra parte lhe vão nem lhe podem ir os ditos gados, porque não os há nos sertões de São Paulo nem nos do Rio de Janeiro. Da mesma sorte se provêm pelo dito caminho de cavalos para suas viagens, de sal feito de terra no rio São Francisco, de farinhas e outras cousas, todas precisas para o trato e sustento da vida.

O rio São Francisco desde a sua barra que faz no mar junto à vila de Penedo, em igual distância de oitenta léguas da Bahia e Pernambuco, de uma e outra parte, assim do que pertence à jurisdição de Pernambuco como à Bahia (para os quais serve de divisão do dito rio) tem às suas beiras várias povoações, umas mais chegadas, outras mais distantes do dito rio; e na mesma forma se vão continuando por ele acima, por espaço de seiscentas léguas, até se ajuntarem na barra que nele faz o rio das Velhas, em cuja altura se acham hoje as últimas fazendas de gados de uma e outra banda do dito rio São Francisco, sem ter da dita barra até esta altura parte despovoada nem deserta em a qual seja necessário dormir ou alvergarem no campo os viandantes, querendo recolher-se 
na casa dos vaqueiros, como ordinariamente fazem, pelo bom acolhimento que nelas acham. (ALMEIDA, 1705 apud ABREU, 1998, p. 140-141, grifos nossos).

A Serra não é mapeada, sequer aparecem os símbolos que denunciam o seu relevo, o que sugere que a estrada do gado, que ladeia o rio Jequitaí, tenha sido aberta em sua beira devido à dificuldade de transitar pelos declives íngremes da região.

A segunda fonte da corografia, o Mapa da Comarca de Sabará - 1778, tem o rio Jequitaí identificado de forma curiosa. Ao lado direito do rio São Francisco, demarcado como Comarca do Serro Frio, ele aparece sem qualquer detalhe sobre o seu entorno, enquanto do lado esquerdo do curso principal, pertencendo à Comarca do Sabará, ele atravessa o rio São Francisco e tem nascentes em terreno montanhoso, porém sem identificação. Levando em consideração a legenda presente no mapa anterior (e ausente neste e nos demais, pois as cartas são um conjunto detalhado das comarcas de Minas Gerais), os símbolos que aparecem nesta porção do documento, tanto à margem do rio quanto nas montanhas, sugerem o "Registos goardas e patrulhas de Soldados".

\section{Mapa 4 - Mapa da Comarca de Sabará}

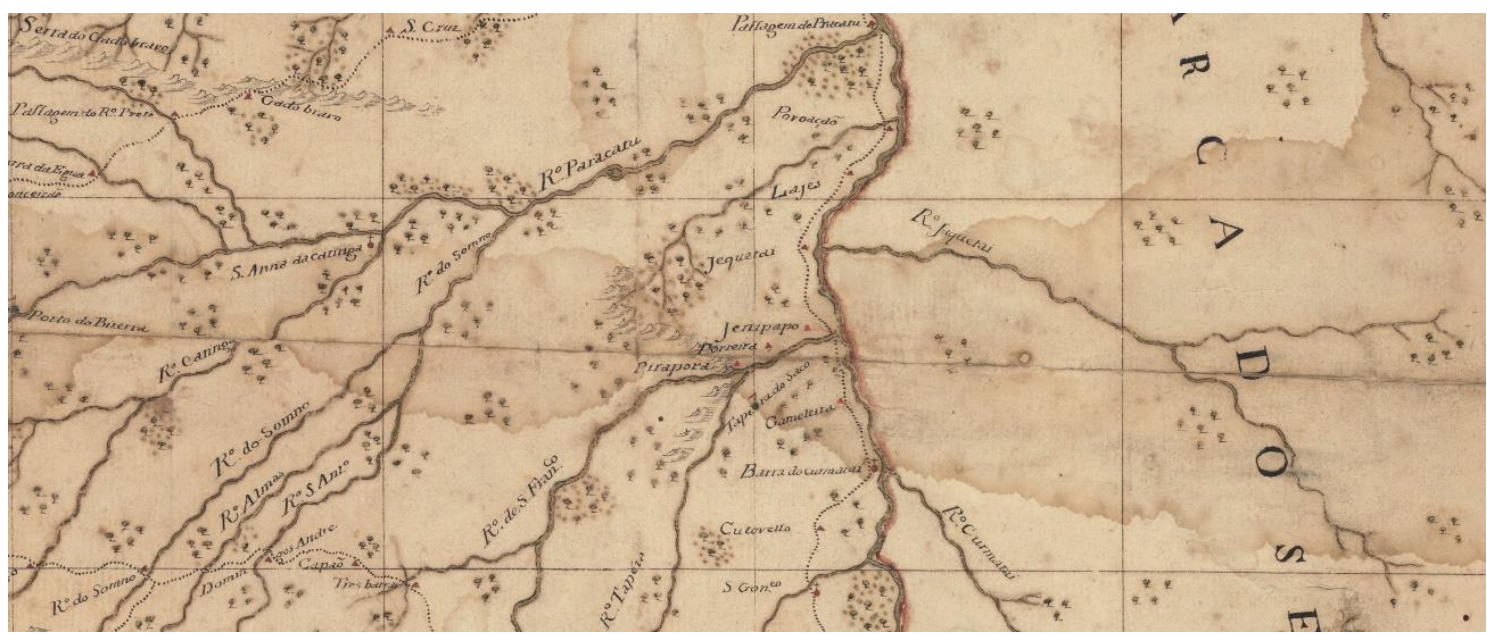

Fonte: APM, 2018.

A informação de guardas e patrulhas de soldados nos mapas interessam, sobretudo por levar a questionar o porquê de tropas presentes nas margens do Jequitaí já em fins dos Setecentos, pois não há registro de povoados ou pontos religiosos na região, a não ser algumas poucas fazendas de gado e de lavoura. A leitura de $O$ teatro das desordens, de Ivana Parrela (2009), que aborda a Serra de Santo Antônio de Itacambiraçu (ou de Grão Mogol) entre 1768 e 1800, instigou considerar que a existência de tropas na região pode estar relacionada à busca de garimpos clandestinos na Serra ou a possíveis rotas de contrabando de diamantes margeando o 
rio, dando pistas do trabalho com pedras preciosas e da ocupação da Serra do Cabral muito anterior ao Império.

\footnotetext{
Para se evitar a extração furtiva dos diamantes, em 1782, o remédio proscrito seria o giro constante de partidas ambulantes, compostas por dez soldados, pelos córregos da Demarcação Diamantina. (APM, SC, Cód. 227, fl. 25 apud PARRELA, 2009, p. 132).

Para além das terras demarcadas, as determinações régias recomendavam, desde 1772, aos funcionários da administração e militares o exame cuidadoso dos córregos da região, pois todos que vertiam para o Jequitinhonha ou que desaguavam em seus afluentes sempre poderiam ter diamantes, especialmente os proibidos.

Para a realização dos confiscos, seria necessário promover rigorosas buscas nos postos fiscais - registros e passagens -, com atenção especial ao exame dos crioulos e mulatos livres, que muitas vezes entravam sem pagamento dos reais subsídios, desde 1756. (APM, SC, Cód. 182, fl. 11 apud PARRELA, 2009, p. 132).
}

A partir de análise documental, a autora mostra o extravio como a grande consequência política e econômica da proibição da exploração de achados diamantinos além da Demarcação, pois uma vez informado às autoridades a descoberta de mina de diamante, se tornavam proibidas as atividades de mineração, cujo custo de realização ficava a cargo do mineiro (PARRELA, 2009). Portanto, os mapas de Rocha induzem a não descartar a ideia de o garimpo ser feito na Serra do Cabral muito antes do que oficialmente informado, porém de forma clandestina.

Em tese sobre o garimpo em Goiás, Helion Póvoa Neto (1998) apresenta as dificuldades que o homem livre pobre encontrava para trabalhar regularmente nas lavras descobertas, apesar de a prioridade de exploração ser concedida ao seu descobridor. A regularização acabava por exigir a doação de propinas às autoridades que controlavam o regime de concessão, que somada às barreiras de natureza técnica, dificultava a extração, praticamente fechando ao sujeito livre pobre a possibilidade de possuir uma lavra legalizada. Com isso, a faiscação, tida como atividade ilegal em relação à lavra, entrava como saída para esses homens, que acabavam extraindo na clandestinidade. Para faiscar, era preciso não anunciar as descobertas, o que se somava a outra visão preconceituosa naquela sociedade: a de que a faiscação não era trabalho e quem a fazia era vadio, ou era trabalho braçal, associado ao escravismo. Talvez por essas condições a Serra não apareça nos mapas, ao mesmo tempo em que os registros de guardas e soldados se faziam presentes, na intenção de fiscalizar a área, aventando a possibilidade de existir faiscação clandestina e, com isso, o não pagamento do tributo.

O terceiro mapa do conjunto, Mapa da Comarca do Serro Frio - 1778 apresenta o rio São Francisco como fronteira da comarca à margem esquerda. Nele, o território aparece com 
maior riqueza de detalhes: apenas na margem direita do Velho Chico, o rio Jequitaí está mais uma vez com dois afluentes não identificados.

\section{Mapa 5 - Mapa da Comarca do Serro Frio}

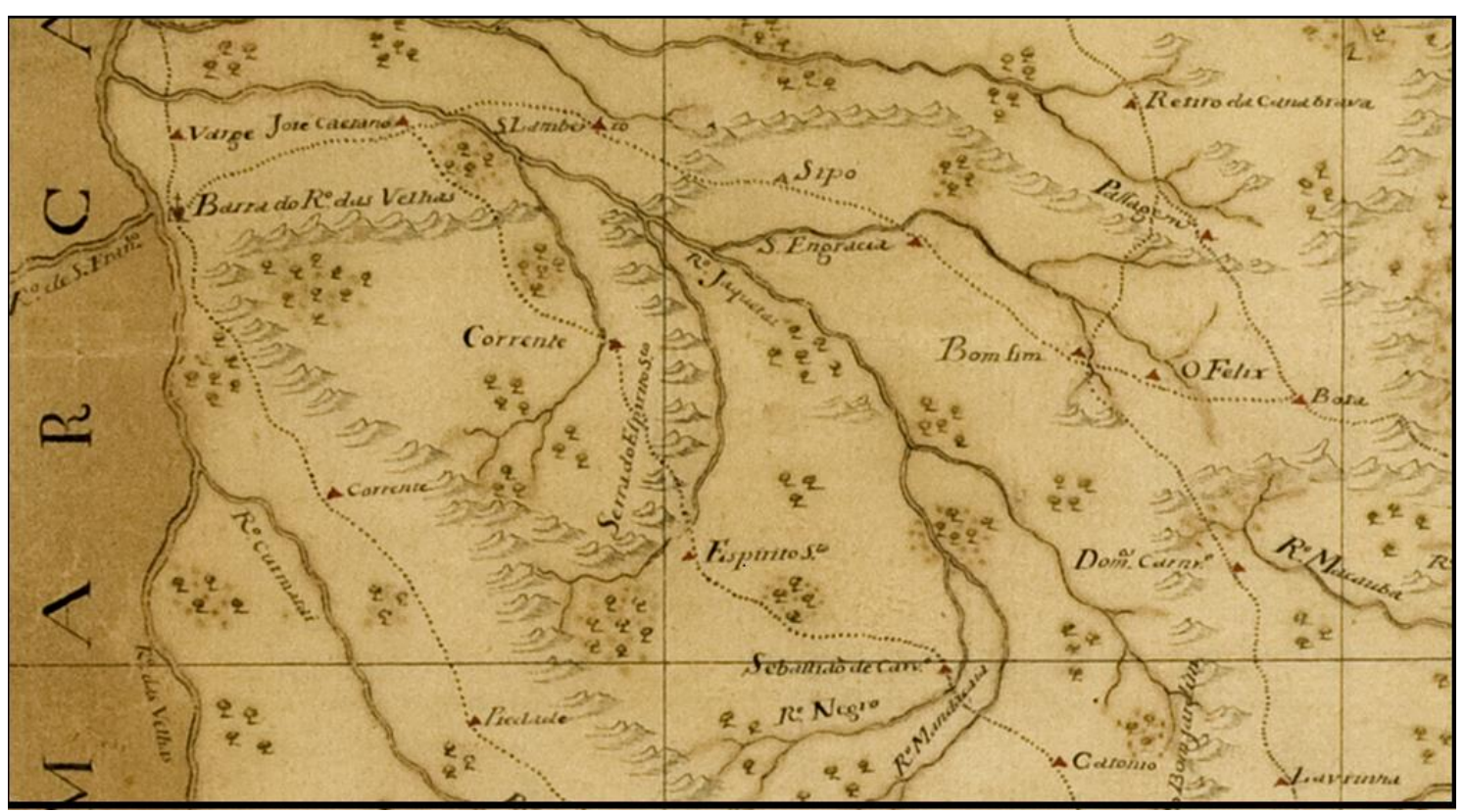

Fonte: APM, 2018.

Na corografia, o autor demonstra conhecimento acerca dos cursos d'água da comarca:

O Rio Jequitinhonha, que rega parte da Comarca do Serro Frio e as suas riquezas de ouro e diamantes, são constantes em toda a Europa. Dentre os rios de menor nome, contam-se, na Comarca do Serro Frio, o Rio Pardo, Rio Verde, Rio Jequitaí, Curmataí, Rio Pardo Grande, Paraúna, Cipó, Rio de Santo Antônio, Rio Suaçuí Grande, Itamarandiba, Rio de São Mateus, Rio Setúbal, Rio Araçuaí e Rio Piauí, que é de onde presentemente se extraem as crisólitas e várias outras qualidades de pedras. O Rio de São Mateus excede a todos na riqueza de pedras, segundo declaram os roteiros do mestre de campo João da Silva Guimarães, de quem falamos quando tratamos da Comarca do Serro Frio, a respeito dos haveres dela. (ROCHA, 1995, p. 161).

A estrada, apresentada no primeiro mapa, aparece novamente, identificando em triângulo vermelho as fazendas de pouso no caminho: São Lamberto, Santa Engrácia e Cipó. $\mathrm{Na}$ sua margem esquerda, reaparecem os símbolos que localizam os registros de guardas e patrulhas de soldados, e na margem direita, uma novidade: a existência de serras entre o rio Jequitaí e um chamado Riacho do Barro, cujas nascentes estão no Retiro da Canabrava. Além desses detalhes, os pontos em vermelho serviam para indicar a existência de indígenas não aculturados pela colonização a viverem pelo sertão ${ }^{48}$. Rocha, pelo excerto, sugere saber das

48 "Na parte leste da comarca do Serro Frio, Rocha desenhou grupos de pontos vermelhos para indicar a existência de aldeias indígenas, descrevendo uma delas como a moradia do "Gentio Panhame que come as mais nações"" (LANGFUR, 2011, p. 40). 
atividades de extração nos rios menores da Comarca, apontando para a elevação que se supõe ser a Serra do Cabral.

Os dois últimos mapas, o da Comarca de Vila Rica - 1778 e o da Comarca do Rio das Mortes - 1778, não serão descritos e analisados por não apresentarem o território pesquisado, porém, devido à data de produção e ao contexto, eles corroboram com a suposição de que em fins dos Setecentos a Serra do Cabral e seu rio mais importante já eram conhecidos das autoridades coloniais, apesar de marginalizados diante do enfoque em Vila Rica e, sobretudo, no Tejuco e sua Demarcação Diamantina. Imagina-se, a partir das informações apresentadas por Rocha, que as margens do Jequitaí já estavam povoadas e abrigavam algum aparelho de governo colonial, detectado a partir da identificação dos registros de guardas e soldados, levando a questionar as intenções reinóis ao instalar as patrulhas na beira daquele rio, no pé da Serra. De posse dessas informações, supõe-se a existência de sentinelas para monitorar os garimpos clandestinos e o possível contrabando de diamantes, que provavelmente já existiam na região. As fazendas e os retiros sugerem a existência de atividades econômicas perenes na Serra, baseadas na pecuária extensiva, presente naquele espaço desde o alvorecer do século XVII.

A segunda fonte cartográfica se refere aos mapas colhidos a partir de visitas ao APM destaca-se a já esperada dificuldade em encontrar documentos que apontem a Serra. Deles, a carta mais antiga entre as selecionadas é o Mappa Topografico e Idrografico da Capitania de Minas Geraes, de fins do século XVIII e autor desconhecido. Para Márcia dos Santos (2010), uma produção rara, pois seria o primeiro mapeamento da capitania com fins físicos, porém salientando as áreas de ocupação.

\section{Mapa 6 - Mappa Topografico e Idrografico da Capitania de Minas Geraes}

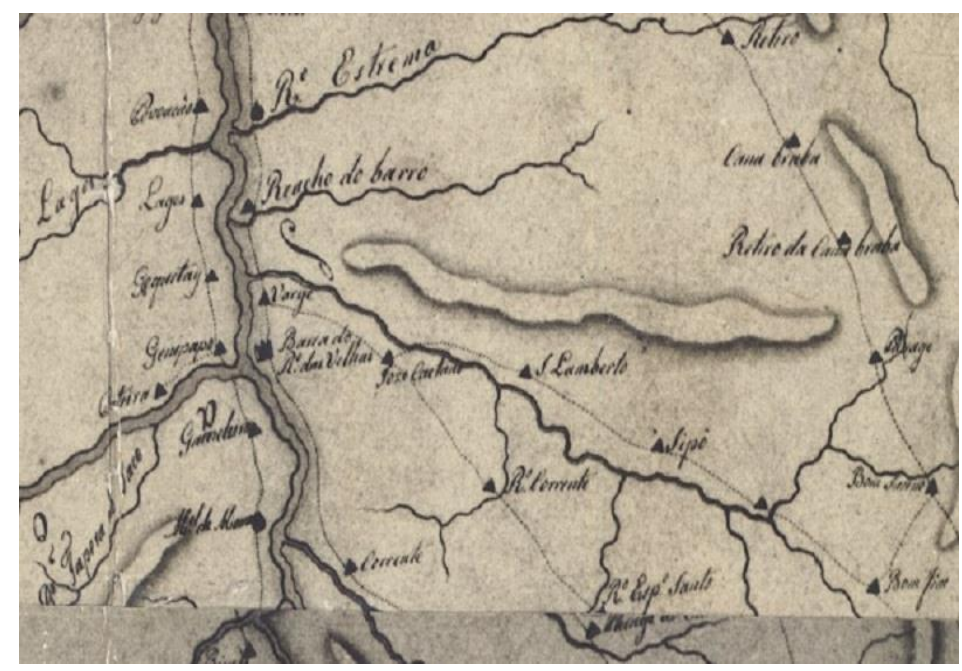

Fonte: APM, 2018. 
Nela, o rio Jequitaí está cartografado e estão localizadas as fazendas de São Lamberto, Sipó, José Caetano, Canabrava e Retiro, todas como ponto de pouso de um caminho que parte do Arraial do Bonfim (apresentado como fazenda) e margeia o rio até chegar no São Francisco. Além dos mapas de José Joaquim da Rocha, este documento também confirma a existência de caminhos e fazendas na Serra, identificando o rio regional principal e acusando a existência de um morro, também sem nome.

O mapa Planta Geral da Capitania de Minas Gerais, de 1800 e autoria de Mannheim Schlicht ${ }^{49}$, apresenta, entre toda a ocupação de Minas Gerais naquele momento, o rio Jequitaí margeando mais uma vez uma serra sem nome. Já acusa a existência deste rio, cuja nascente principal está apontada na Serra do Espinhaço, e o denuncia como receptor de cursos menores com nascentes na Serra do Cabral, como a dos rios Preto, Guavinipam e Cipó e os córregos do Barreiro, da Cachoeira e outros, cujo destino final é o rio São Francisco. O Arraial do Bonfim (hoje município de Bocaiúva) aparece no mapa, ao qual os então povoados de Francisco Dumont, Buriti Grande e outros da Serra se submetiam - porém, não constam no documento. É curioso notar que, em regiões próximas, os gentios bravos e suas etnias estão demarcados nos espaços que denominam "certão".

\section{Mapa 7 - Planta Geral da Capitania de Minas Gerais}

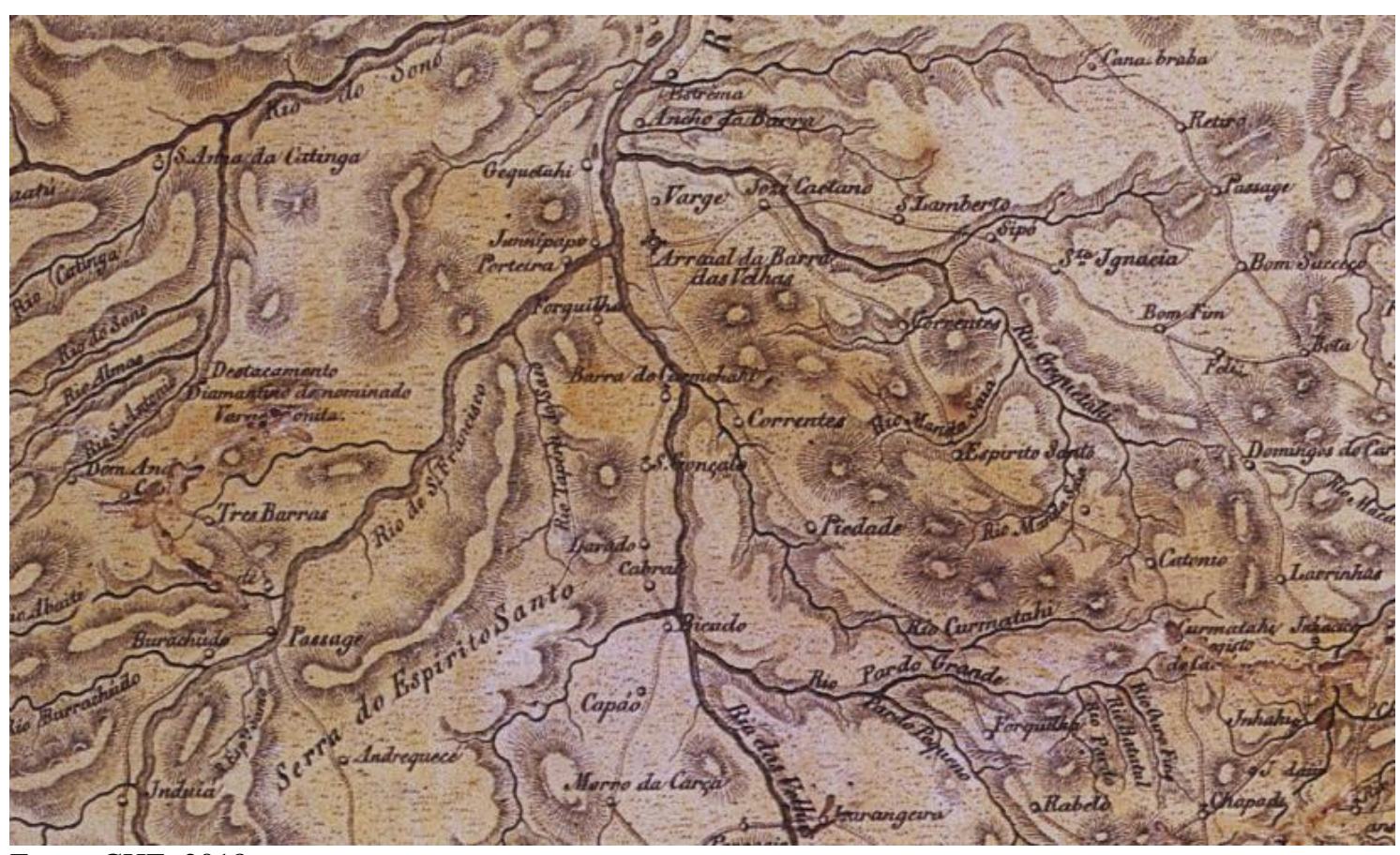

Fonte: CHE, 2018.

\footnotetext{
${ }^{49}$ Não foram encontradas informações sobre o autor.
} 
É curioso o fato de a serra que margeia o rio da região não estar nomeada nesse mapa, tendo em vista que essa não é a regra para a maioria das elevações rochosas nele representadas. Em mapas posteriores, como a Carta da Nova Lorena Diamantina, de de 1802 e autoria de C. R. X. D. Villas Boas ${ }^{50}$, do Arquivo Histórico Ultramarino (AHU), o rio Jequitaí não aparece, muito menos qualquer menção à Serra do Cabral.

Levantam-se, então, duas hipóteses. Uma delas é a importância secundária que a Serra do Cabral, sua ocupação e as atividades econômicas nela desenvolvidas tinham para as autoridades coloniais no princípio dos Oitocentos, ainda mais ao se considerar a decadência da extração de diamantes, que vinha dando sinais já na segunda metade do século XVIII. Essa pouca relevância conferida à Serra pode revelar um povoamento ainda muito rarefeito diante dos resquícios da opulência da Demarcação Diamantina, que ainda concentrava poderes regionais na capitania. Outra hipótese é a ocultação proposital da Serra do Cabral, dado que a extração de diamantes fora do Distrito Diamantino era proibida, havendo ali, portanto, atividade ilegal. A pensar que comerciantes, vaqueiros e soldados transitavam na região desde o século XVII, seja para conduzir mercadorias, seja para garantir o fisco, e que muitos deles podiam se envolver na atividade ilícita, é difícil aceitar o seu desconhecimento.

O rio Jequitaí volta a aparecer na Carta Geographica da Capitania de Minas Geraes, de 1804, porém sem identificação. O que levou a identificá-lo é a sua proximidade com o arraial do Bonfim, a Barra do Rio das Velhas, mais algumas fazendas ou povoamentos bastante antigos nas suas proximidades, como São Lamberto, Santo Inácio, Retiro da Canabrava e Correntes. Mais uma vez, serras são apresentadas nas proximidades, mas sem identificação.

\section{Mapa 8 - Carta Geographica da Capitania de Minas Geraes}

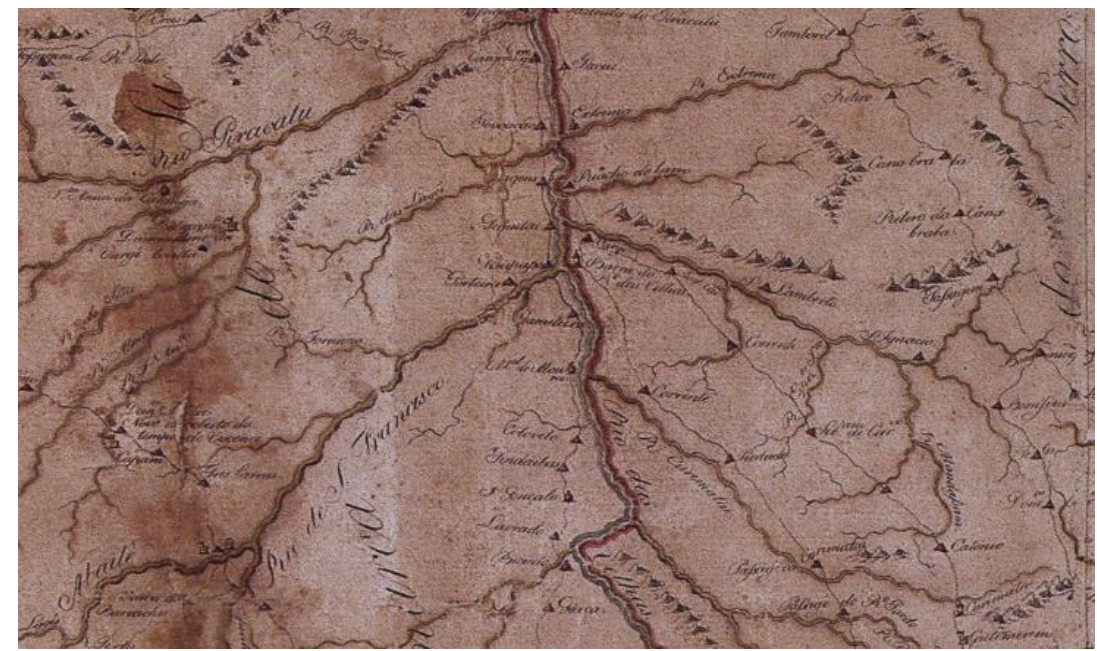

Fonte: AHE, 2018.

\footnotetext{
${ }^{50}$ Não foram encontradas informações sobre o autor.
} 
Outra carta importante é a confeccionada em 1821 pelo Barão de Eschwege, a Theil der neuen Karte der Capitania von Minas Geraes, de 1821. Nascido na Alemanha em 1777, ele veio ao Brasil em 1810, com a preocupação de organizar um gabinete mineralógicogeognóstico no contexto em que D. João VI buscava técnicos para melhor aproveitamento do Reino Unido a Portugal e Algarve. Até a sua partida, em 1821, dedicou-se a pesquisas geológicas, especialmente em Minas Gerais, com destaque para o ferro e o diamante.

Produzido para a Família Real portuguesa com vias a descobrir e melhor explorar os recursos minerais da capitania, o documento é rico em detalhes, especialmente na Demarcação Diamantina. Infelizmente, o mapa é encerrado quando começa a registrar a Serra. O rio Jequitaí está cartografado, bem como os seus afluentes, intitulados rios Guavinipam e da Páscoa - única vez em que este nome aparece no conjunto de mapas analisados. Serras sem nome estão desenhadas dos dois lados do rio, com exceção da Serra das Correntes. Ocupações como Retiro, Canabrava, Manoel de Sousa, Carrapato, Caraíba, Curralinho, Lavagens e Limoeiro estão presentes, bem como um caminho na margem direita do Jequitaí.

\section{Mapa 9 - Theil der neuen Karte der Capitania von Minas Geraes}

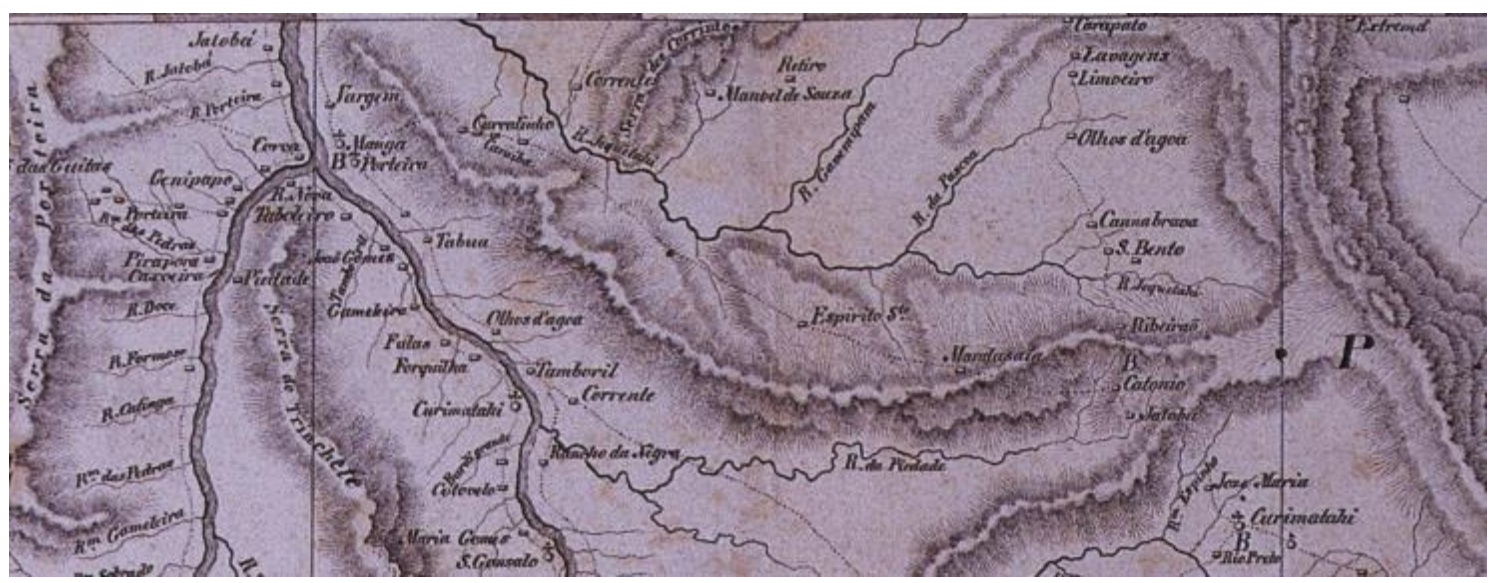

Fonte: BN, CEH, 2018

Seguindo a linearidade dos mapas encontrados, foi achada a Carta Chorographica da Provincia de Minas Geraes, coordenada e dezenhada em vista dos Mappas chorographicos antigos e das observações mais recentes de varios Engenheiros, por Ordem do ILLmo. E EXmo. Sr. Doutor Francisco Diogo Pereira de Vasconcelos, Presidente desta Provincia, por Frederico Wagner. Ouro Preto, 1855, cujo autor era um técnico de mineração, desenhista e cartógrafo alemão integrante da repartição de obras do governo da província. 


\section{Mapa 10 - Carta Chorographica da Provincia de Minas Geraes}

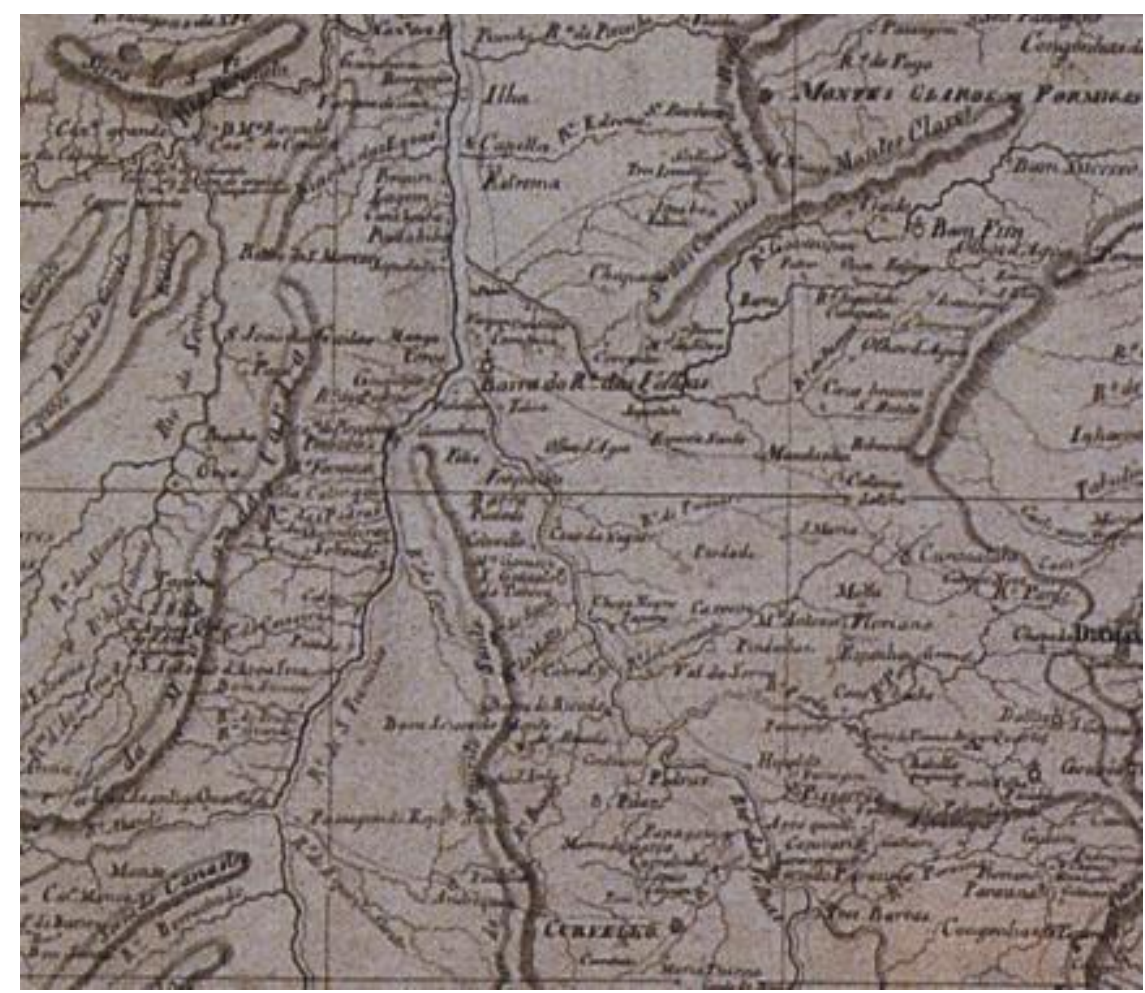

Fonte: CEH, 2018.

Conforme Luis Mundim (2010), as fronteiras internas do Estado não exibiam a conformação hoje conhecida e havia a necessidade de identificar e mapear o território, o que fez com que a administração imperial determinasse providências para tal. Nesse sentido, surge essa carta, a primeira determinação oficial relativa à província, cuja demanda vinha desde 1835 , com vistas ao planejamento dos negócios públicos.

A carta foi um projeto ambicioso, a primeira a ser elaborada por uma comissão de geógrafos, e levou 20 anos para ser concluída. É muito rica em detalhes, constando rios, serras e povoações. Analisando a região de estudo, as povoações da Canabrava e de São Bento aparecem em meio a outros nomes difíceis de serem identificados. O rio Jequitaí aparece junto aos afluentes Guavinipam e Passagem e mais uma serra que, de um lado, está nomeada de Correntes e, do outro lado, surgindo pela primeira vez, está nomeada de Viados, em referência a mais uma fazenda na base da Serra.

O Provincia de Minas Geraes segundo o projeto de nova divisão do Império pelo Deputado Cruz Machado e mandada lithographar pelo ILLmo. EXmo. Sñr. Conselheiro João Alfredo Correia de Oliveira, Ministro do Império e desenhada por José Ribeiro da Fonseca Silvares - 1873 é o último mapa de província levantado no APM; sabe-se apenas que o autor foi funcionário imperial incumbido de cartografar Minas Gerais, oferecendo informações acerca da ocupação e dos atributos físicos gerais. Bastante detalhado, com as serras e elevações 
desenhadas em sombreado, o rio Jequitaí, cujas nascentes principiam perto de Olhos d'Água, surge em área serrana. Afluentes como o Guavinipam, Sucuriú, São Lamberto e Gameleira se destacam em detrimento das fazendas, registradas por preferência nos mapas anteriores, nos quais lugares que possuem igreja ou paróquia e vilas são informados. $\mathrm{O}$ interesse maior pelos recursos naturais condiz com um período de incentivo à descoberta de matérias-primas cobiçadas no comércio internacional, tendo em vista que o Brasil, já independente, afirmava sua condição de exportador de produtos primários no mercado externo.

\section{Mapa 11 - Provincia de Minas Geraes segundo o projeto de nova divisão do Império}

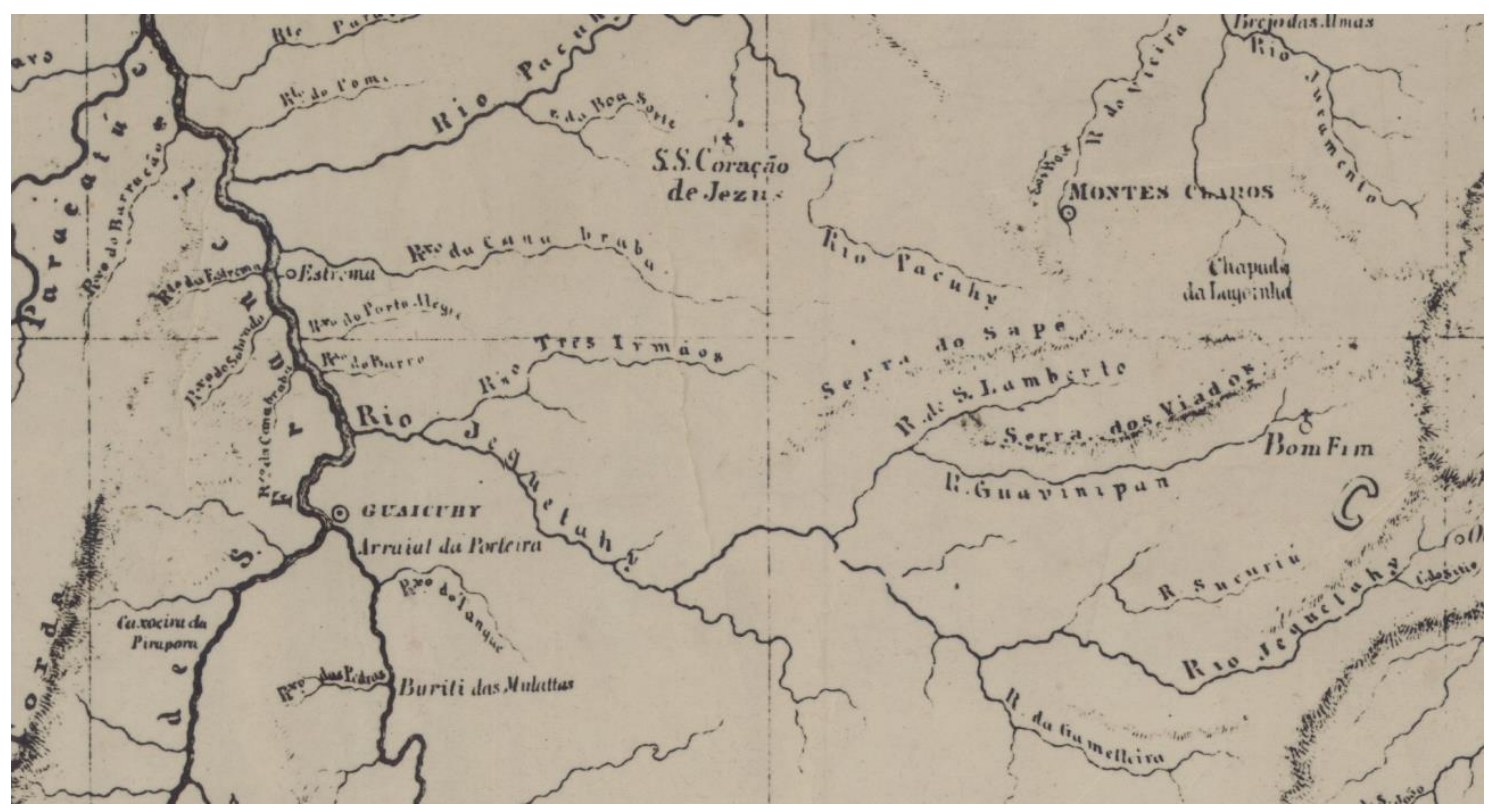

Fonte: AHE, CEH, 2018.

As proximidades da Serra do Cabral são acusadas no mapa como Serra dos Viados, podendo ser também mais uma demarcação de fazenda, conforme o mapa anterior. A tomar partido da primeira hipótese, é a primeira vez que arredores da Serra aparecem nomeados nos documentos analisados. Após essa descoberta, considera-se que a suposição de a Serra do Cabral nem sempre ter sido assim chamada.

Conforme Ivana Parrela (2009), muitos contrabandistas adentravam a Serra de Santo Antônio disfarçados de caçadores de veados, informação que, cruzada à do mapa de José Joaquim da Rocha sobre as patrulhas na beira do rio Jequitaí para o provável confisco de contrabando e garimpo clandestino, pode explicar o possível nome, ainda mais considerandose a proximidade entre as serras e a mobilidade dos garimpeiros que adentravam o sertão à procura de lavras escondidas. 
Ao que a investigação cartográfica e documental indica, não apenas Viados pode ter sido um nome anterior para parte da Serra do Cabral, como também Monte Rorigo ${ }^{51}$, nome que consta na Memória sobre as salitreiras naturaes de Monte Rorigo: maneira de as auxiliar por meio das artificiaes; refinaria do nitrato de potassa, ou salitre; escrita no anno de 1803, de José Vieira Couto (1994), publicado em 1809. Incumbido por D. Rodrigo de Souza Coutinho de levantar as potenciais riquezas da capitania após o arrefecimento econômico mineral, o estudo aventa a exploração do salitre nos sertões mineiros, resultando em um manual de instruções para a extração das nitreiras naturais (cavernas) e artificiais (espécie de estufa artesanal para formar salitre). Segundo o texto, o Monte Rorigo se situaria ora na Serra do Cabral, ora na Serra Mineira, onde hoje estaria Piçarrão, localizado no atual distrito de Senhora da Glória, município de Santo Hipólito, próximo a Augusto de Lima. Apesar da proximidade com a Serra do Cabral, não se considera esta hipótese, uma vez que não se obteve maiores informações nem mapeamento temático. No entanto, nas Memórias do Distrito Diamantino, Joaquim Felício dos Santos menciona a extração do salitre "nos sertões ao longo da Serra do Cabral e nas cavernas da mesma serra" (SANTOS, 1868, p. 308), insinuando que a exploração acontecia para além dos limites de Piçarrão e com descoberta das nitreiras em 1799, o que aponta para o conhecimento da serra com o nome Cabral desde pelo menos no século XVIII.

Outra narrativa assegura o conhecimento da Serra do Cabral com esse nome em fins do século XIX. É o que indica Os Sertões: campanha de Canudos, obra clássica de Euclides da Cunha, referente à Guerra de Canudos (1896-1897), testemunhada in loco pelo autor. Publicada pela primeira vez em 1902, logo na primeira parte, intitulada "A terra", o escritor narra o itinerário que supostamente percorreu para chegar ao local, onde passa não apenas pela serra de Grão Mogol, mas também pela área aqui tratada, descrevendo com minúcia geomorfológica a paisagem que observa.

A serra do Grão Mogol, raiando as lindes da Bahia, é o primeiro specimen dessas
esplendidas chapadas imitando cordilheiras, que tanto têm perturbado aos geographos
descuidados; e as demais que a convizinham, da do Cabral mais proxima, á da Matta
da Corda alongando-se para Goyaz, modelam-se de maneira identica. [...] Sem linhas
de cumiadas, as maiores serranias nada mais são que planuras alçadas, extensas rechans
terminando de chofre em enconstas abruptas, cjua forma resalta como oriunda do
regimen torrencial sobre o terreno permeavel e movel. [...]
Estiram-se então planuras vastas. Galgando-as pelos taludes, que as soerguem dando-
lhes a apparencia exacta de taboleiros suspensos, topam-se, a centenas de metros,

51 “O dr. José Vieira Couto deu á serra do Cabral o nome de Monte Rorigo em memória de D. Rodrigo de Souza Coutinho, denominação que não se conservou e só existe em seu relatório. O dr. Couto foi infeliz nos seus baptismos. Tambem o Abaeté não conservou o nome de Nova Lorena, que elle quiz dar-lhe. É que seus heróes não erão das sympathias do povo, e onde mais se revela a soberania d'este é em seus caprichos" (SANTOS, 1868, p. 309). 
extensas areas ampliando-se boleadas, pelos quadrantes, numa prolongação indefinida, de mares. E' a paragem formosissima dos campos geraes, expandida em chapadões ondulantes - grandes tablados onde campeia a sociedade rude dos vaqueiros (CUNHA, 1905, p. 7-8, grifos nossos).

Ou seja, a Serra do Cabral se sedimentava como parte do caminho que levava aos sertões mais distantes.

Antes de discutir o último mapa escolhido do APM, datado de 1940, é pertinente comentar o mapa Município de Bocayuva, de Affonso Guayra Heberle, de 1927, que faz parte do Album Chorographico, confeccionado por um grupo de especialistas em engenharia, geografia e outros. Sobre o autor, sabe-se que integrou uma comissão responsável por mapear o estado de Minas Gerais no contexto das comemorações do centenário da independência do Brasil, sendo posteriormente convidado a trabalhar no IBGE, onde chegou a publicar um estudo sobre a gruta do Maquiné, no norte de Minas Gerais.

\section{Mapa 12 - Município de Bocayuva}

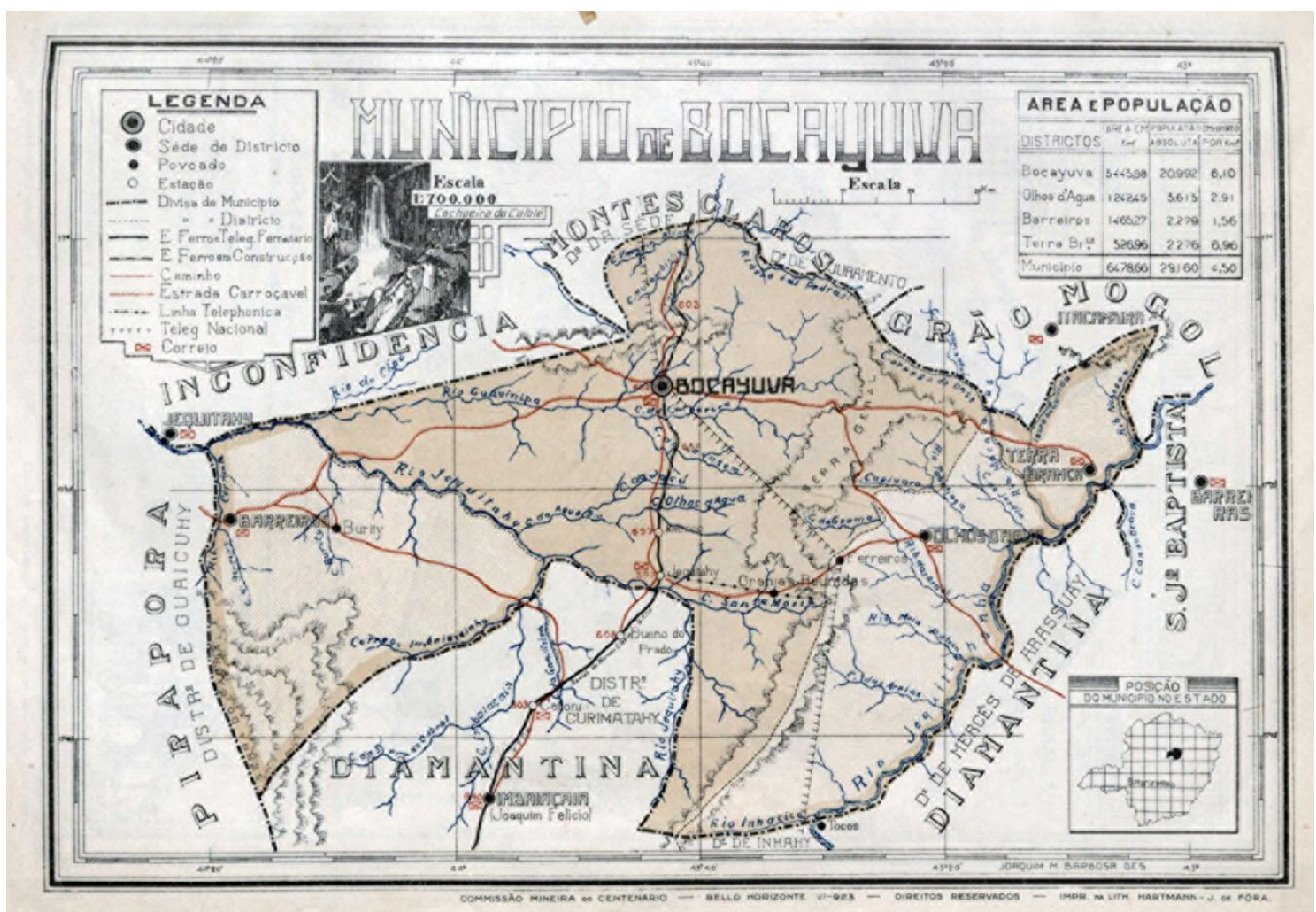

Fonte: Album Chorographico, 2016.

Nele, o rio Jequitaí aparece recebendo os afluentes Guavinipam, Cipó, Água Fria, Buriti e Jacu; as "estradas carroçáveis", as únicas registradas ali, cortam o território em linha vermelha, levando à cidade de Bocaiúva, à sede de distrito Barreiros e ao povoado de Buriti; a Serra do Cabral aparece no canto esquerdo com nome timidamente escrito, fazendo fronteira 
com Pirapora e Guaicuí. Informações sobre a população dessas ocupações são dadas no canto superior direito, com Barreiros somando 2.279 habitantes (considerava-se o Buriti Grande parte de Barreiros). Finalmente, apenas no século XX, a Serra do Cabral aparece na cartografia com o nome pelo qual é conhecida atualmente.

O último mapa a ser analisado pertence ao acervo do APM, o Mapa do Estado de Minas Gerais - Município de Bocaiúva, de 1939 e autoria de Hely Carvalho ${ }^{52}$. Nele, a Serra do Cabral aparece como divisa com Pirapora, havendo detalhes sobre os distritos e povoados sob jurisdição de Bocaiúva. Além disso, traz mais informação sobre os rios e córregos: aparecem os rios Jequitaí, Preto, Imbassaia, Imbassainha, Guavinipam e Traíras e córregos da Gameleira, do Riachão, do Buriti Fundo, do Buriti Velho, do Diamante, do Pindaíba, do Brejinho, Sucuriú, da Lavagem, das Jaboticabas, da Tapera, dos Angicos, da Garapa, da Canabrava, das Pedras, da Lage, Cipó, dos Bois, Sapato de Burro, Buriti, Taboquinha, do Barreiro, da Água Fria, Maria Preta, Tirirical, da Estiva, entre muitos outros.

\section{Mapa 13 - Mapa do Estado de Minas Gerais - Município de Bocaiúva}

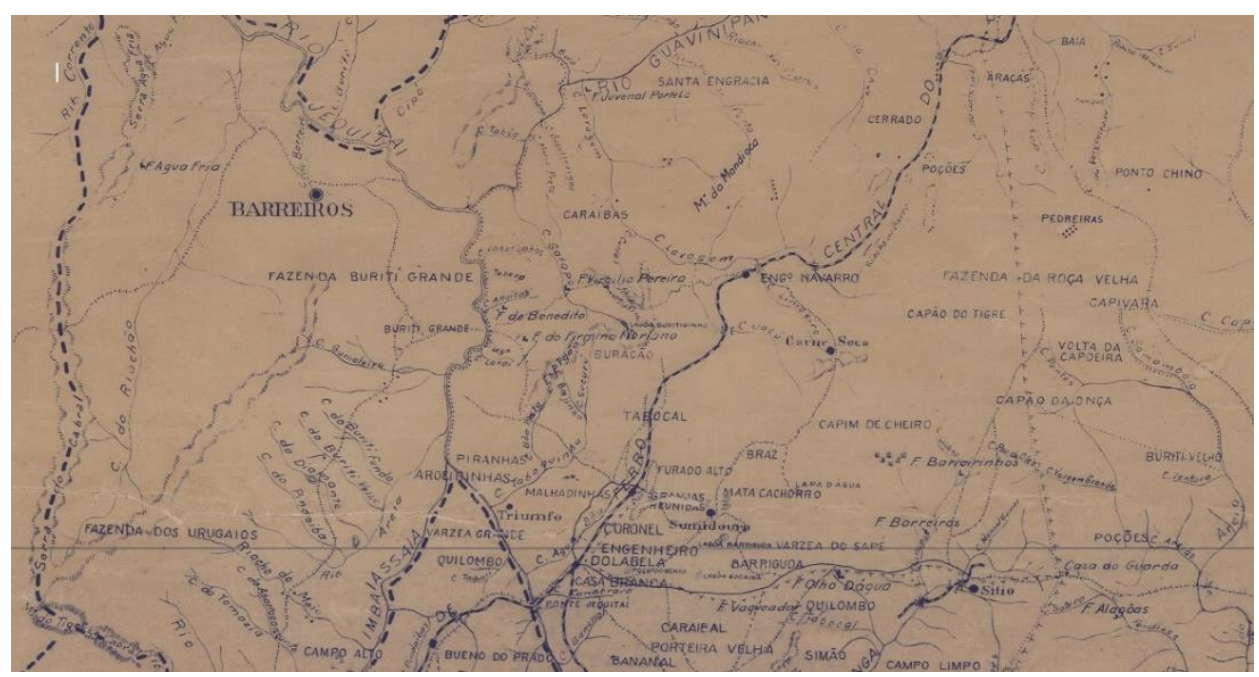

Fonte: APM, 2018.

O relevo é mais detalhado, registrando além da elevação da Serra do Cabral. Aparecem as serras da Água Fria, das Correntes, Serra dos Fonsecas, o Morro do Tigre, da Sepultura, entre outras elevações menores, onde residem as nascentes dos córregos. Outros símbolos estão presentes denunciando áreas de várzea.

Os distritos, povoados e fazendas estão plotados no mapa. Sob a administração de Bocaiúva, aparecem Barreiros, Buriti Grande e Carne Seca, além das fazendas Buriti Grande,

\footnotetext{
${ }^{52}$ Não foram encontradas informações sobre o autor.
} 
Caraíbas, da Água Fria, dos Uruguaios ${ }^{53}$, Santa Engrácia, Triunfo, Piranhas, do Benedito, Virgílio Pereira, Quilombo, entre outras. Estradas de ferro, caminhos de tropas e zonas de mineração também estão marcados, porém no entorno de Barreiros e Buriti Grande não foi colocado nenhum símbolo atestando atividade de garimpo - porque provavelmente este já estivesse no seu crepúsculo - e pecuária - o que é curioso, tendo em vista que as povoações da Serra do Cabral se especializariam na criação extensiva no começo do século XX, conforme informações dos anuários do APM.

O exercício de cartografar reforça a ideia de que produzir mapas é uma forma de territorialização, porque representar o espaço dominado ou conhecido é também uma forma de apropriação. É interessante notar o empenho de cartógrafos e engenheiros - boa parte deles estrangeira - a serviço do Estado português e, posteriormente, brasileiro. A contratação de técnicos evoca a necessidade de conhecer e controlar o território para nele impetrar os projetos de interesse, sejam eles de controle dos caminhos para a arrecadação dos quintos do ouro, sejam para a cobrança de direitos sobre a passagem por rios, sejam para exterminar o gentio e avançar sobre suas terras, sejam para conhecer os potenciais de exploração econômica diversa do país nascente. $\mathrm{O}$ processo de cartografar o sertão do norte mineiro permite acompanhar a formação da fazenda pecuária e dos caminhos com vias a instaurar a produção de mercadorias em um território do qual se vai apropriando, concreta e simbolicamente.

\footnotetext{
53 A presença dessa fazenda corrobora a informação encontrada no anuário do APM e a preocupação em especializar a região na produção pecuária no alvorecer dos Novecentos:

Os criadores uruguayos srs. Manoel Bernardez e Antonio Maldini, fizeram contracto com o Governo Mineiro, em virtude do qual este se comprometteo a vender-lhes cento e quinze mil hectares ou 32 legoas quadradas de terras devolutas na Serra do Cabral (entre este mun. e o de Curvello), para ali serem estabelecidas, pelo menos, tres fazendas de criação de gado bovino e lanigero, tendo cada uma a área minima de tres legoas em quadra. (SENNA, 1918, p. 1339).
} 


\title{
3. Boi: mercadoria que devora os homens
}

\author{
$\hat{E}$ boi Bonito, ê bumba \\ Boi Desengano, ê bumba \\ Meu boi Bonito, boi Alegria \\ Estrela do Norte, fulô do dia \\ $\hat{E}$, ei bumba, folga meu boi \\ Meu boi Bonito, boi Coração \\ Faz uma venda de ventar no chão \\ Meu boi Bonito, meu boi judeu \\ Folga de roda e dá no Mateu
}

Anônimo, século XVII

Há uma farta bibliografia sobre a formação territorial de Minas Gerais, mas não tanto sobre o norte do estado quando o recorte espacial escapa o Vale do Jequitinhonha e seu Distrito Diamantino. Caio Prado Júnior (2006), historiador debutante no viés marxista sobre a historiografia brasileira, ao abordar a importância da pecuária na formação do Brasil, comenta que a atividade era uma das principais da Colônia, porém injustamente delegada ao plano secundário. Conforme as bandeiras e as entradas avançavam sobre os sertões, coube a ela a expansão a oeste dos territórios coloniais, fornecendo os artigos necessários para a reprodução das atividades econômicas destinadas ao comércio triangular ${ }^{54}$.

O autor via na região que abrange a Serra do Cabral um prolongamento da Bahia, devido às formas pioneiras de ocupação, que se deram pelas fazendas de gado que subiram no século XVII as margens do rio São Francisco, alcançando nessa fase o afluente rio das Velhas. "E muito antes de se formar o que seria Minas Gerais, cujo contingente maior e característico de povoadores viria do Sul, o Norte já se achava ocupado pelos baianos" (PRADO JÚNIOR, 2006, p. 197).

Ele vai adiante para tratar dos paulistas no processo de povoamento:

\footnotetext{
Paulistas também, como é sabido, e cujas correrias davam às vezes em estabelecimentos fixos, que vão aliás até a Paraíba (Domingos Jorge Velho). Mas trata-se de estabelecimentos que se destacaram completamente de seu ponto de origem. (PRADO JÚNIOR, 2006, p. 197).
}

Para o autor, não havia na expansão das bandeiras e aventureiros paulistas uma continuidade de povoamento, como se dava com as correntes vindas do Norte, que marchavam progressivamente e iam povoando e colonizando o território que atravessavam, sendo que a

\footnotetext{
54 "Excluída a estreita faixa que beira o mar e que pertence à agricultura, a área imensa que constitui hoje o país se divide, quanto aos fatores que determinaram sua ocupação, entre a colheita florestal, no Extremo-Norte, a mineração no Centro-Sul, a pecuária no resto." (PRADO JÚNIOR, 2006, p. 187).
} 
comarca de Minas Novas pertenceu à Bahia até 1757, quando foi incorporada a Minas Gerais pelo decreto de 10 de maio daquele ano - capitania que só passaria a existir após o desmembramento da capitania de São Paulo, em 1720. Contudo, até o século XIX, a jurisdição eclesiástica da região continuou com o arcebispado da Bahia.

De acordo com a leitura de Leonardo Rolim (2015), em artigo que discute a colonização sobre os sertões do Norte, Caio Prado Júnior dá a impressão de que a ocupação do interior se dava de forma livre e ao gosto da espontaneidade e da aventura. Entendendo projeto como esboço de algo a ser colocado em prática no futuro, Caio Prado Júnior parece não enxergar claramente um plano organizado de colonização por trás da expansão das fazendas de gado. No entanto, ele mesmo parte do Roteiro do Maranhão a Goiaz pela Capitania do Piauhi (c. 17701790), de autor desconhecido, um dos documentos que mais respaldam a noção de que havia um projeto de expansão sobre as terras interioranas e suas gentes, com proposições em torno de comunicar e dilatar os sertões e reduzir os povos indígenas que nele habitam.

Este projecto ainda que pareça conter algumas difficuldades pela extensão do Paiz, e multidão de indios Silvestres, que o habitão, não parecerá comtudo chimerico ou impraticavel a quem conhecer bem no fundo o caráter destas Nações, a natureza do Paiz, e o trabalho que demanda a sua cultura. (ROTEIRO..., 1900, p. 87, grifos nossos).

Escrito em um momento no qual a pecuária já estava assentada no sertão há pelo menos um século, o roteiro propõe desconfiar de uma leitura voltada para a liberdade e a desordem da expansão, sugerindo os interesses e o controle metropolitanos por trás das ações expansionistas. A abertura de caminhos para a circulação da mercadoria bovina era um desígnio da metrópole cumprido por homens que se lançavam na hinterlândia em troca da concessão de benesses, como os títulos de nobreza e o poder vinculado à terra. O apoio à expansão da produção pecuária era crucial para garantir a posterior execução da economia de extração mineral.

Na mesma direção de Rolim, aponta a interpretação de Simeão Ribeiro Pires (1979) a partir do levantamento documental da ocupação do que viria a ser o norte mineiro. Apesar do seu empenho em registrar memórias do norte de Minas Gerais, adverte-se para a sua defesa de um povoamento desencadeado por baianos como justificativa histórica para o seu projeto de criação de um novo estado - a ser discutido neste trabalho. Analisando a correspondência do conde de Assumar (tornado vilão na sua narrativa), nota-se que o Caminho Novo para as Minas não tinha grande importância até 1720. Nas cartas, o governador obriga os moradores a fazerem a manutenção do caminho para a circulação das mercadorias, sob severas penalidades em caso 
de não serem cumpridas as ordens ${ }^{55}$. Estas ordens sobrecaíam em uma área de ocupação já consolidada.

Os caminhos da Bahia para Minas Gerais pareciam mais viáveis do que partindo-se do Rio de Janeiro e de São Paulo. O trecho já era de trânsito desde fins do século XVII, conforme informa a carta de Domingos Afonso Sertão ao governador D. João de Lancastro:

Os caminhos por terra são bons, que por elles se levão os gados do Rio de São Francisco para sostento dos fabricadores das minas do ouro, por lhe não poder vir de outra parte pellos não aver mais perto; e das minnas para São Paulo e Rio de Janeiro tão bem hay estradas, mas dizem serem os caminhos asperos pellas muitas serras que hay. (ANTONIL, 2007, p. 273).

O excerto aponta para caminhos do gado já consolidados. Antonil, codinome de João Antônio Andreoni, foi um padre jesuíta italiano residente em Salvador entre os séculos XVII e XVIII, tendo escrito e publicado em 1711 a obra Cultura e opulência do Brasil por suas drogas e minas sem ter saído do mosteiro onde vivia - ou, pelo menos, sem ter circulado por Minas Gerais (SILVA apud ANTONIL, 2007). Crítico à maneira como a mineração desencadeou a sociedade colonial, teve obra apreendida a mando da Coroa ao dar detalhes sobre os locais e as formas de extração e produção de riqueza na América Portuguesa. Sua verdadeira identidade foi descoberta por Capistrano de Abreu, outro historiador clássico, de valia para a interpretação do povoamento do que viria a ser o Brasil.

55 "Em carta de 18-11-1718 a Garcia Rodrigues Pais:

-- 'Para obrigar a todos os moradores do caminho novo desde a Serra do Mar até o Paraíba a consertar os caminhos e fazerem atalhos nos morros, a fim de se facilitar a passagem dos mercadores e mais pessoas que vêm para as Minas, sob severas penalidades'.

Com a mesma data, outras ordens, inclusive ao Coronel Domingos Rodrigues da Fonseca.

-- 'Encarrego-o de por em boa ordem os moradores do caminho novo, desde sua roça até o Paraibuna, de consertar os caminhos e fazerem atalhos nos morros para que se torne mais fácil a passagem dos mercadores e mais pessoas que vêm para as Minas, sob penalidades severas'.

Ainda em 2-9-1720 baixou Assumar uma ordem:

-- 'Aos moradores do caminho novo para que o consertem dentro dos limites das respectivas testadas'.' (PIRES, 1979, p. 88). 


\section{Mapa 14 - Caminhos da cidade da Bahia para as minas do rio das Velhas}

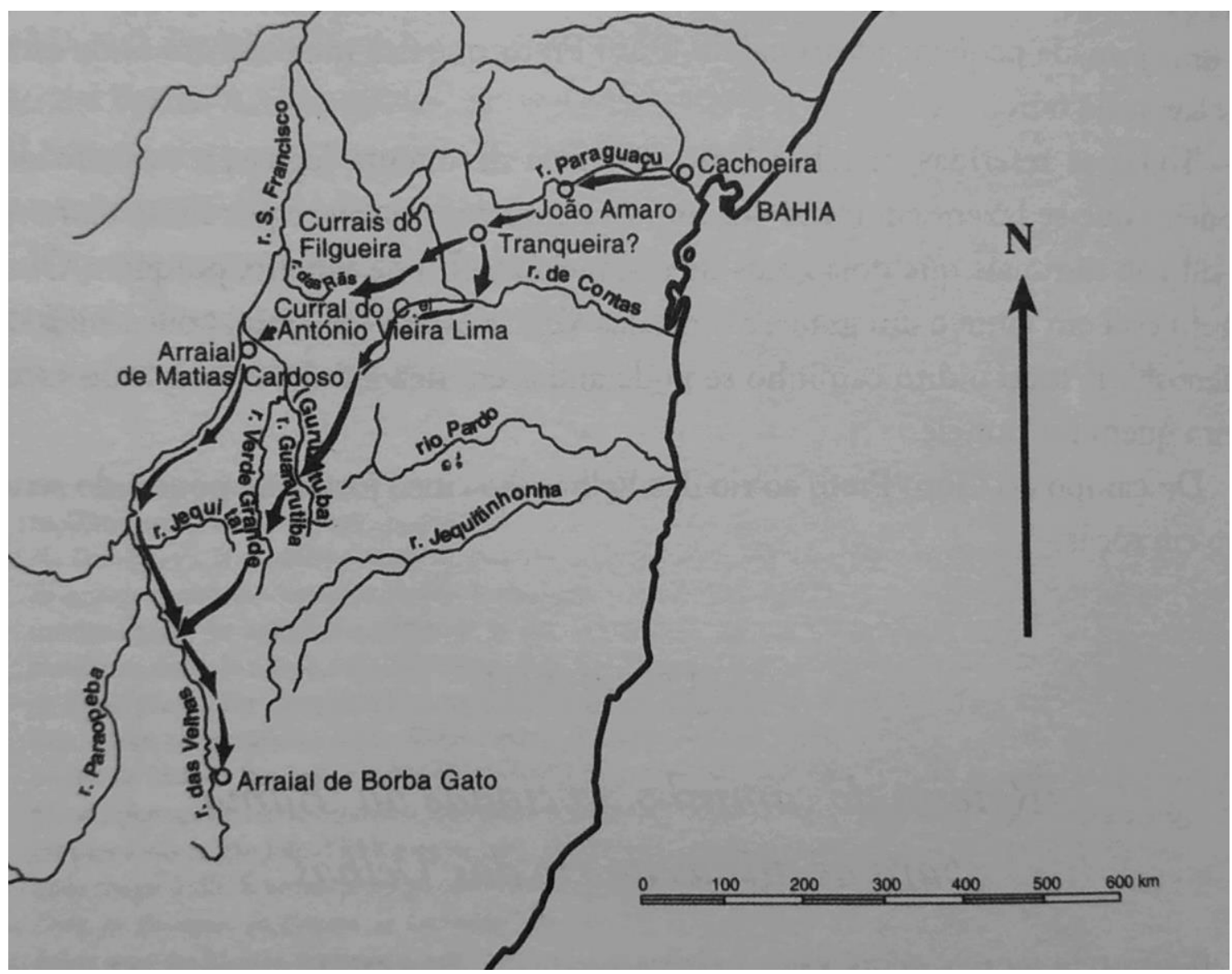

Fonte: Antonil (2007, p. 270).

Segundo o Instituto Histórico e Geográfico Brasileiro (IHGB), Capistrano de Abreu nasceu no Ceará em 1853, filho de major da Guarda Nacional, tendo completado os estudos em capitais regionais e, posteriormente, morado no Rio de Janeiro, ainda capital do Império. Ingressou no Colégio Pedro II como catedrático de História do Brasil Colonial, ocupando a vaga de Joaquim Manuel de Macedo ${ }^{56}$. Galgou o posto assistido pelo imperador, defendendo a tese do descobrimento do Brasil e seu desenvolvimento no século XVI, reproduzindo uma historiografia eurocêntrica sobre clima, terra e raça, empenhado na criação de uma história colonial oficial, com a diferença de não dar ao indígena a pecha de dócil ou bom selvagem, tão comum entre seus contemporâneos.

De acordo com Capistrano de Abreu, o norte de Minas Gerais teve como pioneiros os criadores de gado comandados pelo mestre de campo Antônio Guedes de Brito ainda no século

\footnotetext{
${ }^{56} \mathrm{Um}$ dos mais importantes escritores do Romantismo, foi também memorialista e professor de História e Geografia do Brasil no Colégio Pedro II, muito ligado à Família Imperial, tendo sido professor dos filhos da princesa Isabel. Militou no Partido Liberal e foi deputado provincial (1850, 1853, 1854-59) e deputado geral (186468 e 1873-81). Membro muito ativo do Instituto Histórico (desde 1845) e do Conselho Diretor da Instrução Pública da Corte (1866). Enquanto letrado e partícipe do círculo político, cultural e intelectual da época, integrou o Romantismo enquanto movimento que debutava na busca da identidade do país recém-independente.
} 
$\mathrm{XVII}^{57}$, com terras de 160 léguas (o equivalente a quase 700 quilômetros), abrangendo do Morro do Chapéu até as águas do rio das Velhas, à direita do curso médio superior do rio São Francisco ${ }^{58}$. O morgado dos Guedes de Brito é mais um exemplo do mecanismo de incorporação de gente na conformação do Estado português com seu ímpeto expansionista, pois combinava na mesma pessoa o próprio interesse e o poder de autoridade que lhe fora atribuído. Com isso, deduz-se que a concessão de títulos e patentes, ao descentralizar o poder da Coroa nos particulares, também concentrava poder em um Estado que somente podia se estabelecer através dessa descentralização (LEITE, 2010).

As bandeiras e entradas se caracterizavam pela procura de achados preciosos, tendo em vista o mito da Serra do Sabarabuçu e o alvoroço provocado pela descoberta de Potosí (América Espanhola). Apesar do intervalo de quase quatro séculos, o espectro da utopia do país de Cocanha ainda povoava a imaginação dos chamados aventureiros: a vida de trabalho pesado, o fantasma da fome e a edenização do Novo Mundo moviam as bandeiras a descobrirem, pela necessidade, a terra mítica que lhes traria a fartura e a riqueza ${ }^{59}$. Porém, essa terra não estaria mais coberta de doces e leitões, mas de metais e pedras que marcariam, na modernidade, a nova sociabilidade das relações de troca. Conquistá-la pressupunha se banhar em sangue de índio ${ }^{60}$.

\footnotetext{
57 “Antônio Guedes de Brito, nascido na Bahia (c. 1627), foi um dos grandes sertanistas da segunda metade do século XVII, que se deu especialmente a conhecer na luta contra os índios e contra os quilombos (i.e., as comunidades que os escravos negros fugitivos constituíram nos matos do interior, sendo o Quilombo dos Palmares o mais conhecido). Estabeleceu muitos currais nas regiões onde atuou, especialmente nas Jacobinas. Nomeado mestre-de-campo e regente do São Francisco, tomou parte no governo interino do Brasil entre 1675 e 1678 e foi elevado a fidalgo cavaleiro por alvará de 18.3.1679. A data do seu falecimento situa-se entre 1692 e 1695." (SILVA apud ANTONIL, 2007, p. 294-295, grifos da autora).

${ }^{58}$ Apesar de a família Guedes de Brito ser absenteísta, se valeu de seus escravos que, por sua vez, possuíam cativos, para garantir a ocupação e manter a posse de suas terras, não descartando ser também uma forma de controle dos cativos ao lhes conceder a possibilidade de ocuparem terras e terem eles mesmos os seus escravos. Provavelmente, eram escravos a trabalhar com gado pelo sertão. Sobre escravos com propriedades, é o que apresenta o artigo de João José Reis, que aborda a posse de escravos por escravos para o caso baiano do século XIX:
}

\begin{abstract}
O mesmo talvez se possa dizer do que acontecia em propriedades de alguns grandes senhores absenteístas, como eram os Guedes de Brito no sertão da Bahia. Entre os escravos dessa poderosa família, Gabriela Nogueira descobriu treze que eram donos de 44 escravos, e a maioria também possuía roças. À semelhança dos religiosos de São Bento, os administradores dos Guedes de Brito desenvolveram uma estratégia de controle que favorecia daquele modo uma parte da escravaria. Estes exemplos podem sugerir que somente relações escravistas muito excepcionais explicariam o fenômeno em pauta. Este era, contudo, mais generalizado. (REIS, 2016, p. 37)
\end{abstract}

\footnotetext{
${ }^{59}$ É curioso que em $O$ queijo e os vermes: o cotidiano e as ideias de um moleiro perseguido pela Inquisição, Carlo Ginzburg (2006) reconstrói a vida de Menocchio, moleiro seiscentista julgado pela Santa Inquisição na zona rural do norte da atual Itália, apresentando entre as leituras do suposto camponês herege um texto anônimo do século XVI, o qual discorre sobre uma entre as muitas variações sobre o tema do país de Cocanha, localizado entre as terras descobertas para lá do oceano Atlântico, onde não há apenas abundância, mas também o desconhecimento dos vínculos das instituições sociais, como a família.

${ }^{60}$ Apesar de não haver registros portugueses sobre a utopia medieval do país de Cocanha, ela existia entre os espanhóis, sendo seu provável ingresso na América portuguesa via União Ibérica, momento de maior entrada de bandeiras pelos sertões. Cocanha se situa no interior de uma geografia imaginária, sendo o país "um mundo sem
} 


\section{1. "O sertanejo é antes de tudo um índio"}

Em A Guerra dos Bárbaros, trabalho sobre a violenta submissão dos povos indígenas à colonização do sertão do Nordeste entre os séculos XVII e XVIII, o historiador Pedro Puntoni (2002) aponta a necessidade das fazendas de ocuparem as regiões interioranas devido, entre outros motivos, à valorização das terras próximas dos portos de embarque e dos cursos fluviais.

A pouca noção do tamanho das terras e das distâncias movia homens pobres, geralmente mestiços de portugueses com indígenas, a entrarem nos sertões em busca de metais preciosos e de povos nativos à escravidão. Muitos dos bandeirantes empregados nas guerras no Nordeste não tornavam à suas terras de origem, sobretudo os paulistas, preferindo a vida de proprietários nas terras adquiridas por suas armas. De bandeirantes, passavam a conquistadores, formando estabelecimentos fixos - antes do descobrimento das minas, já havia nas ribeiras dos rios das Velhas e São Francisco mais de cem famílias paulistas, entregues à criação de gado (ABREU, 1998). O período de União Ibérica (1580-1640) assinalou grande expansão de bandeiras e entradas para além do limite de Tordesilhas. Tendo em vista que as duas coroas ibéricas respondiam a um mesmo rei e administração colonial, a expansão territorial para além do Velho Mundo revela o processo histórico de dilatação do capital adiante das fronteiras europeias.

O alcance fácil da via fluvial do São Francisco mais os barreiros de sal e a vegetação herbácea foram considerados fatores naturais para a extensão dos currais ao longo de suas margens, chegando às terras mineiras. Após períodos de seca brava no sertão do Nordeste e devido à maior proximidade dos centros mineradores, o norte de Minas Gerais ocupou o lugar

instrumentos, sem utensílios, sem máquinas" (FRANCO JÚNIOR, 1998, p. 9), onde os rios são de leite, as casas de pão de mel e as aves descem do céu já assadas. Utopia do século XIII, permaneceu viva centúrias adiante devido aos surtos de fome e às desigualdades socioeconômicas que assolavam as sociedades europeias na Idade Moderna. Mas a localização da Cocanha destinada a ter maior sucesso foi a América, já no século XVI:

Na descrição da colônia americana portuguesa recém-descoberta, aparecem vários topoi
paradisíacos absorvidos pela Cocanha. [...] Com o passar do tempo, contudo, tanto a América
portuguesa quanto a espanhola foram perdendo sua aura idílica inicial. Talvez ligado à
formação de uma nova percepção do espaço americano, o sentido positivo do nome "Brasil"
foi cedendo lugar a outro, negativo, que o associava à cor vermelha do pau-brasil e assim ao
mundo infernal e diabólico. Mas não era apenas a América que se desutopizava. A própria
Cocanha, devido às transformações provocadas pela sociedade industrial, aos poucos se
descaracterizava e se esvaziava de sua função sociocultural. (FRANCO JÚNIOR, 1998, p. 220).

O que se pretende com esta utopia e as narrativas míticas da colonização é deixar claro de antemão que a aventura fantasiosa de entrar pelos sertões foi movida pelas necessidades do estômago, que acompanharam o colonizador desde a sua terra natal. Não à toa, Gilberto Freyre desfaz a comparação de Fernão Cardim entre América Portuguesa e Cocanha quando trata da alimentação: "País de Cocagne coisa nenhuma: terra de alimentação incerta e vida difícil é que foi o Brasil dos três séculos coloniais. A sombra da monocultura esterilizando tudo" (FREYRE, 2006, p. 100). Sobre os mitos que envolvem a colonização, ver Holanda (2007) e Capel $(1989,1999)$. 
de principal fornecedor de carne bovina às zonas aurífera e diamantífera ainda no século XVIII, consolidando sua especialização na atividade pecuária ${ }^{61}$.

Conforme Caio Prado Júnior (2006), as fazendas se alastravam com certa facilidade devido ao crescente consumo do litoral e das minas e à praticidade com que eram estabelecidas: levantava-se uma casa coberta de palha, faziam-se toscos currais e introduzia-se o gado, o suficiente para ocupar vastos espaços e formar uma fazenda. Necessitava-se de pouca mão de obra, geralmente de negros e mulatos e, na falta destes, indígenas e mestiços, enfim, gente que transitava pelo sertão e que era afeita à "vida aventuresca"62.

Segundo Puntoni, a explicação para a expansão das fazendas encontra justificativa nas dificuldades da economia açucareira na Colônia no momento posterior à expulsão dos holandeses do Nordeste, em 1654. Some-se aos problemas internos, como epidemias, secas e tragédias afins, os fatores externos associados à concorrência interimperial provocada pela produção antilhana e à consequente inflação dos preços dos escravos a partir de 1680. Nesse sentido, a Coroa buscava uma alternativa para repor as perdas no trato colonial. "Expedições ao interior, antes até desencorajadas, passaram agora a receber apoio e mesmo a ser agenciadas pelo governo-geral" (PUNTONI, 2002, p. 125).

O processo de territorialização da Serra do Cabral, portanto, deu-se primeiro com o boi, mercadoria que conduz a si mesma e avança as fronteiras sertanejas no processo de apropriação territorial. Simeão Pires traz a informação de que o mestre de campo Manuel Nunes Viana ${ }^{63}$, temido chefe emboaba e procurador de dona Isabel Guedes de Brito, já era senhor de grandes

\footnotetext{
${ }^{61}$ Em Geografia histórica da capitania de Minas Gerais, José Joaquim da Rocha (1995) comenta, em meados 1778, que o solo da Comarca do Serro Frio era salitrado e fértil para o gado, "muito criado ali".

62 Termo aqui utilizado de forma irônica, pois, de acordo com Pedro Puntoni, a expansão das fazendas de gado pelo sertão estava relacionada às necessidades do período, e não ao "ethos aventureiro" dos sujeitos expansionistas, como apresenta Sérgio Buarque de Holanda (1995, p. 44).

63 "Uma das importantes figuras do Brasil no início do século XVIII. Manuel Nunes Viana nasceu em Portugal (Viana do Minho) e chegou ainda novo à Bahia. Internou-se no sertão desta capitania e assinalou-se na luta contra os índios. Defendeu os direitos de D. Isabel Maria Guedes de Brito, filha do mestre-de-campo Antônio Guedes de Brito [...], sobre as imensas propriedades legadas pelo seu pai, e foi nomeado pelo governador-geral do Estado do Brasil regente e mestre-de-campo do rio São Francisco. Tal cargo incumbiu-lhe várias responsabilidades: vigiar as criações de gado nos limites compreendidos entre o morro do Chapéu e as nascentes do rio das Velhas, combater os índios insubmissos, aniquilar os quilombos (isto é, os centros onde se agrupavam os escravos negros fugitivos) e castigar ladrões e assassinos. Fundou por conta própria grandes fazendas de gado, mandou construir uma residência em Tábua, perto da confluência do rio das Velhas com o São Francisco. Logo a seguir às primeiras descobertas de ouro, foi às minas de Caeté onde explorou ricos jazigos. Paralelamente a essa atividade, e contra as ordens régias, favoreceu o comércio do gado entre a capitania da Bahia e a região das Minas. Em 1707, quando da Guerra dos Emboabas [...], chefiou o partido dos emboabas contra os paulistas. Em 1710, na sequência da chegada do novo governador de São Paulo e Minas, Antônio de Albuquerque Coelho de Carvalho, Manuel Nunes Viana regressou à sua residência na Tábua, e em 14.2.1715 conseguiu de D. João V o seu perdão. No entanto, por causa dos constantes abusos que tinha cometido quando mestre-de-campo do rio São Francisco, foi obrigado a residir na cidade da Bahia. De 1725 a 1728, esteve em Lisboa, onde recebeu novos favores régios, e regressou à Bahia, onde veio a falecer dez anos mais tarde." (SILVA apud ANTONIL, 2007, 241).
} 
fazendas, "principalmente no Rio Jequitaí e na Tabua, hoje Joaquim Felício" (PIRES, 1979, p. 101), atual município da Serra do Cabral. Segundo o memorialista, Nunes Viana tinha grandes interesses econômicos em comandar os currais de gado e a salga do peixe destinados às minas, sendo seus currais na Tabua um dos fornecedores de carne à zona mineradora. Com isso, tornou-se alvo das preocupações reinóis sobre o crescente poder que tinha no sertão, pois "dispunha de tropas, ordenanças, dentre os quais se destacava o valente preto Bigode, comandante de quase um batalhão de agregados e escravos armados" (PIRES, 1979, p. 119) ${ }^{64}$.

A cartografia, em especial os mapas de José Joaquim da Rocha, que acusa fazendas nas margens do Jequitaí ligando o caminho que conduzia às margens do São Francisco rumo à Bahia, reforça a importância desses estabelecimentos no curso de ocupação da região e sua finalidade específica: dar sustento ao processo de territorialização que, estimulado pelo avanço europeu, se expandia com a apropriação de novos espaços. O motor era o "sentido da colonização", pois "As collonias [...] são estabelecidas em utilidade da Metropole" (ROTEIRO..., 1900, p. 102). Pela Serra do Cabral fazer parte do caminho, mas sequer constar nos mapas, presume-se o seu papel subsidiário na economia e na política na capitania, porém integrada ao andamento da territorialização pela dinâmica do Antigo Sistema Colonial.

Supõe-se também que os caminhos do gado apresentavam precoce e relativa movimentação. Apoiando-se na cartografia precedente, o estadunidense Orville Derby ${ }^{65}$

\footnotetext{
${ }^{64}$ Em dissertação sobre a pecuária e a transformação dos cerrados piauienses, Vicente Eudes Lemos Alves refaz a territorialização daqueles sertões e mostra que o agregado na função de jagunço já estava presente no período colonial. Para tal, apresenta o documento Descrição da Capitania de São José do Piauí, de 1772, redigido pelo ouvidor daquela capitania, Antônio José de Morais Mourão:
}

\begin{abstract}
Além dos senhores das fazendas ou seus feitores, vaqueiros, fábricas e mais pessoas que nelas moram, como uma só família, há outras muitas a que chamam agregados, e são de duas formas: uns que em algumas ocasiões servem como criador inerentes às famílias, outros que nem servem, nem na família se incluem, antes têm fogo separado, posto que dentro da mesma fazenda. Os primeiros, dado que maus, são toleráveis, mas os segundos, são péssimos e danosos em todo o sentido. Disfarçam estes refinados vadios, preguiçosos, ladrões, matadores e pestes da república a sua péssima conduta com duas raízes de mandioca ou de tabaco que fabricam e que nunca chega para os sustentar e suas famílias mais que um ou dois meses no ano, mantendose o resto do mesmo, do que furtam e caloteiam na mesma fazenda em que moram e nas circunvizinhanças, porque nenhum deles tem outro ofício nem qualquer que seus filhos aprendam. Os donos das fazendas os toleram com semelhante vida e com prejuízo seu, parte por medo, pois se os encontram ou querem dela expulsar, só se expõem a um tiro, parte por dependência, porque se fazem mais respeitados com o seu auxílio; e quando se querem vingar de alguém têm prontos os seus agregados para toda a casta de despique [...]. Os seus bens são a casa de palha, que se fabrica num dia, um cavalo, uma espada, uma faca e alguns cachorros que facilmente consigo mudam e com a mesma facilidade sustentam enquanto lhes é preciso andar no mato. São estes demônios encarnados os curibolas, mestiços, cabras, cafus e mais catres de que a terra só é abundante, que acossados pelas justiças das outras capitanias em que delinquem e onde lhes não é fácil ocultar-se por povoadas e abertas, buscam esta como um infalível asilo das suas maldades e lugar próprio para continuarem nelas com todo o desafogo e sossego. (MOTT, 1985, p. 26-27 apud ALVES, 2000, p. 30-31).
\end{abstract}

${ }^{65}$ Orville Derby (1851-1915) foi um geólogo e geógrafo nascido nos Estados Unidos. Ele integrou a Comissão Hidráulica criada pelo conselheiro imperial Cansanção de Sinimbu, em 1879, chefiada pelo seu conterrâneo William Milnor Roberts, para explorar potencial de navegação no vale do rio São Francisco, navegando da foz até 
concluiu, após observações em sua expedição de 1879, que o vale do rio Jequitaí dava acesso mais fácil ao rio São Francisco a partir da seção da Serra do Espinhaço, “cruzada pela antiga estrada indígena" (DERBY, 1901, p. 245 apud CARRARA, 2007, p. 586). Supôs o geólogo ter sido o rio Jequitaí conhecido e frequentado pelos europeus antes do rio das Velhas, tendo estabelecido contato com as nações locais, inclusive usufruindo do seu conhecimento prévio do território.

Com base no Roteiro... (1900), Capistrano de Abreu (1998) informa que o povoamento foi se adensando conforme os moradores se estabeleciam por esses caminhos, dispostos a comprar as reses mais fracas para posteriormente comercializá-las em melhores condições ${ }^{66}$. Assim, os currais iam crescendo, facilitados pela presença de "jazidas de sal na extensão de três graus geográficos”, desde a barra do Salitre até São Romão, no rio São Francisco. Além da criação, os moradores faziam pequenas lavouras, cujas sobras vendiam aos transeuntes, também se empenhando na manutenção dessas vias. No mais, conforme se assentavam, faziam açudes, plantavam cana, construíam engenhocas.

Para tal povoamento, recorreu-se ao uso da violência para subordinar povos que já se encontravam ali anteriormente à ocupação colonial e eram vistos ou como um recurso à territorialização pecuária ou como um empecilho. Entre os primeiros relatos escritos no Brasil a respeito do rio São Francisco, está o de Gabriel Soares de Souza em seu Tratado descriptivo do Brasil, de 1587, informando que o grande rio era conhecido como Opará pelos seus primeiros habitantes. Assinala o português sobre o curso d'água:

[...] mui nomeado entre todas as nações, das quais foi sempre muito povoado, e tiveram uns com outras [nações] sobre os sítios grandes guerras, por ser a terra muito fértil pelas suas ribeiras, e por acharem nele grandes pescarias. (CARRARA, 2007, p. 40-41).

Respondendo, direta ou indiretamente, aos interesses metropolitanos em garantir a acumulação primitiva europeia, a efetivação da ocupação pela economia pecuária teve na

Pirapora. Na comissão estava o engenheiro baiano Teodoro Sampaio, de quem Derby se tornou muito amigo (KIDDY, 2010).

66 "Esta parte que seria inteiramente perdida, serve também de prover a Povoação, e cultura dos dittos Paízes medios para della utilizarem-se vão nelles estabelecerem-se muitos povoadores, os quaes a comprão nas estradas por baixo preço aos conductores das Boiadas postos na precisão de a deixarem, e sem esperança de a poderem mais haver, ou porque pereceria em muitos lugares à sede, ou porque recuperadas as forças se internarião pelos Sertões, e ou porque acharião quem d'ella se utilizasse, sem fazer desembolço algum, como he bem frequente pelas dittas estradas.

Os novos povoadores sustentando-se d'aquellas reses, de que não esperão outro interesse, cuidão em que se restabeleção as que lhes sobrão para as irem no anno seguinte vender aos mesmos portos, e para este fim, como os dittos Paizes são por sua natureza aridos, e paressem pela falta de agoa em muitas partes inhabitaveis não só se aproveitão da que descobrem em alguns lugares mais remotos ; mas procurão com a industria fazer tanques onde a conservão no inverno e por este modo utilizando-se dos gados, que se crião nas Capitanias do interior, passão tambem a estabelecer novas creações em sitios, que serião inteiramente despovoados, se este primeiro interesse não os levasse a elles.” (ROTEIRO..., 1900, p. 113). 
submissão dos grupos ali encontrados um capítulo na territorialização e suas relações de poder. A introdução do capital requer rispidez, a tal ponto que é preciso quebrar o padrão de relações locais para que seu modelo se instale, expropriando de forma brutal os grupos que travam a sua expansão. Com eles - neste caso, indígenas e quilombolas -, a violência é explícita, pois ao não aceitarem a submissão, são eliminados ou agregados à construção da nova lógica. Para abrir caminho à modernização e suas forças destrutivas, o recurso às armas de fogo se fez necessário (KURZ, 1997).

Considerando-se a acumulação primitiva a ação introdutória do capitalismo no Novo Mundo, a imposição das forças produtivas se fez acompanhar de retumbante força destrutiva para abrir caminho à subsequente modernização, entre elas, ainda de acordo com Robert Kurz, a invenção das armas de fogo.

Ao se debruçar sobre as fronteiras coloniais e as populações indígenas em Minas Gerais, Renato Pinto Venâncio (2007) aponta para a combinação da destruição e da assimilação do mundo indígena conforme a expansão da fronteira dava seus passos ${ }^{67}$. O sertão mineiro, por fazer limite com outras capitanias, se tornou o espaço de confluência para as etnias que fugiam da colonização nos litorais, com povos migrando rumo ao interior antes de ocorrer a expansão efetiva da fronteira colonial. Esse movimento por si só já contribuiria para alterar o costume de migração e a destruição dos grupos ${ }^{68}$.

Venâncio ainda aponta para uma mudança de perfil do primeiro eixo de penetração territorial conforme o sertão se tornava alvo da expansão das fazendas de gado, o que revela não só o objetivo de conquistar terras, mas também certa racionalidade econômica na forma de expandir a fronteira e criar o gado. Em certo momento do século XVIII, o fundamental não era mais escravizar o índio, mas conquistar terras. Para tal conquista, não se cultivavam mais os pastos, como se fazia em princípio, mas exploravam-se as espécies nascidas após as queimadas das matas. Além disso, não havia seleção do gado, sendo comum o abate daqueles de maior porte, o que implicava, com o tempo, na redução do peso médio dos animais, incentivando os criadores a aumentarem o tamanho das fazendas, o que causaria, em consequência, a guerra

\footnotetext{
67 Segundo o autor, para Florestan Fernandes, havia para os indígenas três consequências decorrentes da colonização: a preservação da autonomia tribal por meios violentos, a qual teria de tender, nas novas condições, para a expulsão do lavrador branco; a submissão nas duas condições indicadas, de "aliados" e de "escravos"; e a preservação da autonomia tribal por meios passivos, a qual teria de assumir a feição de migrações para as áreas em que o branco não pudesse exercer dominação efetiva. Ele aponta para a não consideração dos movimentos indígenas pelo sertão antecessores desses três processos analisados por Fernandes.

${ }^{68}$ Em obra embasada em farta literatura, mas desapegada dos rigores científicos, Moacyr Scliar (2003) comenta que as migrações dos indígenas, antes em busca da Terra sem Males, passavam a se dirigir não mais para o litoral ocupado pelo homem branco, mas para o sertão, que se transformava em abrigo contra as pestes, ao mesmo tempo em que refúgio de escravos fugidos.
} 
com os povos nativos (VENÂNCIO, 2007). A terra passa a ser o motivo dos conflitos, corroborando a ideia de Puntoni, para quem os embates passam a ser de extermínio, não mais de escravização. Porém, esse não parece ter sido o único destino pensado aos povos originários.

O interesse da ocupação e expansão sertanejas mais uma vez se revela no documento do Roteiro..., onde se faz presente a preocupação sobre como proceder com os povos nativos pósGuerra dos Bárbaros. Para seu autor, não atacar o indígena facilitaria a colonização e abriria a possibilidade de agregá-lo ao Antigo Sistema Colonial, pois, se absorvido pelo Sistema, se fixaria no território a serviço da Coroa $^{69}$. A advertência em não guerrear com os nativos abriria a oportunidade para que se formassem corpos compostos de "indios sem disciplina alguma militar, ou de Paisanos libertinos, e vadios", para que trabalhassem nas lavouras de gêneros comestíveis e abrissem estradas entre os arraiais, com o objetivo de atrair o povoamento, promover a concorrência e "viver em harmonia".

\begin{abstract}
Não atacar povoação alguma das Nações silvestres e transitando-se por ellas, deixar intactos os seus domicilios, e as suas plantações, porque esta nossa nova conducta, e desusado modo de as tratar môva a que ellas fujão da nossa communicação e se persuadão mais facilmente que os nossos intentos só são a viver com ellas em boa armonia, sem destruir seus pobres haveres nem tiral-lhe as proprias vidas. (ROTEIRO..., 1900, p. 90).
\end{abstract}

Já no século XIX, em viagem pelo Brasil entre 1817 e 1820, o alemão Johann Baptist von Spix dispendeu parte do roteiro em Minas Gerais. Entre o Tejuco e o termo de Minas Novas, o naturalista encontrou pelo caminho grupos incorporados à produção de mercadoria e os temíveis botocudos, denominação dada aos aborígenes antropófagos e arredios à colonização ${ }^{70}$.

[...] A mais numerosa e temível nação dos indígenas primitivos, nas matas entre o Rio Doce e o Rio de Contas, é a dos botocudos, muitas vezes indistintamente chamados de frexes, monos, aimorés. [...] Foram fundadas diversas aldeias desses antropófagos, ao longo do rio, e já os botocudos começam a ocupar-se com a lavoura; eles trazem aos colonos, de tempos em tempos, ipecacuanha, papagaios domesticados, peles de onça, etc., para permutar com utensílios europeus, e prestam serviço, como remadores [...]. De fato, ciosos de sua liberdade, ainda não se submeteram aos portugueses, como os coroados e os coropós; contudo, vê o filantropo, com prazer, o contínuo progresso desses filhos das selvas, que, ainda no começo do século, eram, por decreto real, declarados fora da lei e inimigos do Estado, perseguidos pelas patrulhas e entradas, como feras, e capturados e condenados a dez anos de servidão, ou trucidados com crueldade sem precedente. (SPIX, 1981, p. 56, grifos do autor).

\footnotetext{
${ }^{69}$ Cabe lembrar que a segunda metade do século XVIII foi marcada pela discussão entre Portugal e Espanha sobre as terras avançadas em favor dos portugueses para além do limite de Tordesilhas. O Tratado de Madri (1750) estabeleceu o uti possidetis como legitimação de posse, o que fez com que o lado português utilizasse inclusive o indígena como prova de direito ao território no século XVIII (FÁLCON, 1982; MAGNOLI, 1997).

${ }^{70}$ Faz-se oportuno lembrar a filantropia como estreitamente ligada ao "fardo do homem branco" dentro do pensamento ocidental corrente no século XIX, cuja incumbência estaria na civilização dos povos julgados inferiores, sobretudo pelos europeus.
} 
Langfur $(2011)^{71}$ e Paraiso (2011) ${ }^{72}$ mostram que com o declínio da mineração ainda em meados do século XVIII, situação agravada no século XIX, o retorno às atividades agropecuárias em Minas Gerais criava tensões com a apropriação territorial sobre os sertões, cujas terras estavam povoadas pelo gentio. Em 1808, D. João VI declarou guerra aos botocudos, por se tornarem um entrave à expansão das fazendas e das pesquisas mineralógicas.

Diante do contexto da territorialização ocorrendo com a expansão sobre áreas alvo de anexação ao Estado que se engendrava, permite-se concordar com a afirmação de Antonio Carlos Robert Moraes (2002), para quem o território é, entre outras coisas, uma construção militar enquanto resultado de conquista espacial, pois a violência institucionalizada ou estimulada pelo Estado impele à submissão dos habitantes da terra cobiçada. Em complemento, Paraiso afirma que em um contexto no qual o Estado é concebido como uma unidade territorial e sua população compartilha língua, cultura e projeto político, só é possível pensar o conjunto de relações interétnicas pela ótica da dominação, voltada para a destruição de todas e quaisquer formas de diversidade sociocultural, em nome da criação da unidade nacional.

Outra contradição experimentada pelo Estado vinha do fato de que, para determinados segmentos dominantes, residentes em áreas economicamente periféricas, a mão de obra indígena era vital, devendo ser criados, portanto, mecanismos preservadores de sua existência e integração. Já nas áreas de economia mais capitalizada, o índio era visto como um obstáculo que deveria ser eliminado em nome do que consideravam progresso, da expansão econômica e da civilização.

Para a mesma direção, aponta Erivaldo Fagundes Neves (2008), para quem Portugal colonizou o Brasil no encadeamento beligerante das suas conquistas territoriais e, para estender suas instituições jurídico-políticas e socioculturais à Colônia, formou corporações paramilitares submetidas à autoridade dos senhores de terras, que as sustentavam. Assim, o "conquistador", caracterizado de militar "comissionado", constituía-se mais em "guerreiro do que burocrata",

\footnotetext{
${ }^{71}$ Em meados do século XVIII, com a diminuição do boom do ouro, indígenas que haviam conseguido sobreviver para além da fronteira do distrito minerador estavam novamente se tornando o grande inimigo dos colonos, que, por sua vez, estavam empenhados na ocupação de novas terras e no descobrimento de novas fontes de riqueza e esperavam restaurar suas fortunas em franco declínio ou simplesmente garantir a sua sobrevivência (LANGFUR, 2011).

${ }^{72}$ A crise vivida pela economia portuguesa na segunda metade do século XVIII, agravada pelo declínio da extração de ouro em Minas Gerais a partir de meados do século, impeliu à adoção de medidas para promover o melhor aproveitamento dos produtos coloniais e incentivar a exploração de outros, voltados para a exportação. Isso pressupunha a conquista de novos espaços aos indígenas e sua incorporação às rotas de comércio. Vários projetos foram pensados para a América Portuguesa, inclusive para as áreas até então proibidas aos colonos com a finalidade de evitar o acesso indiscriminado às zonas de mineração, ou seja, "os sertões de Ilhéus, Porto Seguro, norte do Espírito Santo e leste de Minas Gerais" (PARAISO, 2011, p. 81).
} 
numa empresa que, apesar de pública, alimentava-se de vantagens pessoais, capazes de equipar as tropas e assegurar o lucro da atividade.

Com isso, a conquista territorial aparece como um empreendimento militar, tornando claro o sentido de existência do Estado moderno e a concretização do capitalismo via Estado e seu monopólio da violência extraeconômica. Ele força os sujeitos a ele submetidos à produção de mercadorias, possibilitando contestar a colonização e a formação do Estado como um processo pacífico de civilização de povos bárbaros. Da colonização e sua acumulação primitiva pela metrópole à colonização sistemática do Estado recém-independente, a violência assume o papel principal na apropriação e constituição dos territórios modernos, sem qualquer pudor. ${ }^{73}$

$\mathrm{Na}$ Serra do Cabral, os povos que a ocuparam primeiro deixaram seus traços tanto nos rochedos - formando desenhos em tons de vermelho, preto, branco e amarelo, que atestam a complexidade dos grupos e a biodiversidade daquele sertão -, quanto nos nomes de alguns rios e lugares e no sangue dos seus descendentes.

\section{Figura 5 - Exemplo de pintura em lapa na Serra do Cabral}

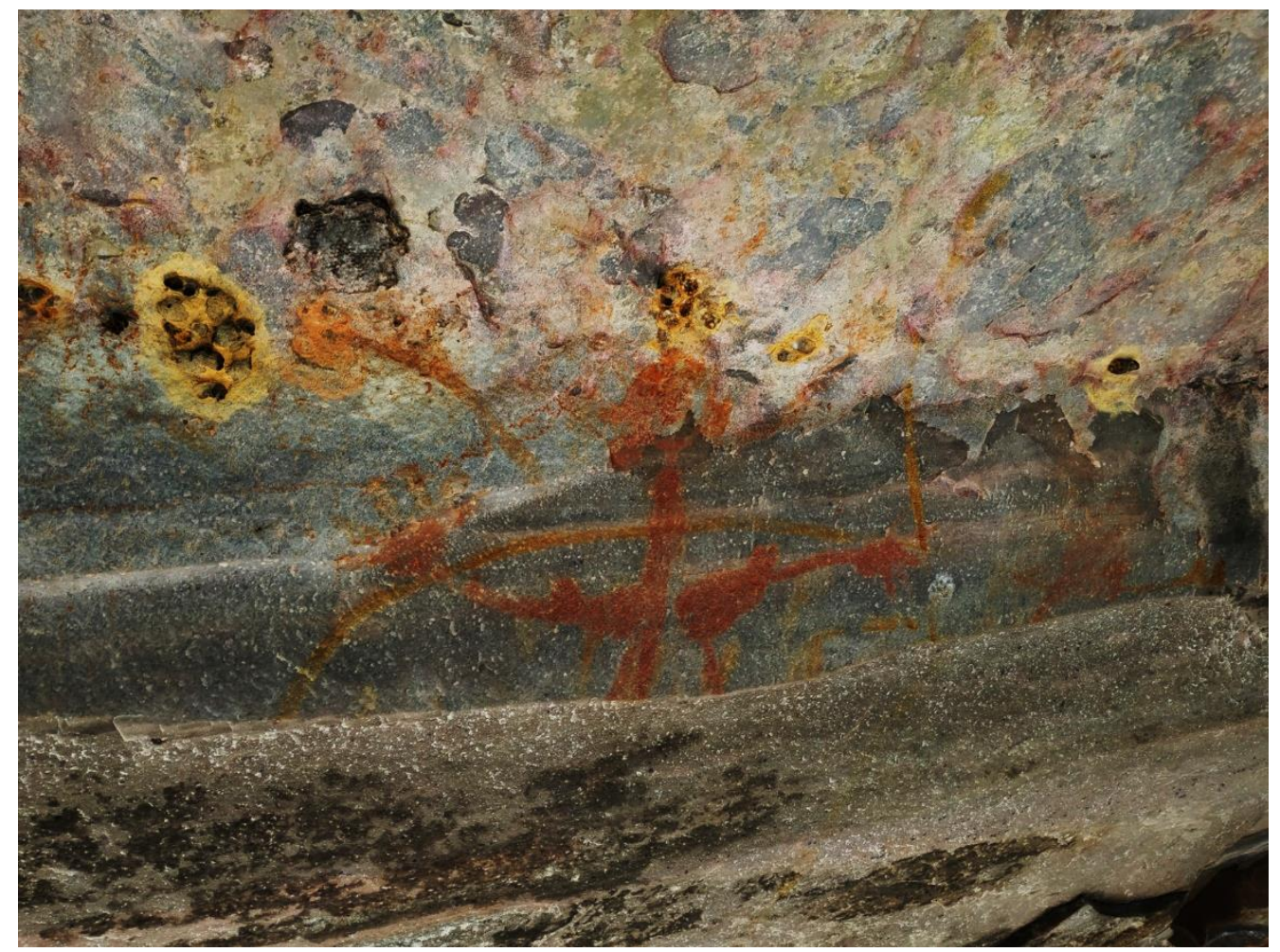

Fonte: acervo pessoal, janeiro de 2017.

\footnotetext{
73 "Na história real, como se sabe, o papel principal é desempenhado pela conquista, a subjugação, o assassínio para roubar, em suma, a violência. Já na economia política, tão branda, imperou sempre o idílio. Direito e 'trabalho' foram, desde tempos imemoriais, os únicos meios de enriquecimento, excetuando-se sempre, é claro, 'este ano'. Na realidade, os métodos da acumulação primitiva podem ser qualquer coisa, menos idílicos.” (MARX, 2013, v. I, p. 786).
} 
As informações do anuário estatístico de Minas Gerais referentes a Bocaiúva e áreas sob sua jurisdição, incluindo a Serra do Cabral, são explicativas desse legado, para além dos dados técnicos:

\begin{abstract}
Os principaes rios que banham este municipio, são: o Jequitahy, que tem as suas nascentes proximas do pico do Itacambira, servindo de linha divisoria do municipio e recebe, como os principaes affluentes, os rios: Guavinipam (o qual recebe por sua vez o S. Lamberto), e o S. Pedro ; é navegavel desde o logar denominado Barra, isto e', desde que recebe o Guavinipam, até a sua confluencia no São Francisco. Damos adeante a descripção do Jequitahy. O Verde, nasce no logar denominado Boi de Carro, correndo sempre na direç̧ão de Sul para Norte, ate' receber o Verde Pequeno, donde toma d'ahi por deante a direcção de Nordeste, ate' entrar no S. Francisco. Seos principaes affluentes são: o ribeirão do Fogo, o rio Vieira (que recebe o Cedro e dos Bois e banha a cidade), o Juramento, o Caetitu, o Gorutuba, que nasce proximo do districto do Brejo das Almas ; o Pacuhy, que nasce 16 kilometros abaixo da cidade e vae despejar suas aguas no São Francisco ; e ainda ha alguns ribeirões, como o Riachão, o dos Bois, o do Ouro, o Canna-Brava, o Canoas, etc. (SENNA, 1909, p. 674-675).
\end{abstract}

Desses rios e serras, alguns têm nomes indigenas, cujas origens passamos a dar: GUAVINIPAM nos parece derivado de goá, baixada - y, rio - pan, que corta, atravessa ; ou <<rio que corta a baixada >>. Guaipon se transformou no vocabulo actual, segundo pensamos.

JEQUITAHY é indigena e corruptela de Jiqui-tai-y, <<rio das formigas >> ; jiquitaia, ou formiga que arde.

(Theodoro Sampaio, op. cit., O tupi na Geogr.. Nacional, pag. 136). (...).

O Rio JEQUITAHY. - E' diamantifero o rio Jequitahy, caudaloso e navegavel por canoas, nas enchentes ; tem nascentes diversamente dadas, por uns, nas proximidades de Itacambira e por outros, na serra de Curimatahy, ou na do Arrenegado.

Corre este rio para N. O. e recebe os affluentes Mandaçaia (ou Mandásaia), Trahyras, São Lamberto (tambem chamado Sipó), indo desembocar no rio S. Francisco, pela margem direita, 28 kilometros abaixo da Barra do Guaicuhy.

Tem o rio Jequitahy 42 legoas de curso, um volume d'agua de 4.800 palmos cubicos e 267 palmos de largura na foz, segundo o engenheiro Henrique Gerber escrevia em 1868.

O engenheiro Catão Gomes Jardim, em 1885, escrevia sobre este rio: $<<O$ Jequitahy nasce nas serras de S. Domingos do Arrenegado, recebe o Catingas pela margem direita e que vem dos campos de Sant'Anna e dos chapadões da freguezia de Olhos d'Agua e Bonfim ; recebe o Guavinipam, o São Lamberto, os corregos de Jatobá e Fundo, alem de diversos outros tributarios ; banha a nova cidade do Jequitahy, onde recebe pela direita o ribeirão do Sitio e vae lançar-se no S. Francisco com um curso de mais de 200 kilometros, sendo 90 da povoação do Jequitahy á sua foz.

Tambem o engenheiro Miguel Telve e Argollo escreveo sobre o rio Jequitahy, dando a sua foz distante 55 kilometros da cachoeira do Pirapóra e avaliando em 250 kilometros a extensão do seo curso, em 59 metros a sua largura e em 48 metros cubicos o seo volume dagua por segundo.

Diz o mesmo engenheiro Argollo: $<<$ Nas aguas ordinarias o Jequitahy e' navegavel até 16 kilometros acima da barra e no tempo das cheias até 154 kilometros, onde a navegação fica interrompida por cachoeiras > (SENNA, 1909, p. 680, grifos nossos).

A entrevista realizada com os irmãos Geraldo e José Telheiro, respectivamente 85 e 80 anos (2017), mais conhecidos como irmãos Telheiro, deu uma amostra do uso da violência sobre os povos autóctones na Serra. Segundo eles, a bisavó era "índia” pega por cachorros para trabalhar nas lavouras de mandioca e outros mantimentos de subsistência, trabalho que 
prosseguiu nas gerações seguintes até chegar aos dois, que quebraram a continuidade ao decidirem, após os 40 anos de idade, se dedicar ao garimpo de diamante. Quando perguntados sobre a etnia da antepassada, disseram ter total desconhecimento, pois era informação ouvida de seus pais e avós.

Acrescido do preconceito corrente, partilha de passado semelhante Teotônio da Silva, 92 anos (2015), garimpeiro em sua juventude no povoado do Buriti Grande: sua avó, batizada Joana Rosa de Moura, era indígena a viver na Serra, nos arredores do povoado. Pedro Bispo, filho do mandatário local Leonel Borém, teve filhos com ela, dentre eles, Pedrelina, mãe do garimpeiro. Não sendo reconhecidos pela família paterna devido à origem, seus descendentes não só não receberam o sobrenome da família, bem como, deserdados, se juntaram à leva de sertanejos pobres a "cavacar" nas grupiaras. O depoimento dos garimpeiros mostra como o capital destrói o passado, pois influi na relação do trabalhador com sua família, sendo o fetiche a máscara dessa crueldade. Tais exemplos também induzem a concordar com Ângelo Carrara (2007), para quem a Guerra dos Bárbaros não se encerrou nos Seiscentos: extermínios e assimilações continuaram acontecendo até a virada do século XIX para o XX na região em destaque - no caso, a Serra do Cabral.

Quando o indígena não é exterminado, ele é integrado. Em sua passagem pelo norte de Minas Gerais entre 1817e 1820, Spix e Martius dão um exemplo do processo de assimilação decorrente do desgaste provocado por conflitos entre as próprias etnias, que já estavam migrando por conta do avanço da ocupação colonial:

[...] Encontramos, pois, este posto em pé de guerra contra aqueles antropófagos, e não podíamos contar com índios a observar, senão os pacíficos macuanis, que aqui se demoravam. Essa tribo, também chamada de maconi, é uma das mais fracas que habitam estas regiões montanhosas, na fronteira entre as províncias de Minas Gerais, Porto Seguro e Bahia, e, pelo terror que têm aos seus poderosos inimigos, os botocudos, tanta amizade fizeram com os portugueses, que, talvez dentro em poucos decênios, tenha ela perdido inteiramente todos os seus característicos. (SPIX; MARTIUS, 1981, p. 63).

Ambos os processos são condizentes com os pressupostos necessários para a formação e manutenção da fazenda pecuária. Nesses casos, a separação entre capital e violência ainda não ocorreu, o que passa a acontecer conforme é desencadeada a autonomização dos fatores de produção. “A tradição dos oprimidos nos ensina que o ‘estado de exceção' em que vivemos é na verdade a regra geral" (BENJAMIN, 2010, p. 226). 


\title{
3.2. Toda coisa que pode ser roubada ou apropriada pode ser mercadoria: a terra e o trabalho
}

Em meados do século XIX, alguma coisa se transformava no que tangia à terra, não apenas na esfera da lei.

\begin{abstract}
Entre 1855 e 1860, realizou-se o primeiro cadastramento imobiliário do domínio privado no Brasil, determinado pelo já referido decreto que regulamentou a "Lei de Terras". Como o Estado brasileiro não dispunha de aparelho burocrático capaz de executá-lo, incumbiu, em 1854, os párocos - então subordinados ao poder civil, remunerados pelas côngruas dos governos provinciais para responderem pelas estatísticas populacionais - desse encargo nas respectivas freguesias, em todo o Império. Em consequência, originou-se a imprópria denominação de "registros eclesiásticos ou paroquiais" para os lançamentos que definiram as terras devolutas ao delimitar o domínio privado e, por extensão, o público. (NEVES, 2008 p. 16).
\end{abstract}

Em se tratando da propriedade da terra, a Lei de Terras (1850) cumpriu papel importante no processo de cercamento e expropriação na Serra - tendo em vista que foi decretada no mesmo ano em que se aboliu oficialmente o comércio de escravos. Do século XVI até o XIX, a terra era propriedade da Coroa, em uma concepção tradicional de prestígio àquele que recebia do rei a dádiva de povoá-la. Já nos Oitocentos, dentro do contexto externo de pressão para a supressão do tráfico e da escravidão em uma economia imperialista que industrializava as potências europeias, ao mesmo tempo em que os mercados internacionais demandavam mais produtos tropicais, a terra deixa de ser vista como prestígio e passa a ser encarada como mercadoria, com poder econômico.

A lei proibia a aquisição de terras públicas através de qualquer outro meio que não a compra, "colocando um fim às formas tradicionais de adquirir terras mediante posses e mediante doações da Coroa" (COSTA, 1999, p. 171). Porém, tornar a terra propriedade privada no Império não significou formar um mercado fundiário; a apropriação foi feita por grilagem violenta, na qual, desde o século XVIII, as sesmarias eram divididas a cada três léguas por terras devolutas $^{74}$ e já havia quem extraísse tributos daqueles que ocupavam as sesmarias ${ }^{75}$.

Quem obteve propriedade ilegalmente por meio de ocupação ou doação nos anos precedentes à lei, pôde registrar e validar seus títulos após demarcar seus limites e pagar as

\footnotetext{
74 “As suas terras são repartidas aos moradores em sesmarias, que ou datas de trez legoas, cuja cultura consiste na creação gados, mais vaccum, que cavalar: Cada huma das sesmarias forma huma fazenda, deixando-se huma legoa para divizsão de huma, e outra fazenda: na ditta legoa entrão igualmente os visinhos a procura os seus gados, sem contudo poderem nella levantar cazas, e curraes." (ROTEIRO..., 1900, p. 79).

${ }^{75}$ Em complemento à passagem de Capistrano de Abreu já citada anteriormente, a qual afirma que desde o século XVII já havia mais de cem famílias paulistas ocupando terras com criação de gado entre os rios São Francisco e das Velhas, Erivaldo Neves acrescenta que elas já pagavam renda para Isabel Guedes de Brito (NEVES, 2008).
} 
taxas, cujo dinheiro seria, em tese, empregado na demarcação de terras públicas e na “importação de colonos livres”. Para tal, criou-se o serviço burocrático de Repartição Geral das Terras Públicas.

\begin{abstract}
$\mathrm{Na}$ época da Independência, a doação de lotes, característica da política de terras coloniais, foi abolida, e até 1850 , quando a Lei de Terras foi decretada, a ocupação tornou-se a única forma de obter terra (exceção feita da compra ou herança). Tal fato criou uma situação anárquica no sistema da propriedade rural, uma vez que os direitos dos ocupantes não foram reconhecidos pela lei. As "posses" resultantes da ocupação aumentaram de forma incontrolável e os posseiros acumularam grandes extensões de terra cujos limites eram vagamente definidos por acidentes geográficos naturais: um rio, uma queda d'água, uma encosta. Apesar de essas propriedades não possuírem estatuto legal, elas eram compradas, vendidas e avaliadas à vontade. (COSTA, 1999, p. 176).
\end{abstract}

A afirmação de Emília Viotti da Costa ajuda a entender o processo de registro das terras, mas não enfatiza a forma mais generalizada de aquisição da terra, a grilagem, que já acontecia no sertão dentro das amarras do Antigo Sistema Colonial. ${ }^{76}$ A vasta sesmaria dos Guedes de Brito, por exemplo, sofria com a ocupação desencadeada pela expansão de fazendas pelos sertões baianos assim que houve a descoberta do ouro, o que exigia dos procuradores vigilantes do patrimônio maior rapidez e habilidade nas negociações para que fosse devidamente legalizada através dos arrendamentos, quando a venda não fosse possível. Nesse processo de povoamento, legalizaram-se posses ilícitas ao arrendarem terrenos ocupados, sob pressão dos procuradores dos titulares absenteístas. "Do mesmo modo vendiam-se sítios e fazendas aos rendeiros" (NEVES, 2008, p. 105).

Chegado o Império, o senhoriato agrário constituía-se no país no único segmento social com acesso ao poder político, o qual emanava da propriedade da terra. Desde a autonomia política, fazia-se necessária a reordenação jurídica da estrutura fundiária - originária do sistema de sesmarias, que pouco correspondia ao momento econômico então vivido - para redimensionar a economia agrária do Brasil. A consolidação do Estado Nacional e as reformas jurídico-políticas vêm ao encontro do fim do tráfico internacional de cativos e à famigerada Lei de Terras de 1850, que pretendia regulamentar o acesso à terra e "estancar o processo de

\footnotetext{
${ }^{76}$ Apesar do suposto anacronismo do termo, Márcia Motta exemplifica a situação:
}

Sobre a utilização de fontes históricas é emblemático o recurso de falsificar cartas de sesmarias, algumas "esquentadas" com datas de mais de 200 anos. Para um leigo, é difícil imaginar o porquê da utilização daquele documento. No entanto, não há nenhum mistério. As cartas de sesmarias são concessões de terras num período onde a demarcação do limite territorial era não somente dificultada pela ausência de agrimensores, mas era também obstaculizada por outros condicionantes históricos. Até o ano de 1822 (quando do término do sistema de sesmarias), a delimitação da terra ocorria via emprego de marcos geográficos, como por exemplo "até os findos do morro X", "até o rio Y". (MOTTA, 2002, p. 84). 
apossamento que vinha ocorrendo indiscriminadamente", tumultuando a ordem jurídica (NEVES, 2008, p. 112).

O interesse do estabelecimento da lei era, na verdade, vedar o acesso à propriedade da terra à população livre pobre e imigrante, sobretudo àquela com seus dias de cativeiro $\operatorname{contados}^{77}$. A lei incrementaria o processo de modernização a partir da imposição de uma aparência fetichizada de autonomia, na qual os membros de uma relação social de produção e acumulação apareceriam como proprietários de mercadorias que lhes auferiam rendimentos (terra, capital e trabalho). Conforme Karl Marx (2013, v. 1), seria esse o mecanismo da teoria moderna da colonização.

Um Estado recém-independente e de fartas dimensões territoriais possibilitaria, em tese, o acesso aos meios de produção não produzidos - no caso, a terra. Para garantir a continuidade da produção de riqueza, era preciso torná-la escassa. Discutindo com a tese de Edward Gibbon Wakefield sobre os territórios da América do Norte, Nova Zelândia e Austrália do Sul, Karl Marx contrapõe a chamada acumulação primitiva e o plano de colonização sistemática apresentado pelo economista britânico (MARX, 2013, v. 1). A legislação fundiária e a política imigrantista no Brasil pós-1850 tiveram em sua formação os preceitos daquele plano.

Em sua tese $O$ colono que virou suco: terra, trabalho, Estado e capital na modernização da citricultura paulista, Cássio Boechat propõe, a partir do caso do oeste paulista, diferenciar o "sentido da colonização" de Caio Prado Júnior do Antigo Sistema Colonial de Fernando Novais, para pensar a reprodução social das ex-colônias durante os Oitocentos. Para ele, a colonização sistemática de Karl Marx como projeto de Estado para viabilizar a acumulação e sua reprodução ampliada desnuda a expansão territorial do valor, considerando que um padrão social de reprodução do capital já estava em vigor no contexto pós-Revolução Industrial, sendo este o modelo a ser perseguido pelos Estados-nações em formação (BOECHAT, 2013).

A existência de um Estado fundamentado no compromisso coronelista, a organizar tanto a apropriação da base fundiária como a exploração do trabalho, traria as condições para a

\footnotetext{
${ }^{77} \mathrm{Em}$ tese de doutorado sobre a disputa por terras entre latifundiários cafeicultores e posseiros livres pobres no contexto da Lei de Terras de 1850, Márcia Motta discorda dessa interpretação. Não é possível aprofundar esse debate, mas é importante apontar a análise da historiadora:
} 
passagem a um Estado planejador, que se autonomizaria da propriedade fundiária e do capital para organizar e fomentar a produção agrícola modernizada, a industrialização e a financeirização, além de seguir organizando a apropriação da base fundiária e a exploração do trabalho (BOECHAT, 2013). Com isso, o monopólio da terra mobilizaria o trabalho, garantindo a cisão dos fatores de produção.

O "sentido da colonização sistemática" deve ser diferenciado do "sentido da colonização", porque este último promoveu a acumulação primitiva do capital permitindo, ao mesmo tempo, a superação do próprio sistema colonial, o que contribuiu para a formação do Brasil contemporâneo. Por outro lado, as mudanças que estavam no âmago do projeto de "colonização sistemática" indicavam um novo "sentido" a ser buscado para a acumulação de capital (BOECHAT, 2013, p. 163).

A lei não só trazia à tona o processo de aparência de autonomização dos fatores de produção, como também inaugurava uma transição para o que significavam propriedade e riqueza no novo país. Junto à autonomização, as mercadorias apareceriam gradualmente como mais importantes do que seus proprietários, assumindo o papel fetichista de agentes da relação social, abstraindo a centralidade dos processos de trabalho e de valorização do capital.

A partir de então, terra, trabalho e capital entrariam num processo de separação, seguindo um projeto de modernização imposto à engrenagem do mercado, que se orientava pelo capitalismo industrial europeu. O Antigo Sistema Colonial era parte do sistema mundial produtor de mercadorias, impondo a abstração das relações de produção, pois na colônia, onde o capitalista é respaldado pelo poder da metrópole, ele procura eliminar à força o modo de produção e apropriação fundado no trabalho próprio $^{78}$.

Voltando o olhar à colonização, ela demandava o escravismo como forma social para a geração de mercadorias, pois a acumulação primitiva europeia nada mais seria do que o processo histórico de separação entre produtor e meios de produção mais as imposições violentas de uma nova relação social aos povos submetidos a essa lógica nos territórios dominados, introduzindo um tipo de cativeiro sobre essas comunidades. Pensando sobre as formas sociais modernas, Karl Marx lembra que "se um negro é um negro, mas somente sob

\footnotetext{
78 “O grande mérito de E. G. Wakefield não é o de ter descoberto algo novo sobre as colônias, mas o de ter descoberto, nas colônias, a verdade sobre as relações capitalistas da metrópole. Assim como o sistema protecionista, em seus primórdios, visava à fabricação de capitalistas na metrópole, a teoria da colonização de Wakefield - que a Inglaterra procurou, durante certo tempo, aplicar legalmente - visa à fabricação de trabalhadores assalariados nas colônias. A isso Wakefield denomina 'systematic colonization' (colonização sistemática)." (MARX, 2013, v. 1, p. 836).
} 
determinadas condições ele se torna escravo" (MARX, 2013, v. 1, p. 836), foi na particularidade da colônia que o escravismo moderno se consolidou.

Durante o Estado absolutista, o exclusivo metropolitano fusionava capital e Estado. O Antigo Regime representou a fórmula da burguesia mercantil se assegurar das condições para garantir sua própria ascensão e criar o quadro institucional do desenvolvimento do capitalismo comercial europeu, pois esse exclusivo consistia em uma reserva de mercado das colônias para a metrópole. Partindo de Fernando Novais (2001), ao desenvolver um modo de produção no sistema colonial, não bastava produzir artigos com procura crescente nos mercados do Velho Mundo. Era indispensável produzi-los de modo a que a sua comercialização estimulasse a acumulação burguesa nas economias europeias. Esse quadro impelia as economias coloniais a se organizarem, de modo a permitir o funcionamento do sistema de exploração colonial, o que impunha a adoção de formas de trabalho compulsório, sendo o seu limite o escravismo.

Com a abolição do escravismo, os libertos não se tornaram de imediato trabalhadores subordinados ao capital, uma vez que a mediação da exploração de seu trabalho parecia passar por intricados mecanismos de dominação pessoal. ${ }^{79}$ Por isso, nessa passagem, o coronelismo aparecia como a forma de ser do Estado organizando a territorialização do valor, ancorado na legislação fundiária e na possibilidade de regular a mesma legislação a seu favor e a de seus interesses. "Neste 'esquema', a personificação do Estado, da Lei, da terra e do capital parecem se concentrar na mesma figura." (BOECHAT, 2013, p. 26).

Resultado da criação da Guarda Nacional de 1831 pelo então ministro Feijó, o coronelismo tem origem no período regencial e foi criado para se tornar uma arma política do governo imperial contra a oposição, tendo sido uma espécie de revivescência modernizada das ordenanças coloniais e com seus oficiais nomeados pelo governo (COSTA, 1999).

De acordo com Vitor Nunes Leal (1975), o coronelismo seria o resultado da superposição de formas desenvolvidas do regime representativo a uma estrutura econômica e

\footnotetext{
${ }^{79}$ Um exemplo dessa condição se encontra nas observações do diário de adolescente de Alice Dayrell Caldeira Brant. Nascida em Diamantina em 1880, publicou sob o pseudônimo de Helena Morley o cotidiano do antigo distrito diamantino na passagem de século e, sendo neta de família de posses, conta que
} 
social inadequada, no qual se estabelece um compromisso, uma troca de proveitos entre o poder público, progressivamente fortalecido, e a decadente influência social dos chefes locais, sobretudo dos senhores de terras. Tal fenômeno só é passível de compreensão considerando-se a estrutura agrária, base de sustentação das manifestações de poder privado ainda tão visíveis no interior do Brasil.

Quanto à Guarda Nacional, cabe um parêntesis. Sua criação se deu durante o período regencial, momento em que o Brasil já tinha a sua independência consolidada e se encontrava sem o imperador herdeiro no trono. Ela foi a resposta imperial às convulsões sociais que sacudiram o período de 1830-1840, protagonizadas principalmente por escravos e sujeitos livres pobres, em especial nas províncias distantes do Centro-Sul. Era necessário a um Estado moderno, inserido nas relações imperialistas do mercado mundial, instituir seu braço armado, mesmo que a princípio ele não fosse autonomizado.

Com isso, a modernização teria o seu caminho aberto pela potência destrutiva que o desenvolvimento das forças produtivas estimulava. Analisando nas condições gerais, Robert Kurz (1997) aponta a invenção das armas de fogo e a estruturação dos exércitos apartados da sociedade civil como grandes responsáveis pelo desenvolvimento da mentalidade capitalista, um recurso da versátil relação moderna entre mercado e Estado com vias à coerção da população, seja em tributo, seja em violência extraeconômica, para que financie a indústria da guerra. O coronel, latifundiário dono do poder econômico, passava a ter também nas mãos o poder da violência.

Apesar de o Estado recém-independente não estar autonomizado, discorda-se da acepção de que o coronelismo tenha sido uma "estrutura econômica e social inadequada". Afinal, complementando a ideia de Karl Marx de que a colônia revela o segredo da metrópole, na situação de país independente e exportador de produtos primários, esse tipo de relação - a combinação do escravismo com o favor - foi eficiente ao garantir ao país um lugar na divisão internacional do trabalho. A estrutura econômica e social seria apenas "aparentemente" inadequada, o que revela por parte de Vitor Nunes Leal o clássico incômodo intelectual com a "torção" das ideias liberais em um país periférico, no qual o cativeiro era o motor das relações sociais de produção ${ }^{80}$.

\footnotetext{
${ }^{80}$ Em artigo crítico ao clássico As ideias fora do lugar, de Roberto Schwarz (1992), Bernardo Ricúpero faz uma análise sobre esse incômodo:
}

Paradoxalmente, nessa "torção", operada na periferia capitalista, se encontraria a verdade do centro capitalista. Até porque muito do que é encoberto no centro poderia ser revelado, sem maiores subterfúgios, na periferia. Já Marx notara que o grande mérito de E. G. Wakefield não teria sido "ter descoberto algo novo sobre as colônias, mas ter descoberto nas colônias a verdade sobre as condições capitalistas da metrópole" (Marx, 1982, p. 296), a escravidão sans phrase 
Para que tal quadro se configurasse, a terra teria de se tornar propriedade fundiária, o que revela o projeto de modernização por trás da relação estabelecida entre latifundiários e Estado. Os primeiros personificavam os problemas regionais, usando da sua liberdade de mando para a coerção dos mais fracos à geração de produto. Os títulos eram concedidos a proprietários rurais, tornando-se decorativos a partir da decisão de centralização do poder em 1850 (LEAL, 1975). Mesmo que decorativos, eles abriam aos seus donos ampla possibilidade de mandos e desmandos locais com o intento de forçar seus agregados à produção de riqueza. Em Grande sertão: veredas, o personagem Riobaldo ilustra em parte essas relações:

\begin{abstract}
Mas, mire e veja o senhor: nas eras de 96, quando os serranos cismaram e avançaram, tomaram conta do São Francisco, sem prazo nem pena. Mas, nestes derradeiros anos, quando Andalécio e Antônio Dó forcejaram por entrar lá, quase com homens mil e meio-mil, a cavalo, o povo de São Francisco soube, se reuniram, e deram fogo de defesa: diz-que durou combate por tempo de três horas, tinham armado tranquias, na boca das ruas - com tapigos, montes de areia e pedra, e árvores cortadas, de través brigaram como boa população! Daí, aqueles retornaram, arremeteram mesmo, senhores da cidade quase toda, conforme guerrearam contra o Major Alcides Amaral e uns soldados, cercados numas duas ou três casas e um quintal, guerrearam noites e dias. A ver, por vingar, porque antes o Major Amaral tinha prendido o Andalécio, cortado os bigodes dele. Andalécio - o que, de nome real: Indalécio Gomes Pereira homem de grandes bigodes. Sei de quem ouviu, se recordava sempre com tremores: de quando, no tiroteio de inteira noite, Andalécio comandava e esbarrava, para gritar feroz: - "Sai pra fora, cão! Vem ver! Bigode de homem não se corta!...” Tudo gelava, de só escutar. Aí, quem trouxe socorro, para salvar o Major, foi o delegado Doutor Cantuária Guimarães, vindo às pressas de Januária, com punhadão de outros jagunços, de fazendeiros da política do Governo. Assim que salvaram, mandaram desenterrar, para contar bem, mais de sessenta mortos, uns quatorze juntos numa cova só! Essas coisas já não aconteceram mais no meu tempo, pois por aí eu já estava retirado para ser criador, e lavrador de algodão e cana. Mas o mais foi ainda atual agora, recentemente, quase, isto é; foi logo de se emendar depois do barulhão em Carinhanha - mortandades: quando se espirrou sangue por toda banda, o senhor sabe: "Carinhanha é bonitinha..." - uma verdade que barranqueiro canta, remador. Carinhanha é que sempre foi de um homem de valor e poder: o coronel João Duque o pai da coragem. Antônio Dó eu conheci, certa vez, na Vargem Bonita, tinha uma feirinha lá, ele se chegou, com uns seus cabras, formaram grupo calados, arredados. Andalécio foi meu bom amigo. Ah, tempo de jagunço tinha mesmo de acabar, cidade acaba com o sertão. Acaba? (ROSA, 1986, p. 143-144).
\end{abstract}

Assim como o jagunço, o agregado também foi um sujeito importante no papel do povoamento do sertão, na medida em que ajudou o fazendeiro a assegurar a posse de seus vastos domínios. Normalmente, lhe era atribuída condição distinta da do escravo, mas apesar de ser homem livre, era dependente do latifundiário, que lhe cedia em seus domínios um pedaço de terra, onde podia construir uma residência precária e plantar pequenas lavouras de subsistência, assim como criar aves, porcos e um número reduzido de reses. Porém, o uso das terras da que prevalecia na metrópole. Tal situação ajudaria a explicar muitas das realizações da literatura russa assim como as de um autor como Machado de Assis, "mestre na periferia do capitalismo". (RICÚPERO, 2008, p. 65). 
fazenda só lhe era permitido mediante o cumprimento de um acordo pré-estabelecido, no qual cabia a ele prestar serviços na fazenda, comumente auxiliando na lida com o gado ou, ainda, trabalhar na lavoura, cuja produção obtida era repartida com o fazendeiro, que a usava para alimentar seus dependentes (ALVES, 2000).

Com a abolição do escravismo, inicia-se o lento processo de autonomização do fator trabalho. Quando a força de trabalho se transforma em mercadoria, tudo tende a virar mercadoria. Consolida-se a sociedade fetichizada: as coisas viram o sujeito da história. No caso particular do Brasil, inclusive da Serra do Cabral, a transição se dá de forma gradual, a considerar não apenas a população livre pobre existente no conjunto da ordem, mas a persistência de relações ainda não mediadas pelo salário. Ou seja, não havendo transição direta do escravismo para o trabalho assalariado, era preciso preservar o caráter colonial e comercial da sociedade brasileira por meio da formação de relações não capitalistas de produção, o que, contraditoriamente, permitiria a acumulação via coronelismo.

Ao discutir a modernização retardatária ${ }^{81}$ organizada pelo território brasileiro a fim de superar a não simultaneidade, identificada pela diferença entre os níveis de desenvolvimento entre os países centrais e as periferias, com enfoque nas mudanças nas relações de produção e na forma de acumulação particulares ao nordeste mineiro, Ana Carolina Gonçalves Leite traz em sua dissertação A modernização do Vale do Jequitinhonha mineiro e o processo de formação do trabalhador "bóia-fria" em suas condições regionais de mobilização do trabalho (2010), entre outros assuntos, a formação do campesinato inserida na territorialização do capital e sua utilidade para a produção de riqueza. Ao se pensar nas relações não capitalistas de produção na transição do trabalho escravo para o assalariado, a autora encaixa esse processo como uma particularidade com vias à modernização do país recém-independente.

O sistema colonial e sua posterior passagem ao imperialismo cumpririam o papel de represar a autonomização, impedindo o desenvolvimento nacional nas bases propriamente capitalistas da industrialização e do trabalho assalariado e retendo os países pós-coloniais na condição de subdesenvolvidos. Ao não cindir tão logo os fatores de produção no país recémindependente, a modernização nacional aparenta ser incompleta e a constituição das categorias

\footnotetext{
${ }^{81} \mathrm{O}$ conceito de "modernização retardatária” está presente em Robert Kurz, ainda sob o nome de "modernização recuperadora":

Pois, nas condições de um nível de desenvolvimento já relativamente alto do sistema produtor de mercadorias no Ocidente e de uma luta de concorrência já muito avançada no mercado mundial, todo novo impulso de modernização nas regiões ainda pouco desenvolvidas tinha de assumir o caráter de um desenvolvimento recuperador, particularmente forçado, em que não apenas se repetia o estatismo dos inícios da época moderna, mas que também se apresentava numa forma muito mais pura, consequente e rigorosa que a dos originais ocidentais esquecidos há muito tempo. (KURZ, 1994, p. 35, grifos do autor).
} 
especificamente capitalistas aparece, por sua vez, como o devir de uma sociedade em formação a ser realizada no futuro. Caberia à teoria sustentar o projeto nacional (e nacionalista), não escapando das divergências que afloram no debate sobre a modernização brasileira (LEITE, 2010).

Ao discutir Lei de Terras e abolição gradual do trabalho cativo, a base do projeto de Estado a ser cindido nas categorias era a aplicação da colonização sistemática que, por sua vez, seria um meio de promover condições semelhantes de expropriação onde elas ainda não estavam dadas - o que se observa nos documentos levantados.

\title{
3.3. Os fatores de produção nos documentos e os seus não ditos
}

Em tempos remotos, o bando de jagunços imaginado por João Guimarães Rosa se embrenhava sertão adentro:

\begin{abstract}
Eu avistava as novas estradas, diversidade de terras. Se amanhecia num lugar, se ia à noite noutro, tudo o que podia ser ranço ou discórdia consigo restava para trás. Era o enfim. Era. - "Mais, mais, há-de dará é para diante, quando se formar combate!" uns proseavam. Zé Bebelo querendo. Sabia o que queria, homem de muita raposice. Já no sair da Nhanva, tinha composto seu povo em avulsos - cada grupo, cada rumo. Um pelo São Lamberto, da mão direita; outro pegou o Riacho Fundo e o Córrego do Sanhar; outro se separou da gente no Só-Aqui, indo o Ribeirão da Barra; outro tomou sempre à mão esquerda, encostando ombro no São Francisco; mas nós, que vínhamos mais Zé Bebelo mesmo em capitania, rompemos, no meio, seguindo o traço do Córrego Felicidade. Passamos perto de Vila Inconfidência, viemos acampar no arraial Pedra-Branca, beira do Água Branca. E tudo correndo bem. Dum batalhão para outro, se expedia gente com ordens e recados. Arrastávamos uma rede grande, peixe grande por pegar. E foi. Eu não vi essa célebre batalha - eu tinha ficado na Pedra-Branca. Não por medo, não. Mas Zé Bebelo me mandou: - "Tem paciência, você espera, para reunir os municipais do lugar e fazer discurso, logo que um estafeta vier relatar qual foi nossa primeira vitória... (ROSA, 1986, p. 113).
\end{abstract}

O excerto acima é uma passagem do Grande sertão: veredas, em que Riobaldo comenta não só os caminhos e as fazendas por onde a tropa de jagunços passa, como também os conflitos. Destaca-se aí a fazenda São Lamberto, situada na Serra e presente na cartografia setecentista levantada. Interessa também lembrar que o chefe Zé Bebelo era fazendeiro na Serra do Cabral, beirando o rio Jequitai ${ }^{82}$.

\footnotetext{
82 “Os dois camaradas, em tanto percebi, eram capangas. Mas sujeitos de seu trato, em altos-e-baixos nem as maiores asperezas, me deram toda consideração. Viajamos juntos quatro dias, quase trinta léguas, bom tempo beirando o Riachão e enxergando à mão esquerda os vultos da Serra-do-Cabral. Meus companheiros quase que não me informavam, de nada ou nada. Tinham outras ordens. Mas, mesmo antes da gente entrar em terras do Palhão, fui vendo coisas calculosas, dei meio para duvidar. Patrulhas de cavaleiros em armas; troco de conversa de vigiação; e uma tropa de burros cargueiros, mas no meio dos tocadores vinham três soldados. Mais perto, em maiores me vi. Chegar lá declamava surpresa. A Nhanva enxameava de gente homem - pralaprá de feira em praça. E era vistosa fazenda assobradada, com grandes currais e um terreirão. Vi logo o dono." (ROSA, 1986, p. 108).
} 
Buscaram-se duas fontes para exemplificar a situação da terra na Serra no século XIX. Uma é o conjunto de inventários post mortem de uma das primeiras famílias a se instalar no povoado do Buriti Grande, de sobrenome Borém ${ }^{83}$, cujos documentos vão de 1833 a 1925 . Os inventários estavam no fórum local de Bocaiúva, mas foram transferidos para o Fórum Lafayette de Belo Horizonte em 2017, por se tratarem de documentos com mais de 100 anos. Outra é o livro de Registro de Terras Públicas, de 1856, da Comarca do Senhor do BonfimMontes Claros, pertencente ao APM.

A narrativa da chegada da família Borém na Serra do Cabral possui desencontros: de um lado, o relato de alguns de seus descendentes, de outro, o que se sabe a partir dos arquivos do APM. No primeiro caso, seus sucessores contam que nobres belgas e franceses receberam do Império Brasileiro terras na Serra em princípios do primeiro reinado e lá se instalaram, havendo até mesmo um brasão ${ }^{84}$. No segundo caso, uma simples busca pelo termo "Borém" no acervo do APM, acusa a residência de oficial português com o mesmo sobrenome em Vila Rica, ainda na primeira metade do século XVIII ${ }^{85}$, o que sugere o interesse de funcionários reinóis pelas terras do norte mineiro, onde as patrulhas de guardas e soldados vigiavam os caminhos do gado.

Em linhas gerais, esses documentos ajudam a entender o que as propriedades produziam, porém não revelam como as terras foram adquiridas ${ }^{86}$ : teriam sido, consoante o processo de territorialização da Serra, obtidas à base da violência? É interessante notar o teor do documento, pois é como se os sujeitos se esforçassem para declarar o que lhes pertencia, demarcando os limites a partir de pontos naturais ou no encontro com quem também reclamava reconhecimento do que supunha ser seu.

No documento mais antigo, o inventário do falecido Bento de Almeida Borém, de 1833, tem-se uma amostra do que se pode considerar registro de propriedade adquirida ilegalmente, pois o acesso à terra em 1850 teve antes um intervalo de desregulamentação em função da

\footnotetext{
83 "Baurém" e "Bourém", nos registros antigos.

${ }^{84}$ Narrativa duvidosa, a se pensar sobre as rivalidades entre França e Inglaterra, que culminariam na ocupação napoleônica de Portugal. Uma hipótese possível estaria na origem de soldados mercenários a receberem terras do Império como gratificação por seus serviços.

85 Trata-se de dois documentos, ambos do acervo da Casa dos Contos, sendo um de 1747 e outro de 1763, nos quais consta que Filipe Antônio Borém seria no primeiro registro, capitão, e, no segundo, sargento-mor de Vila Rica.

${ }^{86}$ Ao consultar o Relatório de Repartição Geral das Terras Públicas de 1861, cuja função era levantar as terras devolutas, Márcia Motta constata que sobre a comarca de Bonfim (atual Bocaiúva) afirma-se que "nem uma só posse ou sesmaria existe que não tenha sido adquirida por título legítimo e, portanto, que não há terras sujeitas às formalidades dos artigos do Regulamento de 30 de janeiro de 1854" (MOTTA, 1996, p. 214-215). Para a autora, uma mentira, dado que a expansão territorial e os conflitos eram anteriores e ainda havia grande extensão de terras não registradas e alvos de disputa, abocanhadas posteriormente por grilagem.
} 
suspensão da concessão de sesmarias em 1822, o que torna a posse a única forma de aquisição de domínio sobre as terras no período. Além disso, o registro permite interpretar como terra e trabalho estavam unidos naquele momento histórico: não há uma delimitação precisa da fazenda Duas Barras, deixada pelo patriarca para esposa e filhos, a despeito de todos os bens estarem arrolados.

Apesar da dificuldade de leitura do documento, entendeu-se que Bento havia deixado uma espingarda velha; 11 escravos - Luciana, crioula, 60 anos, no valor de 45 a 50 mil réis; Isaura, crioula, 32 anos, 250 mil réis; Inácio, cabra, 30 anos, 300 mil réis; Chrispim, crioulo, 50 anos, 250 mil réis; Pedro José, escravo, 44 anos, 4 contos de réis; Lúcio, crioulo, 25 anos, 500 mil réis; João, crioulo, 20 anos, 250 mil réis; Maria, parda, 12 anos, 300 mil réis; Antônia, cabra, 9 anos, 270 mil réis; Polucena, crioula, 2 anos, 150 mil réis; "uma escrava Luíza, filha da escrava Francisca, que ainda não se batizou, 30 mil réis" -; 200 cabeças de gado vacum e cavalar, cada uma valendo 4 mil réis; 83 vacas, 64 mil réis; três cavalos velhos rosilhos, 18 mil réis; sete cavalos mansos mais novos, 84 mil réis; dois potros, 20 mil réis; sete potros, 42 mil réis; 1 légua de terras na fazenda Duas Barras (não delimitada) com uma casa coberta de capim, com três portas, cozinha e curral de caiçara, 228.578 réis.

O segundo inventário post mortem analisado, de João de Almeida Borém, datado de 1851 e registrado na Vila de Montes Claros de Formigas, Comarca do Rio São Francisco, menciona os seguintes bens arrolados: Florinda, cabra, 40 anos; Carolina, cabra, 30 anos; Vicência, cabra, 18 anos; Izidora, cabra, 17 anos; Isabel, cabra, 20 anos; Clemência, cabra, 16 anos; Joaquina, cabra, 8 anos; Francisco, (?); (?), crioulo, 8 anos; José, cabra, 46 anos; Luiz, cabra, 25 anos; Antônio, cabra, 23 anos; Torquato, cabra, 6 anos; Maria, mulata, 5 anos; 30 cabeças de gado de toda sorte; dez éguas de toda sorte; três cavalos mansos, um rosilho e um castanho, 10 anos cada um; um poldro de muda, com um de 2 anos e 1 de um ano; uma parte de terras na fazenda dos Crixás e uma casa velha na dita fazenda. A venda da escrava Umbelina serviria para cobrir os custos de funeral.

O documento contém uma informação interessante: uma licitação para alforriar dois escravos da fazenda Caraíbas - Silvério, pardo, de 3 anos, e sua irmã, "que pretende-se dar o nome de Thereza", também parda, de 7 meses -, pois "como deseja ve-los livres do infame epiteto de escravos (sic) dobre o valor dos mesmos com a quantia de mil reis para forrar". Mais adiante, o inventário atesta ser impossível "dar objeto de partilha o escravo Eusebio, que tem chegado à idade de 80 anos". 
O terceiro inventário post mortem, de Francisco de Almeida Borém, realizado em 1863, após um ano de seu falecimento ${ }^{87}$, arrola os seguintes bens a serem deixados à mulher, aos sobrinhos e aos irmãos, pois não teve filhos: um par de brincos de ouro; um ferro de engomar; um almofariz; um cabeção de ferro velho; uma cangalha; um pilão; dois machados velhos; uma faca velha; um chapéu de pele de lebre velho; uma sela de campo velha; 12 cabeças de gado "de toda sorte"; quatro éguas; dois cavalos velhos; dois potros de segunda muda; uma escrava de nome Irene, parda, 50 anos, 400 mil réis; uma dona de nome Clara, cabra, 47 anos, 500 mil réis; um escravo de nome Vicente, pardo, 8 anos, 700 mil réis; uma escrava de nome Eva, crioula, 9 anos, 800 mil réis; um escravo de nome Martinho, crioulo, 10 anos, 850 mil réis; duas partes de 4 mil, 444 réis no escravo Joaquim, paralítico; uma parte de 33 mil, 333 réis na escrava Thereza, 53 anos; duas partes de terras na fazenda de Santa Engrácia, ambas 178 mil, 403 réis; duas partes na fazenda Caraíbas, de herança e compra, ambas 118 mil, 450 réis, além de dívidas, incluindo o próprio funeral. Ao fim das 114 páginas do documento, o escravo Vicente é oferecido para pagar o imposto do inventário à Renda Provincial de Minas Gerais ${ }^{88}$.

Imaginando que o inventário foi feito muito posteriormente à morte do fazendeiro, são arrolados os escravos e os gados que morreram e nasceram (apenas a morte dos animais é esclarecida: por ataque de onças e pela queda do carro de boi carregado de sal sobre o animal), as dívidas deixadas pelo falecido com a compra de gado vacum e cavalar da fazenda Crixás, fruto de herança de inventário de 1825 , além do pagamento da viúva para a encomenda das almas dos escravos mortos e o funeral do marido. Ao fim, o escravo Lúcio foi deixado como pagamento do inventário, no termo do Curvelo.

Dentre os bens deixados nestes documentos, destacam-se algumas informações. Primeiro, o preço geral dos escravos ser maior do que o da terra e mais alto, se mais jovens e do sexo masculino. Depois, a dúvida quanto ao que fazer com um escravo idoso e a divisão de direitos sobre um escravo deficiente físico. Ainda, as pistas sobre a reprodução das famílias cativas - no sentido de parentesco e convivência familiar, pois havia muitas crianças entre os bens, como a filha de uma escrava no segundo documento.

Para o caso do sertão do Cariri cearense, Ana Irffi (2016) aponta que as fazendas médias tinham de 11 a 20 escravos, retratando a decadência econômica das famílias que, nos Oitocentos, não conseguiam manter um grande plantel. Tal informação deve ser relativizada no

\footnotetext{
${ }^{87}$ Ou seja, pós Lei de Terras. Este sujeito inventariado é o mesmo que aparece entre 1855 e 1856, declarando suas propriedades no Registro de Terras Públicas do Império.

${ }^{88}$ Os preços dos escravos são altos, se comparados com os apresentados por Robert Slenes para os anos de 1831 a 1843, para a Mina de Morro Velho, em Minas Gerais: o preço de um escravo de 20 a 30 anos girava em torno de 525 mil réis a 800 mil réis, que o autor já considerava altíssimo (SLENES, 1988, p. 470).
} 
caso da Serra, que trata de atividade pecuária, o que, em tese, requer menos mão de obra. Isso porque, em linhas gerais, nas atividades rurais, o número de escravos deveria manter estreita relação com a dimensão dos estabelecimentos, dimensão entendida não como área física, mas relacionada às finalidades da produção.

Quanto à questão da terra e do escravo, no livro Metamorfoses da riqueza. São Paulo, 1845-1895, Zélia Cardoso de Mello investiga o movimento das formas de riqueza como expressão do momento de superação do escravismo e de emergência do capitalismo, mais especificamente para a realidade de São Paulo e a cafeicultura. Para a autora, o modo como se deu a passagem do que considera economia tradicional à economia capitalista no final do século XIX, implicando em mudança na forma de riqueza, também indica a constituição e o fortalecimento de um grupo social que personifica interesses diversificados, financeiros, comerciais, industriais e agrários, além de, acrescenta-se, políticos. No caso de a escravaria valer mais do que a terra inventariada, a autora, partindo de Alice Canabrava, explica que os imóveis pouco representavam para a riqueza, pois se avaliavam não pela área territorial, mas pelo trabalho humano, sendo os escravos, portanto, parte dos bens mais valiosos. Tal afirmação é exemplificada pelos pertences arrolados no espólio de Bento Borém: o preço médio de cada cativo jovem girava em torno de 250 mil réis, enquanto sua terra valia 228 mil 571 réis.

Ela também aponta que os valores mais altos dos preços relativos ao sexo e à idade dos escravos correspondiam, para ambos os sexos, às faixas de 15 a 19 e de 20 a 35 anos. No caso das mulheres, o pico correspondia à primeira faixa, e, no dos homens, à segunda. De acordo com a autora, a racionalidade por parte do comprador de escravos o levava a considerar, na decisão de compra, fatores como o risco de rendimento esperado. O preço que estava disposto a pagar variava imensamente ao risco e diretamente ao rendimento esperado. Assim, as crianças, representando maior problema, e os velhos, menos expectativa de rendimento, valiam menos em relação aos cativos em idade ativa, prontos para o trabalho (MELLO, 1985).

Complementando a análise e trazendo para a realidade mineira do século XIX, no artigo Os múltiplos de porcos e diamantes: a economia escrava de Minas Gerais no século XIX, sobre a população de vários distritos de Minas Gerais no ano de 1804, a maioria antigos centros mineradores, Robert Slenes aponta que havia uma proporção substancial de escravos de origem africana ${ }^{89}$. Segundo o historiador, havia um número excessivo de homens comparativamente

\footnotetext{
${ }^{89}$ Para o século XVIII, Maria Lemke (2013) ressalta que os escravizados que chegavam à capitania de Goiás pelo Caminho do Sertão, na intenção de serem empregados na mineração, eram de origem mina, enquanto os que eram empregados na lavoura eram de proveniência angola. Não foram encontrados registros sobre a origem dos cativos trazidos de além-mar para a Serra do Cabral, mas a partir do cruzamento de informações sobre as ossadas dos pretos novos chegados no século XIX ao porto do Valongo, no Rio de Janeiro, e excertos de Grande sertão:
} 
ao de mulheres entre jovens e adultos, e pirâmides de idade com uma base pequena e uma concentração anormal de pessoas nas faixas dos 20 aos 29 e dos 30 aos 39 anos (SLENES, 1988). Ainda de acordo com o autor, segundo o censo de 1872, 20\% dos escravos africanos no Brasil estavam em Minas Gerais.

Ao discutir os motivos de Minas Gerais apresentar escravaria tão grande no século XIX, mesmo após o ocaso do garimpo, o autor defende a ideia de que a província produzia mercadorias para exportação para as outras partes do país, o que gerava um efeito multiplicador na sua economia interna, ou seja, incentivando a sua reprodução. Por estar distante do litoral e com dificuldade para alcançar os produtos oriundos das cidades mais importantes, precisou estimular seu mercado interno até mais do que as áreas de plantation ou mesmo os centros econômicos exportadores dos Oitocentos, como Rio de Janeiro e São Paulo, desde o período colonial.

Para tal, a demanda por escravos era grande. A produção mineira de gêneros diversos (como café, gado vacum e suíno, tecido de algodão, toucinho, queijo e tabaco) para as outras províncias gerava uma renda monetária considerável, que teria incentivado não só a demanda por escravos na economia de exportação, mas teria também criado dentro da província uma forte precisão de mantimentos, bens de consumo e matérias-primas utilizados pelo setor exportador e pelas atividades internas ligadas a ele. Por sua vez, essa situação teria aumentado

veredas, desconfia-se da origem de parcela dos africanos no norte mineiro. No Instituto de Pesquisa e Memória Pretos Novos (IPN), a arcada dentária dos restos mortais de africanos enterrados no porto revela a prática de entalhar e limar os dentes, sendo, segundo o IPN, costume bastante difundido na África Central Atlântica (MACHADO apud ANJOS; PEREIRA, 2019). Já na ficção, a seguinte passagem ajuda a pensar não somente nos homens livres pobres de cor tornados jagunços - não à toa os chefes apareciam com seus "cabras", termo também usado para classificar escravizados nascidos no Brasil com algum grau de miscigenação dentro do discurso racial dos Oitocentos -, mas também na interessante e coincidente (ou não) prática de limar os dentes entre alguns jagunços:

\footnotetext{
Semelhante por este exemplo, como logo entendi: eles queriam completo ser jagunços, por alcanço, gala mestra; conforme o que avistei, seguinte. Pois não era que, num canto, estavam uns, permanecidos todos se ocupando num manejo caprichoso, e isto que eles executavam: que estavam desbastando os dentes deles mesmos, aperfeiçoando os dentes em pontas! Se me entende? Senhor ver, essa atarefação, o tratear, dava alojo e apresso, dava até aflição em aflito, abobante. Os que lavravam desse jeito: o Jesualdo - mocinho novo, com sua simpatia -, o Araruta e o Nestor; os que ensinavam a eles eram o Simião e o Acauã. Assim um uso correntio, apontar os dentes de diante, a poder de gume de ferramenta, por amor de remedar o aguçoso de dentes de peixe feroz do rio de São Francisco - piranha redoleira, a cabeça-de-burro. Nem o senhor não pense que para esse gasto tinham instrumentos próprios, alguma liminha, ou ferro lixador. Não: aí era à faca. O Jesualdo mesmo se fazia, fazia aquilo sentado num calcanhar. Aviava de encalcar o corte da faca nas beiras do dente, rela releixo, e batia no cabo da faca, com uma pedra, medidas pancadas. Sem espelho, sem ver; ao tanto, que era uma faca de cabo niquelado. Ah, no abre-boca, comum que babando, às vezes sangue babava. Ao mais gemesse, repuxando a cara, pelo que verdadeiro muito doía. Aguentava. Assim esquentasse demais; para refrescar, então ele bochechava a breve, com um caneco de água com pinga [...] (ROSA, 1986, p. 141-142).
} 
a utilização de mão de obra livre e escrava na produção para o mercado interno de Minas Gerais (SLENES, 1988).

Apesar dos espólios não apontarem para a presença africana, se Minas Gerais produzia intensamente para exportar para as outras províncias, isso explica não só o apego mineiro à escravidão, bem como os inventários apresentados terem tamanha quantidade de escravos, que teriam de cuidar das criações para o fornecimento de carne, couro e derivados do leite para os centros urbanos e fazendas exportadoras. Além disso, a produção movimentava o trabalho dos tropeiros, que transportavam as mercadorias. Portanto, a economia estava acontecendo, mesmo que a historiografia no geral costume rotular - para o caso mineiro - a situação desse período como um século de regressão econômica devido à decadência da extração mineral.

Ana Carolina Leite (2010) aponta na mesma direção. O processo de modernização impõe progressivamente condições, mesmo que particulares, para que o capital continue se acumulando, ainda que seja com a expansão do rebanho de gado sobre terras em grande parte apropriadas como posses livres e depois regulamentadas pela Lei de Terras. Portanto, a regressão econômica, em se tratando sobretudo do norte de Minas Gerais, é discutível. A reprodução do capital se deu na expansão das fazendas, da qual faziam parte também tanto agregados quanto posseiros ${ }^{90}$ e sitiantes autônomos, mesmo que de formas diferentes.

Quanto à extração mineral, Robert Slenes (1988) é categórico ao afirmar que Minas Gerais só podia importar escravos porque exportava ouro e diamantes ainda na primeira metade do século XIX. Apesar de o autor limitar essa afirmação para princípios dos Oitocentos, páginas adiante afirma que entre 1819 e 1873, "a produção de ouro aumentou bastante durante essas décadas e a extração de diamantes cresceu ainda mais" (SLENES, 1988, p. 476-477), especialmente depois de 1832, quando o monopólio estatal sobre a mineração diamantina terminou, tendo iniciado uma corrida às pedras. O garimpo em massa na Serra do Cabral começa na segunda metade do século XIX, tendo o barão de Jequitaí como um expoente.

$\mathrm{O}$ que se revelou a partir das entrevistas com garimpeiros mais velhos, herdeiros de ofício de seus pais e avós, é que a família Borém, cujos patriarcas mantinham casas no povoado do Buriti Grande, detinha as terras onde os garimpeiros "cavacavam", lhes pagando porcentagem e, ainda, lhes dando preferência na venda dos achados - além de muitos deles também terem investido na faiscação.

\footnotetext{
90 Também presentes desde o período colonial, os posseiros constituíam uma população marginal sem direito à propriedade da terra e eram recusados como agregados nas fazendas de gado, o que os mobilizava a irem em busca de outros locais, longe do domínio dos fazendeiros, para fixar suas moradias. "Avançavam, quase sempre, sobre terras habitadas por grupos indígenas, o que representava grande risco para suas vidas [...]" (ALVES, 2000, p. 3132).
} 
Zélia Cardoso de Mello (1985) faz uma observação importante ao ressaltar que o item “móveis" mereceria uma análise qualitativa minuciosa nos inventários. Para ela, o mobiliário das casas, as joias da família, os instrumentos de que se serviam, os objetos de arte, os livros e as vestimentas permitem precisar a diferença social e cultural existente no interior da sociedade avaliada.

$\mathrm{Na}$ análise dos pertences arrolados nos inventários, não aparece nenhuma ferramenta de garimpo, o que é curioso, já que o auge da extração na Serra começa nesse momento. Apenas ferramentas e pertences de vaqueiro, mobília e utensílios pessoais constam nas listas. Outra curiosidade vem do grande plantel de escravos arrolados em fazendas, onde aparece apenas a atividade pecuária. Se a região já tinha a mineração consolidada no período e ainda assim não há registro nos mapas observados para esse momento, estariam os escravos envolvidos no garimpo para os seus donos, que ocultavam a atividade no documento? Qual o interesse em abstrair o garimpo de diamantes se, de acordo com Slenes (1988), ele era uma das fontes de aquisição de escravos e outros produtos?

Além da observação dos pertences, nota-se que os inventariados e os inventariantes sempre são do sexo masculino, a despeito de haver menção a herdeiras em alguns espólios. Problema semelhante foi verificado por Erick Gabriel Jones Kluck (2019) para o caso das terras de uso comum e de posse dos Brejos da Barra, em sua tese Quando o planejamento vai para o Brejo: a mobilidade do trabalho e o planejamento territorial na modernização do Velho Chico, em que conclui que a mediação pelo valor é a modernidade da tradição, é a essência que camufla a igualdade do diferente, movendo um processo concreto de abstração tornado cotidiano, uma totalidade concreta. Apesar das diferenças entre terras de posse e propriedade privada, bem como a posição social dos indivíduos envolvidos em ambos os casos, mesmo na condição mais abastada, a mulher aparece praticamente excluída da partilha.

Outra questão importante suscitada pelos documentos e seu contexto e que Slenes e outros autores levantam para os Oitocentos mineiros, é a regressão econômica, ideia desenvolvida por Celso Furtado em capítulo sobre a economia escravista mineira no século XVIII, de Formação econômica do Brasil. Publicado em $1959^{91}$, o livro mergulhava no contexto do nacional-desenvolvimentismo e buscava entender o que travava o desenvolvimento

\footnotetext{
${ }^{91}$ Publicado três anos depois de Grande sertão: veredas, de João Guimarães Rosa, o que sugere uma sintonia entre uma geração que pensava o Brasil, seja na literatura ficcional, seja na científica, tendo entre seus demiurgos Caio Prado Júnior, Gilberto Freyre e Sérgio Buarque de Holanda. Posterior a essa geração de 1930, Celso Furtado é entendido como um continuador do debate sobre a formação brasileira. Mais afeito à linha teórica de Caio Prado Júnior, recortou deste a "vida material" para abordar a formação econômica, voltando ao passado para defender o que entende como instabilidade e baixo potencial de acumulação de uma sociedade de origem colonial.
} 
do país a partir da observação do passado. Assim como uma geração contemporânea à sua, o autor repetia, a partir do título de sua obra maior, a palavra "formação", supondo entender um país de passado colonial em processo de formação do capitalismo, na transição linear da juventude para a vida adulta, tendo como farol os Estados europeus ocidentais (RICÚPERO, 2008).

Caracterizando a economia brasileira em ciclos, Celso Furtado aponta já de início que a saída metropolitana da crise estaria na busca por metais. Segundo ele, "Retrocedia-se, assim, à ideia primitiva de que as terras americanas só se justificavam economicamente se chegassem a produzir os ditos metais" (FURTADO, 2007, p. 117, grifos nossos).

$\mathrm{O}$ autor aponta para as maiores possibilidades de o homem livre ascender socialmente na sociedade mineradora. Porém, a natureza dessa empresa não permitia uma ligação à terra do mesmo tipo da que prevalecia nas regiões açucareiras, pois o capital fixo era reduzido, além da incerteza de ganho nas lavras, o que, por sua vez, induzia à constante mobilidade da atividade. Ainda assim, a especialização no ofício e a demanda por consumo de gêneros diversos criaram uma sociedade urbana e semiurbana com menor concentração de renda, dado que a distância do litoral impelia à produção nos arredores mais próximos da extração. O Tratado de Methuen (1703) seria um dos grandes responsáveis por abortar o florescimento de um mercado interno dinâmico já nos Setecentos.

Dada a escassez gradual dos minerais achados, "muitos dos antigos empresários transformavam-se em simples faiscadores e com o tempo revertiam à simples economia de subsistência" (FURTADO, 2007). Num exercício de comparar as vantagens da economia açucareira em relação à mineradora, Celso Furtado defende que com a desarticulação da mineração, os núcleos urbanos decairiam também, dispersando grande parte de seus elementos em uma economia de subsistência, espalhados por uma vasta região de difícil comunicação, culminando no isolamento entre os grupos.

Ainda para o autor, essa população, relativamente numerosa, se expandiria espacialmente em regime de subsistência, originando um dos principais núcleos demográficos do país. Como se deu na economia pecuária nordestina, a expansão demográfica correria ao lado da atrofia da economia monetária, declinando toda uma região que outrora se conformou como uma sociedade próspera economicamente. Sua população, antes mão de obra requisitada, se converteria em uma massa de população desarticulada, trabalhando com baixíssima produtividade na agricultura voltada para a mera sobrevivência. "Em nenhuma parte do continente americano houve um caso de involução tão rápida e tão completa de um sistema 
econômico constituído por população principalmente de origem europeia" (FURTADO, 2007, p. 134, grifos nossos).

Ora, se só a capitania de Minas Gerais detinha $20 \%$ da escravaria no século XIX, junto a uma economia pecuária fornecedora de víveres para as zonas cafeicultoras do Rio de Janeiro e de São Paulo, além de manter a extração de ouro e diamante nos Oitocentos - com a trajetória do barão de Jequitaí como exemplo para o caso da Serra do Cabral -, como concordar com a regressão econômica mineira partindo da ideia de uma redução da atividade à economia de subsistência? O lento movimento de territorialização do capital continuou acontecendo na capitania/província e nos sertões, vide os bens arrolados nos inventários. Slenes defende que Minas Gerais não teria importado tantos escravos se não tivesse tido uma economia de mercado bastante grande, e essa economia, por sua vez, não teria alcançado as proporções que teve se não fosse pelo setor exportador da província. E complementa:

[...] o que mais incentivou as tentativas de escravizar o trabalho ou reduzir a liberdade de acesso à terra não foi a existência do fator Wakefield em si, mas a possibilidade de usar o trabalho e a terra, uma vez subjugados, para a produção mercantil. (SLENES, 1988, p. 486).

Porém, a ideia de regressão econômica prossegue nos anos seguintes, justificando os discursos modernizadores.

Ainda sobre o conteúdo dos inventários, informações importantes também são dadas em relação à cor da pele das posses. Termos como "crioulo" ("criolo"), "cabra" e "pardo" dão pistas sobre a reprodução dos cativos, bem como sua miscigenação com brancos e outras etnias, sejam eles livres pobres ou pertencentes à família proprietária. Ana Irffi (2016) também informa que crioulos e mulatos seriam mestiços de brancos com negros, estando o crioulo mais próximo dos antecedentes africanos. Os cabras seriam mestiços de mulatos e negros ou de índios e negros, tendo, portanto, pele muito escura, porém antepassados já nascidos no Brasil. Os pardos estariam no grupo de pele mais clara, de mestiçagem de branco com negro. Já Erivaldo Neves, ao analisar os inventários utilizados em seu estudo, explica:

Entre os brasileiros, atribuíam-se as denominações de: "crioulo" a qualquer negro nascido no Brasil; "cabra", crioulo filho de mulato e negro, de "cor mais escura do que o mulato"; "mulato", expressão pejorativa - derivada de mulo, animal híbrido para designar o mestiço de branco com negro; "pardo", designativo de cor entre branco e preto, talvez uma intermediação de mulato e branco; "mestiço", apenas uma alusão genérica, atribuível a qualquer miscigenação. (NEVES, 2008, p. 276).

Já João José Reis (2016), historiador dedicado ao escravismo e ao legado africano, sobretudo na Bahia, argumenta que crioulos eram os filhos de africanos, pertencentes à primeira 
geração de nascidos no Brasil. Os africanos eram chamados de "pretos" na documentação com a qual trabalhou sobre a realidade baiana do século XIX. Nos inventários aqui analisados, não consta o termo "preto", o que leva a crer que não havia africanos entre as posses na Serra do Cabral, porém o fato de haver crioulos permite confirmar a circulação dessa primeira geração de filhos de africanos na região ${ }^{92}$.

Chama a atenção as denominações de cabra, crioulo etc., e elas têm importância se se considerar que os inventários pertencem ao século XIX, quando a cientifização resultante do Iluminismo cria a ideia de raça a partir da segunda metade desse século.

No debate sobre a racialização do negro no livro Crítica da razão negra, Achille Mbembe traz à baila a noção de que o conceito de raça, advindo da esfera animal, foi útil para nomear as humanidades não europeias, lhes imputando um estado de degradação da natureza ontológica. Observando que a partir da modernidade o Ocidente decide quem deve se tornar mercadoria, é impossível para o autor discutir capitalismo sem levantar a questão da raça e do racismo - este último como uma chave importante para entender os estereótipos construídos sobre o sertanejo. Para os negros, confrontados com a realidade da escravatura, a perda de humanidade é, antes de mais nada, genealógica - e os inventários dão essa amostra: não só inexiste informação sobre origem familiar dos membros de cor, como eles podem ter seu grupo esfacelado ao gosto econômico de seus donos (MBEMBE, 2017) ${ }^{93}$.

Por mais que apresente o interesse dos mercadores de gente na animalização dos escravizados, a análise de Mbembe não parece ser novidade no debate historiográfico brasileiro. Intelectuais como Clóvis Moura (1994) entendiam o cativo como incapaz de qualquer resistência ao trabalho compulsório que não fosse pelo recurso à violência ${ }^{94}$. Essa abordagem conflita com a corrente historiográfica que, por sua vez, defende a possibilidade do escravizado

\footnotetext{
${ }^{92}$ Essa dedução pode ser contestada a partir da observação de Helena Morley, no ano de 1894:
}

Eu engoli o jantar depressa e fui para a senzala. Palavra que nunca vi uma festa tão divertida. Da África ainda há na Chácara mais três que são Benfica, Quintiliano e Mainarte. Eles cantavam umas cantigas da terra deles, viravam e reviravam batendo palmas e iam dar uma embigada numa negra. Os negros de cá invejaram os velhos que sabiam as cantigas da África e que dançavam com mais entusiasmo. Depois se assentaram na mesa como nós e fizeram saúdes. Todos eles têm suas calças e camisas brancas. Joaquim Angola estava de rebentar de contente. (MORLEY, 2016, p. 134).

93 “Assim, para os Negros, confrontados com a realidade da escravatura, tal perda é antes de mais de ordem genealógica. No Novo Mundo, o escravo negro é juridicamente destituído de qualquer parentesco. Ele é, de facto, um 'sem parentes'. A condição de 'sem parentes' (kinlessness) é-lhe imposta pela lei e pela força. Esta perda de parentesco oficial é, por outro lado, uma condição herdada. Nascimento e descendência não dão direito a qualquer relação de pertença social propriamente dita” (MBEMBE, 2017, p. 68).

94 “Atualmente há uma tendência de cunho neoliberal de subestimar o conflito e dar-se mérito à acomodação por parte da massa escrava, [...] no qual a convivência com o seu senhor era conseguida através de um pacto, um acordo implícito e negociado no qual as contradições eram assimiladas e substituídas pela convivência [...] No entanto, a dinâmica básica do sistema escravista e sua superação estrutural está nos conflitos entre as classes que eram substantivas nesse modo de produção.” (MOURA, 1994, p. 16-17). 
de formar família e outros laços afetivos, bem como negociar condições de sobrevida, na defesa de uma agência do escravo ${ }^{95}$. Apesar da presença de mães cativas com filhos nos inventários arrolados e do caloroso debate sobre o assunto, não se pretende aprofundar nele.

A escravaria apresentada demonstra razoável miscigenação, denunciando um mercado regional de mão de obra escrava, dada a redução da mineração, a dificuldade do tráfico após a supressão oficial e a distância dos portos que traziam sujeitos escravizados da África, havendo reprodução da mão de obra pelo sertão e algum interesse nisso por parte dos donos. Para o caso de Montes Claros, Tarcísio Botelho (2000) apresenta, a partir de documentos que cobrem de 1810 a 1888, não só o número local crescente de escravos e a reprodução das famílias cativas, bem como a oferta dessa mão de obra para o mercado cafeeiro da Zona da Mata mineira. Por isso, seguindo a hipótese do autor, o maior número de mulheres e crianças entre as posses arroladas na região, enquanto a mão de obra masculina era enviada para as plantations de café ${ }^{96}$.

Complementando a análise de Botelho, João José Reis (2016), em estudo sobre a ascensão do africano Ricardo na cidade de Salvador dos Oitocentos, nota a grande presença de mulheres cativas no seu inventário. Para o historiador, a preferência por escravas podia vir tanto do cálculo econômico quanto do político: além de trabalhar, as mulheres "produziam" mais escravos, ao mesmo tempo em que a maternidade funcionava como elemento apaziguador das relações escravistas ${ }^{97}$, prevenindo a fuga e outras formas de rebeldia, empurrando-as ao campo da negociação como estratégia de proteção da família.

Essa mistura étnica, presente não apenas entre os cativos, mas também entre a população livre pobre, já chamava a atenção de Spix durante sua passagem pelo norte de Minas Gerais, contrapondo, inclusive, Slenes, a qual afirma haver grande presença africana na província. A decadência da mineração e a miséria que acompanha o fausto nas sociedades garimpeiras facilitavam uniões entre gente de cor diferente, ao mesmo tempo em que relações violentas

\footnotetext{
${ }^{95}$ É o caso de Robert Slenes (1999), para quem o casamento e os laços afetivos entre os cativos dariam pelo menos vantagens "de ordem emocional e psicológica".

${ }^{96}$ Não se pretende defender a ideia de que a reprodução de cativos era um projeto de seus proprietários, até porque o autor trabalhou com números, sem entrar no debate se havia ou não reprodução regional das famílias. Sobre o tráfico interno de cativos, Paula Beiguelman (2005) se dedicou à sua consolidação a partir da proibição do comércio transatlântico, considerando-o o primeiro grande mercado integrador do território do Brasil, no qual as regiões economicamente decadentes ofereceriam aos latifúndios pujantes do Sudeste os braços que já não chegavam pelos portos.

${ }^{97}$ Sobre a família escrava como elemento apaziguador das senzalas, há controvérsias. Robert Slenes (1999), por exemplo, está entre os historiadores que discordam dessa perspectiva. Em análise das fazendas de café do Sudeste do século XIX, onde a imensa maioria dos escravizados vinha do continente africano ou, se nascidos aqui, eram filhos da migração forçada, o autor defende que a formação de famílias entre os cativos também pode ser interpretada como resistência à brutalidade das fazendas, ao cultivo de recordações e ancestralidade, bem como à adaptação ao mundo em que estavam inseridos. Concordando ou não, notou-se que no diário de Alice Dayrell (1880-1970), a jovem Helena Morley observa considerável quantidade de criados casados na chácara de sua avó.
} 
também geravam mestiços. A sociedade retratada pelo viajante e no inventário desnuda a rigidez das conexões de cor sem, ao mesmo tempo, negar a segregação pelo estigma da pele. $\mathrm{O}$ resultado da observação do naturalista é a descrição do sertanejo dos Oitocentos:

\footnotetext{
O sertanejo é criatura da natureza, sem instrução, sem exigências, de costumes simples e rudes. [...] a maioria consta de mulatos, na quarta ou quinta geração; outros são mestiços de índios com negros ou de europeus com índios. Escravos negros são raros, devido à miséria geral dos colonos; os trabalhos da lavoura e da criação de gado são feitos pelos próprios membros da família. (SPIX, 1981, p. 76).
}

Já o inventário post-mortem de Herculano de Almeida Borém, de 1893, filho do já mencionado João Borém, exemplifica os arrolamentos feitos após a abolição, sem, por isso, constar a mão de obra da fazenda. Apesar do falecido não ter deixado muitos objetos para a partilha, a quantidade de gado vacum e cavalar presente no documento possibilita constatar a especialização regional pecuária: deixa rebanhos e crias, bem como sela de campo, caixa sem encourar, espora, carros de boi, corda para laçar, chapéu e gibão de couro, enfim, instrumentos de trabalho com o gado. O inventário também mostra o rebanho pastando solto em terras dispersas pela Serra do Cabral, com os córregos sempre como referência para localizar os bois: Várzea Formosa, Garapa, Chapadinha, Morro dos Angicos, Várzea da Lontra, Buritizinho e Santa Clara. Nota-se a ausência de cercas, estando as manadas soltas pelo sertão, e algumas rezes pastando raramente em terras vizinhas, cujos donos são identificados.

É perceptível a metamorfose da riqueza nesses registros, explicável pelo contexto brasileiro de então: a partir dos anos 1870, movimentos abolicionistas tomam corpo, e o escravo vai aos poucos se tornando um ativo desvalorizado. A Lei de Terras, elaborada no mesmo ano em que se proibia a importação de escravos africanos, viria para em décadas transferir o valor das formas de propriedade. Zélia Cardoso de Mello (1985) observa o movimento tendencial altista da propriedade imobiliária ano a ano, no sentido de que representava parcela cada vez maior dos ativos, em contraposição ao declínio no preço dos escravos.

Os exemplos de inventários utilizados revelam não apenas a sólida atividade econômica na criação de gado na Serra desde há muito, mas também a ligação dos fatores terra, trabalho e capital. A força de trabalho compulsória era propriedade dos fazendeiros, estando no mesmo patamar das ferramentas e dos bois que pastavam sobre a terra. Se cada uma dessas fontes de riqueza pertence a esferas absolutamente distintas e não apresentam a menor analogia entre si, apenas quando estão associadas que se transformam na famigerada fórmula trinitária (MARX, 2013, v. 3), realizando o capitalismo na Serra do Cabral enquanto relação social. 
Partindo para a análise do Registro de Terras Públicas de 1855-1856, contextualizado pela questão da Lei de Terras de 1850, na primeira fonte aparecem sujeitos declarando suas posses por compra. Um dos casos apresentados é o de Francisco de Almeida Borém, em registros do $\mathrm{APM}^{98}$. Neles, lê-se:

\begin{abstract}
Aos cinco dias do mês de abril de mil oitocentos e cinquenta e seis me foi apresentada esta declaração por Francisco de Almeida Baurém, porque a achei conforme (sic) entregando ao referido declarante um dos exemplares, e ficando outro arquivado por serem em duplicata tudo na forma do Regulamento n. 1318 de 30 de Janeiro de 1854. Bonfim era (sic). O encarregado do Registro, João Baptista Correa Machado. Eu abaixo assinado declaro que possuo por herança uma parte de terra sita no lugar denominado Vaquejador do Meio, que tem uma légua de comprimento, meia de largura pouco mais ou menos, extrema com a Fazenda de Santa Engrácia pelo Riacho da ponta (sic) as confrontações ao Vaquejador do Meio nesta Freguesia do Bonfim. Canabrava, 5 de Abril de 1856. Francisco de Almeida Baurém. Recebi deste Registro um mil duzentos e cinquenta e seis réis. Era supra o Encarregado Corrêa Machado. (MINAS GERAIS, 2010, n. 102, fl. 35).
\end{abstract}

Aos cinco dias do mês de abril de mil oitocentos e cinquenta e seis me foi apresentada esta declaração por Francisco de Almeida Baurém, porque a achei conforme aceitei e registrei entregando ao declarante um dos exemplares, e ficando outro arquivado por serem em duplicata tudo na forma do Regulamento N. 1318 de 30 de Janeiro de 1854. Bonfim era (sic). O Encarregado do Registro João Baptista Corrêa Machado. Eu abaixo assinado declaro que possuo uma parte de terras por compra sitas no lugar denominado Ribeirão Grande nesta Freguesia do Bonfim, a qual extrema com Maria Quitéria e por outro lado com Valencianno Verissimo, por outro lado com Theodoro Alves e pela parte do Sul com o mesmo Theodoro, a fixar na mesma estrada, onde teve princípio, a terra meia légua de comprido e meio quarto de largura pouco mais ou menos. Canabrava, 5 de Abril de 1856. Francisco de Almeida Baurém. Recebi deste registro um mil quatrocentos e dois réis. Era supra. O Encarregado Corrêa Machado. (MINAS GERAIS, 2010, n. 103, fl. 36, grifos nossos).

Aos sete dias do mês de abril de mil oitocentos e cinquenta e seis me foi apresentada esta declaração por Francisco de Almeida Baurém e porque a achei conforme aceitei e a registrei entregando ao referido declarante um dos exemplares, e ficando outro arquivado por serem em duplicata tudo na forma do Regulamento N. 1318 de 30 de Janeiro de 1854. Bonfim era (sic). O Encarregado do Registro João Baptista Corrêa Machado. Eu abaixo assinado declaro que possuo em comum uma parte de terras sitas no lugar denominado Canabrava, e as possuo por herança nesta Freguesia do Bonfim, sendo duas extremas do Buriti ao Retiro Velho das Alagôas, pelas as Alagôas abaixo extremando com Gonçalo Pereira digo Christovão Pereira até a Capoeira e por esta abaixo até o Rio Canabrava extremando com Marcelino dos Santos Franco pela Canabrava arriba até o Buriti e por este arriba as suas cabeceiras em rumo direito ao estreito dos Olhos D'Água extremando com João Alves Carneiro tem duas léguas pouco mais ou menos de comprido e uma de largura. Canabrava, 5 de Abril de 1856. Francisco de Almeida Baurem, recebi deste Registro um mil setecentos e cinquenta réis. Era supra. O Encarregado Corrêa Machado. (MINAS GERAIS, 2010, n. 126, fl. 43).

Os excertos apresentam negociação de terras antes do vigor da lei, bem como o pagamento pelos registros, cujo dinheiro seria destinado aos projetos de imigração e de

\footnotetext{
${ }^{98}$ Citam-se esses três como amostras: 102, 103 e 126. Ao folhear mais páginas do Registro de Terras Públicas do Arraial do Bonfim, verifica-se que os nomes das fazendas registradas em 1856 permanecem, na maioria, os mesmos até hoje.
} 
demarcação das terras. No entanto, a Lei de Terras não criou um mercado fundiário, e elas foram griladas, não compradas do Estado. “A terra, para se tornar um elemento da colonização, tem não apenas de ser inculta, mas propriedade pública, que pode ser transformada em propriedade privada" (MARX, 2013, v. 1, p. 838), já notava Wakefield. Cruzando essas informações com os inventários de integrantes da família Borém, compreende-se melhor o que as fazendas da região produziam e a ossificação dos fatores terra, trabalho e capital. Em um momento em que se discutia o tráfico e o escravismo, a mão de obra fazia parte da fazenda, pois o escravo representava ao mesmo tempo capital e trabalho. Com a gradativa fragmentação dos fatores de produção e do Estado, este passa a fazer a ponte para que a terra deixe de ser objeto de posse para a ser passível de alienação.

Se entre tais fatores, a terra não pode ser considerada produto justamente porque não é oriunda do trabalho humano, ao ser inventariada e registrada como propriedade, passa a se tornar mercadoria, descolando-se do trabalho. Com essa cisão, especialmente num momento histórico em que se discutia a permanência do trabalho compulsório (o escravismo enquanto limite da expropriação), a propriedade privada da terra e dos meios de produção faz com que o trabalho também passe a ser propriedade privada, cujo dono urge ser o sujeito livre. Sobre os livres pobres que existiam no sertão e não tinham acesso à terra, toda alternativa os colocava em posição marginal à economia regional, o que os fadava a compor a base da classe social sertaneja.

Em Os deserdados da terra: a lógica costumeira e judicial dos processos de expulsão e invasão da terra camponesa no sertão de Minas Gerais, livro que aborda o campesinato e o regime de agregação no norte mineiro, Margarida Maria Moura deduz que cessada a possibilidade de existir como "desclassificado do ouro", aos livres pobres se abriram duas alternativas no meio rural: se conformarem à existência social na fazenda, formada ou em implementação, ou se manterem livres, o que pressupunha o afastamento social das áreas nas quais a fazenda tinha interesse em se estabelecer.

A autora apoia essa hipótese no fato de que quem possuía terra de sesmaria ou data para mineração antes à Lei de Terras, constituía-se em classe dominante territorial, excluindo as posses ou afastando seus habitantes para as grotas íngremes e veredas distantes. Depois de 1850, os ocupantes de terras e os possuidores de título de sesmaria ficaram sujeitos à legitimação dos seus direitos, o que foi feito em 1854 , por meio do que ficou conhecido como registro paroquial (MOURA, 1988).

O Registro de Terras Públicas, uma determinação do Estado recém-criado, vinha para legitimar as novas relações econômicas que lançavam o Brasil na engrenagem econômica 
mundial, cujo capitalismo industrial e liberal exigia mudanças nas formas de geração de riqueza interna à ex-colônia. José Murilo de Carvalho enfatiza a permanência dos interesses latifundiários no Brasil independente e discute o duvidoso caráter liberal da formação do país, sem se atentar para o fato de que este discurso liberal construído permitia o escravismo:

\begin{abstract}
A herança colonial pesou mais na área dos direitos civis. O novo país herdou a escravidão, que negava a condição humana do escravo, herdou a grande propriedade rural, fechada à ação da lei, e herdou um Estado comprometido com o poder privado. Esses três empecilhos ao exercício da cidadania civil revelaram-se persistentes. A escravidão só foi abolida em 1888, a grande propriedade ainda exerce seu poder em algumas áreas do país e a desprivatização do poder público é tema da agenda atual de reformas. (CARVALHO, 2003, p. 50-51).
\end{abstract}

Ao se discutir cidadania pós-abolição (inclusive nos dias atuais), há um mascaramento da contradição do trabalho, que passa a ser livre, porém permanece forçado. A coerção do trabalhador brota da liberdade dele: é a autonomização, sua transformação em força de trabalho, pois o escravo em breve seria liberto e dono apenas de si, por isso o Império tinha urgência em fazer o registro e a demarcação de terras. Eis o liberalismo.

Desse modo, terra e trabalho começam a ser aparentemente descolados, desencadeando mobilização da força de trabalho pela Serra. A questão já era discutida no Conselho de Estado desde 1842, com seus integrantes tomando por base os escritos de Wakefield. Como conclusão, a única maneira de obter trabalho livre seria criar obstáculos à propriedade rural, de modo que homens livres, incapazes de adquirir terras, fossem forçados a dispor a sua mercadoria - força de trabalho - para as fazendas. Assim, os trabalhadores livres constituiriam também a clientela do senhor ${ }^{99}$.

A autonomização dos fatores de produção entra em curso já na segunda metade do século XIX, quando a mudança nas formas de riqueza envolve o fortalecimento de um grupo social com características específicas. Para Zélia Cardoso de Mello, à medida que o capital se liberta do escravo, defronta-se com uma variedade de alternativas que produziu o capitalista, desde logo comprometido com a concentração do capital e que já surge como classe que personifica interesses comerciais, financeiros, agrários e políticos, o que lhe exige uma postura diferente diante da complexidade econômica (MELLO, 1985). Passavam a interessar à grande propriedade exportadora trabalhadores livres à disposição do capital. Porém, a abundância de

\footnotetext{
99 “Eu ainda me lembro de quando chegou a notícia da Lei de Treze de Maio. Os negros todos largaram o serviço e se ajuntaram no terreiro, dançando e cantando que estavam livres e não queriam mais trabalhar. Vovó, com raiva da gritaria, chegou à porta ameaçando com a bengala dizendo: 'Pisem já de minha casa pra fora, seus tratantes! A liberdade veio não foi pra vocês não, foi pra mim! Saiam já!'. Os negros calaram o bico e foram para a senzala. Daí a pouco veio Joaquim Angola em nome dos outros pedir perdão e dizer que todos queriam ficar. Vovó deixou, e os que não morreram ou casaram estão até hoje na Chácara”. (MORLEY, 2016, p. 134-135).
} 
terras impedia acessá-los, dada a possibilidade desses braços trabalharem para si e se tornarem proprietários. Era preciso "colonizar para o capital”, transferindo a garantia de crédito do escravo para a terra ${ }^{100}$.

A transformação legal da terra em propriedade fundiária indicava um projeto de modernização, visando alterar o fundamento da reprodução das relações sociais de produção. No entanto, para a Serra do Cabral o projeto de trocar escravos por imigrantes estava fora de cogitação. $\mathrm{Na}$ inexistência de salário, não era possível transformar imediatamente a força de trabalho em assalariada, não havendo, por sua vez, mais-valia. Os sertanejos teriam suas relações com os donos da terra costuradas de forma contraditória: subordinados por relações de dominação pessoal à grande propriedade produtora de mercadorias, participando, quando necessário, nas colheitas, no trato das crias e na proteção da família proprietária, mas sendo também compadres (BOECHAT, 2013). Continuariam forçados à geração de produtos, presos a relações de poder clientelistas comandadas pelos fazendeiros.

Esse grupo de fazendeiros encarnou ali e à sua maneira a personificação do Estado, uma vez que a questão da terra passou a ser tratada como problema regional. Com o Estado ainda não centralizado, o que seria viável naquele momento era a transferência de poder para as oligarquias regionais via concessão de títulos. O coronel é o resultado desse mecanismo, com a incumbência de representar localmente o Estado e a polícia, valendo-se da violência explícita ou extraeconômica para ativar a produção dos seus subordinados. O coronelismo persistiu após a Proclamação da República, articulando seus interesses aos nacionais enquanto impunha relações violentas.

\footnotetext{
100 “Já se mostrou a relação estabelecida entre a necessidade de implantação do trabalho livre, via política de colonização - dada a interrupção do abastecimento externo de escravos e, portanto, a impossibilidade de renovação ilimitada desta mão-de-obra - e o condicionamento da propriedade da terra à posse prévia de capital, cujo reflexo institucional foi a Lei de Terras. J. M. Cardoso de Mello mostrou que interessava à grande propriedade exportadora trabalhadores livres à disposição do capital; a abundância de terras impedia tal coisa, pela possibilidade daqueles produzirem para a própria subsistência e, em vez de assalariados tornarem-se proprietários. Tratava-se, pois, de 'colonizar para o capital'. Como fator adicional, a partir de 1873, as terras e não mais os escravos passam a servir como garantia de crédito. Como consequência desses fatores, 'durante a crise do trabalho servil, o objeto da renda capitalista passa do escravo para a terra, do predomínio num para o outro’.” (MELLO, 1985, p. 87).
} 


\section{4. "O passado era mesmo passado ${ }^{101 "}$ na "terra bonita onde mora a maleita ${ }^{102 "}$ : a região sob a bênção do coronel}

Adentrando o século XX, os anuários do APM consultados ajudam a compreender não apenas a criação dos municípios e o reconhecimento de povoados na Serra, como também as características naturais e sociais da região. No anuário, encontra-se o seguinte sobre a criação do distrito de paz de Barreiros (Francisco Dumont):

XX. Mun. de Bocayuva. [...] foi creado, dentro do seo territorio, um novo distr. de paz, o de Barreiros, pelo n. I do art. $2^{\circ}$ da cit. lei n. 556, que assim dispõe:

$<$ Art. $2^{\circ}$. Ficam creados os seguintes districtos:

I. De Barreiros, no municipio de Bocayuva, com as seguintes divisas: Da barra do corrego Embaiaçaia no Jequitahy até a barra do corrego Corrente, nesse mesmo rio; subindo o Corrente, até a principal cabeceira e suas vertentes e dahi, tomando pelos altos das serras Agua Fria e Cabral, compreendendo todas as vertentes para o rio Jequitahy até a cabeceira do Embaiaçainha: por este abaixo ao ribeirão Embaiaçaia e dahi, aguas abaixo, até o rio Jequitahy>>.

$[\ldots]$

A pov. de Conceição do Barreiro fica no mun. e termo de Bocayuva, ao $\mathrm{N}$ do Estado. Esta pov. de N. Sra. Da Conceição do Barreiro, pelo facto de já ter elementos para se constituir sede de um novo distr. de paz, recebeo essa categoria pelo art. $2^{\circ}$, n. 1 , da cit. lei 556, de 1911.

A lav. de cereaes e a criação de gado são o forte do logar.

Pertence ao distr. de Barreiro a localidade denomin. Burity Grande, onde, a 27 de jan. de 1910, foi install. uma escola mixta municipal, com 30 alumnos matriculados. (SENNA, 1918, p. 313-314, grifos nossos).

Até então, Barreiros era uma povoação do arraial do Bonfim, atual município de Bocaiúva, este último acusado nos mapas desde o século XVII. Versando sobre o povoamento do Brasil pelos bandeirantes a partir das perspectivas antagônicas de Oliveira Viana e Cassiano Ricardo $^{103}$, Aroldo de Azevedo conta em seu texto Arraiais e corrutelas que entre os Seiscentos e os Setecentos, "arraial" significava "exército posto em campanha" ou "o sítio do acampamento, onde estão as tendas e barracas" (AZEVEDO, 1957, p. 3). Com a expansão do bandeirismo minerador, o termo passou a significar acampamento de corpo volante, com aglomeração de gente em caráter mais ou menos provisório. Conforme os mineradores iam se fixando, a palavra tornou-se sinônimo de povoamento, dando origem aos núcleos de ocupação sertão afora. Sinônimo de arraial, "corruptela" significa pequeno arraial de garimpeiros à beira de terras virgens, “"o lugar da corrupção e dos costumes', uma vez que para ali convergem

\footnotetext{
101 "Considerava o progresso de todos - como se mais esse todo Brasil, territórios - e falava, horas, horas. - 'Vim de vez!' - disse, quando retornou de Goiás. O passado, para ele, era mesmo passado, não vogava. E, de si, parte de fraco não dava, nenhão, nunca." (ROSA, 1986, p. 262).

102 "Primo Ribeiro dormiu mal e o outro não dorme quase nunca. Mas ambos escutaram o mosquito a noite inteira. E o anofelino é o passarinho que canta mais bonito, na terra bonita onde mora a maleita." (ROSA, 2006, p. 131). 103 Para o primeiro, a bandeira era um "fragmento do latifúndio" enquanto que, para o segundo, ela era um "fenômeno urbano" (AZEVEDO, 1957, p. 5).
} 
aventureiros de toda espécie, gente cheia de vícios e pecados" (RIBEIRO apud AZEVEDO, 1957, p. 20).

É importante frisar a classificação dos termos apresentados porque sendo o antigo arraial do Bonfim assim denominado, sua fixação teria se dado a partir dos exércitos bandeirantes em marcha pelo sertão em busca de minerais. Somam-se a isso as informações dos mapas, referentes aos registros de guardas e soldados para os caminhos do gado e, posteriormente, o controle do contrabando de ouro e diamantes. Um povoamento de caráter militarizado que espraiou gente para a Serra, a complementar a ordem ou a fugir dela. Azevedo enfatiza que as principais características da corruptela são a heterogeneidade e a mobilidade de sua população, composta desde sertanejos atrás de garimpos até indígenas mansos e gente da mais variada procedência, cujos antecedentes são incertos ou criminosos (AZEVEDO, 1957).

Conforme Senna, a região não apenas não pode ser enquadrada no contexto da regressão econômica - pois "A lav. de cereaes e a criação de gado são o forte do logar", o que propõe pensar na produção para além da subsistência -, como já aparecia com a sua especialidade a pecuária extensiva, cujo maior destino era o mercado de Montes Claros de Formiga ${ }^{104}$, sendo "praça commercial de $1^{\mathrm{a}}$ ordem no sertão" [havendo] "nella uma feira semanal. Gado, sola, tecidos, cereaes, borracha de mangabeira, algodão, etc., - são os generos de seo principal commercio" (SENNA, 1909, p. 672). No anuário de 1918, Barreiros aparece com o nome de Conceição do Barreiro, sendo ainda distrito do município de Bocaiúva, com as mesmas delimitações. Com o projeto da Estrada de Ferro Central do Brasil passando por Montes Claros, a notícia do anuário via com entusiasmo o "progresso do norte de Minas", que exportaria alhures os produtos agropecuários da região, bem como os tecidos produzidos pela indústria têxtil de Jequitaí, ligando-as ao eixo ferroviário Sul-Baiano.

O futuro da região atravessada pelo Prolongamento da E. de F. Central do Brasil para Montes Claros, é promissor de grandes resultados nas industrias agrícola, pastoril, manufactureira, a de tecidos de algodão, principalmente, onde já se encontram em prosperas condições de funccionamento quatro fabricas, uma em Santa Barbara, a doze kilometros da Estação do Curimatahy, no prolongamento; a do Jequitahy, e duas na cidade de Montes Claros. Correndo o traçado da linha entre as Serras de Diamantina e do Cabral, duas fontes inexgotaveis de riquezas mineraes, encontrará o trafego do prolongamento mais um elemento de grande valor, quando a industria extractiva tiver entre nós atingido ao seo desejado desenvolvimento. (SENNA, 1918, p. 529, grifos do autor).

Na tese Em nome da região, a serviço do capital: o regionalismo político norte-mineiro, pesquisa que debate o regionalismo e o papel da Sudene no norte mineiro, Laurindo Mékie

${ }^{104}$ Fundada por bandeira de Matias Cardoso, sua importância remonta ao século XIX, quando "foi erecta freguezia desde 1832 (resolução de 14 de julho). Pertence ao extenso bispado de Diamantina” (SENNA, 1909, p. 674). 
Pereira mostra como a construção da estrada de ferro, que atravessava o norte mineiro conectando o centro de Minas ao sul da Bahia, também teria incrementado o comércio de gado. Segundo o historiador, às margens da ferrovia desenvolveram-se as chamadas invernadas, fazendas destinadas à engorda e posterior comercialização dos bovinos para os centros urbanos, como Belo Horizonte e Rio de Janeiro (PEREIRA, 2007). O terminal de Várzea da Palma, município abrangido pela Serra do Cabral, foi o primeiro a ser construído, inaugurado em 1908; o de Pirapora, em 1911; o de Bocaiúva, em 1924; e o de Montes Claros, em 1926. A ligação com a Bahia se concretizou em 1950.

No mesmo anuário, a especialização pecuária na Serra do Cabral se torna evidente graças à descrição detalhada de quem andou pelas fazendas da região em princípios do século: de touros Hereford e Devon a equinos de "pedrigree" trazidos do Rio Grande do Sul, confirmando a circulação de mercadorias interestaduais.

O mesmo relato aponta a queixa dos fazendeiros "pelo desprezo com que o sertanejo encara os direitos alheios, facto que s. s. julga um dos maiores entraves ao progresso economico da região", pois "qualquer individuo lá se julga no direito de se criar porcos e cabras soltos nas roças alheias. E se o prejudicado ousa protestar contra esse absurdo, esbarra logo com o argumento 'tranchant' da carabina" (SENNA, 1918, p. 531). Fica evidente que os pastos ainda careciam de fecho, sem delimitação precisa das propriedades, que avançavam sem cerca serra adentro: "Mas o gado, escolhendo por si e sem tocada, mas depois de solto por boa regra, pegara ida espaçada mais virante acima, aonde devia haver, para se lamber, salinas de barreiro" (ROSA, 1986, p. 351).

Nota-se, portanto, que o capitalismo produz uma forma sistêmica de conflito, com a violência cumprindo o seu papel. A disputa pela terra estava acontecendo entre os fazendeiros que, ao investirem as suas produções em gado, exemplificam o movimento de centralização do capital e as hostilidades que daí passam a ocorrer. As lembranças sobre as disputas do fazendeiro Selorico Mendes, padrinho de Riobaldo, ilustram o quadro:

\footnotetext{
- “Ah, a vida vera é outra, do cidadão do sertão. Política! Tudo política, e potentes chefias. A pena, que aqui já é terra avinda concorde, roncice de paz, e sou homem particular. Mas, adiante, por aí arriba, ainda fazendeiro graúdo se reina mandador todos donos de agregados valentes, turmas de cabras do trabuco e na carabina escopetada! Domingos Touro, no Alambiques, Major Urbano na Macaçá, os Silva Salles na Crondeúba, no Vau-Vau dona Próspera Blaziana. Dona Adelaide no CampoRedondo, Simão Avelino na Barra-da-Vaca, Mozar Vieira no São João do Canastrão, o Coronel Camucim nos Arcanjos, comarca de Rio Pardo; e tantos, tantos. Nisto que na extrema de cada fazenda some e surge um camarada, de sentinela, que sobraça o pau-de-fogo e vigia feito onça que come carcaça. Ei. Mesma coisa no barranco do rio, e se descer esse São Francisco, que aprova, cada lugar é só de um grande senhor, com
} 
sua família geral, seus jagunços mil, ordeiros: ver São Francisco da Arrelia, Januária, Carinhanha, Urubu, Pilão Arcado, Xiquexique e Sento-Sé”. (ROSA, 1986, p. 94).

Sobre o conflito entre fazendeiros e sertanejos em relação às criações pastarem nas terras alheias sem cerca, cabe dar relevo ao fato de que a disputa pela terra estava acontecendo em um momento no qual a expansão das propriedades se processava também na Serra do Cabral. As terras, apesar de notadas nos registros paroquiais de 1854, eram expandidas. Em $O$ cativeiro da terra, José de Souza Martins explica que com a transição do escravismo para o trabalho livre, o capital deixa de se configurar no trabalhador para se configurar no resultado do trabalho. Apesar de o autor se deter na particularidade da cafeicultura paulista, cuja herança colonial era a produção subordinada ao mercado e dedicada à exportação, nota-se um nexo entre esta realidade e a produção pecuária voltada para o mercado interno na Serra.

A fazenda se expandia sobre a mata do cerrado para a ampliação dos pastos, tendo em vista a crescente especialização produtiva - de touros Hereford e Devon a equinos de "pedrigree" -, desenrolando a reprodução ampliada do capital pecuário. Nesse decurso, o latifundiário se depara com sujeitos livres pobres que habitam aquilo que Márcia Motta (1998) chama de "fronteira aberta", não submetidos ao poder do fazendeiro e, portanto, não trabalhando para ele.

Para José de Souza Martins, as mudanças ocorridas com a abolição da escravatura não se limitaram à simples transformação na condição jurídica do trabalhador, mas em algo maior no que concerne à noção do que era a liberdade, tendo em vista que o pensamento corrente nos Oitocentos era de que "a escravidão desonrou o trabalho"105, sendo necessário transformar essa visão, já que sem isso não seria possível passar da sua coerção predominantemente física para a preeminentemente ideológica. A exploração da força laboral teria que ser considerada legítima não mais apenas pelo fazendeiro, mas também por aquele que a ela se submetia, não havendo nessas relações lugar para o trabalhador que considerasse a liberdade negação do trabalho, mas, apenas para quem o considerasse uma virtude da liberdade (MARTINS, 2004).

No contexto sertanejo, ser expropriado e ter que se submeter a um senhor de terras estava muito aquém da absorção da ideologia de liberdade. Utilizando a ficção como exemplo, uma passagem do Grande sertão: veredas apresenta uma pequena margem de escolha entre os sujeitos livres pobres: ou permanecem lavradores, ou ingressam no "sistema jagunço". Na

105 "Para o escravo, a liberdade não é o resultado imediato do seu trabalho, isto é, trabalho feito por ele, mas que não é seu. A liberdade é o contrário do trabalho, é a negação do trabalho [...]. Para o homem livre, despojado dos meios de produção, ao contrário, o seu trabalho passa a ser condição de liberdade. É no trabalho livremente vendido no mercado que o trabalhador recria e recobra a liberdade de vender novamente a sua força de trabalho [...]" (MARTINS, 2004, p. 17). 
posição de chefe, Riobaldo recruta sertanejos para compor o seu bando, "alguns com as caras secando os brotes das bexigas, más marcas, feito mijo na areia [...] Aquela gente depunha que tão aturada de todas as pobrezas e desgraças” (ROSA, 1986, p. 391). Os homens reunidos ali tinham roça e família, mas se deslumbravam com a possibilidade de correr o sertão, usar a força na vingança de líder famoso e, sem trabalhar, juntar riqueza pelo saque ${ }^{106}$. Supõe-se que a atração que o caminho da valentia exercia sobre esses expropriados teria a ver também com a negação ao trabalho e a delegação da reprodução da família às mulheres, que permaneciam no mesmo lugar enquanto eles ingressavam na "aventura":

\begin{abstract}
Que um, o sem pescoço, baixinho descoroçoou, na desengraça, observou: - “... Quem é que vai tomar conta das famílias da gente, nesse mundão de ausências? Quem cuida das rocinhas nossas, em trabalhar pra o sustento das pessoas de obrigação?..." O que falou, tinha falado por todos. - “... Pra os roçados? Pra os plantios...” E mesmo um outro, de mãos postas como que para rezar, choramingou: - "Dou de comer à mea mul'é e trêis fi'o, em debaixo de meu sapé..." - e era um homem alto, espingolado, com todos os remendos em todos os molambos. - "Como é a tua graça, seô?" - indaguei. Se chamava Pedro Comprido. Mas, aí, eu já tinha pensado. - "Pois vamos! As famílias capinam e colhem, completo, enquanto vocês estiverem em glórias, por fora, guerreando para impor paz inteira neste sertão e para obrar vingança pela morte atraiçoada de Joca Ramiro!..." - eu determinei. - "Ij' Maria, é ver, nós, de Cristo, jagunceando..." - escutei, dum. Daí, declarei mais: - "Vamos sair pelo mundo, tomando dinheiro dos que têm, e objetos e as vantagens, de toda valia... e só vamos sossegar quando cada um já estiver farto, e já tiver recebido umas duas ou três mulheres, moças sacudidas, p'ra o renovame de sua cama ou rede!...” Ah, ô gente, oh e eles: que todos, quase todos, geral, reluzindo aprovação." (ROSA, 1986, p. 392-393).
\end{abstract}

Já para Márcia Motta (1998), discordando de José de Souza Martins (2004) em relação à noção de trabalho pós-abolição em escala nacional, houve também a possibilidade de caipirização da população livre e liberta, porque nenhum ardil ideológico foi suficientemente forte para convencê-la a trabalhar para outrem, pois parcela desses sujeitos livres pobres da virada do século XIX se recusou a trabalhar nas fazendas, não porque confundisse o trabalho com a escravidão, mas por compreender que essa era uma das últimas alternativas possíveis na luta pela sobrevivência. Quando ameaçados pelo poder do fazendeiro, tenderiam a se afastar ou, como o relato de Nelson de Senna aponta, a enfrentar o adversário. Ou seja, o conflito sistêmico que o capitalismo engendra esteve presente na Serra: sujeitos livres ocupantes de terras, a "criar porcos e cabras soltos" e que participavam também do comércio local, em conflito com os fazendeiros expansionistas. Os homens livres pobres, ao contrário de uma

\footnotetext{
${ }^{106}$ Considerando o jagunço um "anachronismo ethnico", Euclides da Cunha aponta como semelhança entre ele e o cangaceiro, além da violência, a mobilidade pelo território, fruto possível da pobreza econômica: "Os cangaceiros nas incursões para o sul, e os jagunços nas incursões para o norte, defrontavam-se, sem se unirem, separados pelo vallado em declive de Paulo Affonso" (CUNHA, 1906, p. 363).
} 
existência "sem razão de ser", como colocou Maria Sylvia de Carvalho Franco (1997) ${ }^{107}$, "ajudaram a construir o mercado interno, experimentaram e cultivaram novos produtos agrícolas, criaram e recriaram estratégias de sobrevivência para salvaguardar os seus recursos" (MOTTA, 1998, p. 78).

O debate suscitado pelos autores, em referência às maneiras como veem essa população não submetida ao poder da fazenda e não enquadrada ao trabalho como forma categorial moderna, permite pensar nos dissociados do valor na constituição dessa sociabilidade. O teorema do valor-dissociação, sugerido por Roswitha Scholz (1996) ${ }^{108}$ com o objetivo de reformular a crítica radical desenvolvida pelo grupo Krisis ${ }^{109}$, afirma essencialmente que a forma da mercadoria apresenta uma conotação de gênero e uma condição prévia, sendo a dissociação o "outro", o reverso da sociedade de mercado ou o seu oposto imanente. Ele propõe enxergar o movimento histórico como de gênero, em que a forma da mercadoria é conotada como masculina, enquanto o feminino, relegado ao universo privado e sem forma, seria a outra metade desse paradoxo que co-constitui a moderna relação, pavimento da realização fetichizada, porém presente no ambiente privado e não oficial da vida.

Partindo-se desse teorema, a contribuição da autora permite pensar as demais formas de alteridade dentro do contexto geral da sociedade capitalista, com atenção à particularidade social brasileira. Seria parcela desses sertanejos alheios ao domínio da fazenda pecuária, chamados por Maria Sylvia de Carvalho Franco (1997) de "sem razão de ser", o dissociado na formação brasileira? Estaria Márcia Motta advertindo que esses sujeitos não são o "resto", mas o reverso inevitável de uma formação paradoxal moderna? Sendo co-forjados com a relação fetichista, "os elementos dissociados são na realidade um enorme espaço de reprodução" (KURZ, 1992a), indispensáveis à esfera produtiva.

\footnotetext{
107 "Esta situação - a propriedade de grandes extensões ocupadas parcialmente pela agricultura mercantil realizada por escravos - possibilitou e consolidou a existência de homens destituídos da propriedade dos meios de produção, mas não de sua posse, e que não foram plenamente submetidos às pressões econômicas decorrentes dessa condição, dado que o peso da produção, significativa para o sistema como um todo, não recaiu sobre seus ombros. Assim, numa sociedade em que há concentração dos meios de produção, onde vagarosa, mas progressivamente, aumentam os mercados, paralelamente forma-se um conjunto de homens livres e expropriados que não conheceram os rigores do trabalho forçado e não se proletarizaram. Formou-se, antes, uma 'ralé' que cresceu e vagou ao longo de quatro séculos: homens a rigor dispensáveis, desvinculados dos processos essenciais à sociedade. A agricultura mercantil baseada na escravidão simultaneamente abria espaço para sua existência e os deixava sem razão de ser" (FRANCO, 1997, p. 14).

${ }^{108}$ Será melhor explicado e debatido no capítulo 3.5.2.

${ }^{109}$ Grupo que fundou a revista de mesmo nome em 1989, disposto a dar enfoque à critica do valor, que é a de que a compreensão que a análise marxiana da mercadoria faz do fetichismo dela forma o verdadeiro "escândalo da socialização capitalista", tornando imperativa a necessidade de suplantação integral deste modelo por meio de uma "ruptura ontológica" com as categorias de base do capitalismo: trabalho, valor, dinheiro e capital. Em 2004, as divergências dos membros editoriais em virtude da teoria da dissociação-valor levaram à cisão da revista Krisis, com a retirada de Robert Kurz e Roswitha Scholz, que, por sua vez, fundaram a revista Exit!, editada mesmo após a morte de Kurz, em 2012. (MENEGATTI, 2019, p. 26).
} 
Ficção e realidade estimulam a pergunta porque apresentam uma possibilidade de conexão com o teorema para além da conotação de gênero, sobretudo porque, no caso brasileiro, a constituição social moderna e escravista não pode ser meramente derivada do valor, mas também imanente a ele.

No primeiro caso, Guimarães Rosa (2006) exemplifica no conto "A hora e vez de Augusto Matraga", esses sujeitos libertos ou seus descendentes, afastados do grande latifúndio, ao narrar o socorro concedido por um casal de pretos velhos a Nhô Augusto, quando este é tocaiado para morrer. Ao ter seu corpo jogado no barranco, o casal, que morava na boca do brejo, o acolheu em seu casebre, "que era um cofo de barro seco, sob um tufo de capim podre, mal erguido e mal avistado, no meio das árvores, como um ninho de maranhões" (ROSA, 2006, p. 353-354).

Matraga, fazendeiro mandão, representante masculino do universo público da mercadoria, é cuidado no ambiente privado por dois sujeitos dissociados produzidos pela mesma sociabilidade, jogados para a fronteira aberta, ilustrando o que Robert Kurz chama de "o pátio das traseiras e a entrada de fornecedores ou, por outro lado, o gabinete particular privado e o recanto silencioso, o não-sistémico do sistema” (KURZ, 1992a). A recuperação da personagem, destroçada pela concorrência de mercado e pela névoa moral sobre ela erguida, só foi possível porque ela foi despejada para ser socorrida por aqueles que, mesmo invisíveis, são elementos da totalidade social e, por isso, indesejavelmente vistos quando são enxergados pela modernização.

Da ficção ao campo, os antepassados de João Batista, conhecido como João da Serra, 53 anos (2019), se enquadram no grupo de sertanejos que viviam fora do domínio das fazendas, sobrevivendo da lavoura e de atividades complementares. Seu avô materno, nascido na região, era o famigerado João Caçador - "Vô era caçador mesmo, de catingueiro, aquele veado pequeno sem galha que fica no mato". A família de posseiros, cuja terra se situava na Vargem do Chico, trabalhava com cada atividade a depender da estação: roça - "Tudo o que cê planta na Serra dá. A terra é boa!" -, coleta de sempre-viva - "Não tinha estrada na Serra nesse tempo não! Em época de chuva, a gente ficava dias isolado lá, sem poder descer" - e garimpo de cristais na sua posse - e, por isso, sem pagar porcentagem. Todos os produtos tinham compradores no comércio local: a sempre-viva era vendida para a família de Zé Prado, tradicional no comércio local de coleta de frutos da Serra; o cristal era negociado com Zé Machado, de Joaquim Felício, parente distante dos Dumont. Perguntado sobre como a família tinha acessado a terra, respondeu: 
A Serra, uns anos atrás, não tinha dono. Cê podia comprar arame e cercar um terreno. Quando vô chegou em Francisco Dumont, nem Sócrates tinha terra lá na Serra, depois é que os Dumont foram brigar com os Campolina.

$[\ldots]$

Antes, era fácil conseguir documento. Quando o pai de mãe veio pra cá, nem Sócrates tinha terreno lá. (informação verbal) ${ }^{110}$.

Quando as reflorestadoras chegaram, seu pai vendeu a posse às empresas no fim da década de 1970 por um preço irrisório e recebeu também uma casa simples na periferia de Francisco Dumont. A família de João seria, assim, um exemplo de sertanejos livres pobres não submetidos diretamente ao poder dos fazendeiros, porém conectados ao mundo da mercadoria às avessas a partir do seu trabalho para vender parte dos produtos cultivados e extraídos da Serra. Em seu relato, era uma serra de fartura, cheia de animais e com muitos lagos nas vargens, com brejos de vereda difíceis de atravessar em tempo de chuva, de tanta água que minava da terra.

\section{Figura 6 - Rancho de coletores de sempre-viva na Serra do Cabral, 1970}

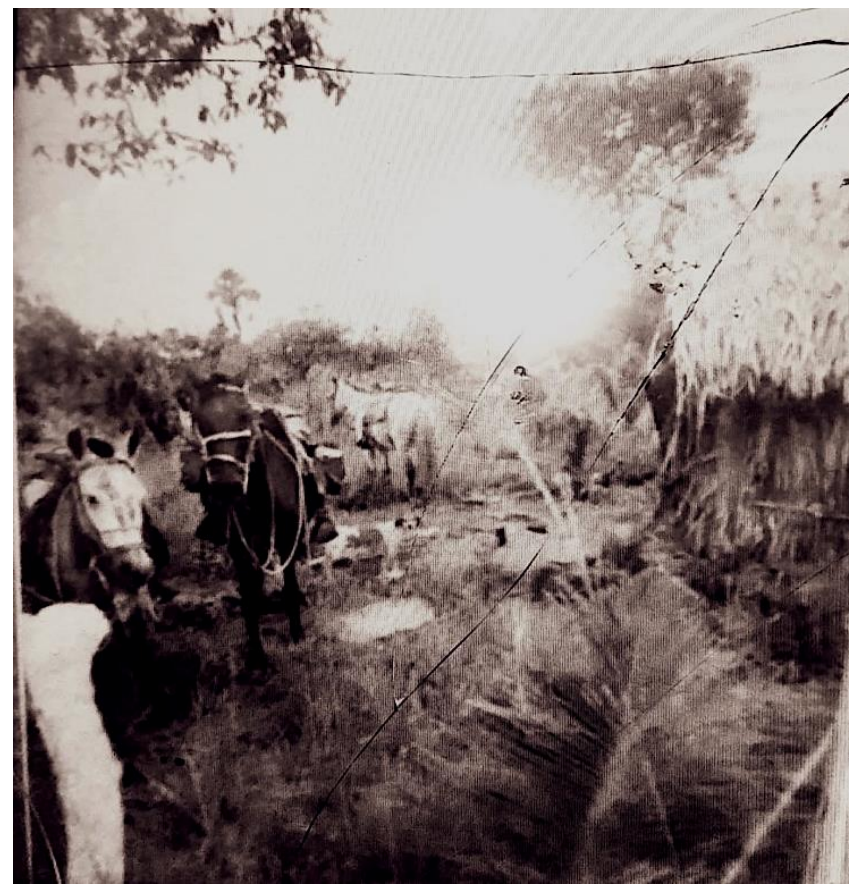

Fonte: acervo pessoal de Odilon Duarte, janeiro de 2018.

A Serra do Cabral parecia, então, denotar belezas. Ainda sobre a narrativa do anuário, o autor se deslumbra com seu panorama natural e as fazendas de gado. O percurso que fez pela região no alvorecer dos Novecentos, contribui com informações sobre a paisagem, as formas de ocupação, a constituição das fazendas e a crescente especialização na criação bovina, que

\footnotetext{
${ }^{110}$ Depoimento fornecido por João da Serra em entrevista durante pesquisa de campo em Francisco Dumont, em janeiro de 2019.
} 
deixava aos poucos de ser economia subsidiária para posteriormente virar commodity. Algumas

fazendas existentes desde o século XVIII, permanecem com sua atividade pecuária 200 anos depois, enquanto novos donos aparecem, como os Dolabela ${ }^{111}$.

Deixando Buenopolis, penetrei no sertão ignoto, sem caminhos, sem pontes, valendome das veredas da gadaria, e orientando-me pelos accidentes do terreno, em busca das Fazendas dos srs. Dolabella \& Portella, situadas entre as margens do Jequitahy e as alti-planicies da Serra do Espinhaço.

Essas Fazendas abrangem uma região de 15 legoas de comprimento por 7 de largura, cobrindo mais de cem legoas quadradas de superficie. São terras, na sua maioria, argilo-silico-calcareas, as melhores que encontrei na minha excursão. Nas margens do Jequitahy existem grandes baixadas alagadiças, lembrando os pantanaes de Matto Grosso, terrenos de espantosa fertilidade. Ha legoas e legoas de terras cobertas de mattas virgens, quer nos amplos baixadões humosos, quer nas chapadas seccas e calcareas ou nas encostas ladeirosas da serrania. Sobre uma vasta chapada em fórma de "plateau", existem os campos nativos de capim jaraguá, que eu atravessei durante tres horas successivas. E' um espectaculo impressionante aquelle jaraguasal immenso e "gelado", na expressão significativa do sertanejo, e alli somente á espera dos aramados divisorios, para se transformar nas mais soberbas invernadas.

Das 16 fazendas que constituem o "condado" dos srs. Dolabella \& Portella, as de "Alagoas" e "Sant'Anna", ficam nas alti-planicies, a mais de 1.000 metros sobre o nivel do mar, gosando um clima saluberrimo, constantemente batidos os seos lindos campos geraes pelos ventos frescos das alturas. Ellas se destinam á criação de carneiros, lá existindo já um pequeno rebanho de ovelhas. O "Timburé" está reservado para a criação de porcos, alli já iniciada ; e "Boa Vista", "Sumidouro", "Cannabrava", "Tirirical" e "Sucuryú", constituirão os grandes campos de criação bovina, já promissoramente iniciada. "São Caetano" e "Santo Antonio", destinamse á criação asinina e equina. "Sitio" e outras, mas proximas do traçado do ramal ferreo de Montes Claros, serão os centros de grandes culturas, notadamente de algodão e cereaes, de que já existe um bom começo. [...] A região que eu venho de atravessar encerra riquezas colossaes: milhões de metros cubicos de madeira de lei, o ferro, o manganez, as pedras preciosas, os calcareos, o salitre, abundando as cavernas, moradia millenar dos morcegos e da bicharia. E acima de tudo estão as terras humosas do Jequitahy, e as chapadas de massapé rôxo da Boa Vista, maravilhosas para a producção algodoeira ; as ricas pastagens do sitio e os campos geraes de Sant'Anna e Alagoas, no alto da serra, formando os famosos "dois verdes", incomparaveis, na exploração pastoril. Tudo inteiramente desaproveitado, porque estando apenas na entrada do grande sertão, a duas marchas da estação de Buenopolis, parece estar no fim do mundo, pela ausencia absoluta de estradas. Os caminhos são feitos a pé e de boi e casco de burro, e os rios e riachos, vadeados nas épocas favoraveis, fecham completamente as communicações no tempo das aguas. As terras argilo-silicocalcareas do sertão do Jequitahy, são as melhores possiveis para a cultura do algodão. $[\ldots]$

A região é diamantifera, possuindo, entre outras, a famosa lavra das "Duas Barras", e é eminentemente pastoril, rica em magníficos campos nativos de capim melloso.

$[\ldots]$

O gado. - A gadaria do trecho de sertão que percorri, é toda Creoula, sem raça definida: mixto de Curraleiro, Sertanejo e Caracú. E', no geral, de pequeno porte; mas apparecem frequentemente animaes de boa corpulencia, lembrando o gado Caracú. Os individuos de melhor talhe vão aos poucos formando um typo especial, ao qual os vaqueiros dão o nome de "Malabar", denominação a meo ver impropria, por lembrar uma região da India, patria do Zebú, do qual os malabares sertanejos nenhum signal

\footnotetext{
${ }^{111}$ De acordo com Laurindo Mékie Pereira (2007), entre 1910 e 1930, Alfredo Dolabela adquiriu 33 mil alqueires de terra na microrregião de Bocaiúva, investindo no cultivo de cana-de-açúcar, no fabrico de açúcar e na criação de gado. Posteriormente, sua propriedade foi vendida à família Matarazzo, que batizou a usina de cana-de-açúcar com o nome da matriarca da família, Malvina.
} 
apresentam. Elles parecem mais uma mistura do Caracú e Sertanejo, a julgar pela descripção que do gado sertanejo faz, na sua "Fazenda Moderna", o eminente mestre dr. Cotrim. O Malabar de que falo é um execellente gado de sertão, magnifico para o cruzamento com animaes finos. Vi nas fazendas que visitei vaccas dessa variedade, avaliadas em 14 a 16 arrobas.

Trata-se, por conseguinte, de um gado que merece ser aproveitado pelos criadores intelligentes, que agora estão penetrando em todo aquelle sertão. (SENNA, 1918, p. 531-532, grifos do autor).

Além do destaque para a fertilidade das terras da Serra - a partir dos anos 1960, os técnicos do governo contestariam essa afirmação como mecanismo para levar outros projetos para o norte mineiro como um todo -, nota-se a queixa referente ao acesso à região pela carência de estradas, pois esperava-se grandes mudanças com a ferrovia, integrando o sertão da Serra com os centros econômicos, num deslumbre com a modernização prometida pela linha do trem. Seus atributos naturais são realçados com vias ao potencial econômico a ser explorado: terra boa, madeira e minério.

Permanecia o discurso de isolamento regional, vinculado à pecha de decadência econômica, frequentes muito antes do Brasil republicano. Analisando os argumentos que defendiam a separação do norte de Minas Gerais, Jequitinhonha, Mucuri, sul da Bahia e de partes de Pernambuco e Goiás para a criação de uma nova província, Laurindo Mékie Pereira apresenta o reforço das classes dominantes regionais à ideia de isolamento e abandono desde a primeira proposta autonomista, de 1854. Em 1873, com nova investida no projeto de emancipação, a "fala do trono" na abertura da Assembleia Geral do mesmo ano chegou a recomendar a separação, alegando que terras tão férteis às margens do rio São Francisco mereciam nova circunscrição administrativa "para aquela extensa e afastada zona do território nacional, até hoje privada, em grande parte, dos influxos e vantagens da civilização" (PEREIRA, 2007, p. 91).

Apesar de não se ter como escopo os movimentos autonomistas, faz-se pertinente apresentar alguns dos discursos embrionários do que se percebia como região norte mineira. Sobre o projeto autonomista de 1873, o Ministro da Guerra João José de Junqueira teria reafirmado o apoio do imperador ao projeto ao participar da sessão da Assembleia Geral, sob o argumento dualista que ressalta os potenciais econômicos ao mesmo tempo em que não só enfatiza o isolamento e o abandono por conta da distância dos grandes centros, mas também retoma a ideia de sertão indomável pela lei e pela ordem.

Valle do São Francisco esta destinado a ser um grande emporio de riqueza, de industria, de civilização, se por ventura com o tempo, com o discernimento preciso, formos lançando os fundamentos desta futura grandeza. Quando se considera que ao Oeste do Império existe aquelle valle magnífico, intermedio entre o littoral e outras regiões mais longuinquas do occidente, um rio que tem um curso navegável de 
centenas de léguas, que é por assim dizer nosso Mediterrâneo, que pode formar o elo pra ligarmos províncias, todos concordarão que é necessário lançar ali os fundamentos de um importante centro administrativo.

[...]

Estas razões, e o conhecimento que tem o governo, como os nobres senadores igualmente teem, da falta de maiores luzes e instrução naquellas paragens que se teem tornado celebres algumas vezes nos annaes do crime, porque o braço da administração não pode chegar vigoroso ate la e a sua ação é muito lenta e retardada, é que determina a creação desta província. (BRASIL, 1873 apud PEREIRA, 2007, p. 92-93).

A proposta de estender a ferrovia até as proximidades do rio São Francisco foi negada diante da reivindicação dos vereadores montes-clarenses junto à Superintendência da Estrada de Ferro Bahia e Minas, porém prometeu-se trabalhar para o "engrandecimento dessa grande e uberrima zona conhecida por Norte de Minas, que como bem dizem v. sas, parecia jazer em completo esquecimento e atrazo" (BRASIL, 1873 apud PEREIRA, 2007, p. 94). Laurindo Mékie Pereira também reflete que se a terra era fértil e seus filhos "inteligentes e laboriosos", o que lhes faltava?

Um favor dos poderes públicos, para tornar-se grande para ahi germinar a mais adiantada industria, para os produtos de sua agricultura disputarem a preferência em todas as exposições internacionais. (PEREIRA, 2006, p. 47-48, grifos nossos).

Esse favor era, naquele momento, a ligação ferroviária. A esperança depositada na ferrovia partia da expectativa dos fazendeiros na ação interventora do Estado, que reproduzia via seus técnicos o mesmo pensamento. Tem-se, com isso, um exemplo de como o capital desistoriciza as relações sociais, que são, por sua vez, as construtoras do território. Ao apagar a historicidade moderna fundada na ocupação para a produção seja de gado, seja de diamante, naturaliza-se o objeto, com vias a torná-lo alvo do planejamento modernizador do Estado. À medida que a Serra foi se especializando nas mercadorias que produzia, sua organização social criou historicamente uma região, tomada como desigual pelos enunciados planeadores.

Com isso, o Estado deveria entrar na Serra para territorializá-la com a ferrovia e estimular os mercados, que circulariam os produtos e introduziriam a divisão do trabalho, pois “estando apenas na entrada do grande sertão, a duas marchas da estação de Buenopolis, parece estar no fim do mundo, pela ausencia absoluta de estradas" (SENNA, 1918, p. 531-532). Na ficção, Riobaldo não deixou de notar o entusiasmo do fazendeiro seo Assis Wababa com a notícia da chegada futura do trem naquelas paragens:

Seo Assis Wababa oxente se prazia, aquela noite, com o que o Vupes noticiava: que em breves tempos os trilhos do trem-de-ferro se armavam de chegar até lá, o Curralinho então se destinava ser lugar comercial de todo valor. Seo Assis Wababa se engordava concordando, trouxe canjirão de vinho. Me alembro: eu entrei no que imaginei - na ilusãozinha de que para mim também estava tudo assim resolvido, o 
progresso moderno: e que eu me representava ali rico, estabelecido. Mesmo vi como seria bom, se fosse verdade. (ROSA, 1986, p. 105-106).

Não só a ferrovia era alvo dos desejos modernizadores da classe dominante, mas também a navegação. O vale do São Francisco se tornou um depositário dos sonhos e desejos desse grupo ao longo do século XIX, culminando na realização do que Elizabeth Kiddy (2010) chama de um destino manifesto próprio associado à busca de uma identidade nacional brasileira. Elencando os projetos concernentes à comunicação do sertão com o mar, a historiadora remonta a 1807, ano do primeiro projeto de construção de um canal a partir da cachoeira de Paulo Afonso, para que os produtos agropecuários pudessem ser transportados mais facilmente aos mercados das grandes cidades do litoral. Mais adiante, D. João VI se entusiasmaria com a ideia de canais do grande rio até o Ceará, e, no Império, muitas foram as saídas com vias a examinar as possibilidades de navegação, com destaque para a primeira expedição imperial, de 1852.

Essa expedição teve em seu comando o engenheiro alemão Henrique Guilherme Fernando Halfeld ${ }^{112}$, contratado por D. Pedro II, incumbido de fazer um levantamento sobre o rio São Francisco e um recenseamento dos povoados e vilas ao longo do mesmo. Dado o alto custo de abrir a navegação a vapor, o projeto naufragou, seguido por outros, como o realizado pelo geólogo estadunidense Charles Hartt (1870), a viagem não oficial do explorador e cônsul britânico Richard Francis Burton (1869) e a Comissão Hidráulica do estadunidense William Milnor Roberts (1879), composta pelo geólogo Orville Derby e o engenheiro baiano Teodoro Sampaio.

Os deputados da corte, entusiastas da navegação, comparavam o São Francisco ao Mississipi, defendendo que todas as ferrovias que rasgassem o interior do país deveriam dar na grande bacia sertaneja. A eloquência nos argumentos de integração nacional justificava o projeto, dado que poucas décadas antes o espectro da fragmentação territorial se fazia ameaça possível com a Confederação do Equador. Portanto, havia por trás dos planos e discursos de navegação no rio São Francisco, interesses econômicos de grupos seletos em conectar seus

\footnotetext{
112 De origem prussiana, Halfeld chegou ao Brasil em 1835, onde principiou trabalhando na Companhia de Mineração de São José del Rey, em proveito da função de engenheiro de minas em Hartz. Atuou como capitão de artilharia na Revolta Liberal de Barbacena em 1942, dada a sua experiência na Batalha de Waterloo, além de ter sido sócio correspondente do Instituto Histórico e Geográfico Brasileiro. Condecorado pelo Império, lhe foi confiada a expedição à bacia do rio São Francisco, onde não apenas cartografou, mas também desenhou a paisagem, fez a planta da cachoeira de Paulo Afonso e levantou uma população estimada em 1,5 milhão de habitantes para 1858, delimitada entre Pirapora e a foz do São Francisco. Faleceu em Juiz de Fora em 1873 (PEREIRA, 1944).
} 
mercados com as regiões litorâneas e uma ideologia política de dominação territorial associada ao fardo de civilizar o sertão e criar a identidade nacional ${ }^{113}$.

Talvez, já estivesse no horizonte do plano a abertura da região para desencadear o processo de metropolização, identificável décadas depois. Era reforçada a visão naturalizada de que não há mercado nem civilização se não há caminhos e meios de transporte para promover a circulação de mercadorias. O sertão seria encarado, ainda, como o atraso e a barbárie, fora dos circuitos de trânsito e ausente do mercado.

\begin{abstract}
Se tais são, portanto, as vantagens do transporte fluvial ou marítimo, é natural que os primeiros aperfeiçoamentos das artes e da manufatura se operem lá onde essa circunstância abrir mercado do mundo inteiro para a produção de cada tipo de profissão e que esses aperfeiçoamentos levem muito tempo para estender-se ao interior do país. O interior do país pode durante muito tempo não ter nenhum outro mercado para a maior parte de suas mercadorias a não ser a região circunjacente, que o separa da costa marítima e dos grandes rios navegáveis. Por conseguinte, a extensão de seu mercado deverá durante muito tempo ser proporcional à riqueza e à reduzida densidade demográfica daquela região, e consequentemente seu aprimoramento sempre deverá vir depois do aprimoramento da região. (SMITH, 1983, p. 54-55).
\end{abstract}

Contrapondo-se a Adam Smith, a partir do que mostram os mapas, a Serra do Cabral era abrangida por caminhos do gado desde o século XVII, o que evidencia um mercado consequente da economia subsidiária pecuária. Entrado o século seguinte com as descobertas minerais, a região norte mineira apresentou grande dinamismo não apenas na extração de ouro e diamante, mas também na produção de mercadorias para o abastecimento dos núcleos mineradores, com os artigos chegando aos seus destinos distantes em lombo de burros ${ }^{114}$.

Durante os Oitocentos, a região continuou com o vigor econômico, a despeito da polêmica queda na mineração, o que permite rebater a ideia de retrocesso econômico; Minas Gerais como um todo fornecia ao litoral do Vale do Paraíba carne, mão de obra e mantimentos para a plantation de café. O rio São Francisco, ao atravessar o sertão, já era largamente utilizado desde os Seiscentos; não à toa, foi navegado posteriormente por Richard Burton, em 1867.

\footnotetext{
113 "Os novos expedicionarios ao atingirem-no perceberam esta transição violenta. Discordancia absoluta e radical entre as cidades da costa e as malocas de telha do interior, que desequilibra tanto o rhythmo de nosso desenvolvimento evolutivo e perturba deploravelmente a unidade nacional. Viam-se em terra estranha. Outros habitos. Outros quadros. Outra gente. Outra lingua mesmo, articulada em gyria original e pintoresca. Invadia-os o sentimento exacto de seguirem para uma guerra externa. Sentiam-se fóra do Brazil. A separação social completa dilatava a distancia geographica; creava a sensação amargurada de longo afastamento da patria." (CUNHA, 1905, p. 519).

114 "Além de servir como vias de abastecimento, há que se considerar a importância que a doação de sesmarias com vistas à produção agropastoril assumiu ao longo dos caminhos, de maneira que tais fazendas pudessem, não apenas abastecer os centros urbanos, mas também pudessem 'fornecer mantimentos básicos para viajantes, condutores e animais de tropas que se dirigiam para as Minas [...]' (Guimarães e Reis, 2007; 325)" (LEITE, 2010, p. 127).
} 
Saint-Hilaire, Spix e Martius, em visita ao Distrito Diamantino, foram uníssonos ao opinarem ser o arraial o mais rico e organizado da capitania.

\section{Figura 7 - Homens do mutirão para a construção da estrada de Conceição do Barreiro} (sem data)

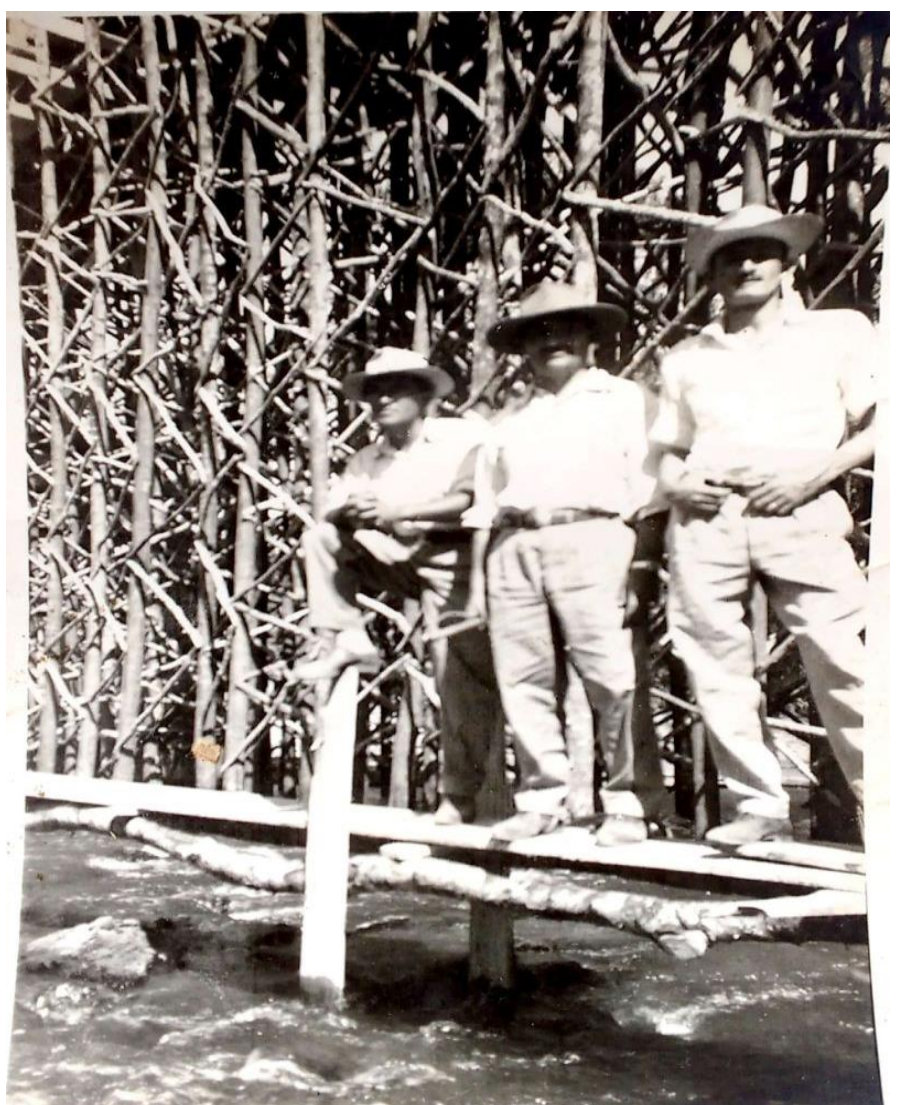

Fonte: acervo da Casa de Cultura Ercília Rosa, Francisco Dumont, 2017.

A economia subsidiária não produzia apenas para a subsistência. Ela formou um mercado interno, se autonomizando ao dar origem a novos setores de produção mercantil mesmo quando da queda da mineração. As atividades econômicas que agregam de forma subsidiária parte da população e dos capitais durante o auge da mineração persistem movimentando as cidades e vilas nas quais a extração declinou. Essas atividades prosseguem abandonando sua condição de secundárias, configurando novas dinâmicas de territorialização das relações de produção e uma produção autonomizada de mercadorias (LEITE, 2010). Ao se cindirem, é iniciada a busca pela especialização.

A partir dos trechos do anuário de 1918, nota-se que no século XX a propriedade fundiária aparece pouco a pouco desvinculada do trabalho, que se metamorfoseia em assalariado na Serra apenas depois de meados daquela centúria, enquanto a terra se consolida como mercadoria: 'E' um espectaculo impressionante aquelle jaraguasal immenso e 'gelado', 
na expressão significativa do sertanejo, e alli somente á espera dos aramados divisorios, para se transformar nas mais soberbas invernadas" (SENNA, 1918, p. 531-532, grifos nossos). Cercar as terras, portanto, já era uma intenção que a especialização exigia.

As famílias que vendem a sua força de trabalho, divididas entre as que recebem salário e as que recebem vale, exemplificam a estratificação em classes naquela sociedade, pois ao deixarem as relações escravistas acabam caindo, por certo tempo, nas relações de favor, historicamente violentas na particularidade social brasileira e exemplares da autonomização ainda não consolidada. Enquanto agregados, esses sujeitos não cedem apenas o seu tempo de trabalho ao fazendeiro, pois estão, eles e suas famílias, disponíveis ao dono da terra o tempo inteiro. A personificação do latifundiário apresenta uma face da autonomização dos fatores de produção em curso ${ }^{115}$.

O mesmo anuário, páginas adiante, descreve o sertanejo da Serra do Cabral, detentor da força de trabalho empregada nas fazendas e em atividades complementares:

\begin{abstract}
O homem. - Quem visita a região que eu venho de atravessar sente a alma confrangida pelo espectaculo doloroso da suprema decadencia organica do sertanejo. Nas confluencias dos riachos, nas margens das lagoas, nas immediações dos pantanaes, perambula uma população de vencidos ; homens, mulheres e creanças de côr amarello-esverdeada, ventres entumecidos, pescoços deformados, rostos edemaciados, boccas desdentadas, maxillares desgastados, olhos totalmente despigmentados. Seguramente $80 \%$ da população, representados por enfermos e degenerados, incapazes de elaborar a evolução economica daquelle sertão immenso, vão e vasio. Vi casarões seculares em completa ruina, velhos solares dos antigos donatarios, victoriosos sobre o indigena de outr'ora. Esses castellos de aroeira e barro, paredes de páo a pique, amarrado com guascas de couro de veado, recordam uma raça inteira de bravos pelejadores, que alli bateram, seculos passados, os fundamentos de uma civilisação hoje desaparecida. (SENNA, 1918, p. 532).
\end{abstract}

As considerações apresentadas são consonantes ao pensamento de teoria racial da época, tendo como expoente o médico e cientista Raimundo Nina Rodrigues (1862-1906), para quem a mestiçagem resultava em degenerescência e desequilíbrio mental. Considerando-se o sertanejo um mestiço, a estereotipia caía bem. Dela também não escapou Euclides da Cunha ao dissertar sobre os sertanejos de Canudos: "gente ínfima e suspeita", avessa ao trabalho, "homem

\footnotetext{
115 “Os meios de trabalho como tais são, então, capital, e a terra é, como tal, propriedade fundiária. A autonomização formal dessas condições de trabalho em relação ao trabalho, a forma específica da autonomização que tais condições apresentam diante do trabalho assalariado é, pois, um atributo inseparável delas como coisas, como condições de produção materiais, um caráter imanente e intrínseco que lhes corresponde necessariamente como elementos de produção. [...] Renda, lucro e salário parecem brotar, assim, do papel que, no processo simples de trabalho desempenham a terra, os meios de produção produzidos e o trabalho, ainda que consideremos esse processo de trabalho como ocorrendo apenas entre o homem e a natureza e desconsiderando qualquer determinação histórica." (MARX, 2013, v. 3, p. 888).
} 
permanentemente fatigado" (CUNHA, 1905, p. 115) ${ }^{116}$. Gilberto Freyre, apologista da miscigenação, não deixaria de dar a sua contribuição poucas décadas depois ao buscar a origem do que chama de inúteis, para se referir aos livres pobres, enquadrando os sertanejos no grupo. ${ }^{117}$ Dessa caricatura se valeu Guimarães Rosa para compor o conto "Sarapalha”, que, não à toa, integra seu primeiro livro, Sagarana, cujo título anterior era Sezão, escolhido para apresentar o sertão como lócus da febre da malária (PELISSARO, 2011, p. 38).

Febre, miscigenação e pobreza naturalizada compunham a cesta de ingredientes que pesava no ideal de povo brasileiro pensado pelas camadas dominantes da época. Cientificamente afeitas à questão racial e convencidas de que o horizonte de progresso jazia na Europa ocidental, questionavam como fundar uma nação recém-independente com um povo que não só era heterogêneo, como descendia de escravizados. A trajetória de ações governamentais desde a emancipação política reage à negação das diferenças e seus modos de organização social em variadas formas de massacre e assimilação étnica sertões adentro, com vias a eliminar quem não se encaixava no ideal da ordem econômica.

Depois de tornado latifundiário nas barrancas do rio São Francisco, Riobaldo empresta sua arma para matar "um bezerro branco, erroso, os olhos de nem ser [...] Cara de gente, cara de cão: determinaram - era o demo. Povo prascóvio. Mataram" (ROSA, 1986, p. 1). Ao ingressar no grupo dominante, o ex-jagunço consente que se mate um bezerro que não se parecia com o seu gênero. Em uma leitura metafórica, a criatura exótica não poderia se encaixar no projeto totalizante de povo uno. Quem o erradicou era "prascóvio" (ingênuo), contextualizado em um modelo social que ainda não incorporaria as diferenças em benefício da mercantilização. Antes das mudanças na engenharia social do valor, promovidas pela microeletrônica e suas formas de agregação das diferenças pelo mercado, o sertanejo seria visto como presença abjeta no corpo da nação sonhada.

É interessante comparar a descrição do sertanejo da Serra no anuário de 1918 com a que é feita pelo jagunço Riobaldo na virada de século, conforme avança com seu bando pelo sertão

\footnotetext{
116 Darcy Ribeiro (1995) foi outro a não escapar da estereotipia do sertanejo: para o sociólogo, ele tinha uma cultura atrasada e defasada, se comparado ao habitante do litoral.

117 "Senhores e escravos que se consideramos bem alimentados - em certo sentido estes melhor que aqueles - é apenas em relação aos matutos, caipiras, caboclos, agregados e sertanejos pobres - os seis milhões de inúteis no cálculo de Couty para uma população de doze, o vácuo enorme que lhe pareceu haver no Brasil entre os senhores das casas-grandes e os negros das senzalas. 'La situation fonctionnalle de cette population peut se résumer d'un mot: le Brésil n'a pas de peuple', escreveu Couty. Palavras que Joaquim Nabuco repetiria dois anos depois do cientista francês: 'São milhões', escrevia Nabuco em 1883, 'que se acham nessa condição intermédia, que não é o escravo, mas também não é o cidadão...’. Párias inúteis vivendo em choças de palha, dormindo em rede ou estrado, a vasilha de água e a panela seus únicos utensílios, sua alimentação a farinha com bacalhau ou charque; e 'a viola suspensa ao lado da imagem'.” (FREYRE, 2006, p. 98).
} 
na incumbência de vingar a morte de Joca Ramiro. Ao seguir rumo ao seu destino, ele se depara

com homens na estrada, insistentes em impedir sua passagem:

[...] Um eu vi, que dava ordens: um roceiro brabo, arrastando as calças e as esporas. Mas os outros, chusmote deles, eram só molambos de miséria, quase que não possuíam o respeito de roupas de vestir. Um, aos menos trapos: nem bem só o esporte de uma tanga esfarrapada, e, em lugar de camisa, a ver a espécie de colete, de couro de jaguacacaca.

$[\ldots]$

Gente tão em célebres, conforme eu nunca tinha divulgado nem ouvido dizer, na vida. $\mathrm{O}$ das esporas foi se amontar num jumento - esse era o único animal-de-sela que ali tinham. Acho que montou para oferecer à gente maior vulto de respeito; tocava batendo palma de mão na anca do jegue, veio vindo, para primeiro se presenciar. Olhei para todos. Um tinha a barba muito preta, e aqueles seus olhos permeando. Um, mesmo em dia de horas tão calorosas, ele estava trajado com uma baeta vermelha, comprida, acho que por falta de outra vestimenta prestável. Ver a ver o sacerdote! "Ih! Essa gente tem piolho e muquiranas..." - o Nélson disse, contrabaixo. Todos estavam com alguma garantia: que eram lazarinas, bocudas baludas, garruchas e bacamartes, escopetas e trabucão - peças de armas de outras idades. Quase que cada um era escuro de feições, curtidos muito, mas um escuro com sarro ravo, amarelos de tanto comer só polpa de buriti, e fio que estavam bêbados, de beber tanta saeta. Um, zambo troncudo, segurava somente uma calaboca, mas devia de ser de braço terrível, no manobrar aquele cacete. O quanto feioso, de dar pena, constado chato o formo do nariz, estragada a boca grande demais, em três. Outro, que tinha uma foice encabada muito comprido, e um porongo pendurado a tiracolo por uma embira, cochichava com os restantes uma séria falação: a qual uma espécie de pajelança. Artes vezes ele guinchava, feito o demônio gemedeiro. Esse, que por nome de Constantino acudia. Todos eles, com seus saquinhos chumbeiros e surrões, e polvorinhos de corno, e armamento tão desgraçado, mesmo assim não tomavam bastante receio de nossos rifles. Para o nosso juízo, eles eram doidos. Como é que, desvalimento de gente assim, podiam escolher ofício de salteador? Ah, mas não eram. Que o que acontecia era de serem só esses homens reperdidos sem salvação naquele recanto lontão de mundo, groteiros dum sertão, os catrumanos daquelas brenhas. O Acauã que explicou, o Acauã sabia deles. Que viviam tapados de Deus, assim nos ocos. Nem não saíam dos solapos, segundo refleti, dando cria feito bichos, em socavas. Mas por ali deviam de ter suas casas e suas mulheres, seus meninos pequenos. Cafuas levantadas nas burguéias, em dobras de serra ou no chão das baixadas, beira de brejo; às vezes formando mesmo arruados. Aí plantavam suas rocinhas, às vezes não tinham gordura nem sal. Tanteei pena deles, grande pena.

$[\ldots]$

- "Ossenhor uturje, mestre... Não temos costume... Não temos costume... Que estamos resguardando essas estradas... De não vir ninguém daquela banda: povo do Sucruiú, que estão com a doença, que pega em todos... Ossenhor é grande chefe, dando sua placença. Ossenhor é Vossenhoria? Peste de bexiga preta... [...] nem estão enterrando mais os defuntos deles... (ROSA, 1986, p. 336-339) $)^{118}$.

${ }^{118}$ A descrição ficcional parece endossar o processo de povoamento do território da Jaíba, apresentado por João Batista de Almeida Costa (2006). Segundo o que chama de Território Negro da Jahyba, a ampla área do vale do rio Verde Grande era recoberta com uma floresta de caatinga arbórea e com a presença de milhares de lagoas, apresentando-se para os bandeirantes e colonizadores como um espaço impróprio para a constituição da vida social bandeirante naquele período. A existência de endemia de malária propiciou aos mesmos denominarem essa área como jahyba, palavra tupi-guarani com a qual procuravam informar a existência da malária e a impossibilidade de ocupação. Tais condições a tornou propícia à tomada por escravizados que, buscando instituir espaços de liberdade, adentraram no interior da floresta e fundaram um número elevado de pequenas comunidades. 
No anuário de 1918, a solução para o sertanejo febril está no saneamento ${ }^{119}$ - visão defendida por Zé Bebelo e endossada por Riobaldo, para quem "os benefícios que os grados do Governo podiam desempenhar, remediando o sertão do desdeixo", de forma a acabar com a peste: "Urgentemente é se mandar portador, a lugar de farmácia, comprar adquirido remédio forte, que há, para se terminar com a maleita, em definitividade!" (ROSA, 1986, p. 374-375). Nelson de Senna observa:

Com raras excepções, os ultimos descendentes dos colonisadores dos seculos XVII e XVIII, esgotados pelas hostilidades do meio malsão, vencidos nas competições do trabalho, pela miseria organica e pela ignorancia, cedem agora as suas terras a conquistadores de nova especie: vencedores pela arma irresistivel do ouro. Alli só se fala em negocios de terras:

- Compro a dois por um, a tres, a quatro por um..

- Cinco por um? Fechado! E o sertão inteiro muda de donos, vendidas as terras a duas, quatro, cinco, dez vezes acima das antigas avaliações, onde não raro se viam lotes de gado "situado"; isto é, inclusive o custo das terras occupadas pela criação. Assim vaese operando alli a substituição completa de gerações inteiras, anniquiladas pela malaria, a ankylostomiase, o mal de Chagas - novo Moloch, a cujos pés vêm tombar, extenuadas, as levas humanas que lá chegam, em ondas intermittentes. E inutil ha de ser esse sacrificio de vidas preciosas, emquanto o colonisador não fôr precedido pelo engenheiro e pelo medico. A solução do magno problema sertanejo, está principalmente na viação e na hygiene ; aquella encurtando as distancias, e pondo o sertão em contacto directo com os centros populosos do paiz, donde virá a força creadora da civilisação, mobilisando e saneando pela movimentação as riquezas adormecidas do sólo. E esta - a hygiene - protegendo a integridade organica do povoador contra os assaltos insidiosos do "morbus" proteiforme. Do esforço consorciado da engenharia e da medicina está dependente a transfiguração economica e social do nosso sertão. "Governar é povoar" - disse alhures um estadista eminente. Governar é sanear - eis a traducção desse axioma politico-social, segundo a feição do caso brasileiro. (SENNA, 1918, p. 532-533).

A terra como mercadoria aparece novamente em destaque. Debruçando-se sobre a situação dos cafezais paulistas, para José de Souza Martins (2004), o fim do escravismo transforma o capital em renda territorial capitalizada, já que o montante investido não é mais imobilizado no escravo comprado. Se a economia capitalista só existe ao se pegar lucro (fictício) emprestado do futuro para realizar o presente, a abertura de novas fazendas sobre a mata nativa explica a lógica, pois a expansão abriria a possibilidade de maior produtividade

\footnotetext{
${ }^{119}$ Dialogando com os intelectuais de seu tempo e na justificativa da formação de um povo original, pautado na positividade da miscigenação, Gilberto Freyre não escapa do viés higienista, de forma a combater o discurso de raça e clima na caracterização do brasileiro:

São populações ainda hoje, ou melhor, hoje mais do que nos tempos coloniais, pessimamente nutridas. Entre caboclos do Norte as pesquisas de Araújo Lima fizeram-no concluir que a maior parte desse elemento - liricamente considerado pelos ingênuos a grande reserva brasileira vive reduzida a um "estado de inferioridade orgânica [...] às vezes de falência declarada". $O$ caboclo, escreve esse higienista, "anula o seu valor econômico e social numa insuficiência nutritiva que, secundada pelo alcoolismo e pela dupla ação distrófica do impaludismo e das verminoses, tem de ser reconhecida como um dos fatores de sua inferioridade física e intelectual. (FREYRE, 2006, p. 97).
} 
futura, tendo em vista as terras virgens e mais férteis ${ }^{120}$. Para o autor, o que antes era pago aos traficantes passa então para as mãos de companhias imobiliárias e grileiros, gerando uma renda diferencial produzida pela maior fertilidade das novas terras. Acrescenta, ainda, o surto ferroviário da segunda metade dos Oitocentos como elemento explicativo à renda diferencial acrescida pelo encurtamento das distâncias.

Por mais que para a pecuária a fertilidade da terra não tenha tanto peso quanto possui para as lavouras, é notória a expansão das fazendas na Serra, a lembrar o depoimento de João da Serra: “Antes, era fácil conseguir documento. Quando o pai de mãe veio pra cá, nem Sócrates tinha terreno lá". As terras careciam de cercas, conforme o anuário acusa, cercamento que não demoraria acontecer.

Nesse momento, também é o próprio anuário que aposta no progresso com a chegada da ferrovia, mais um fator a estimular a expansão das fazendas, com Nelson de Senna já tendo denunciado o conflito entre fazendeiros e posseiros, e João a lembrar das rusgas entre os Dumont e os Campolina na disputa pelas cercas. A grilagem aparece como parte endógena do processo de expansão do capital nas fazendas, situação que, seja no norte de Minas Gerais, seja em São Paulo, estava acontecendo de forma generalizada para que o país se realizasse na economia comercial, com a conivência do Estado, gradualmente capturado pelo mercado.

Cabe definir o que se entende por grilagem de terras nesse contexto. Ela não pode ser considerada um movimento espontâneo e repentino, posto que é planejada nos seus mínimos detalhes e necessita da participação de diversas instituições, como cartórios, prefeituras, institutos de terras etc. Em torno da grilagem, passa a existir uma complexa rede de relações, cujo principal beneficiado é o próprio grileiro, que se apropria das terras não com o intuito de torná-las produtivas, mas, desta vez, de incluí-las no mercado fundiário, tornando-se um

\footnotetext{
120 “A minha hipótese é a de que o capitalismo, na sua expansão, não só redefine antigas relações, subordinandoas à reprodução do capital, mas também engendra relações não capitalistas igual e contraditoriamente necessárias a essa reprodução. Marx já havia demonstrado que o capital preserva, redefinindo e subordinando, relações précapitalistas. Provavelmente, o caso mais significativo é o da renda capitalista da terra. Sendo a terra um fator natural, sem valor porque não é o resultado do trabalho humano, teoricamente não deveria ter preço. Mas, antes do advento do capitalismo, nos países europeus, o uso da terra estava sujeito a um tributo, ao pagamento da renda em trabalho, espécie ou dinheiro. Essas eram formas pré-capitalistas de renda decorrentes unicamente do fato de que algumas pessoas tinham o monopólio da terra, cuja utilização ficava, pois, sujeita a um tributo. O advento do capitalismo não fez cessar essa irracionalidade. Ao contrário, a propriedade fundiária, ainda que sob diferentes códigos, foi incorporada pelo capitalismo, contradição essa que se expressa na renda capitalista da terra. Tal renda nada mais tem a ver com o passado pré-capitalista, não é mais um tributo individual e pessoal do servo ao senhor; agora é um pagamento que toda a sociedade faz pelo fato de que uma classe preserva o monopólio da terra. A nova forma que ele assume é caracteristicamente capitalista, é oposta ao tributo historicamente anterior: nem os burgueses nem os proletários transferem diretamente uma parte dos seus lucros ou de seus salários aos proprietários. Entretanto, a composição orgânica diferencial do capital entre agricultura e indústria encarrega-se de fazer aparecer nas mãos do proprietário a renda absoluta que aparentemente não é extraída de ninguém." (MARTINS, 2004, p. 19-20).
} 
especulador de terras (ALVES, 2000). Talvez o papel do grileiro e todas as suas articulações com as instituições apenas revelem a forma de ser do Estado e do capital, visto que para este não existe qualquer preocupação de ordem moral.

\begin{abstract}
Mas surge o grileiro e tudo se transforma. Terras paradas, terras inexpurgáveis á cultura, que velhos barbaças detêm aos milheiros de alqueires para delas tirar um prato de feijão e uns porquinhos de céva, e que vêm vindo assim de avós a netos, e que permaneceriam assim toda a vida; terras devolutas, que a inercia do Estado conserva a monte, sem saber por que nem para que; terras legitimamente, legalmente "aproprietariadas" - nada disso é obstáculo á solercia do grileiro. Ao partir para o sertão ele deixou em casa, na gaveta, os escrupulos da conciencia. Vem firme, vem "feito" como um gavião. Opera as maiores falcatruas; falsifica firmas, papeis, selos; falsifica rios e montanhas; falsifica arvores e marcos; falsifica juizes e cartorios; falsifica o fiel da balança de Temis; falsifica o céu, a terra e as aguas; falsifica Deus e o Diabo. Mas vence. E por arte dessa obra-prima de malabarismo, espoliando posseiros ou donos, sempre firmados na gazua da lei, os grileiros expelem das terras, num estupendo parigato, todos os "barbas ralas" que ali vivem parasitariamente, tentando resistir ao arranque da civilização.

[...] Acaba o marasmo da terra porque o grileiro é o precursor da Onda Verde. O seu cri-cri anuncia a aproximação do tanque. O peregrino espirito de Assis Chateaubriand já explanou em traços gerais, mas incisivos, esta função social e civilizadora do grilo. Definiu-o a arte de tirar o direito do nada. (LOBATO, 1922, p. 11-13).
\end{abstract}

Enquanto isso, a população de vencidos, "parasitária", é a parcela dos sujeitos expropriados da terra e dos meios de produção, uma maioria "incapaz de elaborar a evolução econômica daquele sertão imenso" (SENNA, 1918, p. 532, grifos nossos). O anuário, um portavoz das pretensões de quantificar a produção de riqueza no estado de Minas Gerais e levantar seus potenciais econômicos, adota um discurso oriundo de uma intelligentsia à serviço do Estado, que via a região como um "vão e vazio", pronta para receber não só a ferrovia e a estrada, mas todos os insumos possíveis que o capital disporia para que a terra rendesse valor.

O uso da palavra "sertão" está imbuído de significado na citação de Nelson de Senna, pois, nesse contexto histórico, ele representa não apenas os espaços distantes do litoral, onde domina a natureza, mas também, numa concepção dualista de território, o espaço atrasado, disposto a receber a civilização prometida por um Estado que buscava construir uma unidade territorial e uma identidade nacional (AMADO, 1995).

A condição histórica de expropriação é apagada do trabalhador, encarnado no sertanejo, que "perambula" pelas margens dos rios adoecido e "degenerado", decadente de passados tempos áureos de domar o meio e "civilizar" o tapuia. O seu socorro viria de engenheiros e sanitaristas, sendo este último sinônimo de médico que toma conta do corpo social. Para exercer tal empreitada, ele teria de estar ligado ao poder, e quanto mais centralizado esse poder, teoricamente, mais eficiente o seu trabalho (SCLIAR, 2003), que carecia de organização militar 
para impor a higiene aos habitantes sujos, degenerados e doentes. Ou seja, o Estado é impelido à autonomização, inclusive para manter biologicamente seu corpo social de trabalhadores.

Em Um sertão chamado Brasil: intelectuais e representação geográfica da identidade nacional, Nísia Trindade Lima explica o pensamento fortemente datado e corrente entre os intelectuais e técnicos que pensavam o país na República e quem era o sertanejo que Nelson de Senna (1918) descreve de forma decadente. Segundo ela, para os médicos higienistas e cientistas dedicados à saúde pública no começo dos Novecentos, o debate sobre a natureza não se resumia à questão das doenças. Uma forte ideia é a que identifica uma espécie de fase intermediária entre o selvagem e o civilizado. $\mathrm{O}$ primeiro, mais próximo à natureza, teria uma vida mais saudável e harmoniosa, enquanto o intermediário, "que identificam com frequência ao caboclo, revela uma relação puramente predatória com a natureza" (LIMA, 1999, p. 113), além de artefatos culturais e comportamentos sociais que sugerem desleixo, o que impactaria sobre a saúde desse homem, que até podia deixar a vida selvagem, mas não poderia ser considerado um civilizado.

A terra, como mercadoria, só teria como fornecer a riqueza esperada quando em socorro de nova colonização vierem os cientistas, planejadores de novas e eficazes formas de ocupação do sertão vazio, conectando a hinterlândia aos centros de poder econômico para homogeneizar o Brasil ${ }^{121}$. Para tal, caberia aos engenheiros e médicos "sanear" o sertão, pois, influenciados pelo movimento higienista europeu e estadunidense de meados do século XIX, as febres sertanejas seriam mais produto da imoralidade do que da desigualdade social - retomando o debate sobre a vadiagem, já presente desde o século XVIII ${ }^{122}$.

\section{5. "Botando pontes, baseando fábricas, estreando mil escolas": o projeto de progresso para o sertão e a Serra}

O Brasil republicano se rendia ao canto da ciência, a grande aliada do capital na virada de século. Com os olhos voltados ao sertão, três expedições chefiadas por cientistas do Instituto Oswaldo Cruz percorreram as localidades objetos da atenção da Inspetoria de Obras Contra as Secas durante o ano de 1912. Pouco depois, de abril a julho de 1915, os médicos e cientistas Adolfo Lutz e Astrogildo Machado percorreram o Vale do São Francisco, de Pirapora, em

\footnotetext{
121 “A ideia da existência de 'dois Brasis' tenderia a ser vista a partir de uma concepção linear de tempo histórico, geograficamente representada pela concepção de uma parcela de território estagnada, atrasada, e de outra mais suscetível de receber a influência de correntes modernizantes" (LIMA, 1999, p. 27).

${ }^{122}$ Tal discussão já apresenta Antonil (2007), no capítulo "Cultura e opulência pelas minas do ouro", escrito em 1711.
} 
Minas Gerais, a Juazeiro, na Bahia, visitando a maioria dos povoados ribeirinhos. Para eles, esses lugares configuravam uma região atrasada devido à questão racial, ao clima e à distância de muitos povoados em relação ao litoral. Uma visão cheia de estereótipos dessas populações é apresentada no relatório da viagem, em que os cientistas consideram que “... não pode haver progresso onde a gente se contenta a vegetar sem melhorar as condições da sua vida" (LIMA, 1999, p. 84). Na rápida observação que fazem sobre a influência da raça no atraso da região, acentuam a pequena presença do indígena e o predomínio de mestiços do branco com o negro (LIMA, 1999).

Entre o Império e a primeira metade do século XX, o sertão foi palmilhado por expedições científicas que não visavam apenas comprovar os potenciais mineralógicos da região, mas também avaliar a aptidão agropecuária sertaneja. Para o caso mineiro, destaca-se o Congresso Agrícola, Industrial e Comercial, organizado em 1903 pelo Governo do Estado de Minas Gerais em parceria com a elite econômica, tendo à frente da sua idealização o futuro governador João Pinheiro da Silva. De acordo com Otávio Dulci (2005), as proposições gerais do evento configuravam um projeto de recuperação e desenvolvimento econômico diversificado, que deveria estimular a modernização da cafeicultura e da pecuária, principais setores da economia mineira, e incentivar a policultura e o setor industrial. Ao Estado caberia o papel de auxiliar e coordenar tais ações, sem concorrer ou tutelar a iniciativa privada (PEREIRA, 2007).

Fazer expedições científicas e promover feiras e congressos é condizente ao consenso da época, que assimilava civilização à ocupação do território, cabendo defender a tese de que esses espaços, vazios ou então povoados pela miséria, careciam de projetos, claramente identificados com a reprodução ampliada do capital. A partir desse momento, o termo "cerrado" passa a ser empregado com fins disciplinares para classificar flora, fauna, clima, solos e hidrografia, considerando a paisagem propensa à pecuária, com seus bons pastos naturais em contraposição aos solos ruins, devido à laterização. Na mesma corrente de pensamento, denunciava-se o problema do sertanejo como a causa do atraso dos cerrados (SILVA, 2019).

Considera-se a República um arranjo de interesses entre os proprietários de terra com poder local e o governo federal - este cada vez mais afeito à ciência e às crescentes reflexões acerca da identidade nacional, com o bacharelismo e o cientificismo passando a ocupar espaço estratégico no plano de condução do país. Como lembra Vitor Nunes Leal (1975), o coronel sempre tem como aliado um intelectual, um “doutor” que, quando não é um advogado ou um médico, é um padre. O coronel ou a sua geração de herdeiros torna-se aos poucos absenteísta, indo morar na capital ou mandando seus filhos estudarem na Europa. No retorno, essa geração 
de bacharéis, que viria a pensar e dirigir o país, encarava como uma oposição as contradições da não simultaneidade da modernização brasileira frente à europeia. Essa interpretação deságua no entendimento de que o sertão era o atraso ao progresso nacional.

\begin{abstract}
Colocando em outros termos, poderíamos sugerir que, para tal geração de bacharéis, a não-simultaneidade da modernização brasileira frente à europeia, vivida contraditoriamente pelos seus membros escolarizados no exterior, fazia-lhes transformar essa contradição em oposição. Assim, a sociedade rural, escravocrata e retrógrada se lhes opunha aquela que aparecia como urbana, liberal e moderna. Dessa maneira, podemos considerar que, aos olhos dessa geração, a agricultura organizada em moldes extensivos, a exploração do trabalho escravo e o patriarcado rural lhes pareciam irracionalidades. Porém, tudo em termos relativos, há que se dizer. (BOECHAT, 2013, p. 311, grifos do autor).
\end{abstract}

Aderindo ao pensamento de que "do esforço consorciado da engenharia e da medicina está dependente a transfiguração economica e social do nosso sertão" (SENNA, 1918, p. 533), inaugura-se na virada de século a penetração do bacharelismo e do cientificismo na esfera política, com projetos também para a educação. Os arranjos se faziam de cima para baixo, consoante José Murilo de Carvalho no texto "Ouro, terra e ferro: vozes de Minas", integrante da obra Minas e os fundamentos do Brasil moderno, uma coletânea que aborda de forma elogiosa a vida e a atuação política de João Pinheiro, considerado o precursor do desenvolvimentismo no Brasil, cujo berço estaria (pretensiosamente) em Minas Gerais.

O livro traz nas suas entrelinhas a defesa da mineiridade na figura de João Pinheiro, apresentando uma Minas Gerais homogênea, como o estado síntese da nação, precursor do desenvolvimento nacional. $\mathrm{O}$ gérmen desse projeto estaria em uma política de conciliação das gentes do ouro - os rebeldes liberais de cor local que clamavam por liberdade - , da terra - a tradição e o conservadorismo da agropecuária - e do ferro - os apologistas do progresso via indústria e siderurgia (CARVALHO, 2005). Parecia haver o desejo de parir uma burguesia nacional comprometida com a modernização, só possível por meio de um pacto entre os componentes das camadas dominantes de então.

Buscava-se uma intelligentsia para tomar as dianteiras do projeto. Conforme aborda Laurindo Mékie Pereira (2015) sobre Simeão Pires e Expedicto Mendonça e seus discursos de antimineiridade, justificadores do projeto de emancipação estadual do norte de Minas Gerais, o seu oposto - a mineiridade - busca uma identidade unificadora, procurando agrupar no universo cultural e político as diversas e heterogêneas regiões do Estado. Porém, conforme argumento baseado em Stuart Hall, as identidades territoriais são negadoras das diferenças: o discurso nacionalista (no caso, regionalista) encobre os recortes de classe, de gênero ou de etnia, sendo 
a identidade mineira um dispositivo unificador, que não necessariamente nega as diferenças, mas se sobrepõe a elas, reclamando uma lealdade superior.

Para José Murilo de Carvalho (2005), o êxito dos desenvolvimentistas em Minas Gerais exigiu certa conciliação com a tradição agrária, pois o investimento dos "homens do ouro" fracassou com a inconfidência e o ocaso minerador, bem como o dos "homens da terra", que governaram sem ousar mudar. Para ele, João Pinheiro, seu filho Israel e Juscelino Kubitschek teriam deixado marca na política estadual e nacional, pois fizeram acordos tentando modernizar a agricultura e evitando tocar na questão rural ${ }^{123}$. Havia, assim, um programa de modernização conservadora.

João Pinheiro teria sido um divisor de águas na política mineira. "O menino sem eira nem beira, portanto, conseguira se enobrecer: pelos estudos, pela política e pelo casamento" (GOMES, 2005, p. 84). Nascido em meio à pobreza no Serro, norte de Minas Gerais, estudou direito no Largo de São Francisco, de onde retornou com ideias republicanas. Casou-se com filha de grande latifundiário, tendo se tornado dono de terras e, posteriormente, de fábrica de porcelana. Foi também professor de Escola Normal e de faculdade, além de ter exercido os cargos de prefeito, governador e senador. Morreu cedo, quando governava pela segunda vez o estado mineiro, tendo nos descendentes a continuidade da família na política, tanto estadual quanto nacional: seu filho Israel Pinheiro, engenheiro, anos mais tarde atuou na Companhia Vale do Rio Doce, na Companhia Urbanizadora da Nova Capital do Brasil (Novacap) e no governo do estado, desenvolvendo projetos voltados à agricultura e aos transportes. Seus netos também se envolveriam nesse meio.

Ângela de Castro Gomes ressalta que o político teria inaugurado uma visão econômica de Brasil, confrontada com um bacharelismo que até então governava o país e só atenta ao problema político. Para João Pinheiro, as "elites bem formadas assegurariam a interação positiva entre um aumento de produção econômica e uma maior mobilidade social" (GOMES,

\footnotetext{
${ }^{123}$ Apesar da aparente ruptura iniciada pelos Pinheiro, a hipótese de Laurindo Mékie Pereira é de que se percebe uma relação entre os projetos de país de determinado segmento da classe dominante mineira e a formação de um discurso identitário e ideológico que justifique suas ações, dando respaldo a uma prática política com traços particulares.
}

Nesse texto, interessa especificamente essa fração política da mineiridade que Dulci denomina de subcultura política mineira cujos traços fundamentais seriam: a) o apego à tradição e à continuidade, b) a valorização da ordem e da estabilidade, c) uma visão evolucionista da história, d) o centrismo, a aversão pelas soluções radicais, e) o pragmatismo, a acomodação de interesses e f) a perspicácia e habilidade políticas. Para o autor, a mineiridade teria três funções ideológicas: 1) é ideologia da classe dominante, contribuindo para organizá-la, fornecendo-lhe uma concepção comum, um código unificador; 2) contribui para legitimar o poder das elites na medida em que é compartilhada por parte da sociedade e 3) dá suporte aos interesses do Estado nos embates nacionais. (PEREIRA, 2015, p, 105). 
2005, p. 94). Tratava-se de "associar autoridade política a planejamento, postulando um projeto de capitalismo liderado pelo Estado e capaz de grande poder de arregimentação" (Idem).

Segundo João Pinheiro Neto, em entrevista dada à autora, as ideias do seu avô já apontavam para a necessidade da intervenção estatal, "da correção dos desequilíbrios econômicos e sociais entre as regiões do país" - um dualismo às claras - "para a importância da industrialização, da área dos transportes, da energia. Tudo isso, sem abandonar a questão da modernização do campo" (GOMES, 2005, p. 97-98) - ou seja, a modernização e a ideia regional/desenvolvimentista caminhando juntas. Ele tinha interesse em expandir escolas técnicas voltadas à agropecuária ${ }^{124}$, pretensão que faz pensar no processo de autonomização da formação daqueles que viriam a personificar a técnica e as novas formas tecnificadas, cada vez mais exigidas pela reprodução social. Mais uma vez, a literatura ficcional se torna interessante alegoria da sociedade daquele momento a partir do personagem Zé Bebelo, fazendeiro interessado nos estudos e com planos de modernização do sertão via carreira política:

\begin{abstract}
Porque ele tinha me estatutado os todos projetos. Como estava reunindo e pervalendo aquela gente, para sair pelo Estado acima, em comando de grande guerra. O fim de tudo, que seria: romper em peito de bando e bando acabar com eles, liquidar com os jagunços, até o último, relimpar o mundo da jagunçada braba. - "Somente que eu tiver feito, siô Baldo, estou todo: entro direito na política!” Antes me confessou essa única sina que ambicionava, de muito coração: e era de ser deputado. (ROSA, 1986, p. 110). $[\ldots]$

- "Sei seja de se anuir que sempre haja vergonheira de jagunços, a sobre-corja? Deixa, que, daqui a uns meses, neste nosso Norte não se vai ver mais um qualquer chefe encomendar para as eleições as turmas de sacripantes, desentrando da justiça, só para tudo destruírem, do civilizado e legal!" [...] Ao quando falava, com fogo que puxava de si, Zé Bebelo tinha de se esbarrar, ia até na varanda ou na janela, a apitar o apito, ditar as boas ordens. Daí, mais renovado, voltava para perto de mim, repunha: - "Ah, cujo vou, siô Baldo, vou. Só eu que sou capaz de fazer e acontecer. Sendo que fui eu só que nasci para tanto!" Dizendo que, depois, estável que abolisse o jaguncismo, e deputado fosse, então reluzia perfeito o Norte, botando pontes, baseando fábricas, remediando a saúde de todos, preenchendo a pobreza, estreando mil escolas. Começava por aí, durava um tempo, crescendo voz na fraseação, o muito instruído no jornal. Ia me enojando. Porque completava sempre a mesma coisa. (ROSA, 1986, p. 111-112).
\end{abstract}

Ao analisar a trajetória de João Pinheiro, percebe-se que a intervenção dos fazendeiros e coronéis no poder se transforma: ao passo que o Estado nacional vai se fortalecendo, os filhos da oligarquia regional se tornam "academizados", ocupando cargos na burocracia estatal, enquanto mantêm os empreendimentos da família, cada vez mais autonomizados no papel de administradores.

\footnotetext{
${ }^{124}$ Idolatrado pelos seus pares, é criado em 1909 o Instituto João Pinheiro, uma escola bem ao feitio do seu patrono. Dedicada ao ensino de técnicas agrícolas, voltava-se "para a clientela de meninos pobres que existiam nos campos de Minas" (GOMES, 2005, p. 92).
} 
O caso de João Pinheiro serve para o caso de duas famílias na Serra: os Borém e os Dumont. Apesar de ambas não terem nenhum antepassado com a patente da Guarda Nacional, eram proprietárias de terra com forte poder local. Os descendentes da primeira família seguiram o caminho da medicina, enquanto os da segunda se espraiaram entre o direito e a engenharia, com alguns quadros de ambos os lados ingressando na política local e regional. Os laços matrimoniais faziam parte da manutenção do poder.

\section{Figura 8 - Pais de Sócrates Dumont, recém-casados (sem data)}

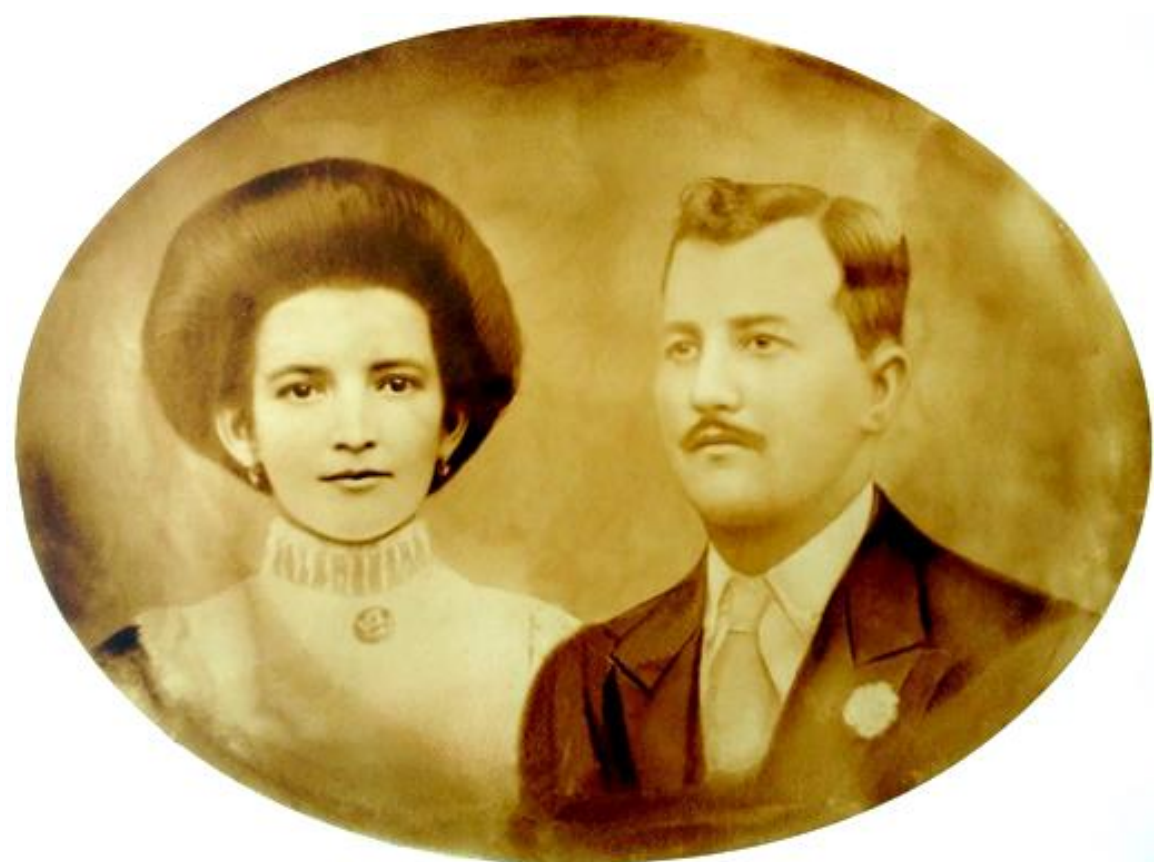

Fonte: acervo da família Dumont, Francisco Dumont, dezembro de 2016.

No livro Mobilidade do trabalho e acumulação do capital, Jean-Paul de Gaudemar, considerando a força de trabalho livre e autonomizada dos fatores de produção, salienta que na sociedade capitalista, os membros de todas as classes sociais são mobilizados para a produção de valor. Para o economista, à mobilidade da força de trabalho explorada e submetida, responde efetivamente à mesma mobilidade dos representantes do capital, dos múltiplos portadores dos diferentes aspectos do seu poder. Poder que dá acesso ao domínio da ciência e da técnica para além da mera posse do dinheiro, exercendo comando sobre os aparelhos de reprodução, político, de Estado... Enfim, mobilidade das suas funções, mobilidade nos locais definidos por essa hierarquia dos poderes, mobilidade em relação ao conjunto dos locais em que o capital exerce o seu domínio (GAUDEMAR, 1977). Nessa situação, todas as personificações do capital, incluindo o coronel, o político e seus filhos doutores, estão sujeitadas às suas demandas. 
Figura 9 - Ata da abertura da escola para meninos, Barreiros, 1927

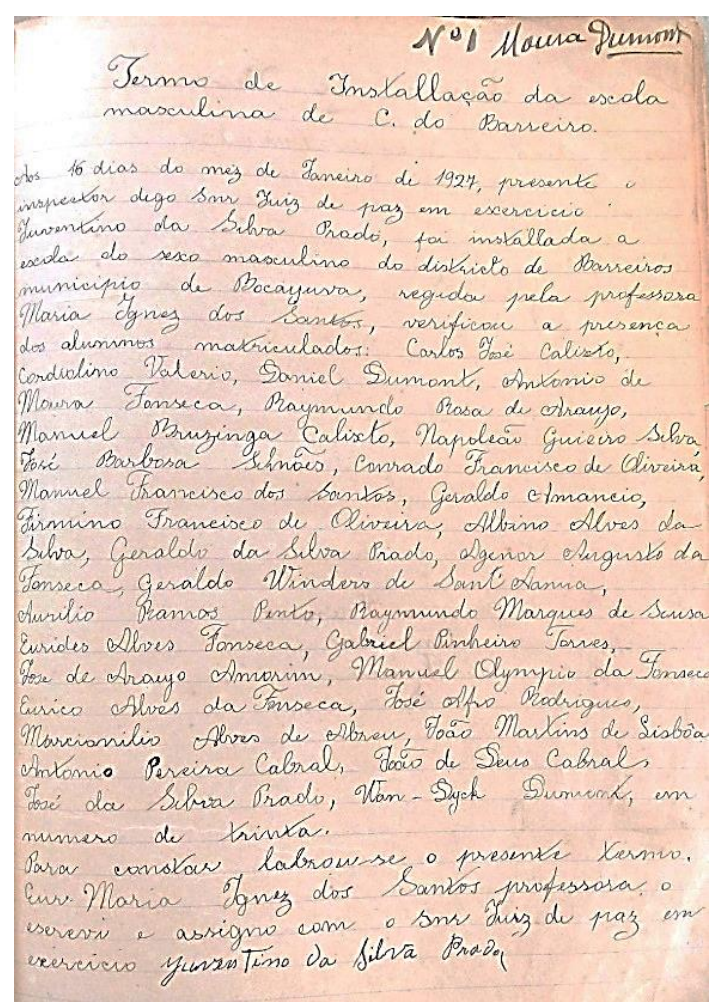

Fonte: Casa de Cultura Ercília Rosa, Francisco Dumont, 2018.

A escola aparece no discurso de Karl Marx (2013) como realizando as formas produtivas ou circulantes não espaciais da mobilidade do trabalho. Ela produz força de trabalho e, portanto, mobilidade. De acordo com Jean-Paul de Gaudemar (1977), essa mobilidade é a disponibilidade da força de trabalho ao uso tanto intensivo quanto extensivo do capital. Conforme aumentam as necessidades de circulação das mercadorias - vide os projetos de estradas e a ferrovia, incluindo-se, além dos transportes, as comunicações e os aparelhos administrativos -, novos ramos e profissões começam a despontar, e a escola, dentro dos serviços necessários à produção de riqueza, se encaixa nesse contexto. Se a educação no Brasil até então era privilégio para uma pequena classe dominante, o esforço de modernização e o projeto de autonomização tornam a expansão do ensino um desígnio republicano de forma a desvalorizar ainda mais as forças de trabalho, situação que apenas gerações posteriores à de Zé Bebelo e João Pinheiro presenciariam no sertão (GAUDEMAR, 1977).

Apesar de as duas famílias mencionadas não terem patentes, sabe-se que a Serra tinha os seus capitães e coronéis, muitos com os títulos concedidos pela Guarda Nacional. Teve-se a oportunidade de visitar no povoado do Carrapato os escombros do casarão e da senzala do major Domingos - de quem não se descobriu mais nada. O barão de Jequitaí, tido como o maior fazendeiro de gado do norte de Minas Gerais na virada de século, ilustra os títulos cedidos aos 
mandões locais. Assim também a valsa Jequitaí: tocada apenas pelas bandinhas durante as festividades tradicionais nos municípios da Serra, foi composta por um sujeito chamado capitão Egídio.

O coronelismo aparecia como a forma de ser do Estado organizando a territorialização do capital, ancorado na legislação fundiária e na possibilidade de regularizá-la em favor de si mesmo e de seus interesses. Concentrava-se no mesmo sujeito a personificação do Estado, da lei, da terra e do capital (BOECHAT, 2013), cuja perpetuação de poderes se faria pelos arranjos matrimoniais entre pessoas de cabedal e de patentes e títulos concedidos pelo governo.

\subsection{1. "Uns, aboiavam sem bois": o trabalho nas fazendas na Serra}

Conforme visto, chegado o século XIX, muitas das fazendas representadas nos mapas permaneceram sob a mesma alcunha, bem como outras foram surgindo. $\mathrm{O}$ ocaso do diamante no norte de Minas Gerais impeliu muitos sujeitos à lavoura e à pecuária ou teimou em sussurrar em seus ouvidos a tentação de buscar por novas lavras.

Os esforços voltados à criação extensiva de gado configuraram a Serra como especialista na produção dessa mercadoria, nascendo daí a regionalização econômica do território e, por consequência, a sua maior dependência do mercado. Relegada à condição de economia subsidiária, acabou desenvolvendo uma especialização pelas características fisiográficas, associadas à sua forma de ocupação e à produção da mercadoria boi. Uma região colonial pecuária foi se tecendo no norte de Minas Gerais, e a Serra do Cabral como parte ${ }^{125}$.

Aqueles que eram abastados donos de gado, foram aprimorando suas criações respeitados o contexto histórico e as carências regionais. O Distrito Diamantino, conforme Ivana Parrela (2009) ressalta, acabava por dispersar muitos de seus moradores, que buscavam novas terras para assentar seus negócios. Assim como os do Tejuco chegavam para somar aos que já se instalavam nas margens do Jequitaí, outros vinham de rumos diversos, muitos deles desconhecidos, em variadas condições.

\footnotetext{
125 "Na formação socioeconômica do Brasil, delineada 'por estruturas de produção colonial, neocolonial e, de forma mais abrangente, capitalista', desenvolveu-se a 'centralização de pólos dinâmicos da economia em algumas áreas geográficas', a partir dos quais se atribuiu o conceito de região 'aos espaços geo-econômicos que não participavam de sua prosperidade'. Desse modo sinonimiza pobreza, dependência, decadência, marginalidade, para revelar postura ideológica hegemônica e impor sua realidade histórica sobre o conjunto de diversas realidades contidas no espaço brasileiro" (NEVES, 2008, p. 26, grifos nossos). Conforme se discutirá adiante, a região é um produto histórico da organização do valor no território, na mira do planejamento estatal ao ser considerada na sua negatividade.
} 
Sem considerar o trabalho violento de submissão dos povos que já habitavam o sertão, Caio Prado Júnior (2006) afirma que formar uma fazenda não era tarefa das mais difíceis e dispendiosas, e os componentes naturais (rios, morros etc.) cumpriam a função de cercas, com os bois pastando livres pelas baixadas da Serra, alimentando-se do capim-meloso e dos barreiros de sal naturais. Porém, o capital depende da sua reprodução ampliada para existir, o que implica em expansão territorial. Conforme a cerca aparece no norte de Minas Gerais, o movimento de expansão e cercamento das fazendas culmina na assimilação dos sujeitos expropriados, já na condição de livres ao longo dos Novecentos, ou os empurra para as fronteiras a serem posteriormente cobiçadas pelo movimento de dilatação do latifúndio.

Apesar do Estado ter iniciado seu processo de centralização com a cisão dos fatores de produção a partir de 1930, somente nas décadas de 1960 e 1970 a autonomização do trabalho aconteceu na Serra, com o assalariamento do trabalhador. Antes disso, os moradores de favor ${ }^{126}$ viviam em condições não muito diferentes de tempos anteriores. Em passagem pela fazenda de seô Habão, o então jagunço Riobaldo observa o comportamento do latifundiário com título de capitão, ao tratar do povoado do Sucruiú e da peste da bexiga preta, que estava em suas terras:

E o que indagou foi se eu soubesse se tinham feito muitos estragos nos canaviais. “... O que eles deixaram em pé, e que lobo ou mão-pelada não roeram, sempre há-de dar uns carros, se move moagem..." Agora ele conservava os olhos sem olhar, num vagar vago, circunspecto, pensava aqueles capítulos. Disse que ia botar os do Sucruiú para o corte da cana e fazeção de rapadura. Ao que a rapadura havia de ser para vender para eles do Sucruiú, mesmo, que depois pagavam com trabalhos redobrados. De ouvir ele acrescentar assim, com a mesma voz, sem calor nenhum, deu em mim, de repente, foram umas nervosias. Ao que, aqueles do Sucruiú, fossem juntas-de-bois em canga, criaturas de toda proteção apartadas. Mas eu não tinha raiva desse seô Habão, juro ao senhor, que ele não era antipático. Eu tinha era um começo de certo desgosto, que seria meditável. - "Para o ano, se Deus quiser, boto grandes roças no Valado e aqui... O feijão, milho, muito arroz..." Ele repisava, que o que se podia estender em lavoura, lá, era um desadoro. E espiou para mim, com aqueles olhos baçosos - aí eu entendi a gana dele: que nós, Zé Bebelo, eu, Diadorim, e todos os companheiros, que a gente pudesse dar os braços, para capinar e roçar, e colher, feito jornaleiros dele. Até enjoei. Os jagunços destemidos, arriscando a vida, que nós éramos; e aquele seô Habão olhava feito o jacaré no juncal: cobiçava a gente para escravos! (ROSA, 1986, p. 365).

A observação de Riobaldo, ainda jagunço porque o pacto para ascender socialmente não estava concretizado, revela não apenas uma desconfiança quanto ao fato de seô Habão ser um fantoche do capital, mas também quanto à posição social do jagunço naquela sociedade: sujeito provisório e, sendo expropriado e não branco, vulnerável aos desmandos de quem tinha o poder

${ }^{126}$ Pessoas que, sem acesso à terra, vivem nas terras alheias e trabalham para o dono como forma de pagamento pelo favor de ocupar a propriedade. Também pagam a moradia com parte dos produtos que cultivam ou criam. 
nas mãos ${ }^{127}$. A ilusão de liberdade de escolha para ser jagunço ou lavrador caía por terra nessa passagem. Levando-se em conta o sertão enquanto território do capital, Jean-Paul de Gaudemar (1977) lembra que a disciplina capitalista assegura a repartição dos indivíduos no espaço, de modo que cada um deles tenha o seu lugar e cada lugar o seu indivíduo, num vasto dispositivo de enquadramento das atividades e dos espaços. Enquanto a região esteve fechada, o lugar não foi apenas uma questão de classe, mas também geográfica.

Manoel Lopes, 90 anos (2019), e sua família são um exemplo da agregação nas fazendas da Serra do Cabral. Teve-se contato com ele e sua esposa no ano em que o casal comemorava 70 anos de união. Apesar de ter nascido em Cuiabá, seus pais e avós nasceram e viveram na Serra, para onde ele retornou aos 9 anos de idade. Seus antepassados paternos já eram agregados nas terras do "chefe" Amâncio Lopes, em uma área chamada Malhadinha, formando pés de café. Seus pais, por não encontrarem trabalho nas fazendas - "Naquele tempo, tinha muita fartura, mas era uma dificuldade tremenda! Só achava serviço de roçar manga" -, seguiram para Mato Grosso. No retorno ao norte de Minas Gerais, foram na condição de favor para a região da serra dos Fonseca, terra de sua mãe, onde gerações da família Lopes vivem ainda hoje. Lá, foi morar junto aos pais na fazenda Santo Antônio, trabalhando para o fazendeiro Silivério, pois não tinham a própria terra.

Sobre as condições de vida e como se dava o trabalho, informa que

\footnotetext{
- Naquele tempo, chovia muito, tinha muito milho, muito feijão, muito arroz. A gente colhia bastante, a gente tinha porco, criava galinha. A gente não comprava um do outro porque todo mundo tinha, tinha com fartura. Não é igual hoje! Aqui hoje não tem. A produção daqui da nossa região hoje acabou, não tem nada.

- E como é que funcionava o trabalho de agregado na fazenda? Seu pai morava lá, podia plantar roça?

- É o seguinte: os fazendeiros davam uma casinha e davam um terreno pro camarada trabalhar, plantar roça na meia. Metade era pro fazendeiro, metade pro trabalhador. - Pelo o que o senhor disse, seu pai já era agregado. O que ele fazia na fazenda?

- Pai roçava manga, fazia cerca de arame, cuidava da roça, limpava a roça do fazendeiro... Era o serviço que tinha na época.

- Vocês ganhavam em vale, do mesmo jeito que era nas fazendas dos Dumont?

- Ganhava em dinheiro o que trabalhava fora da lavoura. Não lembro muito, mas era mais ou menos uns 50 a 250 réis. (informação verbal) ${ }^{128}$.
}

\footnotetext{
127 A provisoriedade social dos sujeitos pretos e miscigenados seria, na interpretação de Clovis Moura (1994), resultado do abandono dessas populações a partir do que o autor chamou de escravismo tardio. Esse momento, compreendido entre 1850 e 1930 e sucessor da periodização que o autor intitulou escravismo pleno (1550-1850, portanto, no auge da economia colonial), corresponde ao fim do tráfico humano internacional, dando lugar ao inter-regional, ao mesmo tempo em que no Centro-Sul desembarcavam os imigrantes, havendo desvalorização da força de trabalho nacional, que agora, na condição gradual de livre, passava a não ter serventia alguma, impelida a realizar serviços tais quais o romance roseano exemplifica.

${ }^{128}$ Depoimento fornecido por Manoel Lopes em entrevista durante pesquisa de campo em Francisco Dumont, em janeiro de 2019.
} 
A família de Manoel Lopes já expressava a necessidade de se mover em busca de trabalho, chegando a alcançar estados distantes, onde a fronteira estava sendo aberta. Prender à terra o sujeito expropriado era uma forma de forçá-lo ao trabalho para outrem, situação em que essa família resistiu até ceder à condição de agregado novamente.

A necessidade de fixar o trabalhador nas fazendas é evidência da ausência de uma superpopulação relativa nesse contexto. Conforme Marcia Motta (1998) aponta, caso o agregado tivesse alguma desavença com o dono da terra para quem trabalhava, uma das alternativas era mudar de fazenda e de "chefe". Sobre o motivo da mudança para Mato Grosso, Manoel Lopes não entrou em detalhes, alegando apenas a dificuldade de conseguir serviço na Serra.

A mobilidade espacial entre os sertanejos expropriados em virada para o século XX é denunciada na fala de Riobaldo - que passou de agregado a jagunço, depois tornado fazendeiro na beira do Urucuia -, ao tratar de um meeiro de sua propriedade. Cabe pensar se o "gostar de mudar" é mesmo gostar ou é ilusão de liberdade, mascarando uma necessidade real dado o contexto pós-abolição do enredo.

\begin{abstract}
Quem é pobre, pouco se apega, é um giro-o-giro no vago dos gerais, que nem os pássaros de rios e lagoas. O senhor vê: o Zé-Zim, o melhor meeiro meu aqui, risonho e habilidoso. Pergunto: - "Zé-Zim, por que é que você não cria galinhas-d'angola, como todo o mundo faz?" - "Quero criar nada não..." — me deu resposta: — "Eu gosto muito de mudar..." Está aí, está com uma mocinha cabocla em casa, dois filhos dela já tem. Belo um dia, ele tora. É assim. Ninguém discrepa. Eu, tantas, mesmo digo. Eu dou proteção. Eu, isto é - Deus, por baixos permeios... Essa não faltou também à minha mãe, quando eu era menino, no sertãozinho de minha terra - baixo da ponta da Serra das Maravilhas, no entre essa e a Serra dos Alegres, tapera dum sítio dito do Caramujo, atrás das fontes do Verde, o Verde que verte no Paracatu. [...] Gente melhor do lugar eram todos dessa família Guedes, Jidião Guedes; quando saíram de lá, nos trouxeram junto, minha mãe e eu. Ficamos existindo em território baixio da Sirga, da outra banda, ali onde o de-Janeiro vai no São Francisco, o senhor sabe. (ROSA, 1986, p. 31).
\end{abstract}

Manoel Lopes foi criado junto aos irmãos na fazenda Santo Antônio, onde começou a trabalhar ainda criança como vaqueiro, carreiro e lavrador. $\mathrm{O}$ fazendeiro colocava os meninos para ordenhar as vacas pela manhã e olhar o campo, pois o gado pastava na manga fechada. Quando Manoel estava com 15 anos, o vaqueiro morreu, resultando no convite do dono para que cuidassem da fazenda. A partir de então, ficou por lá exercendo a mesma função por 30 anos, recebendo pagamento a cada 15 dias.

Perguntado sobre como aprendeu a cuidar de bois - pois seu pai lidava com roça -, respondeu que foi um vaqueiro velho quem o ensinou a trabalhar com gado, desde boi solteiro, garrote, manga de maternidade com vaga "amojada" (prenha e parida) a outras situações. Era 
um preto vindo de Coração de Jesus, de nome Antônio Candeia, que já estava na propriedade quando ele chegou. Sua rotina na fazenda não parece ter sido muito diferente daquilo que Capistrano de Abreu descreveu para séculos antes:

\begin{abstract}
Adquirida a terra para uma fazenda, o trabalho primeiro era acostumar o gado ao novo pasto, o que exigia algum tempo e bastante gente; depois ficava tudo entregue ao vaqueiro. A este cabia amansar e ferrar os bezerros, curá-los das bicheiras, queimar os campos alternadamente na estação apropriada, extinguir onças, cobras e morcegos, conhecer as malhadas escolhidas pelo gado para ruminar gregariamente, abrir cacimbas e bebedouros. Para cumprir bem com seu ofício vaqueiral, escreve um observador, deixa poucas noites de dormir nos campos, ou ao menos as madrugadas não o acham em casa, especialmente de inverno, sem atender às maiores chuvas e trovoadas, porque nesta ocasião costuma nascer a maior parte dos bezerros e pode nas malhadas observar o gado antes de espalhar-se ao romper do dia, como costumam, marcar as vacas que estão próximas a ser mães e trazê-las quase como à vista, para que parindo não escondam os filhos de forma que fiquem bravos ou morram de varejeiras.

Depois de quatro ou cinco anos de serviço, começava o vaqueiro a ser pago; de quatro crias cabia-lhe uma; podia assim fundar fazenda por sua conta. Desde começos do século XVIII, as sesmarias tinham sido limitadas ao máximo de três léguas separadas por uma devoluta. (ABREU, 1998, p. 135, grifos nossos).
\end{abstract}

Cabe aqui um parêntesis para observar que a frase em destaque na citação talvez ajude a explicar a existência de muros de pedra que cortam boa parte da Serra do Cabral, dentro dos limites de Francisco Dumont - uma parte deles acompanha o caminho até o garimpo mais antigo da região, Barreirinho. São muros muito antigos, e ninguém sabe ao certo desde quando estão lá, nem o motivo de terem sido construídos, a não ser que foram feitos "no tempo dos escravos". São rochas grandes encaixadas umas nas outras, de forma irregular, dispostas em valas. Talvez eles deem pistas sobre a demarcação de terras na Serra, considerando-se que muitos dos terrenos ali eram terras devolutas até a década de 1970, quando começam a cercar terrenos sem dono. Outra hipótese possível seria a construção de barreiras para desvio de rios, de modo a otimizar a extração de diamantes - dado que o muro aparece desde a baixada do córrego do Açudão, dentro do município de Francisco Dumont e onde hoje é uma piscina pública, dando vazão para o antigo garimpo do Barreiro, e segue até o garimpo do Barreirinho. 


\section{Figura 10 - Muros de pedra ao longo da Serra do Cabral, Francisco Dumont}

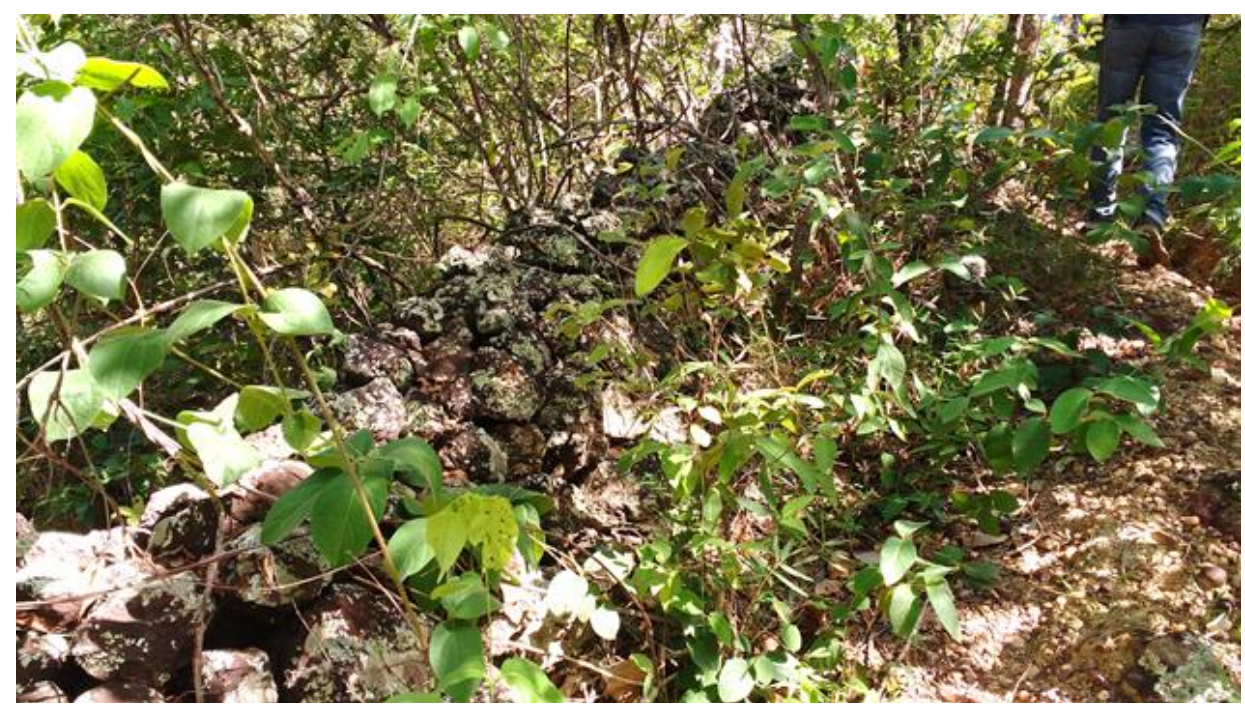

Fonte: acervo pessoal, dezembro de 2016.

Manoel Lopes podia então mais uma vez cultivar em um pedaço de terra cedido pelo dono, então só ia a Barreiros (Francisco Dumont) uma vez por semana para comprar aquilo que não produzia: café, querosene e sabão. A primeira vez que foi ao município foi em 1940, quando não tinha ainda 20 anos completos. Todo o trajeto era feito no lombo do cavalo. Se alguém adoecia, o remédio tinha que vir do mato ou, em casos graves, o moribundo ser levado a cavalo até Navarro ou Granjas Reunidas, fazenda dos Matarazzo onde havia um médico instalado. Em último caso, recorria-se a Bocaiúva. O gado ela levado ao longo de um dia até a estação de trem em Engenheiro Navarro. "Naquele tempo, o boi era no mato, não tinha estrada", conta. Por vezes, tinham que levar as rezes até a fazenda Tupinambá, a única na região que tinha balanças para pesar o animal antes do embarque, pois ficava perto da estação. Os bezerros de engorda vendidos e embarcados em Navarro seguiam para outras regiões.

Décadas depois, foi a vez de trabalhar para outro fazendeiro, Antônio Leite, para quem foi vaqueiro ordenhador por três anos, além de cuidar de mais de 10 mil cabeças de gado. Esse serviço não era feito sozinho: mais três vaqueiros trabalhavam juntos, um deles seu filho, todos no regime de agregação, vivendo na fazenda do dono. Manoel era o único casado, e os vaqueiros solteiros, Galdino e Hermes, moravam nos fundos de sua pequena casa. "O Galdino morreu. Agora o Hermes saiu por esse mundo afora, nunca mais vi.” Ele diz que nessa fazenda o serviço era mais pesado porque não havia pasto, e o gado era levado para os tabuleiros da Serra para pastar no mato. "Conheci essa serra toda! Fui vaqueiro na Serra do Cabral. Hoje, não conheço mais." Além disso, cabia a eles a manutenção da fazenda, realizando todo tipo de serviço.

Por trabalhar em diversas funções, Manoel aprendeu carpintaria sozinho. Coube a ele, mesmo após estar aposentado como trabalhador rural, rodar pelas fazendas para construir casa, 
cobertura de curral, entre outros serviços do ramo, também solicitados nas cidadezinhas. São Lamberto foi a fazenda onde mais trabalhou no talhe da madeira. Outro ofício que aprendeu foi o de pedreiro, tendo circulado com seus atributos por Francisco Dumont e Buriti Grande.

Apesar de Jean-Paul de Gaudemar (1977) lidar apenas com situações de trabalho livre assalariado, a movimentação de Manoel Lopes por distintos ofícios apresenta o que o economista afirma sobre a mobilidade enquanto capacidade que permite à força de trabalho adaptar-se às variações não só da jornada laboral, mas também à permutação dos postos de ocupação e aos efeitos de uma divisão do trabalho cada vez maior.

Depois de sair da condição de agregado em fazendas, Manoel Lopes foi morar na parte alta de Francisco Dumont. Ele conta que em épocas difíceis, para garantir a renda da família, chegou a garimpar diamante e cristal e, quando não achava pedras, colhia sempre-viva na estação propícia. Quando as reflorestadoras apareceram, já em fins dos anos 1970, foi ele quem construiu para Antônio da Serra a sede da fazenda Santa Maria, tendo feito também tanques e carvoeiras. Apesar da idade, conquistou um terreno na Água Branca, onde ainda planta a sua roça. De todos os serviços, disse que prefere os de carpintaria e pedreiro, pois é melhor não ter patrão. A ideia de liberdade e autonomia contraposta à experiência de agregado como sujeito preso às relações de favor ficam claras em sua fala.

O desenvolvimento de relações plenamente autonomizadas entre terra, trabalho e capital faria, mais tarde, parte do processo de modernização dentro e fora das fazendas na Serra. Os vínculos do favor, em que transparece a violência extraeconômica sobre o sertanejo, anos depois daria lugar a conexões em que a aparente igualdade entre o trabalhador e o proprietário permitiria trocar trabalho por salário. No caso da Serra do Cabral, a mudança do pagamento em vales para dinheiro passou a ocorrer apenas após a década de 1970, bem depois do processo de centralização do Estado. A nitidez da violência extraeconômica dá lugar à aparente relação de liberdade e de troca entre iguais, consolidando a abstração real, em que tudo vira mercadoria.

Por sua vez, a abstração real é desmascarada na existência objetiva de classes, que aparecem nos momentos de sociabilidade nos municípios da Serra. Fazendo com que coisas diferentes possam ser igualadas por seu valor, a relação abstrai as diferenças qualitativas dos produtos do trabalho e seus processos históricos de formação, desnudando a expropriação e a acumulação em camadas sociais distintas. Ao discutirem a mobilização do trabalho e o estudo da região, Cássio Boechat e Carlos Toledo explicam a personificação da propriedade da terra e dos meios de produção a que os trabalhadores estão sujeitos: 
Os meios de produção produzidos por processos de trabalho passados apresentam-se na reprodução das relações de produção como passíveis de serem igualados no tempo de trabalho que é vendido pelos trabalhadores. Esses meios de produção são personificados por seus proprietários. Aquele tempo de vida vendido é personificado pelos trabalhadores. Não é apenas isso, os meios de produção não produzidos (a terra) também entram no processo de reprodução das relações de produção como coisa de valor. Assim, também a propriedade da terra pode ser personificada por seu proprietário. (BOECHAT; TOLEDO, 2012, p. 459-460).

Em situações em que o trabalhador ganhava em dinheiro pelo trabalho feito, a troca de equivalentes escondia o trabalho não pago. O fazendeiro extraía o mais-produto dessa relação e o investia gradativamente em técnicas que aprimorassem sua produção, o que sugeria uma nova forma de acumulação. Com isso, transforma-se o modo de confecção de mercadorias, já que dos anos 1970 em diante, a relação de favor vai arrefecendo na Serra, entrando o assalariamento sem qualquer outro vínculo, bem como o maquinário, pois a qualidade e a quantidade do que se produzia e consumia também muda gradualmente.

Nesse decurso, a migração interna também passou a ser estimulada, a terra passou a ser objeto de intervenção do planejamento e o poder de coerção se concentrou no monopólio da polícia e do exército, diluindo aquilo que Willi Bolle (2004) chama de "sistema jagunço" " Porém, consoante Cássio Boechat (2013), nem essas mudanças se aplicariam por decreto, nem a assim chamada oligarquia regional seria abolida, sendo ela mesma a condutora de muitas dessas transformações. A região, até então fechada, começava a ser aberta para a introdução de novas relações produtoras de mercadorias.

\subsubsection{Lica de Zé Peão, Maria de Bruno Facão, Vanja de Manoel Lopes e Ifigênia de Dodô: dois dedos de prosa sobre família, trabalho, cor e valor-dissociação ${ }^{130}$}

As relações sociais de produção e a forma regional de acumulação do capital sugerem pensar que a formação do trabalho livre constituiu a sua autonomização em relação à propriedade do capital. Um pressuposto para o desenrolar desse processo teria sido a composição da família regional, conforme adverte Carlos de Almeida Toledo (2008) em seu estudo sobre as lavras baianas. A reprodução familiar seria uma parte histórica da gênese da

\footnotetext{
${ }^{129} \mathrm{O}$ autor propõe pensar a jagunçagem como uma organização armada, um exército ou policiamento particular dos fazendeiros coronéis que, a seu serviço, cumprem a função de manter a ordem no sertão, ordem essa que vai de acordo com os seus interesses particulares. Os jagunços seriam homens livres pobres, muitos na condição de moradia de favor desses fazendeiros, recrutados pela valentia e atraídos pela ilusão e sensação de liberdade que empunhar uma arma lhes causava.

${ }^{130}$ É interessante apontar para o fato de que no sertão, quando as mulheres se casam, elas deixam de ser associadas ao pai para serem relacionadas ao marido, sendo chamadas de "fulana de sicrano", como se fossem posses da figura masculina que responde por elas. Já os homens, são quase sempre chamados pelo nome seguido de sobrenome, apelido, profissão ou também pelo nome do pai. Às mulheres cabe apenas a associação ao cônjuge.
} 
região, fornecedora de braços para o trabalho nas fazendas, tendo existido à sombra da sociedade escravista, enquanto na pós-abolição passou a ser essencial para a permanência daquela dinâmica.

Quando se procurava por vaqueiros ainda vivos para ouvi-los sobre o trabalho nas fazendas no período pré-autonomização, surgiu a curiosidade pelas mulheres, presentes também no garimpo, porém em muito menor escala. Tal interesse parte da premissa levantada por Roswitha Scholz no texto O sexo do capitalismo: teorias feministas e metamorfose pósmoderna do patriarcado, em que a autora propõe o teorema do valor-dissociação, pondo em questão a própria forma da mercadoria como princípio da socialização da moderna sociedade mundial, interessada em discutir para além do marxismo operário e seu limite à crítica à maisvalia, bem como para além do feminismo, que a crise da modernidade fragmenta ao rotular tudo como trabalho ${ }^{131}$.

O suporte para essa preocupação foi acrescido com a advertência de que o capitalismo é também uma história sexual cindida, de acordo com o que Jéssica Cristina Luz Menegatti apresenta em sua dissertação Mulher sem valor: o pensamento de Roswitha Scholz para a crítica radical do capitalismo e das relações de gênero. Iniciando sua argumentação com Simone de Beauvoir, a autora atenta para o fato de que a forma mercadoria não poderia ser pensada como uma categoria "sexualmente neutra". Ao contrário, ela contém em si uma dualidade em contradição, e é justamente essa cisão na sua unidade o que coincide com o modelo de assimetria de gênero que constitui as bases do patriarcado capitalista tal como se conhece, nos seus estereótipos de "feminilidade" e "masculinidade".

Assim, a sociedade capitalista identifica o feminino na categoria de valor de uso em oposição ao masculino enquanto valor de troca, atribuindo a estes a figura de "sujeitos" do valor-dinheiro e o protagonismo de sua realização, que se dá na esfera pública, o mercado, onde se efetiva o valor de troca, de modo que à masculinidade são aderidas identificações imediatas com o dinheiro e o trabalho abstrato. Às mulheres, por sua vez, resta a vinculação ao que aparece em uma esfera radicalmente refratária: a privada ou doméstica, relacionada à realização do valor de uso ${ }^{132}$ e que, como oposto ao valor de troca, perde primazia, "figurando como mero

\footnotetext{
${ }^{131}$ Sobre as demandas do feminismo operário, o problema é o fim em si absurdo da conformação totalitária da mercadoria e do dinheiro, sendo que a "distribuição justa" no interior desta forma permanece submetida às leis do sistema e às restrições dela decorrentes - logo, uma pura ilusão. Uma simples redistribuição na condição da mercadoria, do valor e do dinheiro, seja qual for a modalidade, não pode evitar as crises, nem acabar com a pobreza global engendrada pelo capitalismo. O problema decisivo não é como sacar a riqueza abstrata na forma insuperada do dinheiro, mas essa mesma forma (SCHOLZ, 2000).

${ }^{132} \mathrm{Na}$ esteira da crítica a essa identificação que a sociedade capitalista faz, Robert Kurz (1992a) acautela que o valor de uso também é um momento da abstração real, sendo, portanto, parte do universo masculino da sociabilidade abstrata e dessensibilizada. Somente no consumo humano e individual os produtos são libertados
} 
suporte, uma concepção que aparta as mulheres das relações de poder e perspectivas de ação direta sobre a condução da sociedade" (MENEGATTI, 2019, p. 24).

Para Roswitha Scholz (2000), o feminino, o trabalho de casa etc. sofrem uma "dissociação" do valor, do trabalho abstrato e das formas de racionalidade que lhes estão ligadas, sendo que determinadas qualidades com conotação feminina, como sensibilidade e emocionalidade, são atribuídas à mulher, enquanto ao homem compete a força do entendimento, a fortaleza de caráter, a coragem etc., revelando uma dissociação calcada numa relação dialética recíproca, pois a dissociação é o valor, e o valor é a dissociação, estando um contido no outro sem serem idênticos, ambos momentos centrais essenciais da mesma relação social em si contraditória e fragmentária, que devem ser compreendidos no mesmo nível da abstração. As qualidades atribuídas à mulher como momento dissociado são imanentes à sociedade capitalista, ainda que não imanentes à forma do valor.

Com isso, o "dissociado" feminino vai além do consumo e da preparação de bens de uso comprados para tal, abrangendo da prestação de cuidados ao erotismo, dificultando distinguir o que é atividade obrigatória e manifestação existencial da vida. É essa dificuldade que para Roswitha Scholz torna acabrunhante o conjunto de atividades de reprodução feminina, ao invés da situação do "trabalhador abstracto"133.

Conforme relatam os entrevistados, a rotina de trabalho nas fazendas de gado não mudou muito do século XVIII até a primeira metade do XX. Maria de Jesus Leite, conhecida como Lica, 90 anos (2017), filha de garimpeiro e nascida em Francisco Dumont, foi uma das depoentes. Casada desde os 19 anos com Zé Peão (falecido há quase dez anos) - vaqueiro que ilustra a responsabilidade desses sujeitos pelo povoamento do sertão - , contou que o casal morou por anos em uma fazenda em um lugar de difícil acesso hoje - ironicamente por causa do asfalto -, pertencente à família de Wandick Dumont, de quem eram compadres. Seu marido, encarregado de administrar a fazenda e de conduzir o gado até a estação de trem, lidava com o ramo desde menino ${ }^{134}$.

\footnotetext{
para o uso real, e é lá que o dissociado se encontra. "Nesse sentido, o próprio valor de uso continua a ser uma categoria fetichista da economia abstrata" (KURZ, 1992a). É nesse consumo que se concede à verdadeira não universalidade da forma abstrata universal, e é na realização da mercadoria que se percebe a fraqueza da totalidade, pois ela está nua ao revelar o mundo que não queria que existisse.

${ }^{133}$ Como será desenvolvido mais adiante, a questão de gênero não é suficiente para abordar os dissociados no contexto periférico. Essa percepção vai de encontro às considerações finais da análise de Jéssica Menegatti (2019), ao contestar a dissociação-valor como "meta-estrutura" do capitalismo, conforme defendido por Roswitha Scholz. 134 “O vaqueiro foi dos personagens mais importantes na expansão dos currais pelos sertões nordestinos. No Piauí pode ser atribuído a ele o verdadeiro povoador daquelas terras, tendo em vista que na maior parte do tempo o fazendeiro estava ausente, não somente porque muitos deles moravam em núcleos urbanos fora do Piauí, mas também pelo fato de possuírem várias fazendas, e se alternarem entre elas. Era designado ao vaqueiro, neste caso, manter ou ampliar o patrimônio do patrão." (ALVES, 2000, p. 26).
} 
Mesmo tendo vivido com o marido no tempo em que a modernização já adentrava a Serra - o rebanho era levado até o trem em Engenheiro Navarro -, ela comenta que o dia a dia na fazenda, pelo o que lembra de o marido contar, era de acostumar o gado no pasto, amansálo, cuidar dos doentes e organizar sua alimentação e suas crias.

A princípio, o marido recebia um bezerro a cada quatro nascidos (quarteação ${ }^{135}$ ), o que também lhes permitiu adquirir um pedaço de terra e formar a Fazendinha, propriedade deles. A partir de determinado momento (não soube dizer ao certo quando), o dono da fazenda passou a pagar seu marido pelo trabalho em dinheiro, afirmando que nunca tiveram problema em relação ao quanto ele ganhava, nem sobre a existência de atrasos.

Ela não recebia pagamento, mas trabalhava na casa da fazenda e fazia todo tipo de serviço: passava, lavava, cuidava da pensão, cozinhava para os camaradas (vaqueiros), atendia serradores, ferreiros, pedreiros e carpinteiros que faziam a manutenção da terra, cuidava dos filhos dos donos da fazenda, tricotava, buscava água de cisterna e do rio Jequitaí, criava porcos, tirava leite e fazia queijo, requeijão e sabão de pequi colhido no mato, da mesma maneira que muitas sertanejas fizeram décadas antes ${ }^{136}$. Foi morar na fazenda porque lá seu marido conseguiu emprego e ela era a responsável pelo preparo do almoço das tropas, tendo que cozinhar todas as noites para o dia seguinte. ${ }^{137}$

${ }^{135}$ Um dos poucos trabalhos pagos desde a Colônia por fazendeiros já absenteístas, explicado pelo Roteiro...:

O uso inalteravel nos Sertões de fazer o vaqueiro sua a quarta parte dos gados que cria, sem poder entrar nesta partilha antes de cinco annos, não só faz que os dittos vaqueiros se interessem como senhores, no bom trato das fazendas ; mas faz tambem com que os gados que lucrão, passem a estabelecer novas fazendas, e que hum morador do Maranhão, Pará, e Piahui, possa mandar estabelecer fazendas em lugares remotos ; e possuillas sem deixar a sua habitação, e outras culturas, que mais exigem a sua assistencia, e industria, tanto para traçar as lavouras, como para conservar com humanidade, e applicar com proveito hum maior numero de escravos. As mesmas trez legoas de terra, que sendo aptas para a creação de gados, não carecem de mais de dez, ou dôze pessoas ; sendo proprias e destinadas as lavouras das canas de Assucar, do Tabaco, e mais generos do Paiz, não chegarião a ver a sua cultura em hum estado de perfeição com os braços de oitto centos, ou mil escravos. Esta differença mostra bem que em menos tempo, com quanto menos despeza, e menos individuos se pode adiantar a Povoação, e cultura do referido Paiz. (ROTEIRO..., 1900, p. 89).

136 "Uma das coisas com que vovô embirrava era de fazer sabão na Fazenda. Vovó disse que ela não podia compreender viver na Fazenda comprando sabão. Então mandava os negros, no tempo dos pequis, buscar cargueiros deles para fazer sabão. Quando vovô via chegar aquela porção em casa, perguntava a vovó para que ela queria tanto pequi. Ela respondia: 'É para fazer velas, Batista'. Ele então perguntava: 'Faz-se velas de pequi?'. Ela respondia: 'Muito boas'. Ele dizia: 'Pois eu quero vê-las depois de prontas'. Vovó enchia o tacho de pequis, fazia sabão escondido e ele acabava se esquecendo das velas.” (MORLEY, 2016, p. 49).

${ }^{137}$ Resguardadas as diferenças em relação às mudanças sociais, o relato de Lica remete às observações de Johann Baptist von Spix pouco mais de 100 anos antes, ao ter andado pela mesma região:

[...] As fazendas isoladas estão privadas de todo auxílio dos centros mais habitados; cada fazendeiro rico vê-se, portanto, forçado a prover por si mesmo às necessidades de sua casa, mandando ensinar ofícios aos seus escravos. Em geral, encontram-se, nestas fazendas, oficinas com todos os operários como sapateiro, alfaiate, tecelão, serralheiro, ferreiro, pedreiro, tijoleiro, caçador, mineiro, lavrador, etc., ofícios que, num país povoado, estão divididos em corporações próprias. À testa dos negócios está um feitor, mulato ou negro de confiança, e a ordem do dia é determinada como num convento. O fazendeiro figura, por assim dizer, como governador, juiz, 
Os serviços de Lica são essenciais para que a fazenda continue produzindo, porém, como dissociado feminino, seu trabalho é o que está à parte, permanecendo ao mesmo tempo dependente e menosprezado, porque se trata de um momento desintegrado no contexto de toda a produção social. Lica não produzia diretamente mercadorias, mas criava as condições para que a fazenda funcionasse e continuasse se realizando como tal. Seu trabalho, entendido como cindido, não é visto como lógico, sendo por isso naturalizado o fato de não receber pagamento.

Assim que o casal se aposentou, decidiu morar de vez no município. Antes desse momento, Lica comenta que queria que as filhas estudassem, por isso investiram em uma casa em Francisco Dumont com a ajuda do patrão, mesmo com o marido passando a semana fora. Ela mesma estudou apenas quatro anos, pois a escola não oferecia formação além e o casamento aconteceu cedo. Apenas depois de aposentada ela passou a exercer atividades em que o dinheiro chegava em suas mãos: fazia quitanda (biscoitos e doces) e crochê sob encomenda, tudo realizado dentro do ambiente doméstico. Conseguiu formar os filhos, que para tal tiveram que se deslocar para cidades maiores, como Bocaiúva e Belo Horizonte, não seguindo o destino dos pais.

Semelhante à Lica é Evangelina Teles da Fonseca, Vanja, 88 anos (2019), esposa de Manoel Lopes, nascida no povoado do Carrapato. Seu pai tinha um pedaço de terra na comunidade, fruto de partilha de herança com os irmãos. Porém, como morreu cedo, sua mãe precisou distribuir os seis filhos para que pudessem crescer com um mínimo de condição. Assim, Vanja foi aos 12 anos de idade morar no povoado de Santo Antônio com uma tia casada com o fazendeiro Silivério.

Tendo sido criada na fazenda, coube a ela desde cedo os serviços de lavoura e fazer requeijão e queijo - "No Santo Antônio, fazendeiro sobrevivia era do gado, mexendo com leite, fazendo requeijão..." -, recebendo em troca um lugar para morar, comida e roupa. Conseguiu estudar por três anos, porém o trabalho precoce impediu que continuasse, apesar do desejo de prosseguir aprendendo. A partir de então, passou a cozinhar para a fazenda sem receber qualquer pagamento até os 18 anos, quando saiu de lá para voltar a viver no Carrapato, casada com Manoel Lopes.

Como o seu marido vivia na condição de agregado, ela o seguiu. Ao ter filhos, teve de lidar com a criação dos pequenos, além dos serviços de cozinha. A família se mudou para

e médico, em sua propriedade. Muitas vezes, também faz papel de padre, ou requer para a capela da casa os ofícios do pároco da vizinhança. O seu principal cuidado consiste em aumentar os numerosos escravos, o capital da fazenda, e protege-los contra as doenças. Quando ocorrem moléstias, ele consulta a tradução portuguesa, muito espalhada por aqui, da "Medicina Doméstica” de Buchanan. (SPIX, 1981, p. 18). 
Francisco Dumont após décadas vivendo de favor, pois tinha o desejo de dar aos dois meninos a oportunidade de estudar.

A vida no município impeliu Vanja mais uma vez ao trabalho, tendo em vista que a família não dispunha mais de lavoura para o consumo de víveres ${ }^{138}$. Assim, intercalava os períodos de coleta de sempre-viva na Serra com o trabalho que surgiu com as reflorestadoras. Nos anos 1980, fez plantio de pinho para a Andrade Valadares, Santa Maria Floresta e Serra do Cabral Agroindústria (Scai). Depois, passou a trabalhar nos reparos e nos viveiros de mudas, até finalmente voltar a lidar com cozinha, dessa vez dos alojamentos, passando a semana na Serra. Pela primeira vez na vida, recebeu salário e teve carteira assinada.

Tendo saído da silvicultura, voltou a trabalhar como cozinheira de fazendeiros, recebendo meio salário mínimo sem, no entanto, viver de favor no domínio da fazenda. Ela ia e voltava todos os dias, muitas vezes andando por quilômetros. Nessa época, as fazendas não possuíam mais agregados, pagando em dinheiro pelos serviços prestados, sem estabelecer qualquer outro vínculo entre o trabalhador e a terra alheia, onde exercia seus ofícios. Fez ali o que já fazia desde jovem: cozinhava, limpava, lavava e passava roupa e cuidava da criação de galinhas. Segundo ela, foi com o Governo Collor que passou a receber um salário inteiro, vindo a se aposentar como trabalhadora rural.

Sobre o trabalho, Vanja enfatiza: "Bendito seja Deus, que me deu força pra trabalhar! Nunca tive medo de trabalho". Convertida à Igreja Batista desde a infância - os batistas chegaram ao Santo Antônio há 78 anos, hoje todo o povoado é convertido -, sua fala denota o inconsciente moldado no consentimento à exploração de sua força de trabalho, relacionada à ideia de superação do sofrimento pelo labor presente na ética protestante. Segundo ela, no tempo de convívio com os batistas durante sua condição de favor - o latifundiário também era da igreja -, havia um senso ilusório de comunidade, sendo a solidariedade o contraponto às relações de submissão e abuso de poder dos fazendeiros ${ }^{139}$.

Com o ritmo de vida marcado pela natureza, era difícil dissociar o tempo de trabalho do tempo de diversão. Foi possível ouvir de Eliane Leite Rosa, 61 anos (2019), nascida em Francisco Dumont, que no tempo de colheita de determinados frutos, ela e sua mãe eram

\footnotetext{
${ }^{138}$ Advertidas as diferenças contextuais, Silvia Federici (2004) aponta que a transição para o trabalho assalariado na realidade europeia da baixa Idade Média dificultou não apenas a percepção do trabalhador sobre o que era produzir para si e a exploração para outrem, como também gerou seu empobrecimento a partir do momento em que a mediação do dinheiro se torna a via para aquisição dos mantimentos necessários à própria reprodução.

${ }^{139}$ Apesar de trabalhos relevantes apresentarem os movimentos anabatistas do século XVI como postulantes a um convívio comunitário, conforme apresentado por Carlo Ginzburg em $O$ queijo e os vermes, Silvia Federici vai em outra direção, descortinando a opressão que o sexo feminino sofreu dentro de veios da nova doutrina, narrado em Calibã e a bruxa. Com isso, compreende-se melhor a absorção da apologia ao trabalho defendida por Vanja.
} 
convidadas a atravessar de canoa o rio Jequitaí para aproveitar o leite e as espigas nas fazendas à margem, onde passavam o dia fazendo doces, como curau, goiabada e de leite. Atravessar o rio era relatado como uma aventura, assim como passar a tarde mexendo nos tachos de cobre enquanto outras mulheres, no ambiente privado, debulhavam o milho ou descascavam as frutas, momentos de solidariedade também partilhados nas cozinhas e nos quintais das casas, quando se reuniam para passar o dia fazendo as quitandas (biscoitos) enquanto cuidavam em conjunto dos filhos e dividiam as experiências de vida e de culinária sertaneja ${ }^{140}$.

Outro fato narrado por algumas entrevistadas era a entrada no mato fechado na Água Santa, lugarejo da Serra, para buscar lenha para cozinhar na época da estiagem: um trabalho delegado às mulheres com e sem marido ${ }^{141}$, que, juntas, seguiam as picadas cantando e contando causos enquanto cortavam os melhores paus e os equilibravam sobre a cabeça ${ }^{142}$. Mesmo com toda a imposição da divisão sexual das tarefas e o sofrimento promovido pela dissociação, era nessas situações de sociabilidade e solidariedade que as mulheres reuniam condições para suportar a opressão patriarcal.

Situação diferente das famílias de Zé Peão e Lopes foi encontrada a partir do relato de Maria de Oliveira, 88 anos (2017), nascida em Claro dos Poções (município próximo à Serra). Conhecida como Maria Facão (seu marido, Bruno, era "homem valente", por isso o apelido),

\footnotetext{
${ }^{140}$ Em Calibã e a bruxa: mulheres, corpo e acumulação primitiva, obra em que Silvia Federici constrói a historicidade do capitalismo nos seus liames com o patriarcado, a acumulação primitiva possibilitou impor uma nova divisão sexual do trabalho, diferenciando não somente as tarefas que os homens e as mulheres deveriam realizar, como também suas experiências, suas vidas, sua relação com o capital e com outros setores da classe trabalhadora. Em um esforço considerável de apresentar outras possibilidades sociais em disputa no fim da Idade Média que não o capitalismo, a autora, a partir da vertente de resistência dos camponeses à nova sociabilidade, exibe a perseguição aos laços de solidariedade entre as mulheres, argumentando que a transição imposta e nada natural da lógica do valor serviu para submetê-las ao domínio masculino direcionado à acumulação de riqueza. Passado o tempo, desenvolvidas e transformadas as forças produtivas que permaneceram oprimindo as mulheres - detalhes que a autora parece não dar a atenção necessária -, a persistência de convívio nas relações de trabalho e além denotam, inconscientemente, uma forma de resistência às imposições patriarcais modernas.

141 "Por mim, o que pensei, foi: que eu não tive pai; quer dizer isso, pois nem eu nunca soube autorizado o nome dele. Não me envergonho, por ser de escuro nascimento. Órfão de conhecença e de papéis legais, é o que a gente vê mais, nestes sertões. Homem viaja, arrancha, passa: muda de lugar e de mulher, algum filho é o perdurado. Quem é pobre, pouco se apega, é um giro-o-giro no vago dos gerais, que nem os pássaros de rios e lagoas." (ROSA, 1986, p. 31). Assim Riobaldo ilustra como várias famílias sertanejas pobres se formaram, não sobrando às mulheres deixadas pelos pais de seus filhos muitas alternativas além de viver agregadas e trabalhar no serviço pesado para o sustento dos filhos. O personagem central da trama seria filho de fazendeiro com mulher pobre e parda.

142 "Graças a Deus Maria Balaio vai seguindo seu curso. Tudo simplesmente, é verdade; mas ela é pouco inteligente e é com muita dificuldade que tem conseguido passar nos exames. Só eu na Escola conheço a sua vida pois a mãe, Siá Joaquina Balaio, é lenheira e mamãe costuma comprar a lenha dela. Gosto muito de ver o esforço que ela e a mãe fazem, coitadas, e se há um passeio aonde vou com prazer é ao Cruzeiro, só para ir ao rancho delas. Se eu disser que lhes invejo a sorte ninguém acredita; mas se elas vivem a vida de que eu gosto! Moram num rancho e não dá trabalho para arrumar e no meio do campo largo com uma vista maravilhosa! Nem sei como elas tiveram ideia de fazer ali o seu ranchinho. Só há lá o delas e elas não têm o menor medo, pois são protegidas pelo Cruzeiro que é muito próximo. O cômodo é um só, com um jirau e um colchão de palha para as duas e um caixote para assentar. $\mathrm{O}$ fogão também é no quarto e elas me disseram que no tempo de frio se aquecem muito bem com canela." (MORLEY, 2016, p. 187).
} 
viveu de agregada nas fazendas de Sócrates e Daniel Dumont por quase 60 anos. Filha de pais lavradores, trabalhou fazendo cerca, plantando para os donos da terra "com enxada e foice" e em carvoarias quando as monoculturas de pinho começaram a chegar à região, além de cuidar da casa e dos filhos.

Maria Facão e sua família, assim como Vanja e Manoel Lopes, apresentam a situação dos agregados nas fazendas, expropriados e mobilizados para o trabalho. Quando a propriedade privada questiona a terra devoluta, ela transforma seus ocupantes em moradores de favor, o que remete à graça e ao consentimento, mas não ao direito de ali estarem; as relações desses ocupantes com a terra são transformadas em relações de trabalho rural. $\mathrm{O}$ espaço preenchido com o favor, a permissão ou o contrato, ausenta e evapora os vínculos permanentes com a terra, que caracterizam a existência social de diferentes frações de lavradores.

Enquanto Lica e Vanja, brancas, trabalharam na maior parte de suas vidas dentro da casa dos patrões, à Maria, negra, coube o serviço fora do ambiente privado, exercendo muitas vezes funções delegadas aos homens. Faz-se notar que o fim da escravidão havia acontecido há poucas décadas, e nas regiões não metropolizadas do país ainda era muito nítida a distinção social pautada na cor e em toda a bagagem do cativeiro pretérito que a tez escura trazia. As relações de favor, lidas como mediação entre os sujeitos livres pobres e os senhores na reprodução de ambas as classes, que assegurava às duas partes nessa relação, em especial à mais fraca, de que nenhuma era escrava, perduraram mesmo após a abolição (SCHWARZ, 1992). Por mais que o favor orne a violência da exploração na relação informal e íntima entre senhores e livres pobres, nem ela, nem qualquer construção ideológica tributária deu conta de mascarar a brutalidade concreta da expropriação e da desigualdade promovida pelo espectro do passado escravista, mesmo quando se denuncia as assimetrias na questão de gênero.

Como alerta Étienne Balibar (2007), é importante cotejar a raça e o racismo com seus contextos de classe, sexo e religião, vislumbrando compreender suas variantes particulares no passado e na contemporaneidade. A ficção também traz à baila o assunto, dado que Riobaldo compara pela cor da pele o papel social de duas mulheres que atravessaram sua vida. Com Otacília, moça branca e filha de fazendeiro, ele se casa; com Nhorinhá, moça de pele escura e filha da cigana "bruxa" Ana Duzuza, os prazeres da carne sem compromisso. Impelido a seguir o padrão de organização da família tradicional brasileira, vigente entre as camadas altas da sociedade e em vigor até o fim do século XIX, o chefe de bando coloca o matrimônio com a moça branca da fazenda à frente dos afetos, para realizar a função ordenadora das relações 
sociais condizentes ao poder ligado à terra ${ }^{143}$, enquanto à mulher pobre, de cor e em mobilidade - e talvez por isso mais livre sexualmente, porém não liberta do patriarcado -, foi preterida na contração da relação familial, mesmo sendo a preferida emocionalmente.

[...] Toda moça é mansa, é branca e delicada. Otacília era a mais.

Mas, na beirada da alpendrada, tinha um canteirozinho de jardim, com escolha de poucas flores. Das que sobressaíam, era uma flor branca - que fosse caeté, pensei, e parecia um lírio - alteada e muito perfumosa. E essa flor é figurada, o senhor sabe? Morada em que tem moças, plantam dela em porta da casa-de-fazenda. De propósito plantam, para resposta e pergunta. Eu nem sabia. Indaguei o nome da flor.

- "Casa Comigo" - Otacília baixinho me atendeu. E, no dizer, tirou de mim os olhos; mas o tiritozinho de sua voz eu guardei e recebi, porque era de sentimento. Ou não era? Daquele curto lisim de dúvidas foi que minou meu maisquerer. E o nome da flore era o dito, tal, se chamava - mas para os namorados respondido somente. Consoante, outras, as mulheres livres, dadas, respondem: - "Dorme comigo..." Assim era que devia de haver de ter de me dizer aquela linda moça Nhorinhá, filha de Ana Duzuza, nos Gerais confins; e que também gostou de mim e eu dela gostei. Ah, a flor do amor tem muitos nomes. Nhorinhá prostituta, pimenta-branca, boca cheirosa, o bafo de menino pequeno [...]. (ROSA, 1986, p. 164, grifos do autor).

Por isso, não se reduz o debate sobre valor-dissociação à questão de gênero, sobretudo nas formações sociais onde o escravismo moderno esteve presente ${ }^{144}$. Jéssica Menegatti lembra que para Roswitha Scholz as diferenças devem ser significadas "como algo que está sempre de certo modo diluído [...] na forma da dissociação-valor como forma de socialização dominante" (SCHOLZ, 2000 apud MENEGATTI, 2019, p. 83), não devendo considerar o racismo como forma de discriminação de segunda ordem, porém com o cuidado para não cair no debate fragmentado e neoliberal das diferenças.

Apesar de o racismo científico se consolidar como teoria somente na segunda metade do século $\mathrm{XIX}^{145}$, a questão da cor perpassa a formação social brasileira, adquirindo protagonismo nos projetos de nação pós-independência ${ }^{146}$. Ao se considerar a raça e o racismo

\footnotetext{
143 “Talvez se possa mesmo aventar que a enorme importância e solidez das relações familiais na antiga sociedade brasileira provenha do fato de proceder-se, em seu curso, à unificação dos controles sociais cuja legitimidade emanava de fontes diferentes, nas quais se refletiam as duas 'facetas' da sociedade brasileira: o lar e a empresa, amálgama de que se fez a grande propriedade fundiária.” (FRANCO, 1997, p. 45). Na interpretação da autora, família e terra se ligam, dando a impressão de estarem voltadas à concepção da Geografia clássica, sendo que, para os livres pobres, o modelo de família tradicional parece não ter encaixe, a não ser quando algumas dessas famílias estabelecem vínculos íntimos com os fazendeiros.

${ }^{144}$ Em Scholz e em Federici, a caça às bruxas, tanto no medievo tardio europeu quanto na colonização do Novo Mundo, fornece uma pista para pensar a abrangência da dissociação:

A definição de negritude e de feminilidade como marcas da bestialidade e irracionalidade era correspondente à exclusão das mulheres na Europa, assim como das mulheres e dos homens nas colônias, devido ao contrato social implícito no salário e à consequente naturalização de sua exploração. (FEDERICI, 2004, p. 364-365).

145 A trajetória do racismo científico, a influência do darwinismo social e os maiores expoentes teóricos (como Gobineau, Lapouge e outros) estão apresentados, por exemplo, em Maria Augusta Bolsanello (1996) e em Lilia Moritz Schwarcz (1993).

146 Dois exemplos que abordam a mesma questão, apesar de cada um propor uma solução diferente, é Memoria sobre a necessidade de abolir a introdução dos escravos africanos no Brasil: sobre o modo e condições com que
} 
tecnologias e discursos mais sofisticados do liberalismo na sua abrangência mundial, é preciso investigar não apenas o lançamento da mulher no mundo do trabalho abstrato já em crise, mas também de que maneira essas esferas se cruzam.

Da vida na fazenda, Maria Facão disse que até meados da década de 1970, sua família não recebia em dinheiro, mas em vale, que era trocado por mantimentos apenas na venda autorizada pelos proprietários. O que conseguia de comida não dava para alimentar os 11 filhos, tendo que completar a alimentação com frutos colhidos no mato (araçá, jatobá, pequi, cagaita, goiaba, cafezinho, cajuzinho do mato, ingá e jenipapo) e na pequena roça que lhes era permitido cultivar.

A casa em que moravam era um rancho feito de palha. Enquanto o marido negociava o trabalho e tomava a frente nos serviços, a ela cabia plantar a roça, roçar manga para os bois e lavar roupa para fora, vez ou outra ajudando Bruno a fazer as cercas. No teorema do valordissociação, fica claro que cabe ao sujeito masculino esclarecido, como socialmente determinante, representar a força de se impor, de pensar e de demonstrar caráter, estruturado inconscientemente ele mesmo sobre esta "dissociação" (SCHOLZ, 2000).

Os frutos do cultivo eram divididos meio a meio com o dono da terra, que às vezes fornecia leite e mandioca para os filhos pequenos. A permanência na terra alheia requeria o pagamento em tributo ao dono, atentando para o fato de que, apesar de não haver assalariamento, essa relação é capitalista e está posta como naturalizada. Se os produtos se tornam um poder autônomo frente aos produtores, o proprietário fundiário personifica a terra, exigindo a sua participação no produto, independentemente do fim que dê a ele. Assim, capital e terra monopolizada como fatores em interação são postos como naturalizados ${ }^{147}$.

Se alguém adoecia, era no mato que se procurava o remédio. A busca por dinheiro para comprar o que faltava era feita acessando a Serra, com a colheita sazonal de sempre-vivas e palha de coco para serem vendidas. Um de seus filhos, Célio, presente no momento da conversa, comentou que uma de suas alegrias de menino foi aprender a pescar, pois a partir de então

esta abolição se deve fazer e sobre os meios de remediar a falta de braços que ela pode ocasionar, de João Severiano Maciel da Costa, ou Marquês de Queluz, e a Representação à Assembleia Geral Constituinte e Legislativa do Império do Brasil sobre a escravatura, de José Bonifácio de Andrada e Silva.

147 “Assim como no capital e no capitalista - que, com efeito, é tão somente capital personificado - os produtos se tornam um poder autônomo frente aos produtores, também no proprietário fundiário se personifica a terra, que do mesmo modo se ergue e, como poder autônomo diante dos produtores, exige sua participação no produto criado com sua ajuda, de modo que não é o solo que recebe a parte que lhe cabe do produto para repor e incrementar sua produtividade, mas é o proprietário da terra que recebe uma parte desse produto, seja para negociar com ela, seja para dissipá-la. É evidente que o capital pressupõe o trabalho como assalariado, mas é igualmente evidente que, se partirmos do trabalho como assalariado, de modo que a coincidência do trabalho em geral com o trabalho assalariado se apresente como algo patente e natural, então também o capital e a terra monopolizada terão de aparecer como forma natural das condições de trabalho frente ao trabalho geral." (MARX, 2013, v. 3, p. 887). 
passou a comer algum tipo de carne toda semana. Segundo Maria, a vida sofrida na fazenda a manteve distante do dinheiro por muitos anos, seja pelo pagamento em vale, pelo analfabetismo ou mesmo pela relação conjugal, em que o marido tomava as rédeas da reprodução social familiar e impunha pela força a sua autoridade na vida doméstica. Dado o desconforto em lembrar o passado, Maria teve dificuldade em dar detalhes sobre o modo de ser naquela condição pretérita, sendo intermediada pelos filhos durante a conversa.

A fala de Maria faz referência à formação do mercado de trabalho na Serra. Considerando-se a sua transição de cativo para livre, a ausência de salário para a família ilustra a particularidade das relações laborais na região, ao menos até a metade do século XX. Apesar de o dinheiro não mediar as relações da família Facão, observa-se a mão de obra se tornando mercadoria concomitantemente ao processo de alienação da terra, visto que no mesmo momento as fazendas estavam se expandindo e produzindo.

Entendendo o salário como a compra do tempo socialmente necessário para se produzir mercadoria, no caso de Maria, sua ausência não anula a produção de riqueza. Ela e sua família, assim como outras ouvidas em campo, são exemplos de expropriados da terra e dos meios de produção, que trocaram seu trabalho no trato do gado pela permissão de viver dentro da fazenda, numa relação particular contraditória de serem livres, porém disponíveis ao fazendeiro além do tempo de trabalho, e desvinculadas dos meios de produção, mas com acesso à terra para cultivar um mínimo para sobrevivência própria. Com isso, era o trabalhador quem pagava com a formação dos pastos ao fazendeiro o direito de usar um pedaço de terra para a produção de alimentos, e não o contrário - a fazenda produzia, a partir de relações não capitalistas de produção, grande parcela do seu próprio capital (MARTINS, 2004).

Apesar da empatia à proposta de uma crítica interna negativa, a qual não aceita o trabalho como base ontológica positiva ${ }^{148}$, dada a existência do sujeito moderno, a produção da força de trabalho consiste em sua própria reprodução ou manutenção, e, para tal, o indivíduo precisa de certa quantidade de meios de subsistência, já que ao acionar o trabalho ele "gasta determinada quantidade de músculos, nervos, cérebro etc. humanos que tem que ser reposta" (MARX, 2013, v. 1, p. 245). Ao aceitar que o preço do seu trabalho se reduza ao mínimo de subsistência, a família de Maria Facão só poderia se manter e se desenvolver de forma precária,

\footnotetext{
148 "Trabalho não é, de modo algum, idêntico ao fato de que os homens transformam a natureza e se relacionam através de suas atividades. Enquanto houver homens, eles construirão casas, produzirão vestimentas, alimentos, tanto quanto outras coisas, criarão filhos, escreverão livros, discutirão, cultivarão hortas, farão música etc. Isto é banal e se entende por si mesmo. O que não é óbvio é que a atividade humana em si, o puro 'dispêndio de força de trabalho', sem levar em consideração qualquer conteúdo e independente das necessidades e da vontade dos envolvidos, torne-se um princípio abstrato, que domina as relações sociais.” (KRISIS, 1999, p. 22).
} 
sem muita resistência às condições colocadas. Uma semelhança entre as falas das três mulheres, com destaque para a de Maria Facão, é que, apesar da exploração do trabalho e do tom de conformismo sobre as relações a que se sujeitaram, todas se consideram afortunadas por terem tido um lugar para morar, o que comer, a proteção dos fazendeiros e podido criar os filhos "longe da vadiagem". Elas ilustram a necessidade moral do capital de adestrar o trabalhador, naturalizando a relação social e tornando a situação de submissão irresistível ao sujeito. Marx aponta que, conforme o desenvolvimento do capitalismo, com todos os seus requintes de expropriação e dependência mais a naturalização desses vínculos sociais, as resistências do trabalhador são quebradas:

\begin{abstract}
Não basta que as condições de trabalho apareçam num polo como capital e no outro como pessoas que não têm nada para vender, a não ser sua força de trabalho. Tampouco basta obriga-las a se venderem voluntariamente. No evolver da produção capitalista desenvolve-se uma classe de trabalhadores que, por educação, tradição e hábito, reconhece as exigências desse modo de produção como leis naturais e evidentes por si mesmas. A organização do processo capitalista de produção desenvolvido quebra toda a resistência; a constante geração de uma superpopulação relativa mantém a lei da oferta e da demanda de trabalho e, portanto, o salário, nos trilhos convenientes às necessidades de valorização do capital; a coerção muda exercida pelas relações econômicas sela o domínio do capitalista sobre o trabalhador. A violência extraeconômica, direta, continua, é claro, a ser empregada, mas apenas excepcionalmente. (MARX, 2013, v. 1, p. 808-809).
\end{abstract}

Ao passo que Lica percebia as relações de trabalho e o pagamento pelos serviços do marido como normais - o que expressa a naturalização do dinheiro como quantidade de valor de uso específico autonomizado da mercadoria como equivalente universal -, Maria, na ênfase de seu sofrimento enquanto trabalhadora, transparece melhor a exploração para a coerção ao trabalho por não receber em moeda. O caráter enigmático do dinheiro enquanto mercadoria reside na forma socialmente válida de representação do valor, pois oculta em seu corpo a relação social que o constitui - ou seja, o puro dispêndio de força de trabalho em condição de exploração.

Sem o dinheiro e sua fantasmagoria, o depoimento de Maria Facão sobre os pagamentos em vales explicita o sofrimento em relações claramente desiguais na fazenda, já que o dinheiro mascara e dificulta tal percepção. Além disso, o pagamento em vales e as condições particulares de criação de produtos na Serra do Cabral denotam a região consolidada, prestes a se abrir aos movimentos de autonomização.

A existência regional de relações não capitalistas de produção expressa não só uma forma de reprodução ampliada do capital, mas também a reprodução ampliada das contradições do capitalismo, consoante José de Souza Martins. Esse movimento contraditório não é só de 
subordinação de relações pré-capitalistas, mas também de criação de vínculos antagônicos e subordinados não capitalistas. Nesse caso, o autor adverte que o capitalismo cria a um só tempo tanto as condições da sua expansão, pela incorporação de áreas e populações às relações comerciais, quanto os empecilhos à sua expansão, pela não mercantilização de todos os fatores envolvidos, ausente o trabalho caracteristicamente assalariado (MARTINS, 2004).

Décadas depois, com 11 filhos criados e a mudança na manutenção das fazendas, a geração seguinte dos Facão se viu como força de trabalho liberada para buscar outros postos. Seus filhos e netos hoje ilustram a situação: alguns migraram para cidades maiores ou foram garimpar cristal em terras alheias e os que ficaram sobrevivem do assalariamento do plantio de eucalipto ou da coleta para venda de plantas e frutos ornamentais e medicinais na Serra, como é o caso de Célio. Em janeiro de 2019, conhece-se outro filho seu, Jota, de 56 anos, com mais de 30 passados dentro das fazendas dos Dumont. Na ocasião da conversa, aparentava dividido entre a preocupação e a ansiedade, pois estava procurando serviço para pagar a conta de luz atrasada, enquanto se entusiasmava por tirar seu primeiro RG.

Tais narrativas evidenciam a expropriação da terra como fundamental na relação social que vinha se consolidando na Serra desde muito antes. A partir dos relatos de pessoas que trabalharam nas fazendas, deparou-se com a questão do trabalho livre naquela realidade. Enquanto para uns poucos o pagamento pelo serviço era feito em bezerros e depois em dinheiro, para outros pagava-se com vales e cobrava-se a dívida da família, caso houvesse pendências com o dono.

As relações diferenciadas entre agregados e patrões revelam predileções nas quais não se pretende adensar, mas que não são de hoje. Sobre a quarteação e o trabalho livre de vaqueiro, por exemplo, Pedro Puntoni (2002) argumenta que ambos não eram a norma nas fazendas de gado durante os séculos XVII e XVIII, o que desnaturaliza essa forma de pagamento. A comparação de relações sociais, apesar do hiato do tempo, ajuda a pensar sobre como se realizou a formação da mão de obra disponível na Serra, bem como a transição para o trabalho livre na região, devendo-se dar o devido peso às relações clientelistas e suas particularidades ${ }^{149}$.

As narrativas de Lica, Vanja e Maria desanuviam o momento histórico do processo de autonomização dos fatores de produção. As famílias viviam na terra, expropriadas e trabalhando sem receber salário, mas um vale que garantia o mínimo de consumo de alimentos; elas se

\footnotetext{
149 “Creio, contudo, que esta não era a norma. Posto que a alternativa existisse em teoria, a própria sobrevivência do vaqueiro e de seus ajudantes (por vezes escravos), assim como o trato da boiada, deveriam consumir toda a paga. Ao que se somava o fato de que esta 'liberdade' do trabalho, na situação geral do escravismo, implicava responsabilidades extremadas, motivo pelo qual todos os possíveis prejuízos eram descontados nas costas do vaqueiro" (PUNTONI, 2002, p. 36).
} 
reproduziam ali, de onde nasciam os braços que por coerção extraeconômica geravam riqueza para o dono geração pós geração. A partir do momento em que o assalariamento se insere no contexto, autonomizando a mercadoria força de trabalho do dinheiro, as relações de produção tornam-se independentes umas das outras e os componentes de valor se ossificam em formas autônomas, dificultando a conexão interna desses fatores no processo de produção (MARX, 2013, v. 3).

A história do país mostra que as políticas de terras e de mão de obra andam relacionadas e dependem, por sua vez, dos processos econômicos. Lica, Vanja e Maria exemplificam os laços de compadrio e de favor que suas famílias estabeleciam com os donos das terras. Mesmo essas passagens tendo se dado há mais de 50 anos, elas demonstram relações construídas em gerações passadas que viveram a transição econômica e normativa para o trabalho livre e foram privadas do acesso à propriedade rural para que não lhes restasse outra saída senão o trabalho nas fazendas alheias.

A reprodução dessas famílias formou a mão de obra necessária para o trabalho nas terras na Serra, a se desprender posteriormente para o mercado de trabalho. A violência de privar os sujeitos de alimentação adequada e de acessar a riqueza que geravam esclarece o processo: a criação de gado era uma especialização que os fazendeiros coronéis buscavam e dedicavam ao máximo suas fazendas, o que se manteve até a entrada do planejamento regional, encabeçado pela Sudene, Codevasf e outros órgãos do Estado centralizado.

Outra senhora entrevistada foi Ifigênia de Moura Silva, 78 anos (2018), costureira aposentada, cuja família viveu e trabalhou nas terras de Daniel Dumont. Sua família saiu da beira do Pacuí quando ela tinha 5 anos, indo atrás de serviço pago por dia. Na fazenda onde acabaram se instalando, não se podia sequer plantar feijão, pois todas as terras eram destinadas às mangas para o boi.

Cultivar repolho, criar galinhas e cuidar dos filhos do dono da terra aos 12 anos de idade não eram suficientes para a sobrevida da família, tendo ainda jovem desenvolvido a prática da costura, trabalho que fazia à noite para conseguir o dinheiro que não circulava na fazenda. Logo o fazendeiro lhe comprou uma máquina, a quem Ifigênia pagou aos poucos, roçando manga durante o dia e dobrando o trabalho de costura noite adentro. Mal saldou o débito, perdeu sua ferramenta: com a doença do irmão mais novo e os gastos dos pais, a máquina de costura foi tomada pelo latifundiário como garantia da quitação dos remédios.

$\mathrm{O}$ que se deduz das prosas com essas senhoras, que mal acreditaram no interesse por suas vivências - pois reproduzem inconscientemente que "o valor é o homem" (SCHOLZ, 1992) -, é que na Serra, elas e suas antepassadas já eram duplamente socializadas, porque a 
urgência em alimentar os filhos as impeliam aos cuidados da família e ao trabalho para outrem, sem qualquer vínculo afetivo e/ou remotamente consanguíneo. Às mulheres das camadas inferiores a crise foi uma constante, em que contraditoriamente viviam o papel tradicional de donas de casa e também o de trabalhadoras precoces, porém um labor carente da forma abstrata. Apesar de inseridas em formas não totalmente capitalistas de produção, elas têm um pé fincado na modernidade, pois a dissociação é historicamente construída. O teorema do valordissociação joga luz às vivências apresentadas, porém a complexidade da realidade analisada requer ir além da divisão de gênero como espaço cindido "para fora" da forma mercadoria, incluindo outros espaços exteriores à sociabilidade moderna, como a questão de cor.

\subsection{3. "O sertão que estremece debaixo da gente": o dissociado entre a realidade e a ficção}

Sem dúvida, sabe-se que a ficção tem relativa autonomia em relação à existência sobre a qual ela é inspirada, não havendo por isso um fiel compromisso em abordar a realidade tal como ela é. Na Literatura, o conceito de verossimilhança versa sobre esse dilema.

De acordo com o Houaiss da Língua Portuguesa (2001), verossimilhança significa "negação, nexo ou harmonia entre fatos, ideias etc. numa obra literária, ainda que os elementos imaginosos ou fantásticos sejam determinantes no texto; coerência". Ela se torna essencial para explicar o confronto entre seres humanos de contornos definidos e definitivos, integrados num denso tecido de valores de ordem moral, religiosa, político-social e cognoscitiva, revelando momentos em que a vida empírica não os apresenta de modo tão nítido e coerente, mas tona-se inspiradora para enredos. A personagem de ficção se apresenta como um ponto forte de percepção do indivíduo no espaço em foco, pois seus conflitos traduzem a interação social no seu universo particular (PELISSARO, 2011). No caso deste estudo, o suporte do diário oitocentista da adolescente Helena Morley (2016) e, sobretudo, o enredo ficcional de Grande sertão: veredas induzem a interpretar o sertão contido nessas obras como alegoria do sertão concreto do norte de Minas Gerais.

Assim, de posse tanto das advertências do conceito literário quanto da teoria desenvolvida por Roswitha Scholz (1996), algumas reflexões sobre a conexão entre a ficção e

o território sertanejo foram se desdobrando. É dentro desse contexto histórico que a ficção Grande sertão: veredas penetra as frestas dos documentos e discursos oficiais, para pregar peças no pensamento canônico. A incongruência percebida nos campos e nas ficções indica, ao mesmo tempo, convívio e conflito e pode ser essa a luta da personagem Riobaldo, que 
representa o masculino da forma mercadoria, de jagunço a fazendeiro, tentado a aceitar o bom, o belo e o sensível que jazem em si e em Diadorim, indivíduo transeunte entre o mundo público da valentia e o privado do afeto, que precisa ocultar o feminino para se impor e sobreviver à selvageria dos cabras violentos.

Na modernidade, o amor entre os dois, alheio à convenção social, resultou no sacrifício de Diadorim, ou Maria Deodorina da Fé Bettancourt Marins, dado que amor em guerra de vingança e fora das formas padronizadas pelo patriarcado produtor de mercadorias não poderia se consumar. Mesmo não realizado, esse afeto insiste em se fazer presente, dando amostras de que "a vida é muito discordada" (ROSA, 1986, p. 445). A riqueza da trama aponta para tensões existenciais em que a totalização do valor não consegue exercer seu poder integral, perceptível pelos questionamentos de Riobaldo ao longo de toda a obra, nas frestas da sua condição de jagunço quando reflete sobre "a matéria vertente"150.

Paralelo ao enredo do amor vedado, se desdobram as lutas pelo poder na dicotomia traiçoeira de civilização e barbárie. Se o sertão já é concebido como um paradoxo do moderno, é com a centralização do Estado e os processos de autonomização dos fatores de produção chegando e alterando as sociabilidades, presas ao capital e, ao mesmo tempo, marginais a ele, que os poderes "invisíveis" lutam para que desapareça. O sertão norte mineiro se apresenta, na sua particularidade, como uma alegoria dos territórios tomados pela lógica da mercadoria.

Após o fazendeiro modernizador Zé Bebelo atravessar o caminho do introspectivo professor Riobaldo, algo muda. O jovem pobre e letrado se torna a lagarta Tatarana, que, no decorrer do enredo, se identifica como jagunço e exerce essa função como sobrevivência e em nome dos interesses de fazendeiros. Sua atividade é garantir pela violência o poder desses coronéis. Ao mesmo tempo, a personagem se reconhece sujeito provisório, não branco e ilusoriamente livre nos seus desejos.

A metamorfose maior se dá no pós-pacto com o Demônio, pois Tatarana se converte no chefe de bando Urutu Branco, depois rendido à ascensão social com casamento arranjado. Porém, após ser aceito entre os homens de terras e arregimentar seus agregados, lembra melancolicamente sua vida na beira do rio, cuja correnteza segue levando os destinos. $\mathrm{O}$ narrador naturaliza ou não a trajetória?

\footnotetext{
150 “Eu queria decifrar as coisas que são importantes. E estou contando não é uma vida de sertanejo, seja se for jagunço, mas a matéria vertente. Queria entender do medo e da coragem, e da gã que empurra a gente para fazer tantos atos, dar corpo ao suceder. O que induz a gente para más ações estranhas é que a gente está pertinho do que é nosso, por direito, e não sabe, não sabe, não sabe!” (ROSA, 1986, p. 83-84).
} 
Com base em Michael Taussig (2010) e seus levantamentos antropológicos, o pacto com o Demônio surge nas comunidades tradicionais na América do Sul a partir do processo de colonização, apenas os homens recorrendo a ele. Talvez o façam por absorver nas colônias o padrão abstrato de homem branco ocidental que lhes foi imposto, mimetizando à sua maneira as relações do centro, lançados que são ao sistema produtor de mercadorias.

Como mero jagunço e chefe de bando, o protagonista estaria, ao mesmo tempo, presente na esfera masculina do mercado enquanto homem que vai à guerra, mas também nas suas margens, haja visto que se submete em boa parte do enredo ao homem abstrato portador de terra, trabalho e capital. A mimese que os homens subjugados à forma social realizam para se sentirem integrantes da totalidade do valor levou Riobaldo, na sua identidade masculina, ao pacto com o Diabo, não apenas para ascender socialmente, mas também para expurgar o afeto conflituoso por um de seus pares.

O protagonista se rendeu à imposição do valor valendo-se de suas limitadas ações para integrar o mundo dos senhores, mas também sacrificou aquilo que escapa à produção e tange os desejos, castrado pelas normas da territorialização no sertão, que naquele contexto não admitiam as transgressões à ordem da mercadoria. Para ascender socialmente, recorreu ao Diabo. Tornou-se barranqueiro, se reintegrando a esse mundo em nova posição.

Conectando a ficção e a realidade pelo território em comum, o sertão e suas metamorfoses se dão a cada demanda ocasionada pelas mudanças das forças produtivas do capital. A urgência da modernização, que se repõe a cada momento histórico, recria o sertão como território estéril e arisco ao valor. A ideologia como ferramenta nega a historicidade e, na contradição em processo, o capital se impõe sobre um território temporalmente já imiscuído pelas relações de valor-dissociação. As incongruências do capital, que querem acabar com o sertão, o recriam para dinamizar seu colapso. Não à toa, Riobaldo transcorre toda a obra dizendo o que esse território é e não é, sem dar conclusão satisfatória. "O sertão é isto: o senhor empurra para trás, mas de repente ele volta a rodear o senhor dos lados" (ROSA, 1986, p. 249).

O contexto de vivência do autor, João Guimarães Rosa, e de publicação da obra, imerso em um sentimento de que finalmente o país se desprovincianizava via nacionaldesenvolvimentismo com suposto pacto de conciliação entre as classes, foi sabotado com a imposição dos rearranjos tecnológicos do capital dos países centrais. O horizonte do desenvolvimento e o turbocapitalismo iniciaram a atrofia da imaginação e do lúdico, extinguindo o universo rico de palavras que o sertanejo inventa para traduzir o que vive, sendo Riobaldo alegoria do resíduo desse movimento. 
Conforme apresenta Roberto Schwarz (1999), o golpe de Estado de 1964 acelerou o processo de desintegração social e as desilusões nacionais - tanto que hoje se fala em golpe civil-militar, em que implicitamente se compreende que não houve pacto conciliatório algum. Para que Riobaldo ascendesse socialmente, teve que ceder ao pacto com o Diabo, o negociante e intermediário dos desejos no sertão purgatório. Elevado à posição aspirada, termina os dias ciente de que nem pacto, nem Diabo há, "mas homem humano"151. Em sociedade forjada no sentido da colonização construtor do capitalismo metropolitano, não há conciliações, porque no mundo da mercadoria, é impossível unir o que já nasce dissociado. Por isso, a morte de Diadorim; por isso, a infelicidade de Riobaldo.

Apesar da resignação da personagem, "siô Baldo" reconhece que "o sertão está movimentante a todo-tempo" (ROSA, 1986, p. 456). Ele permanece na sua metamorfose constante. É essa incongruência entre moderno e atrasado, capitalista e refratário, típica dos opostos binários do mundo racional ilustrado, que instiga todo o debate sobre o que é o Brasil, onde tudo parece estar positivamente em formação, inclusive estando o país na composição do capitalismo europeu e o sertão na constituição do capitalismo mundial. A Serra do Cabral integra tudo isso, no dinamismo da reterritorialização.

151 “Amável o senhor me ouviu, minha ideia confirmou: que o Diabo não existe. Pois não? O senhor é um homem soberano, circunspecto. Amigos somos. Nonada. O diabo não há! É o que digo, se for... existe é homem humano. Travessia." (ROSA, 1986, p. 538). 


\title{
4. O garimpo de diamante, "a mais preciosa das inutilidades"152
}

\author{
O que vocês diriam dessa coisa que não dá mais pé \\ O que vocês fariam pra sair dessa maré \\ O que era sonho vira terra \\ Quem vai ser o primeiro a me responder \\ Sair dessa cidade, ter a vida onde ela é \\ Subir novas montanhas, diamantes procurar \\ No fim da estrada e da poeira \\ Um rio com seus frutos me alimentar \\ O que vocês diriam dessa coisa que não dá mais pé? \\ O que vocês fariam pra sair dessa maré \\ O que era terra vira pedra \\ Quem vai ser o segundo a me responder \\ Beber minha cerveja numa ilha com minha mulher \\ Tirar todas as roupas e esperar o sol nascer \\ Respirar as formas da pureza \\ Aos ventos e às águas quero me entregar \\ O que vocês diriam dessa coisa que não dá mais pé? \\ O que vocês fariam pra sair dessa maré \\ O que era pedra vira corpo \\ Quem vai ser o terceiro a me responder \\ Andar por avenidas enfrentando o que não dá mais pé? \\ Juntar todas as forças pra vencer essa maré \\ O que era pedra vira homem \\ E um homem é mais sólido que a maré
}

Fernando Brant, $1972^{153}$

Mostrou-se como a pecuária extensiva abriu os caminhos para que a mineração penetrasse o sertão mineiro, estabelecendo ao longo do tempo uma relação subsidiária da primeira com a segunda, tendo a ação bandeirante seu protagonismo na historiografia sobre o tema ${ }^{154}$. Apesar de o registro oficial de achados diamantíferos na Serra do Cabral datar do século XIX, a presença de fazendas de gado já no século XVII preparava o terreno para sustentar a atividade. Não à toa, suspeita-se da inexistência da Serra nos mapas setecentistas, período de maior rigidez sobre o garimpo, mesmo sendo o caminho do gado corrente ali.

\footnotetext{
152 "O diamante é para mim a mais preciosa das inutilidades." (GORCEIX, 1977, p. 266).

153 "Saídas e bandeiras n ${ }^{\circ} .2$ ", Clube da esquina. Canção integrante do disco que comporia a obra do movimento Clube da Esquina, iniciado em 1972. Analisado por Tales Ab'Sáber como expressão de desencanto diante do fracasso do desenvolvimentismo associado à ditadura militar, denotando a imposição do capital global que abre a região e, sintonizado com o sentimento de Claro enigma, de Carlos Drummond de Andrade, expressa a melancolia e a frustração com o futuro (AB'SÁBER, 2017).

154 “Posteriormente à instalação das primeiras empresas comerciais - voltadas para o plantio de cana-de-açúcar e para a construção de engenhos - que não se desenvolveram muito devido à concorrência desvantajosa com a produção do Nordeste (que contava com melhores terras e se localizava a menor distância dos portos europeus), os colonos de São Vicente lançar-se-iam ao interior em função de outras empresas que viriam a sustentar a territorialização do que representava o sertão, tanto da Bahia como de São Vicente. Empreendimentos tais quais a agricultura, a implantação da fazenda pecuária no sertão, o prosseguimento da pesquisa mineral e a disputa pelo controle dos indígenas, estabelecida entre colonizadores e jesuítas, da qual resultou o tráfico e a catequização de nativos." (LEITE, 2010, p. 53).
} 
Com o discutível ocaso da mineração, a situação se inverte, sendo a atividade de procurar pedras, reduzida à faiscação, dependente da territorialização promovida pelas fazendas de gado, cada vez mais especializadas na produção dessa mercadoria. Tal dependência se verifica não apenas no pagamento de porcentagem do diamante do garimpeiro ao latifundiário como tributo, como também nos gêneros produzidos pela lavoura no mercado interno, que garantem a reprodução do garimpo.

Apresentado o vínculo entre as duas atividades, cabe assinalar de antemão que tal relação é parte do processo de territorialização. As economias subsidiárias mobilizaram trabalho, terra e cabedais, que permitem reproduzir o trabalhador, seja ele escravizado ou livre, para garantir o sistema produtor de mercadorias no sentido da colonização (e da colonização sistemática). A modernização que se desdobra desse movimento se faz, com isso, motor de apropriação territorial no sertão.

Entendendo-se a mineração como mais um processo de territorialização colonial, passase então a discutir a particularidade do garimpo diamantífero na Serra do Cabral como mais um incremento da produção de mercadoria e de sua objetividade social fantasmagórica do valor, cuja existência permanece nos dias de hoje.

\subsection{Saídas e bandeiras e as descobertas: de bandeirante a garimpeiro e os vadios}

Se inicialmente Portugal não dava a devida atenção à mineração, foi com a União Ibérica (1580-1640) que a Coroa Espanhola, já temerosa do declínio das minas de prata a oeste de Tordesilhas, estimulou as entradas com o objetivo de achar metais no interior da vasta Colônia. Com a Restauração e o consequente endividamento português, o estímulo à procura de jazidas prosseguiu. De acordo com Helion Póvoa Neto (1998), apenas a partir de fins dos Quinhentos que passou a existir uma conexão forte entre a política de incentivo às descobertas e as iniciativas concretas de prospecção e exploração.

O ano de descobrimentos minerais na Colônia ainda é controverso, não havendo consenso entre cronistas e autores sobre datas, tanto oficiais quanto não oficiais, apesar da aceitação de ter sido em fins dos Seiscentos. Também não há concórdia sobre quem de fato fez as descobertas: Antonil defendia o encontro das pedras por um mulato, enquanto Sérgio Buarque de Holanda suspeitava de indígenas. O que há em comum entre essas abordagens é o préstimo do achado ter na sua dianteira sujeitos nas posições mais débeis da sociedade colonial, consonante com o trabalho de garimpar entre homens livres pobres, conforme se verá: enquanto uns fugiam do cativeiro, outros fugiam do fisco. 
A data oficial de notificação à Coroa sobre os achados foi posterior à elevação do arraial principal do norte mineiro ao patamar de vila, sob o nome de Vila do Príncipe, em 1714. Em torno desse período, algumas pessoas de discernimento na mineralogia pela primeira vez identificaram diamantes pelo o que eles realmente eram, resistindo o quanto puderam a informar oficialmente a sua existência. Enquanto foi possível, o garimpo correu solto, e somente em 1729 o poder real passou a ter conhecimento da existência abundante das pedras em seu território colonial $^{155}$.

A relutância em tornar pública a boa nova se deve, provavelmente, à resistência dos descobridores - a princípio paulistas - em comunicar os achados e, ao tornar a notícia oficial, serem esses pioneiros impedidos de continuar as expedições particulares - dado o interesse reinol em controlar exclusivamente para si a exploração -, além da possível instauração da fiscalização e das cobranças. Embora outros critérios reconhecessem a prioridade do descobridor em explorar a lavra, a regularização das datas acabava por exigir a doação de propinas às autoridades que controlavam o regime de concessão.

Somando-se a isso os obstáculos de tipo técnico que embaraçavam a extração, era praticamente impossível ao pobre possuir uma lavra legalizada: as jazidas descobertas tinham de ser comunicadas às autoridades competentes, que realizavam a demarcação dos terrenos auríferos e das datas. A estas últimas correspondiam os lotes distribuídos aos mineradores, cuja escolha era permitida ao descobridor, em primeiro lugar, seguido da Fazenda Real, que separava uma data para si e a vendia posteriormente. As demais eram atribuídas aos concorrentes, de acordo com o número de escravos, sendo 2 1 1/2 braças para cada escravo, até o máximo de 30 braças (LEITE, 2010).

\footnotetext{
155 “Aquelas pedras tinham sido revolvidas em grandes quantidades pelos mineiros e seus escravos, ao lavarem o cascalho do leito dos rios, em busca de ouro, mas pensavam êles tratar-se apenas de um certo tipo de cristal. Usavam-se como fichas e marcadores de pontos nos jogos de cartas, e por muitos anos passaram elas, livremente, de uma mão para outra. Quando alguém - a tradição difere quanto se foi um frade ou um juiz - que estivera na Índia, finalmente reconheceu sua natureza real, a descoberta foi mantida em segrêdo por aquêle homem e seus comparsas, que, muito caladamente, garantiram para êles próprios o mais que puderam, sem levantar suspeitas. Em 1726, algumas dessas pedras foram ter às mãos de Dom Lourenço de Almeida, então governador de Minas Gerais. Também êle fingiu não saber de que se tratava, embora as tivesse identificado imediatamente, pois se tornara um conhecedor de tais gemas durante sua longa residência em Goa, centro do comércio de diamantes. Dom Lourenço também reuniu quantos diamantes pôde, junto dos desprevenidos mineiros, mas alguém em Vila Rica logo descobriu o jôgo. Turbas de aventureiros, com seus escravos, passaram da lavagem do ouro para a de diamantes, penetrando nas partes mas remotas do Sêrro do Frio. Dom Lourenço que não tinha agora outra alternativa senão relatar à Coroa o que se estava passando, o que fêz nas palavras hàbilmente compostas de seu despacho de 22 de julho de 1729. [...] Respondendo em 8 de fevereiro de 1730, a Coroa censurava severamente Dom Lourenço por não ter comunicado mais cedo a descoberta, pois que diamantes estavam chegando regularmente do Brasil, trazidos por passageiros, a bordo das frotas, havia dois anos já." (BOXER, 1969, p. 223224).
} 
Com estada no Tejuco e circulando pelas adjacências entre 1817 e 1820, Spix e Martius (1981) afirmam que já havia fraude na extração no Distrito Diamantino, cujos diamantes foram descobertos, segundo os autores, por volta de 1710: só se podia trabalhar com 600 escravos, mas trabalhava-se com mais; só o contratador, com dez mil. Ou seja, corrobora-se que era muito difícil para o pobre conseguir uma lavra legalizada, dada a concorrência com os homens de cabedal. Helion Póvoa Neto (1998) acrescenta que a partir do Regimento de 1702, como estímulo a novos achados, os descobridores de minas deviam ser em tudo favorecidos; para os demais, que manifestavam interesse em minerar, o desempate sobre a concessão de datas tinha como critério o número de escravos, o que não só mantinha a instituição do escravismo, como também favorecia determinados segmentos sociais.

Assim, sem a data precisa das descobertas, depara-se na corografia com a realidade da mineração já acontecendo:

Essa Capitania toda é povoada de mineiros, roceiros, negociantes e oficiais de diferentes ofícios. Os mineiros são os que dão mais utilidade ao Príncipe, no quinto que recebe do ouro, ainda que estes são presentemente os mais pensionados, pelas grandes despesas que fazem em escravos, ferro, aço e pólvora, tudo indispensável para a laboriação das suas feitorias.

$[\ldots]$

Os roceiros se ocupam na cultura das plantas nas suas roças, pagando dízimos de todos os frutos que colhem nelas, dos quais também percebe Sua Majestade avultada utilidade, cujo contrato foi (ar)rematado por tempo de seis anos e cinco meses, que principiaram em $1^{\circ}$ de agosto de 1777 , por $397.778 \$ 958$ rs. Os mais povos cada um dá utilidade conforme o uso do seu viver, ainda que entre estes há muitos vadios, sem o exercício de qualidade alguma, o que não aconteceria se não houvesse tanta abundância de víveres nas Minas e a liberalidade que há nos habitantes delas, em darem de comer a todos aqueles que a horas o procuram. (ROCHA, 1995, p. 163, grifos nossos).

O excerto citado, redigido em fins do século XVIII, dá uma pequena demonstração da quantidade de habitantes e da complexidade de suas funções em relação à capitania como um todo. Nota-se, em especial, o termo "vadio". O difícil acesso do livre pobre à exploração de uma lavra corroborava para que esses sujeitos fossem desclassificados socialmente, o que não significa que tivessem sido inúteis àquela sociedade ${ }^{156}$.

Também empregado por Antonil no texto "Cultura e opulência pelas minas do ouro", o termo "vadio" tem peso, servindo para mostrar a "mistura" de gente de todo tipo. Em Formação do Brasil contemporâneo, Caio Prado Júnior menciona a formação de uma "camada intermediária" e "inorgânica", investigada posteriormente por Laura de Mello e Souza, que os

\footnotetext{
156 "Negação do trabalho, trabalharam. Negação da revolta, revoltaram-se com frequência [...]. Negação da Ordem, embrenharam-se pelos matos no encalço de quilombolas e de índios bravos. Camada fluida, indefinida, fugidia, imprecisa, espalhou contudo os seus borrões no seio de uma sociedade estamental e, espraiando-lhe os contornos, só nela pôde existir." (SOUZA, 2004, p. 90).
} 
encaixa no grupo dos "desclassificados socialmente". São sujeitos livres, sobretudo de cabedais, a exercerem tarefas indefinidas, periféricas ou ilegais. São esses mesmos vadios que, conforme apresenta Joaquim Felício dos Santos em suas Memorias sobre o Districto Diamantino, foram expulsos da demarcação em 1757, impelidos a vagarem pelos sertões.

Conforme já abordado, o monopólio da terra naquelas condições se apresentava como mecanismo de subordinação do trabalho àqueles que não podiam ter acesso à mesma, pois, voltada para a produção de gêneros cuja comercialização favorecesse o máximo de acumulação do capital nos centros hegemônicos europeus, esses sujeitos desclassificados na verdade eram inseridos na sociedade mesmo que de forma frágil. Eram usados, sob a violência das autoridades, para trabalhos de utilidade pública ou não confiados aos escravos. Ou, ainda, engrossavam as atividades clandestinas e mesmo aquelas que, dos bastidores, davam sustento à reprodução social da mineração, seja nas funções de produzir alimentos que abasteciam as zonas extrativas, seja nos pequenos serviços prestados à sociedade - cabendo mais uma vez pensar até que ponto eles eram sujeitos sem razão de ser. Foram forjados na sociedade mineradora de forma sui generis, úteis às economias subsidiárias à grande produção de exportação, mais tarde também autonomizados ${ }^{157}$.

Deve-se lembrar, conforme notado por Capistrano de Abreu (1998), que a existência da mineração em Minas Gerais foi antecedida pela instalação de fazendas de gado oriundas da atividade bandeirante. As fazendas seriam uma espécie de frente pioneira na expansão territorial do sertão, possibilitando a ocupação com fins econômicos. Nos mapas analisados, os arredores da Serra já apresentavam fazendas como pontos de pouso para o caminho do gado que margeava o rio São Francisco, com destaque para as mais mencionadas como São Lamberto, Cipó, Santa Engrácia e Caraíbas.

Para Carlos Toledo (2008), a existência de minérios cobiçados - neste caso, o diamante -, desencadeia uma mudança de sentido no processo de caracterização da área, cuja historicidade permite romper com distinções abstratas. Essa caracterização, baseada em um novo produto a ser gerado, dá pistas para a diferenciação de áreas como processo de formação, o que envolve personagens e interesses em nome desta composição ${ }^{158}$. A dinâmica da

\footnotetext{
157 “Ainda que assinalemos a importância determinante do sistema colonial no processo de acumulação fundada no trabalho cativo nas colônias, o emprego do trabalho escravo acabou por criar condições sui generis de inserção dos homens livres (e pobres) na sociedade colonial. Entretanto, esses homens livres e pobres que não foram apenas desclassificados do ouro, mas de toda uma ordem escravocrata, acabaram por encontrar espaço em atividades subsidiárias à grande produção de exportação, que depois se autonomizaram, constituindo elas próprias novos setores da produção de mercadorias." (LEITE, 2010, p. 131).

158 "A base para que o processo de diferenciação de áreas se dê a partir da forma mercadoria é um processo de territorialização, no sentido da definição de quem personifica a terra, e de que forma o capital e o trabalho são
} 
descoberta diamantina no interior da região pecuária, criou um processo social que fez com que elementos definidos historicamente, a princípio desconhecidos ou secundários, ganhassem centralidade. Esse movimento não foi isento de conflitos, gerando disputas territoriais entre os grandes empreendimentos capitalizados e os expropriados - o que sugere considerá-lo como parte dos interesses em manter o garimpo uma atividade clandestina.

Aos livres pobres, diante da necessidade de sobrevivência, havia um intercâmbio entre o trabalho nas fazendas e o garimpo, na sua maioria ilegal. Essa situação já aparece no século XVIII no norte de Minas Gerais ${ }^{159}$, mais especificamente na serra de Grão Mogol, sendo o garimpo uma alternativa à lavoura quando esta não rendia o mínimo necessário.

\begin{abstract}
Outro aspecto importante para a instalação rápida de grandes contingentes na Serra ao que parece também menosprezado pelas autoridades portuguesas neste caso e em outras áreas, era a existência de fazendas formadas desde o final do século XVII nos arraiais e povoados à sua volta, como a de Itacambira e a do Brejo das Almas (hoje, Francisco Sá). Essas populações passavam naquele momento por um processo de perda de alguns de seus mercados tradicionais nas minas, pela substituição de seus produtos agrícolas e, principalmente, pecuários por outros das áreas mais próximas. Os próprios militares, ao começarem a se instalar na Serra, já chamavam atenção para isso, "[...] em distância de uma ou duas léguas e pouco mais da mesma Serra há várias fazendas, que se não cultivam por não terem saída os gêneros”. (APM, fl. 206 apud PARRELA, 2009, p. 31-32).
\end{abstract}

A presença de muitas fazendas no norte mineiro aponta para uma diferença em relação ao sul da capitania, onde se minerava ouro anteriormente. Enquanto nesta "não se pode crer o que padeceram a princípio os mineiros por falta de mantimentos, achando-se não poucos mortos com uma espiga de milho na mão, sem terem outro sustento" (ANTONIL, 2007, p. 234), naquela a existência de produtos agropecuários se fez por já haver anteriormente uma formação econômica em torno do boi, cujas fazendas precisavam produzir outros gêneros para se reproduzirem, dada a distância do litoral e das cidades maiores. Ou seja, pecuária e garimpo coexistiram no norte mineiro, uma dando suporte ao outro, desde o século XVIII.

De acordo com Caio Prado Júnior (2006), a mineração diamantina era extremamente rígida e proibida fora da Demarcação. Ivana Parrela (2009) analisa como a mineração clandestina de diamantes persistiu em uma região particular do norte de Minas Gerais durante a administração colonial, gerando a violência como forma de resistência e embate ao poder colonizador, já que era feita fora dos limites da Demarcação. A existência de fazendas

mobilizados no processo. A violência usada ou não no cotidiano da valorização de capital, pelo poder público ou privado, é territorialmente condicionada." (TOLEDO, 2008, p. 16-17).

${ }^{159}$ Não só no século XVIII, como mais além. Joaquim Felício dos Santos, apesar de a princípio defender que o garimpeiro só vivia do trabalho do garimpo, no final das suas memórias cede ao fato de que "á mineração ajuntárão a agricultura" (SANTOS, 1868, p. 436). 
fornecedoras de víveres daria sustento à atividade ilegal, consolidando o território da pecuária e, a partir de então, também do garimpo.

Helion Póvoa Neto, cuja tese de doutorado discute o garimpo e sua mobilidade no Centro-Oeste, das descobertas até o ocaso dos Novecentos, resgata a discussão referente aos Setecentos mineiros para mostrar o surgimento do garimpeiro como personagem histórica, apesar de o registro do conceito aparecer apenas em fins do mesmo século, quando emergia a territorialização do controle sobre as áreas diamantíferas. Para ele, a existência do garimpeiro não decorria apenas de um processo seletivo imposto pelas condições de produção, "mas sobretudo do rigor da legislação, da arbitrariedade na sua aplicação, da injustiça reinante" (PÓVOA NETO, 1998, p. 54). Cabe acrescentar que o Distrito Diamantino foi criado em 1740, pensando no controle do garimpo e do contrabando, além de garantir a alta do preço da pedra no mercado $^{160}$.

As autoridades coloniais discutiam a famigerada atividade, distinguindo o extraviador do garimpeiro, sendo o primeiro aquele que, tendo uma atividade regular lícita, foi pego evadindo ouro, pedras preciosas ou impostos, o segundo refere-se àqueles homens que fazem da extração clandestina seu meio de vida, colocando-se como marginais ao sistema e vivendo fora do convívio social regular (FURTADO apud COUTO, 1994).

Para Joaquim Felício dos Santos e muitos memorialistas dos séculos XIX e XX, o garimpo na sua origem era a mineração clandestina do diamante. $\mathrm{O}$ garimpeiro muitas vezes tornava-se "aquelle que obrigado a expatriar-se ou a passar uma vida de miserias, porque com a prohibição da mineração se lhe tirava o unico meio de subsistencia, ia exercer uma industria, a mineração clandestina, que julgava um direito seu" (SANTOS, 1868, p. 68), injustamente

\footnotetext{
${ }^{160}$ Em viagem pelo Brasil entre 1807 e 1811, o britânico John Mawe observa que a descoberta dos diamantes no Serro do Frio deixou marcas no comércio das pedras: "os diamantes do Brasil foram importados de forma considerável, o que provocou uma apreensão geral entre os comerciantes que estavam preocupados com uma grande deterioração no preço das pedras" (RODRIGUES, 2014, p. 36). Segundo o naturalista britânico, chegouse a mentir no Velho Mundo que os diamantes fossem de origem indiana, para que pudessem ter mercado garantido (SANTOS, 1868). Em 1751, o joalheiro inglês David Jeffries publicou a segunda edição de $A$ treatise on diamonds and pearls, reservando um capítulo especialmente aos diamantes do Brasil, no qual escreveu sobre a desvalorização das pedras brasileiras:
}

No ano de 1733 , os diamantes brutos não valiam nem vinte shillings por quilate; no ano de 1735 , não valiam trinta shillings; no ano de 1742 , não valiam mais de trinta shillings por quilate [...] toda essa desvalorização foi provocada claramente pelas grandes quantidades de vendas públicas de diamantes feitas nos anos mencionados. (MAWE apud RODRIGUES, 2014, p. 3637).

Essa situação levou o Estado português a pôr em prática efetiva o seu absolutismo monárquico; Charles Boxer está entre os historiadores que mais enfatizam a ideia do Distrito como lugar cercado e controlado pela metrópole, acentuando ainda mais "o isolamento do Distrito Diamantino", tornando-o "uma colônia dentro de outra colônia (BOXER, 1969, p. 196). 
usurpado, o que lhe dava uma característica positiva. Já Spix traz uma definição bem mais pejorativa:

\begin{abstract}
Essa gente revolve o cascalho dos rios e regatos nas mais remotas partes do Distrito, ou roubam, durante a noite, os serviços do rei, nos lugares onde o cascalho já está preparado para ser lavado. Não raro são até escravos fugidos que vivem escondidos nos penhascos e cavernas da montanha de difícil acesso, e dali saem a praticar toda sorte de furtos. Todavia, parece que nos serviços da Junta Diamantina é necessária a máxima vigilância [...] (SPIX, 1981, p. 34).
\end{abstract}

Por ser atividade quase sempre clandestina, entende-se por que os mapas aqui analisados não mencionam o garimpo entre as ocupações econômicas na Serra - apesar de alguns dos inventários já se situarem após o fim do Regimento, nem mesmo eles fazem alusão à função. Discorrendo sobre a origem da atividade e sua etimologia, Helion Póvoa Neto aponta que ao longo dos Setecentos, seja apenas um trabalhando por conta própria ou um número pequeno a mando de um senhor, aos livres pobres era aceitável minerar na sombra das extrações de grande vulto. Apesar de ser um ofício tolerável pelas autoridades coloniais, era desvalorizado por ser associado à condição escrava. A este trabalho, acessível aos livres pobres, dava-se o nome de faiscação, referindo-se ao brilho do ouro que atrai o olhar nos riachos de pequena profundidade. A faiscação era ocupação sobretudo de livres pobres ${ }^{161}$.

Ainda para Helion Póvoa Neto, o termo "faiscador" antecede "garimpeiro". Apesar de ambos terem o mesmo significado atualmente, o segundo vocábulo sofreu maior estigma social. Etimologicamente, garimpar é palavra tributária de grimpar: “[...] antepositivo, prov. do fr. grimper, 'trepar, subir, elevar-se com o auxílio das mãos e dos pés, estender-se progressivamente para cima"” (HOUAISS apud JERÔNIMO; DE PAULA, 2013, p. 71), sendo a grimpa, para Aurélio Buarque de Holanda Ferreira, o "ponto alto, cocoruto, crista" (PÓVOA NETO, 1998, p. 67). Ou seja, sujeito que sobe as serras para buscar aquilo que procura, também passível de ser interpretado como aquele que foge ou se esquiva de algo ou se mostra soberbo ou insubmisso.

Helion Póvoa Neto (1998) argui que a palavra “garimpeiro” é um neologismo de origem brasileira, surgido no século XVIII para se referir à situação ilegal e à mobilidade espacial dos

\footnotetext{
${ }^{161}$ Em 1773, o Distrito Diamantino, e provavelmente o norte da capitania como um todo, padeceu de longo período de estiagem seguido de chuvas torrenciais, o que arruinou muitas roças e elevou o preço dos alimentos. Aos homens livres pobres, já impedidos de trabalhar nos limites da demarcação, restou a procura por catas sertão adentro, conforme conta Joaquim Felício dos Santos:
}

O povo tirava recursos das faisqueiras, unica mineração ao alcance da classe mais pobre, e continuavão ellas prohibidas. Resultou que por não terem onde trabalhar, para evitarem a miseria, muitos se embrenhárão pelas serras, e fôrão correr a vida arriscada e aventureira do garimpo, apesar dos rigores das penas á que se sujeitavão. (SANTOS, 1868, p. 174). 
trabalhadores que, refratários ao esquema produtivo polarizado entre senhor e escravo, mineravam por conta própria em áreas rigorosamente interditadas para tal. Vistos como afronta às políticas oficiais, desrespeitavam não só as limitações régias alusivas tanto a áreas de lavra quanto a procedimentos previstos para comercialização e tributação, pois como eram pobres, precisavam sobreviver. Assim, explica-se a hostilidade dos governos no tocante aos garimpeiros, que ainda desafiavam também a pretensão de controle absoluto sobre territórios tidos como estratégicos para a ordem colonial.

Encarado como um incômodo às autoridades reinóis, o garimpeiro aparecia como um estranho à ordem escravista, posto que sua atividade clandestina criava tensão com o governo justamente porque escapava ao domínio colonial: seria ele um dos primeiros exemplos de trabalhadores que se deslocavam voluntariamente no espaço em função do seu ofício (TOLEDO, 2001).

Em estudo sobre a Chapada Diamantina, Carlos de Almeida Toledo (2008) salienta que a mobilidade garimpeira é uma dinâmica surgida no período colonial, formadora da região e em constante tensão com ela, ou seja, útil à Coroa na ampliação dos domínios coloniais, porém arredia à ordem reinol. $\mathrm{O}$ alto valor dos diamantes mobilizava os mineradores clandestinos na busca de novas áreas de extração, às escondidas das autoridades, o que, mesmo que à revelia do poder colonial, promovia a territorialização pela expansão sobre o interior. Seriam estes os sujeitos desclassificados socialmente, em trânsito pelos sertões desde o século XVIII.

Um exemplo da situação é a Carta Régia de 1731. Ela determina a suspensão dos trabalhos e a expulsão de todos os mineiros das áreas diamantíferas, até os moradores do local. Mesmo com o abrandamento das medidas, determinou-se ainda que "mulatos e negros forros e vadios" deveriam ser presos e expulsos da capitania ou forçados a trabalhar na cultura das terras, na mineração e nos ofícios mecânicos.

Apesar da rigidez, a produção de diamantes seguiu sem controle, a ponto de provocar queda no preço das pedras no mercado europeu no prelúdio da exploração. Em 1732 e 1733, visando reverter a situação, o governador ordenou a expulsão de todos os negros e mulatos da comarca do Serro Frio, bem como a proibição da compra e venda de diamantes fora do arraial do Tijuco e o bloqueio ao funcionamento noturno de tavernas e ao ingresso no distrito de "vagabundos e mendigos" e mulheres tidas como devassas. Também se passou a cobrar uma taxa de capitação por escravo empregado nas minas. Em 1771, com o intuito de evitar o contrabando, o Regimento Diamantino passou a excluir até os contratadores, tendo apenas a Coroa permissão de extrair as pedras (PÓVOA NETO, 1998). 
Esse deslocamento voluntário só seria possível a essas pessoas na condição de sujeitos, livres e expropriados (incluindo os forros). Apesar do rótulo de vadios ou desclassificados, realizavam não só a tarefa necessária para a sua reprodução, mas o trabalho produtivo, ou seja, que valoriza o capital. "A classe dos mineiros, em geral” era, na acepção de Joaquim Felício dos Santos, "pobre e [com] falta de recursos, só trabalhava para enriquecer a real fazenda, dar interesse aos commerciantes, sem nunca poder arranjar um peculio, acumular um capital" (SANTOS, 1868, p. 283).

Nas particularidades regionais que a colonização tropical engendrou - tendo em vista que a sociedade colonial ainda não apresentava seus pressupostos bem formados -, os garimpeiros já se inseriam nas relações sociais mediadas por coisas - a lembrar que o diamante é, segundo Gorceix (1977), a mais preciosa das inutilidades, cambiável por valores de uso necessários à sobrevivência, não produzidos pelos garimpeiros. A função ilícita que esses homens executavam contribuiu para desenvolver um conjunto de atividades econômicas ligado à mineração, como os setores de serviços, comercial e agropecuário, circulando mercadorias.

O garimpo, atividade exercida também como alternativa de sobrevivência em uma sociedade restrita a funcionários públicos burocratas e escravos alugados, apesar de permitido sob a sombra dos grandes empreendimentos, não deixou de ser perseguido e estigmatizado, tendo sido alvo constante da administração colonial. De maneira a permitir a comercialização do diamante obtido, montou-se em torno dos garimpeiros uma rede paralela e especializada de circulação de mercadorias afins.

O "capangueiro" era quem lhe comprava o produto às escondidas, repassando os diamantes, posteriormente, na rede de comércio mais ampla. $\mathrm{O}$ "cachaceiro" comercializava cachaça nas lavras, mas era constantemente acusado de promover o contrabando de pedras. $\mathrm{O}$ quilombola se articulava, por vezes, com os grupos de garimpeiros escondidos nas serras, vendendo-lhes mantimentos - que também não podiam comerciar legalmente, visto que se encontravam na condição de foragidos (SOUZA, 2004 apud LEITE, 2010) ${ }^{162}$. Por trás de toda essa rede clandestina, havia algumas autoridades coloniais no contrabando das pedras, pois, como explica Fernando Novais (2001), esse tipo de atuação envolvendo corrupção e desvios era um processo que operava dentro do sistema, não o negando - daí a contradição em conflito:

\footnotetext{
${ }^{162}$ Helion Póvoa Neto comenta que os quilombos parecem inclusive ter sido atuantes na descoberta de ocorrências minerais, o que levou estudiosos do tema a falar em "quilombolas... desbravadores do interior e descobridores de novos veios auríferos" (PÓVOA NETO, 1998, p. 21), perseguidos pelos portugueses que organizavam bandeiras exclusivamente para assumir o controle de tais minas.
} 
seriam mesmo os garimpeiros fortemente combatidos pelas autoridades que usufruíam da expansão territorial e dos achados ou seriam apenas tolerados?

Coexistindo com a escravidão, este homem livre pobre, resultado de uma colonização sui generis, se desloca pelo sertão de apropriação não consolidada para exercer o garimpo. O importante não é o deslocamento geográfico em si, mas o seu significado, pois ele põe em questão a emergência concreta e especializada do capitalismo. Isso requer considerar que a modernidade já mobiliza sujeitos para o trabalho desde então, não apenas no espaço, mas também dentro das camadas sociais, tendo em vista a "composição inorgânica" destacada por Caio Prado Júnior (2006), camadas intermediárias que sonham com o fausto diante da ilusão mobilizadora de encontrar os diamantes, para além de suas necessidades, salpicadas pelo vasto território do interior e nas dianteiras da expansão territorial.

Se esses homens se moviam pelo território a ser apropriado, o faziam à procura de formas de sobrevida dentro de uma sociedade que já impunha o trabalho como um pressuposto da relação social e que os rotulava como vadios em uma ordem escravista que associava o trabalho à condição do cativeiro. Criou-se sobre o garimpeiro uma aura de liberdade e indisciplina, enquanto, na realidade, a fantasia de enriquecer com a sorte de um achado era alimentada por necessidades básicas que, aparentemente, o deslocava dentro daquela ordem social.

Assim, nem os viajantes oitocentistas escaparam da estereotipia dos homens dos trópicos diante da questão do trabalho, sendo consenso entre Spix, Martius, Eschwege e outros enfatizar o desinteresse dos livres pelo labor. Tal visão contrastava a disciplina no trabalho agrícola com o imaginário que cercava a busca e a exploração de minerais preciosos, considerada uma atividade livre e sem patrão - naquele momento, ter um superior indicava ser escravo.

\footnotetext{
Dentro desse quadro mais geral de rejeição a condições de trabalho associadas à escravidão, incluía-se também a opção por formas de ocupação que implicavam na mobilidade espacial frequente. A capacidade de mover-se para prover a subsistência, traduzida na expressão "viver sobre si", associava-se à liberdade, já que ao escravo estavam em princípio vedados os deslocamentos.

Nesse sentido, a profissão de lavrador diferenciava-se, conforme observa Hebe de Castro, não só do escravo como também do "homem móvel e desenraizado" [...]

Assim, o trabalho agrícola espacialmente estável podia significar, para o homem livre, não só a opção por uma maior "fixidez" espacial como também o atendimento a um pré-requisito de inserção social que o reconhecesse também como detentor de certos direitos. (PÓVOA NETO, 1998, p. 154-155, grifos nossos).
}

A análise de Helion Póvoa Neto levanta a questão da liberdade desses vadios que faiscavam. Podia até haver uma visão de liberdade associada ao sujeito que aparentemente não 
trabalhava ou que estava se movendo pelo território em busca de riquezas, porém, apesar de se tratar de sociedades onde a força de trabalho é livre, partilha-se da observação de Jean-Paul de Gaudemar, para quem toda a estratégia capitalista de mobilidade é igualmente estratégia de mobilidade forçada: "o uso capitalista das disponibilidades dos homens, da docilidade (Foucault) dos seus corpos" (GAUDEMAR, 1977, p. 17). O que há é mera ilusão de liberdade e de opção, em uma sociedade em que o acesso à terra, por exemplo, está vedado aos sem cabedal. Se não se moviam espacialmente em busca de jazidas, se mobilizavam dentro do leque de funções que podiam exercer: trabalhando nas fazendas, plantando lavouras ou colhendo frutos no mato - todas as atividades assegurando ou a confecção de produtos ou a sobrevivência e a reprodução dessa mão de obra útil, porém dispensável numa sociedade escravista.

Posto isso, é preciso ressaltar que, apesar de o trabalho livre ainda não estar pressuposto na sociedade colonial, não se deve desconsiderar a América Portuguesa como uma formação não capitalista e sem a imposição da mobilidade. Essa ressalva, feita por Carlos Toledo (2008) com respaldo em Robert Kurz sobre o trabalho de Jean-Paul de Gaudemar, se torna necessária por lembrar que o capitalismo, apesar de ser um movimento de homogeneização e totalização, tem suas nuances e processos em cada território onde sua relação social se impõe $e^{163}$.

A situação dos faiscadores se tornou mais complicada quando foi lançada a Carta Régia de 1817, que privilegiava na extração os grupos capitalizados, restringindo a mineração aluvionar, geralmente feita por homens isolados ou em pequenos grupos, tendo à disposição poucas ferramentas. Com isso, o pequeno minerador via suas possibilidades de trabalho e de ganho cada vez mais reduzidas.

O crescente cerco ao faiscador promovia na contramão a busca clandestina por outras jazidas, o que não deixava de ser de interesse da Coroa diante da queda na produção já em fins dos Setecentos. O memorialista José Vieira Couto, nascido no Tejuco em 1752 e incumbido por D. Maria I de escrever sobre a Comarca do Serro Frio, comenta em 1799 que os diamantes

\footnotetext{
163 “A colonização como peça de um sistema diz respeito a um processo que na Europa torna os trabalhadores livres das coações feudais e da propriedade dos meios de produção, sem opção a não ser vender sua força de trabalho para o capital. A isso, Gaudemar chama mobilização. A mobilização, para o autor, ocorreria também no capitalismo já formado. A acumulação primitiva, neste sentido profundo sugerido por Novais, é muito mais do que o processo de expropriação do campesinato. Ela é a montagem de uma economia mundial capitalista e como tal, profundamente desigual em relação às suas regiões coloniais e pós-coloniais. Assim, é a consideração do sistema colonial que revela a explicação do processo de acumulação primitiva como não mais do que um caso o inglês é insuficiente. O caso inglês é um caso particular, mas como o capitalismo é um sistema mundial trata-se do caso mundial. Os outros países terão de fazer suas acumulações primitivas já estando em relação à Inglaterra industrial. Como a Inglaterra industrial já existe, a industrialização destes países terá de competir com os produtos ingleses. Nos demais Estados, em oposição à Inglaterra, o processo de formação das condições necessárias à reprodução das relações sociais de produção nos termos do que Marx caracterizou como capitalismo, ocorre um processo de modernização recuperadora ou retardatária (Kurz, R., 1999).” (TOLEDO, 2008, p. 114, grifos do autor).
} 
estavam muito além da Demarcação Diamantina, o que revela a ciência das jazidas e de prováveis lavras ilegais fora do controle reinol. Por ser um sujeito encarregado de dar por escrito os pormenores da capitania à rainha, oferece boa descrição sobre como as pedras eram encontradas no meio natural:

\begin{abstract}
Esta Demarcação forma quase um círculo de 14 léguas de diâmetro, e poja em roda pouco mais ou menos 12. Entenderam os primeiros, que a Demarcação em utilidade do patrimônio régio, que tinham compreendido nesta circunferência todos os diamantes do Brasil: porém, a natureza muito mais abundante os espalhou muito além destas balizas e hoje sabido é que eles existem quase por toda a parte, ou mais ou menos. (COUTO, 1994, p. 54-55, grifos nossos)
\end{abstract}

O diamante é comum em muitas partes do Brasil: ouço dizer que até em outras Capitanias, fora esta, os há. Porém, o lugar que se tem feito mais célebre por eles é o Serro do Frio; por toda a parte os há nesta Comarca e agora de próximo também se tem descoberto na Comarca do Sabará em vários rios e córregos que vertem para o de São Francisco, como o Abaeté e outros. Esta pedra é toda cristalizada na superfície da terra e nunca em veeiros, que se entranham pelos montes. Jamais se lhe achou base ou hosta, que lhe servisse de assento como matriz para a mesma cristalização e a forma das mesmas pedras em pião, pontudas por uma e outra parte, triangulares, arredondadas e por todas as partes faceadas e lisas; tudo isto é prova que a sua cristalização é dispersa, solitária e não continuada. Por esta razão é que, criando-se esta pedra na superfície da Terra e não se achando presa em uma base ou veeiro, nem entranhada pelos montes, o tempo, os aluviões das águas, as revoluções da terra, estes grandes agentes da natureza os têm conduzido já quase todos aos rios, às suas baixas e leitos antigos. Estes são os lugares mais ordinários em que se acham os diamantes: nesta terra também o temos visto (ainda que sempre mais raras vezes), nos picos das serras e em algumas planícies elevadas e muito retiradas dos rios e que nunca foram seus leitos, nestas paragens se pode dizer que eles estão ainda no lugar natural das suas cristalizações e, por isso, sempre à flor da terra. (COUTO, 1994, p. 83-84, grifos nossos).

Couto observou as características fisiográficas das potenciais jazidas, argumentando que a terra era a única fonte de riqueza e que somente o trabalho sobre ela geraria acumulação, vendo a mineração como incerta, com maus olhos - sendo, por isso, considerado por Júnia Furtado (2009) um fisiocrata, ou seja, um adepto à corrente do Iluminismo que defendia. Couto, em contraposição à agricultura, acreditava que a colonização devia se valer da menor derrubada das matas, da introdução de camelos e da domesticação de antas ${ }^{164}$.

Em 1803, D. Rodrigo de Souza Coutinho o incumbiu de levantar a potencial exploração de salitre nos sertões da capitania, tendo em vista o arrefecimento da produção das pedras brilhantes. O resultado da sua Memória sobre as salitreiras naturaes de Monte Rorigo,

\footnotetext{
${ }^{164}$ Da mesma forma que Vieira Couto, apesar das linhagens teóricas distintas, Antonil via a mineração aurífera, muito menos fisiocrata. Para ele, a lavoura seria "a verdadeira mina de ouro" da América Portuguesa. Em Caio Prado Júnior (2002), nota-se o mesmo pensamento quando o autor compara as sociedades construídas a partir da plantation de cana-de-açúcar e da mineração: a sociedade orgânica que o autor comenta como consequência da lavoura seria a verdadeira riqueza da Coroa.
} 
publicada em 1809, já acusava a realização da atividade na já então nomeada Serra do Cabral ${ }^{165}$, confirmada por viajantes que posteriormente visitaram o norte mineiro ${ }^{166}$.

Na sua Memória, Couto descreve a Serra, chamada por ele de Monte Rorigo, como "formada de uma terra vermelha, pesada, e fertil, coberta de matas e campinas, e por onde asperejão penedias; estas são de natureza calcarea, de um cinzento-escuro", apresentando "estalactites, assento natural do nitrato de potassa", sendo tal "a fertilidade da terra, que o monte se mostra frondoso, verde-negro e cheio de viço"; como tinha conhecimento em minerais, observa a abundância de cavernas, "sendo dominantes os nitratos de potassa, cal e magnesia", podendo "só as nitreiras dos sertões do districto diamantino [...] supprir de polvora o Brasil inteiro" (COUTO apud SANTOS, 1868, p. 309-310).

No entanto, a ideia de extração das nitreiras não entusiasmou as autoridades coloniais: "Nem nos consta que se désse providéncia alguma para a exploração das nitreiras da Serra do Cabral, que mais ou menos clandestinamente, pela proibição, mas sem ordem e methodo, forão sempre exploradas pelos particulares" (SANTOS, 1868, p. 311), o que resultou no estrago de muitas delas. Sabe-se, a partir de Joaquim Felício dos Santos, que em 1808 foi concedida pela família real, já assentada no Rio de Janeiro, a franquia para explorar o salitre na Serra. Ainda assim, o empreendimento não evoluiu: “A principal causa, ou antes a unica, é a difficuldade da exportação. Não temos estradas, e nenhum meio de transporte. Fabrica-se sómente o necessário para o consumo" (SANTOS, 1868, p. 313).

Apesar da avaliação negativa da extração diamantina, Couto defendia a modernização da atividade mineradora, sugerindo a introdução da metalurgia na Colônia para extração e fabrico do ferro. Também defendia o uso de máquinas nas lavras, pois em uma mina 100 escravos seriam insuficientes, além de desordeiros. Para o melhoramento das atividades, os homens que trabalhavam com metais deveriam ser melhor instruídos no reino, a notar como se fazia em países europeus. Sobre o trabalho de minerar, fez críticas referentes ao despreparo dos envolvidos:

\footnotetext{
165 "Sem dúvida, a camada da população mineira que se dedicou com exclusividade à exploração do salitre se caracterizava pela marginalidade econômica, composta na maioria por homens livres, desprovidos de grandes recursos. O trabalho escravo é muito pouco citado na documentação.” (GOMES; PILO, 1992, p. 87).

166 "Salitreiras da região de Montes Claros e Coração de Jesus, que foram, certamente, as mais importantes e produtivas em toda Minas Gerais. Foram visitadas por diversos cientistas: Saint-Hilaire, Eschwege, Spix e Martius (os três últimos na chamada Lapa Grande) entre os anos de 1818 e 1822. Todos atestam o estado de decadência em que estas já se encontravam, mas afirmando que o salitre ainda era a maior riqueza daquelas populações sertanejas. Spix e Martius visitaram Lapa Grande especialmente à procura de ossos fósseis, o que de fato encontram e recolhem, anotando que os habitantes do sertão referiam-se à existência de tais ossos nas cavernas." (GOMES; PILO, 1992, p. 89).
} 
Deve-se notar mais nesta mineração o mau método nas lavagens e colheitas dos diamantes. Os nossos mineiros, no princípio, inventaram as lavagens dos diamantes propriamente como as do ouro que eram as que unicamente conheciam e onde eles começaram a apanhar os primeiros diamantes e assim foram estas coisas até agora. De que diferente natureza é o ouro e o diamante! E como pode ser que um mesmo método de lavar se acomode a uma e outra coisa. O ouro é lançado juntamente com a terra em um lavador, a que chamam bolinete, quando ele é maior; a canoa, quando é menor: uma porção de água corre continuamente sobre a terra e um escravo a mexe com um instrumento que chamam almocafre: nesta ação, a terra se faz como fluida e o ouro, que tem uma gravidade específica, muito maior do que a mesma terra e areias com que se acham misturadas, se precipita e se assenta no fundo do lavador, donde ao depois o recolhem. Porém, os diamantes maneados do mesmo modo e que a sua gravidade específica não é maior, ou muito pouco difere dos mais corpos com que se acham confundidos, que razão há para que eles se depositem no lavador em que se mexe a terra com a água e não fujam por ela abaixo? Aquele que observa estes mesmos lavadores, vê que na ação de se mover e manear o cascalho neles correm a cada passo pedras que poderão ter mais de meia libra de peso e como não correrão os diamantes de meio grão? (COUTO, 1994, p. 85).

No século XIX, impressões interessantes sobre os métodos de garimpo também foram tecidas pelo barão Eschwege, em Pluto brasiliensis. Nascido na Alemanha em 1777, ele veio ao Brasil em 1810, com a preocupação de organizar um gabinete mineralógico-geognóstico, dentro de um contexto em que D. João VI buscava técnicos para melhor aproveitamento do Reino Unido a Portugal e Algarve. Até a sua partida, em 1821, dedicou-se a pesquisas geológicas, especialmente em Minas Gerais, com destaque para o ferro e o diamante ${ }^{167}$.

Com conhecimento técnico e experiência desde a sua terra de origem, ao habitar Minas Gerais afirmava que "todos os outros rios que nascem nesse sertão devem ser ainda pesquisados, pois, esgotado o cascalho dos rios diamantíferos do Serro Frio, poderão garantir, por muitos séculos ainda, uma boa produção" (ESCHWEGE, 1979, v. 1, p. 108), partilhando da mesma assertiva de Vieira Couto.

Tão interessante quanto as análises mineralógicas que fez sobre os rochedos do Distrito Diamantino e seus arredores, foi a série de observações sobre os métodos de garimpo e as relações de trabalho. Quanto à maneira como se garimpa diamante, escreveu:

O primeiro trabalho a realizar é a extração do cascalho. Quando se encontra em tabuleiros, abrem-se cuidadosamente trincheiras, que se aprofundam até o cascalho virgem, de modo a possibilitar espaço para os negros encarregados da extração.

O cascalho bravo, de cima, e a terra vegetal são constantemente atirados para trás. $\mathrm{O}$ de baixo, que contém diamantes, é raspado cuidadosamente e transportado em carumbés até os lavadouros, onde é amontoado.

$[\ldots]$

Se o trabalho deve efetuar-se no leito dos rios, a água é desviada de acordo com os meios e o espaço de que se dispõe. [...]

Além disso, o baixo aluguel que se paga por escravo empregado e a diminuta despesa que exige sua alimentação, têm-me feito duvidar mais de uma vez se seria de fato

167 Seu mapa sobre a capitania de Minas Gerais está parcialmente exposto no capítulo 2 desta tese, sobre a cartografia regional. 
preferível substituir o trabalho escravo pelo de máquinas. Há a considerar, ainda, a necessidade contínua de transportar o maquinismo de um para outro lugar, em terreno escorregadio e acidentado.

$[\ldots]$

Os funcionários consideram excelente indício de presença de diamantes a ocorrência de minério de ferro brilhante e rolado, de um mineral silicoso xistificado, semelhante ao lidito, fragmentos compactos de óxido negro de ferro e hematita em grande quantidade, seixos de quartzo leitoso e cristal de rocha amarelado, e, sobretudo, de várias espécies de rocha, diferentes das que existem nas proximidades. (ESCHWEGE, 1979 , v. 1, p. 127-128, grifos do autor).

Discorrendo sobre a mercadoria no primeiro capítulo do livro I d'O Capital, Marx menciona o barão. Ao explicar o trabalho abstrato como aquele que desaparece na mercadoria trocada - pois "Prescindindo do valor de uso dos corpos das mercadorias, resta nelas uma única propriedade: a de serem produtos do trabalho" -, ele afirma que só se mede o valor de algo produzido pela quantidade de trabalho abstrato nele contido, explicando que "A própria quantidade de trabalho é medida por seu tempo de duração, e o tempo de trabalho possui, por sua vez, seu padrão de medida em frações determinadas de tempo, como hora, dia etc." (MARX, 2013, v. 1, p. 116).

Se para Eschwege, o baixo aluguel que se pagava por escravo empregado e a diminuta despesa que exigia sua alimentação por vezes o fez duvidar se seria de fato preferível substituir o trabalho escravo pelo de máquinas ${ }^{168}$, entende-se que o desenvolvimento das forças produtivas, com a introdução do investimento em capital constante representado por máquinas modernas, levaria a uma redução do tempo de trabalho em minerar, o que, por sua vez, poderia levar à queda do valor do diamante. Marx (2013, v. 1) adverte para o fato de que essa possibilidade depende de múltiplas circunstâncias, como o grau médio de destreza dos trabalhadores, o grau de desenvolvimento da ciência e de sua aplicabilidade tecnológica, a organização social dos meios de produção, o volume e a eficácia dos meios de produção e, neste caso particularmente, as condições naturais.

Lembrando que a mão de obra empregada nas extrações de grande vulto era escravizada e que a mineração é incerta por depender de condições naturais imprevisíveis, e o emprego do trabalho cativo mais a sorte de achar um mineral raro são os condicionantes do interesse em manter alto o preço do diamante. O uso do escravo na extração, considerado por quem comanda o chicote como alguém que além de não ser sequer dono de si, também é desprovido de

\footnotetext{
${ }^{168}$ Por motivos além e em referência à extração em 1813, Joaquim Felício dos Santos também condena o uso de máquinas, alegando que apesar de dispensar "centenares de braços", não podiam ser aplicadas na exploração devido à especialidade da mineração de diamantes e ao solo cheio de declividades e rochedos. Além disso, "A immensa machina, quasi fixa, pesada, complicada, não podia ser commodamente transportada, e cada serviço demandava quasi a construcção de outtra nova com grandes despezas e difficuldades", sobretudo em uma extração de "minerava por saltos", ou seja, o serviço "durava um anno, ou quando muito dous ou tres", passando a outro em lugar diferente. (SANTOS, 1868, p. 316).
} 
qualificação arrojada para o ofício, realiza o trabalho de minerar num tempo maior, o que materializa mais trabalho humano abstrato na mercadoria final.

\begin{abstract}
Segundo Eschwege, oitenta anos de exploração das minas de diamante brasileiras não havia atingido, em 1823, o preço do produto médio de um ano e meio das plantações brasileiras de açúcar ou café, embora ela representasse muito mais trabalho, portanto, mais valor. Com minas mais ricas, a mesma quantidade de trabalho seria representada em mais diamantes, e seu valor cairia. Se com pouco trabalho fosse possível transformar carvão em diamante, seu valor poderia cair abaixo do de tijolos. Como regra geral, quanto maior é a força produtiva do trabalho, menor é o tempo de trabalho requerido para a produção de um artigo, menor a massa de trabalho nele cristalizada e menor seu valor. Inversamente, quanto menor a força produtiva do trabalho, maior o tempo de trabalho necessário para a produção de um artigo e maior o seu valor. Assim, a grandeza de valor de uma mercadoria varia na razão direta da quantidade de trabalho que nela é realizado e na razão inversa que força produtiva desse trabalho. (MARX, 2013, v. 1, p. 118).
\end{abstract}

Partindo de uma visão modernizadora justamente por criticar o aproveitamento improdutivo da riqueza, Caio Prado Júnior (2006) aponta as técnicas rudimentares da mineração como impeditivas à sua reprodução ampliada, o que teria levado à crise das extrações de grande porte. Por isso, afirma o autor, o trabalho escravo vai sendo substituído sistematicamente pelo trabalho do faiscador, indivíduo isolado ou escravo, que não emprega nada além da bateia, do carumbé e umas poucas ferramentas ${ }^{169}$, podendo trabalhar por conta própria. Seriam, na maioria das vezes, os livres pobres, conforme foi comentado ${ }^{170}$.

Na mesma direção aponta Helion Póvoa Neto, para quem o declínio da mineração se justifica pelas técnicas limitadas. Em 1832, no contexto de Brasil recém-independente, põe-se fim à administração diamantina, que segue agonizando até 1841. Para o autor, os distritos diamantinos tornaram-se plataformas a partir das quais partiam trabalhadores práticos na mineração, acostumados na ilicitude e expostos a riscos ${ }^{171}$, chegando-se a falar na historiografia sobre uma “diáspora” rumo aos sertões (DEL NERO apud PÓVOA NETO, 1998, p. 117).

\footnotetext{
${ }^{169}$ Carumbés e bateias são recipientes de madeira ou de metal utilizados no garimpo de diamantes.

${ }^{170} \mathrm{~A}$ visão genérica de que os cativos não tinham conhecimento técnico vem caindo por terra, conforme apresenta o estudo de Eduardo França Paiva (2002) sobre os escravizados em Minas Gerais. Para o historiador, o tráfico se empenhou em equipar a região mineradora da Colônia com mão de obra especializada, oriunda da Costa da Mina, de onde vinham africanos providos de conhecimento técnico apurado. Além disso, o autor também salienta a importância das mulheres na mineração.

${ }^{171}$ Para exemplificar, Joaquim Felício dos Santos narra a descoberta das lavras do Curralinho, por volta de 1830, contradizendo a sua própria visão de que o garimpeiro se dedicava apenas à extração:
}

\begin{abstract}
Os campos do Curralinho e do Bom-Successo contiguos ainda estavão virgens. Os invasores lavravão os gorgulhos: erão riquissimos e de facillimo lavor. Novo incentivo para afluírem outros invasores. Agricultores, negociantes, homens de todas as classes, deixavão suas profissões e partião para o novo descoberto. Em breve mais de seis mil pessoas trabalhavão nos campos do Curralinho. (SANTOS, 1868, p. 432).
\end{abstract}

Depois de extincta a Extracção, e, póde-se dizer, com a acquiescencia tacita do govêrno e mais autoridades, os terrenos diamantinos começárão a ser geralmente occupados pelos mineiros. Já 
Sabe-se que já na segunda metade do século XVIII, o diamante do Distrito Diamantino dá sinais de escassez, pelo menos a pedra de superfície, de mais fácil extração. Com vias a introduzir uma exploração especializada, duas empresas britânicas de mineração se instalaram em Minas Gerais logo após a independência, uma em Santa Bárbara e outra em Morro Velho. Ambas lidavam tanto com escravizados quanto com trabalhadores livres que, sem salário regular, partiam para as lavouras de milho na época da colheita.

Tal cenário não só corrobora as observações feitas ainda no século anterior sobre a relação entre fazendas e garimpos, como permite retomar a discussão sobre a suposta regressão econômica no ocaso da mineração, defendida por Celso Furtado. Helion Póvoa Neto sustenta em sua tese que tal situação sugere que em um momento de transição como o da independência e tudo o que ela trouxe consigo - o interesse científico em pesquisar recursos passíveis de exploração, uma conjuntura externa imperialista e a decadência da mineração de grande vulto -, vasto contingente populacional permaneceu integrado de forma irregular às atividades produtivas, recorrendo eventualmente a diversas ocupações como complemento da subsistência. Com isso, tanto em Minas Gerais quanto em Goiás observa-se que o garimpo se somava à pequena lavoura como uma das alternativas de sobrevivência desses homens (PÓVOA NETO, 1998).

Ou seja, a articulação entre ambos os trabalhos esteve presente entre os livres pobres durante todo o auge da exploração, não apenas na sua crise, caminhando juntos. Retomando a crítica à ideia de regressão, é preciso lembrar que essa produção de subsistência não se restringia apenas à produção para o consumo, mas movimentou mercados locais e abriu a possibilidade para a especialização da pecuária assim que a mineração de grande porte não vingou na virada de século. Apesar de ser economia subsidiária, foi dinâmica e, também por ter essa característica de ser secundária, abrangeu garimpeiros que se revezavam sazonalmente entre catar nas grotas e aboiar ${ }^{172}$ nas terras dos outros.

Juridicamente, o Brasil independente seguiu estigmatizando o garimpeiro, o que contribuiu para a situação de sujeitos exercendo tanto o garimpo quanto a lavoura. A Constituição de 1824 determinava que os terrenos diamantinos só poderiam ser explorados por companhias, distribuídos em datas, semelhante ao que era feito durante o período colonial. O

não havia mais lugar algum impedido; já não se minerava mais ás ocultas; os mineiros forão se estabelecendo por toda a parte, assentárão fábricas, construirão casas de vivenda, fizerão bemfeitorias de valor, e á mineração ajuntárão a agricultura. Estas occupações mais ou menos arbitrarias ou violentas forão motivadas pela necessidade; não se dava destino ás terras diamantinas, e não podia ficar occiosa a immensa população, que o franqueio das lavras attrahíra á demarcação. (SANTOS, 1868, p. 436).

172 “Aboiar - Cantar á frente do gado; toada pouco variada e triste, serve para guiar e pacificar as rezes e sobre estas exercer muita influencia quando saudosa e em viagem.” (CUNHA, 1905, p. 127). 
comércio de pedras foi proibido, sendo estas vendidas somente à Fazenda Real e segundo uma tarifa estipulada por ela.

O garimpeiro só era liberado e tolerado em áreas de mineração já decadentes, mais uma vez legalmente impedido de se embrenhar pelos matos e subir as serras para "cavacar" em busca de riqueza. Apesar das restrições, permaneceu no ofício, expandindo as fronteiras de ocupação sertaneja nas serras, onde o gado dificilmente pastava: mesmo estigmatizado como vadio, cumpriu com o papel crucial de descoberta, desbravamento e exploração dos recursos minerais almejados pelas autoridades coloniais, sendo o ofício uma das formas de sobrevivência para os também oriundos do escravismo, já que a condição de garimpeiro não demarcava a origem social do trabalhador, abrangendo sujeitos de estirpe diversa, inclusive do cativeiro. No fim dos Oitocentos, Riobaldo observa em suas andanças pelo sertão:

Dali vindo, visitar convém ao senhor o povoado dos pretos: esses bateavam em faisqueiras - no recesso brenho do Vargem-da-Cria - donde ouro já se tirou. Acho, de baixo quilate. Uns pretos que ainda sabem cantar gabos em sua língua da Costa. E em andemos: jagunço era que perpassava ligeiro; no chapadão, os legítimos coitados todos vivem é demais devagar, pasmacez. A tanta miséria. O chapadão, no pardo, é igual, igual - a muita gente ele entristece; mas eu já nasci gostando dele. As chuvas se temperam... (ROSA, 1986, p. 23).

É nesse contexto que o diamante é descoberto na Serra do Cabral, cujo momento é oficialmente apontado para a segunda metade do século XIX.

\section{2. "Esses bateavam faisqueiras": apurando e resumindo na Serra}

As informações levantadas em pesquisas de campo entre dezembro de 2016 e janeiro de 2017 associadas à bibliografia estudada indicam a existência de garimpo de diamantes na Serra do Cabral desde, ao menos, o início dos Oitocentos ${ }^{173}$. Tido como o garimpo mais antigo da Serra, o Barreirinho está abandonado há mais de 100 anos. As ruínas e os restos da área minerada permitem supor a existência de moradias feitas de rochas locais, tendo em vista a disposição do material, sugerindo cômodos simples e fogões feitos de pedra de forno, conforme foi apresentado por antigos garimpeiros que estavam presentes no campo. A cerca de 1 metro de profundidade e distante dos montes de cascalho amontoados em mais de 50 metros, um

\footnotetext{
173 Joaquim Felício dos Santos menciona, entre os bens arrolados da herança do contratador João Fernandes de Oliveira em 1755, um morgado que inclui, entre "todas as suas fazendas nos sertões de Minas", a "Do Jequitahy" (SANTOS, 1868, p. 153). O autor não dá mais informações, porém a curiosidade parte da existência de propriedade de figura tão poderosa e interessada na mineração diamantina nas imediações da Serra do Cabral. Tanto o memorialista quanto vasta historiografia atestam participação ou conivência do contratador em exploração e comércio clandestinos de pedras, levantando a suspeita de que o garimpo já podia acontecer na Serra, envolvendo sujeitos de grande cabedal.
} 
morador de Francisco Dumont, Zé Carlos Calixto, encontrou dois cachimbos, tendo um deles dois rostos talhados, mais cacos de louça britânica esmaltada e decorada, cacos de cerâmica rústica com decoração em alto relevo e tintura simples, cabos de talheres de prata, moedas de uma pataca e ferramentas enferrujadas de garimpo, como pá, correntes e pequenas foices.

\section{Figura 11 - Vista do garimpo do Barreirinho com o município de Francisco Dumont ao fundo}

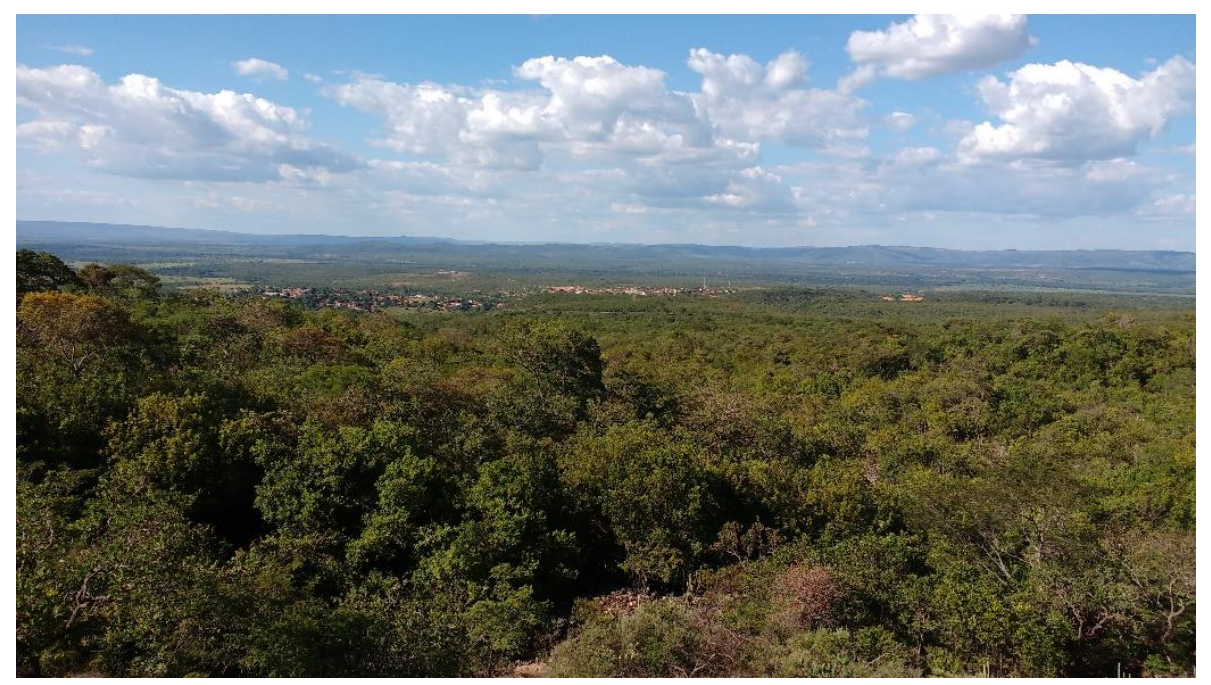

Fonte: acervo pessoal, dezembro de 2016.

Figura 12 - Achados no solo do garimpo do Barreirinho

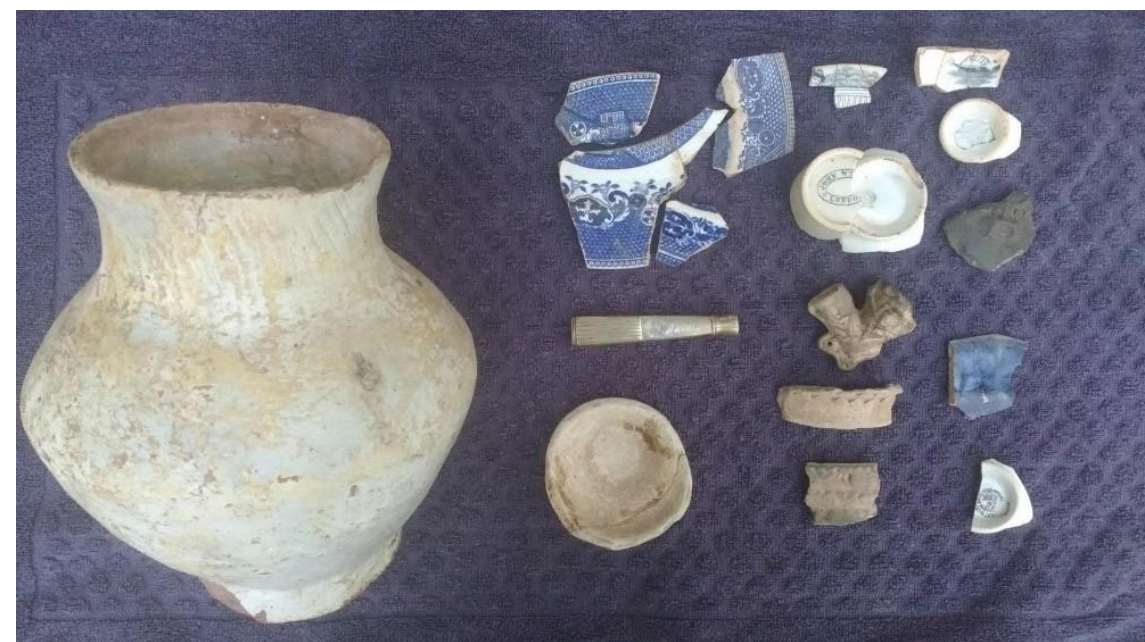

Fonte: acervo pessoal, dezembro de 2016.

Da esquerda para a direita: uma moringa de barro, fragmentos de louça esmaltada marcada made in London e de cerâmica adornada, porém rústica; cabo de talher de prata e cachimbo com rosto com detalhes em alto relevo. 
Figura 13 - Cascalho acumulado do garimpo do Barreirinho com a vegetação do cerrado regenerada devido ao abandono do local

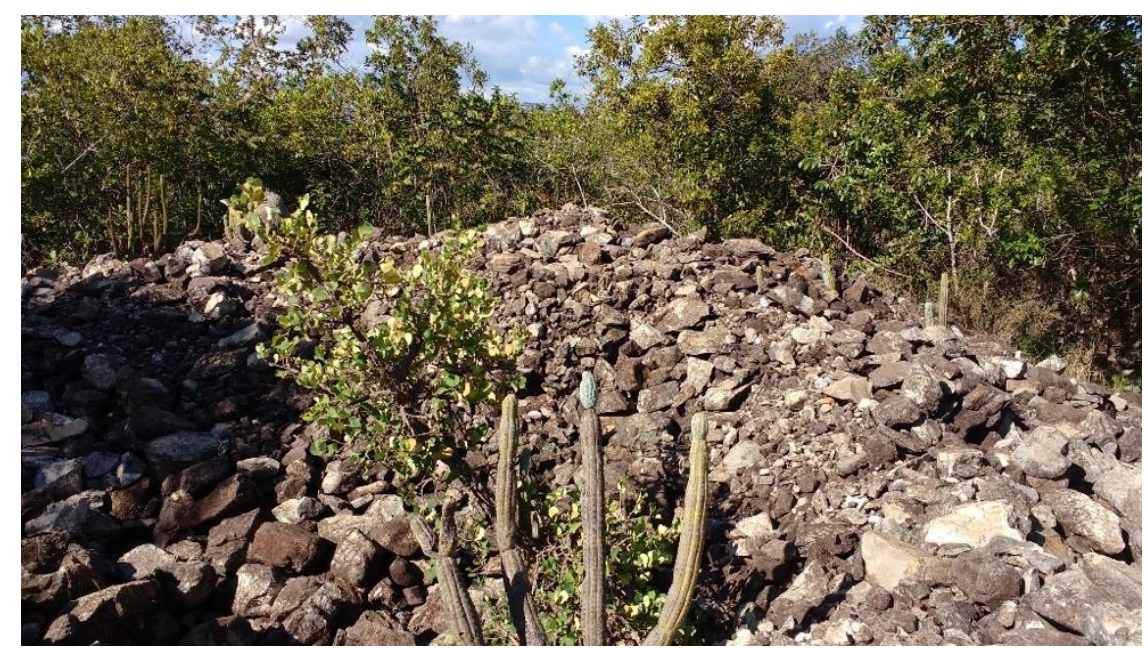

Fonte: acervo pessoal, dezembro de 2016.

Figura 14 - Vestígio de casa no garimpo do Barreirinho

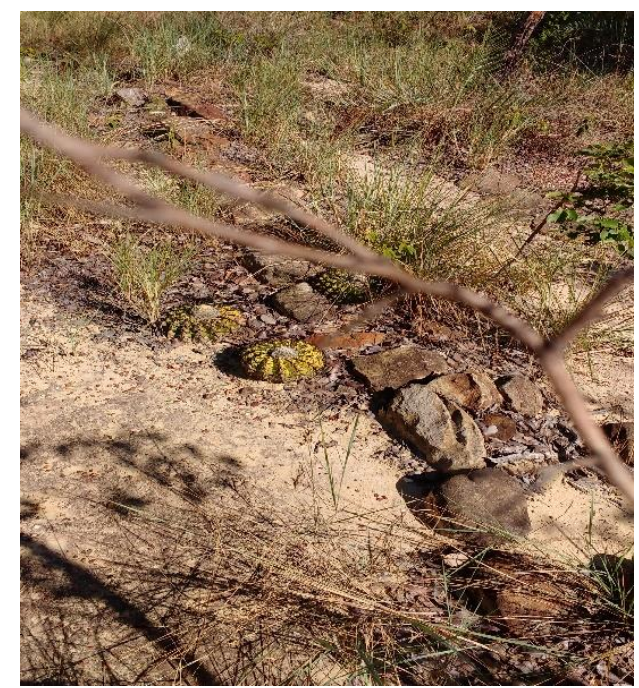

Fonte: acervo pessoal, dezembro de 2016.

Nota-se a sequência das rochas, sugerindo divisão de cômodos.

Figura 15 - Ferramentas de garimpo encontradas no subsolo do garimpo do Barreirinho

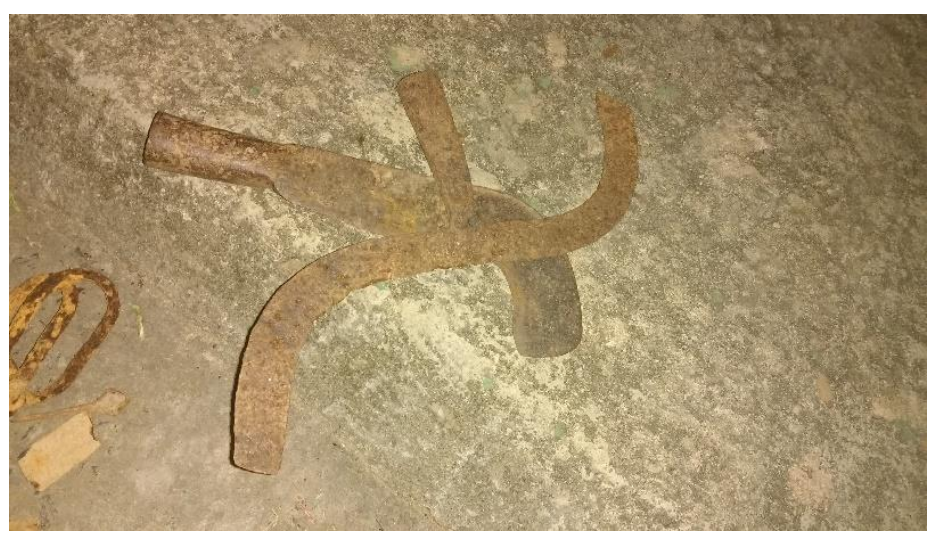

Fonte: acervo pessoal, dezembro de 2016. 
Cabe abrir um breve parêntesis sobre os objetos apresentados. Sem a pretensão de debater cultura material, os achados induzem a pensar sobre hábitos, costumes e estratificação social dentro do tema analisado. Os cacos de louça britânica, por exemplo, sugerem uma hierarquia social na qual os donos ou gerentes de garimpo, incrustrados nas grotas da Serra do Cabral, acessavam produtos importados, provavelmente via comércio de tropeiros, conectando a economia diamantina sertaneja com a produção industrial de louça europeia de além-mar, enquanto os escravizados e demais subordinados na escala da mineração provavelmente produziam ou adquiriam utensílios de cerâmica para consumo próprio, presumindo-se que essa habilidade e as técnicas envolvidas podiam se conectar a supostas ancestralidades desses sujeitos. Conforme observa Marcos Rogério Ribeiro de Carvalho (2003) em estudo arqueológico sobre os sítios do centro paulistano, esses materiais dão pistas sobre as relações comerciais entre Brasil e Portugal, quando restritos ao período colonial, e sobre a expansão capitalista de países imperialistas, como França e Inglaterra, ao longo do século XIX.

No mesmo período, outro campo foi realizado nos arredores do povoado de Buriti Grande, no garimpo do Licuri, abandonado há um século. Ali, entre os montes de cascalho lavado e a vereda, foram observadas rochas dispostas da mesma forma do Barreirinho, sugerindo moradias. De acordo com Teotônio da Silva, nascido no povoado na virada do século XIX para o XX, o lugar chegou a ser mais movimentado do que Conceição do Barreiro, com farto comércio alimentado pelo garimpo e venda de diamantes. Escola, farmácia, casa de baile, venda de secos e molhados, cartório e outros serviços animavam as ruas de terra do Buriti Grande, cuja origem remonta às fazendas da família Borém.

As lembranças de Teotônio sobre o movimento local não estão isoladas: Manoel Lopes, vaqueiro, também chegou a garimpar por um curto período nos arredores do povoado, na Varginha, terras de Zé Borém e área de vereda na Serra. Segundo ele, a Varginha parecia um povoado durante o dia, de tanta gente aglomerada "cavacando" atrás de diamante. No fim da tarde, todos desciam a pé para o Buriti para negociar as pedras e consumir nos armazéns. De acordo com suas memórias, o movimento era grande o ano inteiro: "Com baile, cartório, escola, padaria, serraria... De dia, não tinha ninguém, mas à noite os garimpêro descia e tinha festa todo dia. Os garimpêro gastava tudo que ganhava de noite no Buriti”.

Outro que se lembrou bem do movimento no povoado até por volta dos anos 1950, foi Liopoldino da Fonseca, vulgo Pixico, 102 anos (2018), comerciante nascido no Buriti Grande. Solteiro e sem filhos, foi encontrado no asilo de Bocaiúva, concedendo seu tempo e suas lembranças à entrevista. Seu pai, comprador de diamante nascido em Diamantina, chegou ao povoado em busca de negócio, onde conheceu a esposa e formou família. Órfão desde cedo, 
Pixico rodou São Paulo, Mato Grosso e outros estados atrás de trabalho até morar em Engenheiro Navarro, município da Serra do Cabral. Entre os ofícios exercidos, chegou a garimpar em parceria com um amigo, Otávio Rosa, pagando porcentagem ao famigerado Zé Borém. A sua expropriação era tão grande que metade do que ficava do diamante vendido era dada ao fornecedor, pois ele fornecia desde comida a ferramentas. Também pela pobreza, não pôde se casar com uma jovem professora da família Borém, de nome Celina.

A notar pelo Distrito Diamantino e pelas povoações hoje chamadas de cidades históricas mineiras, além da discussão apresentada por Aroldo de Azevedo (1957), em que tanto a mineração de grande vulto quanto a de faiscação acontecia, o povoamento se adensava, chegando a formar cidades. Esses núcleos se tornavam praças comerciais locais ou até regionais, onde a riqueza oriunda da extração promovia a circulação de mercadorias. Manoel Lopes enfatizou que o comércio não se restringia às pedras: "Era um movimento de cavalo, de boi... As rua era de manga por isso". Ele mesmo chegou a levar gado capado e vacas para fazer negócio entre os fazendeiros Pedro Furtado e Silivério. Pixico acrescentou que com a "fofoca do diamante", a maioria das pessoas que moravam lá era de fora. Por volta de 1917, até músico do sul da Bahia foi levado ao povoado, incumbido de formar banda e tocar nos bailes das famílias mais abastadas, o que revela o grau de complexidade das relações sociais daquele núcleo no auge do garimpo diamantino, no esforço de imitação dos centros urbanos do país.

Se as descobertas de diamante na Serra de Santo Antônio do Itacambiraçu entre 1770 e 1780 e no Curralinho nos idos de 1830 teriam atraído gente diversa para o norte de Minas Gerais como um todo, não parece impossível a hipótese de que muitos desses "vadios" circulavam pela Serra do Cabral, pois nos Setecentos já se dizia que "a exemplo da Serra de Santo Antônio, não há canto, serra, nem córrego pelo sertão que não seja visto e examinado dessa gente vadia, a ver se topam algum haver, que lhes faça conta" (APM, fl. 16 apud PARRELA, 2009, p. 57). No mesmo período dessas descobertas, funcionários reinóis já circulavam pelos rios e córregos correntes na Serra do Cabral, confirmando o conhecimento territorial dos mapas de José Joaquim da Rocha, de 1778:

Em 1782, o comandante Sayão dizia ter enviado "um soldado de quem faço conceito e este com o maior cuidado socavou as cabeceiras do Embasaya Grande, Rio Preto e Gameleira e nada achou que pretendia" (APM, SC, Cód. 229, fl. 63v). Além disso, os comandantes dos destacamentos efetivavam compras de mantimentos extras nas redondezas para a ração das tropas e animais, adquiriam muitos cavalos, para proceder às perseguições nos terrenos onde fosse possível, alugavam pastos e compravam bois para alimentar seus homens em ocasiões especiais, como o Natal. (PARRELA, 2009, p. 110). 
Ou seja, se a região era território de trânsito, com registros de guardas, comércio, criações e povoamento desde o século XVIII, cabe pensar se tal expedição omitiu a existência de lavras clandestinas e como o comércio se mantinha numa área relativamente marginal do ponto de vista econômico. Era provável o conhecimento das autoridades sobre o garimpo e o comércio ilegais, e um exemplo está em Joaquim Felício dos Santos: fiando-se em suas memórias oitocentistas sobre o Distrito Diamantino, ele informa que "Muitos soldados d'esta guarnição, como mostra a experiencia, que não são mais os mesmos que antes, chegão a ajustar com aquelles para os deixar trabalhar a seu salvo" (SANTOS, 1868, p. 194).

A partir da análise do estudo de campo no córrego do Barreirinho, considerado pelos garimpeiros mais velhos a lavra mais antiga e já desativada há mais de 100 anos, acredita-se que havia garimpo intenso na Serra do Cabral pelo menos em princípios do século XIX. Nos diálogos, alguns desses garimpeiros comentaram que nem seus pais, já na profissão, chegaram a trabalhar nessa lavra, mas que ouviam histórias de ferreiros e artesãos circulando pelo garimpo, tropas de cavalos e de bois subindo o trecho da Serra que lhe dava acesso e até padre indo rezar missa em meio ao cascalho. Manoel Pereira de Souza, Neco, 79 anos (2017), um dos entrevistados, mencionou que seu pai lhe contava sobre um ex-escravizado que trabalhou no Barreirinho e terminou seus dias de liberdade morando em uma tapera no município de Jequitaí. Paulo Lopes, vulgo Paulo Fura Olho, 92 anos (2017), um dos mais velhos entre os ouvidos, contou que, por volta dos seus 7 anos, chegou a conhecer esse ex-cativo, de nome Mané Canguçu. Segundo ele, o garimpeiro estava muito senil na ocasião, vivendo só em uma casa bastante precária, afastado de todos, porque corria a fama local de ser feiticeiro, conformando todos os estereótipos negativos inculcados sobre a população afrodescendente naquele período.

As informações colhidas no garimpo são corroboradas pelos depoimentos dos entrevistados. A lavra fica próxima à água corrente, sendo um córrego que desce em rochedo, formando um buraco (uma "panela", como dizem por lá), o que sugere ser um garimpo "croado". Levou-se mais de 40 minutos a pé para chegar à base do Barreirinho e, depois, mais uma hora andando por ele, sobre monturos de cascalho com mais de 50 metros de altura, bastante irregulares. As camadas de cascalho lavado sugerem que ali não houve trabalho de uma ou duas décadas apenas.

Mais adiante no terreno, há uma parte mais retilínea, com solo mais firme e arenoso, onde observam-se rochas dispostas em formato de cômodos, organizadas em linhas geométricas, apesar de não haver nenhuma parede; uma delas se assemelha a um fogão. Os artefatos mencionados anteriormente foram encontrados nesse trecho do garimpo. Mais adiante, 
ao subir uma laje rochosa, veem-se vestígios de uma escada bem grosseira, quase imperceptível pelas canelas de ema do entorno.

Caminhar pelo Barreirinho debaixo de sol a pino, buscando equilibrar o corpo sobre o cascalho de tamanho variado, irregular e amontoado, é uma vivência relativamente próxima das descrições contidas em Spix (1981), que empreendeu viagem pelo Brasil entre 1817 e 1820, tendo palmilhado de Vila Rica até o Distrito Diamantino.

Impressões acerca dos modos de minerar foram registradas pelo contemporâneo de Spix, seu conterrâneo Eschwege. Parece que as técnicas descritas por ele em princípios dos Oitocentos permaneceram iguais até, pelo menos, a primeira metade do século XX. Teotônio explicou que na Serra havia duas formas de garimpo: o croado e o barrancado.

Segundo o antigo faiscador, o garimpo croado é aquele em que só se extrai o cascalho, geralmente em beira de rio ou córrego, sendo um trabalho mais fácil e mais próximo a cursos d'água ${ }^{174}$. Já o trabalho barrancado é mais difícil, pois mesmo estando próximo de água corrente (o que é pouco provável, pois geralmente esta maneira se dá a seco), é preciso revolver todo o barranco de terra para se chegar à camada de cascalhos e rochedos, onde as pedras preciosas estão escondidas. Acompanhando o garimpo diamantífero durante viagem empreendida pelo norte de Minas Gerais em 1867, o naturalista britânico Richard Burton deixou registrado em diário uma descrição sobre o trabalho, semelhante à definição de Teotônio, permitindo entrever as maneiras barrancada e croada:

\begin{abstract}
A prospecção de diamantes é feita da seguinte maneira: o humo vegetal, a argila subjacente e o desmonte, ou areia da inundação, são removidos com o almocafre, até que seja alcançado o "cascalho" ou "gorgulho", portador da pedra preciosa. Esse trabalho inicial consiste, geralmente, num corte aberto de alguns centímetros quadrados. Os fragmentos maiores de quartzo são, então, removidos manualmente, o cascalho é lavado em um "baco", "canoa" ou "cuiaca" e, finalmente, emprega-se a bateia.

[...]

De acordo com mineradores desta parte do Brasil, a melhor diamantação (para empregar uma expressão regional) é encontrada no gorgulho, massa solta de pedras pontudas. Contam-se histórias maravilhosas de suas riquezas, descobertas de cinco ou seis diamantes arrancando-se um tufo de capim [...] (BURTON, 1977, p. 120-121).
\end{abstract}

Gumercindo Amaral (1983, p. 10), garimpeiro de Francisco Dumont nascido em 1916 na fazenda da Lapa e já falecido, deixou em seu livro de memórias que trabalho garantido era o de grupiara, ou seja, garimpo em morro onde tem cascalho diamantífero; provavelmente

\footnotetext{
${ }^{174}$ Jerônimo e De Paula, ao entrevistarem garimpeiros de Goiás, ouvem que o diamante croado "tem sua motivação relacionada ao verbo croar". Assim, "Quando a forma é mai[s] baxa cê bate, bate, o diamante saía por ribinha assim ó, croado [..] é pur ribinha, cê já catava ele [...]” (JERÔNIMO; DE PAULA, 2013, p. 81, grifos dos autores).
} 
seria o mesmo que o croado. Nele, dificilmente se fazia "garimpo comprido"175, sem encontrar sequer um "chibiu"176.

Quanto à presença de outros minerais junto ao cascalho, as conversas com os garimpeiros Dermeval Pereira Leite, Neco, Ademar Arcanjo Cabral (Dê), Peargentino (Tino) e Lúcio Alves Costa, Valmir Bezerra e outros apontaram a existência do que chamam de "forma diamante". Para eles, isso significa a quantidade de minerais distintos que aparecem no cascalho miúdo durante a lavagem, sendo muitos deles batizados: Santa Maria (supõe-se ser ferro), rubim (pedra semelhante à granada), quartzo, caboclo (mineral preto e mais leve que o diamante) etc. Muitos anos antes, Richard Burton (1977) descreveu os indicadores de diamante, chamados por ele de "pinta em diamantes": cativo, siricória, pingo d'água, fava, feijão, caboclo, esmeril, ferragem, pedra Santa Ana, osso de cavalo, palha de arroz, agulha, caco de telha, piçarra folhada e pedra pururucu. Esses minerais pequenos se aglomeravam no fundo da peneira, junto ao diamante e, ao que parece, mais tarde passaram a ser procurados para fins industriais diversos, pois até então eram descartados junto ao cascalho grosseiro.

Para Eschwege, o sertão do Rio São Francisco e o que se localiza entre o Paranaíba e o Rio Grande, foram, desse modo, povoados continuamente, enquanto a população das regiões auríferas decrescia na mesma proporção. Assim é que, na sua obra, produziu uma tabela para o ano de 1821, referente à população da capitania, atentando que "A população dos livres para os escravos é, assim, de 90 para 50; a dos homens de cor para os brancos, de 145 para 50" (ESCHWEGE, 1979, p. 263-264). Num país recém-formado em que se discutia a liberdade, a cor tinha grande importância ${ }^{177}$.

Ao observar a composição populacional de Minas Gerais, Eschwege também fez suas reflexões acerca do labor na capitania. Se o trabalho não é nada além de dispêndio de tempo e energia e é necessário conceder ao trabalhador o mínimo para que ele sobreviva no dia seguinte a ponto de ter condições de produzir riqueza, ao escravizado é preciso dar condições mínimas para que produza, por mais que esteja inserido nas relações como uma mercadoria e que tenha feito a mobilidade de maneira forçada.

Observando o quadro de reposição das energias dos escravos garimpeiros, o autor detalhou a alimentação dos cativos, que recebiam milho, fubá para o angu, feijão preto e um punhado de sal; caça, só se houvesse. À noite, a refeição consistia em canjica com melado. Uma

\footnotetext{
${ }^{175}$ Expressão usada na região para jazidas onde se trabalhava muito (um ano ou mais).

176 Diamante pequeno.

${ }^{177}$ Hebe Mattos (2009) apresenta boa discussão sobre o assunto, pois ser "de cor" e provar a liberdade era tarefa constante até para ir e vir no território do Brasil recém-independente, quando se discutia a liberdade de propriedade, incluindo a do escravo, e os direitos civis.
} 
vez por semana, recebiam um palmo de fumo de rolo para o cachimbo ou rapé (ESCHWEGE, 1979). Segundo o barão, iam ao trabalho dispostos, esperançosos de escamotear alguma gema. Por ser impossível manter relações com estranhos, os achados preciosos eram trocados por ninharias em forma de recompensa, que "se limita a peças de roupa, guloseima, bebida e fumo. Então, grande é a satisfação do mísero quando, aos domingos e dias santificados, pode divertirse, dançando a noite toda com sua bela" (ESCHWEGE, 1979, p. 131).

A esperança no trabalho era alimentada pela possibilidade da alforria, que se transformava num pequeno espetáculo ${ }^{178}$. De modo geral, o barão indagava à sociedade mineira sobre o trabalho dentro de uma linha de pensamento afeita à produtividade - tendo em vista o contexto social em que deixava seu país de origem -, permitindo-se perguntar sobre uma sociedade de classes ${ }^{179}$ dentro de um universo escravista:

\begin{abstract}
Dessa população, qual é a classe dos trabalhadores? Propriamente, apenas a classe servil. O branco, mesmo quando pobre, não move uma palha, pois até na vadiagem encontra com que viver. O mais das vezes, limita-se a possuir um escravo, que se encarrega de sustentá-lo.

Também o mulato livre possui escravos. [...]

O negro forro pertence, incontestavelmente, à classe dos deserdados. Nunca dispõe de meios para adquirir um escravo que o ajude. (ESCHWEGE, 1979, p. 164).
\end{abstract}

As observações de Spix também permitem reconstruir os fatores de produção e como o trabalho era organizado nas lavras escravistas. A quantidade de trabalhadores envolvidos permite entender melhor como se desdobrava o povoamento na Serra do Cabral. Com o Barreirinho já em atividade, beiras de outros córregos e rios começaram a ser explorados, entre

\footnotetext{
178 “Tenha o escravo, porém, a felicidade de achar um diamante de mais de dezessete quilates e meio, é logo enfeitado de grinaldas de flores e conduzido em alegre procissão até a administração. Esta lhe concede a alforria, que é paga ao dono pela caixa" (ESCHWEGE, 1979, p. 137).

179 A crítica do barão diante do fato de um mulato possuir escravo abre a possibilidade para se pensar a estratificação social em uma colônia que caminhava para o seu processo de independência dentro de um contexto de construção do liberalismo enquanto modelo de sociedade. A transformação econômica, desencadeada na Europa ocidental no século XVIII pela Revolução Industrial, colocava em pauta o direito de propriedade privada, bem como, no século seguinte, engatinhava a discussão acerca de direitos civis. Isso significava que no Brasil, sobretudo durante o Império, os homens livres pobres, incluindo os "de cor", usavam mecanismos diversos para inserção em uma sociedade fortemente estratificada, cujo sinônimo de poder econômico era, entre outras formas, ter a propriedade de escravos. Ivan Vellasco, analisando o recurso dos livres pobres à justiça nas Minas Gerais, afirma que o contexto em que a capitania se tornava abastecedora do Centro-Sul e da Corte demandava a existência de um mercado, cuja viabilidade se articulava com a presença do fórum. Para ele, os sujeitos livres que não estavam nos extremos da estrutura social escravista já não eram mais movediços, ou seja, os "desclassificados" já haviam sido absorvidos socialmente, mesmo que em condições marginais. Havia, naquele período, um alargamento na base social de pequenos proprietários de escravos, o que garantia a base de sustentação política e social do regime escravista. O que mulatos e negros livres desejavam era ascensão e inclusão sociais no Império, e a posse de escravos era uma porta aberta, "Ou seja, estariam eles, tanto quanto os brancos proprietários, suficientemente comprometidos com o sistema escravista para não desejar a sua desestabilização, vale dizer, para não desejar a desestabilização da ordem reinante sobre as coisas e os homens" (VELLASCO, 2005, p. 175). Querer fazer parte da sociedade escravista e reconhecer a justiça era legitimar o Estado moderno brasileiro que então nascia, cujas relações de trabalho afirmavam o ethos de sua existência naquele contexto mundial.
} 
elas as do córrego do Barreiro, que posteriormente daria origem e consistência ao povoamento de Conceição do Barreiro e Buriti Grande.

\begin{abstract}
Vigiam muitos capatazes feitores, o trabalho dos negros; daqueles havia, no ano de 1818, uns cem. Para esse ofício, escolhem-se, de preferência, homens brancos, e costuma-se pagar a cada um $300 \$ 000$ anuais. É sua obrigação incitar os negros ao trabalho; vigiá-los, a fim de que entreguem devidamente as pedras achadas; e, nos dias de descanso, nas suas casas ou na ocasião de suas festas barulhentas, velar para que observem ordem e sossego. Dez administradores exercem não somente o controle sobre os feitores e pesam diariamente, ou ao menos uma vez por semana, os diamantes achados, que, logo em seguida, guardam num saquinho de couro, e prendem à cinta, até que os entreguem à administração de Tejuco; dirigem eles também os trabalhos maiores em parte de mineiro, como: a limpeza dos leitos de rio, o arrebentar de rochas com explosivo, a colocação dos maquinismos, a escolha do cascalho e da areia a serem lavados etc.. Os administradores moram, portanto, sempre ao lado das lavras, serviços mais importantes, de onde uma vez por semana vão, a cavalo, ao Tejuco a fim de fazer a entrega dos diamantes à Junta de Extração. Esta Junta faz um exame mais rigoroso das pedras preciosas, pesa-as novamente, e registra-as no livro segundo o peso, ou cada uma ou em partidas. Para o pagamento do aluguel e sustento dos escravos, compra de aparelho de mineração, construção de máquinas e salário dos numerosos funcionários, recebe a Junta Diamantina, anualmente, do erário real de Vila Rica, 300.000 cruzados. Hoje, 120.000 cruzados dessa quantia emprega a Junta nos salários, 100.000 no resgate de obrigações, que ela emitiu em lugar do pagamento em espécie, em tempos passados, quando se empreenderam dispendiosas obras de mineração, até a vultosa quantia de 1.000 .000 de cruzados. Toda a dívida deverá ser amortizada em dez anos e, em seguida, de novo se empregará no trabalho maior número de negros. (SPIX, 1981, p. 33-34, grifos do autor).
\end{abstract}

A descrição de Spix ilustra não apenas a divisão do trabalho, estratificada pela cor da pele, como também as etapas do serviço de mineração, que envolvem uma transformação constante da paisagem natural. Ela traz ainda a informação de maquinário introduzido nas lavras, havendo investimento em capital constante, além dos salários pagos aos trabalhadores livres e o lucro adquirido, que seria empregado tanto na aquisição de mais maquinário quanto na compra de mais escravos.

Em sua queixa, o barão de Eschwege retoma a questão do trabalho e seu estigma numa sociedade escravista, na qual a visão social do serviço estava associada ao cativeiro, conforme já mencionado, além da já comentada interpretação preconceituosa dos estrangeiros que aportavam nos trópicos, cujos comentários naturalizavam as relações que observavam sem qualquer reflexão prévia sobre a dependência metrópole-colônia.

A abolição da escravidão ocorreu em um momento em que a extração de diamantes no sertão encontrava concorrentes no mercado externo, como a União Africana, atual África do Sul, submissa aos britânicos. Apesar da crise, a pedra brilhante continuou movendo homens em busca de novas lavras, não sendo a maioria proprietário de terras ou assalariado. Porém, dada a complexidade da sociedade mineradora, os Oitocentos também abrangeram nas atividades antes clandestinas gente de cabedal interessada nas pedras luzidias, com o aval das autoridades 
imperiais. Conforme se verá, a extração na Serra assimilou gente de cor e de condição diversas, já em processo de absorção social.

\subsubsection{Os diamantes do barão retinto por uma narrativa outsider}

Tem-se buscado apresentar as personificações de terra, trabalho e capital para compreender a territorialização do valor. Algumas vezes, o processo revelou personagens na tessitura das relações sociais na Serra do Cabral. Tão importante quanto essas personificações dos fatores de produção, é desvelar quem está por trás da narrativa, considerando-se os interesses e as significações dados àquilo que se conta ou registra. Um caso é o barão de Jequitaí, exposto pelo memorialista montes-clarense Simeão Ribeiro Pires.

Enquadrado pelo historiador Laurindo Mékie Pereira sob a ótica gramsciana, Simeão Pires (*1919-†1999) seria um intelectual agente organizador das classes, aquele que as ajuda a se expressarem politicamente e em nome de seus interesses, uma figura indispensável a qualquer organização (GRAMSCI, 2004 apud PEREIRA, 2015). O autor, a partir de sua origem, dos meios por onde circulou e dos relatos que escolheu produzir tem muito a dizer sobre si, sobre o barão de Jequitaí e sobre as narrativas e vantagens em disputa entre o norte mineiro, o estado e o país. Ele se torna peça importante a partir dos anos 1950, exercendo seu papel de intelectual regionalista durante as décadas seguintes.

Buscando escrever sobre o norte de Minas Gerais, o memorialista nascido em Coração de Jesus revirou documentos no APM e no AHU para buscar informações sobre a história do povoamento na região, se queixando de ser o seu torrão preterido na historiografia nacional:

\footnotetext{
A pesquisa histórica no Brasil tem sofrido do mesmo mal que o cronista imputava ao colonizador - ficar caranguejando pelas praias, não se aventurando em sertões desconhecidos (PIRES, 1979, p. 21).
}

Sua defesa de uma nova narrativa histórica sobre as Minas setentrionais não é ingênua. Indo na contramão do discurso da mineiridade, Simeão Pires foi ativo na defesa da criação do estado de Cabrália, um projeto que buscava formar uma nova unidade administrativa que abrangeria o norte e o noroeste mineiros mais o sul da Bahia, desejo estimulado quando da anexação regional à Sudene. Para ele, o norte de Minas Gerais era menosprezado nas políticas estaduais e federais, sendo preciso redividir o território para planejar o desenvolvimento do sertão dos Gerais. Ele e Expedicto Mendonça ${ }^{180}$ foram agentes decisivos na construção da

\footnotetext{
${ }^{180}$ Nascido em Montes Claros, é economista de formação. Partidário da criação do estado de São Francisco, com limites muito semelhantes ao projeto de Cabrália, via o norte mineiro como depositário de relações feudais e
} 
antimineiridade e do que Laurindo Mékie Pereira chama de nordestinização no norte de Minas Gerais: "Mais do que um discurso ou uma teoria, eles fizeram parte do movimento social e histórico que produziu essas ideias" (PEREIRA, 2015, p. 114).

Para compreender o trabalho do memorialista, que escreveu uma história regional ufanista, é preciso considerar a sua personificação também enquanto sertanejo letrado, filho de duas famílias importantes no norte mineiro - especialmente os Ribeiro, cuja atuação era diversificada, incluindo os segmentos da política, da pecuária, do comércio e da indústria. Seu pai, Luiz Antônio Pires, por exemplo, era coronel.

A maneira como narra a trajetória do barão de Jequitaí e escreve a história regional reflete bastante a sua biografia. Industrial, pecuarista, catedrático em Química, engenheiro civil, ex-prefeito de Montes Claros e membro da Academia Montes-Clarense de Letras (PIRES, 2001), capitalista e, posteriormente, burocrata a serviço de um Estado brasileiro contextualizado no momento do MDB militar. Sua formação inicial de engenheiro civil pela Universidade de Minas Gerais em 1943, corrobora a visão política de começo de século, a qual considerava a Engenharia e a Medicina cursos mais pragmáticos para os envolvidos com os projetos de modernização do país.

Simeão Pires trabalhou como empreiteiro de obras na construção da ferrovia que ligava o norte de Minas Gerais ao sul da Bahia, surgindo desse momento o interesse pela história regional. Mais tarde, em 1957, liderou o I Congresso do Algodão em Montes Claros, representando os industriais e, por isso, requerendo da esfera estadual assistência técnica, crédito e incentivos fiscais. No ano seguinte, foi eleito prefeito de Montes Claros pelo Partido Republicano (1958) e, mais adiante, entre 1966 e 1973, foi vereador pela Aliança Renovadora Nacional (Arena). Sua administração se deu sob a crise pós Governo Juscelino Kubitschek (JK), com a região assolada pela estiagem e pela fome. Foi nessa conjuntura que emergiram o clamor pela adesão regional à Sudene ${ }^{181}$ e os ensaios emancipacionistas, embrião do discurso regionalista em busca de uma identidade sertaneja.

Durante o trabalho com a ferrovia, ele descobriu o códice da Casa da Ponte, tendo despertado ali o interesse por histórias. Seus textos começaram a ser publicados em 1964, no contexto da nordestinização. Além de ter escrito obras ficcionais - como Gorutuba: o padre e a bala de ouro -, Simeão Pires atravessou o Atlântico em busca de documentação que

modernas, carente da presença do Estado. Trabalhou em Brasília nos anos 1960, sendo ferrenho defensor do desenvolvimentismo e da antimineiridade.

${ }^{181}$ De acordo com Laurindo Mékie Pereira (2015), essa adesão foi fruto de negociação política no Congresso Nacional, sustentada por pressões da elite econômica regional, composta por grandes criadores de gado e comerciantes, diante da resistência dos governadores nordestinos. 
apresentasse a formação do morgado dos Guedes de Brito, resultando no livro Raízes de Minas, um dos textos-base para Erivaldo Fagundes Neves na pesquisa sobre a passagem histórica da sesmaria ao minifúndio no sertão baiano. Para justificar a adesão do norte mineiro à abrangência da Sudene, o autor recorreu a uma narrativa histórica que apresentasse a maior ligação entre Minas Gerais e o Nordeste, heroicizando o mestre de campo Manoel Nunes Viana enquanto vilanizava o conde de Assumar, governador da capitania de Minas Gerais ao longo do século XVIII. Nessa obra, ele defende o pioneirismo baiano na colonização do território que viria ser o norte de Minas Gerais por meio da pecuária e que posteriormente, na sua interpretação, seria invadido pela sociedade mineradora.

\begin{abstract}
A primazia baiana ou paulista na colonização do norte de Minas é um antigo debate. Para os objetivos deste artigo, importa identificar os argumentos de Pires. Para este, antes da mineração, os baianos haviam constituído os "currais" às margens do Rio São Francisco e do Rio Verde. Do ponto de vista administrativo, a margem esquerda do São Francisco pertencia à Capitania de Pernambuco e a margem direita à Bahia. A materialização do domínio baiano seria a exploração efetiva realizada pelo "regente do São Francisco", Antônio Guedes de Brito. (PEREIRA, 2015, p. 121).
\end{abstract}

Com certa dose de vaidade, Simeão Pires tinha pretensões de ser lembrado como um intelectual que enfatizava a ocupação baiana nos sertões mineiros, minimizando a importância do povoamento bandeirante do Sudeste, conforme ressalta a historiografia paulista da primeira metade do século $\mathrm{XX}^{182}$. Sem as amarras de um historiador comprometido com os métodos do conhecimento historiográfico, produziu uma obra em que escolheu a dedo os documentos que corroboravam suas ideias, sem questionar sua veracidade ${ }^{183}$. O conteúdo que apresenta é relevante, apesar da pouca neutralidade na abordagem que deu, pois tomou partido em muitos momentos narrados nos seus textos. Ainda assim, sua contribuição ao conhecimento do barão e dos fatos norte-mineiros são muito importantes e foco de particular interesse.

A obra que se considera mais relevante é um lançamento póstumo, Serra Geral: diamantes, garimpeiros e escravos, que aborda, além do assunto enunciado no título, o pouco que se sabe sobre o barão batizado de Jequitaí, nome do rio que margeia a Serra do Cabral.

\footnotetext{
${ }^{182}$ Apesar das abordagens diferentes no que concerne às bandeiras, ao reforçar a presença baiana na ocupação das margens do rio São Francisco, Simeão Pires caminha para a mesma direção que Aroldo de Azevedo ao observar que os paulistas geralmente passavam e não ficavam:
}

Descobriam, exploravam, povoavam, mas nunca permaneciam nos lugares que descobriam. Todos os grandes nomes das Bandeiras foram morrer longe do lugar que descobriram ou fundaram. Nenhuma cidade mineira conserva os ossos de seus fundadores, ou, ao menos, os seus descendentes. (AZEVEDO, 1957, p. 17).

${ }^{183}$ Em Raízes de Minas, por exemplo: "Segundo o depoimento de Antonil, que esteve na região das minas de 1701 a 1703 [...]" (PIRES, 1979, p. 69). Antonil escreveu toda a Cultura e opulência do Brasil sem ter saído de Salvador, nunca tendo posto os pés na capitania das Minas Gerais. 
Simeão Pires (2001) comenta que os diamantes são descobertos no Serro entre 1700 e 1730; em 1781, acham-se pedras na Serra de Santo Antônio do Itacambiruçu, com muita gente escorraçada do Tejuco indo para lá. Com a rigidez de acesso e de vivência no Distrito Diamantino, essa leva de sujeitos impedidos de garimpar naqueles limites e embrenhados pelo sertão extramuros da Demarcação compôs parte daqueles que se instalaram na Serra do Cabral com o intuito de buscar diamantes ${ }^{184}$.

O estudo de Ivana Parrela sobre o caso de Grão Mogol, cuja serra é próxima à Serra do Cabral, corrobora a afirmação de Simeão Pires, pois na prática,

[...] locais como a Serra se tornariam pontos de fuga para a população pobre das Minas, excluída das possibilidades de riquezas oferecidas pelas lavras diamantinas ou, mesmo, às auríferas, com as quais se misturavam. (PARRELA, 2009, p. 162).

Para a autora, a Serra de Santo Antônio de Itacambiruçu vinha sendo explorada clandestinamente muitos anos antes do Regimento Diamantino, sendo ocupada pelos garimpeiros ilegais camuflados de caçadores de veados. Segundo as autoridades metropolitanas, “a exemplo da Serra de Santo Antônio, não há canto, serra, nem córrego pelo sertão que não seja visto e examinado dessa gente vadia, a ver se topam algum haver, que lhes faça conta” (PARRELA, 2009, p. 15, grifos da autora).

A análise dos mapas, em destaque o acervo de José Joaquim da Rocha, supõe que o garimpo de diamantes na Serra do Cabral já era realizado clandestinamente pelo menos desde princípio dos Oitocentos. Apesar de não se ter encontrado grande registro oficial de descoberta e instalação de garimpeiros e fazendeiros na Serra do Cabral além do acervo de anuários constante no APM, tem-se a narrativa de Simeão Pires sobre o Barão de Jequitaí, Cipriano de Medeiros Lima, tido como o maior criador de gado do norte de Minas Gerais no século XIX e pioneiro no empreendimento de garimpar diamantes à beira do rio que lhe deu o nome.

\footnotetext{
${ }^{184}$ Qualquer atividade de extração além do Distrito que remeta ao período colonial, era clandestina. Sabe-se que na Serra do Cabral, a divulgação oficial dos achados foi posterior. Sobre o Distrito Diamantino e o regimento de 1771 , lugares, a extração era severamente proibida, medida que se adotara para reduzir a produção e manter os preços, bem como para facilitar a cobrança dos direitos da coroa e impedir o contrabando. (PRADO JÚNIOR, 2006, p. 181).
} 
Figura 16 - Barão de Jequitaí (sem data)

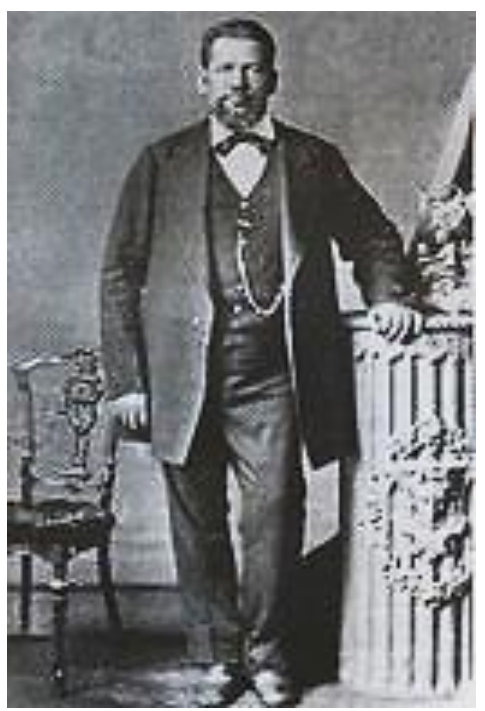

Fonte: acervo do IHGMC.

Figura 17 - Escombros de uma das casas de fazenda do barão, povoado do Carrapato

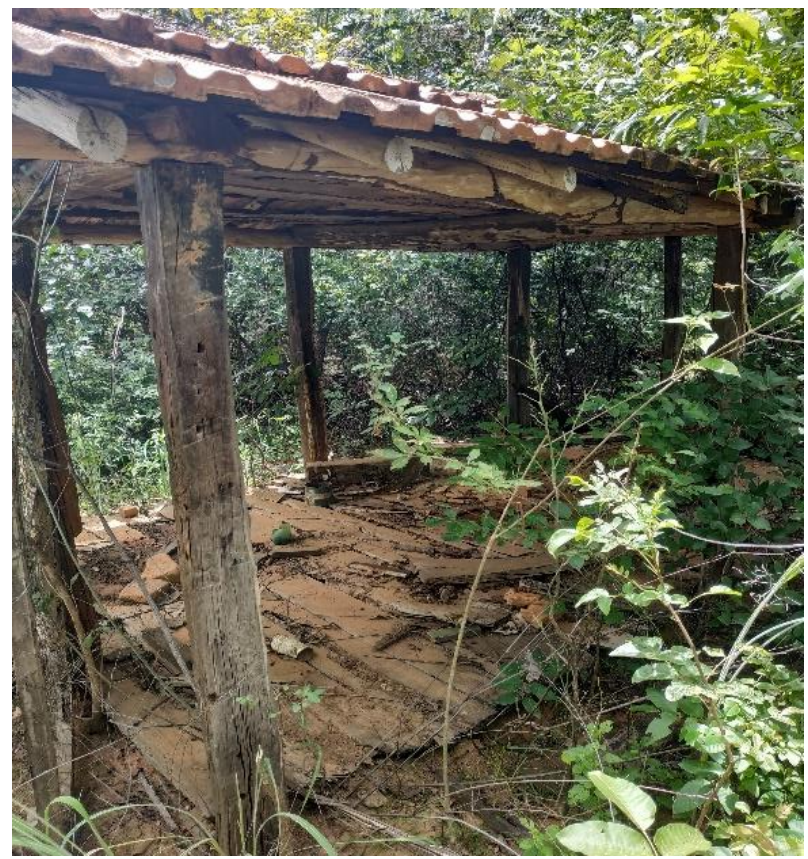

Fonte: acervo pessoal, janeiro de 2018.

Nascido na fazenda do Cedro no arraial do Bonfim em 1829, Cipriano de Medeiros Lima teve acesso ao que o autor chamou de "estudo primário". Ainda jovem, foi trabalhar na fazenda Brejo Grande, cujos donos mais tarde morreram sem deixar herdeiros. Simeão Pires não informa como, apenas que Cipriano conseguiu recursos e arrematou a fazenda de porteira fechada. A partir dela, começou a aumentar seu patrimônio. Não foram encontradas informações sobre sua ascendência. 
Tendo se tornado senhor de terras e grande pecuarista, ganha concessão do Império e se torna major comandante da seção da reserva do $28^{\circ}$ Batalhão da Guarda Nacional dos municípios de Montes Claros e Guaicuí. Seu cabedal foi construído sobre a cobrança de dívidas dos fazendeiros da região do Urucuia onde, dada a fama popular do local, predominava a lei da valentia. Cipriano comprava as dívidas dos comerciantes com um desconto de $50 \%$ e, para fazer o negócio, chegava nas fazendas à frente de sua tropa particular - leia-se jagunços - com armas colocadas à vista, ar solene e disposto a ditar as regras da quitação.

Discorrendo sobre a criação e o exercício da Guarda Nacional, Erivaldo Neves (2008) a vê como certa continuação das milícias coloniais, pois apesar de serem autônomas, estavam a serviço da Coroa, com o objetivo de manter a posse territorial. Expressão do poder local, cujo mando emanava da propriedade fundiária, a milícia instrumentalizava o domínio colonizador, insubordinando-se à Coroa conforme seus interesses particulares eram ameaçados. $\mathrm{O}$ sentimento nativista desencadeado por ela figura entre os responsáveis pelo colapso colonial.

As estruturas paramilitares da Colônia não se modificariam na transição para o Estado Nacional. A curta existência do Exército e da Armada, criações da constituição de 1824, constituídas por tropas regulares remuneradas e coexistentes à persistência das milícias, daria lugar à Guarda Nacional em 1831. Esta, vista como uma tropa de elite, ganhou prestígio na conjuntura de civismo do pós-Independência: pertencer aos seus quadros seria a maior honra que um homem de posses poderia aspirar, para dar provas de sua importância social e política em uma sociedade onde não havia nobreza. Com isso, os títulos tornaram-se objeto de disputa entre as famílias mais abastadas, especialmente entre os "lordes da violência organizada da elite latifundiária, que comandava exércitos particulares de jagunços” (NEVES, 2008, p. 238).

Ao mesmo tempo, a Guarda Nacional representava o instrumento militar que o segmento social dos senhores de terra e de escravos necessitava na luta para se manter no controle do aparelho de Estado. A Guarda seria a expressão de um pacto que não poderia ser sustentado para sempre entre os grandes empreendimentos agroexportadores e a monarquia escravista, ambos parte do sistema colonial, definidos pela falta de autonomia (e de aparência de autonomia) entre o capital comercial escravista e o exercício do poder como ferramenta de territorialização desse capital. Conforme aponta Ana Carolina Leite, "a acumulação (comercial) do primeiro significava a acumulação primitiva do último” (LEITE, 2010, p. 167).

O barão se valeu dessas condições, ou seja, tanto de garantir o poder sobre terra e escravos quanto do uso e abuso da violência para a prosperidade dos seus negócios. Integrante da Guarda Nacional, ele se utilizou de uma instituição que permite criar condições regionais 
para produção e apropriação de excedentes, compondo uma esfera pública que era interpretada por seus quadros como particular para realizar a acumulação.

Em suas andanças, percebeu o potencial viário do rio São Francisco, considerando que os núcleos de povoamento de todo o norte de Minas Gerais consumiam mercadorias do Nordeste chegadas pelo rio. Entusiasmado, por meio da lei n. 3.694 conseguiu a concessão do governo da província de Minas para a construção e administração da estrada de ferro de Montes Claros ao porto de Extrema (atual município de Ibiaí), que depois foi vendida para uma companhia da Corte do Rio de Janeiro.

O barão era pardo, o que se considera um exemplo concernente à absorção, mesmo que muito pequena, da gente de cor à sociedade oitocentista ${ }^{185}$. Sobre o barão e o diamante na Serra, Simeão Pires relata:

Nos últimos anos de sua vida, Cipriano tornara-se uma potência: rico, trabalhador e com numerosos amigos.

Ao tempo não existiam bancos.

O numerário para os serviços da lavoura e compra de gado era conseguido com ele, pois se tornara um banco sempre aberto para os amigos.

Entretanto, Aprígio Pereira Lima, um amigo bem distante, teve dificuldades financeiras para tocar um serviço de virada de rio (desvio do curso do rio em pequeno trecho) no Rio Jequitinhonha.

Da Vila de Terra Branca envia uma carta solicitando empréstimo de cinco contos de réis.

O também conhecido Aprígio Terra Branca era afamado garimpeiro e capangueiro (comprador de diamantes) na região do Jequitinhonha.

$\mathrm{Na}$ carência de capital para os serviços, sempre se servia do velho amigo Cipriano.

Foi portador da carta um preto escravo de sua absoluta confiança.

Prontamente atendido pelo destinatário, ao se despedir de Cipriano, o escravo ajoelhou-se aos seus pés para uma revelação fantástica:

- Sinhozinho, o Rio Jequitaí tem diamantes e dos bons. Da banda de lá, na hora que eu estava comendo a matula (farofa de carne) no dia de ontem, eu vi um caldeirão na praia, cheio de pedra roladeira, no jeitinho das que conheço no Rio Jequitinhonha. Juntei com as mãos e lavei elas no meu chapéu de couro. E foi nesta ocasião que brilhou estas duas lindezas de pedras.

Passando às mãos de Cipriano um picuá ${ }^{186}$ de taboca de bambu com dois belos diamantes, os olhos vivos de Cipriano brilharam intensamente, vendo a luz do sol refletir nas facetas das duas gemas preciosas.

Tal fato aconteceu no ano de 1875 e o relato foi colhido pelo jornalista José Alves Macedo. Do então prefeito de Jequitaí - Coronel Daniel da Fonseca Júnior. O Desembargador Antonio Augusto Veloso confirma a exatidão da data de descobrimento do diamante. (APM, vol. II p. 597).

Narra a tradição oral que Damião, o escravo de Aprígio, regressou à Terra Branca levando o numerário pedido, junto a uma carta em que Cipriano solicitava, com

185 Cabe salientar que essa absorção, conforme Ivan Vellasco (2005) defende, se insere no lento processo de transição para uma sociedade de trabalho livre, cuja absorção era econômica, mas ainda muito restrita ao campo político. Complementando essa interpretação com a clássica proposta por Gilberto Freyre em Sobrados $e$ mucambos, o barão representaria a ascensão do mulato em um país recém-independente e posto diante da inevitabilidade de se modernizar.

186 “Picuá é de origem tupi, uma espécie de balaio ou cesto utilizado pelos índios. Já no garimpo, era uma 'peça geralmente de chifre em que os mineiros guardam diamantes' (HOUAISS; VILLAR, 2009)" (JERÔNIMO \& DE PAULA, 2013, p. 82). 
urgência, escravos entendidos do serviço de mineração, mais os seguintes apetrechos, por indicação do preto escravo: duas alavancas de ferro, seis carrinhos de pau, quatro bateias e uma roda d'água.

[...]

Em poucos meses, graças à administração direta de Cipriano e ao número de escravos no serviço, alguns quilos de diamante foram colhidos. (PIRES, 2001, p. 213-214, grifos do autor).

Com capital inicial para investir na extração oriundo da cobrança de dívidas e da atividade pecuária na região, o barão de Jequitaí iniciava o trabalho na beira do rio São Francisco. Com jazidas promissoras, surgia na margem do curso d'água a primeira lavra de diamantes oficial na Serra, com escravos no serviço. O labor na beira do rio começou bem, pois ali "foi achado, em 1884, um diamante com o peso de 14 oitavas e 46 grãos. Ahi fizeram fortuna na mineração de diamantes o fallecido Barão de Jequitahy (Cypriano de Medeiros) e outros mineiros" (SENNA, 1909, p. 679).

Para Caio Prado Júnior (2006), a indústria mineradora já se encontrava em ruína no alvorecer do século XIX, sendo que em 1882, antes da descoberta "oficial" de diamantes nas margens do rio Jequitaí, o monopólio oficial de extração do mineral já estava extinto, sobrando à iniciativa privada o interesse, caso houvesse. Quando as dificuldades de garimpo apareciam e sua produção era limitada, surgiam os trabalhos individuais e nômades de faiscação, o que será comum ao longo do século XX e muito mal visto do período colonial ao Império, pois o garimpeiro era considerado arredio, imagem que muda ao longo do século $\mathrm{XX}$, se transformando no verdadeiro desbravador do sertão e expansionista das fronteiras nacionais, bem representado por Joaquim Felício dos Santos (1868).

Em relação à dinâmica de produção, é preciso lembrar oportunamente o contraponto entre a regressão econômica de Celso Furtado (2007) - para quem o ocaso da mineração revolve as atividades de vulto, tornadas economicamente pobres e de subsistência - e a vívida economia interna apontada por Robert Slenes (1988), Márcia Menendes Motta (1998) e outros - ele apresenta a continuidade da mineração e o comércio regional de cativos, enquanto ela argui sobre o dinamismo da produção agrícola. Condizendo com esta última posição, apesar de reduzida à extração de diamantes, ela continuou acontecendo e foi o que permitiu aos mineiros mais abastados comprarem escravos ao longo do século XIX. A decadência da Demarcação Diamantina e o fim da proibição de garimpar fora dela estimularam buscas por pedras em todo o norte mineiro, que já aparecia como promissor a partir da expedição de Vieira Couto à mando 
de D. Maria. Ou seja, a mineração ainda acontecia com ímpeto no sertão no século XIX, do barão de Jequitaí a Felisberto Dayrell ${ }^{187}$.

A crise diamantífera não significou, portanto, o fim da extração. Para o caso das lavras na Chapada Diamantina, Carlos Toledo analisa a organização da extração das pedras na Bahia, apresentando um quadro semelhante ao da Serra. Se o empreendimento era promissor, surgia a exploração em lavras, espécies de empresas munidas de aparelhamento especializado e com direção central, em que trabalhava mão de obra escrava, com o emprego excepcional de homens livres - como intentado pelo barão. Se os achados escasseavam, a faiscação aparecia, representada por explorações individuais e nômades. Os garimpeiros podiam se reunir no mesmo ponto, porém cada qual trabalhando individualmente e por conta própria, valendo-se de instrumentos rudimentares. As faiscações sempre existiram, porém se generalizavam no ocaso da mineração (MACHADO NETO; BRAGA, 1974 apud TOLEDO, 2001).

Se é verdade que o diamante foi oficialmente descoberto nas margens do Jequitaí no último quartel do século XIX, a atividade foi realizada com braço cativo por pouco tempo. Como já se tinha alertado, não só a Guarda Nacional se sustentava sobre uma realidade de condições limitadas, como a narrativa de Simeão Pires lamenta a abolição do trabalho escravo poucos anos depois. Para ele, esta seria a causa da decadência do barão, uma vez que não haveria mais braços para revolver o cascalho do rio e levar o mais-produto ao seu proprietário. Condizente com a sua atuação intelectual e política, Simeão Pires acusa as decisões do poder centralizado de inconsequentes para a involução do norte mineiro; tivera o escravismo permanecido, as Minas Gerais setentrionais seriam prósperas, pois o empreendedorismo de sujeitos como o barão necessitava de incentivos.

Assim, em 1891, Cipriano faleceu empobrecido (conforme julgou seu memorialista), quando entregava cerca de mil cabeças de gado em lugar denominado Pedra da Brígida, nas proximidades de Várzea da Palma, não chegando a colher as benesses do novo empreendimento em que se arriscava.

Por ironia, mal se abriam as perspectivas altamente promissoras para os garimpos do Jequitaí, fechavam-se todas elas baseadas no braço escravo. Também, naquela época, chegaram ao fim as rígidas determinações do Livro da Capa Verde, pela exaustão completa dos serviços fáceis do Tijuco e do Grão Mogol, de apenas colher nas areias do rio e em pequenas cicatrizes de desmontes hidráulicos, os diamantes e o ouro. (PIRES, 2001, p. 216).

\footnotetext{
${ }^{187}$ Pai de Alice Dayrell Caldeira Brant, de pseudônimo Helena Morley. No século XIX, com a abertura de novas atividades na América, como as minas, tanto de ouro quanto de diamante, houve um afluxo de população europeia, pondo-se ela também a fazer trabalhar a mão de obra indígena ou mesmo de origem africana: "A população emigrante pôde então escapar ao seu destino de proletária na Europa, para se tornar exploradora no Novo Mundo!" (GAUDEMAR, 1977, p. 365).
} 
Apesar de ter legado um patrimônio menor do que tivera acumulado no auge da vida, Simeão Pires apresenta uma lista de fazendas deixadas pelo barão como herança para os filhos (de quem não se teve notícia) e para os funcionários da fazenda. Todas as propriedades estão localizadas na Serra do Cabral, duas delas em Francisco Dumont, onde até há pouco resistiam os escombros da casa sede (PIRES, 2001) ${ }^{188}$. Boatos ventilam que deixou 25 fazendas, totalizando mais de 35 mil alqueires com mais de 30 mil cabeças de gado e mais de uma centena de casas em arraiais e povoados, além de 600 contos de réis em diamantes, mais de 800 contos de réis em empréstimos e cerca de 500 contos de réis em dinheiro vivo.

A queda do barão exemplifica o lento processo de declínio dos coronéis, pois a Guarda Nacional teve que se submeter a novas condições diante da transição para o regime republicano e o fim da sociedade que defendia, escravista e monárquica. Contudo, permaneceu por mais algumas décadas na condição de instrumento do poder local das oligarquias fundiárias, com os coronéis da velha milícia a formar seus exércitos particulares de jagunços, guerreando entre si e contra governos estaduais (NEVES, 2008).

Assim como o barão, Riobaldo, personagem de Grande sertão: veredas, também era sertanejo pardo, nato homem livre pobre que ascendeu socialmente pelos idos do século XIX, após suposto pacto com o Demônio. De expropriado e bastardo a jagunço valente, ascendeu a chefe de bando até se tornar barranqueiro na beira do Urucuia, contraindo casamento com filha de fazendeiro e herdando terras de seu padrinho. Enquanto pobre e homem provisório, tinha consciência de seu lugar naquela sociedade. Conforme termina vitorioso a batalha contra o bando rival e recebe as notícias de casamento e herança, se vê repentinamente cercado de amigos da mesma posição social.

\begin{abstract}
Mas em tanto, com as mudanças e peripécias, no afinco de tudo lhe referir, ditas conforme digo - não toco no nome de Otacília? Nela eu queria pensar, na ocasião; mas mal que, cada vez, achava mais custoso. A ser que se nublando a sustância da recordação, a esquecida formosura. Assim a nossa conversação de amor, lá na Santa Catarina, não consistisse mais do que em uma estória alheia, escutada de outra pessoa contar. Sei que eu queria uma saudade. Para isso rezei, a todas as minhas Nossas Senhoras Sertanejas. Mas rebotei de lado aquelas orações, na água fina e no ar dos ventos. Elas, era feito eu lavrasse falso, não me davam nenhuma cortesia. Só um vexame, de minha extração e da minha pessoa: a certeza de que o pai dela nunca havia
\end{abstract}

${ }^{188}$ Novamente, as memórias de Riobaldo cruzam imaginação e veracidade, tanto no seu sertão fictício quanto na realidade da Serra:

Agora, por aqui, o senhor já viu: Rio é só o São Francisco, o Rio do Chico. O resto pequeno é vereda. E algum ribeirão. E agora me lembro: no Ribeirão Entre-Ribeiros, o senhor vá ver a fazenda velha, onde tinha um cômodo quase do tamanho da casa, por debaixo dela, socavado no antro do chão - lá judiaram com escravos e pessoas, até aos pouquinhos matar... [...] (ROSA, 1986, p. 60, grifos do autor). 
de conceder o casamento, nem tolerar meu remarcado de jagunço, entalado na perdição, sem honradez costumeira.

$[\ldots]$

Eu já estava de todo bom, forme para as arremessadas, quando ali na Barbaranha se surgiu para mim igualmente a visita de seô Habão - ele com o seo Ornelas se tivessem entre tempos pacificado. Homem baseado. Demonstrou que tinha muita satisfação em me ver, assim como para mim vinha trazendo outro cavalo de presente - o qual era ruço-rodado, ordem de valor e estampa. Ali agraciado aceitei, meu sinceramente. Mas ele portava causa maior - a que tinha ido confirmar e saber, e agenciar, por seus bons préstimos. E era que meu padrinho Selorico Mendes acabara falecido, me abençoando e se honrando, orgulhoso de meus atos; e as duas maiores fazendas ele tinha deixado para mim, em cédula de testamento. Seô Habão queria logo me levar lá, no Curralim, no Corinto, para eu entrar em paz de posses. Rejeitei; adiei, isto é. Porquanto, de fato, fui, e tudo recebi em limpo em, sem precisão de tocar demandas, por falta de outros mais legítimos herdeiros, e o que também devido dou ao advogado meu que zelou a sucessão - Dr. Meigo de Lima. (ROSA, 1986, p. 360-361).

Cerro. O senhor vê. Contei tudo. Agora estou aqui, quase barranqueiro. Para a velhice vou, com ordem e trabalho. Sei de mim? Cumpro. O Rio de São Francisco - que de tão grande se comparece - parece é um pau grosso, em pé, enorme... (ROSA, 1986, 534-538).

Assim como Riobaldo, que galgou posições conforme se valia de sua valentia, Cipriano também andava cercado de seus jagunços e enriquecia cobrando as dívidas alheias. Em uma sociedade em que a tez diferenciava o tratamento, ambos pardos e sertanejos integraram uma pequena parcela de gente de cor que teve acesso à alfabetização, sendo a personagem ficcional uma alegoria do homem que soube gerar patrimônio por meio da violência e astúcia.

O barão de Jequitaí deixou claro em seu espólio aquilo que os Borém ocultam: a extração de diamantes. Diferenças à parte - o barão investiu pesado na empresa, enquanto, ao que parece, os Borém preferiam apenas controlar o acesso à terra e comprar as pedras -, Cipriano representa bem as formas diversificadas de investimento para a sua época, destacandose a relação entre garimpo e pecuária na Serra. Ao cobrar as dívidas rodeado de jagunços e ter uma vida cercada de amigos, personifica o coronel com valentes e clientes à sua volta, com vias à imposição da violência para extrair riqueza.

\subsection{Os garimpeiros na travessia da modernização}

Comentou-se a partir do texto de Aroldo de Azevedo (1957) que no processo de povoamento da América Portuguesa a fundação de arraiais se deu, em sua maioria, por obra do assentamento de mineradores, provavelmente precedidos por garimpeiros instalados provisoriamente devido ao já mencionado caráter clandestino do ofício que exerciam. Até o século XX, o atual município de Bocaiúva era arraial do Senhor do Bonfim, tendo sob sua administração um conjunto de povoados na Serra do Cabral. 
O arraial foi fundado ainda no século XVI pelas expedições de Spinoza e Navarro, antecedentes da bandeira de Fernão Dias Paes, todas à procura de riquezas. Oficialmente, não há registros de achados preciosos no momento de sua fundação, mas a solidificação do assentamento na região se deu graças à instalação de fazendas de pecuária e à consolidação dos caminhos do gado, que posteriormente levariam às minas.

As fazendas que se espalharam pela Serra mantiveram o caráter de dispersão populacional na região. Porém, a historiografia aponta para a existência dos garimpeiros que transitavam pelo sertão para exercerem seu mister às escondidas. Ao descobrirem uma jazida, logo construíam uma choça para o abrigo das intempéries ${ }^{189}$. Muitas vezes, a família inteira habitava as palhoças, que iam se firmando com material mais resistente conforme o trabalho perpetuava; muitos outros garimpeiros eram atraídos pelo descoberto, propiciando aglomeração de gente.

As memórias de Joaquim Felício dos Santos descrevem a formação dos povoados oriundos do garimpo. O mineral extraído da terra estimulava a concentração de gente, dando lugar a casas de alvenaria. Estabelecia-se uma olaria na vizinhança, aperfeiçoavam-se as primitivas edificações e tratava-se logo de procurar um sacerdote e edificar uma capela debaixo da invocação do santo que se escolhia como padroeiro (SANTOS, 1978 apud PÓVOA NETO, 1998). Abertamente partidário da caracterização do garimpeiro como sujeito livre, aventureiro, rebelde e responsável pela expansão territorial do país, o autor compara as formas de ocupação empreendidas por mineiros e agricultores. Para ele "o mineiro é alegre, prodigo, descuidado, indiscreto, só vê o presente; o agricultor é severo, economico, amante da riqueza, desconfiado, circumspecto, e inimigo dos prazeres ruidosos" (SANTOS, 1868, p. 430). Acredita-se que o processo de ocupação descrito tenha se dado de forma semelhante na maior parte das povoações da Serra sob a jurisdição do arraial do Bonfim. ${ }^{190}$

\footnotetext{
189 Repetindo as formas de improviso do século XVIII, nas quais os garimpeiros, incluindo os reinóis aqui desembarcados em busca de "fazer a América" antes da intromissão do Estado, "não se ocupavam em providenciar maiores comodidades às suas vidas que um casebre de pau a pique para se protegerem das intempéries, um jirau, ou uma rede, para dormirem, algumas poucas ferramentas e alimentos" (DIAS; DIAS, 2018, p. 305).

190 "Para não procurarmos exemplos longe de nós, comparem-se a Govêa, Curimatahy, Rio Manso, Penha, Rio Preto, Arassuahy, povoações agricolas, com o Mendanha, Curralinho, S. João, Chapada, Datas, povoações mineiras. Na distáncia de menos de uma legoa mudão-se repentinamente o aspecto das povoações e o genio dos habitantes. É que a vida do agricultor é tranquilla, pacifica, serena: elle só se inquieta com as irregularidades das estações : a vida do mineiro é mais ou menos aventureira, cheia de azares, de vicissitudes ; tudo póde contrarialo, as estações, a terra, as pedras, as aguas, os rios, os areões, os rochedos, e mais que tudo a pobreza do terreno ; vive em eterna luta com a adversidade, mas sempre esperançoso e confiado na sua boa estrella ; em certos momentos o mineiro é até supersticioso.” (SANTOS, 1868, p. 430).
} 
Em 1906, Carlos Ottoni empreendeu uma viagem de Diamantina ao São Francisco, tendo deixado na Revista do Arquivo Público Mineiro as seguintes impressões sobre a Serra do Cabral e alguns de seus povoados:

\footnotetext{
A fortuna, porém, do sertão é o gado.

Eu tenho tantas cabeças de gado, diz o capitalista do sertão, como dizem os banqueiros - eu tenho tantos contos de réis.

A serra do Cabral é uma serra de abas largas, para cujo cimo o gado refugia-se no tempo da secca, procurando pasto verde ; mas a onça arsola os bezerros, ficando as vaccas com os ubres cheios.

Nessa risonha serra ha tambem grandes serviços de mineração.

Ao continuar a viagem rasgaram-se a meus olhos os mais formosos panoramas, sempre com multicôres tóques de luz.

Vi uma linda varzea polvilhada de aves aquaticas, um pouco além - o Embaiassaia, considerado a emboscada da morte - um dos logares mais pestilentos do caminho. Quem viaja precisa de estar precavido dos antidotos contra as febres.

A temperatura era de fogo, o calor escaldante de queimar a pelle. Nenhuma viração nas folhas.

Atravessamos seis corregos seccos, inteiramente cortados.

E dormi no Barreiro - um lindo local, onde vimos correr touros por amadores sertanejos. As mulheres do logar enfeitavam-se garridamente com flores vermelhas de papagaio.

No dia seguinte, transpondo o rio, abraçava o velho coronel Almeida no serviço de sua mineração.

$\mathrm{O}$ rio Jequitahy é um rio diamantino de pedras torneadas, formando cavernas e rebojos, com diversas cachoeiras em todo o percurso.

A Lavra e rica. Nesse rio, em 1884, achou-se um diamante com o peso de 14 oitavas e 46 grãos. (OTTONI, 1906, p. 673, grifos do autor).
}

O excerto denuncia a permanência da mineração no alvorecer dos Novecentos, no momento realizada por um velho coronel no córrego Embaiassaia. Diferentemente dos inventários, a revista expõe o trabalho de coronéis latifundiários criadores de gado e sua relação com a exploração de pedras que vinha acontecendo, apesar da historiografia em peso defender o fim de um ciclo mineral ainda no século anterior.

Reforça-se na descrição a dedicação econômica à pecuária na Serra - pois "o gado é a fortuna do sertão" -, enquanto o serviço de mineração era distribuído ao longo do rio Jequitaí, ambas as atividades fomentando os núcleos de povoamento. O observador captou também o problema das febres sertanejas, além de oferecer uma breve descrição do atual município de Francisco Dumont, então Barreiro.

Três anos depois, o anuário de 1909 noticia a descoberta de jazida de ouro que, pelo que se sabe a partir das entrevistas, foi um pequeno achado no povoado do Buriti Grande, logo esgotado: 


\begin{abstract}
A Verdade, de Montes Claros, em março de 1908, noticiava uma descoberta aurifera nesse sitio, sob os seguintes titulos:

$<<$ Importante descobrimento - Mina de ouro - Grande riqueza - Será a região de Montes Claros um novo Klondyke?

E' certo que o descobrimento, nas immediações da cidade, de um magnifico pedaço de ouro, pesando 760 grammas, chamou a attenção do povo nestes ultimos dias. Centenas de pessoas foram no logar denominado Vargem do Barreiro, distante da cidade legoa e meia, avidas de ver o sitio tão afamado, tão rico.

Diversas pessoas acharam muitas pepitas de excellente ouro puro, provando assim a existencia de jazidas riquissimas, de verdadeiro thesouro. $>$

Posteriormente, em maio, informava : <<Continua, animadissimo, o serviço de mineração na Vargem do Barreiro, alli a legoa e meia desta cidade.

De lá, além de muitas que sahem todos os dias, appareceo uma grande pepita que pesou 180 grammas. Está mais que provado que na lavra da Vargem do Barreiro existe uma grande riqueza. (SENNA, 1909, p. 675, grifo do autor).
\end{abstract}

Pouco depois, versando sobre Bocaiúva e seus distritos, o mesmo anuário informa a existência de jazidas diamantíferas e de mineração animada:

- O municipio é muito rico quanto ao reino mineral, encontrando-se em todo o seo territorio, o diamante, o carbonato, cal, salitre, etc., [...].

A mineração está tambem bastante animada nos districtos de Barreiros e Olhos d'Agua. O carbonato (diamante negro) porém, só tem sido encontrado no rio Macaubas. (SENNA, 1918, p. 534).

O "serviço animadíssimo", seja do ouro ou do diamante, era resultado da atração de gente de todo lugar, decidida a revolver aquela paragem sertaneja, movida pela sensação de autodeterminação. Enquanto os donos de fazenda investiam na criação de gado, cabia aos homens e mulheres sem posses revirar os leitos dos rios da Serra - o mito fundador do povoado de Barreiros jaz na disputa narrativa entre duas mulheres garimpeiras: Ana Bonfim, apelidada de Ana das Caveiras, que se arranchou no córrego do Sassafrás para garimpar ainda nos Oitocentos, e Agda, que no mesmo período deixou Grão Mogol para encontrar catas na Serra do Cabral. Entrado o século XX, algumas terras na Serra ainda estavam sem demarcação ou nas mãos da Igreja, o que estimulava o garimpeiro a entrar no mato e improvisar o tempo que passaria embrenhado no sertão procurando riqueza. A atração de gente de vários lugares para as lavras expunha a expropriação da terra daqueles que lá chegavam.

A forma provisória de se instalar no mato, tenha ele dono ou não, revela a instabilidade do garimpo. Esta passagem de Grande sertão: veredas ilustra a precariedade dos homens que se moviam pelo sertão em busca de minerais:

Daí, deu um sutil trovão. Trovejou-se, outro. As tanajuras revoavam. Bateu o primeiro toró de chuva. Cortamos paus, folhagem de coqueiros, aumentamos o rancho. E vieram uns campeiros, rever o gado da Tapera Nhã, no renovame, levaram as novilhas em quadra de produzir. Esses eram homens tão simples, pensaram que a gente estava garimpando ouro. (ROSA, 1986, p. 257). 
O romance se passa em fins dos Oitocentos e, mesmo tomando-se o devido cuidado com o caráter ficcional da obra, a verossimilhança não pode ser desprezada. É interessante notar nessa passagem que os jagunços, alojados em uma fazenda de gado, são confundidos pelos vaqueiros com garimpeiros devido à provisoriedade do rancho que faziam dentro das terras da fazenda para passar o tempo ${ }^{191}$. Isso induz a pensar tanto na forma como o garimpo estava acontecendo na Serra, sobretudo após a abolição, quanto a considerar que vaqueiros e gente pobre de função diversa revezavam seus ganhos com a extração mineral nas terras alheias.

Apesar das descobertas, a faiscação foi marcante no século XX, cujas técnicas de extração permaneceram aquelas realizadas por africanos nas minas centenas de anos antes. Não necessitando de grande aporte financeiro, coube aos homens livres pobres lançarem-se à sorte de encontrar os brilhantes.

Geraldinho Crente, 95 anos (2017), é um exemplo. Morador de Jequitaí, contou ter nascido em Coração de Jesus, sendo negro e filho de pai escravo (morto na década de 1950, com 116 anos, afirma). Chegou à Serra à procura de trabalho na construção da barragem do Cachoeirão, após ter passado a juventude trabalhando em roça alheia, criando porco e bezerro e plantando abóbora na vazante. Da família, era o único a receber salário, 200 réis por dia, ainda rapaz. Atrasos no pagamento, "cansado de viver nu" e sendo vaidoso, desejoso de vestir terno, foi embora, vindo parar no município de Jequitaí - residindo na rua Cipriano de Medeiros Lima até sua morte, em 2018. Bastante lúcido, contou que começou nas lavras da Coruja e de Pau de Fruta, terras sem dono, onde se podia garimpar à vontade.

Geraldinho comentou que a libertinagem da vida garimpeira o fez carecer de regras, tendo se convertido ao cristianismo e, por isso, se tornado o responsável pela organização na área, proibindo a entrada de bebida alcoólica, por exemplo ${ }^{192}$. Segundo ele, só no Pau de Fruta,

\footnotetext{
191 “O jagunço, saqueador das cidades, succedeu ao garimpeiro, saqueador da terra. O mandão politico substituiu o capangueiro decahido." (CUNHA, 1905, p. 218, grifos do autor). Ou seja, as confusões pareciam ser comuns. 192 A conversão ao cristianismo e o rigor de Geraldinho no trabalho não podem ser naturalizados. Silvia Federici (2004), analisando como a burguesia europeia impôs historicamente determinados hábitos de forma a domar o corpo social do proletariado, retoma o debate dos Setecentos europeus, no qual o desenvolvimento capitalista absorveu tanto a ideia de René Descartes - para quem o corpo humano, máquina de ações involuntárias, deveria ser domado pela razão da mente e agir em autocontrole -, quanto a concepção de Thomas Hobbes - que, por sua vez, advogava que, sendo os homens presos aos instintos, caberia ao Estado comandar os corpos dos indivíduos e suas atitudes. Michel Foucault acrescentou à análise que a mecanização do corpo impôs a repressão aos desejos e outros comportamentos, enquanto desenvolveu novas faculdades nos indivíduos, dando origem ao conceito de identidade individual, o que culminaria no homem abstrato dentro da perspectiva marxista. O ideal burguês, deslumbrado pela etiqueta e obcecado pelo corpo, tratou de conquistar o proletariado, esse "ser material bruto e por si mesmo desordenado", que "personificava os 'humores enfermos' que se escondiam no corpo social, começando pelos monstros repugnantes da vagabundagem e do alcoolismo" (FEDERICI, 2004, p. 281). Apesar dos contextos espaço-temporais distintos, observa-se que o trabalhador, representado por Geraldinho, introjetou a autodisciplina como forma de organizar a produtividade, sendo ele mesmo quem impunha sobre os outros garimpeiros e suas famílias a ordem dessa sociabilidade.
} 
houve época em que mais de 700 famílias se arrancharam para viver da extração. Famílias inteiras se ajeitavam em casas de barro e de palha, com mulheres e crianças também envolvidas no trabalho. Até a entrevista, ele possuía uma tapera de garimpo nas imediações, mas, pela idade, os filhos não permitiam que se deslocasse para lá, porém um de seus filhos lhe satisfazia o desejo de lavar cascalho levando toda semana um caminhão cheio de material de garimpo, para que o resumisse no quintal da casa - esta adquirida com o lucro do trabalho de décadas.

Do acervo pessoal da família Rosa, valeu-se da obra Minha luta pela sobrevivência, um conjunto de memórias autobiográficas e poesias de Gumercindo Vieira Amaral, que registrou o dia a dia dos expropriados da Serra, compondo o painel da instabilidade do garimpo em princípios do século XX no local.

Nascido em 1916 em uma fazenda no distrito de Conceição do Barreiro, o autor relata que durante sua infância o pai garimpou diamantes na cata Água Santa, a seis quilômetros do distrito. O serviço era de meia-praça, ou seja, o trabalho era dividido com outrem, geralmente um morador do lugar "onde o meia-praça entra com o serviço ou a mão de obra e o morador dá a cama, comida e ferramenta; o resultado do serviço, ou seja, o diamante que sai daquele trabalho é dividido meio a meio" (AMARAL, 1983, p. 2). A situação dos meias-praças era de tamanha expropriação que dependiam de quem pudesse fornecer os víveres para viabilizar o trabalho. Apesar da dependência, as memórias desse período são de fartura, sendo possível à família comprar uma casa na praça da igreja do distrito de Barreiros e mais dois terrenos, além de seis vacas leiteiras com bezerros (AMARAL, 1983).

Poucos anos depois, ao ingressar aos 14 anos no mesmo ofício do pai, descreve o garimpo na Serra como escasso: “O garimpo naquela época por lá estava ruim, não dava quase nada e quando achávamos algum diamantinho, não dava quase nem prá pagar o que nós estávamos devendo nas vendas" (AMARAL, 1983, p. 4). Nas páginas seguintes, o autor conta a sua saga em busca de catas diamantíferas ao subir mais ao norte de Minas Gerais até chegar a Goiás e ao atual Tocantins, sua vida ilustrando a mobilidade espacial garimpeira na Serra e alhures. Tal trajetória corrobora a análise do rush garimpeiro de 1919 rumo a Goiás por garimpeiros procedentes das beiras do São Francisco, estudado por Helion Póvoa Neto.

Gumercindo Vieira Amaral morreu em São Paulo, cidade onde se casou e constituiu família. Tal foi a surpresa ao encontrar um registro local da vivência do garimpo, pois há escassez documental para o período. Buscou-se informações nas prefeituras, casas de cultura e casas paroquiais de Francisco Dumont e Buenópolis e na sede da associação de garimpeiros de Jequitaí, sem sucesso. Também se vasculhou o que restou dos livros e arquivos de um 
fazendeiro local, Sócrates Dumont, porém o material era pequeno, estava em mau estado de conservação e não apresentava apontamentos de impressões pessoais, apesar de seu relevo.

Os locais onde os trabalhos de campo foram realizados não guardaram registro documental das suas relações sociais, sendo os documentos analisados encontrados nos anuários do APM e na obra ficcional de João Guimarães Rosa, que, assim como Gumercindo Vieira Amaral, somente após sair do sertão é que colocou no papel as interpretações do que viveu: é na cidade que se produz documento, que se burocratiza a vida e que, dado o maior anonimato no meio urbano, torna-se mais confortável produzir materiais que possam lidar com as personificações de poder locais. Quanto ao APM, o interesse científico de seus fundadores em documentar para fins de planejamento contrasta com o interesse dos coronéis, tendo em vista o desejo destes de manter as relações de poder locais, enquanto satisfazem os anseios cientificistas e técnicos de seus filhos e netos.

\subsubsection{Ouvindo os garimpeiros}

Grande parte dos garimpeiros entrevistados não se dedicou exclusivamente a este ofício o tempo inteiro. Muitos se dividiam entre o trabalho nas fazendas de gado, nas lavouras e na coleta de frutos da Serra, a depender da estação do ano e da situação econômica. Se suas famílias eram de origem camponesa - portanto, já forjadas dentro das relações modernas na particularidade colonial -, a mobilidade do trabalho, seja ela espacial ou entre funções, expressa a condição de expropriação sua e de seus antepassados, pois muitos herdaram dos pais a ocupação e a condição social.

Carlos de Almeida Toledo propõe olhar para a formação da família como a chave do entendimento do processo de transição do trabalho escravo para o livre na formação regional: “O que define a situação de expropriação é a reposição da condição de membros da família forçados a trabalhar para viver. Define-se, portanto, em oposição à classe dominante, que vive de seu capital" (TOLEDO, 2008, p. 212), considerando-se que a regionalização emerge no Brasil de uma forma particular de territorialização, cujo sentido é a produção de mercadorias, que se vale dessa força de trabalho livre.

Conforme relato de Parceiro, garimpeiro ainda na ativa, as terras na Serra estão apropriadas, mas ainda existe garimpo cuja terra é livre, sem dono. Violeiro nascido em Francisco Dumont, seu pai saiu de Guanambi, Bahia, junto ao avô, fugindo de um crime cometido por este. Chegaram ao município já decididos ao trabalho de garimpo de diamantes e de cristais, alternados com a coleta de sempre-vivas, pois, de acordo com o próprio, durante a 
Segunda Guerra Mundial, as flores eram exportadas tanto para ornar os caixões quanto para o fabrico de pólvora. Parceiro comentou que desde os 9 anos de idade garimpava com o pai, seu mestre de ofício ${ }^{193}$.

Em seu depoimento, disse que os garimpeiros na Serra se dividiam na variedade de mercadorias a serem produzidas. O entrevistado ainda informa que, no caso das flores, há duas épocas para colhê-las - a do tempo, no mês de março, e a de flor maior, de outubro a novembro, ambas em período de chuva, que tem se reduzido e comprometido a safra. Quando não garimpa, Parceiro recorre à colheita, pois dá dinheiro, o que também atrai mulheres e crianças para o trabalho. As flores ainda são enviadas para Diamantina e de lá são exportadas.

Parceiro disse ter trabalhado primeiro em "São Fel” (São Félix), a 36 quilômetros do município, porque as terras ainda não tinham dono e, por isso, não se pagava porcentagem, tendo dado boas pedras no passado. Além dela, faiscou em outros lugares antes de serem apossados: Água Branca, Pedra de Forno e Diamante - todas lavras na Serra do Cabral. Já o Boi Morto e o Licuri, onde hoje atua, têm proprietários, a quem disse ceder entre 10 e $20 \%$ nos achados e estar isento de pagar porcentagem na lavra de cristais. Ele conhece a Serra quase na sua totalidade, pois passou a vida transitando de uma grupiara para outra, o que lhe proporcionou enorme conhecimento de plantas medicinais do cerrado.

O trabalho de garimpar deu a Parceiro e a tantos outros entrevistados a sensação de liberdade e autonomia. No entanto, tais sentimentos perduravam até o momento de pagar a porcentagem ao dono da terra sobre cada diamante achado. A contribuição não deixa de ser uma espécie de tributo que o faiscador, na situação de expropriado, paga para ter acesso à terra alheia. Ela aparece como uma espécie de renda da terra em uma relação em que não há assalariamento, por isso a sensação de perda de liberdade e de exploração. O tempo do garimpo não coincide com o tempo abstrato de uma relação de trabalho contratual. Tal contrato inexiste porque o garimpo é um serviço de incertezas, devendo ser paga apenas a porcentagem sobre o que é extraído.

Parceiro comenta que chegou a trabalhar oito anos junto a amigos e, como resultado, tirou 480 diamantes no período. Vendia as pedras em Jequitaí e Diamantina para atravessadores, vulgos "capangueiros", após pagar ao dono da terra a porcentagem devida. Muitas vezes, o preço de cada diamante não coincidia com o valor de todo o esforço empreendido, pois há lugar

\footnotetext{
193 Simeão Pires também aponta a extração regional de matéria-prima para fabrico de pólvora, que ocorria desde o período colonial: "Ao longo da Serra do Cabral, inúmeras eram as nitreiras localizadas nas cavernas formadas principalmente por excrementos de animais (morcegos, entre outros)" (PIRES, 2001, p. 39). Segundo o autor, esse recurso seria usado para fabricar pólvora a pedido do $12^{\circ}$ Intendente, Manoel Ferreira da Câmara Bittencourt de Sá, em 1807.
} 
que requer o uso de ponteiros e marretas para quebrar as cangas, enquanto a extração em beira de rio costuma render mais por ser serviço mais leve. Segundo ele, no passado, com um diamante de quatro grãos dava para comprar uma vaca, diferentemente de hoje, pois a pedra é avaliada em dólar. Com a mediação do dinheiro, as pedras perderam valor ao longo do tempo.

Como grande conhecedor do meio sertanejo, disse que as formigas cabeçudas é que dão a pista de onde há diamante, pois ao revolverem a terra para a construção das tocas, mostram onde "dá garimpo", tanto raso quanto fundo. Lúcio, 81 anos (2017), garimpeiro de sua geração e seu conterrâneo, contou que até sonhar com a pedra ou ouvir barulhos estranhos no cascalho era considerado pista para procurá-lo. Mas nem a superstição ou todo o conhecimento das jazidas promissoras garante bons achados, sendo necessário recorrer ao crédito nas vendas para comprar mantimentos, pagando depois a juros altos; em situações muito precárias, Parceiro, Lúcio e outros buscavam trabalho na coleta e venda de sempre-viva e outros frutos do mato, o que dizem ser complicado hoje, pois a silvicultura reduziu a água das veredas, diminuindo as flores.

Apesar de aposentado, Parceiro continua garimpando e disse preferir os cristais, que ficam "à flor da terra”, mais fáceis de extração e sem pagamento de porcentagem. Há poucos anos comprou um pequeno sítio a partir do desmembramento de uma das fazendas da família Dolabela e de lá tira o sustento para levar para a Serra e passar a semana: cultiva horta e pomar e cria galinhas, não precisando assim de quem lhe forneça os víveres. Ainda possui os instrumentos de trabalho fabricados pelo finado João Firmino, de quem ele e o pai eram meiaspraças: o artesão fornecia as ferramentas e fazia a feira de comida para seis dias, recebendo apenas quando o diamante era achado.

Diante de sua explicação sobre as relações de trabalho na faiscação, cabe lembrar que há diferentes acordos no garimpo, que foram mudando ao sabor das adversidades e do tempo: um deles é o garimpeiro ser autônomo e ter que pagar um tributo para entrar na terra, muitas vezes embutido na porcentagem do diamante; outro é o garimpeiro perder a sua autonomia e ter que fazer uma espécie de contrato para poder consumir até mesmo comida; também há o garimpeiro assalariado (que, durante o escravismo, era alugado), recebendo apenas por tempo de trabalho, sem acesso a nenhuma parte do produto.

A mobilidade garimpeira esteve presente na vida da maioria dos entrevistados. Outra narrativa de enorme quilate foi a de Joaquim Pontaria. Ele deixou a cidade de Poções, na Bahia, com 16 anos de idade junto a quatro amigos para fugir da fome e foi subindo até o norte de Minas Gerais, parando primeiro em Capitão Enéias, perto de Montes Claros, trabalhando na 
derrubada da mata para a lavoura alheia. Ao saber do polo de trabalho em Granjas Reunidas ${ }^{194}$, pegou pau-de-arara e trem de Montes Claros até lá, onde arranjou serviço na derrubada da mata e na construção de pontes. No meio do caminho, conheceu Milton Borém, de família já citada, para quem foi trabalhar com gado e cerca na fazenda no povoado de Buriti Grande. Ao lidar com a terra, ficou conhecendo Pedro Furtado, fazendeiro para quem também trabalhou, conhecendo por sua vez seu cunhado, Zé Borém, que lhe ensinou o ofício do garimpo.

Figura 18 - Usina de açúcar em Engenheiro Dolabela, início da década de 1950

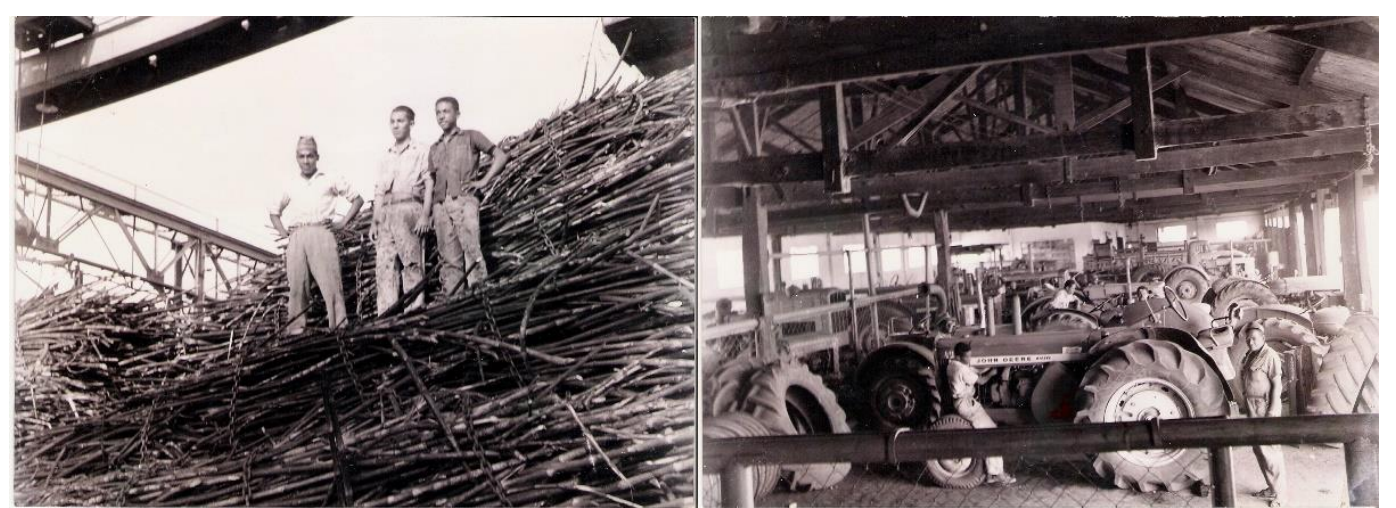

Fonte: acervo pessoal de Gê Dolabela, julho de 2017.

Joaquim viveu nove anos no Buriti Grande, justamente no período de opulência do povoado. Na década de 1950, chegou a Francisco Dumont já disposto a se dedicar apenas ao garimpo, profissão de maior liberdade e ganho. Disse que, partir de então, trabalhou em todos os lugares possíveis da Serra, sob o acordo de pagar $10 \%$ dos diamantes encontrados para Milton Borém, no Buriti Grande, e 20\% para Daniel Dumont, em Francisco Dumont, pois ambos eram fazendeiros poderosos e donos das catas na região. Com as empresas de reflorestamento na Serra e problemas na coluna, Joaquim interrompeu o trabalho, estando hoje

194 O distrito de Granjas Reunidas tornou-se Engenheiro Dolabela, hoje administrado por Bocaiúva, e parece o povoado de Luvina, descrito por Juan Rulfo em Chão em chamas: uma paragem aparentemente desolada pelo tempo, um lugar que já viveu seu tempo áureo na produção de açúcar. Gumercindo Vieira Amaral descreve sobre ele:

Quando eu estava com 15 anos, em janeiro de 1931, meus pais resolveram mudar dali para um lugar chamado Granjas Reunidas do Norte, na Estrada de Ferro Central do Brasil, distante 42 km aonde a Companhia Dolabela e Portela era dona de toda aquela região que era enorme e que ali era uma espécie de país independente: tinha sua própria polícia (que lá era chamado de batepau) tinha sua própria estrada de ferro chamada Malvina, tinha até o seu próprio dinheiro chamado Boró e tudo ali dentro do seu (território) pertencia aos irmãos Dolabela e que hoje pertence ao Matarazzo. Um único estabelecimento, uma espécie de supermercados - uma única farmácia, um só açougue. E se por acaso a gente desejava passear em algum lugar, ou mesmo resolvesse mudar dali ou comprar alguma coisa - em outro lugar, porque ali não tinha, a gente era obrigado a ir ao escritório da firma e trocar o boró por dinheiro bom como se chamava por lá. Naquele tempo, toda aquela região era maleitosa e além disso todo mundo - que lá chegava, logo depois de 15 ou 20 dias aparecia uma ferida nos pés, mas não ficava um sem ser contaminado. (AMARAL, 1981, p. 4-5). 
aposentado como lavrador pelo Fundo Rural. Desde os 16 anos não voltou mais à terra natal nem recebe notícia dos pais.

Em linhas gerais, a liberdade de garimpar sem pedir licença ou pagar porcentagem ao dono da terra não durou muito, não havendo um entrevistado que não tivesse pago a sua cota ao possuinte de terreno. As relações de favor camuflavam, pelos acordos em palavra, a desigualdade pela relação de classe e a submissão dos envolvidos, pois no acordo, a palavra final é a de quem tem o poder econômico na mão. Ao garimpeiro, que não tinha o acesso à terra, era preciso negociar com o fazendeiro para que pudesse entrar na propriedade alheia para revolver solo e cascalho, só permitido se ao dono fosse vantajoso, ou seja, lhe fosse possível lucrar também. Acordos feitos, os trabalhos eram realizados e os sentimentos naturalizados de liberdade e de autodeterminação eram decantados no garimpeiro.

Nas entrevistas, os sentimentos mencionados se destacam entre a maioria. Em todos os casos, cada um fazia questão de enfatizar que as ferramentas de trabalho (carumbé, "levanca", picareta, foice, peneira, machado e enxada) eram suas; enquanto alguns teriam feito os próprios instrumentos, os mais velhos mencionaram os ferreiros e outros moradores de Francisco Dumont como feitores do material, como os falecidos Ramiro e Adão Gamela; outros os compravam em Bocaiúva, Jequitaí ou Pirapora. Na segunda visita a Joaquim, em janeiro de 2019, ele abriu um cômodo aos fundos de uma casa na parte alta da cidade e mostrou seus picuás ${ }^{195}$, guardados com zelo junto aos outros utensílios de trabalho, dizendo que era o que mais gostava do tempo de garimpo, por denotar a fartura das pedras acumuladas no canudo.

Em todas as falas, há ênfase na escolha do trabalho no garimpo, visto como de maior liberdade e autonomia em comparação ao trabalho nas lavouras e pastos - os irmãos José e Geraldo Telheiro são dois claros exemplos dessa escolha: foram lavradores até os 40 anos, tendo partido para o garimpo convencidos da independência no trabalho e na possibilidade de riqueza. A ilusão da liberdade presente em todos os depoimentos revela a sua contradição no momento em que cada um, contando passagens de suas vidas, reconhece a labuta na cata não apenas como um trabalho viciante, aventureiro ou de ilusão, mas uma necessidade para a reprodução da própria vida, visto que a ossificação dos fatores de produção está posta, e o trabalho, o verdadeiro gerador de riquezas, tem na sua personificação o sujeito de onde são extraídos os bens excedentes. Em Karl Marx,

195 “Picuá é uma pequena peça ôca cilíndrica, de chifre, ou de qualquer outra materia, em que os mineiros costumão guardar os diamantes que extrahem." (SANTOS, 1868, p. 406, grifos do autor). 
[...] o capital durante o processo social de produção que lhe corresponde, extrai determinada quantidade de mais-trabalho dos produtores diretos ou dos trabalhadores, mais trabalho que o capitalista recebe sem equivalente e que, conforme sua essência, continua sempre a ser trabalho forçado, por mais que possa aparecer como resultado de um contrato livremente consentido. Esse mais-trabalho se representa num maisvalor, e esse mais-valor existe num mais-produto. (MARX, 2013, v. 3, p. 882).

O diamante aparece como uma mercadoria que não tem valor de uso para quem a extrai. Como está implícita nas mercadorias a contradição de serem ao mesmo tempo valores e valores de uso - por isso elas podem ser trocadas -, o garimpeiro acessa os artigos que precisa por meio da pedra, angariada por meio de seu trabalho. É no consumo que o valor de uso se efetiva, revelando que a mercadoria é o conteúdo material da riqueza, independentemente da forma social desta. Descobrir os diversos aspectos de utilidade da mercadoria e as múltiplas formas de uso das coisas é um ato histórico (MARX, 2013), já que o diamante mobilizou gente e consolidou formas de relação social num dado território.

$\mathrm{Na}$ troca do diamante por metros de linho para se confeccionar um terno, conforme desejava Geraldinho, ou por comida e querosene para a família, conforme necessitava a maioria dos entrevistados, as qualidades tanto do diamante quanto do tecido, do alimento ou do combustível, são abstraídas, pois precisam ser igualadas, restando a todos apenas a propriedade de serem produtos do trabalho ${ }^{196}$. Essa mediação da forma mercadoria determina a reprodução das relações de produção na Serra a cada momento, o que, por sua vez, determina a forma de ocupação que lá se consolida no século XX. O garimpo, portanto, realiza a abstração real naquela sociedade, quando o garimpeiro vende o diamante para satisfazer as suas necessidades, não importando se "elas provêm do estômago ou da imaginação" (MARX, 2013, v. 1, p. 113).

Na troca de mercadorias, se opera o câmbio de unidades abstratas de tempo de trabalho, cristalizadas nos corpos dessas formas, em um processo que anula a substância socialmente constituída, o trabalho, e a historicidade por trás daquilo que se permuta. $\mathrm{O}$ diamante movimenta a produção e a circulação para o consumo e a reprodução social: ele viabiliza lavradores, artesãos, tropeiros e comerciantes que estabeleciam a ponte entre o campo e a cidade

\footnotetext{
196 Sobre tal relação, Karl Marx explica:
}

Como valores de uso, as mercadorias são, antes de tudo, de diferente qualidade; como valores de troca, elas podem ser apenas de quantidade diferente, sem conter, portanto, nenhum átomo de valor de uso. [...] Prescindindo do valor de uso dos corpos das mercadorias, resta nelas uma única propriedade: a de serem produtos do trabalho [...]. Consideremos agora o resíduo dos produtos do trabalho. Deles não restou mais do que uma mesma objetividade fantasmagórica, uma simples geleia de trabalho humano indiferenciado, de dispêndio de força de trabalho humana, sem consideração pela forma de seu dispêndio. Essas coisas representam apenas o fato de que em sua produção foi despendida força de trabalho humana, foi acumulado trabalho humano. Como cristais dessa substância social que lhes é comum, elas são valores - valores de mercadorias. (MARX, 2013, v. 1 p. 116). 
na circulação dos artigos que depois virariam valores de uso em seus destinos finais ${ }^{197}$, dinamizando toda uma região e consolidando o modo de produção capitalista.

Não só por mãos forasteiras foram reviradas as catas da Serra do Cabral, como também os nativos o fizeram. Um dos garimpeiros entrevistados, Neco, nasceu em Francisco Dumont, assim como seu pai, Genoíno, de quem herdou a profissão. Ele abriu sua casa para a entrevista, alojando os presentes na sala. Chamou a atenção a sua esposa, Maria José Alves de Souza, que fez questão de ficar o tempo todo recolhida na cozinha, apesar de muitas vezes ter sido mencionada pelo companheiro enquanto contava passagens de sua vida. Apesar de ela ter tomado a iniciativa de não se envolver naquele momento, a postura de se marginalizar durante uma conversa em que podia ter participado - pois ela também foi lavradora agregada e garimpeira, nascida na Serra - endossa o pressuposto do modelo de civilização da produção de mercadorias: humilhar e segregar as mulheres, que, empurradas para a esfera da reprodução, levam uma existência separada, tacanhamente privada (SCHOLZ, 2019).

Além de faiscador, o pai de Neco exercia as funções de pedreiro e carpinteiro, como complemento à renda da família. Ele e seus irmãos começaram a garimpar aos 12 anos no Tira Couro, em meio a homens e mulheres no cascalho baixo, aprendendo o ofício pela observação. Também faiscou na Pindaíba e no Totoni, e, no início do casamento, chegou a levar sua esposa, a quem ensinou o trabalho, pois ela tinha nascido no Cipó e trabalhou em roça quando solteira.

Dentro da sociabilidade da mercadoria diamante, não se pode deixar oculto aquilo que a relação social moderna faz questão de esconder: a tarefa de reprodução ou o não trabalho que está por trás da realização do garimpeiro. A venda do brilhante para a aquisição de produtos, que por sua vez se transformam em valores de uso no ambiente familiar, desnuda o dissociado quando é este quem prepara essas mercadorias para o consumo, frutos do trabalho abstraído, para que o faiscador prossiga à procura das pedras. Foi mencionado por alguns entrevistados que no passado havia mulheres nos garimpos, não só acompanhando seus maridos, arranchadas com os filhos nas choças para cuidar da família (o que Geraldinho disse sobre as catas de Pau

\footnotetext{
${ }^{197}$ De acordo com Andrea de Paula (2009), os tropeiros eram camponeses que conduziam tropas de animais de cargas do campo para a cidade, comercializando os produtos. Durante o trajeto entre os dois ambientes, negociavam artigos, como carne seca (salgada), couro, querosene, sal, entre outros. Eram também mensageiros oficiais, portadores de bilhetes e recados e aviavam mercadorias encomendadas e receitas. Constituíam, para Maria Sylvia de Carvalho Franco (1997), parte dos homens livres pobres. Em Grande sertão: veredas, os tropeiros aparecem circulando os produtos e informações:
}

\footnotetext{
Essa tropa, que passara por nós, dias antes, rumava para o Abaeté, com carga de fumo, mantas de borracha, couros de onça e de lontra e cera de palmeiral, pouca coisa. Fossem atravessar o rio, num porto; iam passar por terras minhas conhecidas, nos sertões menores... Agora, eu queria saber.

- "Aquele levou um recado meu. Instruí o homem que levasse um recado...”. (ROSA, 1986, p. 413).
} 
de Fruta e Coruja), como também diretamente envolvidas na extração do mineral - cabendo lembrar o protagonismo de duas faiscadoras originando o povoamento de Francisco Dumont. O comportamento distante de Maria foi mais um notado entre as esposas de faiscadores ao longo das entrevistas com alguns dos antigos garimpeiros, mesmo a maioria deles não tendo se casado ou já estando viúvo. As poucas vezes que as mulheres apareceram, foi no ambiente restrito das cozinhas e quintais de suas casas, sem se envolverem nas conversas, que ocorriam nas salas e nos alpendres.

A partir do momento em que foi se tornando difícil garimpar - o que Neco e a esposa atribuem à chegada das empresas de reflorestamento, que cercaram as terras na Serra e impediram o acesso às grupiaras -, Neco passou a trabalhar com madeira, roçando manga e em lavoura, salientando que só não lidava com gado. Comentou que antes das empresas chegarem, havia muito serviço para vaqueiro, sobretudo nas fazendas dos Dumont, pois as mangas eram só mato e o gado era bravo. Ainda assim, para ele, a população preferia trabalhar com garimpo, na ilusão de ficar rica.

Perguntado sobre como funcionava a negociação para garimpar e a repartição do diamante encontrado, Neco disse que, quando achada, a pedra era mostrada diretamente para o dono do terreno, a quem se dava preferência na venda e se pagava entre 10 e $20 \%$ do valor, como forma de tributo por ter acessado a terra.

Havia garimpeiro que, na tentativa de ganhar mais, escondia a pedra achada para negociar na surdina com algum comprador interessado, na esperança de vender por fora sem pagar a porcentagem e conseguir mais dinheiro. Ao comprador também era interessante, pois sabendo que a mercadoria estava sem o tributo, conseguia comprá-la mais barato. A isso ele chama de "bater a bucha", o que dava má fama a alguns faiscadores, sendo preteridos nas negociações. No fim das contas, dizia que era impossível um garimpeiro esconder que "batia a bucha", pois ao consumir mais coisas na cidade, especialmente roupa nova, todo mundo olhava e pensava "ou é garimpeiro ou é ladrão". Como o sucesso do trabalho era de conhecimento de todos, alguns que usavam do artifício, caso tivessem cavalo, o vendia para dizer que o dinheiro vinha do negócio - artimanha vã, pois garimpeiro que usava roupa nova era visto como ladrão, e a punição era não trabalhar em nenhum terreno, pois a fama de "batedor de bucha" corria de boca em boca $^{198}$.

\footnotetext{
${ }^{198}$ Apesar de não ser um relato de "bater bucha", mas sobre a frouxidão da fiscalização sobre a mineração, Joaquim Felício dos Santos (1868) conta a história da Lavra do Pagão, descoberta por um garimpeiro, que não conseguiu mantê-la em segredo porque o seu consumo ostensivo na Chapada acabou atraindo o interesse de outros faiscadores.
} 
Neco ia e voltava a pé dos garimpos todos os dias. Ele levava comida para passar o dia: ovo, farinha, carne (mais osso do que carne: costela e espinhaço), fissura (vísceras de porco ou de boi), frango (que a maioria criava no quintal), arroz "canjiquinha", fava (mais barata, substituía o feijão) e o pequi colhido no meio do caminho, quando era época. Carne pura era difícil, sendo comum, nos tempos difíceis, cozinhar cabeça de boi e de porco - o que estigmatizava seu consumidor pelas ruas ao passar com a cabeça no ombro: era o miserável levando os restos do açougue, que dava para dois dias. Água era a da Serra.

Perguntado sobre as mudanças, Neco disse que muita coisa melhorou, exceto para o trabalho de garimpo, hoje proibido por causa do meio ambiente. Segundo ele, antes, o diamante dava fartura, sendo possível comprar roupa, cavalo, comida, novilho, entre outras coisas. Quando as empresas foram chegando e adquirindo as propriedades, ficou proibido "cavacar" a terra, pois sujava a água. Conforme pinho e eucalipto foram plantados, a seca foi se tornando uma constante, o que também dificulta o garimpo, que requer água para lavar o cascalho. Hoje, aposentado e tratando da hanseníase, Neco vive em uma casa de adobe, conquista de anos de trabalho em catas. Ao ouvir o elogio sobre a morada, comentou que os filhos pretendiam derrubar a construção para levantar casa de tijolos, pois para eles aquilo era coisa atrasada.

Questionado sobre a propriedade das terras, disse que a maioria delas pertencia à família Dumont, que, além de receber doações da Igreja, foi se apossando de tudo o que pôde. A geração mais nova de fazendeiros não costumava expulsar ninguém, mas fazia as famílias trabalharem para ela. Antes, no tempo do fazendeiro Francisco Dumont, a terra era invadida mesmo com gente morando, e, se houvesse resistência, a expulsão era feita à força pelos jagunços.

Sobre os conflitos entre proprietários, Antônio Duarte da Fonseca, 90 anos (2017), conhecido como Antônio de Clara, relatou a tentativa de grilagem de terra de Daniel Dumont sobre a sua propriedade já na década de 1980. Negro, nascido na roça de São Humberto (crê-se ser São Lamberto), com avós escravizados e pais lavradores vindos de Claro dos Poções, conseguiu se tornar fazendeiro na Serra após comprar os primeiros alqueires do finado Pedro Simão. Conforme trabalhava para o antigo dono plantando cana-de-açúcar, mandioca, feijão, arroz e milho e fazendo farinha e rapadura, foi juntando o dinheiro que recebia por empreitada por dia e adquiriu o seu pedaço de terra, além de comprar boi, burro e porco, construindo o seu patrimônio.

A contenda começou, segundo ele, com Daniel Dumont expandindo a cerca para cima de sua propriedade, de olho no alcance da margem do Jequitaí. O caso foi parar na justiça, e Antônio disse ter ganhado porque, garante, suas terras tinham documentação, enquanto as de Daniel não, pois já eram griladas desde o estabelecimento da família na região. Sem poder 
provar para o juiz, seu rival, apesar de pertencer à família mandatária daquelas bandas, perdeu a causa.

O relato de Antônio é exceção. Escrevendo suas reminiscências, a poesia "A patota”, de Gumercindo Vieira Amaral, registra um caso de grilagem em Barreiros, tendo havido a intermediação encenada da justiça, com o desfecho comumente esperado no sertão:

Eu vou contar uma estória

Verídica e bem real

Dum pobre e um fazendeiro

E um magistrado imoral

Pois o dinheiro infeliz

Aqui em nosso país

Chega até comprar juiz

Numa demanda final

Esse caso aconteceu

Há meio século passado

Lá nas Minas Gerais

No norte daquele estado

Com um pequeno roceiro

Contra um rico fazendeiro

De gado e muito dinheiro

Que dos pobres era roubado

Esse rico fazendeiro

Já estava acostumado

Grilar as terras vizinhas

Dos sitiantes dos lados

Por causa dessa malícia

Do fazendeiro e a cobiça

Foram parar na justiça

Nas mãos de um magistrado

Lá na sala de audiência

Quando o pobre foi chegando

Já encontrou o ricaço

Com o juiz dialogando

Dava ricas gargalhadas

Pois já tinha assegurada

A terra que foi roubada

Em mais de um caso nefando

Enquanto o pobre afirmava

Pelo seu depoimento

Que o terreno era seu

Exibindo os documentos

Quase que no seu nariz

$\mathrm{O}$ fazendeiro feliz

Exibia pro juiz

Uma nota de quinhentos

O juiz dizia ao pobre:

Você tem toda razão!

A escritura do terreno

Está aqui na minha mão

E você tá percebendo 


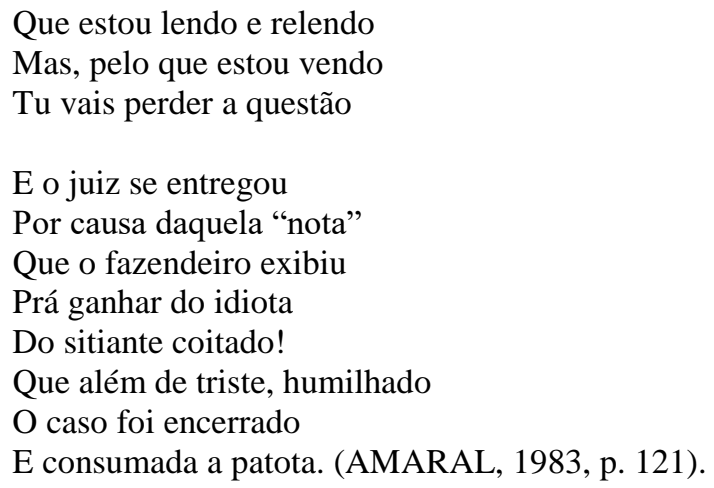

Personificado o trabalho, atenta-se à personificação da terra, representada no seu dono. Tanto nas entrevistas em Buriti Grande quanto em Francisco Dumont, são mencionadas duas famílias de fazendeiros: Borém, já apresentada anteriormente, e Dumont. A partir de breves consultas ao acervo Ultramarino e à Casa dos Contos do APM, sabe-se que a primeira já possuía funcionários nos serviços administrativos coloniais desde a segunda metade do século XVIII, estendendo seu poder com o latifúndio no já apresentado Registro de Terras Públicas. Sobre a segunda, o que se sabe é que o caixeiro viajante diamantinense Francisco de Assis Dumont teria chegado à Serra em fins do século XIX, para garimpar ouro às margens do Jequitaí; outras fontes informam que ele era capangueiro e ourives, tendo chegado à Serra atrás do comércio das pedras. Há ainda a versão presente na biblioteca do IBGE (sem data), que informa que seria Francisco de Moura Dumont, comerciante de tecidos, o primeiro da família a chegar ao local, logo após os garimpeiros Francisco e Ana Bomfim terem ali se estabelecido, por volta de 1800 . A construção de uma capela e a instalação da fazenda Vargem Mimosa dariam perenidade ao povoamento, com a introdução do gado. Com o passar dos anos, casamentos realizados com membros de famílias importantes da vila de Jequitaí e o investimento na pecuária fizeram do clã grande latifundiário e poderoso localmente.

Ambas as famílias detinham a maior parte das terras na Serra, e era a elas que tanto os garimpeiros quanto os lavradores expropriados tinham que se submeter e entregar seu maisproduto; o vaivém entre o garimpo e a lavoura foi concomitante ao crescimento do poder desses clãs. Houve envolvimento na política local e regional das duas partes, sendo esse o propósito do envio de seus filhos e netos às escolas e faculdades em cidades grandes em princípios dos Novecentos, moldando o coronelismo na Serra: Wan-Dyck Dumont, fazendeiro e irmão de Sócrates Dumont, chegou a ser prefeito de Bocaiúva; Sócrates e seu sobrinho Dalmo foram prefeitos de Francisco Dumont. O político como profissional remunerado realizaria o desdobramento da autonomização entre capital e Estado, sendo o coronelismo um momento desse processo (TOLEDO, 2008). 
Por meio do poder do fazendeiro, entrelaça-se o interesse político subordinado ao econômico, sendo o coronelismo um produto da modernização regional em curso - e o coronel, um fantoche do poder do dinheiro. A necessidade dessas famílias em manter a propriedade fundiária, construção que remonta ao período escravista, revela a naturalização dessa relação com a terra.

Cria-se assim uma teia de relações em que os favores pessoais, marcados pelo paternalismo e o mandonismo, estabelecem hierarquias e distinguem aliados de adversários, estes reconhecidos na luta pela posição dominante na região para adquirir o poder de violência e o controle do capital comercial. Para aqueles que estavam na base da pirâmide social, restava a relação de compadrio como uma das formas camufladas de violência, em contraposição ao seu caráter mais brutal, o qual expulsava gente da terra ou a obrigava ao trabalho ${ }^{199}$. Na região, o coronel personifica tanto a propriedade da terra quanto o capital comercial e o Estado, e é para manter-se nessa posição que ele precisa ter o poder de violência, que não pode ser compreendido sem que se leve em conta as relações com o poder territorial estadual ou provincial nos tempos do Império (TOLEDO, 2008).

De acordo com Vitor Nunes Leal, nem todos os chefes de facções municipais e nem todos os coronéis eram aliados do oficialismo estadual; eles podiam estar na oposição, mas lhes era desconfortável. O que cada corrente política pretendia, por mais que entre elas houvesse ódio mortal, era obter as preferências do governo do Estado: "batem-se para disputar, entre si, o privilégio de apoiar o governo e nele se amparar" (LEAL, 1975, p. 49), com o propósito de perpetuar seu poder econômico, dado que a participação política no Brasil permaneceu censitária mesmo quando a lei aboliu este critério. Com isso, o acesso à participação política estaria restrito a um pequeno número de famílias com poder enraizado na propriedade da terra e do capital ${ }^{200}$.

${ }^{199}$ Para o caso dos lavradores que passam a morar como agregados nas fazendas, Margarida Moura explica que

A "razão social" das expulsões atuais começa a ganhar contornos claros. O temor de ações judiciais iniciáveis por agregados sob ameaça de expulsão, ou mesmo expulsos, ocupa lugar marcante na justificativa do fazendeiro para impor contratos escritos aos mesmos, nos quais devem negar relações de trabalho permanentes, assinar acordos de trabalho avulso, confirmar moradas de favor. Outras razões sociais devem ser mencionadas: a dissociação do corpo do trabalhador do lugar onde trabalha é a forma de dissociar do solo-mercadoria a presença física de quem o habita em função do trabalho. A propriedade, enquanto mercadoria, não pode tolerar nos seus limites lavradores que moram e trabalham para si, para que se torne possível trabalhar para outro. Estar na propriedade só se justifica em hora de trabalho. No limite, esse procedimento dispensa, até mesmo, ao fazendeiro o ato de morar. $\mathrm{O}$ fato de que frequentemente há alusão ao proprietário que não se encontra na fazenda, mas na capital, mantendo fechada a casa-sede da fazenda, é significativo. (MOURA, 1988, p. 97-98).

${ }^{200}$ Em artigo, Letícia Canêdo aponta que a elite política mineira é tecnocrata, com intelectuais formados para pensar os problemas de governo, não sendo afeitos à elite cafeicultora. Tinha trato com as questões públicas de forma centralizada e os laços de família para a ascensão ao centro, esfera política para o exercício da dominação 
Em julho de 2017, teve-se acesso ao que sobrou dos documentos de Sócrates Dumont, um dos fazendeiros mais poderosos de Francisco Dumont, falecido em 2013, próximo de completar um século de vida. Tendo morado no sobrado centenário construído pelos seus antepassados e cuja arquitetura não deixa dúvida quanto à relação sólida da família com Diamantina, foi aberto à despretensiosa observação alguns de seus papéis e fotos, graças ao seu sobrinho Guilherme. Do que sobrou da pequena biblioteca, livros que abordam o golpe militar - chamado de "revolução de 1964" -, a obra ficcional de Simeão Pires, Gorutuba: o padre e a bala de ouro, e documentos sobre a fundação da escola primária para meninos. Porém, o mais interessante são as atas de reunião da União Democrática Nacional (UDN) - estas, de 21 de abril de 1963, comemorando a transformação do distrito de Conceição do Barreiro no município de Francisco Dumont - e da Arena.

\section{Figura 19 - Casarão centenário da família Dumont}

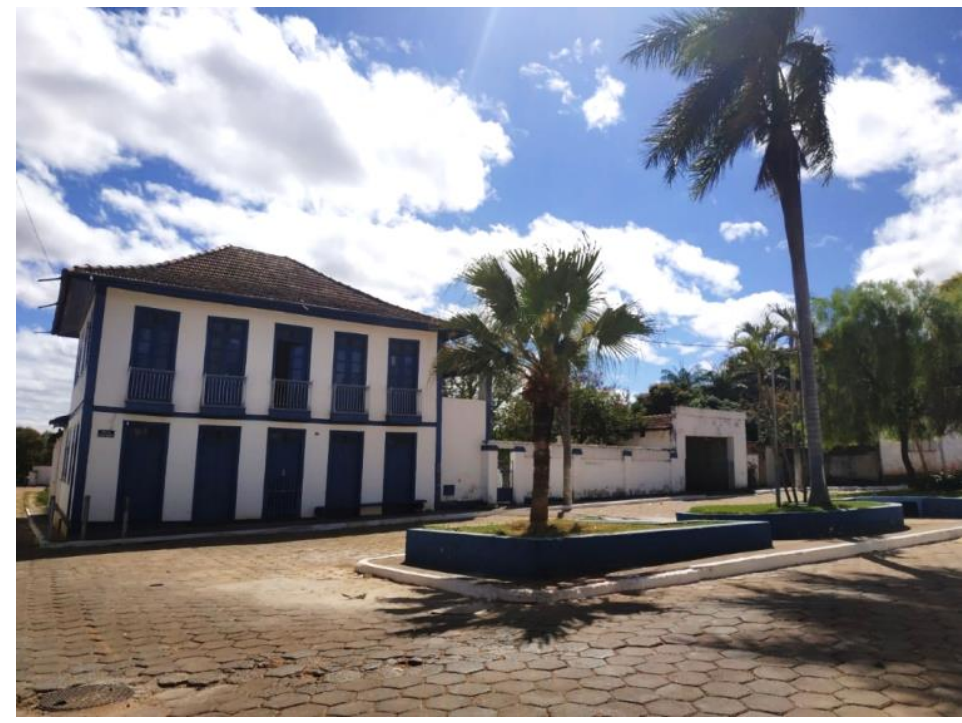

Fonte: acervo pessoal, julho de 2017.

oligárquica. Porém, no caso da Serra, terra e família estão, historicamente, fortemente ligadas, sendo a esfera política um campo de manobra para os interesses particulares da classe, o que deve ser destacado na tentativa de compreender o tratamento dos fazendeiros para com seus agregados e garimpeiros: por tempo considerável eram essas famílias as mediadoras entre o poder local e o central, o que não pode ser ignorado.

Ao naturalizar a organização partidária e o interesse pelo voto que pacifica a competição entre elites, ignorando (pela condenação) a presença do parentesco como vetor de redes políticas e condição de acesso aos mandatos eletivos, os analistas não puderam refletir sobre o universo de representações que a política carrega com ela. E desprezam a influência que este universo exerce na nossa percepção do poder, bem como a marca que deixa presente no princípio de organização e de coordenação da ação política. (CANÊDO, 1994, p. 95). 


\section{Figura 20 - Capa da Ata de reunião de fundação do Diretório Municipal da União Democrática Nacional - UDN, Francisco Dumont, 1966}

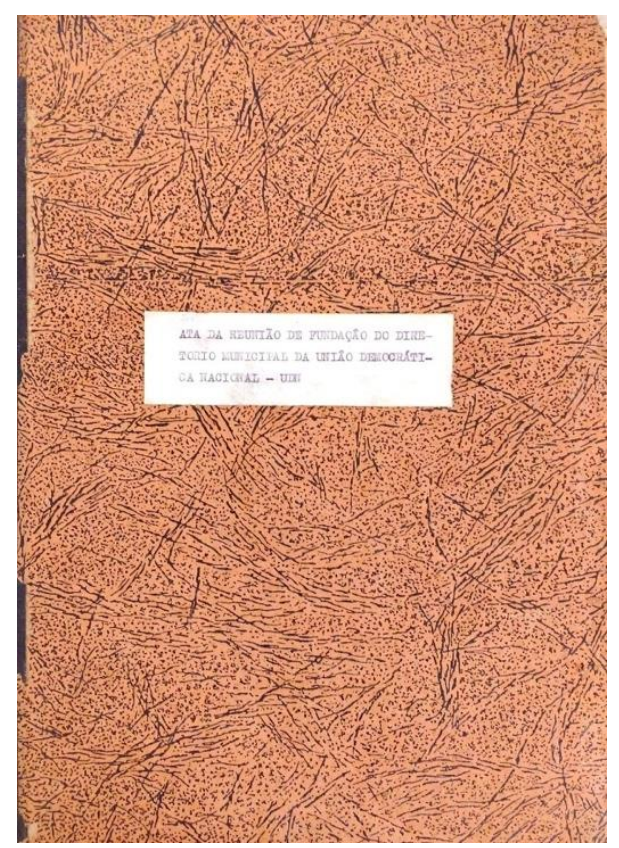

Fonte: acervo pessoal da família Dumont.

A articulação dos interesses da classe proprietária na Serra com a situação federal demonstra os laços para a manutenção do seu poder regional, reforçado na fazenda de gado, de menor risco em comparação ao garimpo. Dos anos 1960 em diante, os filhos "doutores", tecnocratas com estudo, se infiltrariam na arena política, com o intuito de permanecerem controlando a produção regional.

A emancipação do município e os desdobramentos do planejamento regional minaram em três décadas o poder dessas famílias na Serra, que passaram a competir com novas personificações do capital que ali ascendiam, respaldadas pelo Estado modernizador. Nos depoimentos colhidos dos trabalhadores, a partir de 1970, a questão da venda ou arrendamento das fazendas com a chegada das empresas silvicultoras apareceu como o maior problema para a extinção do trabalho. Agora, os donos da terra afrouxavam as rédeas da violência, perdendo gradualmente a autonomia sobre a região. A violência se tornara monopólio do Estado, mas os fazendeiros continuaram servindo ao poder centralizado, pois ainda era necessário manter a expropriação e produzir riqueza à mando do capital. 


\section{4. "Feito promessa para cumprir quando ficasse bom" "201: as festas religiosas na Serra e suas sociabilidades}

A produção do espaço oriunda da territorialização fetichista no Brasil promoveu desdobramentos reveladores da complexidade das relações sociais, além da produção de mercadoria. Discutindo a urbanização e o urbanismo nas regiões das minas, Nestor Goulart Reis (1999) defende a ideia de que somente com a extração mineral foi possível florescer uma sociedade tão diversa nas várias manifestações artísticas e de pensamento na América portuguesa. Discutindo sobre a importância da mineração para a formação de núcleos urbanos no século XVIII, o autor também aponta para uma crítica à maneira clássica comparativa ao povoamento espanhol e português, da qual Sérgio Buarque de Holanda (2007) é tributário. Os espaços urbanos forjados do ouro e do diamante permitiram maior complexidade social, possibilitando a criação de música, poesia, artes plásticas e arquitetura barrocos e pensamento filosófico simpático ao Iluminismo, porém com forte cor local - o que não deixa de apresentar um viés dualista.

Consideradas as condições de trabalho, parte-se para o momento em que o lúdico se torna ferramenta para entender a sociabilidade na territorialização na Serra do Cabral. Em conformidade com Carlos Toledo, que se deparou com a manifestação do jarê na Chapada Diamantina enquanto religiosidade local, "junto ao processo histórico de formação da região, forma-se também uma visão de mundo que naturaliza as relações sociais de uma forma particular e parece se refletir nas práticas religiosas" (TOLEDO, 2008, p. 178).

N'O 18 de brumário de Luís Bonaparte, Karl Marx interpreta os fatos que se desenrolam na França a partir de 1848, sob o viés do materialismo histórico. A despeito de o conteúdo factual do livro não compor o tema aqui trabalhado, vale-se da afirmação do autor em relação à ligação entre as bases materiais das classes e a produção de suas visões de mundo. Para ele, sobre as diferentes formas da propriedade, sobre as condições sociais da existência, se eleva toda uma superestrutura de sentimentos, ilusões, modos de pensar e visões da vida distintos e configurados de modo peculiar. Toda a classe a cria e molda a partir do seu fundamento material e a partir das relações sociais correspondentes.

\footnotetext{
201 "Pois tinha sido que eu acabava de sarar duma doença, e minha mãe feito promessa para eu cumprir quando ficasse bom: eu carecia de tirar esmola, até perfazer um tanto - metade para se pagar uma missa, em alguma igreja, metade para se pôr dentro duma cabaça bem tapada e breada, que se jogava no São Francisco, a fim de ir, Bahia abaixo, até esbarrar no Santuário do Santo Senhor Bom-Jesus da Lapa, que na beira do rio tudo pode" (ROSA, 1986, p. 85).
} 
As visões de mundo e as criações também chamaram a atenção nos campos realizados, com atenção para o fato de essas manifestações serem historicamente produzidas e, por isso, presas às formas categoriais. Consideradas as divergências regionais, culturais e simbólicas inerentes ao próprio sertão e resultadas do assentamento do capital naquele território, as lutas de classes e todas as contradições do mundo fetichizado permitem avaliar a festa como um momento de todos esses fatores imbricados na Serra do Cabral.

Embora as manifestações religiosas e culturais não sejam o foco, a festa pode auxiliar na compreensão do território e das relações de classes em um evento em que, aparentemente, não há trabalho - considerando-se o capitalismo como relação que domina o processo da vida social. Para tal reflexão, contribuiu também a pesquisa Formação territorial sul piauiense: modernização, agropecuária e resistência camponesa, de Vicente Eudes Lemos Alves, que se debruça sobre as festas religiosas camponesas no sul do Piauí e suas transformações diante da modernização agropecuária.

O termo "festa" é ambíguo, e, pelo menos desde Durkheim, os cientistas sociais vêm buscando formas de transformá-lo em conceito. Partindo-se da definição de Louis Marin, João Adolfo Hansen (2001) afirma que a festa é um processo coletivo que manipula o espaço por meio de certos movimentos em um certo tempo e, simultaneamente, produz seu espaço específico segundo regras e normas determinadas que ordenam esses movimentos e esse tempo. $\mathrm{Na}$ festa religiosa, se destacam as "esperanças manifestas", não de transformar o mundo, mas de, mediante a promessa, obter, em troca, benefício pessoal. O pacto aparece como uma relação estabelecida entre a condição humana concreta e um invólucro de santidade que a rodeia, sendo parte de uma visão de mundo dentro da qual constitui um modo de comunicação essencial. Seu preparo com sua devoção se aproxima do sacrifício, "ao mesmo tempo em que se insere no quadro de uma economia, a da troca" (SANCHIS apud MAGALHÃES, 2001, p. 940).

A Festa do Divino é o momento mais aguardado do ano pelos moradores de Francisco Dumont e arredores. Ela tem sua origem em Portugal, no século XIV, e foi trazida para a América Portuguesa com a colonização ${ }^{202}$, presente nos arraiais tornados municípios. Tanto lá como cá, o festejo foi aprimorado e se tornou alegoria do Antigo Regime, que, situado no

\footnotetext{
${ }^{202} \mathrm{O}$ culto festivo de pentecostes em honra ao Divino Espírito Santo chegou ao Brasil trazido de Portugal e Açores. Típico da religiosidade portuguesa que aqui se estabeleceu, popularizou-se por todo o território. Como acontece em terras portuguesas, as procissões com bandeiras vermelhas ostentando a estampa do pombo, o imperador, a imperatriz e seus pajens (mordomos), ricamente trajados, a farta distribuição de alimentos e os conjuntos musicais ambulantes marcam esse festejo religioso de norte a sul do país. Sua música apresenta características que remetem à Idade Média europeia, com instrumentos de origem portuguesa, como violas, rabecas e caixas (MONTEIRO; DIAS, 2010)
} 
movimento barroco ${ }^{203}$, tinha o fim pedagógico de reforçar a hierarquia social por meio do luxo com que o imperador e sua corte, numa clara representação do império português, desfilavam em público pelas ruas principais ao longo da procissão, acompanhados pelos serviçais e por banda de música a tocar marchas selecionadas.

A festa é realizada anualmente em muitos municípios brasileiros, e os festeiros são escolhidos dentro da comunidade católica. Além deles, que recorrem a doações para organizar o evento, há também o mordomo do mastro - responsável pela bandeira - e os devotos e confrades, figuras de maior prestígio e responsabilidade pública em sua realização. Ela é preparada lentamente durante os meses que antecedem a procissão, que inclui missa, folguedos, leilões e barracas. O centro das atenções fica por conta do casal de imperadores, que não são os únicos que pretendem ser vistos; o registro da jovem diamantinense Helena Morley dá a entender que o festejo era um grande evento social:

Eu acho a festa do Divino uma das melhores que nós temos. Isto de a música levar nove dias indo a todas as casas buscar, debaixo da bandeira, as pessoas que fazem promessas, alegra a cidade muitos dias seguidos. Há três anos seguidos que eu não deixo de levar cera debaixo da bandeira. Vovó faz promessa todo o ano e quando chega a festa do Divino eu ganho um vestido novo para levar a cera. [...]

Eu desejo muito que meu pai também saia imperador, mas já estou perdendo a esperança de ele ser sorteado.

A beleza da festa depende do imperador. Este ano esteve muito mais animada e teve muito mais fogos do que no ano passado [...] (MORLEY, 2016, p. 36).

Mesmo a festa sendo também encarada como um momento de inversão de papéis ${ }^{204} \mathrm{e}$ possibilidade de protesto social - o que acontecia com muitos dos festejos na Minas colonial, dada a maior mobilidade social na zona mineradora -, na Serra essa hierarquia permaneceu forte, e a participação e a contribuição dos integrantes para o evento eram uma oportunidade de demonstração de poder econômico. Em estudo sobre a Festa do Divino em Sabará, do século

${ }^{203}$ De acordo com Affonso Ávila, o estilo barroco nasceu em circunstâncias históricas bastante específicas, caracterizando um determinado período.

\footnotetext{
Êste, como convencionam quase unânimemente os especialistas, abrangeria desde os primórdios do século XVII até a metade do seguinte, uma etapa, portanto, marcada por grandes transformações materiais para o mundo e, paradoxalmente, por uma crise filosófica deflagradora de choques ideológicos e embates religiosistas, com repercussões universais e a longo prazo. A colonização das Américas e a expansão mercantilista, ao mesmo tempo que a contra-reforma e o absolutismo político, são as principais coordenadas do quadro histórico dentro do qual se insere o barroco. (ÁVILA, 1970, p. 13).
}

Sobre análises mais profundas acerca do barroco, ver Maravall (1997).

204 “Agora é que eu vi como fica caro para os pobres dos negros serem reis por um dia. Júlia com o vestido e a coroa já gastou muito. Além disso teve de dar um jantar para a corte toda. A rainha tem uma caudatária que vai atrás segurando na capa que tem uma grande cauda. Esta também é negra da Chácara e ajudou no jantar. Eu acho graça é no entusiasmo dos pretos neste reinado tão curto. Nenhum rejeita o cargo, mesmo sabendo a despesa que dá.” (MORLEY, 2016, p. 36). 
XVIII ao XX, Beatriz Ricardina Magalhães (2001) aponta que desde o tempo colonial a identidade dos devotos e confrades era composta por uma plêiade de homens ilustres, de deputados a senadores do Império, alguns com títulos de nobreza, além de médicos, boticários, advogados, engenheiros etc.

Abaixo, a passagem de Grande sertão: veredas demonstra bem os homens de poder na dianteira das celebrações, fazendeiros que organizavam e sediavam os louvores aos santos. Às mulheres agregadas na fazenda cabiam os serviços domésticos de cuidar dos detalhes:

\footnotetext{
- "De uns três dias foi o São João, então amanhã é o São Pedro..." - alguém disse, de voz.

Soubessem que esse seo Ornelas era homem bom descendente, posseiro de sesmaria. Antes, tinha valido, com muitos passados, por causa de política, e ainda valesse, compadre que era do Coronel Rotílio Manduca em sua Fazenda Baluarte.

- "Ao que ele tem, mas tem mesmo, muita coragem?!" - eu me fiz.

- "Aí falam em sessenta ou oitenta mortes contáveis..." o Marcelino Pampa afiançou "... e ainda não esmoreceu os ânimos..."

Chegamos, com proceder seguro, e o céu por cima dali estava muito sereno. $\mathrm{Na}$ fazenda tinham levantado um mastro, na frente do pátio; vi movimentos de gente. As mulheres, na boca do forno fumaçando, mexiam com feixes verdes de mariana e vassourinha e carregavam as latas pretas de assar biscoitos. Só aqueles formosos cheiros das quitandas e do forno quente varrido, já confortavam meu estômago. No mastro, que era arvorado para honra de bandeira do santo, eu amarrei o cabresto do meu cavalo. (ROSA, 1986, p. 398).
}

As imagens a seguir ajudam na visualização das relações objetivas de classe em um momento de descontração no município de Francisco Dumont. As fotografias, referentes à tradicional festa católica do Divino Espírito Santo e da padroeira, Nossa Senhora da Conceição, revelam a classificação social por meio de quem pode e quem não pode representar o império naquela sociedade.

\section{Figura 21 - Festa do Divino Espírito Santo e Nossa Senhora da Conceição, Francisco Dumont, 1950}

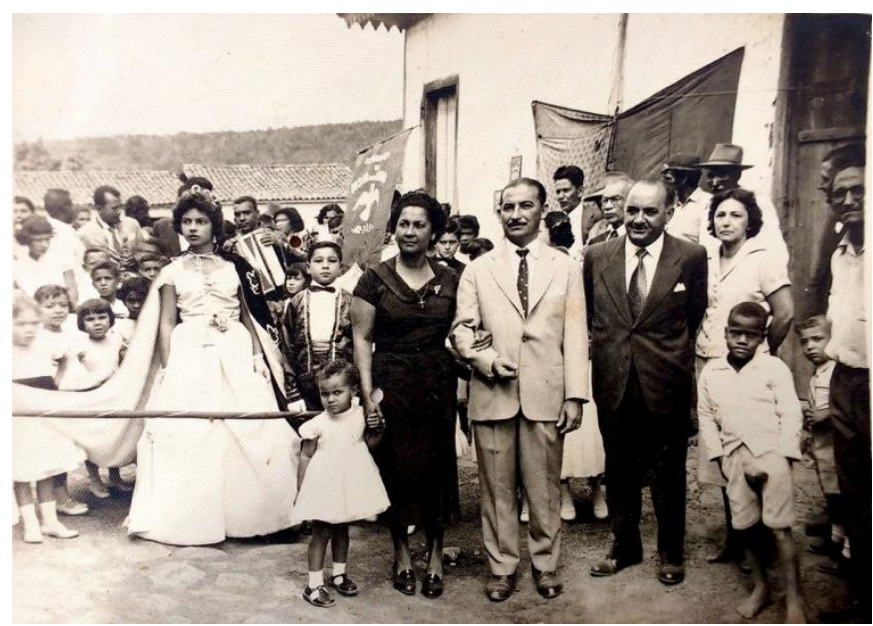

Fonte: acervo da Casa da Cultura Ercília Rosa, Francisco Dumont. 
Figura 22 - Festa do Divino Espírito Santo e Nossa Senhora da Conceição, Francisco Dumont, 1960

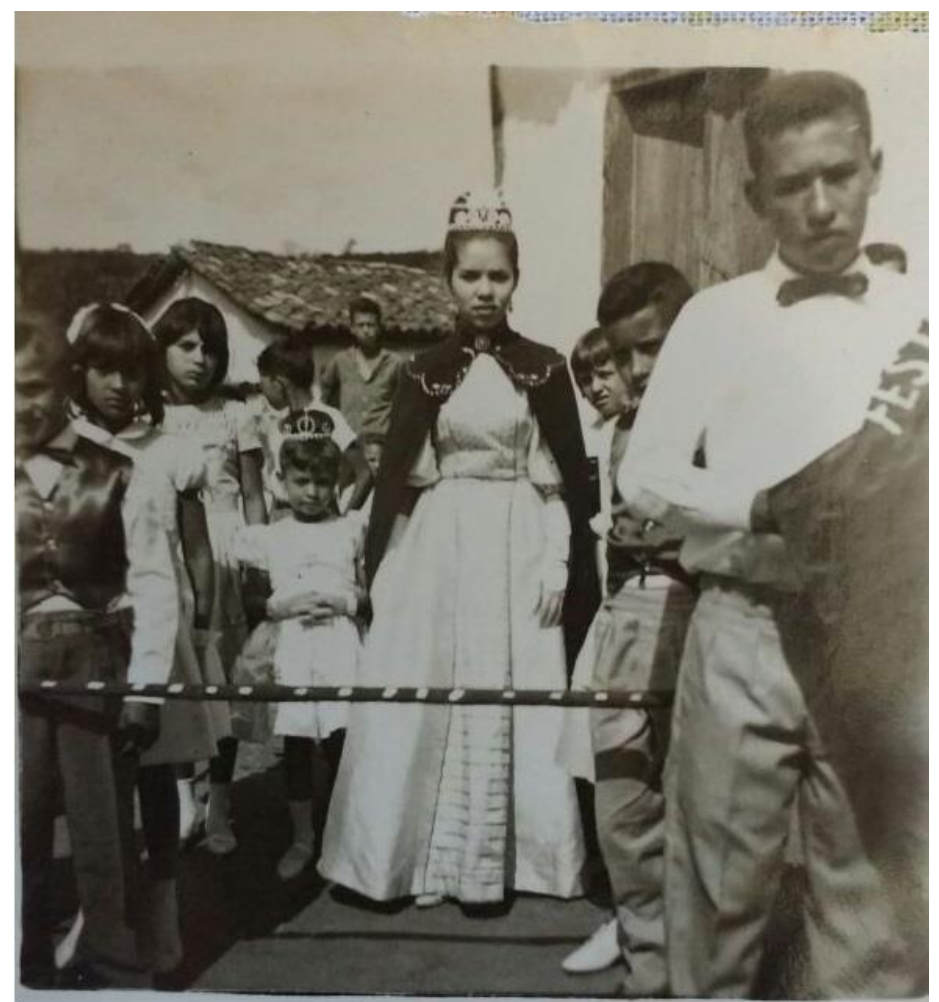

Fonte: acervo pessoal de Marta Bruzinga.

Figura 23 - Folia de Reis organizada pela família Prado, Francisco Dumont (sem data)

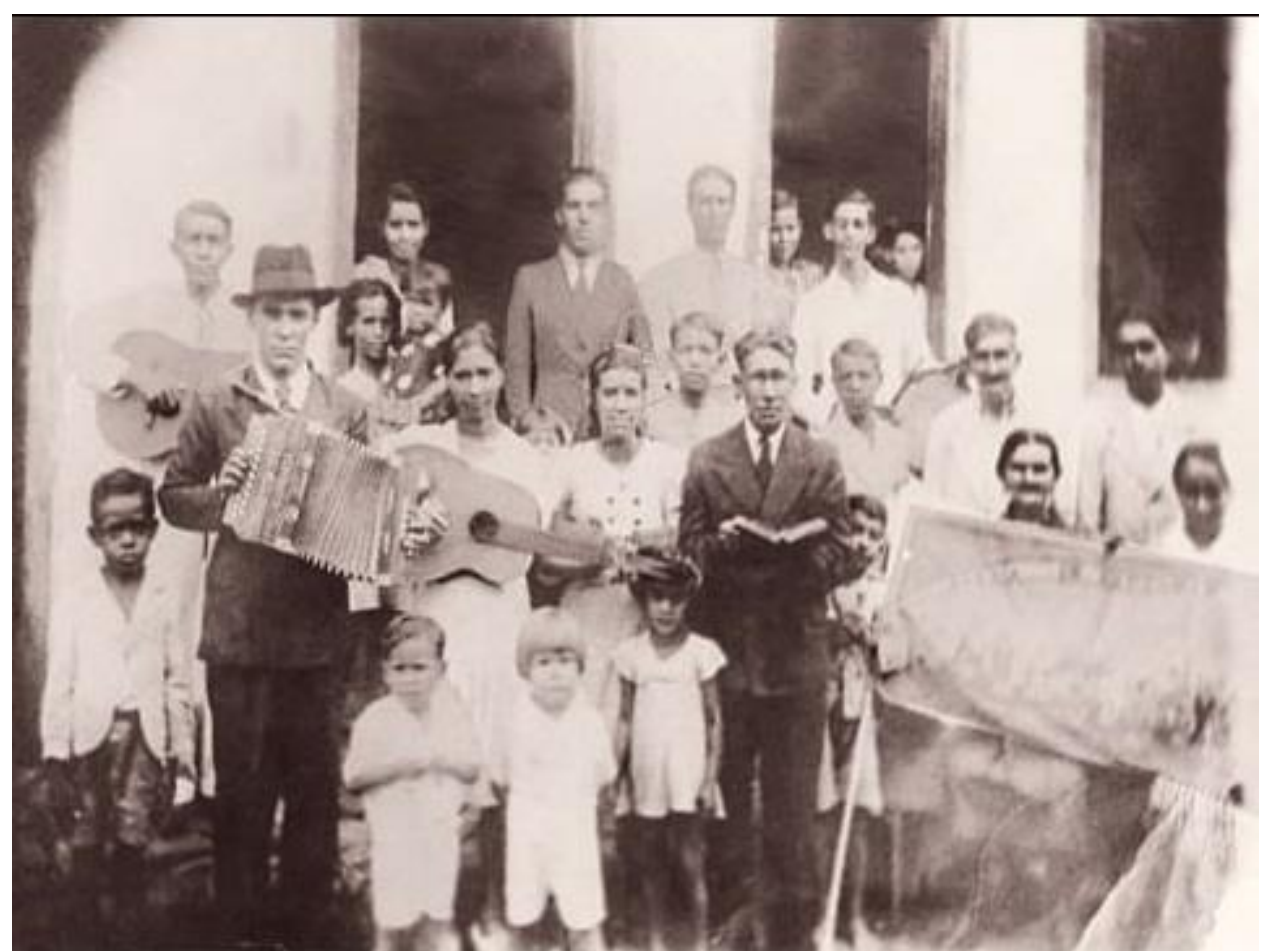

Fonte: acervo pessoal de Airton Prado. 
É possível notar na Figura 21 os festeiros ao lado do casal de imperadores. Apesar de a população ser bastante miscigenada, os jovens de pele mais clara é que eram escolhidos para representar o papel da família imperial. Atrás da imperatriz, crianças brancas seguram a vestimenta, enquanto um menino negro descalço está do lado de fora do cordão. Acompanhando a procissão, músicos negros e pardos se encarregam da trilha sonora. Na Figura 22, de poucos anos depois, mais uma vez, imperatriz e princesa são meninas brancas, pajeadas por damas de tez mais escura.

Diferentemente, a Figura 23 retrata outra manifestação religiosa vinda com os portugueses: a Folia de Reis ${ }^{205}$. Ela apresenta um outro tipo de organização, com base social diferente. Tradicional na realização do festejo, a família era composta por coletores de flores e frutos do cerrado e garimpeiros que, em tempos difíceis, revezavam os ganhos com o plantio de pequenas roças. O líder local do festejo era Geremias, pai de Édio Geraldo Prado, conhecido como Nem de Bico. De acordo com Nem, seu pai herdou dos avós o costume, cuja família, com gerações voltadas à coleta das flores, compunha a maioria do grupo de foliões. "Eles tinham a roupinha deles, os instrumentos e saíam nas casas arrecadando coisas, um dinheiro, um frango... E dia 6 faziam a festa." Mortos os seus antepassados, não sobrou nada. Nem de Bico acredita que com a chegada das empresas reflorestadoras, o assalariamento e a vida moderna, ninguém mais se interessou em manter a tradição.

No caso da folia, realizada entre a véspera do Natal e o dia 6 de janeiro, a base da organização é de trabalhadores pobres, todos músicos amadores e devotos das divindades católicas. Ao circularem pelas casas de gente mais abastada, visitam os presépios com suas cantigas e aproveitam para "fazer o saco", que significa comer e beber de graça em cada residência que entram. Visando ter acesso à comida, muitas pessoas se juntam aos foliões na peregrinação, sem deixar de lado o compromisso com o ritual religioso.

Para Norberto Guarinello (2001), seriam incompletas as definições de festa como ato coletivo ritualizado, de caráter essencialmente sagrado, próprio das chamadas sociedades primitivas e que decairia com a laicização e o individualismo próprios da sociedade contemporânea. Também não preenchem seu significado a interrupção programada da vida

\footnotetext{
205 Os festejos associados ao ciclo natalino, compreendendo o nascimento de Jesus e a Epifania - visitação dos Reis Magos -, é mais um caso de tradições antigas portuguesas reelaboradas no Brasil em diferentes manifestações de música, dança e teatro popular, que vão do dia 25 de dezembro ao dia 6 de janeiro (Dia de Reis). Parentes dos vilancicos ibéricos, as lapinhas, pastorinhas e pastoris do Nordeste são grupos cênico-musicais que dramatizam episódios relacionados ao nascimento de Cristo e à adoração dos pastores e dos Reis Magos. No Centro-Sul, são mais frequentes as folias ou ternos de reis, grupos que, visitando as casas ao longo de extenso percurso, refazem a viagem dos Reis Magos. Os foliões reconhecem diferentes estilos entre as folias de reis, que variam entre as regiões e são notáveis pela forma de cantar e pelos instrumentos adotados (MONTEIRO; DIAS, 2010).
} 
cotidiana, ou mesmo sua inversão completa, como forma de descarregar energias e tensões reprimidas; a instauração do caos da natureza, negação da ordem social, subversão. Também a denotação como manifestação coletiva especificamente popular, caracterizada pelo riso, pela alegria transbordante, pelo grotesco etc. não seriam, a rigor, incorretas.

O autor propõe uma abordagem que encare a festa como parte da estrutura do cotidiano, sendo ela seu produto necessário. Ele pensa na rotina não como uma dimensão particular da existência humana, mas como o tempo concreto de realização das relações sociais. Sendo laboriosa e materialmente preparada, a festa implica uma determinada estrutura social de produção, segundo regras particulares à vida habitual do coletivo que envolve, tornando-se símbolo de uma identidade, capaz de criar uma memória coletiva tornada afeto coletivo. A festa é, num sentido amplo, produção de memória e, portanto, de identidade no tempo e no espaço sociais, porém nem sempre criadora de consenso - dado que essa identidade e essa memória, para o caso analisado, estão presas à forma social da mercadoria. "É produto da realidade social, e como tal expressa ativamente essa realidade, seus conflitos, suas tensões, suas cesuras, ao mesmo tempo que atua sobre eles" (GUARINELLO, 2001, p. 971-972). Portanto, ela unifica, mas também diferencia, tanto interna quanto externamente, produzindo fronteiras durante a sua realização.

Apesar das transformações com o tempo, ao retomar anualmente uma celebração advinda do Portugal absolutista, a Festa do Divino permaneceu com sua função pedagógica ao apresentar o lugar de classe dentro da sociedade sertaneja, embora permitisse pequenas incursões de não brancos do lado de dentro do cordão da procissão. Já a folia deixou de ser organizada pelos Prado ao longo dos anos até desaparecer, representando bem a instabilidade da economia de garimpeiros, coletores e mais pobres que se juntavam: sem o acesso à Serra para faiscar e colher frutos, não há dinheiro para organizar anualmente o rito, que inclui vestimenta, bandeira e manutenção dos instrumentos.

Vicente Alves (2000) traz para o debate o conceito de modo de vida desenvolvido por Marx e Engels. Para esses autores, a importância da noção de modo de vida ocorre em função da análise das relações sociais de produção, dadas concretamente, que permite constatar outros fenômenos envolvidos, como, por exemplo, os conectados à temporalidade e à cultura - esta não apenas no sentido material, mas em conformidade a tudo que diz respeito à regência das conexões entre os homens.

Assim, a manifestação do modo de vida de um determinado grupo resulta das condições materiais que asseguram a sua reprodução social (incluindo o meio natural e o conhecimento técnico), o seu desenvolvimento social e a sua divisão social em classes. Cada uma dessas 
classes reproduz suas práticas cotidianas particulares, que se manifestam a partir de um conjunto de representações e tradições diferenciadas.

Entre as práticas, destaca-se aqui a religiosa, porque a Festa do Divino e a celebração da padroeira (Nossa Senhora da Conceição) eram momentos em que o ritmo do trabalho era alterado. Os garimpeiros desciam da Serra para os municípios e povoados; os lavradores interrompiam o trabalho na roça, assim como os vaqueiros, deixando as fazendas e os povoados para se dirigirem aos cortejos; o pequeno comércio fechava nos horários das procissões, missas e queima de fogos, enquanto as famílias se organizavam para acompanhar os festejos. O sino, os fogos e a banda de música local, com suas próprias composições de valsas, marchas e dobrados, anunciavam os três dias de festa a partir do meio-dia da terceira sexta-feira do mês de julho, que os sertanejos esperavam tanto para negociar espiritualmente seus pecados e pagar com gratidão suas graças alcançadas, quanto para dançar nos bailes profanos após a dedicação ao sagrado.

\section{Figura 24 - Trecho de partitura de dobrado composto por Mestre Lôro para a Banda de Música de Francisco Dumont, 1946}

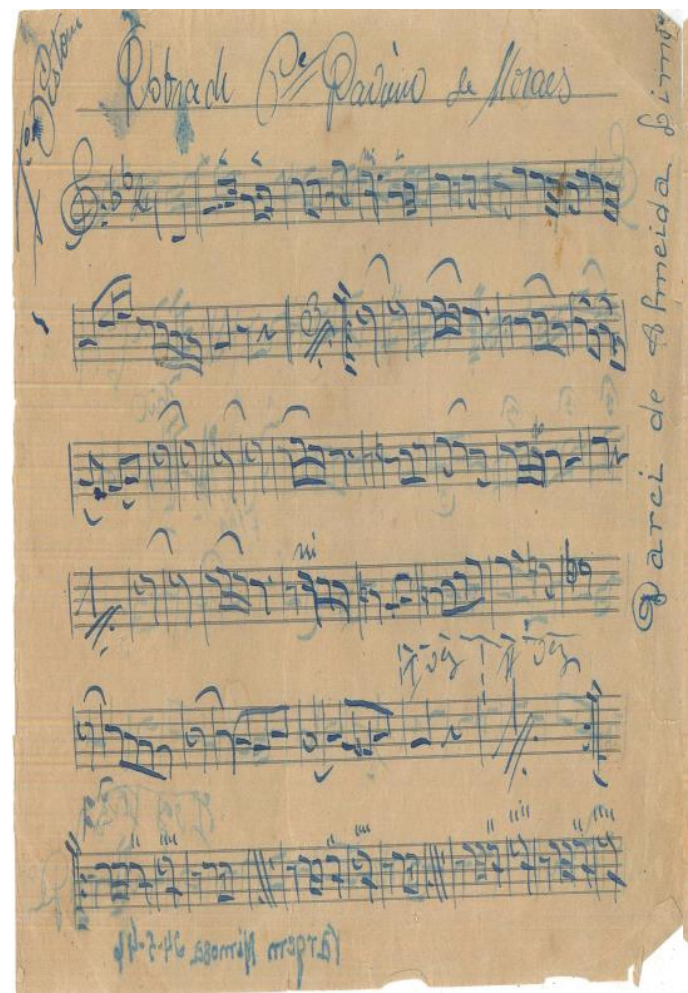

Fonte: acervo pessoal de Pedro Leite da Silva.

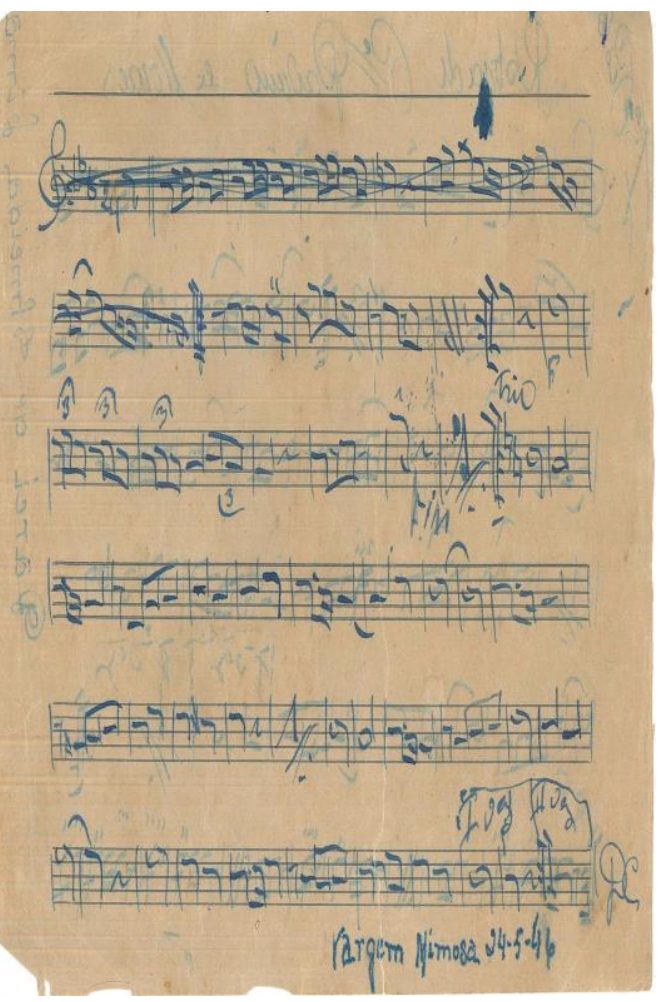

A Figura 24 é uma das poucas composições deixadas pelo regente Mestre Lôro. Infelizmente, não há certeza se o nome verdadeiro do maestro e compositor é Laurindo Louro, conforme Pixico tentou se lembrar. O que se sabe, a partir de depoimentos colhidos por músicos 
mais velhos e pelo entrevistado, é que ele era negro e desceu do sul da Bahia disposto a ensinar música e a formar bandas pelo norte de Minas Gerais ao longo da primeira metade do século XX. Assim como chegava, de repente, também partia, sem deixar rastro. Esta é uma das poucas partituras escritas à mão por ele, guardadas pelo ex-membro da Banda de Música de Francisco Dumont, Pedro Leite da Silva. Mestre Lôro foi responsável por sua formação e também pela banda de música do povoado do Buriti Grande, onde Teotônio e seu pai aprenderam a tocar clarineta. As festas religiosas de muitas localidades da Serra tinham em seu repertório as composições do mestre, entre valsas, marchas e dobrados, um dos poucos rastros de sua presença.

A formação de bandas de música nos povoados e cidades interioranas, sobretudo dirigidas por lideranças miscigenadas, pode ser entendida como um esforço de mimetização dos grandes centros urbanos, sobretudo a capital federal no momento, o Rio de Janeiro. As casas de baile, as composições melódicas, a moda e os códigos de sociabilidade endossavam o processo não só de mestiçagem da população, mas também de inserção dos não brancos nos espaços onde as camadas sociais dominantes circulavam, em destaque os ambientes urbanos. Seria, para Gilberto Freyre em Sobrados e mucambos, parte do processo de diluição do patriarcado, dado que, para o autor, a formação de uma cultura única no Brasil se deu porque o patriarca era tolerante com seus submissos, tese com a qual não se concorda, mas se crê interessante por se ater a detalhes que procuram desnudar as transformações sociais pelas quais o país passava.

A presença da partitura, bem como todo o contexto que ela traz à pesquisa torna necessário captar a complexidade social da Serra a partir do movimento de interiorização da metrópole, observado por Maria Odila Leite da Silva Dias (2005) desde a transferência da Corte portuguesa para os trópicos, cravando costumes metropolitanos no interior do Centro-Sul do novo continente, até a necessidade, durante o Império, de garantir a integração nacional, cimentada pela dependência e colaboração das classes dominantes. Dado o enraizamento europeu na Colônia, as inter-relações entre nativos e lusitanos eram estimuladas via comércio, costumes, casamentos, equipamentos administrativos etc., que, com isso, intentavam centralizar a administração, dominar os vastos recursos naturais, conectar as regiões e evitar as desagregações.

Maria Odila Dias reforça as consequências posteriores da interiorização da metrópole para todo o período do Império, mas ressalte-se que esse movimento introduz a metropolização sertões adentro: não apenas a necessidade de produzir mercadoria penetra os lugares mais distantes, mas os arquétipos de sociabilidade praticados nas cidades litorâneas do Sudeste 
também integram um processo de assimilação cultural que vai além no recorte temporal, permitindo a suspeita de um projeto em que há uma máscara de nacionalidade, enquanto por trás do seu encadeamento são os ditames gerais de produção que impelem à integração de diferentes camadas sociais, ao consumo e à mimetização dos centros urbanos.

Passado o tempo e com o a efetivação da autonomização dos fatores de produção na Serra, as manifestações religiosas e suas festividades se transformaram. O aumento da circulação de dinheiro promoveu o desencanto com a tradição religiosa, e os calendários agrícolas e de colheita já não têm mais tanta importância para uma economia que gira em torno de outras mercadorias, cada vez mais descoladas da natureza pelo excesso de técnica. Com a diluição do poder das famílias tradicionais a partir da centralização do Estado, arrefece-se o interesse dos pais na luta pelos lugares mais arrojados para os filhos nos quadros das procissões. Também se verifica o crescimento de igrejas evangélicas, entre elas, as que pregam a teologia da prosperidade, que disputam cotidianamente os fiéis das cidades pequenas.

A Folia de Reis dos Prado não existe mais, e a Banda de Música de Francisco Dumont perdeu totalmente as características originais, sem saber sequer uma música do repertório original. A Festa do Divino permanece anualmente, porém o rito religioso é o que menos interessa àqueles que buscam o calendário festivo regional. Ambulantes de lugares distantes se apinham nas ruas estreitas, interessados na venda de seus produtos, que vão de roupas e bebidas alcoólicas a panelas. O palco montado na praça principal, a oferecer apresentações gratuitas de cantores populares modernos da região, atraem espectadores de cidades próximas, garantindo o que a prefeitura e os comerciantes anseiam: o consumo.

Se, por um lado, a festa popularizou o acesso da população mais pobre aos festejos, como a participação nos shows em praça pública, por outro, o festejo aos poucos se descola do motivo religioso tradicional. As dificuldades de arrecadação para as festas aumentam a cada ano, e o comércio local não para durante os cortejos. O som das variadas igrejas evangélicas disputa ouvintes com os cânticos eclesiásticos. As procissões, cada vez mais com número reduzido de fiéis, prosseguem tendo em suas fileiras a população mais velha, tanto do município quanto da zona rural, para quem o momento ainda faz sentido.

A ideia do sacrifício simbólico durante a procissão e os ritos perdem o significado historicamente construído. Se a manifestação religiosa antes aparentava não envolver trabalho, hoje a labuta é uma das coisas que ela mais escancara: vendedores ambulantes dormindo debaixo das barracas nos três dias de festa, para virarem a noite em busca de alguns trocados. Ao fim do terceiro dia, ao desmontar as tendas e se mobilizar rumo a outra cidadezinha sertaneja onde se possa comercializar, a gratidão ao poder abstrato pelo dinheiro adquirido. 


\title{
5. Do sertão ao cerrado: o Estado maquinal e sua absorção pelo capital
}

\author{
No sertão da minha terra, fazenda é o camarada que ao chão se deu \\ Fez a obrigação com força, parece até que tudo aquilo ali é seu \\ Só poder sentar no morro e ver tudo verdinho, lindo a crescer \\ Orgulhoso camarada, de viola em vez de enxada \\ Filho do branco e do preto, correndo pela estrada atrás de passarinho \\ Pela plantação adentro, crescendo os dois meninos, sempre pequeninos \\ Peixe bom dá no riacho de água tão limpinha, dá pro fundo ver \\ Orgulhoso camarada, conta histórias prá moçada \\ Filho do senhor vai embora, tempo de estudos na cidade grande \\ Parte, tem os olhos tristes, deixando o companheiro na estação distante \\ Não esqueça, amigo, eu vou voltar, some longe o trenzinho ao deus-dará \\ Quando volta já é outro, trouxe até sinhá mocinha prá apresentar \\ Linda como a luz da lua que em lugar nenhum rebrilha como lá \\ Já tem nome de doutor, e agora na fazenda é quem vai mandar \\ E seu velho camarada, já não brinca, mas trabalha.
}

Milton Nascimento, 1967.

O processo de apropriação das terras na Serra do Cabral - como no Brasil - foi feito na base da grilagem, legitimada desde 1850, com o aval do Estado. A ode à grilagem, escrita em teor jornalístico por Monteiro Lobato em 1922 para se referir à expansão dos cafezais em São Paulo, expõe bem o desejo dos dominantes que personificam capital e poder para seguir com o projeto de territorialização do valor-cisão.

No entanto, a arte do grilo não seria, para esta perspectiva, a de tirar o direito do nada, mas a da expropriação em nome da onda verde a ser implantada mais adiante: o eucalipto, que abriria caminho para que o Estado conduzisse ao que chama de civilização aqueles que aos seus olhos resistiam a ela, na promessa da mobilidade do trabalho e da fartura econômica. Do sertão ao cerrado, reforça-se o discurso da técnica e do planejamento, para cobrir de um verde exótico as chapadas e veredas, que forneceriam o que os militares chamam de progresso: o carvão para as siderúrgicas mineiras.

No livro Onda verde, Monteiro Lobato dedica dois capítulos ao eucalipto, tecendo elogios e esperanças de modernização e independência econômica nacional a partir do "páo exótico". Além de escritor, editor e latifundiário, ele foi adido comercial nos Estados Unidos e crítico ao Governo Vargas, tendo a sua trajetória contribuído para que escrevesse sobre o Brasil para além dos textos ficcionais.

Observando os 8,5 milhões de eucaliptos cultivados pelo Serviço Florestal da Companhia Paulista em Rio Claro sob os cuidados de Edmundo Navarro, já informava o criador do sítio do pica-pau amarelo que "A Companhia de Morro Velho, visando a futura exploração do ferro de Itabira, planta 200.000 annuaes" (LOBATO, 1922, p. 81). A silvicultura desponta, 
no raiar do século, como parte do projeto de industrialização tardia brasileira, provando que os discursos encontrados na década de 1970 e nos anos 2000, apresentados no decorrer dos capítulos, não surgiram de repente.

O mesmo autor afirma que "Matta é riqueza unicamente quando homogenea, formada d'uma só especie vegetal", devendo ser útil: "Num alqueire de terra crescem dois, tres mil vegetaes differentes, o que é lindo á luz da esthetica, optimo para tirar cipó, mas, do ponto de vista da utilidade economica, um desastre" (LOBATO, 1922, p. 87-88).

Mesmo sabendo da consequência ambiental - "Do segundo anno em deante, como é em extremo rapido o crescimento das arvores [...] a terra por ellas ocupada só se presta para receber o capim catingueiro, dando um pasto soffrivel para carneiros e bovinos" -, Monteiro Lobato insiste na silvicultura como "a solução nacional do problema do combustivel para nossas vias ferreas" (LOBATO, 1922, p. 90-93), já defendendo, no alvorecer do século, os pesticidas à base de sulfuretos contra as formigas, apontadas, junto à figura do Jeca Tatu, entre os grandes males do país. Torna-se notório que a posterior teoria do nacional-desenvolvimentismo, apoiada na aceleração da modernização com um horizonte de independência nacional, encontrou suas bases a partir da centralização do Estado, concretizada poucos anos depois do texto "A Onda Verde", urdida por intelectuais que também personificavam a economia naquela passagem. Grilar terras e cultivar o que se convinha chamar de útil eram (são) ações amalgamadas.

Sendo o território um resultado da apropriação do espaço pelo capital, ele não pode ser compreendido como um dado natural. No capítulo sobre a teoria moderna da colonização, Karl Marx já apontava para a necessidade de enxergar a expansão capitalista como manifestação de uma relação social firmada na violência da submissão aos desígnios econômicos, os quais também movimentam para a formação do Estado moderno e seus desdobramentos no processo de autonomização das categorias de mediação social - terra, trabalho e capital.

A partir de 1930, novas configurações econômicas impeliram a novas relações entre os fatores de produção e o Estado, antes pulverizado no poder do mandonismo local. Do ponto de vista político, durante a Revolução de 1930, a aliança do capital agrário exportador com o urbano industrial selaria os anseios brotados das intenções de João Pinheiro. Começava a ser posto em prática o pacto entre as camadas dominantes, alegorizadas pela cena de Riobaldo durante sua convalescença na fazenda Barbaranha, de seo Ornelas, conforme interpreta Luiz Roncari (2006). Este, representando o fazendeiro sesmeiro de linhagem e tradição, acolhia o chefe de bando, em alusão às relações de favor entre amigos, quando recebeu a visita de seo Habão, que simboliza o homem do capital comercial. Seo Habão vinha para noticiar a morte de 
Selorico Mendes, padrinho de Riobaldo, que lhe deixava herança ${ }^{206}$. Na mesma cena aparece Otacília, com quem Riobaldo veio a contrair matrimônio, integrando o grupo seleto de donos de terra pelo casamento arranjado e pelo espólio, domesticando-se na condição de fazendeiro "homem-de-bem" nas barrancas do rio São Francisco.

Eu estava na Barbaranha, no Pé-da-Pedra, hóspede de seo Josafá Ornelas. Tomei caldo-de-galinha, deitado em lençóis alvos, recostado. [...]

Mas o que mormente me fortaleceu, foi o repetido saber que eles pelo sincero me prezavam, como talentoso homem-de-bem, e louvavam meus feitos: eu tivesse vindo, corajoso, para derrubar o Hermógenes e limpar estes Gerais da jagunçagem. Fui indo melhor.

Até que, um dia, eu estava repousando, no claro estar, em rede de algodão rendada. Alegria me espertou, um pressentimento. Quando eu olhei, vinha vindo uma moça. Otacília.

Meu coração rebateu, estava dizendo que o velho era sempre novo. Afirmo ao senhor, minha Otacília ainda se orçava mais linda, me saudou com o salvável carinho, adianto de amor. Ela tinha vindo com a mãe dela, e a mãe dela, os parentes, todos se praziam, me davam Otacília, como minha pretendida. [...]

Eu já estava de todo bom, firme para as arremessadas, quando ali na Barbaranha se surgiu para mim igualmente a visita de seô Habão - ele com o seo Ornelas se tivessem entre tempos pacificado. Homem baseado. Demonstrou que tinha muita satisfação em me ver, assim como para mim vinha trazendo outro cavalo de presente - o qual era ruço-rodado, ordem de valor e estampa. [...] Mas ele portava causa maior - a que tinha ido confirmar e saber, e agenciar, por seus bons préstimos. E era que meu padrinho Selorico Mendes acabara falecido, me abençoando e se honrando, orgulhoso de meus atos; e as duas maiores fazendas ele tinha deixado para mim, em cédula de testamento. (ROSA, 1986, p. 533-534).

O Estado se transformou em poder centralizado com tentáculos institucionais que organizariam as formas de produção de valor. A partir desse momento, a região, herança das particularidades que a territorialização colonial deu forma, aparece aos olhos dos burocratas desprovida de historicidade e como impasse à homogeneização econômica, cabendo ao Estado assumir o papel da totalização via planejamento, numa tentativa forçada de alcançar as grandes potências.

$\mathrm{Na}$ Serra, os movimentos oriundos da transição política e econômica foram perceptíveis décadas mais tarde, expostos na paisagem, nas relações e na mobilidade do trabalho, que apesar de já existente desde a territorialização colonial, a partir deste momento aparece como projeto e também consequência das mudanças ali impostas.

\footnotetext{
${ }^{206}$ Diferentemente de Heloisa Starling, que em Lembranças do Brasil: teoria, política, história e ficção em Grande sertão: veredas analisa a obra como uma metáfora da proclamação da República, Luiz Roncari, em $O$ Brasil de Rosa: o amor e o poder e $O$ cão do sertão, interpreta o romance como alegoria da ascensão de Vargas ao poder e o projeto de modernização. Coincidência ou não, Grande sertão: veredas foi lançado em 1956, no auge do nacional-desenvolvimentismo, que tinha como traço importante o pacto entre as classes dominantes, na tentativa de moldar uma burguesia nacional modernizadora. Como funcionário do governo e próximo a Vargas e a JK, é difícil desdenhar da hipótese de que João Guimarães Rosa não estivesse também pensando a formação do Brasil, inclusive pela linguagem que apresenta, misturando o erudito e o popular. Seria uma proposta de conciliação, almejada por contemporâneos como Celso Furtado, Darcy Ribeiro e outros?
} 


\subsection{O Estado Novo e o embrião do novo Estado: a região aparecendo}

Até o momento, houve um esforço de reconstituir o processo de territorialização da Serra do Cabral pela ótica das relações capitalistas. Como seu resultado dinâmico, aparece a região pecuária e diamantífera como herança da territorialização colonial ao Império. Os dois reinados viram a relativa decadência da mineração em todo o norte de Minas Gerais, apesar de homens e mulheres livres pobres continuarem penetrando as grotas da Serra, vindos de lugares diversos e movidos por um só motivo: a sobrevivência condicionada pelo fetiche da mercadoria, característica definidora daquela sociedade.

O garimpo, enquanto atividade não renovável por depender da sorte de achar o recurso finito no subsolo (fazer o diamante é uma impossibilidade que não requer custo de produção, enquanto procurá-lo sim), se transformou de trabalho coletivo organizado no escravismo para a faiscação - o que não significa que seu exercício fosse realizado por pessoas solitárias. Esgotadas as grandes possibilidades de catar as pedras de superfície (como no método croado), aos sujeitos sem instrumentos arrojados para as implosões coube o deslocamento para pontos cada vez mais distantes na Serra em busca de um achado. Por conta do empobrecimento dessa economia, a pecuária se assentou como atividade econômica mais estável, havendo investimentos como estímulo à sua especialização. Do território apropriado para produzir as mercadorias, concebeu-se uma região do gado, que continuou ofuscando a persistência na atividade garimpeira.

Sendo a região uma consequência histórica forjada na relação com o mercado internacional, ao mesmo tempo em que se constitui mantendo ou criando formas de produção do valor bastante diferenciadas (OLIVEIRA, 1988), a Serra do Cabral, pela criação bovina, se formou ligada ao comércio interno de mercadorias, indiretamente vinculada aos mercados internacionais - contato mais objetivo com o exterior quando feito pela mercadoria diamante. Direta e indiretamente, a produção de artigos para o mercado externo era a lei de reprodução social no nível mais geral que, ao mesmo tempo, criava formas de geração de produto bastante distintas, o que confere a particularidade de cada região. 


\section{Figura 25 - Centro do povoado de Conceição do Barreiro, atual município de Francisco Dumont, com carroças circulando e extinta birosca (mercearia) do Boresca, início do século XX}

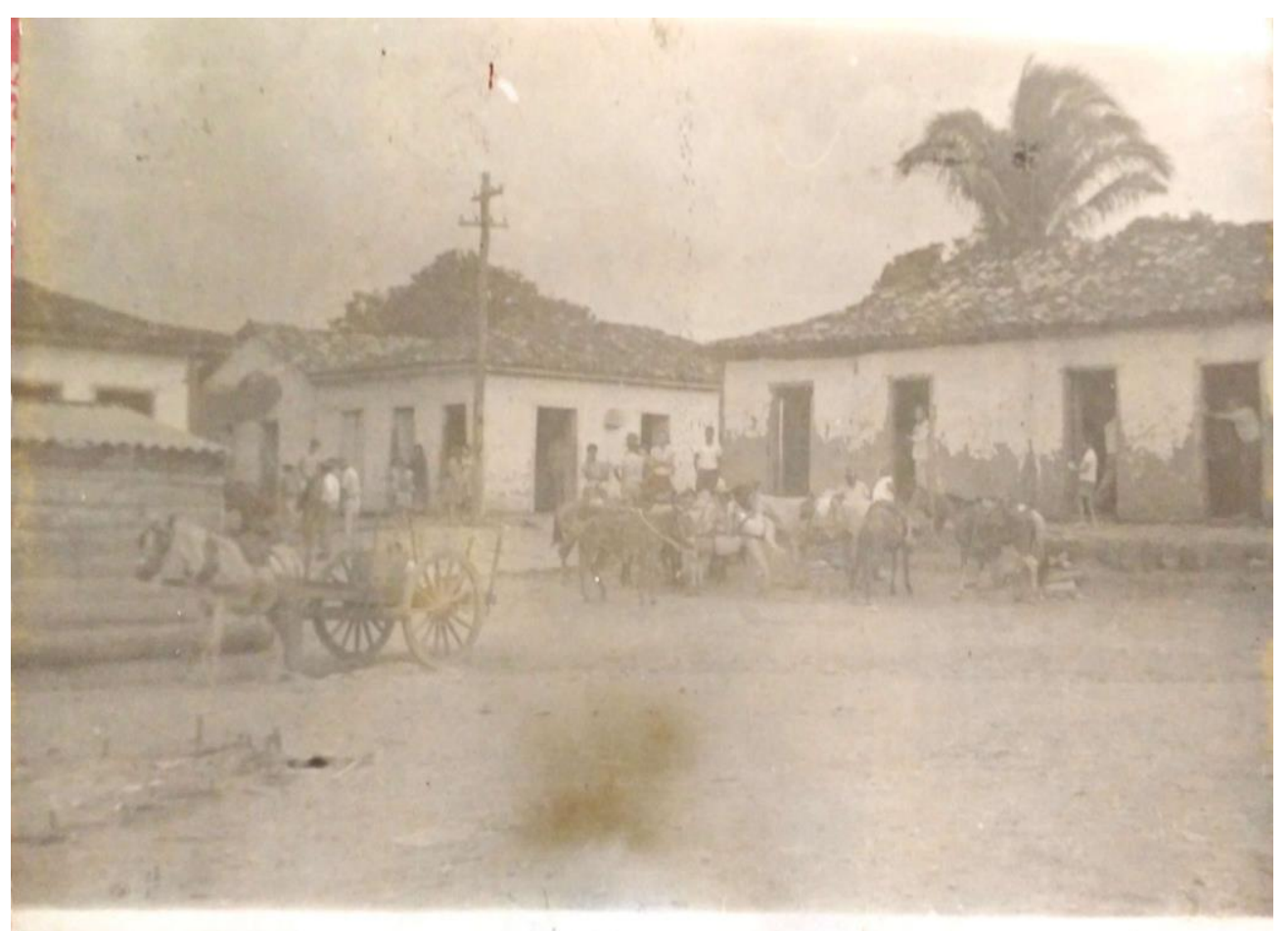

Fonte: acervo pessoal da família Dumont, 2017.

A pecuária se sedimentou nas terras do norte mineiro, consolidando o poder dos coronéis. A decadência do garimpo delineou a Serra como produtora de carne, couro e derivados ao longo do século XX, tornando-a um espaço socioeconômico onde a forma então vitoriosa do capital - o boi - se impôs às demais, homogeneizando-a como uma região pela predominância da atividade pecuária e pelas relações de classe, cuja hierarquia e poder de quem a produzia eram determinados pelo lugar e pela forma em que eram personas do capital e de sua contradição básica (OLIVEIRA, 1988).

Toda região tem uma base territorial, por isso nenhum dos dois conceitos pode ser encarado como naturalizado. Concorda-se com a concepção de região proposta por Francisco de Oliveira (1988), para quem ela se fundamenta na especificidade da reprodução do capital, nas formas que o processo de acumulação assume, na estrutura de classes peculiar a essas formas e, portanto, também nas formas da luta de classes e do conflito social em escala mais geral. Nela, o político e o econômico se fundem, amalgamando interesses de grupos específicos na reprodução do capital.

A região, enquanto produto histórico, sucede à territorialização. Esta última já era a modernidade desabrochando, iniciada no momento colonial. Os atributos fisiográficos específicos de cada porção do espaço apropriado conferem formas próprias de organização da 
produção, criando relações sociais particulares. Nestas relações restritas é que a região se torna evidente, e essa nitidez foi captada nos discursos e projetos ao longo do século XX, que a despiram de sua historicidade para justificar intervenções.

Desistoricizar a região seria, portanto, retirar dela a bagagem social que a conformou, tornando-a empecilho ao movimento geral do capital e um vazio passível de intervenção porque sua particularidade passa a ser interpretada como disparidade, decorrente do questionável isolamento e do atraso, e não como consequência da própria modernização nem da posição da forma social de mediação na reprodução do capital. Tal ótica abriu caminho para que o Estado, diante do ímpeto centralizador e consolidador do seu território, buscasse por meio do planejamento a correção das desproporções, na tentativa de homogeneização das regiões consideradas problema, lhes conferindo novas funções.

Essa corrida com o fim de alcançar as grandes potências, apresentada por Robert Kurz (1994) como modernização retardatária, contém na sua base não a liberdade do Estado em se modernizar, mas a sua inserção no decurso do capitalismo a um sistema mundial, o que torna a história geral uma totalidade concreta e contraditória e transforma as condições do desenvolvimento econômico e social de maneira qualitativa. Nesse transcurso, estágios sociais diferentes daqueles das grandes potências ocidentais são considerados atrasados pela ótica do capital e de sua reprodução ampliada e territorializante, que se articulam no processo de totalização, apesar das diferenças. Essa é a base da teoria do desenvolvimento desigual e combinado.

A teoria do desenvolvimento desigual e combinado, desenvolvida por Leon Trotsky, é uma tentativa de explicar o tipo de dominação que o capital exerce nas formações sociais onde subsistem relações que o autor chama de pré-capitalistas e, por consequência, de dar conta da lógica das contradições econômicas e sociais do capitalismo periférico ou dominados pelo imperialismo (LÖWY, 1995).

Lançados pelo imperialismo, os Estados periféricos anulam sua historicidade alicerçada nos processos violentos de abrangência do mundo da mercadoria e tentam se inserir nos mercados internacionais, cada vez mais dinâmicos na produção e na troca. Constrangidas pelo sentimento de retardo por estarem a reboque dos países avançados e na compreensão de que o desenvolvimento econômico se dá em etapas, essas sociedades saltam suas fases intermediárias rumo aos estágios mais avançados da produção, invocando a violência na sua execução qual um rolo compressor. Assim, realizam os programas de modernização na ilusão de alcançar o futuro, sem consegui-lo: as particularidades locais e regionais possuem limitações, cuja coação à assimilação deflagra o caráter contraditório e retardatário do desenvolvimento. 
Além da impossibilidade de tocar o futuro, é difícil definir o que é arcaico e o que é moderno no capitalismo, dado que o capital e as relações sociais a ele inerentes nem sempre se apresentam da mesma forma. Se, como comentado, a produção de artigos para o mercado externo foi a lei de reprodução social no nível genérico que, coetaneamente, manteve ou criou formas de geração do valor bastante diferenciadas e culminou na particularidade de cada região, a teoria do desenvolvimento desigual e combinado parte de opostos binários dentro de um pensamento preso à moderna relação, desconsiderando a co-constituição do dissociado na forma do valor como um processo dialético e que não se dá o tempo todo da mesma maneira. Isso significa que a própria teoria não escapa ao dualismo, como alertou Maria Sylvia de Carvalho Franco (1997): ao apontar a conciliação de dois princípios reguladores da atividade econômica que são essencialmente opostos - produção direta de meios de vida e produção de mercadorias -, a economia colonial não pode ser representada como dualidade integrada, mas como unidade contraditória.

Sendo o dualismo uma composição de opostos, a polaridade é imanente ao sistema produtor de mercadorias e responsável por seu movimento, impulsionando as sociedades taxadas de periféricas à corrida rumo à modernização.

Em si, a relação do valor é uma identidade negativa, sendo que, enquanto tal, não pode permanecer somente consigo mesma. Por isso, vê-se obrigada a cindir-se permanentemente em oposições imanentes e polarizadas, tal como seu próprio pressuposto baseia-se, já, numa clivagem, a saber, justamente na cisão sexualmente determinada de todos os objetos, momentos e vida etc. que não são absorvidos pela forma do valor. Como relação de cisão, a relação do valor é, já de si, uma identidade cindida, instituída enquanto polaridade. Essa identidade negativa forma a raiz a partir da qual novas clivagens crescem mais e mais, e, com elas, novas polaridades.

Não se trata, aqui, de dualismos em si mesmos estáticos e complementares, tais como, por exemplo, aqueles que se encontram nas formas misticamente expostas das culturas pré-modernas, senão que de polaridades hostis e exasperadoras, que travam uma permanente luta de aniquilação, em que pese o fato de constituírem apenas dois lados da mesma identidade. Nessa medida, tais polaridades formam o modo em que se manifesta o impulso à morte da subjetividade do valor: a luta de opostos hostis, levada ao esgotamento e, por fim, à aniquilação, é a única forma possível de existência e de movimento imanente da relação do valor e da cisão. Nesse processo, as oposições polarizadas terminam por se transmudar reiteradamente umas nas outras, revelando sua identidade negativa até coincidirem, no ponto final da história da modernização, imediatamente nesta identidade destruidora. Isso vale tanto para a estrutura quanto para a dinâmica histórica da relação global, em si mesma fraturada. (KURZ, 2010, p. 104-105). 
Aponta-se, então, para a necessidade de se pensar a forma social do capital, que aparece como formas particulares da reprodução social historicamente determinadas da modernização, transmudando qualitativamente, a cada momento, em um sentido crítico e negativo. ${ }^{207}$

Assim, a territorialização, enquanto processo histórico que envolve a expansão sobre novas áreas ou lhes confere a aparência de novas funções em nome de uma mesma intenção, é um processo de abrangência da modernização, que, por sua vez, enquadra-se na transição de uma forma concebida como estática para uma forma dinâmica de sociedade. A modernização é, portanto, "um processo de transformação permanente, que sempre volta a sacudir toda a estrutura de reprodução" (KURZ, 1995), é parte do processo de reprodução ampliada do capital.

Para ligar o Brasil ao movimento mundial de modernização, faz-se interessante observar o imperialismo contemporâneo. Dialogando com os pensamentos voltados à resolução das crises nas metrópoles europeias dos Oitocentos, David Harvey (2006) permite pensar esse processo de expansão do capital no elo entre sua reprodução ampliada, imperialismo e resolução dos problemas da superacumulação nos países-cerne dessa dinâmica. Para tal, ele parte da teoria moderna da colonização de Marx em comparação às preocupações de Hegel e Von Thunen sobre a harmonia econômica de suas sociedades.

Para o geógrafo, o capital tem um impulso para criar o mercado mundial, para produzir novas necessidades e novos tipos de produtos, "para implantar novos recursos produtivos em novas regiões" (HARVEY, 2006, p. 117). Ele explica que o capital excedente pode ser emprestado para um país estrangeiro, criando novos recursos produtivos em novas regiões. As altas taxas de lucro prometidas oportunizam um incentivo "natural" para tal fluxo e, se atingidas, aumentam a taxa média de lucro no sistema como um todo. Temporariamente, as crises ficam resolvidas.

Porém, o autor destaca: temporariamente. Para ele, os lucros maiores significam crescimento na massa de capital que busca aplicação rentável, com consequente tendência à intensificação da superacumulação em uma escala geográfica expansível.

O ajuste espacial - termo utilizado por David Harvey para esses movimentos de expansão do capital a fim de resolver as crises dos países de origem - não pode acontecer sem expropriar as populações anteriormente assentadas nos espaços visados, criando os excedentes

\footnotetext{
207 "Esta perspectiva da contradição em processo, que tem de chegar ao seu fim, não tem de resto nada a ver com um ponto de vista do optimismo do progresso [...]. Uma maneira de ver que assume um clímax do capitalismo, pelo contrário, move-se num plano OBJECTIVO de teoria da acumulação, em que o desenvolvimento das forças produtivas não é simplesmente contado como positivo, como no marxismo tradicional ou nas concepções neooperaístas; as forças produtivas e as respectivas tecnologias também podem ser forças destrutivas." (SCHOLZ, 2016).
} 
de foça de trabalho. $\mathrm{O}$ autor aponta para a necessidade de uma relação orgânica entre reprodução expandida e processos violentos de espoliação ${ }^{208}$. Essa conexão tem, para ele, uma dinâmica histórica que envolve a associação entre a constitucionalidade burguesa e a formação do Estado, as quais permitiram a criação de duas formas de ajuste para a questão da sobreacumulação, ambas dialeticamente relacionadas: a temporal e a espacial.

A forma de ajuste temporal se pautaria em um processo de desvalorização geral, tendo os juros como cerne de sua regulação. A forma espacial seria a expansão geográfica, em que incidiriam outros processos de acumulação por espoliação, relacionadas às despossessões de terras e recursos, e a imposição do trabalho assalariado. Assim, a acumulação por espoliação libera ativos a custo muito baixo, abocanhados pelo capital superacumulado que lhes confere imediatamente um uso lucrativo. Sobre esses ativos incide o interesse de produção e circulação de mercadorias, cujos meios de fazê-las se dá com empréstimos disponíveis, movimentando o capital sobreacumulado, que se valoriza (KLUCK, 2019).

Esse ajuste seria para David Harvey (2006) uma forma provisória de resolução das crises econômicas, pois a superacumulação de capital também tenderia a acontecer nas regiões que recebem os empréstimos, reproduzindo o movimento de ajuste e arrastando consigo as regiões antigas. Para ele, tal imperativo seria produto da real geografia histórica do capitalismo, que enquanto relação social contém a marca da contradição. $\mathrm{O}$ ajuste espacial se tornaria um recurso constante às crises do capital, cuja saída estaria na intensa racionalização da transformação e expansão geográfica no sentido de absorver sociedades ainda não agregadas à lógica da mercadoria - como se ainda houvesse lugar no mundo que direta ou indiretamente não esteja submetido à sociabilidade do valor, pronto para ser saqueado pela eterna acumulação primitiva...

Apesar da importância da abordagem de David Harvey, é preciso questionar criticamente se os novos territórios espoliados pelo ajuste espacial não estavam, cada qual à sua maneira e anteriormente, já envolvidos nas relações econômicas modernas. Cada sociedade estabelece relações com a produção do valor de forma particular, estando mais ou menos "economificadas" com o processo de totalidade (SCHOLZ, 2016). A mudança qualitativa do capital, que é histórica - e, portanto, tem um fim -, não pode ser ignorada, sobretudo conforme

\footnotetext{
${ }^{208}$ Em A produção capitalista do espaço, ele parte da análise de Rosa Luxemburgo para compreender esse processo de desterritorialização de comunidades camponesas para que o capital se recupere de sua crise estrutural, transformando a terra em ativo e explorando a força de trabalho a baixo custo - o que a autora denomina imperialismo. Segundo David Harvey, quando essa lógica territorial capitalista encontra entraves à sua expansão, entra em cena o Estado, responsável por aniquilá-las e promover a mobilidade do trabalho (HARVEY, 2006; KLUCK, 2019). Tanto Luxemburgo quanto Harvey apostam em uma eterna e repetitiva acumulação primitiva, ignorando as novas bases produtivas que impelem a expansão do capital.
} 
a desvalorização do valor, provocada pela dessubstancialização do capital, que esvazia a justificativa de expansão territorial para a captura de ativos. Porém, como a maioria das teorias, esta pode servir a interesses específicos.

Considerando-se o ajuste espacial um sermão e uma ação exógenos ou da crista hierárquica política e econômica que nem sempre reflete a realidade dos territórios, para o caso do Brasil, ele traz consigo o discurso da modernização, desconsiderando as formas particulares de inserção social no mundo da mercadoria. O Estado, alicerçado na academia, é quem toma para si o planejamento como maneira de modernizar o território nacional idealizado na homogeneidade. O planejamento seria, assim, uma ação de ajuste espacial, atendendo às exigências de expansão do capital fictício ${ }^{209}$ tanto do Centro-Sul do país, quanto dos centros econômicos mundiais.

Modernização e territorialização são, neste caso, duas ações de apropriação espacial que pressupõem o atraso como condição a ser superada, com discurso carregado de dualismos. Cada transformação das relações do capital requer novas maneiras de organizar esses espaços para que deem conta de suas demandas. Tanto o subdesenvolvimento quanto o dualismo são conceitos apresentados como mera oposição formal que oculta um processo real em que há uma simbiose e uma organicidade, uma unidade de contrários em que o "moderno" cresce e se alimenta da existência do "atrasado"; o capitalismo cria a ilusão do subdesenvolvimento como produção de sua expansão (OLIVEIRA, 2013). Com isso, o discurso do subdesenvolvimento alimenta os planos de modernização, arraigando uma ação contraditória e impossível de homogeneizar os territórios do capital.

No Brasil, tais demandas e discursos se encontram a partir do processo simultâneo de conformação e centralização do poder do Estado, iniciado em 1930, configurando a chamada autonomização (TOLEDO, 2008) e o processo de institucionalização de suas ações, tornando o planejamento uma de suas balizas. Para que o poder estatal desse conta de tal projeto, foi necessária uma mudança na sua forma de ser e de agir, o que significou impor transformações no poder local e sua reprodução, requalificando a região.

\footnotetext{
209 "O conceito de 'capital fictício' foi desenvolvido por Marx no terceiro volume d'O Capital para designar o capital que se baseia exclusivamente na especulação e na expectativa de ganhos futuros; logo que alguém exija o pagamento real das dívidas, a 'bolha' não poderá deixar de rebentar com falências em cadeia [...] Até ao final do ciclo fordista, a especulação financeira seguia mais ou menos o ritmo e as dimensões da acumulação real. Tudo isso mudou enormemente a partir do momento em que a acumulação real, apesar de todos os créditos, estagnou. A partir de então, o recurso ao crédito serve para estimular uma acumulação inexistente e para prolongar artificialmente a vida de um modo de produção que já está morto [...] maior parte são acções, obrigações, créditos, valores imobiliários, 'dinheiro electrónico', etc. - o que contribui para tornar esse processo completamente incontrolável. Mediante uma reviravolta grotesca, que nem mesmo Marx foi capaz de prever, a produção real passou a ser um apêndice do capital fictício." (JAPPE, 2006, p. 10-11 apud MENEGATTI, 2019, p. 70-71).
} 
Se antes os coronéis, no jogo contraditório da relação capital em territorialização e com o poder reconhecido pelo Estado, monopolizavam o controle sobre a terra e o trabalho, a partir de 1930, com a extinção da Guarda Nacional, opera-se uma forma de o Estado se impor a esse poder, que, conforme discutido, não era inadequado nem inútil enquanto foi eficiente na territorialização e na produção de bens.

Muitos desses donos do poder foram agregados pela política modernizadora. No livro Quando o planejamento vai para o brejo: a mobilidade do trabalho e o planejamento territorial na modernização do Velho Chico, Erick Kluck apresenta como o Estado efetivou a institucionalização de suas ações, de seu aparato e de seu financiamento centralizando a reprodução capitalista. De acordo com o autor, isso decorreu da arrecadação de impostos e da capacidade de endividamento, com empréstimos aos setores industrial e agropecuário. Para o caso do médio vale do São Francisco, recorte espacial da obra, ele se dedicou às contradições do Estado em planejar a região para mais tarde, a partir dos anos 1980, criar políticas territoriais pautadas nos territórios de identidade e na gestão de crise via crédito, enquanto também abre o vale sanfranciscano para introduzir o capital privado via grandes projetos.

Pautado em Francisco de Oliveira, para Erick Kluck essas mudanças na forma de ser do Estado significaram transformações no poder local e sua reprodução, requalificando a região como região planejada, cerne da discussão sobre o caráter do atraso e da modernização. O autor acrescenta que essa modernização é tratada como retardatária, marcada, entre outras coisas, pela mobilização do trabalho por meio do Estado e de iniciativas privadas, transformando fundamentalmente o sentido da reprodução ampliada, generalizando o mercado de terra e de trabalho, o que requereu diversos processos violentos (GAUDEMAR, 1977; KLUCK, 2019).

No decurso de institucionalização de suas ações, o Estado recorreu ao aparato científico e técnico, bem como ao suporte jurídico, de modo a dar respaldo aos seus feitos. Não à toa, já se observa na virada do século XIX o movimento dos filhos dos coronéis à cidade ou a outros países para estudar e retornar como tecnocratas ao domínio de seus progenitores, se autonomizando das condições de seus antepassados, comprometidos naquele momento com o fortalecimento e a centralização do poder estatal diante da crise da reprodução do poder local. O contato com os espaços urbanos, sobretudo nos centros imperialistas, foi essencial para que retornassem com novas ideias, voltadas à administração, à urbanização e à difusão do trabalho complexo, além do forte sentimento de desconforto, já evocado em gerações anteriores na interpretação de Roberto Schwarz (1992) ${ }^{210}$.

\footnotetext{
${ }^{210}$ Esse desconforto não será aqui analisado, porém vale mencionar que muitos desses filhos de coronéis, saindo de suas regiões fechadas e em contato sobretudo com os centros urbanos europeus e estadunidenses, desenvolvem
} 
Os excertos dos anuários estatísticos de Minas Gerais de começo dos Novecentos apontam para a transformação que é do capital, mas também da mentalidade de parte das personificações das classes dominantes: o sertanejo, em especial o que habita a Serra do Cabral, é visto como um sujeito doente, miserável e ignorante, passível de ser "produzido" e tornado útil pela educação técnica e pela soltura das amarras locais do patronato, algo só possível de realização ao se mobilizar o trabalho e privatizar a terra, anseios já explicitados ficcionalmente por Zé Bebelo.

Esse momento de ruptura, que já vinha sendo engendrado desde o segundo reinado, se deu formalmente com a ascensão de Getúlio Vargas ao poder pela primeira vez. As bases políticas desses marcos (mobilização do trabalho, privatização das terras e interferência direta do Estado nas regiões via planejamento) são identificáveis na institucionalização das ações do Estado Novo, ligadas à administração pública, à segurança nacional, à produção de estatísticas socioeconômicas, à constituição do ensino secundário, técnico e superior, entre outras atitudes.

O recurso do Governo Federal ao conceito de segurança nacional serviu para criar uma série de empresas estatais estratégicas que garantiriam nas décadas seguintes a ampliação do processo de industrialização. Para dar cabo dessa nova política econômica, era preciso criar mecanismos de controle do território, abarcando o conhecimento dos aspectos físicos da superfície e do subsolo, dos padrões espaciais da ocupação humana e econômica e de um ordenamento regional condizente com a escala territorial do Brasil, além do seu mapeamento sistemático.

Erick Kluck (2019) salienta que tais transformações criaram um discurso contendo dialeticamente uma origem na reprodução da totalidade concreta. Nesse momento surge, em 1934, o Instituto Nacional de Estatística, embrião do IBGE, coordenado por Teixeira de Freitas, com experiência em informações territoriais acumulada com o cargo de Delegado Geral do Recenseamento de Minas Gerais nos anos 1920. Sob sua coordenação, o levantamento do território do estado foi o mais completo possível para o período, e, não à toa, ele esteve na chefia do instituto.

Teixeira de Freitas, junto a Juarez do Nascimento Fernandes Távora (militar experiente no interior brasileiro por ter sido tenente na Coluna Prestes) e Francisco Luís da Silva Campos (burocrata com visão modernizadora do ensino universitário e da saúde pública) se articularam

uma lírica do exílio em suas interpretações do Brasil, que vai da literatura ficcional, como em Gonçalves Dias (1846), ao ensaísmo sociológico, como em Sérgio Buarque de Holanda e sua ideia de o brasileiro ser um "desterrado em sua própria terra". O desconforto tem como base a positivação das condições materiais de formação do país e a condição de classe desses sujeitos letrados, que permanecem abstraídas pelo discurso de identidade. 
ao longo da década de 1930 para criar um sistema de planejamento centrado no gerenciamento de informações que teria que alcançar até a instância municipal, o que expõe o tentáculo normatizado do Estado chegando diretamente aos poderes locais ${ }^{211}$.

Roberto Schmidt de Almeida comenta que a década de 1930 foi de trabalho intenso para o trio. Foi nesse período que as noções de integração técnica entre Estatística, Geografia e Cartografia tomaram corpo, sobretudo em termos de preparação das equipes profissionais que iriam gerenciar a referida agência a partir daquele momento. Da Lei Geográfica, implementada em 1938 para dispor sobre o mapeamento das malhas municipais e distritais, até a Campanha Censitária de 1940, o conceito de regionalização se consolidou no instituto. Em 1941, o IBGE oficializou a macrorregionalização do território brasileiro, com a finalidade de homogeneizar o território a fim de coletar dados estatísticos com maior precisão para subsidiar o processo de planejamento nas décadas seguintes (ALMEIDA, 2003).

Dialogando com o IBGE, datam também dessa época os convênios internacionais para a organização de cursos universitários no Brasil, como a vinda de professores franceses para iniciarem os cursos de Geografia em São Paulo e no Rio de Janeiro e a de especialistas austríacos em Geodésia. Ao analisar o contexto, nem a ideia de universidade teria tido força o bastante para se tornar uma realidade concreta e viva, nem o recurso às missões estrangeiras teria tido eficácia se as mudanças de estrutura econômica e social não tivessem operado as transformações de mentalidade e a formação de novos ideais de cultura (TAVARES; VIDEIRA, 2020). Ciência e política estavam caminhando explicitamente juntas, fomentando meios de ação conjunta.

Destarte, institucionaliza-se o ensino superior no Brasil, incluindo o curso de Geografia. Assim como a cartografia imperial do território era encomendada a técnicos de maioria anglosaxã, no século XX, a função do técnico estrangeiro não era apenas realizar um serviço pago pelo Estado para revelar os recursos do território, mas fundar as bases de um pensamento científico ilustrado favorável ao novo Estado e reprodutor das relações mediadas pela mercadoria, por meio da consolidação de instituições, como a universidade, tendo a incumbência de participar do projeto nacional. A esta, caberia desenvolver, por um lado, linhas de pensamento que refletissem sobre a formação do país e seu povo, e, por outro, adotar atitude pragmática sobre o corpo territorial que o abrigava.

\footnotetext{
${ }^{211}$ A atuação precisa de Teixeira de Freitas à frente da coleta de dados sobre Minas Gerais corresponde ao período dos dois últimos mapas analisados no capítulo referente à cartografia da Serra do Cabral: a Serra aparece apenas no período de sua gestão, em 1927, no mapa de Affonso de Guayra Heberle (quando provavelmente era Delegado de Recenseamento no estado), e em 1939, na carta de Hely Carvalho, quando já compunha o Instituto Nacional de Estatística.
} 
Desse modo, a ciência se traveste de um discurso neutro, se posicionando acima dos interesses particulares e em nome da governabilidade - uma das armas do Estado para fenecer os poderes locais. No entanto, conforme desenvolve David Harvey no texto "População, recursos e a ideologia da ciência", a ciência é naturalizada para atender aos interesses de quem a utiliza como ferramenta de poder, abstraindo sua condição de produto histórico imbuído de ideologias.

Ao abordar como Thomas Malthus, David Ricardo e Karl Marx interpretavam a relação entre população e recursos no século XIX no contexto europeu, David Harvey apresenta como Karl Marx criticava seus contemporâneos por não relacionarem o objeto de suas preocupações ao modo de produção que os utiliza ou os produz - atentando para a historicidade da relação e suas dinâmicas complexas sendo jogadas de escanteio. Com isso, perdia-se a oportunidade de análise dos encadeamentos dentro da totalidade.

$\mathrm{Na}$ conexão sujeito-objeto, David Harvey aponta que Karl Marx defende o conhecimento como interno à sociedade e parte da totalidade, sendo a ciência também uma relação social concebida dentro de seu contexto histórico. Para aquele, "se se supõe que todos os métodos científicos são eticamente neutros, então os debates sobre metodologia raramente são importantes" (HARVEY, 1981, p. 22), um comportamento que vem de encontro aos interesses de quem advoga pela neutralidade científica em nome de uma população inteira, omitindo a defesa de objetivos muito particulares.

Ainda, para ele, o materialismo dialético seria o método mais adequado de tratamento das complexas relações população-recursos, pois seria a única ou mais acurada forma de entender que por trás do discurso de neutralidade científica, sempre há uma pretensão ideológica. Portanto, ao se pensar a normatização do Ensino Superior - dentro dele, o curso de Geografia - em um quadro de realização do Estado Novo e seus projetos, torna-se possível analisar criticamente o discurso de neutralidade e superioridade científica, a qual porta consigo a posição iluminista de verdade incontestável, como ferramenta de alteração das relações de poder pretéritas.

No moderno sistema produtor de mercadorias, diferentes áreas de conhecimento desenvolvem-se numa direção comum. A inauguração dos cursos de Geografia em São Paulo e Rio de Janeiro mais a criação do IBGE, todos na mesma década, são parte de um mesmo plano do Governo Federal. O trânsito de docentes e pesquisadores entre as universidades e o instituto elucida a produção de um discurso científico de suporte às ações estatais. Pedro Pinchas Geiger é um exemplo desse engajamento da universidade com as instituições modernizadoras estatais. 
Considerado pelo próprio IBGE um dos principais pesquisadores da segunda geração do Conselho Nacional de Geografia do órgão, onde ingressou em 1942, teve uma trajetória de produção acadêmica na qual pensava, entre outros assuntos, a regionalização, julgada por ele um campo que "vem interessando a estudiosos das ciências sociais e às camadas esclarecidas da população" (GEIGER, 1969, p. 5; grifos nossos). Para ele, o planejamento deveria dedicar importância aos aspectos espaciais da economia e reconhecer na regionalização uma expressão do processo de desenvolvimento, cabendo à tecnologia o papel da totalização do espaço. Ele defendia que a Geografia tinha muito a contribuir para as formas e condições de regionalização, surgindo como disciplina diretamente integrada ao planejamento. Em suas palavras,

\begin{abstract}
A difusão do progresso tecnológico só se pode realizar com a melhoria dos transportes, das comunicações e da transmissão de energia, que permitem o contacto mais denso e rápido entre as vastas áreas geográficas. Êste progresso de transportes e comunicações destina-se, ou deve se destinar, a servir à expansão da produção e à distribuição mais equilibrada das riquezas entre a população, fenômenos ligados ao processo contínuo da industrialização. Realmente, não se pode dissociar expansão do progresso e de modernos fatôres de vida pelo interior dos países e processos de industrialização. Não há regionalização sem desenvolvimento industrial. (GEIGER, 1969, p. 10-11, grifos nossos).
\end{abstract}

Para o geógrafo, o subdesenvolvimento era identificado pela ausência de determinadas estruturas regionais, cabendo ao planejamento dirigir a regionalização para as áreas menos evoluídas, definindo esta como a maior homogeneização do país, de forma a integrar melhor o conjunto nacional. Pensando os processos econômicos brasileiros como fases ao invés de contradições e tendo publicado o artigo em fins dos anos 1960, Pedro Pinchas Geiger se sintoniza à linha de pensamento desenvolvimentista, cuja perspectiva se insere na concepção evolucionista, a qual fazia da história uma sucessão de etapas rigidamente pré-determinadas, cuja caminhada da sociedade, se conduzida linearmente, levaria muito lentamente ao progresso $^{212}$.

Com isso, o Estado passa a se valer não apenas da academia como seu suporte, mas também de teorias que endossem o seu projeto de modernização retardatária. Tornando-se ferramenta de submissão, o saber e o conhecimento, determinados por um contexto histórico social, são condicionados por formas sociais fetichistas que implicam relações de coação e

\footnotetext{
212 “O desenvolvimento recente do país, desde a Segunda Guerra Mundial até o início da década de 60, calcado fundamentalmente na industrialização, é relacionado a um processo de substituição de importações. Agora, dizem economistas, trata-se de iniciar outra fase, onde a expansão econômica só poderá ter apoio numa ampliação de mercado. E mais, que uma excessiva concentração da distribuição da renda deve ser superada, para que se efetive esta ampliação do mercado." (GEIGER, 1969, p. 17; grifos nossos).
} 
dominação, tornando-se ideologia (KURZ, 2005). Para isso, o desenvolvimentismo se converte em uma teoria abraçada pelo horizonte político e econômico das classes dirigentes do país.

Analisando de forma elogiosa o pioneirismo de Minas Gerais no desenvolvimentismo brasileiro, Otávio Soares Dulci resume o termo, explicando que

\begin{abstract}
Desenvolvimento, no terreno socioeconômico, é uma ideia referente à superação intencional de uma situação de atraso relativo. Envolve, portanto, uma clara dimensão política, que se traduz em ações governamentais - mediante graus variáveis de intervenção - e também em articulações de classes e grupos diversos (sobretudo as elites políticas, econômicas e intelectuais) em torno da meta de superação do atraso. Podemos chamar de desenvolvimentismo ao pensamento que focaliza esse processo numa perspectiva de projeto, realçando seu sentido estratégico e seu potencial mobilizador. (DULCI, 2005, p. 114, grifos do autor).
\end{abstract}

O autor, contribuindo para a seleção de textos de Minas e os fundamentos do Brasil moderno, termina sua participação enaltecedora da trajetória de João Pinheiro, apontando para a concretização do projeto com os esforços de seu filho Israel, engenheiro que debutaria em sua carreira política como secretário dos Negócios da Agricultura, Indústria, Viação e Obras Públicas de Minas Gerais em 1933, tendo depois participado ativamente no Governo JK.

Sob Israel Pinheiro, o Plano de Desenvolvimento Econômico de Minas Gerais, criado em 1935 e publicado dois anos depois, apresentava os dirigentes mineiros integrados à modernização que o Estado Novo adotava. Dentro de um quadro de crise agravado por $1929^{213}$ e pela Segunda Guerra Mundial, o plano buscava diversificar as mercadorias e estava setorializado em produção vegetal, animal e mineral, com ênfase maior na agropecuária - a indústria ainda engatinhava no estado. No entanto, os projetos rodoviário, ferroviário e educacional não foram esquecidos: quanto a este último, deveria se voltar para o ensino agrícola e industrial, diplomando técnicos e mobilizando o trabalhador também no nível do conhecimento útil. É nesse contexto que a Escola de Viçosa e a Escola Superior de Agricultura são transformadas em universidades modelo e é criada a cidade industrial de Contagem, entre outros feitos.

Alguns anos mais tarde, JK seria o governador de Minas Gerais (1951-1955). O desenvolvimentismo, o planejamento regional, a modernização retardatária e todas as contradições encontrariam suas oportunidades de discurso e de ação e, de forma ufanista ou crítica, vê-se em Minas Gerais uma das bases mais sólidas de criação das ideologias desenvolvimentistas e dos projetos de autonomização do Estado.

\footnotetext{
213 Ano marcado pela queda brusca das ações da bolsa de Nova Iorque, provocando a depressão econômica estadunidense e agravando a crise mundial.
} 


\subsection{O desafino do "presidente bossa nova" ao tocar a região}

O Estado Novo preparou as bases para que o planejamento regional se assentasse como projeto de governo modernizador. Do ponto de vista ideológico, o desenvolvimentismo, elaborado já na década de $1930^{214}$, seria o respaldo teórico de convencimento de que o país precisava se modernizar e que o Estado teria o papel de condutor da burguesia nacional, dada por alguns como já formada, enquanto para outros, mesmo à esquerda, como Francisco de Oliveira, ainda não, o que era preciso ser feito - rumo ao progresso.

A década de 1950 se apresenta como um momento em que, passado o autoritarismo e o centralismo do Estado Novo como ferramentas de imposição da modernização retardatária como projeto, o discurso democrático tornaria palatável o desenvolvimentismo como agenda nacional, cabendo aos técnicos, já tomando seus assentos na gestão, pensar e planejar o país na direção da produção de mais valor.

Nesse contexto, em 1955 foi criado o Instituto Superior de Estudos Brasileiros (Iseb), como órgão do Ministério da Educação e Cultura (MEC). O grupo de intelectuais envolvidos em sua formação tinha como objetivo o estudo, o ensino e a divulgação das ciências sociais, cujos dados e categorias seriam aplicados à análise e compreensão crítica da realidade brasileira e deveriam permitir o incentivo e a promoção do desenvolvimento nacional. A preocupação do instituto girava em torno da discussão dos problemas brasileiros correlacionados às problemáticas universais, apesar de ser abertamente nacionalista. Do ponto de vista da Geografia, é importante considerar esse tipo de ação, porque ela revela como os poderes político e econômico e os intelectuais estavam olhando para o território nacional e o que consideravam disparidades regionais. Ao adotar esse método comparativo, antevê-se a base dualista dos discursos de planificação nacional.

Para Hélio Jaguaribe, uma de suas lideranças, o desafio era como alcançar um projeto que resguardasse o máximo de seu propósito nacional e social, mas que, ao mesmo tempo, fosse compatível com a realidade do país, com as forças dominantes e com as condições que prevaleciam na década de 1950. Para ele, a solução que parecia viável naquele momento era

\footnotetext{
${ }^{214}$ Segundo Alberto Acosta (2015), a primeira vez em que se falou em desenvolvimento com conotação teórica foi em 1949, no governo estadunidense de Harry Truman, cuja ideia seria captada e aprimorada por Walt Whitman Rostow, que a tornou "o novo imperialismo". No contexto latino-americano, a teoria do desenvolvimento e seu contrário, o subdesenvolvimento, foi elaborada por Celso Furtado para explicar a relação entre centro e periferia e apontar os obstáculos à prosperidade dos Estados à margem, sugerindo um enfoque faseológico, conforme proposto no último capítulo de Formação econômica do Brasil. Segundo o autor, a análise histórica da primeira metade do século XX, que vai da etapa do café à do mercado interno, com indústria e setores conexos, pode ser encarado "como um processo de articulação das distintas regiões do país em um sistema com um mínimo de integração" (FURTADO, 2007, p. 20).
} 
"um projeto nacional-desenvolvimentista, que atribuía à burguesia nacional uma grande importância na mobilização de um esforço de desenvolvimento industrial encaminhado para um projeto nacional" (JAGUARIBE, 2005, p. 255).

Para seus intelectuais basilares, entre eles Nelson Werneck Sodré e Ignácio Rangel, o Brasil só poderia ultrapassar a fase de subdesenvolvimento pela intensificação da industrialização, com a substituição das antigas elites dirigentes do país. Apesar de o Iseb reunir membros com diferentes pontos de vista, adotavam o método histórico de conhecimento, partilhando, segundo Bresser-Pereira (2004), de uma perspectiva de esquerda moderada e eram, sem exceção, nacionalistas, preocupados com a industrialização e com o que consideravam a Revolução Nacional Brasileira ${ }^{215}$. Acreditando na existência de uma burguesia nacional, a leitura que fizeram de Marx e de sua revolução burguesa permitiu ao Iseb interpretar que esta se daria em duas fases: a do mercantilismo e a do capitalismo industrial, sendo que apenas a última conduziria efetivamente ao desenvolvimento ${ }^{216}$.

Alinhados ao pensamento da Comissão Econômica para a América Latina $(\mathrm{Cepal})^{217}$, seus integrantes acreditavam que o desenvolvimento que emergiria da revolução capitalista seria "sustentado", porque a acumulação de capital e o progresso técnico se tornariam condição de sobrevivência das empresas. Ao contrário do que acontecia no capitalismo mercantil, a empresa que não continuasse a investir na modernização de seu sistema de produção e de seus produtos e serviços pereceria. A partir desse raciocínio, era razoável que o Iseb e a Cepal supusessem que, depois da industrialização, o desenvolvimento se tornaria praticamente automático (BRESSER-PEREIRA, 2004).

Apresentado nesses termos por Luiz Carlos Bresser-Pereira, membro paulista e júnior do Iseb entre os anos 1950 e 1960, o desenvolvimento lhe aparece como revolução capitalista, estratégia e superação do dualismo que divide o país entre atrasado e moderno. Em sua definição, o desenvolvimento é um processo de acumulação de capital e de incorporação de progresso técnico por meio do qual a renda por habitante e o padrão de vida da população

\footnotetext{
215 O Iseb via a Revolução de 1930 como o início da Revolução Nacional Brasileira. Ela começaria com Getúlio Vargas, sob a égide da industrialização substitutiva de importações. Os nacionalistas brasileiros e latinoamericanos e a esquerda nacional eram simpáticos à visão do grupo, além de Celso Furtado, que, apesar de não ter composto seu quadro, chegou a publicar duas conferências pelo instituto.

${ }^{216}$ Robert Kurz (1994) também encontra em Marx esse pensamento, ao analisar o caso da União Indiana e da Inglaterra. A negatividade do moderno sistema produtor de mercadorias foi ocultada enquanto ele cumpria a "missão civilizatória" no Oriente, vencendo todas as relações de produção estamentais, estáticas e, em suas palavras, pré-modernas.

${ }^{217}$ Criada em 1948, a Cepal abrangeu o Caribe posteriormente. Vinculada às Nações Unidas, esboçou uma crítica da lei da vantagem comparativa, estabelecendo os fundamentos econômicos de uma política de industrialização em que o Estado, sua burocracia pública e os capitalistas industriais desempenhavam um papel ativo (BRESSERPEREIRA, 2010).
} 
aumentariam de forma sustentada. O Iseb e a Cepal viam na industrialização o desenvolvimento, "mas, mais do que isto, era o processo mediante o qual o país realizava sua revolução capitalista" (BRESSER-PEREIRA, 2004, p. 55), viável apenas com a formação de um Estado-nação moderno, que definiria e regularia o mercado ${ }^{218}$.

Ou seja, interpretando criticamente, o mercado e o Estado, o dinheiro e o poder, a economia e a política, o capitalismo e o socialismo não são, na verdade, alternativas, mas constituem os dois polos de um mesmo "campo" histórico da modernidade (KURZ, 1994). O desenvolvimentismo escancara o paradoxo do Estado como base para o desenvolvimento do capitalismo, bem como a sua captura pelo mercado.

Não só intelectuais brasileiros teceram suas ideias desenvolvimentistas sobre o país. $\mathrm{Na}$ mesma esteira estava Jacques Lambert, chegado ao Brasil em 1939 para integrar a missão de professores franceses que viriam inaugurar a Faculdade Nacional de Filosofia ${ }^{219}$. Inebriado pelas previsões ufanistas que a industrialização e o desenvolvimentismo faziam do Brasil, mas também sendo crítico pensador de seu tempo, via nos Estados Unidos o grande centro capitalista da Guerra Fria, o modelo maior de progresso. No seu panorama sobre a América do Sul, o Brasil era o país que tinha as melhores condições para se tornar uma grande potência caso seguisse "o progresso econômico e social que tomou conta do Estado de São Paulo" (LAMBERT, 1972, p. 33).

Provido de suas ideologias, em 1956 lança Os dois Brasis, com a colaboração de intelectuais de primeira linha - como Anísio Teixeira, Roberto Moreira, Darcy Ribeiro, Aparecida Joli Gouveia, Jaime Abreu, Alceu Amoroso Lima, L. A. Costa Pinto e José Honório Rodrigues - não como autores, mas como contribuintes teóricos nas formas de pensar o país. O título já anuncia a sua concepção teórica: a formação de duas sociedades num mesmo território, representadas por um Brasil velho e um Brasil novo, separados pelo peso de séculos de distância. ${ }^{220}$

\footnotetext{
218 "O desenvolvimento é um processo de acumulação de capital e de incorporação de progresso técnico por meio do qual a renda por habitante ou, mais precisamente, os padrões de vida da população aumentam de forma sustentada. Para o Iseb, assim como para a Cepal, o desenvolvimento era industrialização, mas, mais do que isto, era o processo mediante o qual o país realizava sua revolução capitalista. Para Marx, era um processo integrado de desenvolvimento econômico, social e político. Para Schumpeter, tinha como agentes os empresários e não significava simplesmente aumento da renda per capita, mas transformações estruturais da economia e da sociedade. Entretanto, todo esse processo só fazia sentido nos quadros econômicos da revolução capitalista e nos marcos políticos da formação de um Estado-nação moderno: o desenvolvimento acontecia em um mercado capitalista definido e regulado pelo Estado." (BRESSER-PEREIRA, 2004, p. 55).

${ }^{219}$ Criada nesse ano por Getúlio Vargas, foi extinta em 1968 pela Ditadura Militar, sendo unificada à Universidade Federal do Rio de Janeiro (UFRJ).

${ }^{220}$ Apesar de já aparecer neste estudo a razão dualista de Brasil nos projetos políticos de, por exemplo, João Pinheiro, cabe advertir novamente que essa concepção já estava presente entre os intérpretes do Brasil muito antes de Jacques Lambert desembarcar nos trópicos. Lia Osório Machado apresenta como as teorias exógenas de
} 
Jacques Lambert (1972) não apenas diferenciava esses dois Brasis pela economia e estrutura social, mas também delimitava geograficamente essas duas unidades, entendendo o desenvolvimento das civilizações corrente em âmbitos regionais, cujo motor da evolução se localiza nas cidades e deve seguir para o campo. Para ele, enquanto o Brasil novo e próspero se caracterizava pela indústria e pela urbanização - "a cidade de São Paulo, a cada hora terminase um prédio" -, o Brasil velho e arcaico, onde "os bois devoram os homens", é representado pela sua ignorância, desnutrição, falta de saúde, miséria e imobilidade e pela fazenda do interior, cujos homens do campo trabalham de enxada e transportam uma colheita insignificante em carroças rangentes que precisam ser puxadas por três ou quatro juntas de bois. Como se não bastasse delimitar as duas realidades entre o Sul e o Nordeste ${ }^{221}$, a fez no âmbito internacional, entre Estados Unidos e Índia ${ }^{222}$.

Os quadros do Iseb estariam, até certo ponto, afinados às ideias de desenvolvimento econômico estrangeiros, não idealizando os entraves ao desenvolvimentismo apenas a partir da teoria dualista, mas, por vezes, concebendo o progresso a partir de etapas, conforme propôs Walt Whitman Rostow em livro publicado na mesma década.

Professor de história econômica do Massachussetts Institute of Technology (MIT), portanto um intelectual estadunidense, e autor do livro Etapas do desenvolvimento econômico, ele defende que é possível enquadrar todas as sociedades, em suas dimensões econômicas, dentro de uma das cinco categorias: a sociedade tradicional, as precondições para o arranco, o arranco, a marcha para a maturidade e a era do consumo em massa (ROSTOW, 1978).

Para que uma sociedade alcance a fase de pré-condições para o arranco, é necessário um Estado nacional centralizado e eficaz, "baseado em coligações matizadas pelo novo nacionalismo, em oposição aos tradicionais interesses regionais agrários, à potência colonialista ou ambos" (ROSTOW, 1978, p. 19) - o que Vargas teria iniciado com o processo de centralização, mas, dada a particularidade local, sem romper com os poderes locais, de base agrária.

\footnotetext{
darwinismo social, eugenia e positivismo influenciaram os intelectuais de virada de século na explicação da convivência entre a ordem tradicional e a modernização, cujos argumentos de que o conhecimento da geografia e da história do país "desvelaria uma sociedade dual, espacial e socialmente desarticulada, cujo caminho para a união era a superação da sociedade patriarcal, organizada em clãs, por outra competitiva e individualista" (MACHADO, 2000, p. 335).

221 "Conquanto o país nôvo e o país velho, colonial, tenham cada qual seu domínio próprio - o primeiro no Sul e o segundo no Nordeste [...]" (LAMBERT, 1972, p. 103).

222 "Conforme o observador se deixe impressionar por um ou outro dêsses dois mundos que tem diante dos olhos, um ao lado do outro, predirá para o Brasil uma evolução no sentido dos Estados Unidos ou no da Índia." (LAMBERT, 1972, p. 106).
} 
A etapa seguinte, a do arranco, é o intervalo em que as antigas obstruções e resistências ao desenvolvimento regular são afinal superadas, sendo a tecnologia o grande incentivo do arranco. Seria este o desafio brasileiro: alcançar a etapa do arranco. Com ela, a indústria cresce e há expansão das áreas urbanas, do setor moderno e da classe empresarial, e "a economia explora recursos naturais e métodos de produção até então inaproveitados" (ROSTOW, 1978, p. 21).

\begin{abstract}
No caso mais geral, o arranco aguardou não só a acumulação de capital social fixo e um surto de evolução tecnológica da indústria e da agricultura, mas também do acesso ao poder político de um grupo preparado para encarar a modernização da economia como assunto sério e do mais elevado teor político. [...]

Difundem-se novas técnicas agrícolas ou industriais, à medida que a agricultura vai sendo industrializada, e um número cada vez maior de fazendeiros se dispõe a aceitar os novos métodos e as modificações profundas que estes acarretam para seu estilo de vida. As mudanças revolucionárias na produtividade agrícola são condição indispensável ao êxito do arranco, pois a modernização da sociedade aumenta radicalmente seus gastos com produtos da agricultura. Em um ou dois decênios, tanto a estrutura básica da economia quanto a estrutura social e política da sociedade se transforma de maneira tal que, a partir daí, pode ser mantido um ritmo constante de desenvolvimento. (ROSTOW, 1978, p. 20-21).
\end{abstract}

Ao enfatizar a introdução da tecnologia na indústria e no campo e a expansão urbana, Rostow desconsidera o investimento industrial em capital constante, a concentração fundiária e a consequente mobilização do trabalho, inclusive na sua modalidade espacial, ocasionada pelo êxodo rural. Para ele, é preciso que as grandes empresas nacionais detenham as rédeas do desenvolvimento de suas sociedades para que as etapas seguintes sejam alcançadas e a sociedade conquiste o Estado de Bem-Estar (ROSTOW, 1978). Ele, ainda, arrisca dar o prazo genérico de 60 anos para que as sociedades que alcançarem a fase do arranco cheguem à maturidade, de forma que do arranco em diante, o desenvolvimento se manteria num ritmo constante, sem levar em conta as contradições e os conflitos sociais oriundos de uma realidade em que a forma de mediação social é o problema maior.

Não se poderia esperar de Rostow uma preocupação de base social, cujo subtítulo do livro supracitado é Um manifesto não-comunista. Escrito durante a Guerra Fria, o distanciamento de qualquer menção ao socialismo em sua obra estava, relativamente, na mesma esteira das preocupações de Hélio Jaguaribe, que, via discussões do Iseb, buscava superar o dilema positivismo-marxismo e "passar daquele modelo socialista-nacionalista para um projeto que conservasse o máximo de sua intenção nacional e social” (JAGUARIBE, 2005, p. 255). Ambos integrantes da intelligentsia de seus respectivos países no contexto histórico bipolar, reproduziam muito bem um discurso da ciência neutra e acima dos interesses ideológicos, 
ignorando ser esta um produto histórico influenciado pelos momentos e locais onde é desenvolvida.

Em 1959, em nome do projeto de "país do futuro", começaram as ações da instituição que viria a ser o marco do planejamento regional no Brasil: a Sudene. A Meta 31, de combate à seca, parte do Plano de Metas de 1956 do Governo JK, junto ao relatório do diagnóstico do Grupo de Trabalho do Desenvolvimento do Nordeste (GTDN), criado em 1957, compuseram o documento base da criação do órgão. Ambos endossavam as disparidades no crescimento das regiões e a urgência de uma política de desenvolvimento para o Nordeste. Em sua apresentação oficial, em fevereiro de 1959, o presidente da República criou o Conselho de Desenvolvimento do Nordeste (Codeno) para articular as primeiras ações, enquanto a lei de criação da superintendência era concluída (KLUCK, 2019). Para coordenar esse conselho e, mais tarde, a Sudene, indicou Celso Furtado, o "evangelista da razão".

Nesse ínterim, a Sudene foi criada. Tida como o primeiro grande projeto nacional de planejamento regional, a autarquia revela o planejamento como a presença de um Estado capturado pelas formas mais adiantadas da reprodução do capital para forçar a passagem no rumo de uma homogeneização do território brasileiro. De acordo com Francisco de Oliveira (1988), a Sudene trouxe no seu programa a marca da intervenção planejada, visando superar o conflito de classes intrarregional e expandir o capitalismo do Sudeste para o Nordeste por meio do poder de coerção do Estado.

À frente da superintendência, Celso Furtado via as desigualdades regionais como consequência do "desenvolvimento espontâneo" do capitalismo, fundamentado no processo histórico de formação do país ${ }^{223}$. Influenciado pela concepção de formação territorial de Caio Prado Júnior (2006), para o economista as regiões seriam fruto de sistemas econômicos isolados, de contornos visíveis desde o século XIX. De acordo com Francisco de Oliveira, até então, a classe dominante dos coronéis, personificados na terra e no capital, "fechava" a região, reproduzindo as relações de classe que lhes convinha e, juntamente, a relação social de dominação e de produção, obstaculizando e bloqueando a penetração de formas diferenciadas de geração do capital e de novas relações de produção. O objetivo do planejamento de governo

\footnotetext{
${ }^{223}$ O nacional-desenvolvimentismo proposto por Celso Furtado se ancorava na aceleração do desenvolvimento, só possível de alcance ao pular as etapas históricas do capitalismo rumo à modernização. Ao escrever sobre o economista no prefácio à $34^{\mathrm{a}}$ edição de Formação econômica do Brasil, Luiz Gonzaga Belluzzo afirma que "Furtado rejeita as abstrações típicas do economicismo ao estabelecer a conexão entre as relações sociais de produção, o estágio das forças produtivas e as formas de poder político que definem determinada etapa histórica, entendida como uma totalidade em movimento" (BELLUZZO apud FURTADO, 2007, p. 11).
} 
era "abrir" as regiões resistentes a novas formas produtivas, sob o guarda-chuva do desenvolvimentismo ${ }^{224}$.

A regionalização tinha em seu horizonte a homogeneização do território nacional via planejamento para obras de conexão entre as áreas "díspares", ideia defendida pelos tecnocratas, como Pedro Geiger. O geógrafo alega claramente que "o planejamento nacional vem dando maior ênfase ao ataque à permanência de violentos desníveis que separa as três grandes unidades ${ }^{225 "}$ (GEIGER, 1969, p. 17), apontando como regiões-problema a Amazônia e o Nordeste. Ambas seriam, para ele, regiões "fechadas", que, com a canalização de recursos através de política ditada pelo poder federal no intuito de abertura, favoreceria "estas chamadas macrorregiões, onde atuam Sudam e Sudene, com incentivos fiscais, objetivando a multiplicação e renovação de empreendimentos econômicos” (GEIGER, 1969, p. 17).

A "abertura" da região e a consequente "integração" nacional, no longo caminho até a pretensa dissolução completa das regiões, ocorre quando a relação social não pode mais ser reproduzida, e por essa impossibilidade, desgasta a hegemonia das classes dominantes locais e a substitui por outras, de caráter nacional e internacional (OLIVEIRA, 1988). Porém, conforme alerta Erick Kluck (2019), parcela desses donos do poder locais seria agregada pelas novas organizações do capital e desfrutaria de suas benesses, enquanto que para as populações alvo do desenvolvimentismo os benefícios permaneceram enquanto promessa.

Anos depois, ao fazer um balanço do que foram os esforços do Iseb e da política nacional-desenvolvimentista de sua geração, Hélio Jaguaribe admitiu ter se decepcionado com o desenvolvimentismo, que não passou de uma modernização conservadora ${ }^{226}$ - ora, "todas as revoluções somente aperfeiçoaram a máquina em vez de quebrá-la” (MARX, 2011, p. 141)! O intelectual desconfiou da perversidade e da incapacidade da modernização em incluir todos os

${ }^{224}$ O ano de 1930 e seus conflitos são lidos como desencadeadores da "revolução burguesa" no país, com a "região" de São Paulo definindo a divisão regional do trabalho na economia brasileira.

Estava-se, em verdade, em presença da implantação de um projeto de estado nacional unificado, em sua forma política, que recobria a realidade de uma expansão capitalista que tendia a ser hegemônica; voltada agora para uma produção de valor cuja realização era sobretudo de caráter interno, podia a mesma impor ao conjunto do território nacional o seu equivalente geral: essa imposição do equivalente geral criava o espaço econômico capitalista nacional unificado. (OLIVEIRA, 1988, p. 75, grifos do autor).

${ }^{225}$ Que seriam, segundo sua proposta de regionalização, a Amazônia, o Nordeste e o Centro-Sul.

226 "A meu ver, o que aconteceu foi que o processo de desenvolvimento que se inicia com Vargas e se acelera extraordinariamente com Kubitschek, foi muito mais um processo de modernização do que de desenvolvimento como acertadamente foi afirmado por Celso Furtado. O Brasil sempre se caracterizou - e isso continua ocorrendo em nossos dias - por ser uma sociedade profundamente dualística, em que há uma massa marginal, que não participa em nada ou apenas insignificantemente dos benefícios da modernização e do desenvolvimento, e ao seu lado um setor mais restrito que, esse sim, se beneficia de todas as vantagens. Essa situação teve e tem consequências extraordinariamente grandes em toda a história brasileira.” (JAGUARIBE, 2005, p. 257). 
sujeitos nos proveitos do que considerava progresso, mas não conseguiu entender que desenvolvimentismo, planejamento regional, ajuste espacial e modernização retardatária, apesar de não serem a mesma coisa, se valem de discursos ilusórios e ações violentas, caminhando juntos rumo a uma mesma finalidade: a valorização do valor.

O desalento de Jaguaribe também seria produto do contexto histórico. Com o golpe militar de 1964, o Iseb foi extinto e seus membros cassados, ao mesmo tempo que a teoria de um desenvolvimento nacional autônomo caía por terra. Enquanto atuante, a sua interpretação dualista de Brasil promoveu em resposta debates acerca dos problemas do país, sendo a formação da Escola de Sociologia encabeçada por Florestan Fernandes, dez anos depois e com sede em São Paulo, uma objeção à discussão do desenvolvimentismo.

A Escola de Sociologia era, por sua vez, um produto por excelência da universidade. Combatendo a proposta do Iseb de aliança de classes e de desenvolvimento nacional obstado pelo imperialismo, a escola paulista adotou uma perspectiva científica, cosmopolita, estruturalista e antidualista, enfatizando o conflito de classes e a questão racial - contrariamente ao discurso do grupo carioca. Os trabalhos de Fernando Henrique Cardoso e Enzo Faletto $(1977)^{227}$ e de Francisco de Oliveira (1972), ao não se comprometerem com uma visão de nação e rejeitarem a ideia de aliança entre empresários e trabalhadores, confrontavam genericamente pelo viés à esquerda o discurso do Iseb. Para Florestan Fernandes, as mudanças no capitalismo tornavam a sociedade latino-americana híbrida, atingindo o âmago do projeto nacionaldesenvolvimentista, o que impossibilitava a integração social. Incapazes de romper com o imperialismo, as camadas dominantes do continente aprofundavam sua dependência econômica (e política) externa, reforçando, por sua vez, uma tradição colonial subserviente (FERNANDES, 2019).

Após o golpe militar, a Escola de Sociologia teve na sua liderança transitória Caio Prado Júnior, que exorcismava a interpretação nacional-burguesa do Brasil propalada pelo grupo do Rio de Janeiro e pelo Partido Comunista ${ }^{228}$. Enquanto a Escola de Sociologia resistiu aos anos de chumbo, o instituto foi desfeito.

\footnotetext{
${ }^{227}$ Estes, mais atinentes à corrente do capitalismo dependente associado, viam que o fracasso do capitalismo autônomo no continente teria como saída a conjugação do capital nacional privado, do capital internacional e do Estado, não limitando a industrialização como única via de desenvolvimento. Para os autores, o desenvolvimento deveria ocorrer associado a outros setores, como a agropecuária, base econômica da América Latina, de forma estratégica a partir das condições encontradas.

${ }^{228}$ De acordo com Bresser-Pereira (2004), o programa do Partido Comunista Brasileiro (PCB) de 1958 tinha grandes similitudes de projeto com a ideologia formulada pelo Iseb, adotando a política de aliança com a burguesia nacional e abraçando o movimento nacionalista.
} 
Contemporâneo aos pensamentos apresentados e em diálogo com eles, surge a proposta de teoria marxista da dependência, de Ruy Mauro Marini, cuja apresentação mais acurada se encontra em seu texto Dialética da dependência. Lançado em 1973, o autor explica a sua interpretação crítica ao desenvolvimentismo e ao planejamento como condição de reprodução do capitalismo. Atento ao problema do imperialismo que Florestan Fernandes denunciava, a interpretação de Marini também conversava com a de Celso Furtado, ao entender que desenvolvimento e subdesenvolvimento não eram etapas do capitalismo, mas simultaneidades.

Em linhas gerais, o autor se ancora na teoria do valor de Karl Marx e é simpático à explicação de desenvolvimento desigual e combinado. $\mathrm{O}$ baixo valor agregado dos produtos exportados pelas economias tidas como dependentes, a remessa de excedentes dos países periféricos para os centrais e a instabilidade dos mercados financeiros internacionais levariam à dependência colonial, financeiro-industrial e tecnológico-financeira. Arguindo que os países centrais só puderam se industrializar graças à subsistência agropecuária e às matérias-primas fabris que os países periféricos forneciam, os latino-americanos facilitaram o crescimento quantitativo dos países industriais, com a acumulação a depender mais do aumento da capacidade produtiva do trabalho do que da mera exploração do empregado. Em consequência, à América Latina caberia a produção de bens primários às custas da superexploração do trabalhador, no intuito de aumentar a oferta mundial de matérias-primas e alimentos, dado que só baixando o custo de produção é que viabilizaria o aumento da mais-valia em suas sociedades.

Ruy Marini não descartou a industrialização periférica, tendo observado que o seu desenvolvimento, mesmo carente de tecnologia e obsoleto, ocasionou ligeira mudança na pauta de exportações, voltada para produtos semielaborados. Para que a industrialização latinoamericana se realizasse, contou com a intervenção do Estado, às custas do rebaixamento dos salários, o que gradualmente transformou a força de trabalho em mercadoria superexplorada, gerando o desgaste prematuro do trabalhador e a redução de seu consumo a ponto de dificultar a sua reprodução social, culminando com a geração de uma massa crescente de descartáveis. Com incapacidade social de criar consumo interno, as economias dependentes tiveram que se voltar novamente para o mercado externo, porém munidas em adição do parco cabedal industrial. Isso ajudaria a entender, por exemplo, a manutenção da dependência desses países via integração continental à divisão internacional do trabalho como fornecedores de matériaprima, como o ferro. 
Embora se considere o contexto de reflexão do autor ${ }^{229}$, bem como suas afinidades teóricas, é impossível não pensar na superexploração como parte de uma ontologia do trabalho que agoniza com o processo de erosão da substância do capital - algo que se faz presente não apenas nas periferias. Sendo a engenharia do valor uma totalidade, sua sociabilidade penetra os centros hegemônicos, apresentando um quadro contraditório para além das fronteiras continentais da América Latina, conforme o neoliberalismo se consolida. Contudo, o esforço em abordar a particularidade social desse conjunto de países, incluindo o Brasil, tem a sua relevância para compreender as incongruências do desenvolvimentismo defendido com eloquência por tantos teóricos, na insistência comum em desdenhar do capitalismo como uma totalidade.

A produção intelectual que pensava o Brasil entre as décadas de 1940 e 1980 e seus debates auxiliam no entendimento das maneiras de enxergar os projetos de país. Apesar de antagônicos, os intelectuais apresentados foram contemporâneos, e mesmo as produções críticas ao dualismo não escaparam à composição de um marxismo nacionalista, e, por vezes, até de burlar um suposto etapismo de horizonte industrial, conceituando uma "usurpação da mais-valia" (SCHOLZ, 2016).

Esse resultado prático da modernização tardia e melancolicamente compreendido por Jaguaribe também pôde ser entrevisto na Serra do Cabral. Estando localizada no norte de Minas Gerais, foi abrangida pela integração norte mineira à Sudene, produto maior do planejamento de então e sua ideologia desenvolvimentista. Esse processo de abertura regional provocou o desgaste dos poderes locais, com suas personificações, sobretudo os fazendeiros de gado, construindo um discurso de regionalismo e defendendo um projeto de modernização mimética de forma a garantir a perpetuação de seus interesses. Segue-se a esta análise.

\footnotetext{
229 A primeira publicação do texto é de 1973, momento crucial para a entrada da microeletrônica nos processos produtivos dos países centrais e a consequente dessubstancialização do valor em nível geral. Ruy Marini se sintonizava com o pensamento da esquerda tradicional de apreensão da mais-valia no território nacional como realização possível do socialismo, sem perceber que no contexto de um "novo modelo de acumulação" à escala global, os trabalhadores superexplorados a quem se refere seriam produto de uma industrialização periférica a meio caminho, com as massas desintegradas da moderna máquina de exploração da economia empresarial (SCHOLZ, 2016). Para ele, fazer a revolução socialista nacional seria se apropriar da produção de um valor que já não é produzido, não reconhecendo os limites internos do capital.
} 


\subsection{Na mão do norte, onde "a cara do chão é minha mais" 230 : o regionalismo norte- mineiro}

Discutir o norte de Minas Gerais - e a Serra do Cabral - como região torna necessário a ressalva de que ela teve seus contornos modificados ao gosto das políticas de planejamento, em especial ao debate que se aprofunda pós-1930. É o que alerta Laurindo Mékie Pereira (2007), para quem é difícil delimitar o norte mineiro como uma região precisa ${ }^{231}$. Segundo o autor, muito do que se conhece como o norte de Minas Gerais foi forjado por suas elites econômicas a partir do desencadeamento da regionalização do Estado, tornando-se discurso em defesa de seus interesses.

Apesar de os esforços de centralização do Estado a partir de 1930 terem concentrado a instalação de suas instituições e indústrias na região Sudeste, o norte mineiro - inclusive a Serra do Cabral - também sentiu os ventos da modernização. A implantação da ferrovia no norte de Minas Gerais, cuja conclusão se deu em 1950, trouxe mudanças nas formas de trabalho nos núcleos de povoamento na Serra.

O depoimento de Abílio Rosa da Silva, 91 anos (2017), conhecido como Biloca, enfatiza isso. Nascido em Francisco Dumont, assim como seu pai, desde os dez anos de idade trabalhou em roças do seu tio Antonino e do seu pai fazendo farinha, plantando e moendo cana e mexendo também com gado, tirando leite e carreando boi. Comentou que por muito tempo foi responsável por levar a cavalo o rebanho bovino até Montes Claros, a maior praça comercial daquele sertão, viajando até noite adentro pela Serra.

Figura 26 - O que restou do trecho da ferrovia que atravessava o distrito de Dolabela

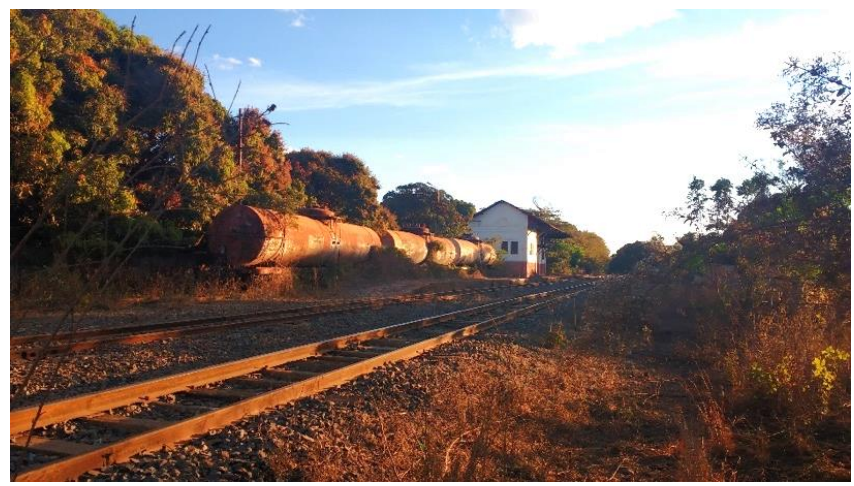

Fonte: acervo pessoal, julho de 2018.

230 “'Descansar?' Quem disse, não foi ouvido. - 'Vou lá deixar essa cambada birbar por aí em sossego?! Bis, minha gente! Vamos neles!' - Zé Bebelo se frigia. Mas o próprio pessoal de João Concliz tinha segurado mão nos cavalos daqueles. - 'Toquemos na mão do norte: lá a cara do chão é minha mais..."” (ROSA, 1986, p. 80).

${ }^{231}$ No século XIX, por exemplo, o norte de Minas Gerais era algo muito mais amplo, integrando todos os "sertões de Minas": o sertão da Farinha Podre (atual Triângulo Mineiro), Paracatu, Serro Frio e Tejuco (atual Diamantina) (PEREIRA, 2007). 
Com a chegada do trem, bastava atravessar o povoado de Buriti Grande com a boiada para alcançar Bueno Prado e lá deixar os bois na estação, que seguiam sobre os trilhos. Por muito tempo, Biloca levava o gado até a ferrovia e, de lá, voltava para a fazenda do seu tio de carroção com produtos como sal, sabão, farinha de trigo e "miudezas", como canela e cravo, já que os fazendeiros proibiam o cultivo de outros gêneros para não ocupar o espaço dos pastos. Com o trem, as tropas traziam mercadorias sortidas de lugares distantes para o consumo das famílias mais abastadas. Diante de tal depoimento, vislumbra-se que as ações modernizadoras estatais alteraram a rotina de trabalho a ponto desta ter sido notada, mudanças evidentes também no consumo, exemplificadas na ficção:

\footnotetext{
Lampeiro, o Quipes entrado em boas roupas, montado num bom cavalo amarelo, pitando maço de cigarros de fábrica; rico feito um Mascarenhas. Arte que puxava um burro e uma burra, adestros, e tinha comprado coisas: até trempe e caçarolas, e açúcar real e chocolate em pó. Ao fagueiro, pujante mesmo.

$[\ldots]$

Só, por terminar, se gabou de ter tido duas ofertas: para servir de jagunço de Dona Adelaide, no Capão Redondo, e do Coronel Rotílio Manduca - em sua Fazenda Baluarte. (ROSA, 1986, p. 429).
}

A Crise de 1929 teve seus reflexos na pecuária, dado o desaquecimento econômico dos centros urbanos. Quando a procura por gado decrescia, incrementavam-se as atividades de subsistência nas zonas de criação, bem como a procura por diamantes - Biloca narrou que garimpou junto ao pai nas terras de seu tio, pagando-lhe a porcentagem requerida. Manoel Lopes também disse ter recorrido à coleta de sempre-viva e ao garimpo nos momentos de dificuldade nas fazendas, pagando porcentagem a Zé Borém. Mas, para este, a atividade só dava dinheiro a quem menos trabalhava - no caso, seu fornecedor, Joãozinho, que "ficou bem de situação em cima do diamante. Ele nunca trabalhou, nunca garimpou, e ficou bem com o garimpo".

Porém, durante a Segunda Guerra Mundial, de acordo com Luciene Rodrigues (2000) o norte de Minas Gerais como um todo se apresentou como tímida alternativa à dinâmica econômica nacional: o rio São Francisco constituiu a única via interna de comunicação entre Sul-Sudeste e Norte-Nordeste, pois a rota marítima estava interrompida e a rodovia Rio-Bahia ainda estava em construção. Desse momento em diante, são reforçados os interesses nos potenciais econômicos do vale do grande rio.

Preocupado com as dinâmicas espaciais do norte de Minas Gerais, José Maria Alves Cardoso (2000) salienta que com a chegada da via férrea em 1926, o comércio de gado se consolidou na região, favorecido pela facilidade do transporte. Partindo da ideia de que o norte 
mineiro permaneceu em relativo isolamento do século XVIII até a chegada das ferrovias ${ }^{232}$, o autor enfatiza que o crescimento da demanda dos núcleos urbanos do Centro-Sul, especialmente Rio de Janeiro e Belo Horizonte, estimulou o comércio bovino em Montes Claros. "O aquecimento deste mercado contribuiu para a exploração de áreas ainda vazias da Região, através da atividade pecuária de engorda, denominada invernada" (CARDOSO, 2000, p. 205, grifos nossos). Conforme apresentado anteriormente, o processo de compra de terras na Serra do Cabral é iniciado pouco antes desse momento, mas é fortemente estimulado a partir dele.

Apesar da Crise de 1929 e seus reflexos na região, o norte de Minas Gerais permaneceu como produtor de pecuária de corte, além do cultivo de algodão, da coleta de frutos do cerrado e, muito discretamente, do garimpo de pedras por faiscadores. Partindo da hipótese de Laurindo Pereira, os fazendeiros, comerciantes e industriais da região, cientes da "perda de substância" de sua economia frente a São Paulo, convergiram e se organizaram como classe, tendo sido também agentes do processo modernizador, durante o qual construíram uma ideologia regionalista, apresentada a seguir.

Os produtores rurais e comerciantes norte-mineiros deram os primeiros sinais de organização nas reivindicações feitas em 1953 na III Reunião Regional das Classes Produtoras, em Montes Claros. Entre os pedidos, busca por crédito, tratamento fiscal privilegiado, treinamento de mão de obra e apoio para a montagem de um frigorífico, clamores que apontam para a ciência da condição de produtores especializados na mercadoria bovina, bem como da ideia de que a região só se desenvolveria com a intervenção do Estado, afinando-se aos discursos institucionais.

Poucos anos depois (1956), no aniversário de Montes Claros, as classes dominantes reuniram-se com o então presidente JK e apresentaram novas reivindicações, como melhoria na Estrada de Ferro Central do Brasil, a conclusão das obras da rodovia Corinto-Montes Claros e a construção da hidrelétrica no rio Jequitaí, na Serra do Cabral. Ao saberem a quem apelar diretamente, percebe-se que as classes dominantes aprenderam a reproduzir aquilo que o planejamento pregava: o Estado como o condutor do desenvolvimento.

Em 1957, outro movimento solicitava mais uma vez a hidrelétrica no rio Jequitaí, justificada pela precariedade no fornecimento de energia na região, um entrave ao seu

\footnotetext{
${ }^{232}$ Para justificar sua ideia de isolamento, José Maria Alves Cardoso recorre ao Regimento das Minas de 1702 e 1703, em que "Nen hua pessoa do distrito da Bahia poderá levar às minas pelo caminho do Certão, outras fazendas ou gêneros que não sejam gados, e querendo trazer outras fazendas as naveguem pela barra do Rio de Janeiro e as poderão conduzir por Taubaté ou São Paulo" (ESCHWEGE, v. 1, 1979, apud CARDOSO, 2000, p. 205). A decisão era devida ao contrabando de ouro e sonegação de impostos, sendo o primeiro realizado pelas águas do São Francisco.
} 
progresso. Com a obra, os municípios de Bocaiúva, Coração de Jesus, Francisco Sá, Brasília de Minas, Pirapora, Jequitaí, Várzea da Palma, Juramento e Montes Claros poderiam arrancar rumo à industrialização. Porém, a Companhia Vale do São Francisco, suposta responsável pelo negócio, descartou o empreendimento alegando inviabilidade econômica. Em troca, JK assumiu o compromisso de construir linhas de transmissão de Três Marias para todos os municípios que seriam beneficiados com o "projeto Jequitaí" (PEREIRA, 2007, p. 52-53).

De olho nos recursos estatais para alavancar seus negócios e integrá-los ao Centro-Sul, os fazendeiros, comerciantes, industriais e políticos pressionaram pelo ingresso do norte de Minas Gerais na abrangência da Sudene, o que só veio a acontecer em 1965. A inclusão na autarquia se deu pelo fato de a região ser classificada fisiograficamente parte do Polígono das Secas (conforme as leis 1.348 de 10/02/1951 e 4.763 de 30/08/1965), ao qual estava integrada desde 1911.

As vozes dos governos estadual e federal cantavam em uníssono: integrar o norte de Minas Gerais aos interesses do Estado Nacional pela via dos capitais nacional e internacional intencionados no desenvolvimento - tendo sido a Sudene o primeiro exemplo de planejamento regional de grande vulto no país. Assim, o Estado entrava no sertão norte-mineiro sem intermediários, desestruturando o coronelismo e propondo a consolidação das relações capitalistas modernas na região, como se antes de 1960, aquelas fossem áreas ainda vazias de gente e apartadas do ancestral sentido da territorialização.

Com incentivos fiscais e crédito para a agropecuária e o reflorestamento, o Estado interveio na região via Sudene, diluindo gradualmente o coronelismo e visando um público prédeterminado, com a pretensão de alterar o caráter das propriedades rurais, incutindo a concepção de que, a partir de então, os agricultores e fazendeiros deveriam incorporar a ideia de que eram "empresários rurais" e a fazenda uma "empresa rural" (CARDOSO, 2000, p. 237 238). O objetivo era reforçar nos proprietários de terra a ideia de "negócio capitalista" no sertão, desconsiderando toda a problemática referente à estrutura fundiária e às relações de trabalho. Coube ao Estado, portanto, o papel de naturalizar a autonomização dos fatores de produção na região, com o objetivo de adaptar o pecuarista tradicional às novas formas de reprodução e facilitar a entrada de capitais exógenos, valendo-se do discurso de modernizar as relações sociais de produção.

Na economia política, os fatores de produção são considerados componentes básicos na produção de bens e serviços. Ana Carolina Leite (2015) salienta que para que pudessem ser articulados em processos produtivos, terra (terras cultiváveis, florestas, minas), trabalho e capital (máquinas, equipamentos, instalações) tinham que estar disponíveis no mercado, 
separadamente e em quantidades adequadas. Porém, para que esses fatores não fossem somente coisas, determinados processos sociais foram necessários para que adquirissem existência reificada e autonomizada. Como consequência, a naturalização de sua separação implicaria no apagamento desses mesmos processos sociais, no qual consiste o desenvolvimento contraditório do capitalismo como processo de modernização. Olhar para a reprodução camponesa de forma integrada à constituição desses momentos seria uma possibilidade de entender o que a naturalização se esforça por anular, pois tanto o fazendeiro coronel quanto os seus agregados e todos os camponeses em geral não estiveram em momento algum plenamente apartados da moderna sociabilidade.

A despeito dos maus olhos de governantes nordestinos sobre a participação mineira no programa, José Cardoso (2000) defende que o fato de o então presidente da República ser do norte mineiro e a região historicamente ter laços mais estreitos com o Nordeste - tendo em vista que já foi parte das capitanias da Bahia e de Pernambuco - foram considerações de peso para a sua anexação.

A justificativa na defesa dos laços norte-mineiros com o Nordeste vem ao encontro do regionalismo enquanto discurso, objeto das preocupações de Laurindo Mékie Pereira, para quem tal premissa precisa ser contestada. José Cardoso seria parte de uma geração posterior de tecnólogos, burocratas, jornalistas, professores e memorialistas, entidades de classe e instituições públicas e privadas que, a partir da década de 1960, participaram e difundiram a ideologia regionalista e autonomista, cujos grandes beneficiários seriam os comerciantes, fazendeiros e industriais (PEREIRA, 2007).

Professor de Economia da Universidade Estadual de Montes Claros (Unimontes), José Cardoso reproduz sem neutralidade o discurso do regionalismo de forma a negar a mineiridade, fazendo coro com Simeão Pires e outros. Organizador do livro Formação Social e Econômica do Norte de Minas, em que participam outros intelectuais regionais simpáticos à sua ideia como Tarcísio Botelho, Marcos Fábio Martins de Oliveira e Luciene Rodrigues -, traz dados interessantes sobre o norte mineiro com intenções bem demarcadas.

É curioso notar a participação de acadêmicos na divulgação do regionalismo como projeto. Ao adotar a abordagem de cunho regionalista, esses trabalhos não conseguem romper os parâmetros colocados pela ideologia hegemônica, porque reproduzem um dos seus mais importantes princípios, isto é, o encobrimento das clivagens sociais sob o manto das categorias generalizantes. Os capítulos do livro apontam, com riqueza de dados, o caráter conservador da modernização regional. Na Apresentação, consta que: 
Ao trazer este trabalho a público pretendemos contribuir para a formação de uma consciência e identidade regional [...] que na comemoração destes quinhentos anos do Brasil, a região saiba (re)descobrir sua história e sua identidade sociocultural. (CARDOSO, 2000).

Há no texto uma forma de vitimização regional. O norte de Minas Gerais seria vítima, também, de uma desconsideração por parte da historiografia. Sua história, especialmente a colonial, teria sido "escondida" porque se tratava de uma região não integrada ao comércio e culturas ocidentais (PEREIRA, 2007). Esse discurso dualista que se valeu da historiografia e dos dados estatísticos para argumentar em favor do projeto autonomista teve seu embrião tão logo a Sudene saiu do papel, sendo ela a responsável pelo aparecimento da região via regionalização pelo governo federal.

Até 1959, o norte mineiro repudiava a sua semelhança com o Nordeste, tendo resistido até onde pôde na integração ao Polígono das Secas, sob o pretexto de desvalorização das terras, não escondendo nos periódicos montes-clarenses o preconceito sobre os flagelados da seca que buscavam refúgio em Montes Claros e em Pirapora entre 1930 e 1950. O discurso mudou na década seguinte, a partir do momento em que as classes dirigentes passaram a vislumbrar a captação de recursos via Sudene e a endossar um projeto separatista. Doravante a segunda metade do século XX para o XXI, houve três tentativas de emancipação: 1967-1968, 1986-1988 e 2000-2002.

Quanto à primeira proposta, o novo estado se chamaria Cabrália e abrangeria o norte e noroeste de Minas Gerais, Vale do Jequitinhonha e sul da Bahia, estando suas classes dirigentes interessadas também na saída para o mar. Com o golpe de 1964 e o Governo Militar já instalado, os criadores de Cabrália astuciosamente se valeram do tema da segurança nacional para convencer à aprovação de um estado cujo projeto foi arquivado em 1971. No entanto, é curiosa a moção dos seus idealizadores, de janeiro de 1968:

$1^{\circ}$ ) Constitui um grande vazio a região norte-mineira - área mais subdesenvolvida de Minas - situada nos mesmos paralelos entre a nova capital, Brasília e o Atlântico, [...] razão pela qual há motivos de imperiosa necessidade desenvolvimentista decorrente da própria segurança nacional

$2^{\circ}$ ) Somente a área abrangida pelos 42 municípios do Polígono das Secas de Minas apresenta os seguintes dados:

Área dos 42 municípios: $120.692 \mathrm{~km}$

População dos 42 municípios: 951.577 habitantes

Habitantes por km2: 7,8

Que só a aludida área (120.692 km2) é superior à área de 9 Estados da Federação [...] Que só a área dos 42 municípios do Polígono das Secas de Minas apresenta grandes reservas de minérios [...] que devem ser aproveitadas na industrialização local e exportação - exigindo como necessidade elementar a remodelação da Estrada de Ferro Bahia-Minas [...]

$4^{\circ}$ ) A existência na região norte-mineira da Jaíba - grande zona de terras devolutas de 310.000 ha [...] inteiramente abandonada pelo poder público estadual. [...] 
Urge dinamizar a Jaíba, principalmente, com os apreciáveis recursos da SUDENE.

$5^{\circ}$ ) Imperiosa necessidade de um governo autêntico para com as nossas características regionais capaz de propiciar um dinâmico e inteligente entrosamento com órgãos federais visando o estabelecimento de estruturas básicas de desenvolvimento. [...]

$6^{\circ}$ ) Louva enfim a Câmara Municipal de Montes Claros a feliz oportunidade de uma nova divisão político-administrativa [...] para o equacionamento e soluções de problemas que se eternizam, trazendo para o espírito do povo a esperança, já quase perdida, de melhores dias em um futuro próximo.

$7^{\circ}$ ) Ressalta, finalmente que decide aprovar o presente movimento separatista, por consultar a um imperativo nacional e cristão, e por considerar que a própria paz mundial, segundo a Encíclica de S. S. Paulo VI, é o desenvolvimento dos povos. (PEREIRA, 2007, p. 100, grifos do autor).

Entre os que a assinaram, estava Simeão Pires, na ocasião vereador em Montes Claros e grande defensor da "antimineiridade", além de simpático ao Governo Militar.

Interessante notar que a moção toca na questão da segurança nacional, talvez porque a Guerrilha do Araguaia já tivesse chegado aos ouvidos das autoridades, havendo como pano de fundo a necessidade de ocupar os "espaços vazios", porque o maior traço do regime foi o combate ao inimigo interno. Com isso, a ênfase ao "grande vazio" da região norte-mineira, à espera do desenvolvimentismo via aproveitamento das terras devolutas da Jaíba pela Sudene que estavam "abandonadas" pelos poderes público e federal - e dos recursos minerais disponíveis à industrialização, mote modernizador da autarquia. Também é notável o destaque à posição estratégica da região, no mesmo paralelo que Brasília e o oceano Atlântico, um elo entre litoral e sertão que só o planejamento e as vias entrosariam, conduzindo ao chamado desenvolvimento dos povos.

Na Serra do Cabral, os feitos econômicos da Sudene chegariam mais tarde, tendo em vista que o investimento maior foi na industrialização de polos como Montes Claros e Pirapora. No entanto, do ponto de vista político, os tentáculos da autonomização do Estado chegaram ainda nos anos 1960, reorganizando a região para a entrada posterior dos capitais exógenos. A maior presença de políticos em visita à região pós-golpe de 1964 e a frequência de militares a circularem nos distritos coincidem com a organização de diretórios políticos dentro da legalidade, como o Movimento Democrático Brasileiro (MDB), em Francisco Dumont, usado para enfrentar os poderes locais em nome de sua substituição pelo Estado autonomizado. 


\section{Figura 27 - O que restou da biblioteca de Sócrates Dumont}

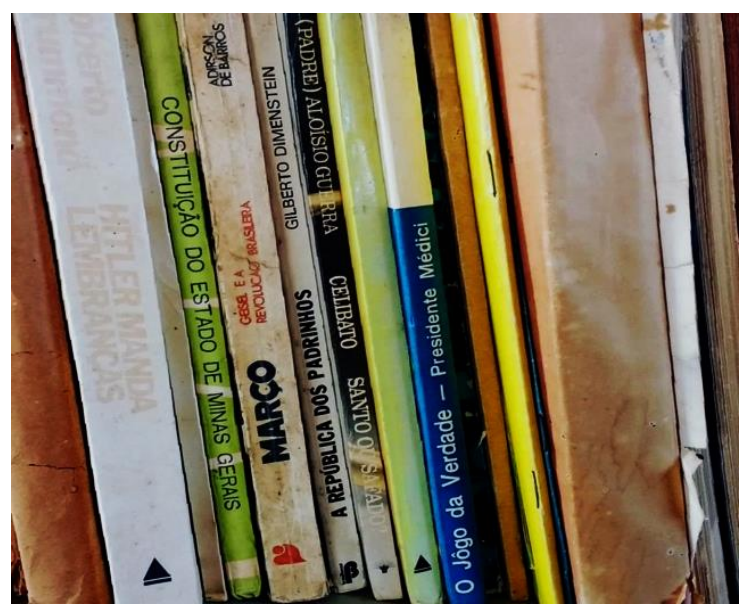

Fonte: acervo pessoal da família Dumont, julho de 2017.

As lembranças de filhas e filhos do falecido Pedro Rosa, um dos fundadores do diretório, exemplificam os objetivos de desobstrução da Serra como alegoria à abertura regional. Suely Rosa Leite, 65 anos (2019), Nagma Leite da Silva, 67 anos (2019), e Pedro Leite da Silva, 51 anos (2019), relatam que seu pai, nascido em Francisco Dumont e tendo passado pelos ofícios de cozinheiro de tropas de vaqueiros, garimpeiro e comerciante, intentava debilitar o poder local da família Dumont não apenas pela fundação do partido, mas também por trazer a primeira linha de ônibus que conectava o município a Bocaiúva e Montes Claros. Sem perceber, Pedro Rosa e outros aliados estavam a serviço da centralização do Estado na região. Donos da primeira pensão da cidade, os Rosa ofereciam seus aposentos não só para os motoristas da Viação Transnorte, como também para os médicos que iam semanalmente ao município e para as primeiras reuniões, tanto do partido quanto do projeto autonomista.

\section{Figura 28 - Inauguração da linha de ônibus da Viação Tolentino (atual Viação Transnorte), Francisco Dumont, 1968}

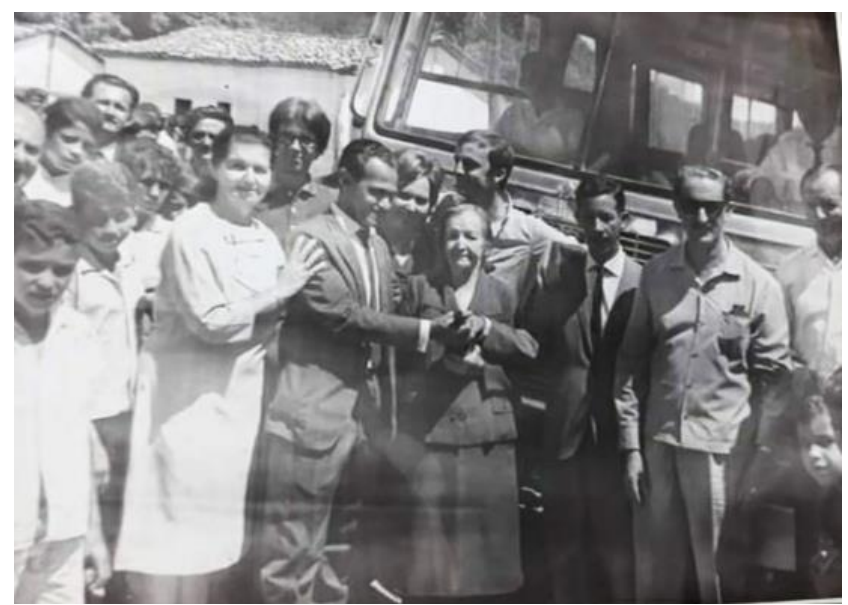

Fonte: acervo pessoal de Pedro Rosa, setembro de 2019 
Dentro daquilo que David Harvey (2006) chama de geopolítica do capitalismo, as alianças regionais de classes, vinculadas vagamente num território e organizadas habitualmente pelo Estado, voltadas à defesa de valores já materializados e da coerência regional estruturada construída, entrariam em declínio com a ascensão do novo arranjo produtivo. Elas não seriam capazes de conter a criação das forças fundamentais desencadeadoras de crises, pois internalizavam divisões de classe e faccionárias potencialmente explosivas, com limites porosos e sujeitos à alteração. Tal explicação permite entender como os poderes regionais tradicionais sucumbem frente a um momento político e econômico de mudanças no centro do capitalismo, datado pelo autor na década de 1970.

Com todos os conflitos consequentes da disputa eleitoral fictícia entre MDB e Arena, boa parte da família Rosa migrou para o ABC paulista. Entre fins dos anos 1960 e princípios da década seguinte, a prefeitura, comandada por um membro da família Dumont (Dalmo), tomou a iniciativa de cercar terras e facilitar as vendas, inclusive roubando as terras dos seus oponentes. As fazendas começavam a ser arrendadas para projetos de reflorestamento e de pecuária especializada que, requerendo grandes extensões de terra, impeliam os pequenos proprietários a vendê-las. Nesse contexto, muita gente migrou da Serra do Cabral, formando núcleos em Santo André e Osasco, na Região Metropolitana de São Paulo.

\section{4. "A Serra que eu não conheço mais" ${ }^{233}$ : o reflorestamento}

A segunda metade do século XX assistiu a um impasse do ponto de vista econômico, motivado pelos rearranjos gerais de produção e acumulação. Até então, as condições regionais de territorialização do capital não possibilitavam a autonomização nem entre terra e trabalho nem entre terra e capital, assim como impediam a autonomização dos rendimentos relativos a cada um daqueles fatores de produção, justamente em razão dos mesmos não terem ainda se cindido. Tais condições constituíram a fazenda tradicional como garantia permanente do investimento agrícola e criaram a base de um processo de mobilização do trabalho em que o trabalhador ainda estava forçado à realização do mais-produto.

Para que essas fazendas pudessem se integrar ao mercado na condição de propriedade apenas, seria necessário sua separação tanto do trabalhador quanto do capital, realizando a autonomização da fórmula trinitária (terra, trabalho e capital). Essa cisão providenciava a instauração de novas e mais modernas condições de territorialização e, com as mesmas, de uma

${ }^{233}$ Frase dita por Manoel Lopes e José Telheiro nas entrevistas concedidas. 
forma alterada de mobilização do trabalho em que a terra, mas sobretudo a sua propriedade, estaria com o seu livre acesso vedado ao indivíduo, passando a operar como fundamento da dupla liberdade do trabalhador, sujeitado a ter que ir e vir como momento da realização de sua condição de expropriado.

Ao discutir a formação e a crise da reprodução do campesinato do Vale do Jequitinhonha, a tese de Ana Carolina Leite (2015) apresenta o processo de expropriação do lavrador da terra e sua cessão pelo Estado às reflorestadoras a partir da década de 1960, como uma não acumulação primitiva - lembrando que este momento já tinha se dado durante o período colonial como parte da mundialização do sistema produtor de mercadorias. O que passou a ocorrer na segunda metade do século XX, não só no Vale e na Serra, mas no norte de Minas Gerais e em outras regiões, foi a autonomização do capital com a sua separação da terra e a formação do trabalhador livre, já emancipado dos processos forçados de mobilização.

Seu curso foi longo e teve descompassos, dada a simultaneidade particular da territorialização do capital, seja em relação ao Brasil e ao mundo, seja intrafronteiras no que toca às regiões, que se apresentavam como desiguais ao invés de diversas. Esse quadro justificou os projetos de desenvolvimento homogeneizador das forças produtivas em escala nacional, transformando a terra de fonte de reprodução social a mero fator de produção capitalizado. É nesse interregno que o Governo Militar, sobretudo após o II Plano Nacional de Desenvolvimento (PND), de 1974, orienta a uma prevalência do planejamento nacional sobre o regional, com vias a promover o desenvolvimento rural integrado em manutenção com outros setores econômicos. As mudanças não se deram apenas na forma de produção e acumulação: foram também cravadas nas vidas e nas paisagens sertanejas.

A conversa com Manoel Lopes foi enfática sobre as transformações regionais a partir dos anos 1970. Quando as fazendas começaram a se modernizar ou mesmo a serem arrendadas para as empresas que estavam chegando, ele, já pressentindo que seu ofício de vaqueiro perdia aos poucos a importância de antes, começou a revezar os ganhos garimpando e colhendo sempre-vivas: "Conheci essa Serra toda! Tinha muita lagoa, muito bicho. Vargem Grande era um lagoão. Hoje, secou. Pisava e atolava. Seu Antônio comprou ela e eu fiz a cerca. Hoje não conheço mais, o desmate mudou a Serra".

Ana Carolina Leite (2015) traz semelhanças sobre a transformação do Vale do Jequitinhonha no mesmo período, seja na apropriação das terras devolutas pelo Estado e pelo capital privado, seja pela mudança ocorrida no interior das fazendas. Além da introdução do reflorestamento, a partir dos anos de 1960, as fazendas locais, que antes eram estabelecimentos agropastoris, tendiam ao pastoreio extensivo puro e simples. Por ser essa atividade mais 
lucrativa, todo o solo foi revertido ao plantio de capim, retendo-se, em média, apenas um ou dois vaqueiros para os cuidados do rebanho, que também passava a se compor de raças selecionadas.

Em conformidade, o discurso científico abraçado pela República e adotado oficialmente pelo Estado Novo tinha como personificação o técnico, que devia racionalizar o modo como o Estado territorializaria suas ações em nome do capital. Se em princípios dos Novecentos o discurso do atraso estava atrelado à figura do sertanejo como sujeito febril e ignorante, a partir de 1930 a ele é adicionada a ideia de que sua forma subdesenvolvida de ocupação do espaço, muitas vezes forçadamente nômade em vista da pobreza econômica, é ecologicamente predatória.

Tal sermão, como se pode desconfiar, não é neutro. De acordo com Múcio Tosta Gonçalves (2006), havia uma ligação entre a crítica à agricultura nômade e "destrutiva" e a política de titulação de terras, perpassada por uma apologia do progresso. Segundo o autor, em Minas Gerais as diversas formas de utilização de florestas para fins energéticos e de construção foram uma permanente fonte de pressão sobre os recursos florestais, chegando o estado a ter apenas $11 \%$ do seu território coberto por matas nativas já em fins da década de 1950. Apesar de se saber que o estilo adotado de crescimento industrial e demográfico urbano era o que pressionava as áreas ainda florestais, o ataque à agropecuária pobre foi a desculpa para explicar a deterioração e o esgotamento dos solos, criando um ótimo motivo para abrir a região em nome do desenvolvimentismo.

Erick Kluck (2019) mostra os passos que a Sudene deu no sentido de concretizar a modernização regional. Após o golpe de 1964, o planejamento estatal sob sua batuta sofreu transformações. Ao analisar o III Plano Diretor de Desenvolvimento Econômico e Social do Nordeste (1966-1968), o autor aponta que a autonomização entre as esferas econômica e social já estava anunciada no discurso do governo. A partir desse plano, o Estado reduziu as verbas e, via isenção de impostos, ampliou a participação de empresas privadas na autarquia. No discurso do plano seguinte (1969-1973), o "êxito" da Sudene é realçado. O contexto pós-AI-5 reforçava o momento de risco à "integridade nacional", com a defesa da industrialização como forma de modernizar o território como um todo. Uma industrialização que, a partir de então, não tinha necessariamente tez nacional.

Todavia, a industrialização permaneceu em áreas seletas: ou aconteceu em regiões estratégicas, como na criação da Zona Franca de Manaus, ou foi reforçada nas grandes capitais do Centro-Sul e do Nordeste. Onde a indústria não estava, era preciso intensificar a 
produtividade agrícola de modo a oferecer matéria-prima para sustentar o seu avanço, casando os objetivos do desenvolvimentismo com os interesses da Revolução Verde ${ }^{234}$.

Olhando genericamente para o rearranjo de produção e acumulação a partir da predominância do capital financeiro na década de 1970, a introdução de novas organizações e interesses com vias a quebrar as alianças regionais permitem acompanhar as ações dos centros econômicos lançadas para as periferias. Os excedentes de capital e força de trabalho nos países centrais teriam como alternativa à desvalorização a sua alocação nos países periféricos, para criar nova capacidade produtiva nessas áreas valendo-se da promessa de colheita de lucro futura. $\mathrm{O}$ investimento se dá a longo prazo, enquanto a expansão contínua de uma economia capitalista regional inteiramente nova cria uma demanda corrente e crescente pelos excedentes de capital e força de trabalho na região natal.

Esse movimento, que David Harvey (2006) chama de "busca por ajuste espacial”, não escapa às antinomias da relação do valor. Segundo o autor, ele levaria a um consequente crescimento da região receptora dos investimentos, criando seus excedentes de capital e força de trabalho, mais e mais difíceis de serem absorvidos. Entrando em competição com o centro e desvalorizando a economia de origem ou, como neste caso, submissa à imposição de formas dependentes de desenvolvimento ditadas pela região central, a economia periférica permanece subserviente, porém também impelida a cuidar do seu próprio ajuste espacial.

Apesar da importância dessa teoria, visto que joga luz à expansão do capital sobre as terras da periferia mundial para resolver os problemas de acumulação do centro, David Harvey permite uma leitura intencionada em uma espécie de acumulação primitiva constante no mundo contemporâneo, negando a geografia histórica do capitalismo que tanto defende. Entendendo a reprodução ampliada do capital como um avanço inédito sobre as terras das periferias, o autor desconsidera as formas de sociabilidade moderna implantadas nos territórios desde o momento colonial, quando os fatores de produção se faziam presentes, apesar de sua autonomização ainda não estar dada.

Além do mais, a análise parece não dar relevo suficiente ao fato de que as transformações produtivas de 1970 em diante erodem o trabalho enquanto substância do capital, que era necessário à conformação histórica do capitalismo. Na contemporaneidade, o processo

\footnotetext{
234 “"A Chamada Revolução Verde’ foi um programa que tinha como objetivo explícito contribuir para o aumento da produção e da produtividade agrícola no mundo, através do desenvolvimento de experiências no campo da genética vegetal para a criação e multiplicação de sementes adequadas às condições dos diferentes solos e climas resistentes às doenças e pragas, bem como da descoberta e aplicação de técnicas agrícolas ou tratos culturais mais modernos e eficientes. Através dessa imagem humanitária, ocultavam-se, no entanto, poderosos interesses econômicos e políticos ligados à expansão e fortalecimento das grandes corporações a caminho da transnacionalização.” (BRUM, 1988, p. 44 apud ALVES, 2006, p. 13).
} 
de produção social deixa de ser um processo de trabalho humano, posto que este, tornado supérfluo, é substituído por capital objetivado cientificizado, levando inevitavelmente ao colapso, ao invés da compensação que o autor defende (KRISIS, 1999).

Para o caso brasileiro dentro do regime militar, a receber os empréstimos do capital excedente para financiamento do plano desenvolvimentista e com consequente endividamento futuro, lidar com a cisão dos fatores de produção ao promover a espoliação dos trabalhadores, além do incentivo agrícola, pode ser uma explicação aceitável para o panorama econômico e político sugerido por David Harvey. Seria essa uma ação do novo imperialismo na busca de segurança para garantir suas transações nas áreas de valorização precária na periferia.

Discutindo a territorialização via agronegócio sobre os cerrados piauienses, na dissertação Formação territorial sul piauiense: modernização agropecuária e resistência camponesa, Vicente Eudes Lemos Alves aponta que a institucionalização do Sistema Nacional de Crédito Rural (SNCR) foi o primeiro instrumento utilizado pelo Estado com vias a garantir a modernização do campo, em especial as regiões tidas como vazias e economicamente atrasadas ou estagnadas. A estratégia consistiu em promover a modernização agropecuária e, ao mesmo tempo, criar mecanismos, via crédito subsidiado, para que se pudesse transferir recursos públicos ao grande capital sem que ocorressem maiores riscos. "Nasce daí a aliança do capital industrial e financeiro com o Estado. E é ela que vai conduzir as transformações que ocorrerão no campo brasileiro a partir de então" (ALVES, 2000, p. 48-49).

Como a produção primária era parte do planejamento, para Múcio Gonçalves (2006), a importância das alterações vislumbradas no movimento territorial das plantações em Minas Gerais explicava parte do norte do estado estar incluído na área da Sudene. Isso estimulou o deslocamento dos plantios para a região e, num movimento análogo ao dos reflorestadores, dos consumidores, crescentemente dependentes do carvão vegetal e da lenha, particularmente as indústrias siderúrgica, metalúrgica, cimenteira e de calcinação, as quais direcionaram suas atividades de desmatamento e carvoejamento para o cerrado.

Junto à necessidade de produção primária para o fornecimento industrial estava o discurso da adequação do cerrado para o empreendimento silvicultor. A defesa da ideia de que o solo é ácido e, em muitas partes, arenoso, portanto impróprio para outros cultivos, bem como o clima de chuvas sazonais aliado às altas temperaturas e à presença de lençol freático e a vegetação feia e inútil, endossaram a introdução do reflorestamento na Serra.

Essa forma de olhar para os atributos fisiográficos destinando-os à especialização das produções anda em par com o que John Bellamy Foster (2012b) apresenta como uma das leis antiecológicas do capitalismo, na qual a natureza é concebida como um presente gratuito para 
o proprietário do capital. Considerando-se a terra como um fator de produção não produzido, ela e a natureza que suporta são encaradas como recursos à espera de apropriação para as finalidades produtivas modernas.

Para que essa apropriação da terra aconteça, é preciso que se negue as formas históricas específicas da propriedade fundiária, transformando-as mediante a influência do capital e do modo de produção capitalista. Assim como esse modo se baseia, em geral, na expropriação dos trabalhadores das condições de trabalho, na agricultura ele se apoia na expropriação do trabalhador rural da terra e sua subordinação a um capitalista, que explora a agricultura visando o lucro (MARX, 2013, v. 3).

Como a modernização retardatária pós-1930 entendeu o progresso como sinônimo de industrialização, encobriu-se o momento histórico basilar da acumulação primitiva como processo inicial de expropriação, assimilando-se a fábrica como o real momento de consolidação do capitalismo ${ }^{235}$. Enxergar os posseiros na sua relação com as veredas e chapadas como refratários à forma social moderna foi um meio de validar as ações planejadoras, o que, no decurso da autonomização do Estado e dos fatores de produção, estimulou a grilagem, o planejamento, entre outras formas que têm na contramão a expropriação daqueles que dependem dela. Por sua vez, a espoliação liberaria a força de trabalho a baixo custo para os planos regionais. A apropriação da terra e de seus recursos naturais pelo capital privado só foi possível no norte de Minas Gerais com o aval do Estado, que, para tal, também devia partilhar da mesma visão sobre terra, natureza, recursos e força de trabalho.

Com a política de incentivos fiscais e o alto custo das terras mais ao sul do estado, os investidores passaram a buscar terras de baixa valia para implantar suas florestas. Ou seja, a partir da consolidação da política de incentivos, o preço da terra passou a ser o principal determinante na escolha da localização dos plantios, uma vez que os resultados financeiros obtidos com a atividade se tornaram independentes do aproveitamento industrial dos maciços. A procura por terras baratas levou os investimentos à Serra.

\footnotetext{
${ }^{235}$ De acordo com Kurz (1997), o marxismo teve essa mesma compreensão ao considerar o motor da história o desenvolvimento das forças produtivas materiais, que entram em conflito com as relações de produção tornadas restritas e obrigadas a uma nova forma de sociedade, cabendo à industrialização o ponto decisivo de transformação social. Porém, o autor chama a atenção para a contradição no argumento, dado que, ao escrever sobre a acumulação primitiva, Marx se ocupou em apresentar períodos posteriores à máquina a vapor, onde a expropriação já acontecia em nome do mercado. A mesma direção segue Guillermo Foladori (2007), mais preocupado em discutir a questão ambiental a partir do metabolismo entre homem e natureza e o papel da renda da terra: para ele, os modos précapitalistas de produção eram agrícolas; o modo capitalista de produção cria a indústria e, com ela, redimensiona as relações com a terra. Conforme apontam este e muitos outros estudos, as mudanças nas relações com a terra, em especial no caso brasileiro, são engendradas antes da passagem industrial, no vínculo com o sentido da colonização e com a teoria moderna da colonização.
} 
$\mathrm{Na}$ Serra do Cabral, o reflorestamento chegou como laboratório ainda no Governo Militar, no fim dos anos 1970. Assim como em todo o norte mineiro, a intensificação das atividades de reflorestamento recebeu o apoio de órgãos governamentais empenhados, como a Fundação Rural Mineira Colonização e Desenvolvimento Agrário (Ruralminas) ${ }^{236}$, que viabilizou a penetração dessas empresas em terras consideradas devolutas, o que, por sua vez, alimentou a grilagem e a concentração fundiária ${ }^{237}$.

A conversa com Antônio Viriato Neto, conhecido por Antônio da Serra, 69 anos (2018), ajudou a entender a chegada das empresas na região. Nascido e criado em Divinópolis, deixou de trabalhar em fazendas leiteiras para se empregar nas companhias siderúrgicas do entorno em meados dos anos 1970. Foi o que o levou à Serra do Cabral em 1980, encarregado de coordenar o reflorestamento em nome da Santa Maria Floresta, empresa privada que se beneficiou com os incentivos do governo. "A firma conseguiu financiamento para 200 hectares na Água Branca. Meu patrão na época, seu Levi Coelho da Rocha, saiu de Divinópolis e fez fortuna." Segundo ele, não havia mais para onde expandir o plantio na região onde morava, e a partir do Governo $\mathrm{Geisel}^{238}$, as empresas foram obrigadas a fazer o reflorestamento, sob a desculpa do receio das matas nativas não darem conta da demanda.

De acordo com Mônica Nogueira (2009), a introdução de florestas homogêneas de pinho e eucalipto na região fazia parte da estratégia desenvolvimentista do Governo Militar, com o uso de mecanismos como o Fundo de Investimentos Setoriais (Fiset) - substituído pelo Banco Nacional de Desenvolvimento Econômico e Social (BNDES) -, o Programa de Distritos Florestais $^{239}$ e, no norte de Minas Gerais, também os incentivos financeiros da Sudene e da Codevasf.

\footnotetext{
${ }^{236}$ Órgão do governo de Minas Gerais responsável na época pelas terras do estado, criado em 1966 para representar o Estado na legitimação da propriedade, uso e reintegração de posse e discriminação de terras devolutas em Minas Gerais, conforme as determinações do Estatuto da Terra, promulgado quatro anos antes, sendo hoje substituído nessa função pelo Instituto de Terras de Minas Gerais (Iter/MG) (NOGUEIRA, 2009).

${ }^{237}$ Cardoso (2000) apresenta a distribuição percentual, por grupo de área, do número e da área dos estabelecimentos agropecuários da Região Mineira do Nordeste (RMNe) em 1970, 1975, 1980 e 1985, a partir de dados do IBGE e da Associação dos Municípios da Área Mineira do Nordeste (Amamn). É clara a concentração fundiária em toda a região.

${ }^{238}$ Ernesto Beckmann Geisel, político e militar brasileiro que presidiu a República de 1974 a 1979, dentro do contexto ditatorial.

${ }^{239}$ Criado pela Portaria n. 43/76 de 16/0276, com incentivos fiscais da Lei n. 5.106, de 02/09.66 e do Decreto Lei n. 1.376 de 12/12/74 (Ruralminas, Doc. II Resumo dos contratos sobre Distritos Florestais, Histórico, Leis e Decretos s/d). No documento, consta:
}

Os "Distritos Florestais" são áreas ecológicas, economicamente estabelecidas, para produção florestal com fins nobres principalmente o industrial. No Norte, Noroeste e Vale do Jequitinhonha tem como base áreas de terras devolutas, de propriedade do Estado de Minas Gerais, inteiramente desocupadas e inaproveitadas. (RURALMINAS, 1974 apud DAYRELL, 1998, p. 77). 
Esta última, uma autarquia criada em 1975, fruto do desdobramento da Comissão do Vale do São Francisco (CVSF) e Superintendência do Vale do São Francisco (Suvale), com uma dinâmica pautada no autoritarismo do governo que a criou, personificou a atuação direta do Estado na ampliação e institucionalização do mercado de terras no vale do São Francisco. Por meio dela, o governo fazia concessão e arrendamento de terras devolutas a preços simbólicos, sobretudo nas áreas de chapada, sem grandes riscos financeiros e visando à produção de celulose e carvão para os mercados interno e externo, considerando a crescente demanda por carvão vegetal para o polo siderúrgico do estado. Os contratos de arrendamento tinham vigência média de 25 anos, correspondendo, aproximadamente, ao ciclo das espécies de pinho e eucalipto que permitem três cortes, um a cada sete anos. Com a isenção temporária do imposto territorial, os fazendeiros também se interessaram no arrendamento de suas propriedades.

Conforme Vicente Alves (2000) aponta, as próprias autoridades públicas encarregadas do processo desenvolvimentista eram enfáticas na defesa desse modelo, como fica claro na declaração do então Ministro do Planejamento sob os Governos Médici e Geisel, João Paulo dos Reis Velloso, responsável maior não só pela criação do Instituto de Pesquisa Econômica Aplicada (Ipea) durante o Governo Castelo Branco, como também um dos principais articuladores das políticas de ocupação dos cerrados 240 .

[...] O cerrado não gosta da agricultura tradicional e sim da agricultura empresarial, com inteligência. Gosta de fertilizantes, de tecnologia avançada e de mecanização. É uma oportunidade que temos de modificar a estrutura da exploração agrícola no Brasil (CNBB, 1976, p. 130 apud ALVES, 2000, p. 55).

Como as áreas pretendidas pelas empresas de reflorestamento ultrapassavam o permitido não só pela legislação de terras do Estado, como também pela Constituição Mineira, era obrigatório a prévia aprovação do Senado Federal na concessão das terras. Tal foi feito; assim, nos anos 1970, a Assembleia Legislativa anuiu o arrendamento com direito à alienação

\footnotetext{
${ }^{240}$ Durante o mandato de Geisel (1974-1979), foi publicada a revista Interior, edição bimestral do Ministério do Interior (Minter), cujos números foram lançados até 1989. A pasta, criada na Reforma Administrativa de 1967, tinha como missão o "desenvolvimento regional", sendo a revista o seu veículo de propaganda. Sinônimo de "sertão", o "interior" que dá nome ao periódico é entendido na concepção mais dualista possível: "vazios demográficos", ou os "vazios econômicos" de um "Brasil distante", no qual o progresso ainda não chegou (IORIO, 2012). As matas e as formas "tradicionais" de vivência compunham o universo temático da publicação, unificado em torno da oposição em relação ao que se considerava a parte desenvolvida do país. Para o Governo Militar e seu corpo tecnocrata, os desequilíbrios regionais seriam mera questão de defasagem temporal incrustrada no espaço, cujos desequilíbrios se justificariam pelos estágios diferentes de desenvolvimento. Caberia às Ciências Econômicas a aptidão para apresentar as soluções necessárias à superação do problema, com o intuito de varrer o atraso do futuro.
} 
quase 1,5 milhão de hectares no norte de Minas Gerais para 18 empresas, concretizando, com o aval do Estado, a expulsão de camponeses dos Gerais (DAYRELL, 1998).

Os incentivos à silvicultura contaram com a oferta de rede de serviços e infraestrutura para se concretizarem. No caso de Minas Gerais, o apoio de órgãos de extensão, fomento e fiscalização deram respaldo ao setor no estado, como a Empresa de Assistência Técnica e Extensão Rural (Emater), a Sudene, a Codevasf, os Bancos do Brasil e do Nordeste e o Instituto Estadual de Florestas (IEF).

Assim, a procura por terras a baixo preço significou um movimento de valorização do capital por meio do aprisionamento de extensas parcelas contínuas de solos. O movimento de conquista dessas terras para extração de vegetação nativa e plantação de florestas homogêneas foi direcionado para as regiões onde elas poderiam ser apropriadas mais facilmente, sem o recurso do mecanismo regulatório do mercado: o contrato de compra e venda. Significou, também, que a expansão da fronteira silvicultora foi responsável por eliminar as antigas estratégias de posse e de agregação da e na terra.

Múcio Gonçalves (2006) acrescenta que terra, propriedade e fazenda não significavam a mesma coisa, e que a aquisição da terra não implicava em troca mediante dinheiro, mas apenas em troca. A presença das plantações serviu como um catalisador e/ou detonador para os processos de expulsão e transformação dos direitos costumeiros, o que alterou radicalmente a feição social do rural em Minas Gerais, especialmente no norte do estado.

Conforme o depoimento de Maria Facão, apenas a partir desse período, com a chegada dos projetos desenvolvimentistas na Serra, sua família conseguiu articular as condições para sair do domínio das propriedades alheias, assentando-se na periferia do pequeno núcleo urbano de Francisco Dumont.

Quando os fazendeiros não recorriam à violência para expulsar as famílias das terras, eles negociavam com elas o fornecimento de um lote ou uma casa simples para a sua transferência para a sede do município - situação também relatada por Carlos Dayrell (1998). O processo de formação de trabalho assalariado na Serra exigia, junto à especialização das produções, a expulsão do agregado da fazenda.

Não apenas os agregados foram expulsos, mas também os posseiros. O pai de João da Serra foi empregado pela Santa Fé ${ }^{241}$ em 1977, primeira empresa de reflorestamento na Serra, que antecedeu a Siderúrgica Santa Maria Ltda. Ele, seu pai e os dois irmãos mais velhos chegavam a ficar a semana inteira no alojamento da empresa para trabalhar, pois não tinha

\footnotetext{
${ }^{241}$ Não foi possível encontrar o nome oficial da empresa. Sabe-se apenas que era uma empreiteira da Siderúrgica Santa Maria Ltda., realizando trabalho terceirizado, conforme depoimento dos entrevistados.
} 
estrada na época. Segundo João, "Só tinha trilha. Foi Sócrates, prefeito na época, e o de Joaquim Felício que combinaram de abrir estradas; daí as empresas vieram e compraram as terras" terras que, como já apresentado, não tinham dono, até as famílias Dumont e Campolina disputarem as cercas, e foi o serviço de cercar com arame que atraiu o pai de Ifigênia.

Aos 17 anos, João conseguiu trabalho na Santa Maria, sendo fichado aos 18. "Trabalhei derrubando a mata nativa também, mas era mais no correntão. Era duas máquina de esteira, uma de lá e outra de cá. Engatava a corrente nelas e o mato ia caindo tudo. Quando chegava em pau grosso, ia batendo com a lâmina." Não só na derrubada trabalhou: "Mexia com tudo, inseticida... Proteção zero. Não me deu problema, mas muitos tiveram. A maioria do corte do eucalipto era no machado, quase não tinha motosserra. Era um na motosserra e dez no machado", num período em que as empresas ainda não terceirizavam os serviços.

\section{Figura 29 - Derrubada do cerrado na Serra do Cabral e produção de carvão com madeira nativa carregada por bois, década de 1970}

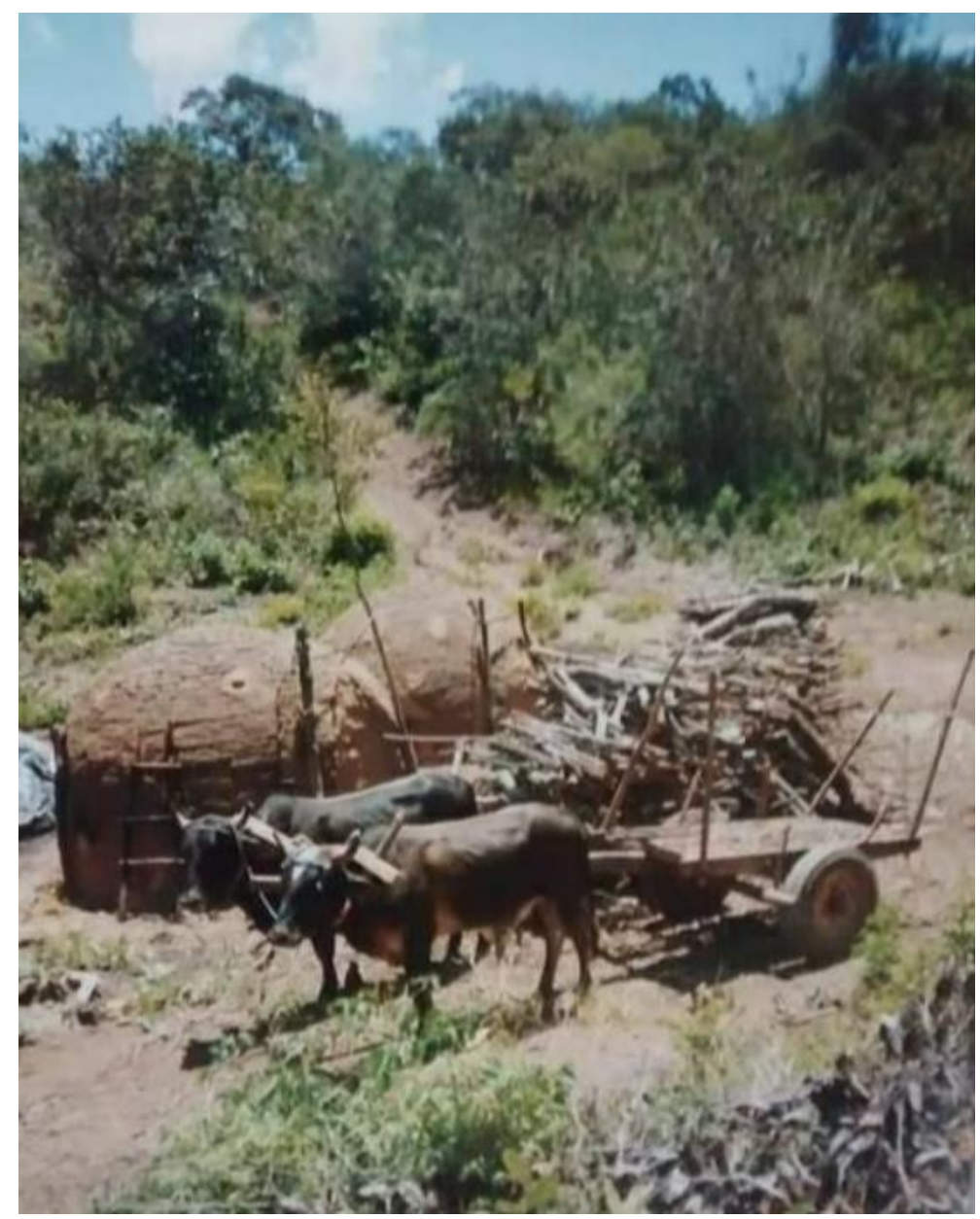

Fonte: acervo pessoal de Odilon Duarte, 2020.

Hoje aposentado, João mora em uma casa simples em bairro periférico em Francisco Dumont, a mesma casa que a família recebeu da Santa Maria ao sair da Vargem do Chico em 
troca de casa e emprego com carteira assinada. Não fazendo ideia de como provar a posse e sequer percebendo que a terra foi tomada, a família aceitou a troca pacificamente, ao que parece.

Apesar de interpretar de outra maneira, o depoimento de Antônio da Serra corrobora a história de João: ao realizar a compra da terra, a Santa Maria "encontrou" uns 20 moradores vivendo em rancho de palha e de barro na Serra, e ele, junto ao engenheiro florestal, ajudou essas famílias a descerem para a cidade e construírem suas casas, o que, para ele, foi muito bom: "O povo fala que antes vivia na Serra, mas vivia numa miséria danada. [...] Esse João Caçador... Seu rancho tinha unha de tamanduá; diz que ele fazia buraco no chão pra entrar e passava hora ali pra matar uma ema. Isso é vida?!". E completa, naturalizando o processo de expulsão: "Eu ajudei, não obriguei ninguém a sair. Isso levou uns quatro a cinco anos. [...] Quem trabalhou comigo melhorou de vida".

A maneira como João Caçador vivia na Serra não pode ser vista apenas como metabolismo entre homem e natureza. Na situação de posseiro, ocupou as veredas mais distantes dos povoados e as chapadas ainda sem dono, porque sua condição de expropriado das fazendas e imediações dos núcleos de povoamento o impeliu a tal. No entanto, a depender da riqueza que a natureza lhe oferecia para sobreviver, de alguma maneira satisfez suas necessidades básicas, interpretadas pelo encarregado da reflorestadora como uma vida miserável, porque para ele, preso à forma social, nela a mediação pelo dinheiro não determinava ainda as relações na sua totalidade.

Para Antônio da Serra, a chegada da Santa Maria só melhorou Francisco Dumont. Ao narrar suas lembranças relatando as dificuldades de transitar com os caminhões pelo município e arredores, riu de quando ouviu de Sócrates Dumont, prefeito na época, lhe dizer que "deixaria tapar os buracos da cidade", como se o lugar fosse propriedade sua. Ainda comentou que quando chegou, "as casas eram da delegacia pra baixo só, não tinha mais nada, só a Copasa ${ }^{242}$. Não tinha posto de gasolina, nem correio. Médico era difícil. Essa estrada aí só passou a existir depois que eu cheguei”.

Um giro pelo município hoje permite observar que a cidade cresceu espacialmente de 1980 em diante, comprovando a expropriação de agregados e posseiros nas últimas décadas. Bairros como Alto Esplanada, Vila Nova, Santa Juliana e tantos outros não existiam até então. "Do centrinho da praça pra lá, era tudo mato. O povo deixava cavalo pastando, e era pra lá que os ciganos arranchavam", lembra Biloca. A primeira foto, tirada nas décadas iniciais do século XX no centro histórico de Francisco Dumont, e a segunda, em um de seus bairros periféricos

${ }^{242}$ Companhia de Saneamento de Minas Gerais. 
em 2018, ajudam a comparar as mudanças na paisagem, o que inclui asfaltamento das ruas, mudança no estilo e no material das casas e até a presença de animais de carga nas vias.

\section{Figura 30 - As transformações no município de Francisco Dumont: o centro e a periferia, o espaço e o tempo}

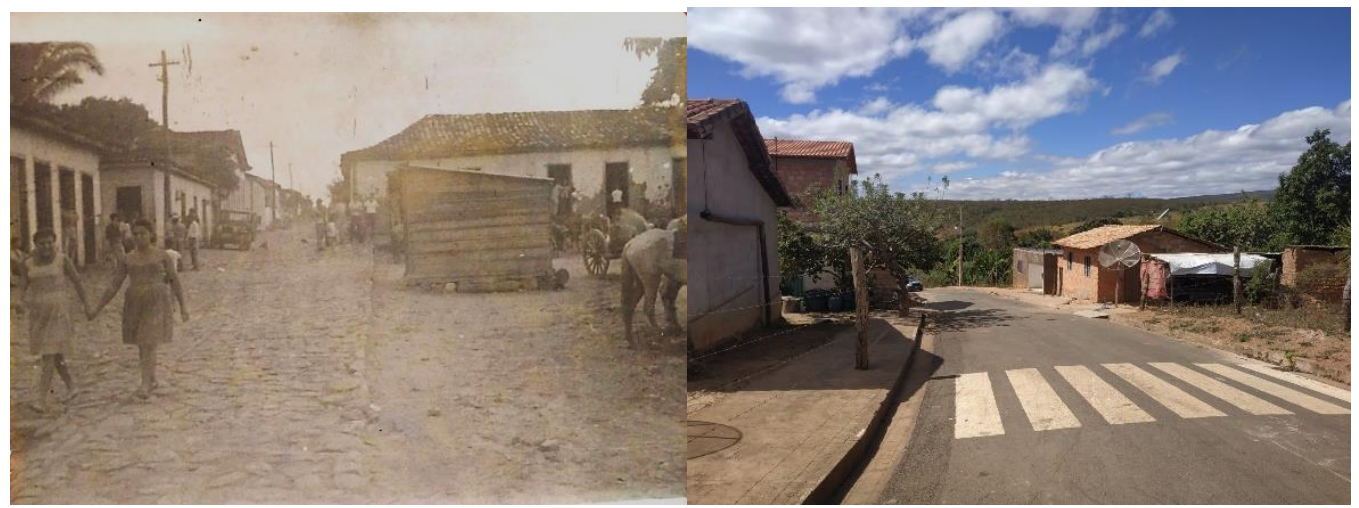

Fonte: à esquerda, Família Dumont, sem data; à direita, acervo pessoal, julho de 2019.

A expulsão do agregado e do posseiro da terra os libera para a busca de emprego, complementando a contradição da liberdade no sistema. Com a autonomização do fator trabalho, a mão de obra também passa a ser uma mercadoria, negociada por meio de um contrato em que, juridicamente, as partes são iguais e livres. Esse processo oculta o fato de o acordo não se dar entre iguais, para garantir a universalização abstrata das ideias de igualdade e liberdade. Por trás desse processo, é abstraído o trabalho concreto, que passa a lidar com a violência institucionalizada do Estado, não mais personificada no jagunço do coronel, mas na força policial e no aparato jurídico.

Dentro de um contexto de governo centralizado e autonomizado, o Estado emerge como uma ferramenta moderna unificadora, voltada ao mascaramento das divisões sociais. Ele não se dispõe à superação das contradições, mas à imposição dos desígnios do capital e suas personificações, com um comportamento impessoal assegurado pela atuação do Direito Civil. Este age como instrumento de regulação das relações sociais em proveito dos dominantes, fazendo com que a dominação não seja tida como uma violência, mas um ato legal e, como tal, que deve ser aceito (CHAUÍ, 2004).

Outro exemplo dessa libertação dos laços da grande fazenda é a trajetória de Clarice, nascida na fazenda Aliança, de Sócrates Dumont, onde sua mãe e seus irmãos já viviam na condição de agregados. Ela cresceu realizando os trabalhos domésticos da propriedade. Quando, nos anos 1990, o proprietário começou a se organizar para se inserir em novas relações de produção, sua família passou a viver na parte alta do município de Francisco Dumont, já na saída do perímetro urbano, em casa também cedida pelo latifundiário. A ela coube se ocupar 
dos trabalhos domésticos na pensão Santa Terezinha e de outros serviços, em troca de menos de um salário-mínimo.

Concordando com Margarida Moura (1988), a dissociação do corpo do trabalhador do lugar onde trabalha é a forma de separar do solo-mercadoria a presença física de quem o habita em função do trabalho. Ao ser criado o mercado de trabalho na Serra, completa-se a cisão entre este e a terra ${ }^{243}$, liberando força de trabalho barata para o projeto de desenvolvimento nacional. "Procedimentos que "conquistaram a terra para a agricultura capitalista, incorporaram o solo ao capital e entregaram à indústria das cidades os braços dóceis de um proletariado sem eira nem beira"” (GAUDEMAR, 1977, p. 268).

Uma mudança fundamental provocada na economia rural da região na percepção dos expropriados foi a geração de empregos assalariados com carteira assinada. Para João, assim como para Vanja e tantos outros que foram ouvidos, ser fichado foi a melhor coisa que lhes podia acontecer. As incongruências nas falas dos entrevistados denotam o quanto não percebem que a sua liberdade das amarras de uma produção social em que a violência extraeconômica estava imposta os condenou ao processo capitalista de socialização, o que dá ênfase à atuação da igualdade jurídica.

A intervenção estatal no desenvolvimento dos potenciais recursos para a produção incluía a implantação de infraestrutura, a formação de um mercado fundiário, a elevação do preço da terra e, evidentemente, a formação do trabalhador assalariado, tanto com a educação técnica quanto com sua "liberação" das relações tidas como arcaicas. Esse processo inclui o enfraquecimento do poder local, pois o Estado, ao penetrar a região, impõe suas normas de maneira a impulsionar a mobilidade do trabalho via sujeição dos homens e mulheres à territorialização planejada do capital. Ao institucionalizar suas ações, o Estado estabelece e qualifica a sua autonomização sob o capital, realizando uma contraditória e crítica forma de reprodução da forma social (KLUCK, 2019).

Preparada a abertura da região, proprietários extrarregionais, considerados personificações do capital, imbuídos do crédito público e dispostos a modernizar aquele sertão, continuaram chegando à Serra. Os incentivos fiscais eram um forte atrativo naquela ocasião, porque permitiam que a atividade silvicultora remunerasse os empresários quando da execução

\footnotetext{
${ }^{243}$ A indiferença em relação ao trabalho determinado corresponde a uma forma de sociedade na qual os indivíduos podem passar com facilidade de um trabalho a outro e na qual o gênero determinado de trabalho é fortuito, e, portanto, lhes é indiferente. Nesse caso, o trabalho se tem convertido, não só categoricamente, mas também realmente em um meio de produzir riqueza em geral, deixando de se confundir com o indivíduo como um objetivo espacial. Esse estado de coisas é o mais desenvolvido na forma de existência mais moderna da sociedade burguesa (MARX, 2008).
} 
dos plantios, e não quando da sua venda, transformando o capital em renda territorial capitalizada. A Santa Maria foi sucedida pela carioca Scai, também de olho no preço das terras e na mão de obra muito barata, além da proximidade dos centros siderúrgicos de Sete Lagoas, pela ligação ferroviária e construção rodoviária com centros consumidores e topografia favorável à implantação de florestas homogêneas. Ela enxergava nas terras de chapada áreas vazias que deveriam ser ocupadas em nome da segurança nacional - e do capital privado, obviamente ${ }^{244}$.

No caso da Scai, seu proprietário, o engenheiro economista carioca Henrique Flanzer, adquiriu as terras na Serra do Cabral, disponibilizadas como devolutas e vazias pelo Governo Militar ao capital privado. Flanzer chegou a ser presidente do Ipea durante o Governo Médici ${ }^{245}$, entre os anos de 1969 e 1974 (D'ARAÚJO; FARIAS; HIPPOLITO, 2005), o que demonstra claro envolvimento dos tecnocratas do Estado com os interesses econômicos privados e a forma de ser do Estado moderno, conivente com a grilagem de terras. Durante sua presidência no órgão, Flanzer chegou a reestruturar o IBGE para atender às demandas do planejamento na Ditadura Militar. Hoje, seus filhos Marcelo e Roberto estão na dianteira da Ecoagrícola, uma nova roupagem dada à Scai para produzir café ecológico para exportação, conforme apresentado no capítulo 6.

\footnotetext{
${ }^{244} \mathrm{Tal}$ ótica explica os projetos para as regiões cobertas por floresta amazônica e por cerrados. No primeiro caso, a BR-230, também conhecida como Rodovia Transamazônica, do Fundo de Investimentos da Amazônia (Finam) e do projeto Grande Carajás. No segundo caso, o Programa de Desenvolvimento dos Cerrados (Polocentro) e o Programa de Cooperação Nipo-Brasileiro para o Desenvolvimento dos Cerrados (Proceder), além do Fiset e da Sudene, no norte de Minas Gerais (DAYRELL, 1998). Foi essa ótica que os autonomistas do norte de Minas Gerais captaram para defender o seu projeto.

${ }^{245}$ O Ipea foi uma incumbência do Plano de Ação Econômica do Governo (Paeg), órgão criado pela gestão autoritária do presidente Castello Branco, na intenção de "reduzir os desequilíbrios regionais e setoriais, aumentar o investimento e o emprego e corrigir a tendência ao desequilíbrio externo", para dotar o mercado de uma "ordem institucional favorável ao grande empresariado e liberando o fluxo de capitais estrangeiros para o Brasil" (OLIVEIRA, 2007, p. 105, grifos da autora). É o que apresenta a tese A política geral do regime militar para construção de suas políticas econômicas (1964-1985), de Marly Job de Oliveira, a qual contrapõe a narrativa dos envolvidos no golpe de 1964 como uma ação espontânea e popular de combate ao fantasma comunista às políticas econômicas planejadas pelo Governo Militar, voltadas à redução das disparidades regionais na intenção do desenvolvimento.
} 
Figura 31 - Anotações de venda de terras de Sócrates Dumont, maio de 1992

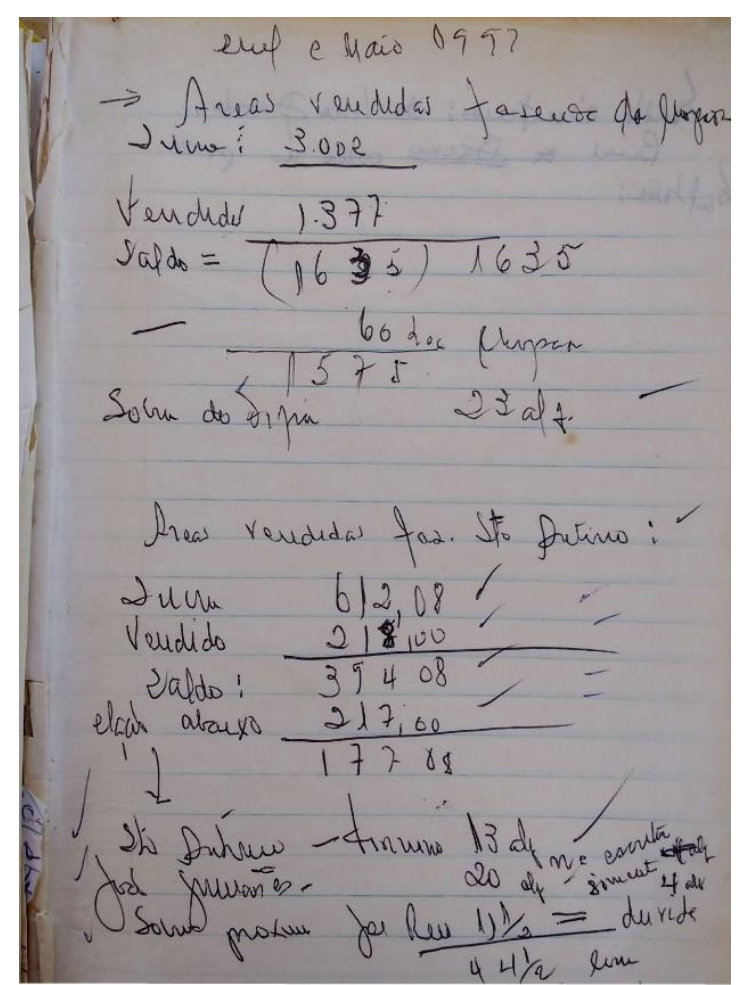

Fonte: acervo pessoal de Guilherme Dumont, julho de 2017.

Criada sob o Governo João Figueiredo, a Scai é consequência de um conjunto de medidas que vinham sendo engendradas desde o Estatuto da Terra, de 1964, implementado imediatamente após o golpe militar. Nele, já havia referência à necessidade de se organizar o financiamento mais consistente da agropecuária, em ação coordenada junto ao antigo Instituto Brasileiro de Reforma Agrária (Ibra), ao Ministério da Agricultura, à Superintendência da Moeda e do Crédito (Sumoc) e à Coordenação de Crédito Rural. No mesmo ano, o governo instituiu o Sistema Financeiro Nacional (SFN) e o Conselho Monetário Nacional (CMN) e, no ano seguinte, institucionalizou o Crédito Rural. Tanto o SFN quanto o CMN são ramos do Banco Central e, até hoje, responsáveis por gestar e coordenar esse crédito (KLUCK, 2019).

Tais medidas, somadas aos incentivos fiscais, fortaleceram os grandes empreendimentos agropecuários da década de 1960 até meados dos anos 1980, os quais, em geral, eram denominados Complexos Agroindustriais (CAIs). De acordo com Erick Kluck (2019), tratavase de uma transformação na própria forma de financiamento estatal do mercado, baseada no endividamento, colocando o capital fictício no centro da reprodução ampliada.

A Scai começou com o plantio de pinho para o carvoejamento, mas interrompeu o cultivo, deixando as terras ociosas até o século XXI. Apesar de o norte de Minas Gerais chegar em 1985 com a produção de mais de $25 \%$ do carvão no estado, a primeira tentativa não foi 
exitosa na Serra, sendo o pinho, inicialmente plantado em veredas, abandonado, dado que demorava muito a virar carvão. O crédito foi reduzido nos anos 1990, mas voltou a ser disponibilizado nos anos 2000, tornando não apenas a Scai e a Santa Maria atuantes na Serra, mas abrindo para outras reflorestadoras, como a Plantar.

De acordo com o relatório de licenciamento ambiental de 2007, a Scai se situa na fazenda Serra do Cabral, localizada na zona rural dos municípios de Várzea da Palma, Francisco Dumont, Augusto de Lima e Lassance, com área total de 2 mil hectares, sendo que o plantio de pinho abrangia uma área de 27.326 hectares, e o de eucalipto cobria 400 hectares, além das benfeitorias arroladas (como estradas e depósitos) ${ }^{246}$.

Para aquele ano, o relatório ainda informa que a grande maioria dos empregados contratados pela empresa era originária e residente nos municípios do entorno da Serra do Cabral, sendo que na época do plantio, conforme registros da empresa e notas da Carteira de Trabalho e Previdência Social (CTPS), o número de empregados era superior a 500, tendo atingido o pico de 1.200 nos anos 1982 e 1983 . Até 2007, o relatório informa que o total de empregos diretos era da ordem de mil, já que se instalaram na região mais de 20 empresas para explorar produtos e subprodutos derivados do reflorestamento (PINTO, 2007).

Dos 1980 em diante, a paisagem da Serra mudou. Tanto nos núcleos urbanos quanto na mata adentro, a transformação tem sido drástica. Muitos dos entrevistados que disseram conhecer a Serra como a palma da mão ressaltaram que hoje já não conseguiriam andar por ela, pois se perderiam facilmente por entre as ruas estreitas de eucaliptos homogêneos - isso se lhes fosse permitido circular por entre os plantios.

Além das propriedades reflorestadas, grandes parcelas de terra na Serra permanecem com sua paisagem intacta, sem função produtiva, porém com as cercas e as placas advertindo propriedade privada. Quando questionado sobre o conhecimento da situação, Manoel Lopes comenta: “Ah, é terreno da Engetel, uma empresa de telefone aí que comprou terra nos anos [19]90 e nunca plantou nada. A gente nunca vê os donos".

A Engenharia e Telecomunicações Ltda. (Engetel) não é a única. Juntam-se a ela a estadunidense TTG Brasil Investimentos Florestais Ltda. ${ }^{247}$, a franco-alemã Vallourec

\footnotetext{
${ }^{246}$ A incoerência entre a área total da propriedade e a área de cultivo levanta duas hipóteses: a de que os números do relatório foram digitados erroneamente ou se confirma a grilagem de terras no confronto entre o tamanho registrado da propriedade e o avanço do espaço cultivado.

${ }^{247}$ A empresa atua junto ao BTG Pactual Timberland Investment Group (TIG), um dos maiores grupos globais em administração de investimentos em agronegócio e ativos florestais, com quase US\$ 3.5 bilhões em ativos e compromissos, e administração de 746 mil de hectares nos Estados Unidos, na América Latina, no Leste Europeu e na África do Sul, aderindo ao discurso do capitalismo ecológico e de combate à corrupção como propaganda (QUEM SOMOS, c2021).
} 
Mannesmann ${ }^{248}$ e a brasileira Ecoagrícola ${ }^{249}$. O fato dessas empresas terem comprado grandes extensões de terra na Serra do Cabral e deixado seus terrenos ociosos não é uma anormalidade. A facilidade em se conseguir recursos estatais via políticas de crédito contribuiu para que no final dos anos 1970 o capital disponibilizado à agricultura fosse disputado por grupos econômicos que não necessariamente mantinham vínculo com este setor. Assim, outros segmentos do capital, sobretudo urbanos e estrangeiros via sociedades anônimas, passam a adquirir terras nas regiões distantes, com o intuito de realizar especulação fundiária. Enquanto as benfeitorias do poder público não chegam, elas permanecem improdutivas e vedadas à população que mora em seu entorno, seja para colher os frutos do mato, seja para faiscar. Assim, dinamizam o capital fictício, reterritorializando áreas onde o capital excedente pode se autovalorizar.

\subsection{Se essa Serra fosse minha...: sem pedrinhas de brilhantes}

Conforme visto, a Sudene não manifestou interesse sobre qualquer projeto relacionado à extração de diamantes. Sua atenção se voltou para o investimento nas atividades agropecuárias, silvicultoras e industriais na região norte de Minas Gerais, visando integrá-la ao território nacional para realizar a economia endógena e conectá-la à dinâmica global. Nesse momento, o garimpo passa a ser economia secundária, dando primazia àquela atividade que historicamente se consagrou como subsidiária: a criação de gado.

Porém, a centralização promovida pelo Estado a partir de 1930 direcionou alguma atenção à extração mineral. Com a crise da cafeicultura, a indústria, sobretudo a de base, ganhou peso na política do Estado Novo, com a mineração assumindo um papel importante na modernização econômica do país.

Foi com Getúlio Vargas, em 1934, que o Estado criou o Código Mineral e o Departamento Nacional de Produção Mineral (DNPM), reconhecendo o garimpo, até então considerado marginal, como atividade ${ }^{250}$. Apesar de se debruçar com mais afinco sobre o aproveitamento da água para fins energéticos e de irrigação, no Código alocava-se para a

\footnotetext{
${ }^{248}$ Com unidades em Minas Gerais, a empresa se subdivide produzindo tubos de aço sem costura e carvão vegetal, que abastece o Alto-Forno das unidades produtoras de tubos e supre as necessidades de abastecimento internas de minério de ferro. A empresa conta ainda no estado com uma unidade de Negócios, provedora de serviços administrativos (QUEM SOMOS, c2019b).

${ }^{249}$ A Ecoagrícola se define como um grupo dedicado a cultivar grãos de alta qualidade para o mercado de cafés especiais de maneira sustentável, juntando ecologia e agricultura. A empresa começou a fazer projetos florestais da Serra do Cabral na década de 1970, mudando para os cafeeiros na década de 2000 (QUEM SOMOS, c2019a).

${ }^{250}$ Dayrell (1998) enquadra o que chama de "garimpeiros artesanais" como parte das populações tradicionais, aqui entendidos como faiscadores já inseridos historicamente na lógica da mercadoria.
} 
garimpagem um conjunto de áreas que compreendia as terras devolutas e os rios da nação, sendo as terras particulares passíveis de serem exploradas desde que houvesse o consentimento de seus donos ou arrendatários, com divisão dos lucros sobre os achados minerais em negociação direta.

Também nesse mesmo ano, foi criado o Código de Minas, o qual reconhecia a garimpagem como categoria legal. A primeira definição de faiscação e garimpagem aparece no decreto 24.193, nos artigos iniciais:

\begin{abstract}
“Art. $1^{\circ}$ - Entende-se por faiscação de ouro o trabalho executado por uma ou mais pessoas que lavrem o ouro aluvionar.

Art. $2^{\circ}$ - Considera-se garimpagem o trabalho de extração de pedras preciosas de rios ou córregos e chapadas, com instalações provisórias e aparelhos simples."

Rezava ainda o artigo $5^{\circ}$ do decreto de 1934 que o faiscador ou garimpeiro terá o direito de faiscar ou garimpar na zona indicada no seu certificado, podendo trabalhar conjuntamente com outros e usar instalações provisórias e aparelhos simples. (PÓVOA NETO, 1998, p. 247).
\end{abstract}

Esse mesmo código passou a reconhecer a realização do garimpo como um trabalho em grupo, e não como um serviço solitário. A conversa com Geraldinho já apresentava o garimpo como uma atividade coletiva: segundo ele, na Coruja, centenas de famílias se arrancharam para realizar o mesmo trabalho.

Figura 32 - Título de eleitor de 1958, onde se reconhece o garimpo como profissão

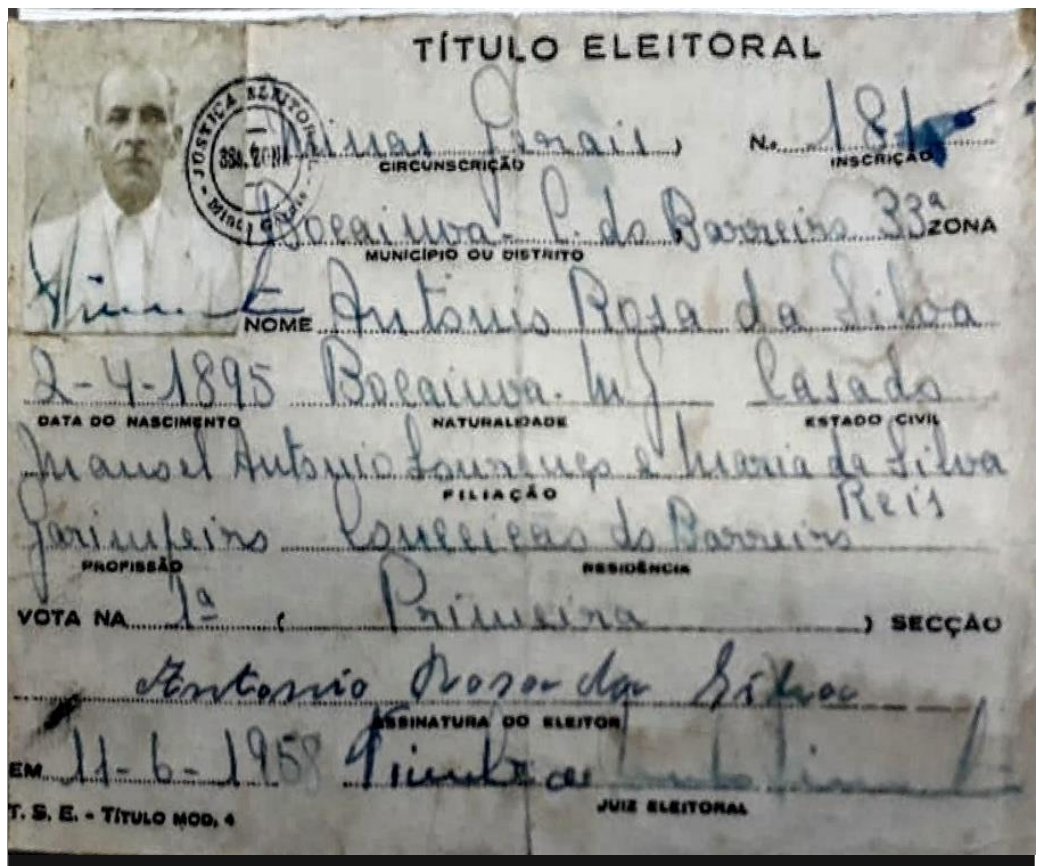

Fonte: acervo pessoal da família Rosa, 2019. 
Apesar de se dedicarem à faiscação muito posteriormente à compilação, as conversas com Dê, Dermeval e Walmir apontam para a permanência do quadro de coletividade no mister de buscar pedras: trabalhavam em grupos, assim como também foi com as gerações mais velhas, como Tino, Lúcio, Paulo e os irmãos Telheiro. Além disso, com o Código estavam liberadas as terras devolutas e os rios públicos, cabendo ao garimpeiro a negociação direta com o dono da terra no caso de extração em propriedade privada.

Como a grilagem estava acontecendo a todo vapor inclusive na Serra, o poder dos coronéis latifundiários permaneceu sobre o garimpeiro, pois estava em jogo o acesso à terra. Teotônio comentou que entre as suas memórias de infância, estava a constante coerção dos Borém ao seu pai para que vendesse as pedras a eles, os donos das fazendas onde haviam as catas. Foi ele, ainda adolescente, quem decidiu vender o achado por fora, pagando ele e sua família um preço alto pela ousadia: não podendo permanecer no lugar, ainda jovem, migrou rumo a Goiás.

Para que o faiscador gozasse dos direitos de garimpar legalmente, era necessário se matricular nas coletorias federais. Institucionalmente reconhecido, ao trabalhador era possível se organizar no Sindicato Nacional dos Garimpeiros, criado em 1935, um órgão que acabou se apresentando pouco articulado. O reconhecimento desse sujeito se insere em um contexto de controle e tentativa de disciplina para o trabalho, uma das fortes características do Estado Novo, regime que permaneceu perseguindo e encarcerando aqueles que considerava vadios.

A consolidação da centralização do Estado requeria também um aparato jurídico que enquadrasse os sujeitos dentro da ordem produtora de mercadorias, pois para levar a cabo a modernização é preciso autonomizar os fatores de produção, entre eles, o trabalho. Se nos sertões as relações capitalistas têm suas particularidades por não se enquadrarem na lei geral de acumulação capitalista exposta por Karl Marx (TOLEDO, 2008), a burocratização para adestrar os homens pobres no moderno sistema produtor de mercadorias implicava condicionar sujeitos que não exerciam apenas o ofício de garimpeiros, mas também se valiam de atividades as mais diversas como forma de complementar o serviço incerto de faiscar.

A matrícula na Coletoria Federal ${ }^{251}$ se tornou uma camisa de força aos sujeitos que precisavam transitar pelo território em busca de jazidas. De acordo com ela, o garimpeiro deveria anular a matrícula em um garimpo se quisesse trabalhar em outro, correndo o risco de apreensão de seus achados e suas ferramentas. Justamente por ser um trabalho que mobiliza espacialmente os homens, a iniciativa não teve êxito.

${ }^{251}$ A Coletoria Federal, criada para fiscalizar a tributação, passou a pertencer à Receita Federal em 1968 para a administração tributária e aduaneira da União. 
Apesar de se tornarem visíveis ao Estado, nem por isso os faiscadores desfrutavam do trabalho em liberdade ilimitada. Não tendo acesso à terra, se submetiam à negociação do tributo de $10 \%$ ao proprietário, a título de indenização por servidões e danos. Da mesma forma,

[...] se por força da localização da lavra, tivesse o garimpeiro que habitar em terreno de domínio privado, vizinho a terras e águas públicas, pagaria indenização nunca superior a 5\% do valor da produção efetiva. (PÓVOA NETO, 1998, p. 250).

Em 1957, Juscelino Kubitschek criou a Fundação de Assistência aos Garimpeiros (FAG), vinculada à Previdência Social, extinta posteriormente no Governo Geisel. Até a década de 1960, o garimpo era visto como atividade rudimentar e de pequena escala; a partir das descobertas minerais na região amazônica, houve mudança nas formas de encará-lo. Com o regime militar, o setor mineral ganhou uma nova dimensão na estratégia de acumulação definida pelo I PND, tendo como agentes não apenas o setor estatal, mas também o capital privado empresarial, inclusive estrangeiro. A atividade de faiscação se tornava novamente proibida.

Entre 1967 e 1968, o Código de Mineração foi editado e regulamentado. A partir de então, além da permissão do uso de instrumentos de trabalho, não era mais necessário o consentimento do proprietário do solo para a exploração da terra, o que favorecia as empresas mineradoras, ficando as decisões a cargo do Ministério de Minas e Energia (MME). O emprego de técnicas modernas daria o tom das explorações, com a proibição de catas em terras e águas de domínio público, restringindo assim o trabalho individual e autônomo de faiscação, comumente realizado por sujeitos pobres. Poucos anos depois, Walmir Bezerra, 56 anos (2017), garimpeiro nascido em Francisco Dumont e ativo nesse período, via os explosivos, as dragas e outras máquinas maiores chegando à Serra, com escavações cada vez mais profundas. $\mathrm{O}$ trabalho passava a ser assalariado.

Tal decisão, ao priorizar as grandes empresas mineradoras, ilustrava a captura do Estado pelo mercado. Com as grandes corporações privilegiadas pela legislação, estas se sentiam encorajadas a optar pelo confronto direto com os garimpeiros ao invés da negociação dos conflitos. Nesse contexto, elas exploraram o estereótipo do garimpeiro como desordeiro, visto que o mesmo território estava em disputa tanto pela empresa quanto pelo faiscador, que cobiçavam também as mesmas riquezas. Por isso o reforço de Geraldinho, enquanto gerente de serra, em manter em pleno regime militar a organização dos garimpos da Coruja e de Pau de Fruta, proibindo a entrada de bebida alcoólica e prostituta. A carteira de garimpeiro legalizado expressa a burocratização do trabalho. 
Com a Constituição de 1988, os minérios foram considerados bens da União, não alterando, porém, as relações entre os proprietários de terra e os garimpeiros. Os contratos informais foram a maneira encontrada para burlar a legislação e continuar a garimpagem.

Buscando oferecer um panorama da extração mineral no Brasil, com destaque para a aurífera, Luciano Rodrigues Costa (2007) aponta que em 1980 assistiu-se a uma expansão do garimpo no país, em muito promovida pelo avanço da fronteira agrícola devido aos projetos de integração regional encabeçados pelo Governo Militar desde a década anterior. Tal movimento estimulou um fluxo migratório para a hinterlândia, mobilizando força de trabalho disposta, inclusive, à mineração. Num momento de crise econômica, o garimpo funcionou como uma alternativa para a população de baixa renda, pois passava a ser tolerado sob a justificativa da mitigação dos problemas sociais decorrentes do desemprego e prometia gerar divisas para um Estado endividado, cuja ideologia desenvolvimentista prenunciava esgotamento.

A mesma interpretação contextual é feita por Helion Póvoa Neto (1998), que analisa o fluxo de garimpeiros rumo à Amazônia a partir dos anos 1970. Segundo o autor, havia a percepção de que em uma economia em crise, o garimpo, juntamente com os centros urbanos a ele vinculados, constituiu um dos poucos focos de emprego, conferindo às áreas de garimpagem uma certa notoriedade, não totalmente justificada, mas, de qualquer maneira, suficiente para exercer um papel polarizador. Eram áreas de expansão de fronteira que, para o autor, não podem ser vistas como impelidas somente pela agricultura.

Ainda de olho nos conflitos entre garimpeiros e mineradoras mais ao norte do país, Póvoa Neto argumenta que é preciso redefinir o conceito de garimpeiro, visto tradicionalmente como um sujeito solitário. Para ele, a maior justificativa para a perseguição aos faiscadores está na crescente importância econômica de sua participação na mineração no país e que, ao trabalhar em grupos, desafiam os poderes institucionais em defesa dos seus interesses. De fato, as mineradoras vão atrás dos focos descobertos por garimpeiros, que se mobilizam pelas matas e serras privados de recursos e movidos pela necessidade, desencadeando conflitos entre os dois polos. Em adição, cabe assinalar para o caso do garimpeiro a crescente crise do trabalho que acomete esses homens provisórios que transitam pelo território à caça de uma jazida.

A descoberta de zonas minerais, como Serra Pelada, estimulou mudanças nas relações de produção e de trabalho. Foram introduzidos tecnologias e maquinário na atividade, aparecendo na relação o empresário e o garimpeiro sob contrato. Além de Geraldinho, que mostrou orgulhosamente a sua carteira de trabalho de garimpeiro, teve-se também a oportunidade de dialogar com Ademar Arcanjo Cabral, Dê, 75 anos (2016), nascido em Francisco Dumont e filho de faiscador. Segundo ele, trabalhou junto a muitos homens na cata 
do Boi Morto, na Serra do Cabral, na década de 1970, em meio a dragas e outras máquinas que permitiam escavações a até 20 metros de profundidade no auge daquela extração. O serviço era realizado na terra de Daniel Dumont, a quem pagava porcentagem. Depoimento semelhante foi colhido em conversa com outros garimpeiros em Jequitaí: entre as décadas de 1970 e 1980, empresas mineradoras chegaram na Serra munidas de maquinário pesado, contratando homens para o serviço.

\section{Figura 33 - Frente e verso de uma das carteiras de registro de garimpeiro de Geraldinho, Jequitaí, 1977}

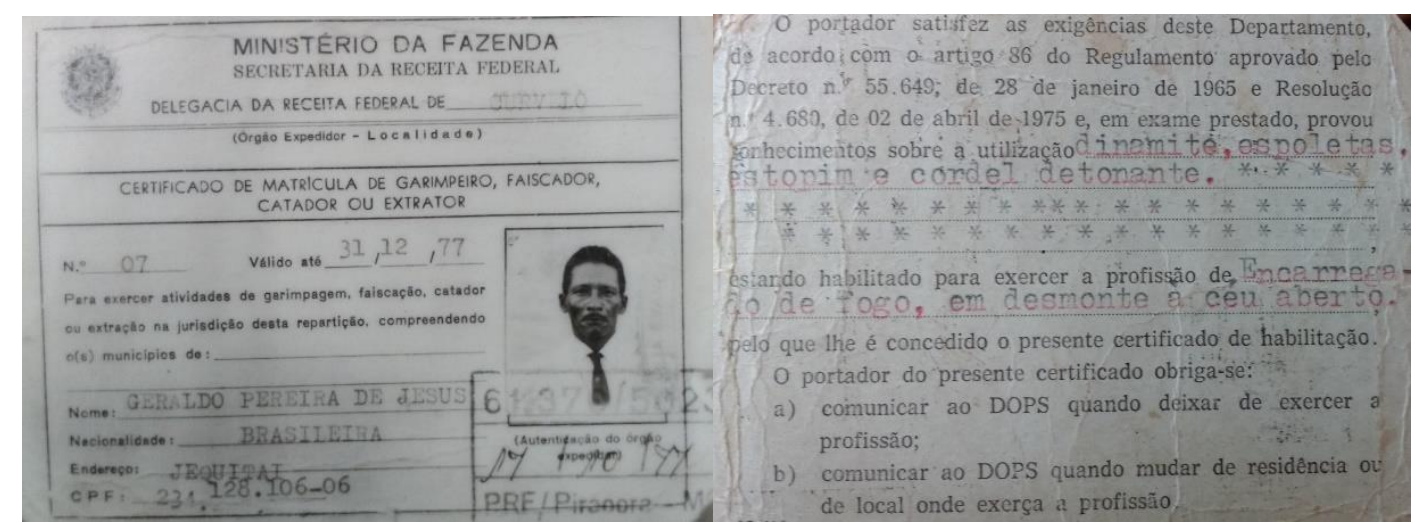

Fonte: acervo pessoal de Geraldinho, janeiro de 2017.

$\mathrm{Na}$ ativa desde os 12 anos de idade e preferindo trabalhar sozinho, Dê conversou muito desconfiado, argumentando que o serviço de garimpo é clandestino. A entrevista foi realizada na cata em que ele estava trabalhando, onde, na ocasião, revirava o gorgulho de um córrego. Segundo ele, o Estado, com o aporte da lei, impede a faiscação na Serra do Cabral com o argumento ecológico de desviar curso de rio, sujar a água e tornar o solo revirado imprestável ao cultivo. Inserido em um trabalho instável, comentou que em "tempo ruim" apela a serviços na roça para conseguir acessar o mínimo para comer, recurso utilizado também por Parceiro, Neco, Dodô e outros. Ao voltar ao trabalho de garimpeiro depois da má fase, Dê busca se valer de um sócio, que lhe fornece comida em troca da divisão do lucro dos achados.

Sobre realizar atividade clandestina, Dê não estava errado. A lei n. 7.805 de 1989 estabeleceu o ordenamento efetivo da garimpagem, supondo ainda a necessidade de prévia autorização de órgão ambiental competente, o estabelecimento de uma área pressionada máxima e de um tempo definido para a concessão. Ou seja, burocracias que perpetuam a garimpagem como atividade transitória, de grande mobilidade espacial, aleatória e adequada apenas à exploração de depósitos, com aproveitamento superficial e rápido esgotamento. Enquanto isso, para as empresas é concedida a exploração de jazidas por longos anos com o aporte de máquinas, para que possam implodir rochas matrizes. 
De acordo com Luciano Rodrigues Costa (2007), a organização do garimpo individual permanece estruturada provisoriamente, seja em função da imprevisibilidade gerada pela fiscalização, seja pelas características naturais e próprias da atividade. De um lado, a profunda instabilidade e incerteza que sempre envolveram a atividade fizeram com que os horizontes temporais dos garimpeiros fossem reduzidos, inibindo investimentos com base em capital fixo de longo prazo. De outro lado, a improbabilidade da regulamentação estatal determina que as transações econômicas se desenrolem em um contexto de ausência de garantias, tornando os atos contratuais excessivamente dependentes de um elevado grau de confiança interpessoal, relação de todos os entrevistados que continuam no ofício, como Parceiro e Walmir, seja na busca de diamante, seja na de cristal, são feitos acordos informais com os donos da terra, que permitem o garimpo mediante o pagamento de porcentagem. Com isso, fragmenta-se para o garimpeiro a possibilidade de se unir aos colegas de ofício para buscar formas de sobrevida no trabalho que realizam, queixa perceptível na fala de Dodô sobre a atividade em Francisco Dumont, considerado o foco de diamantes de melhor qualidade na Serra.

Visando se organizar diante das restrições legais, os garimpeiros de Jequitaí criaram em 1991 a Associação dos Garimpeiros de Jequitaí-MG, no centro da cidade. Realizaram-se três idas ao município, com a expectativa de encontrar a sede aberta e conseguir diálogo, porém todas em vão. Ao perguntar sobre a atuação da associação para Lilo, 60 anos (2017), garimpeiro na cidade e filho e neto de faiscadores, informou este que ela não servia para nada, pois não garante nenhuma proteção ou direito de trabalho, por isso o tempo todo fechada. Sujeitos pobres, os faiscadores da Serra não têm condições de fazer frente a exigências, tais como aquela que regulariza uma lavra, concedida pelo Relatório de Impacto ao Meio Ambiente (Rima). Assim, trabalham na clandestinidade. Em 2018, um garimpeiro morreu soterrado pelo barranco removido enquanto trabalhava na Serra. Como estava na ilegalidade, levaram cinco dias para achar o local e retirar o corpo.

As queixas dos garimpeiros referentes à falta de união e representação não é fruto apenas da clandestinidade na qual têm de trabalhar hoje, mas resultado genérico da diluição da sociedade de classes levada a cabo pelo neoliberalismo, com maior nitidez nos países centrais. Por mais que na Serra do Cabral o nivelamento social não tenha sequer amadurecido, dado que o assalariamento penetrou só nos anos 1970, a totalidade surge no particular na forma de fragmentação e concorrência entre os indivíduos. A "fofoca" que anunciava o achado de uma grupiara e que arregimentava levas de garimpeiros e suas famílias para as lavras agora é guardada a sete chaves. Seja pelo receio da lei, seja pelo medo de dividir a jazida com outro faiscador, condenado como as demais camadas sociais à precarização crescente da vida, os 
sujeitos têm que trabalhar muito mais e sob maiores riscos, na tentativa vã de sair da condição de superfluidade (SCHOLZ, 2008). Ao mesmo tempo que as relações normativas do trabalho estavam chegando na Serra, as máquinas entravam na produção, assalariando os garimpeiros, independentemente do valor das pedras que encontravam. Não à toa, muitos deixaram seu mister para exercer outra atividade que remunerasse, ainda assim, miseravelmente ${ }^{252}$.

Pouco interessa aos poderes concentrados o que move os sujeitos a se embrenharem pelas grimpas da Serra: se são as necessidades da fantasia ou do estômago. O que importa é a transformação do trabalho abstrato em dinheiro e, com isso, a valorização abstrata do mundo. O modo de viver contemporâneo é demasiado unilateral, o mercado é demasiado desintegrador, e a ideologia ocidental é demasiado débil para que esse sistema possa sobreviver sem a existência de um polo oposto (KURZ, 1994). Assim, personagens reais, como Dê, seguem "cavacando" atrás de riquezas na sombra da ilegalidade, reproduzindo relações miseráveis, porém integradas ao moderno sistema produtor de mercadorias.

\subsection{O desenvolvimentismo e o regionalismo que viraram carvão}

A chegada do reflorestamento na Serra, bem como as ações da Sudene no norte de Minas Gerais não satisfizeram por inteiro suas camadas predominantes, muito porque entre elas já havia a sensação de perda de hegemonia regional: o capital externo estava chegando e alterando as relações de poder, até então sob suas rédeas.

Ansiando pela industrialização regional e pela captura de parcela dos recursos estatais, as classes dominantes norte-mineiras voltaram a se organizar em torno de um projeto autonomista e tiveram na figura de Expedicto Mendonça ${ }^{253}$ um de seus expoentes. Economista e partidário da separação do norte de Minaas Gerais com a criação do estado de São Francisco, chegou a desenvolver uma tese de doutorado na década de 1970, que na verdade era um projeto de emancipação com propostas para a nova unidade federativa. Bebendo no dualismo, defendia a industrialização do norte mineiro como a grande saída rumo ao desenvolvimento.

Laurindo Pereira comenta que o ideário de Expedicto Mendonça, à parte o separatismo, aproximava-se do que propunha a Cepal e Celso Furtado. Porém, enquanto estes defendiam a manutenção da democracia como uma condição para o desenvolvimento, o fomento a uma

\footnotetext{
${ }^{252}$ É o caso de Valmir Bezerra, que hoje trabalha de caseiro em terreno na Serra, ficando lá a semana inteira por menos de um salário mínimo e sem qualquer contribuição para previdência ou seguridade social por parte de Deia, seu empregador. Sozinho, corre riscos: onças já atacaram um dos cavalos alojados na casa onde dorme.

${ }^{253}$ Nascido em Montes Claros em 1936 e formado em Economia, Expedicto Mendoça trabalhou em Brasília na década de 1960 como assessor parlamentar. Foi um dos intelectuais defensores do regionalismo norte-mineiro (PEREIRA, 2015).
} 
burguesia nacional de proa e a ação do Estado como um fator de distribuição de renda em conformidade ao que o contexto pós-Estado Novo induzia, aquele acreditava no regime militar, passando ao largo das questões sociais e políticas e crendo que o desenvolvimento industrial sanaria os problemas, "suprindo todas as necessidades da população" (PEREIRA, 2007, p. 110).

Mendonça reacendeu o debate em torno da emancipação do norte mineiro. Juntou-se a ele outro simpático à ideia, Alfredo Dolabela Filho, professor de Economia na Fundação Norte Mineira de Ensino Superior (Funm) da Unimontes e proprietário de terras na Serra do Cabral. Apesar de nascido no Rio de Janeiro, Dolabela Filho tinha fortes ligações com a região, pois seu pai, Alfredo Dolabela, adquirira 33 mil alqueires de terra na microrregião de Bocaiúva entre 1910 e 1930, a maioria na Serra do Cabral. Nessas terras, seu pai não só criou gado, conforme informam os anuários estatísticos de Minas Gerais, como também organizou uma grande plantação de cana e produção de açúcar, a Companhia Agroindustrial Dolabela \& Portella, vendida em 1944 para as Indústrias Reunidas Francisco Matarazzo.

\section{Figura 34 - Restos de uma usina de açúcar abandonada, hoje assentamento de reforma agrária, Engenheiro Dolabela, 2018}

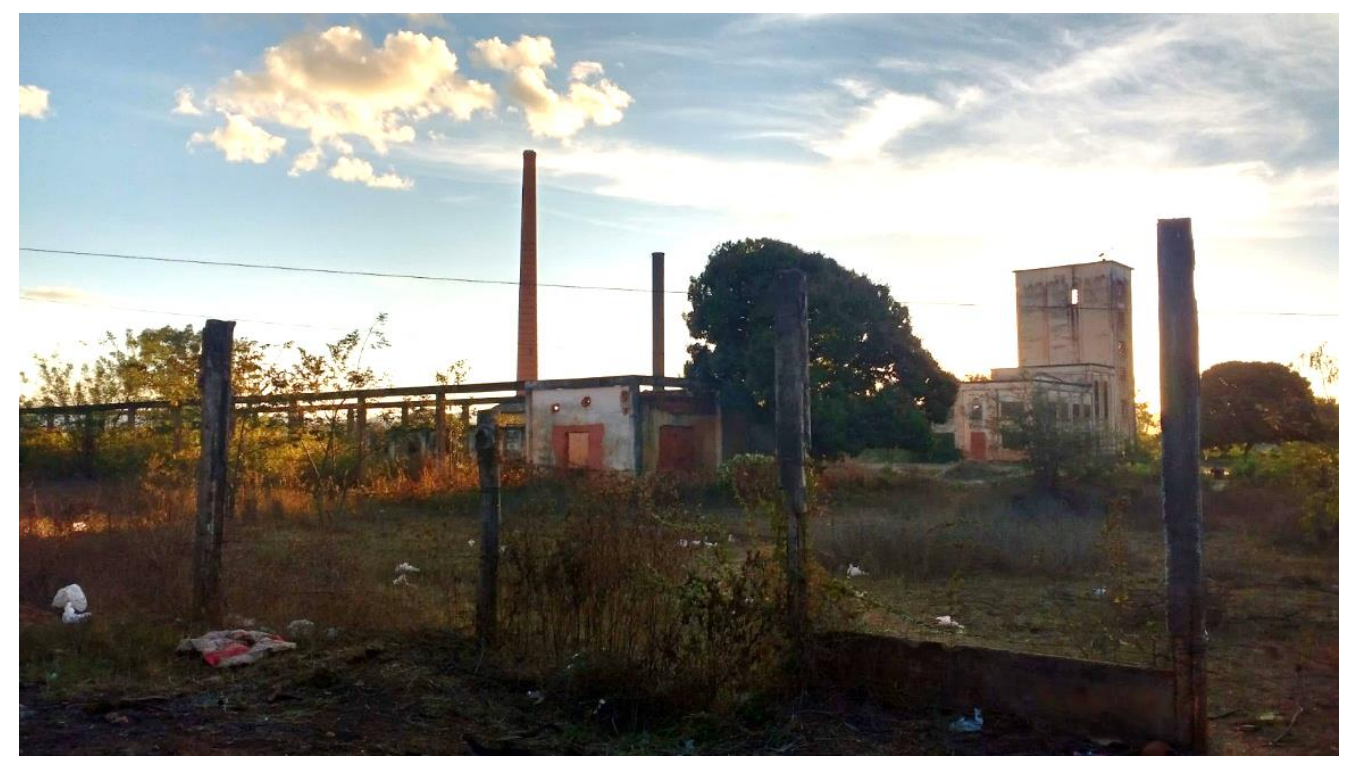

Fonte: acervo pessoal, julho de 2018.

Refletindo sobre os interesses de Dolabela Filho no projeto autonomista, Laurindo Pereira pergunta e responde:

Mas por que Dolabela resolveu investir tanto em uma região àquela época sem maiores perspectivas de desenvolvimento e sem incentivo governamental? Segundo Alfredo Dolabela, o filho, seu pai era amigo e companheiro político de Fernando Mello Viana, governador de Minas Gerais em 1925 e vice-presidente da República entre 1926-1930. Mello Viana seria candidato ao governo de Minas Gerais, em 1930, e teria, entre suas propostas, o projeto de criação de um novo Estado na região, cuja 
capital seria construída exatamente na microrregião em que Dolabela adquiriu os 33 mil alqueires de terra. Concretizado o projeto, os lucros do empresário seriam fabulosos. Porém, “com a revolução de trinta, o grupo ligado ao governo deposto perdeu sua força. O sonho de um estado no norte de Minas ficou afastado, pelo menos temporariamente". (PEREIRA, 2007, p. 111-112).

Alfredo Dolabela Filho esteve à frente de praticamente todos os debates que foram feitos em âmbito universitário sobre o projeto separatista na década de 1970 em diante. Também escreveu artigos em jornais e um livro em três volumes sobre o assunto, tendo realizado um levantamento de dados econômicos e financeiros que demonstrariam a viabilidade do projeto $^{254}$. Sua existência personifica bem o filho de fazendeiro, tecnocrata e intelectual absenteísta que com base em dados estatísticos defende a racionalização de projetos que, enquanto falam em nome da região, defendem interesses de uma classe específica.

O projeto autonomista do norte mineiro desnuda as crises da concorrência regional desencadeadas pelas novas relações comerciais em ascensão, o que promoveu um aumento substancial nos pedidos dos coronéis ao Estado pela implantação de estradas, rebaixamento de impostos, facilitação na aquisição de créditos para a produção, entre outros clamores (KLUCK, 2019).

Assim, percebe-se que a elite regional não estava plenamente satisfeita, apesar de ter confabulado com o Estado enquanto lhe era vantajoso. Antônio da Serra, ao ser questionado sobre como via a Sudene em meio ao reflorestamento, frisou que "Tinha que entrar lá com projeto pra conseguir ser encaminhado. Ela foi ruim porque tudo virou cargo político e corrupção". Mesmo sendo ele apenas um técnico a serviço de uma empresa estrangeira, reproduz bem a ideologia de parte da classe dominante.

[...] tanto a burguesia urbana quanto as empresas transnacionais compreenderam as vantagens de se adquirir terras num País novo, em ocupação, com altas taxas inflacionárias, fácil acesso à crédito subsidiado para empreendimentos rurais e mão-de-obra barata. Pois, tal realidade tornava atraente tanto a exploração produtiva das terras, devido às vantagens auferidas com os baixos custos e amplo mercado, quanto a sua simples detenção como reserva de capital, uma vez que estas se valorizavam numa proporção superior à correção monetária dos ativos financeiros. (CARDOSO, 2000, p. 227, grifos nossos).

José Cardoso incorre em interpretações dualistas tanto sobre o norte mineiro quanto sobre a atuação do Estado no caso, apresentando algumas opiniões divergentes quanto à inclusão de Minas Gerais na Sudene. Se, por um lado, ele defende o discurso de que finalmente

\footnotetext{
${ }^{254}$ Segundo Laurindo Pereira (2007), Dolabela Filho tabulou dados bancários de 1984-1985, arrecadação de impostos federais e estaduais, dados demográficos e do PIB dos estados brasileiros para argumentar que o estado de São Francisco já nasceria em condições melhores do que estados há muito existentes, como Acre, Rondônia, Piauí, Sergipe e Rio Grande do Norte. A comparação, conforme apresentado, é um ótimo recurso para o desenvolvimentismo, negando a não simultaneidade.
} 
as "áreas ainda vazias" se integrariam ao restante do país, havendo modernização das atividades produtivas e grande incremento graças à industrialização dos municípios maiores, por outro, reconhece que a Sudene agravou a concentração fundiária, implantou projetos nem sempre adaptados às condições físicas e sociais regionais, criando como reverso o empobrecimento da população e o aumento do êxodo rural e mobilidade intrarregional ${ }^{255}$.

\begin{abstract}
[...] é interessante notar que, ao se realizar as pesquisas necessárias à execução deste estudo, percebeu-se a existência de diferentes grupos de opiniões acerca das ações da SUDENE, e do Estado como um todo na Região. Nos argumentos utilizados por estes, pareceu ser consensual, a ideia de que a partir das ações da SUDENE, passou a haver uma maior participação dos poderes públicos na Região norte-mineira, e isto teria contribuído fundamentalmente para o processo de transformações econômicas, sociais e políticas verificadas na mesma no decorrer das últimas quatro décadas. Não pareceu haver consenso, entretanto, nas opiniões referentes à forma com que estas transformações se processaram, e tampouco acerca das consequências geradas pelas mesmas.

Entre as diversas formas de se avaliar o processo e as consequências das transformações verificadas, talvez possa-se apontar pelo menos dois grandes grupos de opiniões bem definidas. Um grupo que vê as ações do Estado, especialmente através da SUDENE, como o grande caminho que levou o Norte de Minas a superar, em grande medida, a barreira do isolamento e subdesenvolvimento. E, outro grupo que vê tais intervenções como estimuladoras de um processo de expansão capitalista, que apesar de ter proporcionado algum crescimento para a Região, de uma forma geral, intensificou as suas desigualdades internas motivando e/ou agravando outros problemas econômicos e sociais. (CARDOSO, 2000, p. 223).
\end{abstract}

A despeito de ensaiar uma crítica mais incisiva quanto ao papel do Estado no norte de Minas Gerais, Cardoso cumpriria o papel do intelectual a serviço do regionalismo, consoante Laurindo Pereira. A percepção de que à região foi delegada a produção de carvão para abastecer as siderúrgicas de outras cidades, não havendo projeto de industrialização regional por parte do Estado, passou a servir de argumento para o ataque à silvicultura por parte dos defensores do separatismo. A partir da década de 1980, o carvão seria visto como um problema, pois as florestas nativas eram derrubadas para fazer ferro, cuja riqueza não ia para o norte mineiro (PEREIRA, 2007). O discurso ambiental timidamente começa a dar sinais, apesar de não estar entre as reais preocupações dos regionalistas.

O ataque à silvicultura surge nos anos 1980, quando as empresas de fora já estão assentadas na Serra e os poderes locais não são mais proeminentes. Essas classes dominantes defenderam a entrada do capital externo na região enquanto lhes foi vantajoso, tendo sido,

\footnotetext{
${ }^{255}$ Cardoso (2000) apresenta a taxa de crescimento da população urbana, rural e total do norte de Minas Gerais nos períodos de 1970-1980 e 1980-1991. Nela, verifica-se o crescimento do êxodo rural de 1970 em diante, fruto da concentração fundiária. Para o autor, os esforços para minimizar esse êxodo não deram certo porque não foi possível eliminar os mecanismos pré-existentes de captura do excedente da pequena produção, integrantes de um processo maior de concentração de capital.
} 
portanto, agregadas à nova forma de ser do Estado. A perda de suas propriedades com a consequente perda de poder local as fizeram mudar o discurso.

Antônio da Serra contou que a empresa Santa Maria Floresta chegou na região comprando parte da fazenda Buriti Grande, pertencente a Alfredo Dolabela Filho, enquanto os Dumont venderam suas terras para a Scai. Se essas terras, conforme João e outros afirmam, não tinham dono, é notável que a trajetória de grilagem por parte das famílias com histórico poder econômico local lhes rendeu lucro com a venda, ao mesmo tempo em que eram descartadas gradualmente do jogo de poder na região. Percebendo que a venda as deixava de fora da dinâmica do grande mercado, retomaram o discurso autonomista, com o ataque à produção de carvão.

A tese de Laurindo Pereira é importante por jogar luz ao discurso regionalista, apesar de defender a ideia de que a região, assim como o regionalismo, só pode aparecer na conformação do Estado nacional - enquanto que, aqui, a região é resultado da territorialização do capital, já engendrada desde a colonização. No entanto, o interessante é que ele mostra que o discurso regionalista porta uma ideologia que encobre interesses específicos de uma classe. Valendo-se das teorias gramscianas de hegemonia e intelectuais orgânicos, é crítico ao regionalismo e ao projeto de emancipação defendido por diferentes sujeitos e seus papeis sociais. Contudo, Laurindo Pereira também parte de um discurso acadêmico, ou seja, não neutro.

Irmão de Carlos Mário Pereira, ex-prefeito ${ }^{256}$ de uma das cidades da Serra do Cabral e também proprietário de terras na região junto a um terceiro irmão, Daniel Pereira, cuja fonte de renda maior é a silvicultura, além de Carlos Mário representar os novos latifundiários que não integram famílias tradicionalmente mandatárias locais, é interessante a sua relativa mudez ao problema ambiental como parte das críticas ao projeto de emancipação, apesar de não ser o escopo de seu trabalho: para os regionalistas, a economia de carvoejamento relegada ao norte de Minas Gerais e cujo destino eram os fornos das siderúrgicas, era um dos problemas da pobreza regional, pois em nome da derrubada da mata, a riqueza escapulia. Os irmãos de Laurindo Pereira são alguns dos que lucram ainda hoje com a silvicultura e o carvoejamento, ganhando em troca os lucros de um mercado que se relaciona indiretamente com a exportação de commodities.

Por outro viés, tecendo críticas mais ferrenhas à Sudene, Francisco de Oliveira defende que a introdução das relações capitalistas do Sudeste destruiu as economias regionais. A

\footnotetext{
${ }^{256}$ Candidato pelo Partido do Movimento Democrático Brasileiro (PMDB), Carlos Mário foi prefeito de Francisco Dumont por quatro vezes, exercendo mandato de 1993-1996, 2001-2004, 2006-2008 e 2013-2016.
} 
imposição da troca de equivalente geral do Centro-Sul foi a grande responsável pelo problema, pois levava vantagem a região que tinha em si maior produtividade do trabalho, sendo ela a determinante dos limites e possibilidades de expansão das outras regiões.

A imposição do equivalente geral do Sudeste age em um momento do processo de nacionalização do capital, ou seja, enquanto as economias regionais ligavam-se ao exterior, o capital internacional se realizava regionalizando-se. Para o autor, quando uma das regiões assume o comando do processo de expansão do capitalismo, voltado agora à realização interna do valor, há necessariamente que se realizar um processo de nacionalização do capital (OLIVEIRA, 1988). Analisando de forma mais abrangente os planejamentos de Estado na tentativa de oferecer um balanço ao esforço de romper com o subdesenvolvimento, Francisco de Oliveira contribui com a seguinte nota:

No plano da prática, a ruptura com a teoria do subdesenvolvimento também não pode
deixar de ser radical. Curiosa mas não paradoxalmente, foi sua proeminência nos
últimos decênios que contribuiu para a não-formação de uma teoria sobre o
capitalismo no Brasil, cumprindo uma importante função ideológica para marginalizar
perguntas do tipo "a quem serve o desenvolvimento econômico capitalista no
Brasil?". Com seus estereótipos de "desenvolvimento auto-sustentado",
"internalização do centro de decisões", "integração nacional", "planejamento",
"interesse nacional", a teoria do subdesenvolvimento sentou as bases do
"desenvolvimentismo" que desviou a atenção teórica e a ação política do problema da
luta de classes, justamente no período em que, com a transformação da economia de
base agrária para industrial-urbana, as condições objetivas daquela se agravavam. A
teoria do subdesenvolvimento foi, assim, a ideologia própria do chamado período
populista; se ela hoje não cumpre esse papel, é porque a hegemonia de uma classe se
afirmou de tal modo que a face já não precisa de máscara. (OLIVEIRA, 2013, p. 34).

O planejamento regional, integrante do anseio desenvolvimentista, criou a região na sua negatividade para destruí-la pelo Estado autonomizado. A imposição estatal de novas formas de acumulação forçou a Serra na produção de carvão para alimentar a industrialização e a urbanização longes dali. Os custos sociais, econômicos e ambientais não tardariam a ser cobrados, reproduzindo a região às avessas do plano.

Trazendo um panorama mundial para a situação, Roswitha Scholz (2016) preconiza com ironia que com o "colapso da modernização atrasada" não se abriram perspectivas de reforma com a passagem à economia de mercado e democracia. A ser mantido o sistema produtor de mercadorias e seus critérios, perpetuaram as perspectivas da barbárie, transformando os esforços de planejamento em catástrofe. Para os países do então Terceiro Mundo, a autora aponta para a perda das esperanças no contexto dos anos 1980, a partir dos claros sinais de insustentabilidade do desenvolvimentismo, cujas ilusões jaziam na oferta de crédito nos anos 1970, a década eufórica da modernização. 
Porém, com o colapso do crédito no mundo, muitos países abaixo do equador caíram na miséria, pressionados ao endividamento pelo Fundo Monetário Internacional (FMI) e pelo Banco Mundial. A pretexto do reembolso do crédito junto dessas instituições, os Estados periféricos se viram diante dos "processos de reajustamento estrutural" e da degradação da situação social da maior parte da população, perpetuando a reprodução de vida miserável não mais apenas nesses países, mas até mesmo nas nações ocidentais mais industrializadas. $\mathrm{O}$ valor, o trabalho abstrato e a mediação da forma da mercadoria na base do fim em si capitalista passam a ser completamente obsoletos, mostrando que o colapso da modernização se instala inevitavelmente e cada vez mais em todas as sociedades ${ }^{257}$.

Esses “processos de reajustamento estrutural", presentes entre os anos 1980 e 1990, foram ajustes de fora para dentro das economias agora emergentes, orquestradas pelo FMI e pelos governos. No caso brasileiro, para se chegar a essa situação, o crédito conquistado pelos governos militares durante o "milagre econômico" aumentou a demanda por emissão de títulos de dívida pelo Estado, que não conseguiu arcar com os juros flutuantes pós-fim da conversibilidade do dólar, bem como os beneficiários desse capital a crédito não investiram nas forças produtivas, sobretudo na indústria. Ou seja, com o Estado brasileiro atolado em dívidas, as políticas de ajuste estrutural aparecem para minar de vez o lastro estatal de garantias sociais e de sua própria modernização, uma vez que o capital fictício, forma mais autônoma do capital, é o que comanda a expansão do sistema.

Ao revisar o debate sobre o capital fictício em Financeirização e território: uma revisão da literatura recente, Rodrigo Bonicenha contribui para pensar os liames entre o planejamento regional e as finanças na sua dimensão territorial. Definindo financeirização como um processo recente do capitalismo pós-1970, em que ora é visto como um encadeamento mais amplo de transformação da sociedade e da economia, em que o setor e os mercados financeiros ocupam uma posição dominante, ora se restringe à descrição dos processos e efeitos do crescente poder dos valores e tecnologias financeiras nas corporações, indivíduos e famílias, movimento que caminha junto à globalização e ao neoliberalismo (BONICENHA, 2017).

257 “Desde os anos oitenta, dissiparam-se também no 'Terceiro Mundo' as esperanças de melhores condições de
vida. A perspectiva do chamado 'desenvolvimento', pensado desde sempre de modo fetichista na forma da
mercadoria, que ainda tinha marcado o espírito do tempo até meados dos anos setenta (ligado a uma euforia de
modernização), pareceu temporariamente solucionável através do crédito. Mas, nos anos oitenta, colapsou também
este conceito limitado ao quadro do sistema mundial capitalista e muitos países do Terceiro Mundo caíram na
miséria, sob a pressão neoliberal, que levou por exemplo a um endividamento junto do FMI e do Banco Mundial.
A pretexto do reembolso do crédito junto dessas instituições chegou-se aos eufemisticamente chamados 'processos
de reajustamento estrutural' e à degradação da situação social da maior parte da população. Entretanto é previsível
que estas precárias condições de vida se vão expandir, até nas mais industrializadas das nações ocidentais. O valor,
o trabalho abstracto, a mediação da forma da mercadoria na base do fim em si capitalista tornam-se completamente
obsoletos; o 'colapso da modernização' (Kurz, 1991) mostra-se cada vez mais evidente." (SCHOLZ, 2000, p. 14). 
Quanto à globalização, se faz entendida como um momento contemporâneo que imputa transformações estruturais no capitalismo em escalas cada vez maiores, ao mesmo tempo em que o neoliberalismo seria o papel crescente do mercado a reorganizar a vida social e econômica, capturando o Estado em seu benefício.

Valendo-se de David Harvey (2006), o autor aponta para o papel da produção capitalista do espaço enquanto meio de transferência de capitais excedentes pelos diferentes circuitos de valor, deduzindo que a financeirização pode ser enriquecida quando imbuída de seus elos territoriais. Para compreender a sua dinâmica, é preciso considerar o papel do crédito no sistema produtor de mercadorias.

Se as finanças têm a função de prover uma medida de valor comum a fim de tornar qualquer produto ou serviço uma forma passível de troca, o crédito tem por incumbência permitir que aqueles que têm capital excedente recebam mais capital por meio do pagamento de juros ao emprestá-lo para quem necessita de crédito. Nessa relação, os bancos são os agentes intermediários que lubrificam o processo, articulando a oferta de excedente e a sua demanda (BONICENHA, 2017). Apesar de o crédito e a financeirização já serem praticados dentro do contexto do imperialismo entre os séculos XIX e XX, é a partir da década de 1970 que sua abrangência com o apoio institucional alcança diretamente a população, anunciando o seu colapso $^{258}$.

Compreendendo a função do crédito no seu objetivo de mera valorização do valor, de maneira a quebrar as barreiras alhures que impedem a formação de mercados e a circulação de capital, entende-se tanto o contexto do "milagre econômico" quanto a crítica de José Alves Cardoso quando afirmou anacronicamente que tanto a burguesia urbana quanto as empresas transnacionais compreenderam as vantagens de se adquirir terras num "país novo", em ocupação, com altas taxas inflacionárias, fácil acesso à crédito subsidiado para empreendimentos rurais e mão de obra barata. O capital financeiro ou fictício se converteu na grande estratégia do novo imperialismo, na ilusão de reterritorializar os mercados e adiar as

\footnotetext{
258 "Mesmo sendo o novo capitalismo do mercado financeiro com as suas especificações dominante na orientação, tem de ser sublinhado ainda assim que ele não constitui nenhum novo regime, no sentido de 'regime de acumulação', ou seja, não constitui nenhum novo modelo que represente um novo ciclo de valorização, no sentido de um capitalismo que permaneça eterno; pelo contrário, o capitalismo do mercado financeiro anuncia o fim do capitalismo. Nele se mostra justamente a 'dessubstancialização do capital' e a 'desvalorização do valor', e justamente em relação ao capitalismo como um todo, que não pode ser explicado a partir da natureza das modificações interempresariais." (SCHOLZ, 2016).
} 
crises estruturais do sistema produtor de mercadorias, enquanto altera violentamente as formas de reprodução das sociedades que alcança, reexpropriando seus sujeitos ${ }^{259}$.

$\mathrm{Na}$ Serra, com a desarticulação dos poderes locais e o assalariamento, desnuda-se a autonomização da fórmula trinitária. Os sertanejos, liberados da condição de agregados nos latifúndios, estavam contraditoriamente livres para buscar qualquer emprego, impelidos a realizar o famigerado êxodo rural. Esse movimento descola a força de trabalho de sua relação com a terra, tornando-a uma mercadoria em que o sujeito, voluntariamente, "tem de pôr em movimento para produzir coisas úteis" (GAUDEMAR, 1977, p. 189). A mobilidade da força de trabalho se apresenta como condição de exercício da liberdade do indivíduo se deixar sujeitar ao capital.

\begin{abstract}
A transformação do dinheiro em capital exige então que o possuidor de dinheiro encontre no mercado o trabalhador livre, e livre num duplo sentido. Primeiro, o trabalhador deve ser uma pessoa livre, dispondo à sua vontade da sua força de trabalho como de uma mercadoria que lhe pertence; em segundo lugar, não deve ter qualquer outra mercadoria para vender; deve ser, por assim dizer, livre de tudo, completamente desprovido das coisas necessárias à realização da sua força de trabalho. (GAUDEMAR, 1977, p. 189, grifos do autor).
\end{abstract}

Mas os fluxos não se destinavam apenas às grandes e médias cidades: dada a baixa qualificação profissional e a educação básica inacessível, a mobilidade também ocorreu campocampo, com a força de trabalho submissa à forte exploração. Coube ao Estado pós-1930 institucionalizar as regras do jogo referentes à formação do mercado de força de trabalho, cuja mobilidade se torna uma característica do trabalhador submetido ao capital e, por essa razão, ao modo de produção capitalista (GAUDEMAR, 1977). De acordo com Francisco de Oliveira (2013), a legislação interpretou o salário mínimo rigorosamente como "salário de subsistência", ou seja, de reprodução da classe trabalhadora. Diante de um novo modo de acumulação, as leis trabalhistas precisavam transformar a população em geral, sobretudo essa que migrava em direção às cidades, em "exército de reserva", adequado à reprodução do capital, cuja legislação trabalhista igualava reduzindo o preço da força de trabalho.

\footnotetext{
Ainda em relação à força de trabalho, uma das características do setor primário nos países subdesenvolvidos é a alta proporção de trabalhadores sem remuneração e a baixa monetização no setor. Entre 1975 a 1996, houve algumas modificações estruturais. [...]

No período analisado, ocorreu em Minas Gerais a redução na proporção da força de trabalho não-remunerado, aumento na quantidade de empregados permanentes e temporários. Como consequência da proletarização, observou-se a redução das
}

\footnotetext{
259 Utiliza-se o termo "reexpropriação" porque, no cuidado de analisar a territorialização a partir da forma categorial, a globalização não pode ser entendida como uma nova colonização, na qual as possibilidades de acumulação seriam infinitas (SCHOLZ, 2016).
} 
relações de parceria no estado. O que certamente implica decréscimo de renda. (RODRIGUES, 2000, p. 153, grifos nossos).

Os destaques acima são exemplificados não apenas pelos depoimentos já apresentados de Maria Facão e de Ifigênia, mas também de Dodô. Como, segundo Ifigênia, seus pais viviam agregados numa fazenda na beira do Pacuí e não recebiam dinheiro, pois "Depois de um dia inteiro de trabalho, a gente voltava da casa do patrão com uma banda de rapadura; no outro, um punhado de farinha", a família decidiu viver nas terras dos Dumont sob a condição de receber em vale. Deixaram um rancho de madeira e palha para viver na fazenda Aliança, de Sócrates Dumont, na beira do Jequitaí. A primeira casa da família na propriedade do novo patrão era feita do mesmo material provisório, de forma a impedir o assentamento definitivo dos serviçais e problemas futuros de requerer a terra.

Segundo ela, o fazendeiro oferecia um pequeno quintal próximo à casa do agregado, mas o impedia de cercá-lo, para que não plantasse, pois a prioridade era o gado. Ela relata que só conheceu cerca de arame em Francisco Dumont, por conta da migração da família para o trabalho na fazenda, há mais de 60 anos. O fato de adquirir uma máquina de costura em troca do trabalho dobrado de roçar manga (máquina que depois seria tomada por conta de dívida de doença de um irmão), sugere a oferta de crédito que o fazendeiro dava ao cobrir a despesa do trabalhador, para depois descontar do seu pagamento. A fazenda parecia funcionar à maneira de um banco, agenciando ou mediando o crédito do trabalhador na "praça".

Encontrando relações semelhantes em sua pesquisa, Cássio Boechat (2013) interpreta que o crédito corre junto ao conceito estrito de "promessa de valorização futura", de modo que quem está disponibilizando o crédito para o trabalhador é a própria empresa que está explorando a sua força de trabalho, descontando na fonte, diretamente do seu salário o pagamento pelos adiantamentos feitos. Com isso, desanuvia-se uma concepção invertida de salário como adiantamento do capital ao trabalhador, embora esse salário se revestisse de aparência de crédito para consumo e serviços.

\footnotetext{
Obviamente, isso incorria num volume de circulação de moeda entre os envolvidos, de modo que o dinheiro ficava apenas numa forma nominal abstrata, retido à contabilidade da fazenda, como espécie de signo do dinheiro. (BOECHAT, 2013, p. 203-204).
}

Na mocidade, ao brincar de roda na fazenda, Ifigênia conheceu Dodô, com quem se casou. Ele nasceu em Francisco Dumont, como seus pais. Órfão desde cedo, seguiu a promessa do garimpo, rodando a Serra e cidades próximas, como Grão Mogol e Montes Claros. Ao se casar, levou Ifigênia para o trabalho, se arranchando no garimpo da Lavrinha, em Jequitaí, onde mais tarde chegou a ter casa própria graças às pedras achadas. Receosos de criarem os filhos 
em uma cidade violenta, os dois decidiram voltar para Francisco Dumont, onde dizem ter passado uma fase ruim. Era fim dos anos 1980, e com a crise política e econômica estava difícil conseguir emprego, pois o garimpo na Serra já estava proibido e as fazendas não agregavam mais gente. Precisando criar os filhos, Ifigênia trabalhou cortando lenha no mato, lavando roupa, torrando e moendo café, limpando mocotó, cortando cana-de-açúcar em Dolabela e plantando pinho, junto ao marido, para reflorestadoras, os dois últimos trabalhos sob o regime de assalariamento.

Figura 35 - Córrego do Barreiro, com o antigo chiqueiro e moinho de fubá, onde muitas mulheres iam lavar roupa, 1970

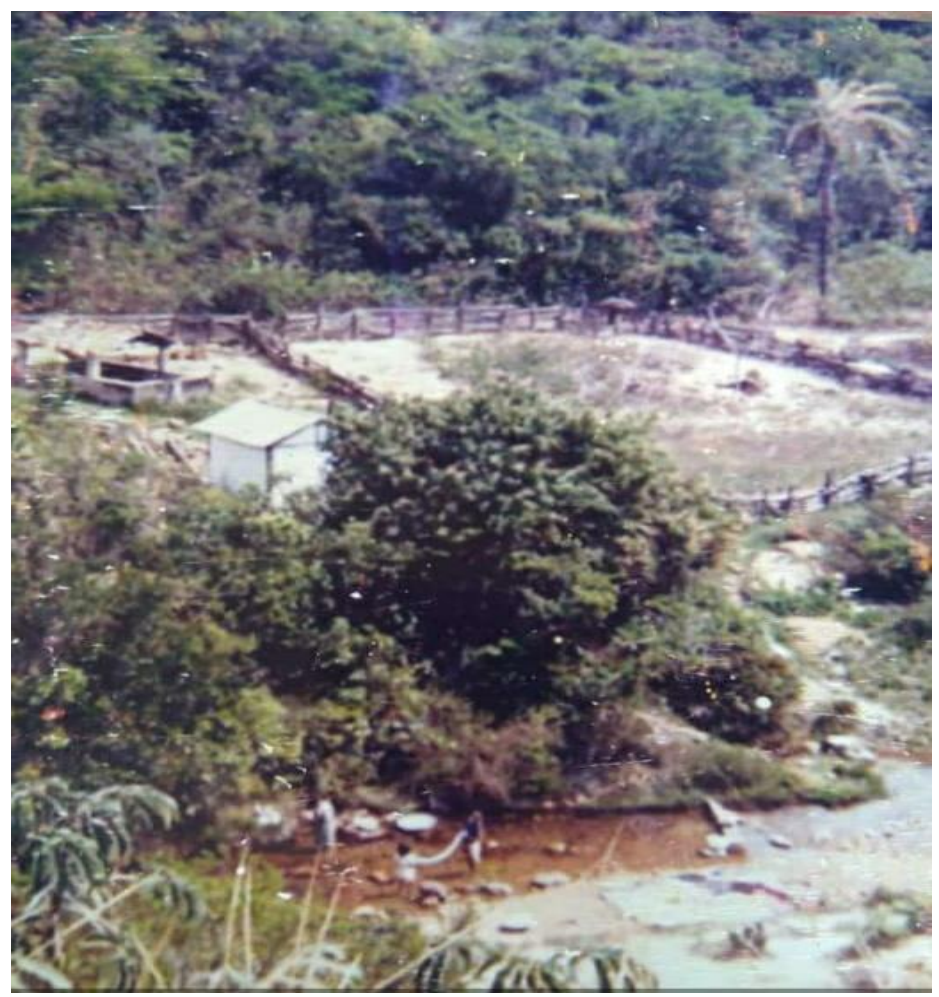

Fonte: acervo de Marcos Calixto, 2020.

A partir do exposto acima, a promessa de oferta de trabalho não se realizou com a implantação dos incentivos econômicos da Sudene nas zonas rurais do norte de Minas Gerais como um todo. A pecuária, como já se esperava, não ofereceria muitos postos, mesmo que modernizada nos pastos e com a melhora genética das raças criadas. No entanto, sua intensificação foi ambientalmente predatória por causa da expansão das invernadas sobre a mata nativa.

Diante da promessa não cumprida de desenvolvimento, o regionalismo reapareceu de forma mais agressiva nos queixumes de Expedicto Mendonça, que, se no passado era favorável à ditadura, aproveitou o processo de redemocratização para atacar o regime após o insucesso 
do seu projeto autonomista na ocasião, perdendo a batalha novamente. Talvez a camada dominante regionalista tenha desconfiado de que a autonomia dos processos no mercado nunca foi sujeita completamente ao comando estatal. Robert Kurz (1997) lembra que no período entreguerras diminuíram as intervenções estatistas, e o paradigma keynesiano compreendeu o Estado expressamente como mero elemento auxiliar na regulamentação do mercado, e não como sujeito de comando superior a este. Os saldos da silvicultura seriam mais visíveis alguns anos depois, quando foi retomado o projeto modernizador na centúria que debutava.

\subsection{Re-luzir perfeito o norte?}

Entre 1990 e 2000, o reflorestamento é retomado na Serra, desta vez com o plantio homogêneo de eucaliptos, sendo o carvoejamento responsável por parcela expressiva das arrecadações do Imposto sobre Circulação de Mercadorias (ICMS) em Minas Gerais na passagem das duas décadas (CARDOSO, 2000). A princípio, a derrubada da mata nativa e o plantio absorveram considerável contingente de mão de obra a baixo custo, o que fomentou o trânsito de sertanejos entre os pequenos municípios. No entanto, passados os primeiros anos e com as mudas em crescimento, a maioria dos trabalhadores era dispensada, havendo necessidade de uma minoria de empregados para a manutenção do plantio.

As atividades que receberam maior volume de investimentos e incentivos foram os projetos de pecuária de corte e de reflorestamento. Consequentemente, a geração de postos de trabalho em ambas as frentes foi muito pequena, seja porque na pecuária extensiva necessitase de poucos vaqueiros, seja porque na silvicultura a mecanização gradual das funções se associou a um processo de concentração de terras e de incorporação de novas áreas, em particular, das pequenas propriedades.

Perguntado sobre o trabalho realizado para o reflorestamento, Dodô disse que, apesar de ser com carteira assinada, não valia a pena, pois como a silvicultura estava começando a adentrar a Serra, o serviço sem maquinário algum era pesado: era preciso derrubar na enxada a mata nativa e depois fazer o plantio das mudas, recebendo muito pouco por isso. Enquanto lamentava a introdução do eucalipto na Serra, mencionou ter saudade do garimpo, atividade impossibilitada por conta das leis e da fiscalização. Voltou a afirmar que em Jequitaí as condições de trabalho ainda são melhores, porque lá o garimpo é legalizado e existem associação e sindicato de garimpeiros, organizações sequer vislumbradas em Francisco Dumont. Segundo ele e a esposa, o eucalipto não só reduziu a água no entorno, como também 
não emprega mais, pois tudo é feito com máquinas. Já sobre o trabalho, os postos são poucos e temporários, os salários, ruins e ainda existe o risco de contaminação por pesticidas.

Dois dos filhos de Maria Facão, Célio Pereira de Souza e Maria Eunice Silva Souza, nascidos e crescidos dentro das terras de Sócrates Dumont, se juntam às testemunhas do momento de autonomização do trabalho na Serra. Assim que seus pais saíram da fazenda, a família conseguiu casa em Francisco Dumont, e, desse momento em diante, eles e os outros irmãos estavam prontos para se empregarem no plantio de pinho e eucalipto, que reaparecia em algumas fazendas arrendadas, como a Santa Maria Floresta e a própria Scai. Como as propriedades ficavam longe, Maria Eunice chegava a passar um mês fora de casa, enquanto a mãe cuidava de seus filhos. As relações trabalhistas, novidade para eles, os deslumbravam: o trabalho era com carteira assinada, e o salário era suficiente para garantir os mantimentos. Diferentemente da opinião de Dodô, para Célio "foi época boa".

Porém, os dois reconhecem que durou pouco. O tempo bom foi pelos idos de 1979, 1980. Célio avalia a silvicultura dizendo que "Ela teve fama só até o primeiro corte, dava emprego pra todo mundo. Hoje, não emprega ninguém, acabou”. Para os irmãos Facão, a introdução de máquinas para o talho de madeira foi um dos motivos do desemprego, associado ao fato de as empresas trazerem gente de fora para o serviço, ao invés de contratar pessoas das redondezas. Os "gatos", homens que oferecem às empresas mão de obra já com motosserras, chegam com uma média de 30 trabalhadores na época do corte, terceirizando a atividade segundo Célio, sem garantia de trabalho e por tempo determinado.

Esse "tempo bom" não foi conhecido pelas mulheres entrevistadas que, mesmo assalariadas, prosseguiram desprezadas dentro de uma sociedade forjada no valor-dissociação. Maria Zélia Moreira dos Santos, 57 anos, (2019), contou que saiu de Dolabela ainda criança para trabalhar com o pai no garimpo de cristal chamado Pimentinha, na Serra. Com a chegada das reflorestadoras, viu a oportunidade de emprego e começou na Santa Fé, passando depois para a Santa Maria Floresta. Ficou empregada dos 14 aos 21 anos, tendo morado nos primeiros alojamentos, "Uns ranchos de palha e madeira. A gente começava do zero, semeando as mudas. Hoje, já vem tudo pronto".

Como era menor de idade e mulher, disse que não só ganhava menos que os homens, como também não foi fichada. A menoridade não era barreira para ter carteira assinada: segundo ela, seu pai, que também conseguiu emprego na Santa Maria, não foi registrado por dois anos. Quando finalmente decidiram fichá-la, o fizeram já dando baixa na carteira. "Eu tava com 9 meses de barrigão, saí sem nada.” Maria do Carmo Santana, 79 anos (2019), sua comadre, 
que estava ao lado durante a conversa cuidando do neto, teve o mesmo desfecho: "Eu era diarista no eucalipto. Era a gente casar e ter filho que era dispensada".

Esses relatos apontam para o universo do dissociado não só além do enquadramento de gênero - o pai de Maria Zélia trabalhou sem ser registrado -, mas também como momento do vivido - enquanto receberam salário, mesmo que menor em relação aos homens, Maria Zélia e Maria do Carmo trabalhavam e produziam valor, apesar das condições comparativas desvantajosas naquele contexto. Nem assim conquistaram posição social diferente, no sentido da emancipação feminina pelo trabalho assalariado.

Interpretando Karl Marx, David Harvey (2006) comenta que a "lei geral" se baseia na capacidade de os capitalistas controlarem tanto a demanda quanto a oferta da força de trabalho. Eles teriam que controlar a oferta de mão de obra criando excedentes de força de trabalho ou mobilizando o que chama de "reservas latentes" - como mulheres, crianças, trabalhadores rurais expulsos da terra etc. - ou, como passou a acontecer décadas depois, criando desemprego tecnologicamente induzido. A expropriação e a mobilização da força de trabalho eram praticadas para garantir o emprego rentável do capital.

Sobre o salário, Karl Marx explica que o valor da força de trabalho estava determinado pelo tempo de trabalho necessário à manutenção não só do trabalhador adulto individual, mas do núcleo familiar. "Ao lançar no mercado de trabalho todos os membros da família do trabalhador, a maquinaria reparte o valor da força de trabalho do homem entre sua família inteira. Ela desvaloriza, assim, sua força de trabalho" (MARX, 2013, v. 1, p. 468). Ou seja, não só as mulheres e as crianças ganham menos, como a força de trabalho de famílias inteiras é mais explorada e o seu valor, reduzido.

Por mais que ainda fosse forte o imperativo de domesticação da mulher em uma unidade familiar restrita, com as mudanças econômicas gerais entrava em jogo a adequação à dimensão do trabalho abstrato que desse suporte à acumulação. Com o desenvolvimento do capitalismo na forma neoliberal, marcado por mercados globalizados e totalização da forma valor, se processa uma inversão de papéis atinente à flexibilização do trabalho, fenômeno observado onde o fordismo, até então bem-assentado, começava a ser diluído pela transigência e pelo individualismo instaurados pelas novas configurações das forças produtivas.

Apesar de as periferias não terem experimentado a fundo nem o fordismo nem o pósfordismo, a simultaneidade é histórica. Nos campos pela Serra, constatou-se que as mulheres das camadas mais pobres já trabalhavam há gerações, colhendo lenha e flores, fazendo quitanda e costurando em casa em troca de dinheiro, enquanto realizavam tarefas reprodutivas nos serviços domésticos das fazendas, não remuneradas e presas ao poder patriarcal dos seus 
maridos, tornando-se difícil separar o que era reprodução da família do que era trabalho. A expropriação e o assalariamento, que chegavam juntos à região, traziam também o desmantelamento de relações que mal se construíram entre essas camadas: não apenas se entoava o réquiem do modelo fordista de organização social, já abortado naquela região em particular, como também a entrada da mulher no trabalho normatizado e já precarizado, o que prenunciava a extinção progressiva do sexo masculino como baluarte da moderna relação de valor-dissociação. ${ }^{260}$

Maria Zélia foi demitida sem direitos, pois, "com barrigão", era dispensável ao trabalho na silvicultura, porque a esfera psicossocial é dominada pela ideia de que à mulher cabe, ontologicamente, a vocação da reprodução, não convindo a ela, pelo olhar do patrão, a compatibilidade com a estrutura do capital.

Pequenas mudanças ocorreram com o tempo: anos adiante, Vanja, por exemplo, já com filhos, ingressaria nas fileiras de trabalhadoras no reflorestamento. A ela pesou a "dupla socialização", refletindo a progressiva crise econômica, pois o trabalho, abstrato e doméstico, constitui as duas faces da mesma estrutura contraditória e fetichista, o que abre caminho para criticar uma forma social que cinde a realidade. Não se trata da ideia simplista de que o ingresso da mulher no trabalho abstrato é uma libertação que carece apenas de conquista de mais direitos, como se subliminarmente o sexo feminino implorasse por uma espécie de humilhação secundária: já existentes como o reverso da forma mercadoria enquanto material humano oculto do processo de valorização, as mulheres bradam por reconhecimento e acesso às modernas relações, sem a percepção de que este já é o seu lugar de inclusão no mundo. ${ }^{261}$

Contrapondo a fala das entrevistadas, Antônio da Serra não só nega a diferença salarial entre homens e mulheres, como explica como selecionava as pessoas e dividia o trabalho: 'Naquela época, não tinha isso de 'menor' não trabalhar, o que é um erro hoje, porque o pai não dá conta de dar nada, e aí vai pro caminho errado". Aos homens adultos e fortes era

\footnotetext{
260 “Atacar a relação exploratória, da mais absoluta importância, mormente em países como o Brasil cuja relação capitalista aparece amalgamada em substratos arcaicos e escravagistas, já não parece tarefa que possa ser empreendida pela figura do proletário, ela mesma em processo de obsolescência. Nem se fale que em contextos de crise paira a ameaça de que uma quantidade enorme de pessoas, participantes das mais diversas categorias e extratos sociais, sejam igualmente alçadas à pauperização, aí se incluindo pequenos empresários, profissionais liberais, estudantes bolsistas, para somente dar alguns exemplos." (SCHOLZ, 2004 apud MENEGATTI, 2019, p. 68).

${ }^{261}$ Tomou-se emprestada a ideia de humilhação secundária de Heinz Dieter Heidemann (2003), que observa esse fenômeno para outros possíveis dissociados na sociedade moderna: os migrantes e os refugiados. Para o geógrafo, a humilhação primária já se deu no início da longa história da modernização, a qual transforma as pessoas em mero material do processo de valorização. A busca por "dignidade humana" que esses sujeitos requisitam, cujas bases residem nos direitos humanos iluministas, caracterizam a segunda humilhação pela qual passam: o direito de se venderem e, com isso, serem considerados seres humanos.
} 
delegado o emprego nos serviços mais pesados - como corte da lenha, transporte para os caminhões, derrubada do mato e carvoeiras -; aos mais jovens, incluindo os menores de idade e, principalmente, as moças e mulheres, dado que "tinham boa cintura pra agachar e levantar", era dado o serviço no preparo das mudas e no plantio, ou seja, a produção "converte-se no meio de utilizar trabalhadores com pouca força muscular ou desenvolvimento corporal imaturo, mas com membros de maior flexibilidade" (MARX, 2013, v. 1, p. 468). Segundo ele, se a família quisesse, todos os seus membros podiam trabalhar de três a quatro meses no plantio, e todos recebiam salário. Depois, se quisessem continuar com o emprego, tinham que se dispor a fazer outros serviços, como bater veneno no cultivo, abrir as bacias para a chuva etc.

Para Roswitha Scholz (2000), a discussão deve ser limitada à modernidade, pois a relação de gênero assume nesse contexto uma qualidade completamente nova, dada a generalização da produção de mercadorias, quando o "trabalho abstracto" se torna um "fim em si tautológico", a "banalidade do dinheiro" se espalha e à mulher, posta agora na esfera pública, é delegado o primeiro lugar na área inferiorizada da produção.

\footnotetext{
Gostaria de agora explicar o androcentrismo como "fenómeno infra-estrutural psicogenético" nos termos da dissociação-valor [...] no sentido de que a repressãodissociação do feminino, a inferiorização das mulheres reais e a existência da dominância masculina radica nas camadas psíquicas profundas; e que aqui a "dissociação", enquanto padrão cultural fundamental da sociedade e mecanismo psicossocial, determina essencialmente a sociedade como um todo, em mediação com a divisão de funções sexualmente especificada. Mesmo na decadência que acompanha a crise do patriarcado produtor de mercadorias, quando a família nuclear se desfaz e os indivíduos são liberados dos seus papéis, é susceptível de se constituir uma memorização das mulheres colocando-as numa posição diferente da dos homens [...] (SCHOLZ, 2000, p. 26).
}

Para Scholz, o sistema dos "dois sexos" foi construído dentro das dicotomias do capitalismo moderno, coadunando com a concepção de opostos binários, na qual há a ilusão de dominação-submissão e homem-mulher, que vem de par tanto com a submissão da natureza como com a subjugação das mulheres a ela equiparadas, devendo ser detectadas como marcas distintivas típicas do patriarcado produtor de mercadorias, dicotomia radicada nas camadas psíquicas profundas. Por isso a naturalidade da fala de Antônio da Serra ao descrever como dividia o trabalho no eucalipto, negando a diferença salarial real entre os sexos.

Betão Calixto, 56 anos (2019), outro entrevistado, trabalhou na Santa Maria Floresta na juventude, tanto na derrubada da mata quanto nos caminhões, plantios e carvoeiras, e testemunhou a péssima condição dos primeiros alojamentos, com ranchos de palha propícios 
ao abrigo do barbeiro, que infectou muitos trabalhadores - entre eles, o pai de João da Serra ${ }^{262}$. Ao dar detalhes sobre a organização das acomodações, disse que "Colocavam moças e rapazes, tudo misturado. Não é à toa que muita menina saiu do eucalipto grávida”.

Entre mulheres e homens relatando sobre seus passados, mesmo com controvérsias quanto ao "tempo bom”, é unânime a opinião de que hoje as coisas pioraram, sobretudo as oportunidades de trabalho. Diante desse quadro, sobrou aos irmãos Facão a procura por qualquer serviço, inclusive em outros estados, o que os inclui como trabalhadores reexpropriados e mobilizados para o emprego.

Célio trabalhou por anos em carvoejamento em Goiás e Mato Grosso, enquanto Maria Eunice deixou os filhos para trabalhar de empregada doméstica por quase dois anos em São Paulo. Suas trajetórias ilustram que quanto mais expropriados são os trabalhadores, mais as relações sociais regionais se aproximam das relações capitalistas, que remuneram o trabalho pelo valor da mercadoria força de trabalho, independentemente do valor do produto.

Conforme aponta Carlos Toledo (2008), esse processo de expropriação não se completa antes dos anos 1980, enquadrando a necessidade de a força de trabalho se tornar móvel, capaz de manter os locais preparados pelo capital, quer tenham sido escolhidos, quer impostos, pois

“o dinheiro vem reforçar esta tendência e assim estimular a mobilidade da força de trabalho" (GAUDEMAR, 1977, p. 190-191, grifos nossos).

Os queixumes recentes de Dodô sobre a falta de união e representatividade dos garimpeiros, assim como a decepção dos Facão quanto à decadência do trabalho na silvicultura, vêm ao encontro da adequação dos sujeitos à máxima individualização para o trabalho que o neoliberalismo promove. Esse modelo pôde pressupor a internalização da forma mercadoria e o ajuste laboral, demandando a autogestão dos indivíduos. Na esfera psicossocial, todos passam a concorrer entre si para postos cada vez mais precarizados, tendo em vista o ingresso da mulher, disputando muitas dessas vagas.

Se antes, num contexto mais genérico ou de grandes cidades, o modelo fordista de trabalho e de organização social exortou a sociedade à organização em classes e à maior presença política do Estado, com o advento da microeletrônica, os arranjos que abriram caminho para a ampla flexibilização do trabalho e a especulação do capital, se iniciou a dissolução desse modelo. O Estado, cada vez mais destituído de suas bases econômicas

\footnotetext{
262 Em 1946, o carvoeiro era definido na Revista Brasileira de Geografia como quem "vive sempre no mato, em grande isolamento, morando em tôscas palhoças de pau a pique ou de palmito, cobertas de sapé, sem nenhum confôrto e higiene". Naquela ocasião, "Alguns dêles, quando o dono da terra permite, têm suas pequenas plantações e criações. Mas, o mais comum é nada plantarem, adquirindo tudo na cidade mais próxima" (SOUZA, 1946, p. 151). A permissão do cultivo para subsistência não foi encontrada na Serra do Cabral.
} 
coerentes, torna-se mero aparato repressivo na administração das crises oriundas de uma sociedade que se desclassifica, se individualiza e se hibridiza ao gosto neoliberal, tornando seus sujeitos fragmentados e supérfluos, egocentrados e incluídos criticamente no universo da mercadoria. Nos países periféricos, a metropolização se torna um meio de pulverizar esse processo, já corrente nos países do centro.

O cultivo de eucalipto permanece na Serra, bem como a produção de carvão. Porém, nem mesmo Antônio da Serra, hoje aposentado, consegue continuar os elogios à silvicultura quando se depara com a realidade atual: "Antes, tinha pouca máquina, machado, trator de esteira, quatro tratores de pneu e dois caminhões. Hoje, o corte tá industrializado e atrapalhou o emprego".

A chegada das empresas animou a população. João da Serra comentou que cortava 450 a 500 eucaliptos por dia. "Quando trabalhava, a gente, eu, meu irmão e meu sobrinho trabalhava com a nossa motosserra. Eles comprava a máquina e o óleo e passava pra gente, pra cortar eucalipto." Antes, segundo ele, tudo era por conta da firma, até os caminhões que buscavam os trabalhadores no município e voltavam com eles toda tarde. O trabalho era mensal, de segunda a sábado. Hoje, o ganho é por produção: "Diminuiu muito o emprego. Na firma terceirizada, hoje só trabalha com corte de eucalipto. A própria firma que faz o plantio, e isso ainda não é terceirizado. Tem muito trabalhador de fora".

Foi unânime a afirmação de que o reflorestamento chegou dando empregos e que melhorou a situação da região. Com o trabalho registrado, corria mais dinheiro na cidade, e as estradas também melhoraram, o que facilitou o acesso ao consumo. Mas, conforme os créditos foram sendo disponibilizados às empresas, as forças produtivas foram se desenvolvendo, o que culminou na crescente expulsão da força de trabalho da produção, ou, quando esta era contratada temporariamente, o tratamento recebido era (e é) de descartabilidade, com o aval do aparato jurídico do Estado.

Para gerir a crise, o Estado passa a ampliar a sua atuação por meio de incentivos, benefícios e subsídios creditícios em diferentes esferas, de forma a garantir a reprodução capitalista abstrata, indo, portanto, além dos meros desígnios políticos. Tal recurso repete a lógica de que quanto mais mercado, mais Estado: ao se reproduzir criticamente, erodindo seu próprio fundamento dentro da marcha da modernização, o capital apela às políticas públicas no intuito de fixar as pessoas ou confiná-las em políticas territoriais. Ou, ainda, por meio do respaldo jurídico, simplesmente deixá-las a ermo ${ }^{263}$.

\footnotetext{
263 "Um dos meios de gestão dessa crise se vincula às ações estatais, munindo de alguma validade, a mobilidade do trabalho cada vez mais anacrônica no processo social, por meio de incentivos, benefícios e subsídios creditícios
} 
Evandro Vieira de Almeida, 41 anos (2019), conhecido como Dim, é um caso desse tratamento recebido. Sem muito estudo, deu continuidade aos serviços braçais que seus pais faziam. Colhia frutos na Serra e, com a maioridade, trabalhou dois anos na Plantar, logo que a empresa chegou, entre 2006 e 2007. Saiu, empregando-se por empreitada na Califórnia Bioenergia e Desenvolvimento Ltda., de Daniel Gatti. Depois, retornou à primeira empresa.

Seu primeiro trabalho na Plantar foi adubando os eucaliptos. Enquanto esteve na empresa de Gatti, trabalhou enchendo os caminhões de carga. O retorno à Plantar foi na produção de carvão vegetal, enchendo os fornos da carvoeira, o que lhe rendeu três hérnias de disco, além de problemas respiratórios e psicológicos, como ansiedade: "Na carvoeira, não tinha proteção. Pegava a poeira e o bafo quente e depois saía no vento frio”. Acrescenta que problema nos rins é comum nesse tipo de serviço, por conta da caloria do forno. Como as turmas começavam às $6 \mathrm{~h} 20$ e terminavam às $14 \mathrm{~h}$, corriam para fazer a maior quantidade possível de carvão, pois ganhavam por produção. Por isso, segundo ele, boa parte de quem trabalhou com eucalipto adquiriu alguma doença. Um de seus vizinhos, disse, trabalhava no corte com motosserra e também teve problema de coluna. Porém, os companheiros deram mais sorte: conseguiram se aposentar ou estão afastados recebendo pelo Instituto Nacional do Seguro Social (INSS).

Dim também recorreu à previdência social por conta dos problemas na coluna, conseguindo um breve afastamento, sem os ajustes da firma. Insatisfeito, foi à Justiça do Trabalho e lá soube que a Plantar tinha feito um acerto com ele no valor de 1,5 mil reais sem o seu conhecimento. Mais uma vez recorreu, e, ao chegar ao tribunal, a empresa apareceu com os contracheques assinados por ele até fevereiro, sendo que ele alega ter assinado só até o mês de novembro anterior, mas não tem as vias para comprovar. Como escreve mal, ficou com receio de dar continuidade à busca por direitos, porque com a nova reforma trabalhista, conforme explicou seu advogado, se não conseguisse provar a falsificação de seu nome, teria que pagar o valor pedido à firma acrescido de $30 \%$ de indenização. Acabou num acordo em que recebeu mil reais e permanece insistindo com a aposentadoria no INSS. Enquanto não a consegue e

em diferentes esferas, sejam supressores dos meios de produção ou conformadores da reprodução do trabalho. Esse aspecto ou caráter assumido pelo Estado não se deve assim, simplesmente à política, mas envolve outros meandros relativos à própria reprodução capitalista, que na atualidade torna-se por seus próprios meios cada vez mais crítica e demandante dessas ações, por destituir, em seu processo, o seu próprio fundamento. Em outras palavras, se coloca no fato do momento atual, o desenvolvimento das forças produtivas expulsarem cada vez mais o trabalho do processo de produção como paradigma da modernização, no qual ao mesmo tempo o Estado territorializa ações promovem a 'fixação' ou confinam (por acesso a políticas públicas) uma parte da população em determinados territórios de reprodução particular, como se constituíssem formações autônomas simulando uma autonomia territorial, como forma de gestar a crise geral.” (KLUCK, 2019, p. 106). 
tendo filhos pequenos, procura por trabalhos com roça, além de contar com o auxílio de sua mãe, já que sua esposa não consegue emprego.

O tratamento descartável, somado à mera aparência de igualdade jurídica na relação patrão-empregado, se justifica pelo investimento no capital constante feito pelas empresas, que precisam contratar funcionários em regimes esmagadores de exploração de força de trabalho e saúde com pagamentos pífios. Essa massa de desvalidos, criada pelo próprio sistema produtor de mercadorias, é abocanhada pelas suas novas configurações produtivas com a imposição de formas de exploração extrema do trabalho com grande precarização da vida. A cada nova tentativa de aceleração da modernização, que busca homogeneizar os processos por meio de relações capitalistas mantidas pelo assalariamento e pelo tempo dinâmico e abstrato, o sistema econômico convive e se alimenta das formas de exploração do trabalho semelhantes às do momento escravista e com a continuidade da concentração fundiária. "A persistência dessas velocidades distintas de modernização é o que caracteriza a não-simultaneidade do processo de formação brasileira" (ALVES, 2006, p. 3).

De acordo com Antônio da Serra, hoje uma máquina faz o trabalho de 150 motosserras e ainda empilha a lenha. "A grua que corta lá em cima é computadorizada”, ou seja, a redução nos empregos foi drástica. Soma-se a isso o caráter temporário dos contratos, pois o plantio, a aplicação de veneno e o corte não ocorrem de uma vez, nem no ano inteiro, bem como a chegada de gente de outros lugares para o serviço, competindo pelas vagas com os locais. A situação apresentada é uma amostra drástica da democracia aparentemente universal, ufanista do uso geral do direito legal, porém excludente para a maioria dos sujeitos do mundo do trabalho descartável.

Figura 36 - Grua em cultivo da Plantar e fornos de carvão na Serra

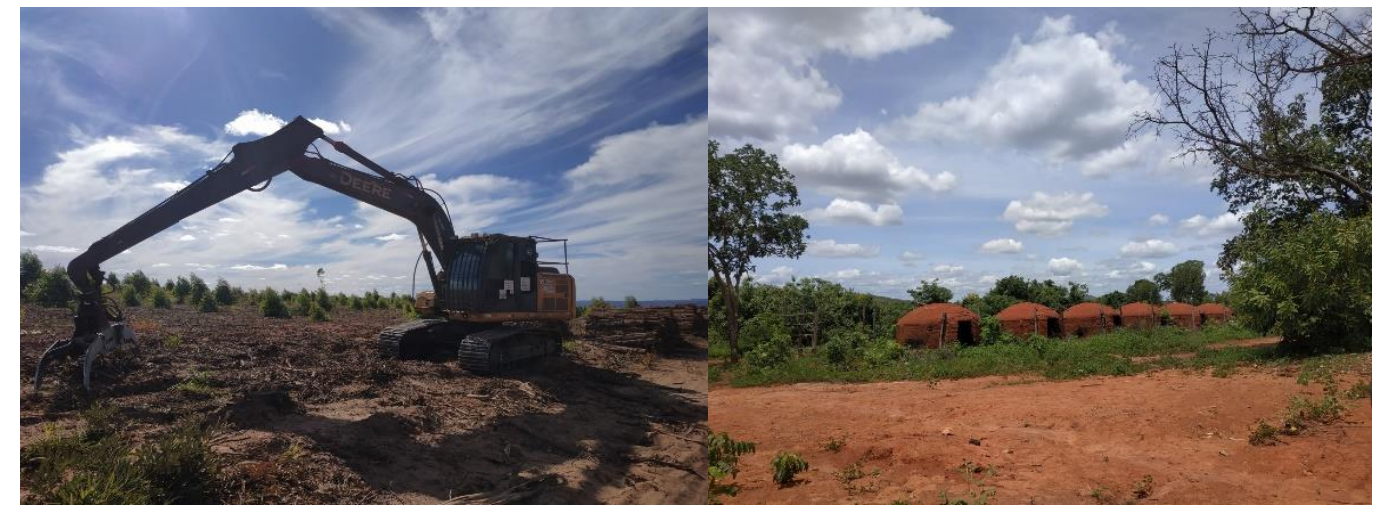

Fonte: acervo pessoal, 2019. 
Dim personifica em parte o sertanejo pobre que, apesar de ser do sexo masculino, ainda assim é descartado pelos modernos laços sociais. Considerando-se que o valor é co-constituído com a dissociação do feminino e, no caso do sertão, também do racismo, da origem geográfica e de outras diferenças que não podem ser consideradas simples derivações do valor, sua situação demonstra a sujeição generalizada de todos às relações de fetiche fundadas na mercadoria. Existe uma base de dominação social em comum que só pode ser superada conjuntamente e em nome de uma humanidade que não pode ser essa que os discursos genéricos defendem: em que todos têm o direito de ser "incluídos" em um modelo de mundo onde dignidade significa trabalho abstrato e normatizado. ${ }^{264}$

A narrativa de Dim é uma amostra de como a modernização impacta no emprego, e o Estado, como feitio social do capital, posto e pressuposto de sua modernização, realça a sua forma de ser contraditória (KLUCK, 2019). Por um lado, ao dar respaldo ao aparato legal em nome das personificações capitalistas, em que a igualdade jurídica tem se tornado mais e mais mera ficção, a ordem normativa garante a captura do Estado pelo mercado. Por outro, dada a descartabilidade dos sujeitos sujeitados ao trabalho, o Estado aumenta as suas demandas sociais, em clara gestão de crise.

O que se anuncia no começo do século XXI é o aprofundamento das antinomias quanto ao papel do Estado. Se a modernização no campo foi motivada pelo avanço das exportações e pela alta de preço das commodities - o que estimulou a produção de carvão na Serra para enviar aço à China e alhures -, agora, com as oscilações negativas nesse mercado, de quem o país é dependente, assiste-se ao colapso de fato. Ao abrir mão de garantir minimamente a reprodução da força de trabalho, o Estado retira de si a responsabilidade em manter as instituições que dão sobrevida aos sujeitos supérfluos.

"Ser soberano é exercer controle sobre a mortalidade e definir a vida como a implantação da manifestação de poder" (MBEMBE, 2018, p. 5), nos dizeres do autor, ao pensar as experiências contemporâneas de destruição humana e as possíveis leituras de soberania e seu poder sobre a vida dos sujeitos. A totalização do capital tem no Estado o seu suporte de

\footnotetext{
${ }^{264}$ Ao discutir o que chama de "o retorno da raça" nos dias de hoje, abordando o racismo atual na sua pluralidade, sem desligá-lo de sua historicidade e do momento econômico mundial e ainda atentando para os humanitarismos e promessas democráticas envoltas em circunscrições territoriais ocidentais, Étienne Balibar (2007) pareia as noções de raça e de racismo a partir da contemporaneidade, em que a globalização permanece inseparável dos fenômenos de dominação e de concorrência, indicativos da presença vívida do imperialismo. $\mathrm{O}$ autor postula que o mercado concorrencial não exclui ninguém, mas institui uma seleção individual generalizada, na qual o limite inferior é a eliminação social dos "inaptos" e dos "inúteis". Seriam, portanto, os variados racismos ferramentas de descartabilidade.
} 
expansão e de violência institucionalizada para que exerça essa autoridade sobre os corpos descartáveis ao moderno sistema produtor de mercadorias. ${ }^{265}$

Ao dialogar com a biopolítica de Foucault, Mbembe (2018) apresenta o biopoder foucaultiano como uma divisão entre vivos e mortos a partir do campo biológico, distribuindo e separando os grupos humanos, rotulando tais diferenças de racismo. Na visão do autor, a biopolítica é um capítulo da história do capital, sendo mais que o simples controle do Estado moderno sobre a vida da população exercido a partir dos dados estatísticos para criar uma realidade - o planejamento como parte desse controle, voltado para garantir a reprodução da força de trabalho.

O Estado teria, a princípio, a tarefa de cuidar de sua população, com vias de torná-la dócil e produtiva. Porém, no movimento histórico, o capitalismo mudou, e com ele também o papel do Estado em relação às garantias sociais. É a partir dessa mudança que Mbembe vê a passagem da biopolítica para a necropolítica, já que com o neoliberalismo a vida passa a ser explicitamente descartável: passa-se de deixar morrer a dever morrer, valendo-se de dispositivos de alteridade, como o racismo.

Com o suporte dessa corrente teórica, sendo o racismo uma tecnologia ocidental destinada a dominar outros povos e a permitir o exercício do biopoder, ele torna justificáveis as funções assassinas do Estado neoliberal - sobretudo daquele pós-catastrófico -, que podem se dar pela violência explícita ou por formas camufladas, quando o mesmo Estado, incumbido de garantir a ordem, necessita gastar com aparato militar enquanto deixa arruinar os aparelhos de reprodução social.

Encarado ora como ser bárbaro e atrasado, ora como ignorante e preguiçoso - e também poucas vezes positivado na mitificação do genuíno brasileiro -, o sertanejo não escapa de classificações negativas, nem o sertão escapa da naturalização, seja pelo Estado, seja pela ciência, ambos em nome do capital. Na sua constituição moderna, o sertanejo já foi a besta-fera a ser domada, o vadio a ser forçado ao trabalho, o Jeca Tatu a ser saneado e incluído no mercado (como se a colonização já não o integrasse precariamente) e hoje vive o seu pôr do indivíduo como um trabalhador, refugo em uma sociedade da mercadoria que destrói a sua medula, posto

\footnotetext{
${ }^{265}$ As transformações sociais têm implicações na esfera psicoemocional e influem nas atitudes dos indivíduos. Já alçado a Urutu Branco, chefe de bando devido ao pós-pacto com o demônio e dando continuidade ao projeto de Zé Bebelo de limpar o sertão de jagunço, a escolha de matar ou não em Riobaldo é mera alegoria do poder do capital personificado:
}

A porque, sem prazo, se esquentou em mim o doido afã de matar aquele homem, tresmatado. $\mathrm{O}$ desejo em si, que nem era por conta do tal dinheiro: que bastava eu exigir e ele civilmente me entregava. Mas matar, matar assassinado, por má lei. Pois não era? Aí, esfreguei bem minhas mãos, ia apalpar as armas. Aí tive até um pronto de rir [...]. (ROSA, 1986, p. 415). 
nas mãos de instituições agonizantes e subsumidas ao capital. Apresentada a trajetória do sertanejo como sujeito vivente no sertão, território entendido como apropriado pela moderna relação social e onde outras formas de organização da vida coexistem e gradualmente se põem conflituosas, não seria ele mais um co-constituído e contraditória e posteriormente tornado supérfluo na forma do valor pertinente à territorialização do Brasil?

Se é preciso ter território para produzir os corpos indignos, o sertão é territorializado e reterritorializado para tal, no movimento sempre reposto de modernização. A esses corpos é dada a tarefa de produzir sob condições de extrema exploração dentro daquilo que ainda pode ser extraído de sua força de trabalho, enquanto ao Estado, a tarefa de travestir seu discurso necropolítico de humanitarismo na ação de gestão da crise de uma situação no limite do suportável ou matar em nome de um discurso moral de ordem. 


\title{
6. O sertão fora e dentro do lugar na modernização
}

\author{
Mais cadê meus cumpanhêro, cadê \\ Qui cantava aqui mais eu, cadê \\ Na calçada no terrêro, cadê \\ Cadê os cumpanhêros meus, cadê \\ Caíro na lapa do mundo, cadê \\ Lapa do mundão de Deus, cadê \\ Mais tinha um qui dexô o qui era seu \\ Pra í corrê o trêcho no chão de Son Palo \\ Num durô um ano o cumpanhêro se perdeu \\ Cabô se atrapaiano c'ũa lua no céu \\ Num certo dia num fim de labuta \\ Pelas Ave-Maria chegô o fim da luta \\ Foi cuano ia atravessano a rua \\ Parô iscupiu no chão pois se ispantô com a lua \\ Ficô dibaxo das roda dos carro \\ Purriba dos iscarro oiano pra lua, ai sôdade \\ Naquela hora na porta do rancho \\ Ela tamém viu a lua pur trais dos garrancho e no céu \\ Pertô o caçulo contra o peito seu \\ O coração deu um pulo os peito istremeceu \\ Soltô um gemido fundo as vista iscureceu \\ Valei-me Sinhô Deus meu apois eu vi Remundo \\ Nas porta do céu, ai sôdade \\ Mais tinha um qui só pidia qui a vida fosse \\ U'a função noite e dia qui a vida fosse \\ Regada cum galinha vin queijo e doce \\ Sonhano a vida assim arriscô mêrmo sem posse \\ Dexano a vida ruim intão se arritirô-se \\ Levô-lhe um ridimúin e a festa se acabô-se, ai sôdade
}

Elomar Figueira de Melo, 1978

A formação de um mercado fundiário na Serra do Cabral deu às fazendas de gado novas funções econômicas, como a plantations de eucalipto, assim como a proibição do garimpo de diamantes nas terras, agora tornadas todas elas propriedades privadas formais. Isso alterou os discursos e os projetos políticos para lá voltados no limiar do século XXI, aventando a fixação da população na região, além de se ver incorporando o discurso ambiental como parte das preocupações aparentes da modernização. 


\section{Mapa 15 - Croqui do projeto da barragem de Jequitaí - Codevasf, julho de 1981}

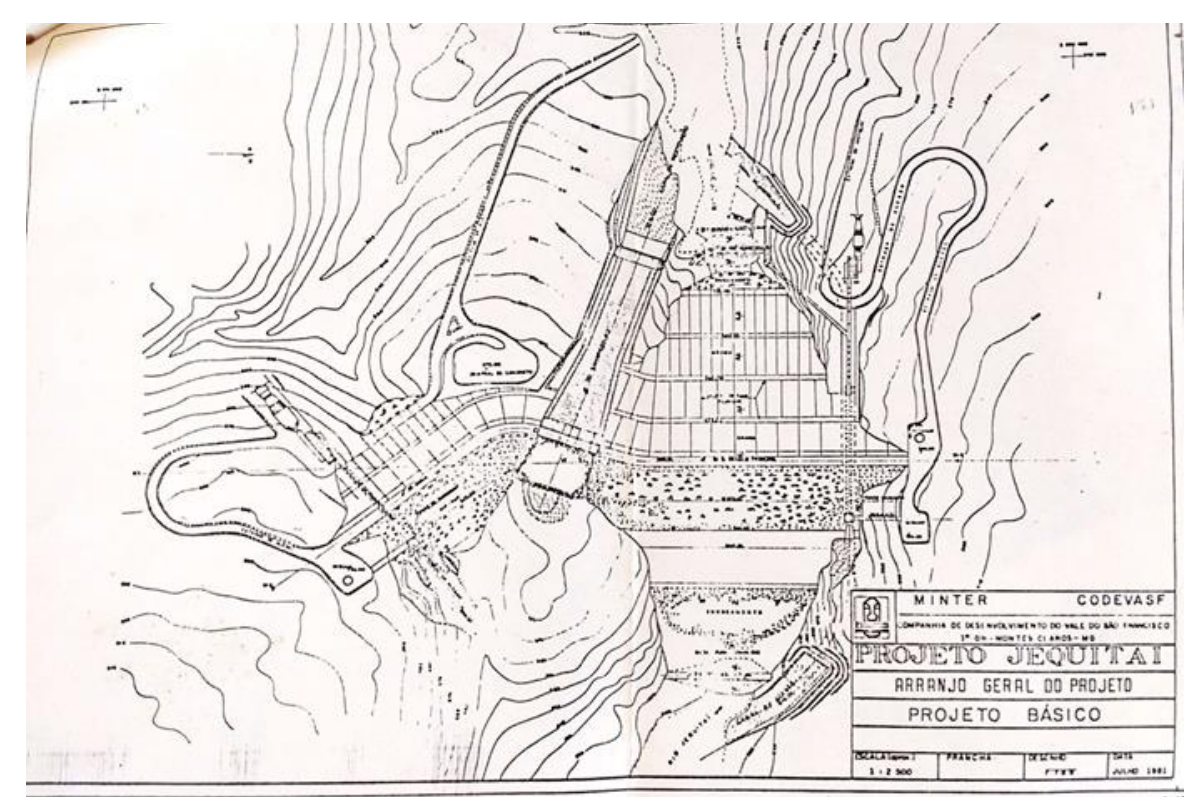

Fonte: acervo pessoal de Guilherme Dumont, julho de 2017.

Ainda nos anos 1960, o norte de Minas Gerais não era alvo da implantação de adubos químicos e técnicas de correção do solo para grandes lavouras, apesar de o Projeto Jequitaí já ser, naquela ocasião, vislumbrado. Este era um projeto de irrigação para o município de Jequitaí, encabeçado pela Suvale e cujo objetivo era tornar irrigada uma área de 5 mil hectares até 1974. As obras foram iniciadas apenas no século XXI, e até o momento estão inconclusas, mas em andamento.

O EIA do Projeto Hidroagrícola Jequitaí apresenta uma síntese histórica dos interesses e planos de construção de obras na região. $O$ texto aponta que a ideia de irrigar o extenso vale do Jequitaí nasceu antes da década de 1950. Em 1949, a Escola Nacional de Minas e Metalurgia da Universidade do Brasil realizou apreciação técnica e econômica de materiais para a construção de barragens $^{266}$ (CODEVASF, 2005).

Na década de 1950, a Comissão do Vale do São Francisco contratou o Bureau of Information ${ }^{267}$ para estudar projetos de desenvolvimento agrícola no curso do São Francisco, visando à sua regularização com aproveitamento energético e para fins agrícolas. Em 1953, a Servix Engenharia realizou para a Comissão do Vale do São Francisco o Estudo do Aproveitamento Hidroelétrico do Rio Jequitaí, com previsão de construção de barragem no cânion deste. Outros estudos foram feitos neste período:

\footnotetext{
${ }^{266}$ Hoje UFRJ, foi criada em 1937 com Francisco Campos e Gustavo Capanema à frente. Vislumbrava padronizar o ensino superior no Brasil, condizente com os projetos estatais de planejamento.

267 Informação fornecida pelo EIA/Codevasf, sem maiores detalhes.
} 
- Convênio Suvale-Chesf ${ }^{268}$-Burec-Usaid (1965): elaborado pelo Canambra Engineering Consultants Group, previu uma barragem de gravidade em concreto e geração de 19,6 megawatts de energia média final.

- Convênio United States Agency for International Development (Usaid) - $1^{\mathrm{a}}$ parte (1967): realizado pelo Bureau of Reclamation (BuRec) para a Suvale, previu uma barragem à jusante do Cachoeirão para a irrigação do vale do Jequitaí, com duas alternativas. A primeira propunha a irrigação desse vale (53 mil hectares); a segunda, a irrigação de terras do mesmo vale (27 mil hectares), juntamente com terras do vale do rio das Velhas (28.300 hectares).

- Suvale/IPT (1971): desenvolvido para a Suvale pelo Instituto de Pesquisas Tecnológicas (IPT) do estado de São Paulo (IPT), realizou estudos para a escolha de eixos barráveis do rio Jequitaí e materiais naturais de construção.

- Convênio Usaid - $2^{a}$ parte (1971): estudos desenvolvidos com redução da elevação do NA para 560 metros, baseados no levantamento pedológico realizado pelo Centro de Estudos de Solos da Escola Superior de Agricultura Luiz de Queiroz (Esalq), da USP.

Em 1975, a Suvale, sucessora da Comissão do Vale do São Francisco, iniciou a implantação de um projeto de irrigação próximo à cidade de Pirapora, entre a confluência dos rios São Francisco e das Velhas. A ideia inicial era montar um piloto que servisse como experimento para o Projeto Jequitaí.

Como não havia recurso para obras de grandes dimensões, seria construído primeiro um perímetro pequeno para que seus resultados servissem de incentivo para a implantação do grande projeto, abrangendo todo o vale do Jequitaí. A obra beneficiaria vários municípios “com pouquíssimas possibilidades de desenvolvimento" (CODEVASF, 2005, p. 11), como Claro dos Poções, Jequitaí, Lagoa dos Patos, Francisco Dumont, Várzea da Palma, Ibiaí e até mesmo Pirapora. Em 1976, a Suvale foi extinta e criou-se a Codevasf, que deu continuidade às obras de implantação do projeto iniciado, conhecido como Projeto Piloto de Irrigação (PPI).

O objetivo então era irrigar cerca de 1,5 mil hectares às margens do rio São Francisco, distante 12 quilômetros da cidade de Pirapora e cortado pela então recém-inaugurada BR-365, estrada que liga Montes Claros ao Triângulo Mineiro e que viria a garantir o escoamento da produção. O PPI foi inaugurado em 1979, sendo o marco inicial para uma ambição maior: ou seja, a implantação futura do Projeto Hidroagrícola Jequitaí, considerado o grande plano de desenvolvimento da região. A partir de 1978, os estudos do programa foram nitidamente

${ }^{268}$ Companhia Hidro Elétrica do São Francisco. 
direcionados para projetos de usos múltiplos, contemplando simultaneamente a irrigação, o controle de cheias e a geração de energia elétrica.

Entre 1979 e 2004, sob a batuta da Codevasf, foram realizados diversos estudos contemplando a utilização do potencial hídrico do rio Jequitaí por diferentes ângulos, quer para fins de irrigação, quer para produção de energia elétrica.

Chegado o século XXI, o projeto da década de 1950 começa a sair do papel. Velhos discursos, velhas intenções: o Projeto Hidroagrícola Jequitaí seria a nova promessa de modernização da Serra do Cabral, tendo como foco a agricultura de irrigação e a produção de eletricidade no rio Jequitaí.

Segundo os relatórios de 2005 do EIA/Rima do projeto supracitado, o mesmo era previsto para ser concluído em 12 anos, porém até 2021 as obras referentes à barragem Jequitaí I ainda estavam em andamento. Conforme o relatório, "Este empreendimento se insere num contexto regional de desenvolvimento associado a outros projetos", como os projetos de irrigação Jaíba, Pirapora e Gorutuba, "além de outras ações regionais implementadas pela Codevasf" (CODEVASF, 2005, p. 1). O projeto é assim apresentado no relatório:

\footnotetext{
O Projeto Hidroagrícola Jequitaí é um empreendimento de usos múltiplos e de desenvolvimento regional, onde podem ser destacados como produtos principais a irrigação, o controle de cheias do rio Jequitaí e a geração de energia elétrica, além do abastecimento humano e lazer.

É composto por dois barramentos, com suas respectivas casas de força, e um perímetro de irrigação a jusante.

A construção dos barramentos no rio Jequitaí permitirá a regularização das suas vazões possibilitando o aproveitamento hidroagrícola de cerca de 35.000 ha de terras situadas no seu baixo curso. (CODEVASF, 2005, p. 6).
}

Tributário do São Francisco, a bacia do Jequitaí se localiza entre a Serra do Espinhaço e a Serra da Onça, por onde corre o rio e cujos divisores de água são a bacia do rio Verde Grande, ao norte, e o rio das Velhas, ao sul. O reservatório Jequitaí I é delimitado ao norte pela Serra dos Fonsecas, a sudeste pela sede distrital de Engenheiro Dolabela, ao sul pela Serra do Cabral e pela Serra da Água Fria e a oeste pela cidade de Jequitaí.

A etapa Jequitaí I, que consiste na construção de uma barragem para irrigação agrícola, permitirá irrigar 18,5 mil hectares de terras públicas agricultáveis no seu vale, aproveitando o "estoque de terras", e os restantes 16,5 mil hectares entregues à iniciativa privada, propondo ser um empreendimento de usos múltiplos e de desenvolvimento regional, cujo objetivo maior é a irrigação. 
a criação de um pólo de desenvolvimento regional e novos vetores de fixação e retorno da mão-de-obra para o campo. (CODEVASF, 2005, p. 7, grifos nossos).

Após o fracasso do nacional-desenvolvimentismo na década de 1980, o Estado parece flertar com o plano. No entanto, chama a atenção a intenção de criar "novos vetores de fixação e retorno da mão-de-obra para o campo”. Se o processo de autonomização do Estado impeliu à abertura regional para mobilizar espacialmente força de trabalho para o Sudeste, o que se assiste neste começo de século é uma tentativa de fixar seus portadores nas suas respectivas regiões, contudo, mobilizando-os para o trabalho sem que saiam do seu lugar.

Ao apresentar o programa de irrigação, o relatório defende que a mão de obra agregada à atividade seria formada na própria região, fomentando o desenvolvimento de cidades e povoados que têm na fruticultura a base de sua economia. Ainda, aponta como vantagem que "Os empregos gerados são mais baratos que aqueles gerados, por exemplo, no setor da indústria, além de aproveitar o potencial de trabalho do homem do campo, em especial, do sertanejo" (CODEVASF, 2005, p. 89).

A interpretação dualista do sertanejo mostra a resistência da ideia de que as populações rurais são responsáveis pela estagnação regional, sendo preciso mobilizá-las de forma a se tornarem eficientes e inseridas no mundo moderno. Mas não é só isso, tendo entendido que os discursos são ferramentas importantes para a legitimação de ações.

Essa observação quanto à fixação da mão de obra no seu respectivo território foi densamente estudada no trabalho de Erick Kluck, para quem o Estado pós-redemocratização passou a priorizar a territorialização das ações confinando suas populações, as quais permanecem em condições cada vez mais críticas, sem melhores perspectivas em outros lugares (KLUCK, 2019). Para isso, o Estado vincula dados estatísticos à localização, na decisão de distribuir os recursos estatais mesmo que desigualmente, com vias a gestar os territórios constrangidos no processo. Com essa conduta, o governo institucionalizou as suas atitudes, qualitativamente se transformando no processo dinâmico da reprodução ampliada do capital ${ }^{269}$.

É notável que ao garantir a oferta de emprego futura, o Estado continua mobilizando trabalho para o capital na Serra. Via projetos modernizadores, como o Hidroagrícola Jequitaí, o mantra estatal repete a promessa de emprego e outras oportunidades em um sistema cuja

\footnotetext{
269 “Com o desenvolvimento das forças produtivas, um dos pilares essenciais e críticos dessa reprodução, o Estado tornou-se cada vez mais central, por sua capacidade de endividamento, dinamizando e garantindo a mobilidade do trabalho - de diferentes formas, inclusive, por meio da disposição do crédito e dinheiro aos empreendimentos mais diversos, alguns no sentido de 'fixar' os camponeses no campo, outros, ao mesmo tempo, constrangendo seus territórios, não sem violência” (KLUCK, 2019, p. 270).
} 
substância é expelida do processo produtivo e só poderia ser ofertada com a redução de custos de produção, ultraexplorando a mão de obra disponível.

A barragem é promessa de ganho vindouro tocada a capital fictício. Junto ao crédito, ambos se configuram como investimentos a longo prazo, gerando demanda sobre o trabalho futuro. Para a realização do seu valor, o crédito deve ser organizado de modo a assegurar uma taxa de retorno sobre o investimento inicial. Porém, como propõe Harvey (2006), o que acontece é que os problemas presentes são absorvidos mediante a contratação de obrigações no porvir. O volume das dívidas cresce, e o trabalho futuro se vê cada vez mais preso dentro de uma moldura de obrigações contratuais, tornando as crises inevitáveis, por mais que possam ser adiadas.

Para assegurar as garantias da superacumulação, o Estado tem papel crucial ao fornecer as infraestruturas sociais e físicas que asseguram a circulação do capital na constante (re)abertura de fronteiras econômicas, dando amparo seguro ao sistema de crédito pelas instituições públicas, financeiras e jurídicas. Por isso, historicamente, quanto mais mercado, mais Estado.

À semelhança do que se pensava nas décadas de 1950 e 1960 (inclusive por suas elites regionais), que o desenvolvimento tinha fome de eletricidade, há a intenção de regularizar as vazões do rio maior e gerar energia elétrica por meio do projeto Jequitaí II, tendo, além da Codevasf, outros órgãos públicos envolvidos, como o IEF, o Instituto de Gestão de Águas Mineiro (Igam), a Agência Nacional de Águas (ANA) e a Agência Nacional de Energia Elétrica (Aneel).

\footnotetext{
As licenças ambientais das barragens de Jequitaí I, Jequitaí II e dos perímetros públicos de irrigação deverão ser conduzidas pela CODEVASF, enquanto as licenças ambientais para a geração de energia e perímetros privados de irrigação deverão ser conduzidos pelos interessados ou empresas concessionárias para a atividade, obedecendo aos compromissos assumidos na LP do empreendimento.

No Perímetro Público de Irrigação, com cerca de 18.500 ha, a área de irrigação terá um arranjo espacial por setores, onde será feita a ocupação por pequenos produtores previamente selecionados pela CODEVASF. O restante da área, correspondente aos setores empresariais destinados à implantação de pequenas e médias empresas, irão compor o Perímetro Privado de Irrigação com cerca de 16.500 ha. Isto totaliza 35.000 ha de área irrigada. (CODEVASF, 2005, p. 3).
}

Mais uma vez, velhos discursos e velhas intenções. O Estado penetra a região com benfeitorias para facilitar a entrada de capitais privados, entre eles, o capital internacional: de acordo com o próprio relatório, a ANA é executora nacional de projetos financiados pelo Fundo 
Global para o Meio Ambiente (GEF - Global Environment Facility) ${ }^{270}$. Na redação, o projeto se justifica como única alternativa para tirar o sertão do atraso econômico, enfatizando que a escassez de água, associada ao predomínio da agricultura de subsistência e à pecuária extensiva predatória e não rentável, é a responsável pela pobreza na Serra. Mesmo ao mencionar a entrada do agronegócio na região, conclui que não foi suficiente para gerar empregos.

São apresentados dados referentes ao pequeno crescimento populacional e ao crescente êxodo rural nos municípios abrangidos pelo projeto (Jequitaí, Francisco Dumont, Engenheiro Navarro, Várzea da Palma e Claro dos Poções), carentes de ações urgentes por parte do Estado. O discurso aponta para a necessidade de investimento estatal na região, estimulando a reprodução da força de trabalho para se tornar atraente à iniciativa privada e sair da estagnação.

\begin{abstract}
Os municípios estudados formam uma região marcada pela pobreza e pela exclusão social. A manutenção da atual estrutura socioeconômica nesses municípios perpetuaria o baixo e desigual nível de renda. E mais, manteria os estímulos à expulsão da população e o esvaziamento demográfico que são característicos de toda a região. $[\ldots]$

Os municípios da área de influência indireta estão entre os mais pobres de Minas Gerais e alguns deles entre os $25 \%$ piores do Brasil e essa situação só não é mais dramática devido as elevadas transferências de renda governamentais. Pobreza e emprego são certamente resultados diretos das limitadas oportunidades econômicas oferecidas pela região, logo intervenções estruturais nesses municípios são necessárias, para se modificar a capacidade da região de criar renda e emprego. Uma dessas intervenções é, por certo, uma oferta mais regular de água, pois permitirá um aumento da produtividade das atividades agropecuárias locais. (CODEVASF, 2005, p. 51).
\end{abstract}

Reforçando a carência dos municípios alvo da barragem, o relatório aponta que os perfis orçamentários da região têm participação expressiva do Imposto sobre Circulação de Mercadorias (ICMS) e do Fundo de Participação dos Municípios (FPM). Entre as receitas tributárias próprias, os tributos de maior peso são o Imposto Sobre Serviços (ISS) e o Imposto sobre Transmissão de Bens Imóveis (ITBI), o que insinua precariedade na arrecadação. A se manter no quadro atual, o discurso é que, dada a baixa produtividade física da agricultura, o único modo de sustentar uma produção competitiva seria por meio da redução dos custos dos fatores de produção ofertados localmente, tendo os trabalhadores rurais e os proprietários de terra suas remunerações encurtadas. Os primeiros teriam seus salários atrofiados até compensar a baixa produtividade da agricultura, enquanto o preço da terra cairia até que a renda fundiária rural alcançasse um patamar que viabilizasse a produção local (CODEVASF, 2005). Por isso a

270 “'O Projeto GEF São Francisco é o projeto de demonstração latino-americana do Programa de Ação Global para a Proteção do Meio Ambiente Marinho devido as Atividades Desenvolvidas em Terra.” (CODEVASF, 2005, p. 130). 
necessidade de o Estado abrir passagem para o ingresso do capital privado, de forma a erguer a região da estagnação.

Ao afirmar que a situação regional só não é mais dramática devido às elevadas transferências de renda governamentais, nota-se que o problema social do desemprego pode ser mais ou menos regulado, em última instância, somente através de intervenções do Estado. No texto A falta de autonomia do Estado e os limites da política: quatro teses sobre a crise da regulação política, Robert Kurz mostra como historicamente quanto mais a economia de mercado se expande estruturalmente, abrangendo toda a reprodução social e tornando-se o modo de vida universal, mais a atividade do Estado precisa ser expandida, gerando um crescente de dívidas. No entanto, o autor adverte que, pela primeira vez na história, a velocidade da "racionalização eliminadora" de trabalho supera a expansão dos mercados, ou seja, a produtividade aumenta com rapidez cada vez maior, ao passo que a expansão do modo de produção, considerada na sua totalidade, dá sinais de limite. Com isso, a substância do capital - o trabalho -, ao ser expulsa do processo de produção, condena o capitalismo, que foi engolido pela própria demanda de desenvolvimento de suas forças produtivas estimuladas pela concorrência.

Descrente de uma solução definitiva para o capitalismo, David Harvey aposta na engenhosidade humana e na ação política como intervenções que alteram o seu ritmo, tanto na sua expansão espacial quanto nas manifestações das crises. São alternativas provisórias, porque o capital tem incorporadas as contradições do crescimento e da destruição. O autor destaca que, para ele, "O sistema tem de se expandir mediante a utilização do trabalho vivo na produção, enquanto a via principal da mudança tecnológica envolve substituir o trabalho vivo - o agente real da expansão - da produção" (HARVEY, 2006, p. 132).

\begin{abstract}
A partir de agora, a autocontradição fundamental, segundo a qual essa sociedade se baseia na transformação incessante de quanta abstratos de trabalho em dinheiro, mas conduziu-se a um ponto no qual não se pode mais mobilizar rentavelmente quanta suficientes de trabalho no patamar dos padrões de produtividade, criados pela própria sociedade, já não é mais um fenômeno cíclico, mas um fenômeno estrutural. Porém quanto mais fraca se tornar a acumulação real, tanto menos o crédito estatal será financiável, e quanto menos o Estado puder ser financiado, tanto maiores se tomarão as suas tarefas em virtude da crise estrutural da acumulação. É nesse círculo vicioso que a própria modernidade produtora de mercadorias se aprisionou. (KURZ, 1995).
\end{abstract}

Se capital e Estado compõem uma relação ineludivelmente recíproca, ambos tendem a colapsar juntos. De forma a salvar o capitalismo em uma situação de desemprego que se dirige para convulsões sociais, o Estado acaba se tornando um gestor de crise, transferindo um mínimo de renda sem ter condições de estimular a produção. Quanto mais convulsões sociais, maior a 
repressão policial e maiores os compromissos para salvaguardar uma relação social cada vez mais contraditória ${ }^{271}$. "De homem que não possui nenhum poder nenhum, dinheiro nenhum, o senhor tenha todo medo!" (ROSA, 1986, p. 341).

Todavia, como o Estado é capturado pelo mercado e as personificações deste têm interesses na disponibilidade de crédito, se persiste na modernização. Em janeiro de 2018, realizou-se breve visita ao escritório do projeto, no município de Jequitaí, recebida de surpresa pelo coordenador de assistência social do programa hidroagrícola, que se apresentou como Pedroso, nomeado para o cargo diretamente de Brasília. Diante de conversa informal bastante desagradável - ele se opôs a disponibilizar o relatório, algo previamente conversado por telefone na época -, o próprio afirmou que conseguiu montar sua empresa de consultoria em energia renovável graças a um curso técnico internacional pago pelo governo federal, deixando no ar a suspeita de que a abertura da sua empresa também teria se beneficiado do dinheiro público.

Para Pedroso, a única grande fonte de renda na Serra são os impostos municipais advindos do plantio de eucaliptos, que, segundo ele, também gera empregos. Crítico à pecuária extensiva e à manutenção da vegetação nativa, comentou que a região era um vazio miserável porque as fazendas, ao não produzirem excedente, não davam lucro, pois deixavam as terras ociosas. A barragem seria o momento de alavancar a economia regional atraindo empresas, uma vez que artigos agrícolas de interesse comercial seriam largamente produzidos e gerada energia elétrica, circulando mais capital e diversificando as atividades produtivas. A conversa terminou com sua indagação sobre a utilidade desta pesquisa para a região, porque, segundo o seu pensamento tecnoburocrata, a universidade pública precisa ser útil oferecendo alternativas de desenvolvimento ao país, ao invés de se dedicar à mera crítica de tudo o que é feito.

No relatório da barragem, a autonomização dos fatores de produção está embutida. No caso da Serra, a modernização envolve práticas estatais e não estatais, desdobramento e generalização de relações sociais por meio de categorias sociais de mediação historicamente determinadas - tais como dinheiro, trabalho, mercadoria, terra (território) -, compondo a reprodução de relações desiguais e violentas da contradição Estado-mercado (KLUCK, 2019).

A terra é o fator por excelência que, com a infraestrutura implantada pelo Estado, passa a se valorizar e atrair grandes capitais: "Não se pode deixar de considerar que o agronegócio de sementes pode vir a se expandir na região, criando novas oportunidades ao Projeto Hidroagrícola Jequitaí, em especial para os pequenos produtores" (CODEVASF, 2005, p. 91).

271 "De qualquer modo, a burguesia necessariamente temerá a estupidez das massas enquanto elas permanecerem conservadoras, e o discernimento das massas assim que elas se tornarem revolucionárias" (MARX, 2011, p. 145). 
O que, na sua forma contraditória de ser, por um lado visa atrair os grandes capitais do agronegócio, enquanto, por outro, tende a transformar o pequeno produtor em microempresário. A este, o projeto promete a livre iniciativa de cultivar por irrigação o milho e o feijão, o que já fazia tradicionalmente, porém, poderá implantar cultivos “mais nobres”, já experienciados no Projeto Jaíba.

Para a eficiência, sugere até mesmo as espécies mais adequadas às características fisiográficas da região, como a tangerina, o maracujá e a manga, frutas destinadas aos mercados interno e externo. Ainda propõe o aproveitamento dos recursos das Parcerias Público-Privadas (PPP) na oportunidade de cultivar cana-de-açúcar para o fornecimento de matéria-prima a empreendimentos alcooleiros, bem como o cultivo de vegetais voltados à agroindústria do biodiesel. Todas as expectativas giram em torno dos capitais disponibilizados para os projetos do vale do São Francisco como um todo, podendo o Projeto Hidroagrícola Jequitaí "se beneficiar com captação direta dos recursos gerados para aquele empreendimento" (CODEVASF, 2005, p. 133).

O papel do Estado se desdobra como garantidor do agricultor na terra via créditos, enquanto conforma o processo geral capitalista, com futuras dificuldades para o pequeno produtor em conseguir se reproduzir (KLUCK, 2019). Ao se colocar como o agente de entrada direta do capital na Serra, o Estado demonstra a sua falta de autonomia, devendo ser ele o operador a viabilizar "a instalação de agroindústrias na região, desdobrando-se sobre outros aspectos da economia" (CODEVASF, 2005, p. 86), a fim de transformar uma região "predominantemente de subsistência para uma economia de mercado" (CODEVASF, 2005, p. $81)$.

A leitura do relatório corrobora a crítica de Robert Kurz, para quem o Estado como empresário aparece sobretudo nas sociedades de "modernização retardatária”, ou seja, entre os países que entraram tarde no moderno sistema produtor de mercadorias (KURZ, 1995). Porém, apesar de se reconhecer o projeto estatal modernizador somente a partir do século XX, é preciso considerar os territórios de passado colonial já inseridos na raiz processual desse sistema desde antes, passando do sentido da colonização, advertido por Caio Prado Júnior, à colonização sistemática na cisão dos fatores de produção.

O relatório apresenta uma lista com todos os projetos de governos anteriores no vale do Jequitaí e na região, com o objetivo de provar que a Serra já recebeu incentivos públicos, porém mal geridos. A promessa de futuro aponta que desta vez a terra será devidamente produtiva, o trabalho finalmente garantido e os capitais assegurados e disponibilizados de forma a ampliar 
a produção, sem ousar questionar se o fracasso de projetos anteriores não acabaria por revelar não a incompetência do Estado, mas os limites de sua reprodução capitalista.

De acordo com o Rima, entre os planos governamentais federais levados a efeito na região nos últimos anos, destacam-se o Plano Diretor para o Desenvolvimento do Vale do São Francisco (Planvasf), o Projeto de Conservação e Revitalização da Bacia Hidrográfica do Rio São Francisco, o Plano São Francisco - Plano de Sustentabilidade Hídrica do Semi-Árido, o PPP, o Probiodiesel, o Programa Desenvolvimento da Agricultura Irrigada, o Pró-Água InfraEstrutura, o Pró-Água Semi-Árido, o Programa de Desenvolvimento Integrado e Sustentável do Semi-Árido (Conviver), o Programa de Promoção e Inserção Econômica de Sub-Regiões (Promover), o Projeto PNUD/BRA/98/012 (Pronaf), os Programas Apoiados pelo BNDES e os Programas e Linhas de Financiamento Apoiados Pelo Banco do Nordeste (BNB). Entre os programas do governo do estado para a região, destacam-se o Programa Viva Vida, o Programa de Desenvolvimento Rural Integrado (PR), o Programa de Irrigação de Pequenas Propriedades (Prospere), o Programa Irrigar Minas, o Plano Integrado de Desenvolvimento do Nordeste Mineiro (Planoroeste), a Modernização Tecnológica da Agricultura Irrigada e o Programa Caminhos de Minas (CODEVASF, 2005).

Nos termos do texto, caberia agora um projeto de uso sustentável para gerar "cerca de 17,3 mil empregos diretos e pelo menos outros tantos indiretos, ampliando a oferta regional de mão de obra em nada menos de 35 mil empregos" (CODEVASF, 2005, p.100), com um longo prazo de amortização dos custos para o produtor irrigante, podendo chegar a 30 anos, "com amortizações anuais calculadas previamente e integralização feita em parcelas mensais" (CODEVASF, 2005, p. 15). Os gastos, previstos em torno de \$360 milhões, são justificáveis pela inserção daquela região nos mercados exportadores "não só pela capacidade de gerar riqueza, como pelo impacto que o projeto causará criando oportunidades de negócios" (CODEVASF, 2005, p. 100), alavancando o agronegócio na Serra.

O projeto também se justifica por fixar espacialmente a população, a ser incluída nas relações trabalhistas modernas e evitando o êxodo para os centros urbanos do norte mineiro, além de circular as mercadorias lá produzidas. O Projeto Hidroagrícola aposta no seu êxito validando o pensamento de Adam Smith (1983), para quem a abertura de estradas e de toda obra de contato com alhures desenvolveria o mercado e, por sua vez, a sociedade progrediria. O relatório enfatiza o sistema viário disponível, com destaque para o rodoviário, cujas BR-365, BR-135 e BR-496 ligarão o mercado criado pelo Projeto aos mercados de Montes Claros, Pirapora e Brasília, alcançando o Centro-Oeste, de forma a se voltar para a zona de maior 
crescimento do agronegócio do país, ao invés da fixação com a saída para o mar, que marcou o movimento autonomista no passado.

Para os crédulos do desenvolvimentismo, propostas desse tipo são ótimas, pois ainda estão absortos no dualismo e na ideia de que o capitalismo é revolucionário. A análise que Bresser-Pereira faz do país desde o seu momento de redemocratização é um exemplo:

\footnotetext{
Quando os muito pobres se tornam pequenos empresários, seja porque obtiveram crédito, seja porque receberam um pedaço de terra, eles estão aos poucos se inserindo no mercado capitalista. Por outro lado, todos os gastos sociais com os pobres, principalmente os de educação e saúde, estão também melhorando a qualidade de vida do setor informal e, dessa forma, integrando-o ao moderno e superando a dualidade, não pela absorção do tradicional pelo moderno, mas pela melhoria das condições de vida dos pobres. (BRESSER-PREREIRA, 2004, p. 67).
}

Condição de vida que perpetua a expropriação e induz a uma educação em uma sociedade em que o emprego se torna cada vez mais escasso. As reflexões de Kluck (2019) para os brejos baianos sanfranciscanos estão sintonizadas com a realidade da Serra. A mobilidade do trabalho, por si, já adquire neste princípio de século um caráter anacrônico, pois a força de trabalho continua disponível a partir da desapropriação, despossessão, expropriação e exploração, ao mesmo tempo em que há maior desenvolvimento das forças produtivas e atuação do capital fictício, como base da reprodução social fetichista. A assim chamada superpopulação relativa continua a existir sem a funcionalidade anterior, tornando-se "um produto crítico da forma social de mediação posta em processo de descartabilidade" (KLUCK, 2019, p. 256). É a produção de sua própria negação, isto é, a ampliação da população para o trabalho quando ela já não pode mais ser incorporada no processo produtivo.

Com a população relegada à miséria, o Estado cumpre o papel de gestor de crise. Os gastos direcionados para o gerenciamento das convulsões nada mais são do que o nível civilizatório da modernidade, havendo, ainda, quem defenda liquidar esse nível para as massas humanas já não mais rentáveis, em virtude de sua falta de "financiabilidade", as enviando à barbárie (KURZ, 1995). Esse é o capitalismo revolucionário do século XXI, que produz civilização e seu oposto. Sem qualquer novidade: o capital não tem compromisso moral.

O texto do Rima em nenhum momento dá relevo à territorialização na Serra do Cabral. Considerando todos os moradores dos municípios atingidos que são proprietários de terras, a fala do Pedroso ignora completamente a existência de expropriados, cuja renda muitas vezes é complementada acessando a coleta sazonal de frutos na Serra. As ações da Sudene e o ingresso da silvicultura ainda no Governo Militar são sequer mencionados pelo relatório, que aborda a criação de gado sem um passado que justifique a produção na região e a concentração fundiária. 
Quanto ao garimpo, nas raras vezes que apareceu, foi para lembrar que existe de forma ilegal nas margens do Jequitaí. O discurso ecológico de desenvolvimento sustentável está no documento como a salvação de uma região onde a vazão do rio precisa ser domada para levar água às terras, atraentes à iniciativa privada que quiser desenvolver plantio de irrigação com vias a futuramente suprimir o cultivo de subsistência. Este, contemplado no projeto como o destino de metade das terras irrigáveis, expõe a integração dialética do modelo econômico que se desenrola no país ${ }^{272}$.

Enquanto a barragem é lentamente construída, famílias de fazendeiros e sitiantes são gradualmente indenizados pela perda de terras, submersas nas águas futuras. Alguns pequenos proprietários vêm usando o dinheiro recebido das indenizações para levantar casas na periferia dos municípios da Serra, divididos entre o significado de viver nos pequenos núcleos urbanos e deixar a lida na zona rural.

Esse relativo crescimento dos municípios atrelado ao planejamento infraestrutural para a Serra está entre os objetivos de transformação regional:

Estão previstos também núcleos administrativos, em número de sete, para atender as funções básicas de armazenagem de grãos, frutas, defensivos e insumos, centro administrativo, posto médico, escola e mercado público. (CODEVASF, 2005, p. 104).

Tal horizonte é parte do processo de metropolização do território em curso, ou seja, a difusão dos códigos metropolitanos num espaço além dos limites das regiões metropolitanas oficialmente demarcadas, com vias a alcançar a escala geral do território, alterando as relações urbano-rurais. Tais manifestações são notadas nas novas formas de gestão em que as intervenções localizadas, como as parcerias público-privadas, ganham ênfase, alterando a

\footnotetext{
272 "O processo descrito, em seus vários níveis e formas, constitui o modo de acumulação global próprio da expansão do capitalismo no Brasil no pós-anos 1930. A evidente desigualdade de que se reveste que, para usar a expressão famosa de Trotsky, é não somente desigual mas combinada, é produto antes de uma base capitalista de acumulação razoavelmente pobre para sustentar a expansão industrial e a conversão da economia pósanos 1930, que da existência de setores 'atrasado' e 'moderno'. Essa combinação de desigualdades não é original; em qualquer câmbio de sistemas ou de ciclos, ela é, antes, uma presença constante. A originalidade consistiria talvez em dizer que - sem abusar do gosto pelo paradoxo - a expansão do capitalismo no Brasil se dá introduzindo relações arcaicas no novo, um modo de compatibilizar a acumulação global, em que a introdução das relações novas no arcaico libera força de trabalho que suporta a acumulação industrial-urbana e em que a reprodução de relações arcaicas no novo preserva o potencial de acumulação liberado exclusivamente para os fins de expansão do próprio novo. Essa forma parece absolutamente necessária ao sistema em sua expressão concreta no Brasil, quando se opera uma transição tão radical de uma situação em que a realização da acumulação dependia quase integralmente do setor externo, para uma situação em que será a gravitação do setor interno o ponto crítico da realização, da permanência e da expansão dele mesmo. Nas condições concretas descritas, o sistema caminhou inexoravelmente para uma concentração da renda, da propriedade e do poder, em que as próprias medidas de intenção corretiva ou redistributivista - como querem alguns - transformaram-se no pesadelo prometeico da recriação ampliada das tendências que se queria corrigir." (OLIVEIRA, 2013, p. 59-60, grifos do autor).
} 
divisão do trabalho e os comportamentos, de forma a transformar a região num espaço híbrido (FERREIRA, 2016).

A população de Francisco Dumont se queixa do aumento de arruaças, roubos e violência desde o asfaltamento da estrada e a construção da barragem, tornando perigoso estar nas ruas até muito tarde em época de festa. Presos ao discurso moral do roubo e do asselvajamento social, os entrevistados não entendem a violência como um desdobramento da precarização da vida, promovida pela modernização. Enquanto a obra avança, jovens deixam suas casas em direção a cidades maiores, como Montes Claros, à procura de emprego e estudos. Nos que ficam, é perceptível o desnorteamento sobre o que fazer diante do eucalipto, que permanece avançando - em janeiro de 2018, terras no entorno do povoado de Buriti Grande foram arrendadas para o cultivo -, enquanto o Projeto Hidroagrícola é ainda uma miragem nem tão paradisíaca.

O planejamento governamental reafirma seu compromisso com a racionalização da reprodução ampliada do capital, rotulando mais uma vez o sertão como locus do atraso e urgente de superação. O projeto impõe a divisão técnica do trabalho, como se desse à Serra a nova função de produtora de gêneros agrícolas para o mercado, descartando a particularidade que conforma a região. A territorialização se veste de novos objetivos, impondo formas de poder ancoradas no aparato de Estado, que arca com os custos de abrir as supostas fronteiras para que interesses privados e excludentes tomem assento. Na contramão da promessa de progresso, desponta a contradição dos conflitos de camadas sociais dos sujeitos historicamente expropriados.

Sem garimpo, sem pecuária, o eucalipto timidamente condenado pelos discursos ambientalistas, a novidade é posta sobre duas barragens e, mais uma vez, as expectativas depositadas na agricultura de larga escala. A modernização dota o território de equipamentos e técnicas para a produtividade, enquanto torna impossível uma outra territorialização, solidária e abolida do trabalho, daqueles que não têm meios. Cada vez mais dependente do capital e da coordenação da ampliação das relações de fetiche, o Estado segue regente da marcha fúnebre de uma serra que agoniza. Aos discursos ambientalistas, de desenvolvimento sustentável (sustentável a quê/quem?) e de resgate dos modos idílicos de vida dos sertanejos, resta a dúvida de serem possíveis de realização ou intencionados em inclusão precária a uma sociedade na qual o capital insere relações diferentes na sua reprodução ${ }^{273}$.

${ }^{273}$ Isso ajuda a entender por que a sugestão do Bem Viver, divulgada pelo economista equatoriano Alberto Acosta (2015), apesar de interessante e assumidamente utópica, ainda não seduz. Sua proposta é romper com as ideias de desenvolvimento, partindo de sociabilidades indígenas e outras formas de organização social resgatem os elos 


\subsection{Progredimos e desaparecemos: o messianismo do discurso ecológico}

Em princípios deste século, após a entrada do Estado associado ao capital privado na Serra, é possível notar não apenas uma modernização dolorosa, mas também a aceleração do processo de desgaste das características naturais da região. No que cabe às florestas homogêneas, o volume das águas do lençol freático tem diminuído, secando muitas nascentes, ao mesmo tempo em que, com as chuvas sazonais, seu solo arenoso, exposto pelo desmatamento e plantio, é transportado chapada abaixo em direção às veredas, assoreando os cursos d'água, pois a infiltração tem cedido espaço ao escoamento superficial ${ }^{274}$. Carlos Dayrell (1998) aponta que até 1970, o norte de Minas Gerais apresentava 85\% da sua cobertura vegetal conservada, com redução para $32 \%$ na década de 1990. A Serra oferece uma paisagem triste: de um lado, o eucaliptal monótono a perder de vista, e, do outro, as veredas mais abaixo, amareladas porque estão morrendo.

\section{Figura 37 - Vereda de Santo Antônio morrendo na Serra do Cabral}

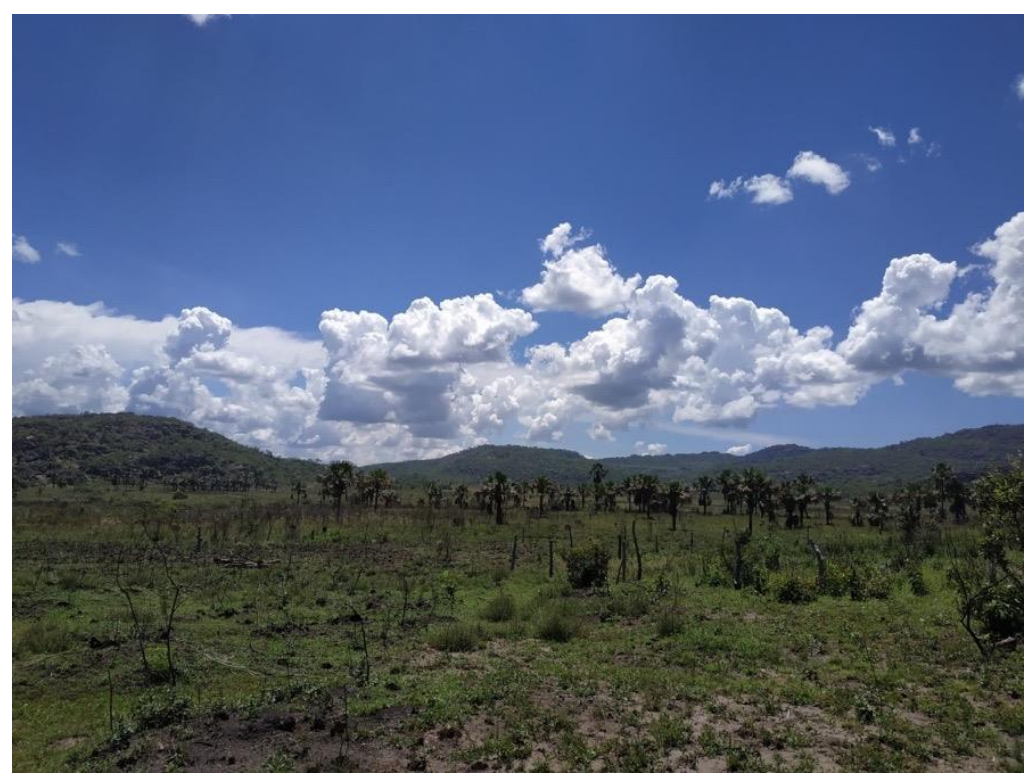

Fonte: acevo pessoal, janeiro de 2018.

entre sociedade e natureza. Porém, defende a dianteira do Estado com suas instituições modernas como agente transformador para novas sociabilidades (sobretudo não eurocêntricas), cabendo a ele, por exemplo, apenas "corrigir o mercado", enquanto o mundo criaria uma moeda alternativa, de forma a garantir a permanência das trocas. Mesmo tendo a cautela de historicizar o capitalismo e não romantizar as relações comunitárias dos povos originários, a perspectiva ontológica do trabalho é reforçada, e o fetiche da mercadoria com suas abstrações persistiria.

274 “Outro aspecto que indica que o Cerrado já entrou em vias de extinção é que as plantas do Cerrado são de crescimento muito lento. Uma canela-de-ema atinge a idade adulta com mil anos de idade. O capim-barba-de-bode fica adulto com 600 anos. Um buriti atinge 30 metros de altura com 500 anos. Nossas veredas - que existiam em abundância até pouco tempo - eram compostas de plantas 'nenês' quando Pedro Álvares Cabral chegou ao Brasil, estavam nascendo naquela época e sua planta mais comum, o buriti, está hoje com 25 metros, 30 metros." (BARBOSA apud GOUVEIA, 2014). 
Com isso, todo um dinamismo nas relações entre moradores e sertão é mais uma vez ameaçado. Célio, um dos entrevistados, atualmente trabalha na Serra com a coleta sazonal de plantas nas propriedades onde lhe é permitido entrar, colhendo favela, capinha de coco, mamoninha e canoinha, ganhando por dia de trabalho. Na época do pequi, se junta a outros homens, mulheres e crianças e se embrenha no mato para colher a fruta e vendê-la para compradores de outras regiões ${ }^{275}$. Fora da estação de colheita de plantas e frutos, ele aceita qualquer serviço de lavoura ou se junta aos sobrinhos no garimpo de cristal, nas poucas terras permitidas. Para ele e Maria Eunice, o eucalipto reduziu drasticamente a biodiversidade, pois a água ficou escassa, a mata foi derrubada e, se antes era preciso andar poucos metros mata adentro para colher material, hoje as caminhadas são bem mais extensas, dada a escassez de plantas nativas ${ }^{276}$.

Em concordância com o já exposto sobre a chegada das reflorestadoras, o eucalipto integra as ações do agronegócio porque o cultivo se volta para o abastecimento industrial de base, absorvendo técnicas modernas e, consequentemente, alterando as paisagens e seu conteúdo. Muito antes, a mobilidade das populações locais ocorria dentro do sertão, com os povos nativos se movendo para a beira dos rios e acessando as chapadas. Conforme os “forasteiros" foram chegando - assim chamados por Andrea de Paula (2009) para se referir aos europeus, bandeirantes, fazendeiros e outros -, a mobilidade foi alterada, não se direcionando mais para o interior do sertão, mas para fora da região. Para a autora, foi a modernização agrícola que causou o desencantamento do sertão e o aparecimento do cerrado, sendo aquele estereótipo do arcaísmo, enquanto este se torna sinônimo de modernidade e receptáculo dos planos de Estado para a promoção do agribusiness.

Essa modernização não se deu da noite para o dia. Ela envolveu um processo que remonta às primeiras formas de ocupação do sertão, bem como seu sentido. Se "a assim chamada acumulação primitiva" significa o saque, a apropriação dos espaços e seus recursos para a reprodução do capital, a separação entre os homens e mulheres e a terra, esta como meio

\footnotetext{
${ }^{275}$ Em janeiro de 2018, a caixa com 30 quilogramas de pequi era vendida por menos de 10 reais no auge da safra, enquanto em princípios da colheita chegou a custar 50 reais. O destino comum são os centros urbanos do CentroOeste, Sudeste e Nordeste.

${ }^{276}$ A coleta de frutos sazonais e materiais para artesanato e fins diversos na Serra foi o sustento de muitas famílias por décadas, seja para vender para compradores de outras regiões, seja para o próprio consumo. Até a chegada do reflorestamento, homens, mulheres e crianças entravam nas áreas de chapada para fazer a coleta, estabelecendo laços de solidariedade e cooperação durante a atividade. Segundo Mônica Nogueira (2009), o trabalho era visto pela população sertaneja como uma dádiva divina, sendo preciso andar pouco pelo mato para conseguir juntar um bom material. Carlos Dayrell (1998) acrescenta que até o fim da década de 1990, o extrativismo contribuía com até $42 \%$ da produção anual bruta do agroecossistema familiar.
} 
de produção, seria a "precondição histórica do modo de produção capitalista" e sua "fundação permanente" (MARX, 2013, v. 1).

Para John Bellamy Foster, em seu texto A ecologia da economia política de Marx, o capitalismo inicia-se como um sistema de usurpação da natureza, que contém a riqueza pública - o problema reside na forma moderna de apreensão do meio natural, pois os seres humanos, como seres materiais objetivos, não podiam ser libertados da apropriação da natureza, isto é, da propriedade em todas as suas variadas formas, que era uma condição objetiva de sua existência.

Para Foster, a riqueza pública consiste em valores de uso não produzidos pelo trabalho - portanto, sem valor -, como água e ar, que existem em abundância, enquanto as riquezas privadas são baseadas em valores de troca, que, por sua vez, demandam escassez. A expansão das riquezas privadas anda de mãos dadas com a destruição da riqueza pública: o padrão de desenvolvimento capitalista foi caracterizado pelo roubo e desgaste dos recursos, tidos como bens públicos, causados pelos métodos de exploração com a finalidade da acumulação, pelo seu desperdício e pela destruição da riqueza natural da sociedade, perdendo material humano enquanto produz, mas também enquanto troca (FOSTER, 2012a). Nesse processo, ganha a riqueza privada, personificada no capitalista, enquanto perde a riqueza pública, encarnada na sociedade.

Segundo o mesmo sociólogo, ao pensar o roubo ( $\mathrm{rabbau}$ ), Marx desenvolveu a ideia de fenda metabólica, para mostrar como a apropriação da natureza e de seus recursos geraram uma fissura no metabolismo entre a humanidade e a terra. Conforme as forças produtivas se desenvolvem, crescem a apropriação e o consumo dos recursos, que induzem à expropriação violenta de comunidades para a realização da lógica da mercadoria, impulsionando, ao que se entende, na reprodução ampliada do sistema no contexto do imperialismo.

A narrativa histórica da territorialização da Serra do Cabral mostra que esse roubo da natureza vem acontecendo desde o processo de ocupação colonial, coetânea ao desenvolvimento do capitalismo. Para Jason Moore (2017), é no desenvolvimento da nova socialização que se operou a cisão entre Homem e Natureza, transformando-os em opostos binários. Ao homem, não como ser biológico, mas como depositário histórico da objetivação do valor, cabe dominar a natureza, que lhe é concebida como alheia, pertencente a uma esfera de instintos e barbárie, pronta a ser domesticada e submetida à realização do valor. A crise ecológica se desdobra a partir dessa dissociação imposta pelo mundo ocidental, dado que a submissão cartesiana da natureza concebida como inesgotável à sociedade tida como racional 
tem como objetivo a produção do capital ad infinitum ${ }^{277}$, expropriando e explorando violentamente grupos repostos como refratários a cada transformação da lógica da mercadoria.

Portanto, não se pode dissociar a usurpação da natureza da apropriação capitalista da terra e suas consequentes imposições de renda fundiária, detalhe sobre o qual Foster pouco se debruçou. Marx já apontava na seção VI do livro 3 d'O Capital, que para vender uma coisa, basta monopolizá-la e aliená-la. Assim se dá o mercado de terra, cujo valor do solo e seu nível de renda dependem do resultado do trabalho social total. Se por um lado, expandem-se o mercado e a demanda por produtos agrícolas, por outro, expande-se diretamente a demanda pelo próprio solo, como condição concorrencial de produção de todos os ramos possíveis da atividade, inclusive os não agrícolas. Uma das consequências é a progressiva expulsão da população agrícola do campo, reduzindo o capital variável na agricultura conforme cresce o capital constante, ou seja, "tal capital só pode crescer na medida em que novas terras forem cultivadas, o que, por sua vez, pressupõe um crescimento ainda maior da população não agrícola" (MARX, 2013, III, p. 699). Com essa passagem, o autor deixa nítida a expropriação da terra e inevitavelmente também de seus recursos.

Entre as consequências deste movimento, é notória a alteração das chamadas relações metabólicas pela modernização. Apesar de se haver salientado que os camponeses encontrados na Serra possuem origem já imersa nas modernas relações sociais, nem por isso ficaram imunes às transformações qualitativas da organização capitalista. Não apenas esse material humano foi posto em marcha, sendo expulso dos processos produtivos - mais do que desperdiçados, tendo em conta que gradualmente não são de todo úteis ao moderno sistema produtor de mercadorias -, mas a própria maneira de se enxergar o sertão nas suas qualidades naturais e em seus potenciais usos sofreu alterações. É essa alteração, que é histórica, que precisa ser problematizada para se chegar ao entendimento do messianismo do discurso ecológico na Serra e alhures.

\footnotetext{
${ }^{277}$ Em uma leitura comparativa dos pensamentos de Roswitha Sholz e Jason Moore, o capitalismo se apresenta como uma relação social que cinde os elementos de sua constituição. Scholz apresenta a crise social e ecológica do mundo como produto dos "potenciais de destruição do sensível" presentes na forma do valor, que resultam do mecanismo patriarcal de cisões que, histórica e estruturalmente, se encontram na base de toda essa relação. Ao apresentar as origens do valor-dissociação e a submissão da mulher, justificada pela sua representação do sensível e de seus elos com a natureza, caberia ao homem, sujeito do valor e detentor da razão, dominar o gênero interpretado como seu oposto, sendo que "O que estava em jogo era um projeto fundamentalmente diverso de relacionamento com a natureza" (SCHOLZ, 1995). Sendo o homem também o sujeito do mundo público e do mercado, ele personifica a Sociedade, que deve se impor de maneira cartesiana à Natureza, no intuito ilustrado de valorização do valor (MOORE, 2017). Com isso, entende-se a crise do valor também como a cisão do que não pode ser cindido.
} 


\section{Figura 38 - Amostra de produtos colhidos na Serra do Cabral e galpão de armazenamento da coleta, Francisco Dumont, 2017}

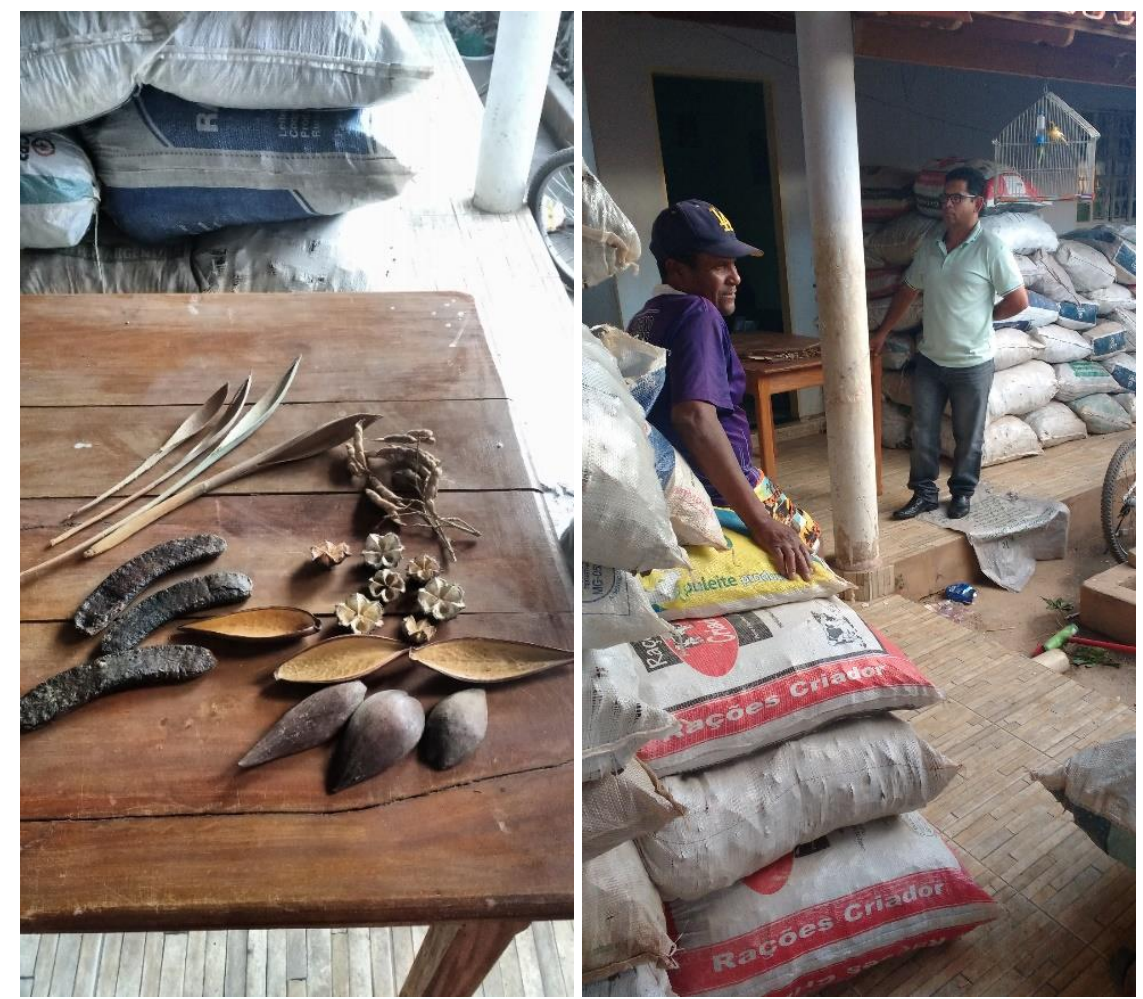

Fonte: acervo pessoal, janeiro de 2017.

O depoimento daqueles que nasceram na região e palmilharam a Serra toda uma vida para sobreviver dos seus frutos, lamentando não reconhecer mais a paisagem, é contraposto aos discursos técnicos. Antônio da Serra foi enfático ao dizer que a história de que o eucalipto seca a terra é mito: "Eu debati muitas vezes e mostrei as nascentes na fazenda. As veredas de fora secaram por fogo, e algumas mudaram de lugar. Desmatamento também não é só eucalipto. Reflorestar é diferente de desmatar".

Ao ouvir certa vez que na Serra deveria ser plantado comida e não eucalipto, debateu que até a soja, se lá plantasse, secava tudo: "No eucalipto, mesmo em área arenosa, você acha um metro de matéria orgânica se cavar". Segundo ele, a cultura anual e o pasto são mais predatórios: "No eucalipto hoje, é cheio de bacias nas estradas pra não deixar a enxurrada levar a terra e a água da chuva infiltra, evitando erodir os brejos".

Sua defesa vai de encontro com a fala de Paolo, engenheiro agrônomo da barragem, para quem o problema é o manuseio: "Se plantasse batata no lugar do eucalipto, ia secar tudo. O problema é o manejo, não o que é cultivado". No mesmo caminho, foi a defesa de Pedroso, ao dizer que o discurso de desmatamento promovido pelo eucalipto é falácia, sendo a pecuária extensiva muito mais agressiva à terra do que a silvicultura, que se vale de técnicas modernas e emprega mais gente. Os burocratas a serviço tanto do Estado quanto do capital monopolista 
têm na Ciência e na técnica o seu escudo para contra-argumentar evidências da realidade, disputando entre si qual das produções - todas predatórias - destrói menos.

Prontificado o discurso ecológico, passa-se à sua aplicação nos poucos funcionários das reflorestadoras. José Adilson Barbosa, conhecido como Neno, 31 anos (2020), é um dos seguranças da Vistec Serviços e Tecnologia, empresa de segurança faz monitoramento territorial para reflorestadoras e cuja atividade emprega a retórica ambiental para lidar com os chamados "problemas vizinhos". Fazendo a segurança patrimonial da SC Flor há três anos, Neno atua no terreno acima do antigo garimpo do Boi Morto, na Serra do Cabral. Foi o emprego que conseguiu depois de lidar com carvoeiras desde os 11 anos de idade, rompendo a sina de seu pai, migrante de Itacambira, que também dividiu seu tempo de trabalho entre as lavouras alheias e os fornos de carvão.

Munido de facão e machado, usa o diálogo para resolver a questão do gado, que pasta ilegalmente nas terras da empresa. Segundo ele, quem solta os bois e cavalos são donos de rebanhos pequenos que não têm terra, que "Querem criar, mas não têm condição" - dando vida à observação de Riobaldo sobre os sertanejos pobres que completavam as fileiras da jagunçagem aboiando sem boi, porém invertendo a forma de propriedade: se antes o gado era a mercadoria difícil de ser acessada, agora é a terra. É nesse momento que o treinamento baseado na conversa entra em ação: na camaradagem, Neno argumenta que o gado é danoso ecologicamente, pois pisoteia as nascentes, prejudicando o meio ambiente, e caso encontre novamente as reses pastando em propriedade alheia, tem que acionar os meios legais para resolver a questão - é a célebre utilização da justiça para resolver os problemas dos expropriados.

Além dos "bois invasores", Neno afirma que os focos de incêndio são outra preocupação corrente. Apesar de nunca ter visto, acredita que $90 \%$ deles são criminosos, provocados por gente que quer formar pastos na Serra. Com isso, seu trabalho de proteger a propriedade silvicultora tem que sustentar um discurso generalizado de que o eucalipto é menos danoso às nascentes e à dinâmica ecológica do que os bois e os vaqueiros sem terra, cumprindo a monocultura de eucalipto um importante papel de guardiã dos recursos naturais que a pobreza e a ignorância dos sertanejos tentam o tempo todo degradar.

O risco de incêndio é também a justificativa para empresas de donos absentistas proibirem os coletores de sempre-viva de acessarem as vargens e areais no período de safra da flor. Nem de Bico foi enfático ao dizer que desde a chegada das reflorestadoras os coletores foram gradualmente encontrando dificuldade para entrar nas terras que, até então, eram livres: "Hoje, não pode mais fazer rancho pra ficar. Eles diz que a gente põe fogo no mato", referindo- 
se à queimada como um estímulo antigo e há muito tempo descartado para o melhor crescimento das flores. “A Scai, a Plantar e Santa Maria não gostam que a gente entra. Hoje, quem permite mais é Daniel [irmão de ex-prefeito], que tem boa parte da Serra, e tem uns pequenos, que têm um pedacinho de terra”, aludindo aos proprietários que são da região, que são os que permitem a colheita em suas terras. "Quando a gente acha um gerente na Serra que ajuda, a gente entra e pega, até porque onde planta eucalipto não é onde a sempre-viva nasce. [...] Essa Serra dá coisa demais! O que tem de coisa que a gente pega nessa Serra e vive disso, cê não sabe!"

Os discursos técnicos referentes ao sertão transitaram da pobreza de recursos à abundância que precisa ser aproveitada, pois a metamorfose das alocuções evidencia como as relações capitalistas convertem as diferenças naturais em sociais, mas também como o progresso técnico tem a capacidade de converter a natureza em produto mercantil a ser extraído. No próprio Grande sertão: veredas, o Liso do Sussuarão, que na primeira travessia era árido e mortífero, aparece como um oásis na segunda cavalgada, quando Riobaldo Tatarana já ascendia ambiciosamente a Urutu Branco ${ }^{278}$. Apesar de nas passagens ficcionais o sertão ser interpretado na sua ambiguidade, e, talvez, como um purgatório onde os homens passam pela provação ${ }^{279}$, não se pode ignorar o contexto de tessitura da obra, em cujo momento o Brasil experimentava submeter seus territórios à tecnocracia.

Os tecnocratas entrevistados entenderam que o cerrado, não mais o sertão, é como um diamante bruto a ser lapidado e vendido a bom preço, e o manejo, sinônimo de técnica, é a chave para a sua gestão. O que atrapalha é o sertanejo, que, dentro do invólucro da mobilização para o trabalho, pode ser educado para aprender a lidar com o meio em que vive, porque cada

\footnotetext{
278 “O que era - que o raso não era tão terrível? Ou foi por graças que achamos todo o carecido, nãostante no ir em rumos incertos, sem mesmo se percurar? De melhor em bom, sem os maiores notáveis sofrimentos, sem em-errar ponto. O que era, no cujo interior, o Liso do Sussuarão? - era um feio mundo, por si, exagerado. O chão sem se vestir, que quase sem seus tufos de capim seco em apraz e apraz, e que se ia e ia, até não-onde a vista não se achava e se perdia. [...]

Eu que digo. Mesmo, não era só capim áspero, ou planta peluda como um gambá morto, o cabeça-defrade pintarroxa, um mandacaru que assustava. Ou o xiquexique espinharol, cobrejando com suas lagartonas, aquilo que, em chuvas, de flor dói em branco. Ou cacto preto, cacto azul, bicho luís-cacheiro. Ah, não. Cavalos iam pisando no quipá, que até rebaixado, esgarço no chão, e começavam as folhagens - que eram urtigão e assapeixe, e o neves, mas depois a tinta-dos-gentios de flor belazul, que é o anil-trepador, e até essas sertaneja-assim e a maria-zipe, amarelas, pespingue de orvalhosas, e a sinhazinha, muito melindrosa flor, que também guarda muito orvalho, orvalho pesa tanto: parece que as folhas vão murchar. E erva-curraleira... e a quixabeira que dava quixabas.

Digo - se achava água. O que não em-apenas água de touceira de gravatá, conservada. Mas, em lugar onde foi córrego morto, cacimba d'água, viável, para os cavalos. Então, alegria. E tinha até uns embrejados, onde só faltava o buriti: palmeira alalã - pelas veredas. E buraco-poço, água que dava prazer em se olhar. Devido que, nas beiras - o senhor crê? - se via a coragem de árvores, árvores de mata, indas que pouco altaneiras: simaruba, o anis, canela-do-brejo, pau-amarante, o pombo; e gameleira. A gameleira branca!” (ROSA, 1986, p. 448-449).

${ }^{279}$ Recorrendo-se à análise comparativa entre as leituras que os literatos fizeram do sertão entre os séculos XIX e XX e A divina comédia, de Dante Alighieri, proposta por Fernando Cristóvão (1994).
} 
vez mais a educação tem se revelado uma ferramenta de controle da população descartável, bem como um meio aparentemente menos violento de inserção à esfera psicossocial moderna.

Em consonância às vozes dos funcionários do Projeto Hidroagrícola Jequitaí, o que consta no seu relatório de impacto ambiental vem ao encontro da preocupação ecológica. $\mathrm{O}$ discurso ambientalista começa a ser timidamente apropriado pelo Estado como estratégia, seja porque precisa reservar parcela de recursos para potencial exploração futura e assim adiar o suspiro final do colapso, seja porque entrevê algum ganho com as reservas, como a especulação futura com as terras, ou seja, ainda, porque criar reservas florestais é diretamente mais uma ferramenta de promover a expropriação em favor de interesses particulares. A tática do Estado em ecoar a crise ambiental encobre a crise da terra, que precisa estar sempre produtiva para o capital.

No caso da barragem, está prevista a formação de um cinturão verde em seu entorno, composto por corredores ecológicos. Assim comenta o estudo:

\begin{abstract}
Ambientalmente o empreendimento terá impactos positivos para a região onde se insere, como será exaustivamente analisado no Prognóstico Ambiental, podendo-se destacar a regularização das cheias e regularização da oferta de água, o estabelecimento de uma área de reserva legal importante para a proteção da fauna e flora local, a geração de empregos diretos e indiretos e o desenvolvimento regional, além de outros impactos de grande importância sobre os meios ambiente físico, biótico e socioeconômico. (CODEVASF, 2005, p. 8).
\end{abstract}

Apesar de se saber que o sistema produtor de mercadorias inerentemente causa danos ao meio ambiente, existe a crença de que é possível um novo "capitalismo natural" ou "capitalismo climático", em que o sistema econômico muda seu papel de inimigo do meio ambiente para seu salvador. Na arguição para o $V$ Colóquio Marx e Engels, ao discutir a atualidade de Marx para o debate ambiental, Antônio Andrioli comenta que a solução de antigas destruições ambientais e o impedimento de novas é esperada, exatamente, da utilização do mesmo mecanismo que contribuiu para que se instaurasse a situação catastrófica em que a natureza se encontra.

Como se não bastasse, o autor alude que taxar as corporações pelos danos ambientais pressupõe que os capitalistas desenvolvam uma espécie de consciência de sustentabilidade para a manutenção do modo de produção vigente. Atinente à falência do sistema em que o mundo está preso, o discurso ecológico é mais uma prova do colapso da modernização, porque é a percepção da destruição do capital sobre a base necessária à reprodução da vida. Mas perceber o colapso não tem significado uma ruptura assente com o modelo em voga; antes, os discursos e as propostas se preocupam mais em salvá-lo. 
No entanto, apesar das mudanças qualitativas da acumulação, em que há um grau decrescente da utilização tanto da capacidade produtiva quanto do trabalho empregável, continua-se a confiar no desperdício em suas várias formas (gastos militares, obsolescência programada etc.) para gerar a escassez e manter os mercados funcionando, cultivando a sua forma contraditória de ação.

Nesse contexto, desde 2008-2009, quando a Plantar começou o seu cultivo de eucalipto em larga escala e as primeiras nascentes da Serra começaram a secar - o que causou esvaziamento periódico das piscinas municipais, abastecidas com a água corrente do córrego do Barreiro e importante fonte de renda para o turismo local -, uma pequena parcela da população de Francisco Dumont começou a se mobilizar em torno da ideia de ampliação dos limites do Parque Estadual Serra do Cabral, cuja sede se situa em Buenópolis.

\section{Mapa 16 - Mapa do Parque Estadual da Serra do Cabral (limites em azul)}

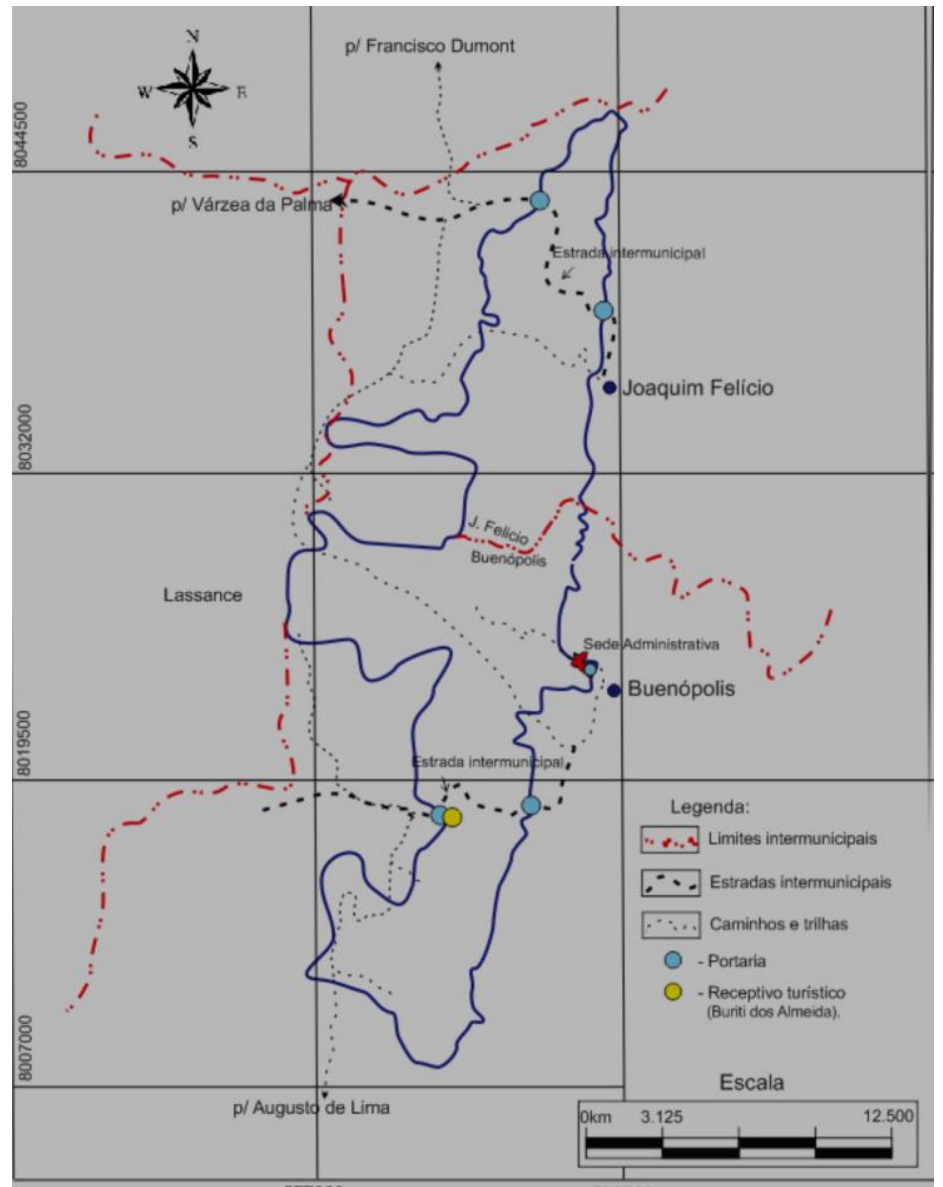

Fonte: Plano de Manejodo Parque Estadual da Serra do Cabral, 2015, p. 160.

O parque foi criado em 2005, mas apenas dez anos depois saiu o seu plano de manejo. Apesar de a maior parte da Serra, inclusive sua biodiversidade, estar em Francisco Dumont, os 
rigores da gestão das Áreas de Proteção Ambiental (APA) não incluem o município; só Buenópolis e Joaquim Felício são abrangidos pelos seus limites.

Na defesa de sua ampliação e na denúncia das violações de leis ambientais estão alguns moradores do perímetro urbano de Francisco Dumont, a maioria pessoas dispensadas do sistema produtivo. A agitação em torno da questão ambiental inicialmente colocou seus membros em inimizade com os adeptos das benfeitorias que as reflorestadoras fizeram desde a sua chegada, como o emprego com carteira assinada, a melhoria das estradas, a arrecadação de impostos municipais etc., pois a população se vê dependente desses empregos escassos e impostos. Porém, conforme a escassez de água passa a prejudicar também a zona rural e os pequenos produtores, ocorre paulatinamente a mudança de visão.

De acordo com os defensores do meio ambiente local, o objetivo maior é ampliar o tamanho do parque, legalizando para isso uma espécie de Organização Não Governamental (ONG) que articule melhor a luta em prol do cerrado. Em 2019, o Instituto Serra do Cabral foi registrado, mas engatinha no tocante às ações ambientais e mesmo em seus objetivos. Como contou-se com a presença de ao menos um de seus membros em todos os campos realizados mata adentro, foi possível coletar depoimentos sobre as intenções do projeto e suas contradições.

Eles não defendem apenas a extensão das APA, mas também a introdução do ecoturismo como fonte de renda, gerando empregos para guias nos variados roteiros que a Serra oferece, a demarcação dos limites territoriais das atrações que devem pertencer ao município, a manutenção das trilhas, a criação de atividades socioeducativas e também de cargos administrativos no parque, que, ao serem criados, postulariam técnicos afeitos à questão ambiental. A permanência do eucalipto também é alvo de preocupação, apesar da sensação de incapacidade em lutar contra sociedades anônimas absentistas. Para amenizar o convívio entre reflorestadoras e meio ambiente, o instituto insiste na obediência às leis ambientais que respeitam a distância das veredas no cultivo do eucalipto para manter as fontes de água, pois a ausência de um discurso ambientalista por parte dessas empresas dá margem para acusá-las da maior devastação na Serra.

O movimento local clama, portanto, por mais Estado moderno e todo o seu aparato jurídico, interessado em incluir sua proposta ambiental no mercado. Em linhas gerais, essa comodificação da natureza se sintoniza com a lógica neoliberal em torno do comércio ecológico encorajado pelo Estado, que monetiza os serviços ambientais e introduz novas relações sociais e novos espaços rurais, pois diz respeito ao uso da terra com a introdução de novos regimes colonialistas sob novos modelos de propriedade. Na Serra, suas lideranças querem trabalho 
assalariado e mercantilização da natureza por meio da valorização econômica do seu conhecimento do território natural, oferecido como serviço para o ecoturismo.

Concordando com Robert Kurz (1995), somaram-se aos problemas sociais os problemas ecológicos enquanto consequência da modernização. O mercado, insuficiente para lidar com a situação, volta à sua racionalidade apenas para a minimização abstrata dos custos de produção, "externalizando" os custos sociais e ecológicos, pois o dinheiro, abstrato por sua própria natureza, é indiferente ao conteúdo sensível. O sertão, que já se digladiava com o avanço das formas econômicas predatórias desde a expansão colonial, ingressa no século XXI vulnerável à perda das suas qualidades sensíveis, empalidecido de seu encantamento e de sua condição dúbia de espaço místico e de provação ${ }^{280}$. Para os marxistas preocupados com a questão ecológica, a concretização do capitalismo monopolista acelerou o uso dos recursos e a consequente devastação das reservas.

Como se as reflorestadoras não causassem inquietude suficiente, a especulação sobre os vastos hectares nas mãos de transnacionais também é preocupante. Muitas das propriedades permanecem intocadas pelas corporações de grande vulto, dando ao capital, via grilagem e outras irregularidades, a garantia de se apropriar gratuitamente da fertilidade natural dessas terras, inacessíveis à população da Serra que, não bastando ser refém da expropriação presente, tem o seu futuro também comprometido.

Enquanto as reflorestadoras têm se apropriado em seu favor apenas parcial e recentemente dos discursos ambientalistas, outros empreendimentos produtivos já se apresentam mais atentos à moda do "capitalismo ecológico", adotando na propaganda dos novos cultivos introduzidos na Serra a ideia da sustentabilidade. É o caso da Ecoagrícola, antiga reflorestadora Scai, que hoje cultiva café selecionado para exportação. Em seu site oficial, a empresa se apresenta assim:

[...] Nossa família começou a fazer projetos florestais na década de 1970, preservando grandes pedaços de terras na Serra do Cabral. Na década de 2000, ao fazer planos para os próximos 30 anos, introduzimos a cultura do café, devido ao seu grande ajuste com a região. Sua altitude, clima, água e terroir são perfeitos para o desenvolvimento de cafés especiais. Também, nós estamos entusiasmados por produzir produtos únicos e sustentáveis de qualidade, como os cafés que nós estamos cultivando cuidadosamente. Nosso primeiro viveiro foi plantado em 2006 e a primeira safra colhida em 2009. Qualidade e produtividade foram testados e alcançaram notas altas. Desde então, alcançamos ótimos resultados e estamos constantemente melhorando. Nossos cafés podem ser encontrados com os nossos parceiros torrefadores e cafeterias de muitos países, em cinco continentes. (QUEM SOMOS, c2019a).

${ }^{280}$ Essa transformação do sertão foi discutida em dissertação de mestrado $O$ sertão $e$ suas metamorfoses em "Sagarana" e "Primeiras Estórias", de João Guimarães Rosa (PELISSARO, 2011), a partir da análise de contos selecionados. 
Ou seja, as transformações qualitativas do capitalismo não só induzem a mudar o tipo de produto, como agora ocorre também a apropriação do discurso ecológico como propaganda em favor da qualidade do que se produz, adotando a moda do greenwashing ${ }^{281}$. Ainda na apresentação, nota-se a reprodução ampliada do capital no sentido não apenas da empresa se apropriar da terra, como, dentro do movimento geral, torná-la produtora de artigos que circulem mundialmente, devidamente embalados para o status de consumo ecologicamente consciente.

Com vias a explicar a excepcionalidade da Serra do Cabral como causa da escolha para os cafezais, a empresa argumenta que o clima é favorável à produção do café de qualidade, pois os meses de colheita (junho a setembro) se inserem no período de estiagem na região, que vai de maio a outubro. Com isso, não havendo nenhuma chuva, é "o clima ideal para secar os cafés em nossos pátios e canteiros", assim como "o clima ameno com dias ensolarados e noites frias fornecem o ambiente ideal para a produção de grãos de alta qualidade". Obviamente, o texto oculta a chegada da empresa à região, que se deu por conta do baixo custo da terra, adquirida a créditos estatais, e do valor irrisório da força de trabalho.

O rótulo de café ecológico e a galeria virtual de fotos de seus donos e representantes em meio a funcionários felizes camuflam outra versão da história, apresentada no depoimento de um ex-funcionário e um funcionário na ativa. Um deles é Júlio César Bruzinga Sousa, Chula, 26 anos (2020), nascido em Francisco Dumont. Sua trajetória é uma amostra recente da sina de muitos jovens da região, que migram sentido Belo Horizonte e outras cidades grandes, mas retornam por conta da escassez de emprego.

Ao voltar para Francisco Dumont, Chula conseguiu emprego desgalhando eucaliptos para as carvoeiras. Após pular de serviço em serviço sem carteira assinada, conseguiu um contrato com registro na Ecoagrícola, de agosto de 2018 a fevereiro de 2019. Lá, ganhava por produtividade - centavos por caixotes preenchidos -, fazendo a derriça do café colhido, pegando os grãos que a máquina dispensava e jogando-os nos quadrantes para a secagem.

Distante de Francisco Dumont 61 quilômetros, a empresa fornece alojamento para seus funcionários passarem a semana, distanciando a 2 quilômetros homens e mulheres. Perguntado sobre como fazia para chegar até lá, o jovem disse que a prefeitura de Francisco Dumont fornece exclusiva e gratuitamente o ônibus para levar os trabalhadores até a Ecoagrícola, mas mesmo assim preferiu deixar o trabalho para retornar às carvoeiras. Apesar de também receber por produção, disse que no carvão a possibilidade de ganho é maior, em torno de 100 reais por dia.

\footnotetext{
${ }^{281}$ Ou "lavagem verde", o termo se refere a empresas públicas e privadas que adotam o discurso de sustentabilidade enquanto suas práticas permanecem danosas ao meio ambiente.
} 
A sazonalidade do café faz com que, após os contratos, quem permanece receba apenas um salário-mínimo para o trato dos cafezais, que não empregam tanto, dado o patrimônio em máquinas de alto valor agregado.

Questionado sobre a qualidade ecológica do café, Chula disse que a empresa é bem cuidada e por isso ganha certificações ambientais, mas que o produto recebe muito veneno. As máquinas fazem a aplicação do agrotóxico, os poucos funcionários que estão na dianteira dessa função usam vestimenta específica e os outros têm de ficar afastados, aguardando o término do serviço.

O uso de agrotóxicos no café ecológico foi confirmado por Ítalo Bernardo Costa Almeida, 28 anos (2020), chefe de turma de serviços braçais na Ecoagrícola há pouco mais de um ano. Segundo o jovem, o café não é totalmente orgânico, visto que recebe insumos por conta dos $10 \%$ de cerejas que as máquinas não alcançam na colheita, que, ao apodrecerem, provocam pragas, justificando assim o uso de agrotóxico.

Nascido em Francisco Dumont, Ítalo crê que o diploma de engenheiro foi um facilitador para o emprego, tendo em conta que os 2 mil hectares da Ecoagrícola empregam pouco mais de 100 funcionários fixos - ele mesmo é responsável por turmas de 30 a 50 pessoas no período da colheita. De todo esse montante de terras, o cultivo de café ocupa apenas 340 hectares, o restante dividido entre o que sobrou do pinho do tempo da Scai e mais de mil hectares de mata nativa. "Tem muita terra parada", afirma.

Segundo ele, o que sobrou da silvicultura ainda é usado na propriedade para o aquecimento das serpentinas dos alojamentos e a secagem artificial do café. A escolha pelos cafeeiros se deu entre os filhos do dono da Scai, após o insucesso do pinho frente à concorrência dos eucaliptos. A abundância de recursos hídricos convenceu os herdeiros, que no começo dos anos 2000 iniciaram o cultivo em 40 hectares, com as espécies arábicas Catuaí (vermelho) e Catucaí (amarelo).

Ao dar detalhes de sua função, Ítalo comenta que é responsável pela etapa de lavagem, seleção e descasque do café, a chamada via úmida. Quando perguntado sobre o mister de seus encarregados, responde que são contratados para a colheita das cerejas que as máquinas não alcançam, pois embora a Ecoagrícola possua três colheitadeiras de café eficientes, os restos precisam ser colhidos por gente. Quanto às máquinas, são duas Matão, que retiram $70 \%$ dos frutos e precisam da tração de tratores, e uma K3 Millenium, ostentando o que há de mais arrojado no ramo: garante a colheita de $90 \%$ de um cafeeiro a partir dos sensores, que lhe conferem locomoção, e da visão permitida ao piloto, alojado em cabine a 10 metros de altura. Importadas, cada uma custa mais de 1,5 milhão de reais, e essa fazenda é um dos dois únicos 
lugares no norte mineiro onde a máquina é encontrada. Para o seu manuseio, a empresa fornece anualmente treinamento in loco, sendo preciso contratar funcionários especializados fora da Serra.

\section{Figura 39 - K3 Millenium na colheita de café na Ecoagrícola}

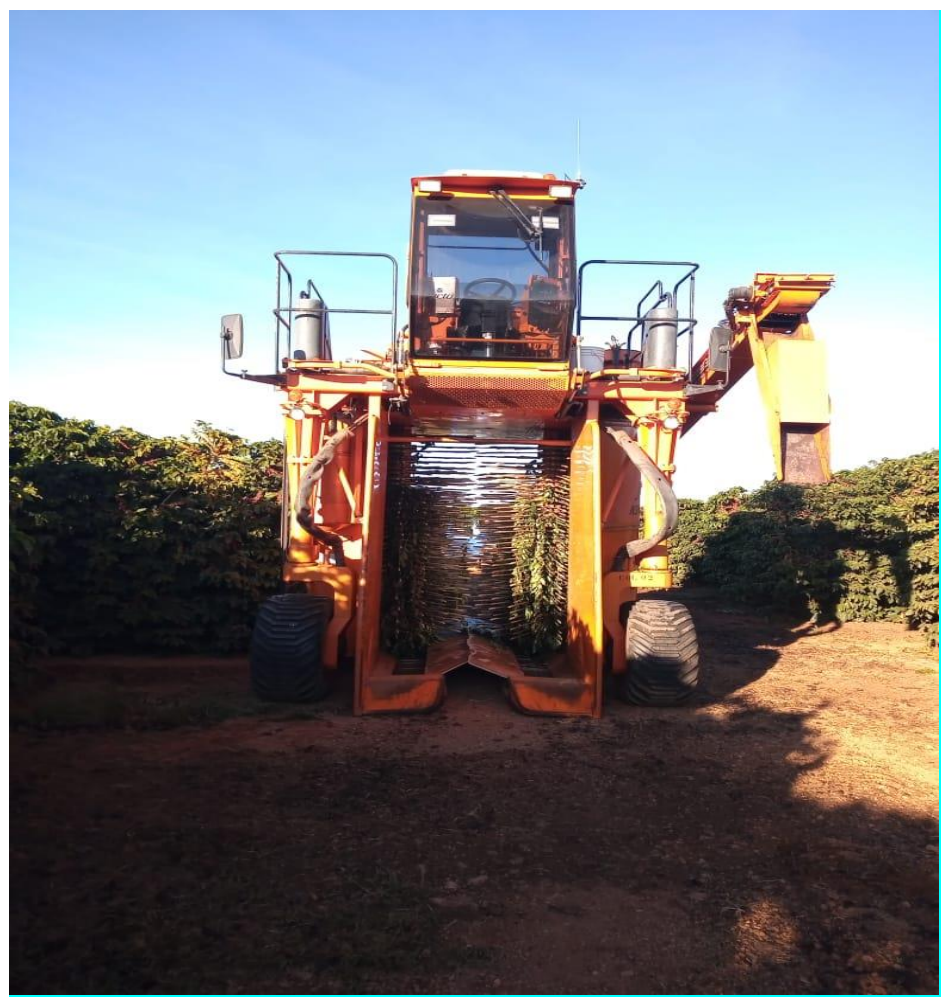

Fonte: acervo pessoal de Ítalo Almeida, 2020.

Perguntado sobre a automação do cultivo, Ítalo deixa claro que a K3 cobre de 1,5 a 3 hectares por dia, serviço que 50 pessoas não conseguem executar no mesmo intervalo de tempo. A manutenção dos pés de café também expulsa força de trabalho: cada roçadeira usada pela Ecoagrícola faz em algumas horas o que 10 funcionários fazem em um dia. Ítalo também lamenta que a empresa está dentro dos limites de Francisco Dumont, mas não beneficia o município, já que movimenta o comércio apenas de Várzea da Palma, que, por sua vez, fornece a maioria da mão de obra empregada, visto que dista da fazenda 52 quilômetros, com estradas melhores e mais movimentadas.

De forma a cumprir com a sua responsabilidade social empresarial, a Ecoagrícola distribui toda semana 10 quilos de café para cada prefeitura da Serra do Cabral, além de possuir um viveiro com espécies nativas para a manutenção das três nascentes que se encontram em sua propriedade, uma delas afluente do Riachão. A propaganda de produção de café ecologicamente sustentável não apenas lhe garante mercado externo - 90\% de sua produção são exportados para países como Austrália, Canadá, Alemanha e Inglaterra -, como também 
lhe rende duas certificações internacionais, a UTZ e Rainforest Alliance ${ }^{282}$, além dos prêmios que o produto vence mundo afora, exibidos em seu site oficial.

Empregando o discurso da sustentabilidade, a Ecoagrícola tem realizado atividades de conscientização ecológica com as crianças das escolas públicas da região. Além disso, para comprovar seu discurso de responsabilidade social e ambiental, consome produtos locais e participa da diretoria da APA Serra do Cabral.

\begin{abstract}
Além disso, compramos os produtos das comunidades locais para o nosso refeitório, como frutas, queijos, doces, carnes, pães. No passado, estes pequenos produtores não podiam vender a empresas, devido à falta de documentos formais. Começamos um programa de Educação Fiscal com eles, totalmente com Emater e agora, além de nos fornecer, eles são capazes de vender seus produtos para muitos mercados.

Ecoagrícola é membro da diretoria do Parque Estadual da Serra do Cabral, que fica a $20 \mathrm{~km}$ da fazenda. Participamos das atividades do parque e ambas as entidades unem forças em nossos programas de Educação Ambiental, direcionadas para escolas e comunidades.

Nossa equipe é constantemente treinada e qualificada, para que todos possamos fazer um trabalho melhor a cada dia e ano após ano.

A fazenda é certificada pelas instituições internacionais UTZ e Rainforest Alliance, garantindo o bom funcionamento de todo o processo. (QUEM SOMOS, c2019a).
\end{abstract}

Perguntado sobre as terras ociosas que a Ecoagrícola possui e se há algum problema com ocupação, Ítalo comenta que a presença de fiscais monitorando a propriedade assegura a integridade da propriedade. Sobre a intenção dos donos de expandir os cafeeiros, Ítalo diz que eles "têm muita terra parada", tendo ouvido que "Estão com um planejamento de no ano que vem [2021] plantar soja - lavoura branca que eles chamam. Mil hectares só disso. Estão com uma parceria pra isso". O rumor é de que a empresa conciliaria soja e outro grão, "um do lado do outro". Boato ou não, o chefe de turma desconfia que a monocultura ocupe o vasto terreno de cerrado nativo. Dados os históricos incentivos fiscais para exportação de commodities, mecanização da soja cerrado brasileiro afora e a tecnologia empregada no cultivo de café, não há como não notar a negatividade da modernização, cujo processo de produção social deixa de ser um processo de trabalho.

Enquanto o plano para a soja não se concretiza, a venda da imagem de uma empresa responsável para com o seu entorno tem seduzido até mesmo os defensores ambientais locais mais radicais. Uma das razões é a urgência do emprego, em que a forma social imposta é a da

282 "A UTZ é um programa de sustentabilidade para café, cacau e chá que opera em conjunto com as marcas existentes. Os fazendeiros podem melhorar sua produtividade, qualidade dos produtos e eficiência, cuidando das pessoas e do meio ambiente. Isso permite que eles produzam maiores volumes por menores custos, o que melhora o padrão de vida das comunidades agrícolas. Os consumidores podem usufruir de sua marca favorita e, simultaneamente, contribuir para um mundo sustentável. [...] As despesas da UTZ são cobertas pela taxa de administração paga pelos compradores registrados na UTZ e por subsídios da União Europeia e de ONGs." (O QUE É A UTZ?, c2021). 
mediação do dinheiro para aquisição dos bens básicos à sobrevida e à reprodução das famílias. Conforme são expropriados e se tornam assalariados, cada vez menos os sertanejos produzem os víveres para consumo, o que se comprova pelo número crescente de mercados e armazéns nos municípios da Serra nos últimos anos.

Uma questão que se coloca é se estaria o discurso ecológico disposto a romper com a forma social capitalista. Após observar por 11 anos o movimento que culminou no Instituto Serra do Cabral, acredita-se que não. Ao não romper com a forma mercadoria, continua-se condenando abstratamente a humanidade e perdoando o sistema que a coloca contra a natureza ${ }^{283}$ - o que não é para menos, afinal, a sociedade contemporânea se compõe de sujeitos autômatos.

Neste ponto, retoma-se a discussão marxista de ruptura metabólica levantada por John Foster (2012a), atentando-se para a perspectiva ontológica de trabalho na relação orgânica entre sociedade e natureza e sua ruptura para se pensar o sertão. No artigo A natureza na "contradição em processo", Daniel Cunha passeia pela questão ambiental presente em alguns autores marxistas a partir do viés particular do autor sobre a crítica do valor. Introduzindo a natureza como capital circulante e parte do capital constante, ele discute como não é suficiente reduzir a crise ecológica à externalização e degradação, exemplificadas nas mudanças climáticas e na finitude dos recursos. A crise ecológica também deve ser internalizada dentro da lógica de produção de valor, relacionada aos limites da valorização: o valor da natureza cresce enquanto as fronteiras de mercadorias se exaurem, ao mesmo tempo em que o trabalho vivo é eliminado do processo imediato de produção.

As fronteiras de mercadorias mencionadas por Daniel Cunha são aqui entendidas como o movimento de reprodução ampliada do capital, o que inclui o avanço territorial sobre espaços onde os recursos naturais, considerados capital circulante em vias de ser apropriado para reduzir o custo de produção, de forma a baratear o capital fixo. Tal visão, porém, não pode descartar a apreensão das formas pretéritas de produção do espaço, que, na ótica da economia moderna, devem ser naturalizadas. Sem dúvida, esse avanço porta consigo a violência comum à

\footnotetext{
${ }^{283}$ Há um debate contemporâneo interessante que advoga em favor de uma nova era, o período Antropoceno, na qual a humanidade, sobretudo a partir da Revolução Industrial, seria a grande responsável pelas transformações climáticas do planeta. Criticando a generalização burguesa e a falta de historicismo, o sociólogo Jason Moore (2017) defende o conceito de Capitaloceno (a "era do capital"), explicando que é o capitalismo em si, na sua longa história iniciada com Colombo, o grande responsável pelo desastre total pelo qual o mundo passa. Portador do pensamento ocidental de cisão entre Humanidade e Natureza e impositor de desigualdade, imperialismo, patriarcado, racismo, mercantilização etc., o Capitaloceno também é chamado de Necroceno, dado que o capitalismo pode ser definido por uma combinação de violência produtiva e, ao mesmo tempo, exterminadora da vida humana e não humana. Apesar de o autor compreender a expansão do capital como uma acumulação primitiva constante, sua análise interessa por não responsabilizar genericamente grupos que seguem vítimas da violência imposta pela socialização do valor.
} 
imposição do valor no decurso da territorialização do capital, o que revela a historicidade do seu movimento.

Historicamente, a expansão do capital teria de compensar a queda da massa de maisvalia através do aumento da taxa de mais-valia relativa, movimento de crise consolidada da própria criação de valor, cujo marco, segundo Robert Kurz (1994), se deu na década de 1970, com a microeletrônica e o consequente avanço do desemprego estrutural mais o colapso de Bretton Woods (CUNHA, 2019).

Assim, o crescimento exponencial tem de avançar sobre espaços sociais ainda não plenamente conquistados pela acumulação de capital - aqui entendidos como uma histórica inclusão precária -, o que inclui o aumento da escala produtiva, incorporando regiões do globo onde também se conquistam ramos da realização do valor sob a forma de subsistência e a criação de novas esferas producentes (novas necessidades) à medida que os antigos meios eliminam trabalho no processo imediato de produção. A crescente produtividade laboral na confecção de mercadorias implica um aumento do volume de energia e de matérias-primas sobre o tempo de trabalho. Porém, as condições biofísicas diferenciadas de extração dos recursos resultam em uma "tendência de queda do excedente ecológico" (CUNHA, 2019, p. 128), deixando implícita a geografia desigual e diferenciada da natureza. Assim, o movimento de expansão das fronteiras de mercadorias, globalmente, mediará o valor da natureza e, em consequência, a composição orgânica do capital.

Referindo-se à noção de ruptura metabólica que Foster (2012a) colheu em Marx e buscou requintar, ela é apresentada e defendida pelo sociólogo como uma noção transistórica de dialética como método universalmente aplicável. Se a mercadoria é o ponto de partida regente da sociabilidade moderna, a dialética que a acompanha também tem particularidade histórica, só podendo ser percebida dentro do histórico sistema produtor de mercadorias ${ }^{284}$.

Partindo-se do valor como categoria fundamental, esse sistema organiza a natureza para produzir capital circulante barato. Conforme os regimes de acumulação e suas tecnologias mudam (da Revolução Industrial ao fordismo e ao neoliberalismo), os regimes ecológicos também se modificam ao produzir "naturezas históricas” adequadas para a valorização do valor. $\mathrm{Na}$ Serra, as areias aluviais e os cascalhos já foram enxergados como recursos passíveis de apropriação pela mineração diamantina, bem como as vargens, com seus pastos naturais, para

\footnotetext{
284 "Foster não percebe a especificidade histórica da dialética, ancorada em um sistema histórico baseado na produção de mercadorias. Assim, fica claro que Foster não pode compreender o fetichismo como inversão real de sujeito e objeto. Essa ontologia da dialética caminha de mãos dadas com o entendimento do fetichismo como mero "véu' e com a ontologia do trabalho." (CUNHA, 2019, p. 133, destaques do autor).
} 
o gado. Com o desenvolvimentismo, as chapadas, antes invisíveis ao regime de acumulação, se tornaram meio natural prenhe de terra, água e outras riquezas, para onde a fronteira das mercadorias investe, pois são estas que, historicamente junto às metamorfoses das técnicas, dinamizam a economia e a acumulação.

Ao tornar a natureza (selecionada) capital circulante, aplica-se o processo moderno de cisão entre esta e a sociedade, conduzindo à aniquilação de ambas. Toda essa dinâmica é o que torna possível classificar o capital como uma contradição em processo, pois ele tem no trabalho abstrato o seu padrão de riqueza, mas ao mesmo tempo elimina a sua substância, o trabalho vivo, do processo imediato de produção à medida que a sua composição orgânica segue a tendência de aumento. Percebe-se o colapso da modernização na escassez das águas e dos frutos do mato, sem se decifrar o motivo do mal-estar existencial de alguns dos entrevistados, provocado pela falência da sociedade do valor e suas expropriações.

Sendo a Plantar, a Scai ou a Ecoagrícola as donas das plantations, ou mesmo a Engetel, a Vallourec Mannesmann e a TTG Brasil Investimentos Florestais as proprietárias-fantasma de terras ociosas, aos moradores da Serra continua vedada a simples circulação pelo mato para buscar até mesmo remédio. Este foi o lamento de José Telheiro, cujo irmão Geraldo estava doente na ocasião da última visita, em julho de 2019: “A gente podia entrar no mato e fazer o que quisesse, ninguém ligava. Hoje, cê entra pra pegar qualquer coisa procê ver, as firma não deixa, cercaram tudo".

Após ter-se ouvido José, supõe-se que o discurso ecológico respalda mais uma forma de expropriação como alicerce do desenvolvimentismo enquanto engrenagem da reprodução capitalista do espaço, permitindo a ele a apropriação dos recursos para exploração futura como forma de solucionar as crises sistêmicas inerentes ao seu processo. Com isso, seja pela iniciativa empresarial de responsabilidade ambiental empresarial, seja pela criação de parques e corredores estatais, o meio ambiente começa a integrar o planejamento regional do Estado moderno, na tenção de perpetuar uma relação social mais e mais estéril.

O planejamento territorial de governo objetiva homogeneizar a reprodução do capital e suas formas, com vias ao desaparecimento das regiões. Porém, as contradições do sistema apontam para uma realidade que destoa dos planos do Estado. "Tal tendência quase nunca chega a materializar-se de forma completa e acabada, pelo próprio fato de que o processo de reprodução do capital é por definição desigual e combinado" (OLIVEIRA, 1988, p. 27). Oliveira, com a assertiva, não deixa de cair no dualismo dentro da própria crítica que faz, apesar de insistir na impossibilidade de homogeneizar o território. Assim, por mais que a Sudene e tantos outros projetos governamentais intentassem integrar o sertão à engrenagem econômica 
nacional e internacional, implantando técnica, o norte de Minas Gerais continuou reproduzindo os conflitos, que têm entre as suas raízes o acesso à terra e ao que ela contém.

\section{Mapa 17 - Cobertura do solo e formas atuais de seu uso na Serra do Cabral (2021)}
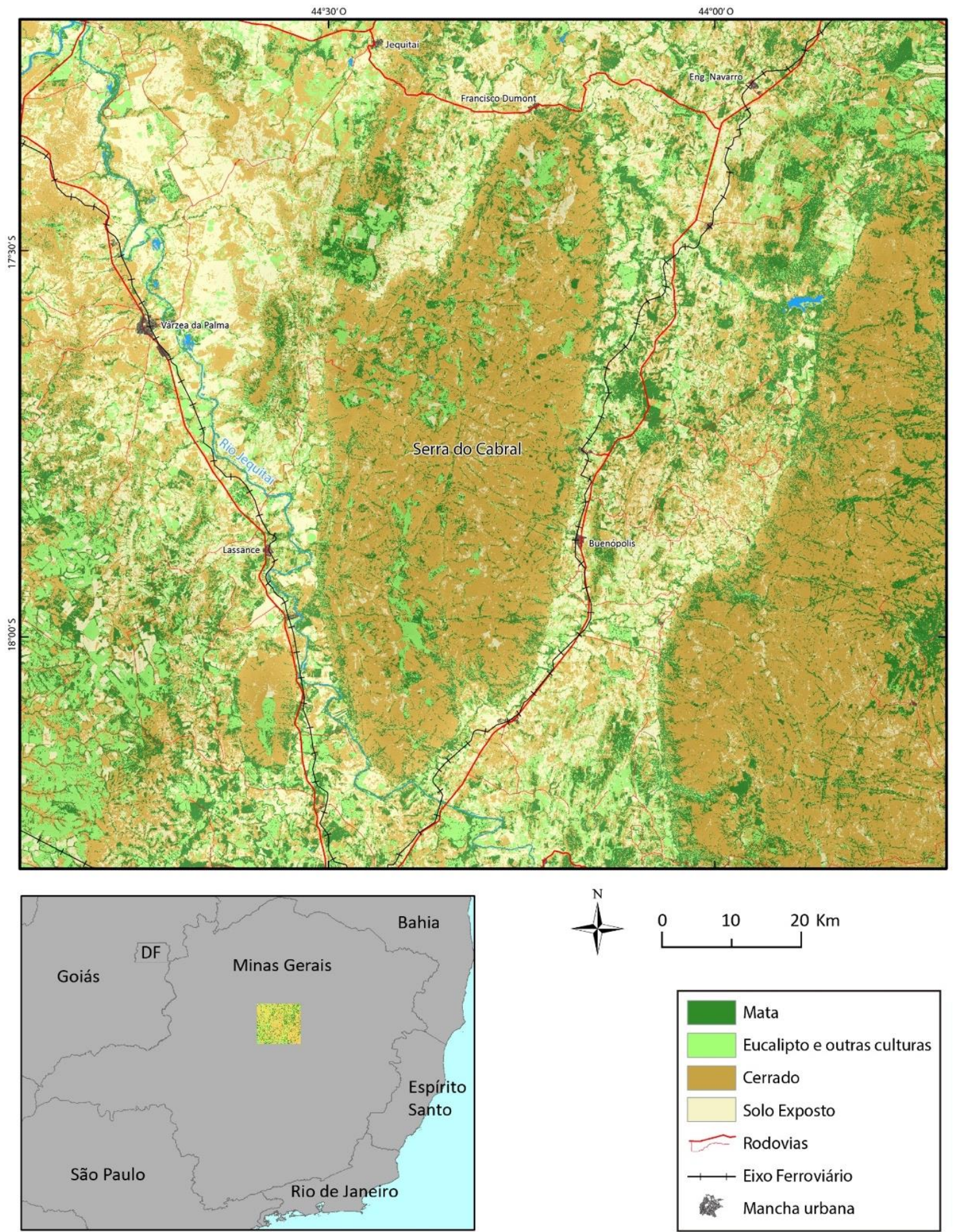

Fonte: Eduardo Justiniano, 2021 (elaborado para este estudo). 
Se as desigualdades persistem porque o mercado cresce, o Estado também deve crescer e se valer intensamente de todos os seus dispositivos para "corrigir" aquilo que considera desordem, pois ele não só é o alicerce e garantidor da realização do mercado, como também tem no seu horizonte um modelo de desenvolvimento a alcançar. Tal modelo, o do sistema produtor de mercadorias ocidental, o impele a impulsos de modernização nas regiões julgadas atrasadas, tendo que assumir o caráter de um desenvolvimento retardatário forçado (KURZ, 1992b).

$\mathrm{O}$ aparato jurídico e a violência monopolizada são duramente empregados sobre os sujeitos monetarizados sem dinheiro toda vez que estes ousam atrapalhar a aparente harmonia da produção de valor. De todos os depoimentos ouvidos, as queixas mais comuns se voltam contra a geração de emprego na silvicultura concomitante às leis governamentais que criminalizam o garimpo de diamantes na Serra justificando que a faiscação degrada o ambiente.

A modernização retardatária é uma promessa de futuro de alcance impossível. Porém, na busca ilusória de alcançar esse porvir, os mecanismos adotados no presente se impõem brutais. Sua máquina destruidora "automatiza, racionaliza e libera grandes volumes de trabalhadores, criando dentro da sua lógica um mundo às escondidas, ilegal, indocumentado e informal" (HEIDEMANN, 1998, p. 3). Esses volumes de trabalhadores descartáveis, presos na liberdade moderna, se submetem a coações extraeconômicas de exploração, o que é visto como oportunidade. $^{285}$

Em sociedades de modernização tardia, o Estado como empresário se torna o agente desbravador das regiões resistentes às novas formas de produção. Para Robert Kurz (1995), tal ação não seria um mero acaso, pois em muitos países somente a máquina estatal, através da

${ }^{285}$ Algumas matérias publicadas em veículos da imprensa denunciam essa violência extraeconômica, por exemplo:

Resgatados em situação análoga ao trabalho escravo no Norte de MG buscam no Ministério do Trabalho acerto com empregador. Quatorze trabalhadores foram encontrados em uma fazenda na zona rural de Jequitaí; dívida entre patrões e trabalhadores gira em torno dos R \$ 100 mil. (G1 GRANDE MINAS, 2017).

Carvoaria mantinha 23 trabalhadores em situação degradante no Norte de Minas. A Inspeção do Trabalho em Minas Gerais resgatou na quarta-feira (14/11/2018), um grupo de 23 trabalhadores submetidos a trabalho análogo ao de escravo numa carvoaria em Jequitaí município da região norte do Estado. (CARVOARIA..., 2018).

Escravos do século 21: auditores do Ministério do Trabalho já resgataram 102 pessoas em flagrante de trabalho escravo no Norte de Minas neste ano. Crime estaria avançando nas carvoarias. A cidade que mais tem registros de mão de obra escrava na região é Coração de Jesus (89), seguida por Jequitaí (53), que está a 102 quilômetros de Montes Claros, maior município do Norte de Minas, que dispõe de unidades do Ministério Público do Trabalho (MPT) e do tem. (ANTONINI, 2019). 
acumulação centralizada do "trabalho abstrato", poderia alavancar o estabelecimento de uma coesão com os países desenvolvidos.

Desconsiderando a historicidade responsável pela formação regional, o Estado "abre fronteiras" implantando agregados infraestruturais: rodovias, energia, comunicação, educação, instituição científica, saúde, lixo, esgoto etc., porque "Quanto mais total for o mercado, tanto mais total será o Estado" (KURZ, 1995), já que ao abranger a reprodução social impondo o modo de vida universal, o mercado impele à expansão estatal, que, por sua vez, precisa incrementar mais e mais o aparelho jurídico para respaldar o processo de expropriação e produção de valor.

Com o processo de centralização do Estado pós-1930 e sua captura pelas classes dominantes, com vias à reprodução das relações sociais capitalistas por meio de planejamentos territoriais voltados à homogeneização econômica, a Serra expõe a falta de autonomia do Estado moderno. Esse movimento apresenta o político submetido ao econômico, pois todas as medidas do Estado precisam estar subordinadas ao mercado, não somente as atividades jurídicas, infraestruturais, entre outras, mas também o poder de violência.

Ao captar impostos e taxas para convertê-los em crédito, o Estado se mostra estruturalmente dependente do faturamento monetário da sociedade civil, para que assim possa financiar a atividade pública, que, por sua vez, está a serviço de uma minoria que comanda o mercado. As condições para que essa minoria possa viver do que acumula estão associadas ao desenvolvimento da relação capitalista, ou seja, da autonomização dos rendimentos de terra, trabalho e capital. Isso só pode acontecer a partir do momento em que a violência tenha se autonomizado do capital e passe a ser monopólio do Estado (TOLEDO, 2008).

No prelúdio do século XXI, baques mundiais profundos estrearam já em 2008 a dinâmica de crises sistêmicas do capitalismo. Terminada a segunda década do século, os holofotes se voltam para o embate ambientalista versus crescimento econômico, trazendo à baila a possibilidade de que o ar, as águas e o clima possam ser submetidos às relações econômicas de escassez e sobre eles imputados os preços de mercado, para serem acessíveis apenas à demanda com poder aquisitivo. Por mais absurdo que seja mercantilizar esses bens não produzidos, é preciso ter em mente que o dinheiro trabalha como um robô social que não é capaz de diferenciar entre saudável e nocivo, feio e bonito e, sobretudo, moral e amoral ${ }^{286}$.

\footnotetext{
286 “Compadre meu Quelemém me hospedou, deixou meu contar minha história inteira. Como vi que ele me olhava com aquela enorme paciência - calma de que minha dor passasse; e que podia esperar muito longo tempo. O que vendo, tive vergonha, assaz.

Mas, por fim, eu tomei coragem, e tudo perguntei:

- 'O senhor acha que a minha alma eu vendi, pactário?'
} 
Neste contexto e particularmente no Brasil, a reprodução ampliada sobre os territórios também implica em apropriação e destruição dos recursos que Foster (2012a) chama de riqueza pública, cabendo aos pobres a responsabilidade e o ônus pela devastação do meio ambiente ${ }^{287}$, enquanto as forças produtivas, no seu desenvolvimento vertiginoso e como propriedade de uma minoria, abocanham o patrimônio natural, dividindo os sujeitos entre os que têm acesso a uma vida rodeada de meios e os que, ao serem espoliado dessa relação orgânica, devem morrer.

Volta-se aqui a lembrar os tecnocratas e os cientistas, submetidos à forma monetária e por ela impregnados, pois enquanto a economia de mercado desfigura o semblante e o conteúdo da natureza, é o Estado que precisa suportar os custos ecológicos subsequentes, criando para tal fim instituições especiais onde esses sujeitos atuam com o máximo de apuro racional, o que faz com que a sua esfera de competência, assim como a sua demanda financeira se expandam uma vez mais (KURZ, 1995; 1996).

Reunidos na ilusão ou má intenção de conciliar "crescimento qualitativo" e “desenvolvimento sustentável”, as personificações do capital, do Estado e da Ciência buscam iniciativas afins clamando a plenos pulmões a necessidade de uma "revolução global" para salvar a natureza e a humanidade. Mas qual humanidade?

Como justificar que somos uma humanidade se mais de $70 \%$ estão totalmente alienados do mínimo exercício de ser? A modernização jogou essa gente do campo e da floresta para viver em favelas e em periferias, para virar mão de obra em centros urbanos. Essas pessoas foram arrancadas de seus coletivos, de seus lugares de origem, e jogadas nesse liquidificador chamado humanidade. (KRENAK, 2019, p. 14).

Em seu livro Ideias para adiar o fim do mundo, a liderança indígena Ailton Krenak traz provocações não enquadradas no rigor acadêmico, que convidam a se pensar o mundo de uma forma que não esteja condicionada apenas pelo viés ocidental. O ativista apresenta o discurso de desenvolvimento sustentável como um mito inventado pelas corporações para justificar o assalto que fazem à natureza presente nas comunidades integradas à força ao moderno sistema produtor de mercadorias. Vale a sua questão: 'Desenvolvimento sustentável para quê? O que é preciso sustentar?” (KRENAK, 2019, p. 22).

Então ele sorriu, o pronto sincero, e me vale me respondeu:

- 'Tem cisma não. Pensa para diante. Comprar ou vender, às vezes, são as ações que são as quase iguais..."” (ROSA, 1986, p. 538).

287 “O pior inimigo do meio ambiente é a pobreza. As pessoas destroem o meio ambiente porque precisam comer. Eles [pessoas pobres] têm todas as preocupações que não são as preocupações das pessoas que já destruíram suas florestas, que já lutaram suas minorias étnicas, essas coisas... É um problema muito complexo, não há uma solução simples." ("O PIOR..., 2020). 
Se "o mundo acredita que tudo é mercadoria, a ponto de projetar nela tudo o que somos capazes de experimentar" (KRENAK, 2019, p. 45), a busca por outras formas de pensar a Serra e o mundo fora do pensamento ilustrado está fora de alcance. Este mesmo começo de século assistiu à chegada de governos que, engessados na forma de ser do Estado na sua comunhão com o capital em crise, ensaiaram a gestão do colapso ampliando o crédito aos mais pobres, enquanto perpetuavam a garantia de endividamento em nome do capital privado. A Serra, no limiar desses tempos, é mais um território a espelhar a reprodução ampliada crítica do capital.

Na Serra do Cabral, como em qualquer lugar, não só a totalização do capital via planejamento estatal reterritorializa de modo a homogeneizar - globalizar - todos os rincões do mundo, como a ideia de humanidade com todos os seus limites só se faz válida enquanto o pacto com a economia moderna for mantido. Sendo a raiz dessa relação o dinheiro, sua intermediação entre homens e natureza por processos violentos só pode levar à destruição desta última, com desdobramentos sociais trágicos.

Considerado uma abstração social por desprezar todo conteúdo sensível e qualitativo do trabalho que o engendra, o dinheiro tem o dom de destruir a realidade (KURZ, 1996). A moeda, portanto, integra a raiz da força destrutiva da economia moderna, para onde irão todas as suas personificações, alçadas à condição de sujeitos sujeitados. Pactários ou não à nova forma social, estão todos condenados. Progredimos e desaparecemos, enquanto essa for a lógica. 


\section{Considerações finais}

Ao longo das páginas, propôs-se argumentar que a Serra do Cabral, abrangida pelo vasto sertão que compõe as terras Brasil adentro, é território constantemente abocanhado pelo dinamismo modernizador. Para tal, iniciou-se o estudo apresentando Francisco Dumont, município sede da pesquisa, a partir dos últimos campos realizados, para prosseguir abordando os mapas como registro da territorialização, da Colônia ao Estado moderno.

No passo da boiada, rastreou-se os caminhos que, regados a sangue indígena, deram passagem para os faiscadores das beiras dos rios. A pecuária deu o tom da territorialização, tornando possível levantar a formação das fazendas a partir da tomada violenta das terras dos povos originários. O movimento de apropriação e dominação desses territórios, somado às transformações na produção de riqueza no contexto político mundial, impeliu o Estado recémindependente a iniciar o processo de clivagem de terra, trabalho e capital.

Esse momento ainda dependia das personificações de poder, e o coronelismo, gestado no Império, não escapa em ser seu maior traço. Essa forma política deu respaldo à conformação econômica regional, em cada lugar operando uma forma particular de articulação dos fatores de produção com vias ao rendimento econômico. Não ainda cindidos, esses fatores amalgamados proporcionavam o incômodo de um capitalismo concebido como arcaico nas periferias do sistema produtor de mercadorias.

A análise dos inventários post mortem não apenas elucidam o movimento de cisão dos fatores de produção, como terra e trabalho, como também mostra na considerável escravaria arrolada - que apresentava famílias entre os cativos - um dinamismo econômico que contesta a decadência regional do ponto de vista da formação do capital. Além disso, a documentação repete o não dito dos mapas: trata da pecuária, mas oculta o garimpo, informação confrontada com as entrevistas e os campos em catas abandonadas.

No rastro do boi, vieram os garimpeiros. De toda condição, foram mobilizados para o trabalho, zanzando pelas cristas e veredas da Serra do Cabral à procura de diamantes. O sertão seria o espaço ideal para produzir o território garimpeiro que empoderava a ordem metropolitana, mas também a desafiava com ocupação forjada na faiscação clandestina, promovida pelos “inorgânicos” funcionais à marcha modernizadora.

Esses sujeitos "desclassificados" socialmente acenderam o debate sobre o trabalho no processo de transição para a liberdade daquela sociedade já independente, mas ainda escravista. Ora encarado como desordeiro e aventureiro, ora visto como herói, o faiscador carregou também em suas costas a estereotipia sertaneja de virada de século, enquanto, na prática, se 
responsabilizava pela fundação de povoados e agitação social dos sertões. Dependente do acaso de achar as pedras, revezava a labuta de cavar e peneirar o cascalho com outras atividades. Alguns chegaram ao fausto econômico; outros, a grande maioria, intercalavam a busca pelas pedras com a pequena lavoura, a coleta de sempre-viva, a lida nas mangas de boi, entre outras formas de sobrevivência.

Apesar do ocaso, o garimpo não deixou de existir, dadas as carências técnicas e a disputa de interesses. Talvez pelas suas incertezas é que crescia o apego à fé, manifesta nas organizações culturais e religiosas, as quais oferecem possibilidades de analisar essa sociedade fetichizada. Dentro dessa transição, ouviu-se dos antigos faiscadores sobre as transformações nas relações de trabalho, a começar pelo acesso à terra. Garimpo e pecuária estavam conectados porque a partir de certo momento, a extração ocorreu dentro das fazendas, que se expandiram sobre os terrenos devolutos, estendendo o domínio da personificação do latifundiário sobre a região que estava se consolidando.

Com o aparente crepúsculo do diamante, investiu-se na especialização pecuária. As fazendas inventariadas demonstram o aperfeiçoamento econômico que moldava a região, servindo de justificativa para solicitar ao Estado as infraestruturas que poderiam conectar esse sertão aos centros econômicos do país, considerado atrasado porque percebido como isolado. A esperança foi depositada na linha do trem e na navegação.

Ancorado na ideologia da ciência, o discurso modernizador, que já despontava no Império, dava seus primeiros passos na razão dualista. O sertão é atrasado porque os sertanejos o são - deduz-se a partir das leituras de Nelson de Senna, Euclides da Cunha, Darcy Ribeiro e tantos outros escritores. Por esse viés, a Serra do Cabral até tinha potencial para se desenvolver, mas a sua gente "febril", "degenerada" e "fruto do caldeamento étnico" impedia o movimento rumo ao progresso.

Na passagem para a República, a burocracia, a tecnocracia e o cientificismo conquistam lugar privilegiado na condução do país. O coronel, que antes personificava o poder do Estado, da lei, da terra e do capital, dá lugar ao doutor, que, a partir de então, veria os fatores de produção autonomizados em nome da maior produtividade.

Enquanto os elementos de produção estavam fusionados, o trabalho era realizado nas fazendas por famílias agregadas, expropriadas do acesso à terra e exploradas pelo latifundiário, com escasso acesso ao dinheiro. Apenas com a cisão desses elementos é que a terra se torna alvo do planejamento do Estado, com sua entrada institucional na região por meio da Sudene.

O ingresso formal do Estado na Serra do Cabral promoveu a metamorfose da terra em mercadoria, diluindo o trabalho das famílias agregadas enquanto as transformava em braços 
disponíveis ao labor normatizado. Essa mudança, própria da dinâmica econômica, encontraria a região, até então invisibilizada, como empecilho à totalização do capital.

Com a centralização do Estado surgem correntes ideológicas que pensam o desenvolvimento, posicionando a região como desigual dentro de um discurso científico dualista que via no planejamento a sua redenção. Essa desigualdade não tardou em servir de argumento para forçar a criação de uma identidade baseada no regionalismo e imbuída de interesses específicos das personificações decadentes do capital regional. Identitarismo que nada mais fez além de expressar a crise da totalidade produtora de mercadorias, dado que capitais exógenos acompanhados do Estado chegam ao norte de Minas Gerais dispostos a quebrar os poderes locais com o intuito de produzir valor sob novas condições produtivas. Autonomizar os fatores de produção, facilitar a grilagem de terras e normatizar o trabalho integram as ações modernizadoras.

Falido o projeto desenvolvimentista, as imposições do modelo neoliberal chegam à Serra do Cabral, privatizando as chapadas e implantando novos arranjos produtivos que expelem trabalho. Diante da catástrofe social que descarta os sertanejos, o apego ao discurso ambiental, tanto dos excluídos quanto do Estado planejador e das personificações do poder, se torna a aposta ilusória de salvação de uma sociedade pós-catastrófica. A globalização, que oculta as formas anteriores de territorialização para que o capital fictício aconteça, traz o propósito de incutir em todos os sujeitos sujeitados modernos o horizonte de uma eterna colonização, abstraindo a contradição em processo do capital e seu limite interno. O asselvajamento do moderno patriarcado produtor de mercadorias resvala para o ecológico, visto que o capital não tem lastro moral.

Boi e diamante, mercadorias que mobilizam seus trabalhadores, assentaram nas grotas, veredas e chapadas, gente da mais diversa origem, de fraca condição. Hipnotizados pelo brilho da pedra, homens e mulheres "cavacaram" barrancos; encantados pelos aboios, homens e mulheres roçaram mangas, mas premidos e seduzidos também por carências diversas. $\mathrm{Na}$ maioria, não eram donos das terras nem dos meios para produzir para outrem, marcando um território de sofrimentos e de esperanças, onde muitos, enfeitiçados pela positivação do futuro, ainda esperam sua hora e vez de ascensão social, envolvidos pelo discurso de serem incluídos no projeto civilizatório do sertão, como se a maneira como existem já não fosse o seu lugar dentro dessa sociedade.

A necessidade, seja ela do estômago ou da fantasia, prosseguiu mobilizando gente. Da Colônia, legou-se o território especializado na gadaria, que camuflava a insistência dos que bateavam nos rios e córregos. O que pouco se contou foi que as flores e frutos do cerrado 
salvaram muitas barrigas da fome nos tempos difíceis: os coletores das "drogas do sertão" nortemineiro atravessaram os tempos e vieram continuar seu trabalho de coleta no século XXI, mesmo ameaçados pelas cercas que fecham pastos e mato. Empurrados para a caminhada distante chapada acima, curvam as costas nas vargens das veredas debaixo do sol causticante para colher coisa que vale pouco: a sempre-viva, delicada e resistente, mesmo quando arrancada do seu lugar e privada de água.

Esse mato, derrubado, grilado e precificado, é inacessível ao sertanejo da Serra do Cabral. Para garantir o futuro, o mercado depende da apropriação dos recursos no presente, expulsando o trabalho enquanto sua substância, tal como tem sido nas fazendas de eucalipto e de café. Essa relação destrutiva, que dirige o sistema produtor de mercadorias para o seu "limite interno absoluto" (KURZ, 2005), revelou a promessa civilizatória capitalista como a grande anedota da modernidade. A trajetória de territorialização do valor-dissociação na Serra é reveladora da violência impositiva dessa forma social. Violência que, entre as muitas funções na contemporaneidade, tem a missão de acelerar o tempo impondo a modernização no território.

Do mestrado para cá, o sertão foi o tema central, na sua acepção geográfica, literária, histórica e simbólica. Ao pensá-lo como espaço produzido pelas modernas relações fetichistas, vinculá-lo apenas ao meio natural não é suficiente, como também não é possível discutir a sua ancestralidade sem recorrer às excepcionalidades naturais. Tampouco se considera possível vestir a carapuça de arcaísmo que tantos consensos e projetos oficiais ofereceram de forma a lhe impor ações modernizadoras. "Lugar sertão se divulga" (ROSA, 1986, p. 1): tal qual a fofoca de uma grupiara, lá está o mercado de olho no vasto espaço a ser apropriado, buscando apagar todos os hieróglifos sociais ali cravados e convertidos historicamente pelo valor, grafando outros.

O sertão é uma contradição em processo. Apesar de ser território concreto, foi convertido em ideologia presa à forma categorial moderna, em que se impõe a aparência dualista de vir a ser um território que supere a sua condição de atraso. Metaforizando o Brasil, ele é um amplo espaço de imperativo da modernização retardatária e de promessa de futuro. Como toda relação moderna, lá reside o contraditório: no sertão, particular e todo se entrelaçam, abstração real e o "não-na-forma-da-mercadoria" (KURZ, 1992a) coexistem. Sertão é, para este estudo, um contexto da territorialização do capital. Se ao longo das páginas foi discutido que este é uma apropriação espacial para a produção de mercadoria, na territorialização do valor sertaneja está co-constituído o dissociado, revelado para além da questão de gênero.

À medida que foi-se chegando ao fim do prazo da tese, perguntas insistiram em aparecer. Considerando-se que cada território apropriado possui excepcionalidades fisiográficas, 
conforme a natureza histórica valoriza determinados recursos devido às mudanças no regime de acumulação e a globalização impondo novas configurações das relações capital e trabalho, a região, produto da especialização econômica, continua a existir? Em caso positivo, se na Serra essa regionalização ainda é encontrada, ela se adapta a essas variações da natureza histórica ou resiste enquanto alvo do dualismo do planejamento com a barragem e o cultivo de soja futuros? Toda essa dinâmica do capital, em nada estática, permitiria entender que o capitalismo é um movimento reposto de territorialização, investindo suas novas forças produtivas e embasado nos discursos de modernização retardatária? Faria o capital vista grossa às historicidades territoriais precedentes, podendo ser considerado um movimento geocida? Como perpetuar a acumulação de riqueza nesses movimentos constantes com a dissolução da substância real e a incapacidade de exploração dos sujeitos tornados supérfluos?

Tal qual Pedro Orósio, sertanejo marcado para morrer acudido pelo recado do Morro da Garça, a Serra do Cabral também manda um recado: também é um recado de luta de morte. $\mathrm{O}$ rio Jequitaí já tem o seu volume d'água reduzido com o desaparecimento de nascentes na Serra, o que implica alterações na sua vazão com o rio São Francisco. Os buritis, "árvores da vida", que levam em média 500 anos para chegar a 30 metros de altura, estão morrendo em uma década com o assoreamento das veredas provocado pela monocultura chapada acima. É a morte, que vem das contradições da economia, de seu esgotamento tanto ecológico quanto inerente ao mercado. É a destruição da sociabilidade que a própria modernização produziu, sem deixar brecha para qualquer outra forma de reconstrução.

Esses sertanejos, sábios sabidos, divididos entre o abandono dos saberes tão descartáveis quanto eles mesmos e a sua subsunção autômata à lógica do valor, talvez possam ouvir o recado se derem as costas ao pacto com o modo esclarecido de produzir o mundo. Como fazê-lo, eis a questão. Nos meses finais da tese vivenciou-se que a vida nas possibilidades de sua plenitude é incompatível com as condições impostas do agora. Abolir o fetichismo da forma social moderna virou necessidade. Enquanto isso não acontece, os sertões permanecem como território da mercadoria e, concomitantemente, o seu reverso, pregando armadilhas a quem tentar decifrá-lo só pela Ciência ou só pelo poético, conforme aprendemos a enxergar as coisas pelos seus opostos binários cindidos. A Serra do Cabral é mais, é "o mundo misturado".

As páginas que materializam este estudo carregam o peso de cinco anos formais de pesquisa, atravessados por uma pandemia. Nelas, estão algumas inquietações sobre como o lugar das lembranças de infância e de reunião familiar se constituiu, bem como qual o lugar desta pesquisadora dentro dessa sociedade complexa. Tentou-se, por isso, desdobrar desde o processo de ocupação da Serra do Cabral nos seus liames com a colonização da América 
portuguesa e sua inserção no capitalismo europeu em gestação, na busca do seu sentido na colonização, sem fechar os olhos para aqueles que já habitavam seus campos e chapadas. Com isso, o sertão foi apresentado como um território habitado por pessoas muito antes dos ditames do mercado penetrarem as suas frestas e imporem aos poucos uma nova sociabilidade. Disto, produziu-se particularmente um mundo novo, onde poético e negativo se abraçam e se digladiam. Ficou-se a pensar esta tese como ferramenta de constante elaboração pessoal, com sua ancestralidade pelo viés negativo, como sujeito sujeitado dentro da sociedade produtora do valor e seus dissociados. "O que em mim sente está pensando" (PESSOA, 1942, p. 108). 


\section{REFERÊNCIAS BIBLIOGRÁFICAS}

ABREU, Capistrano de. Capítulos de história colonial: 1500-1800. Brasília, DF: Conselho Editorial do Senado Federal, 1998.

AB'SÁBER, Tales. Um clube no céu do Brasil. Patuá Discos, [s. l.], 8 ago. 2017. Disponível em: https://www.patuadiscos.com.br/noticias-2/um-clube-no-ceu-do-brasil/. Acesso em: 5 jan. 2020.

AB'SÁBER, Tales. Clube da Esquina, 45 anos. Outras Mídias, 14 ago. 2017. Radiola Urbana. Disponível em: https://outraspalavras.net/outrasmidias/um-clube-no-ceu-do-brasil/. Acesso em: 12 jan. 2019.

ACADEMIA BRASILEIRA DE LETRAS. Joaquim Manuel de Macedo. Biografia. Disponível em: http://www.academia.org.br/academicos/joaquim-manuel-demacedo/biografia. Acesso em: 29 dez. 2019.

ACOSTA, Alberto. O Bem Viver: uma oportunidade para imaginar outros mundos. São Paulo: Elefante, 2015.

ALMEIDA, Maria Geralda de. Em busca do poético do sertão. Espaço e Cultura, Rio de Janeiro: Uerj, n. 6, p. 33-42, jul./dez. 1998.

ALMEIDA, Roberto Schmidt de. A estruturação da tecnoburocracia do planejamento territorial no Brasil. Terra Brasilis, Rio de Janeiro, v. 4/5, p. 113-134, 2003. Disponível em: http://journals.openedition.org/terrabrasilis/356. Acesso em: 14 nov. 2019.

ALVES, Vicente Eudes Lemos. Formação territorial sul piauiense: modernização agropecuária e resistência camponesa. Orientador: Iraci Gomes de Vasconcelos Palheta. 2000. Dissertação (Mestrado em Geografia Humana) - Faculdade de Filosofia, Letras e Ciências Humanas, Universidade de São Paulo, São Paulo, 2000.

ALVES, Vicente Eudes Lemos. Mobilização e modernização nos cerrados piauienses: formação territorial no império do agronegócio. Orientador: Heinz Dieter Heidemann. 2006. Tese (Doutorado em Geografia Humana) - Faculdade de Filosofia, Letras e Ciências Humanas, Universidade de São Paulo, São Paulo, 2006.

AMADO, Janaína. Região, sertão, nação. Estudos Históricos, Rio de Janeiro, v. 8, n. 15, p. 145-151, 1995.

AMARAL, Gumercindo Vieira. Minha luta pela sobrevivência. [S. L.: s. n.], 1983.

ANDRADA E SILVA, José Bonifácio. Representação à Assembleia Geral Constituinte e Legislativa do Império do Brasil sobre a escravatura. Paris: Typographia de Firmin Didot, 1825 .

ANDRADE, Karylleila dos Santos; BATISTI, Carla. Paraupava e Sabarabuçu: estudo dos nomes. Via Litterae: Revista de Linguística e Teoria Literária, Anápolis, v. 3, n. 2, p. 303313, jul./dez. 2011. 
ANDRADE, Manoel Correia de. A terra e o homem no Nordeste. São Paulo: Brasiliense, 1964.

ANDRIOLI, Antônio Inácio. A atualidade de Marx para o debate ambiental. 2007.

Trabalho apresentado no $5^{\circ}$ Colóquio Internacional Marx Engels, Campinas, SP, nov. 2007.

ANJOS, Ana Maria de la Merced G. G. G. dos; PEREIRA, Júlio César Medeiros da Silva. A saga dos pretos novos. 10. ed. Rio de Janeiro: Secretaria Municipal de Cultura, Companhia de Desenvolvimento Urbano da Região do Porto do Rio de Janeiro, 2019. Panfleto.

ANTONIL, André João. Cultura e opulência do Brasil por suas drogas e minas. Lisboa: Comissão Nacional para as Comemorações dos Descobrimentos Portugueses, 2007.

ÁVILA, Affonso. O elemento lúdico nas formas de expressão do barroco. Barroco, Belo Horizonte: Impresa da UFMG, n. 2, p. 7-18, 1970.

AZEVEDO, Aroldo. Arraiais e corrutelas. Boletim Paulista de Geografia, São Paulo, n. 25, p. 3-23, mar. 1957.

BÁBEL, Isaac. O exército de cavalaria. São Paulo: Cosac Naify, 2006.

BALIBAR, Étienne. Le retour de la race. Mouvements, n. 50, p. 162-171, 2007. Disponível em: https://www.cairn.info/revue-mouvements-2007-2-page-162.htm. Acesso em: 1 fev. 2020 .

BANDEIRA, Manuel. Evocação do Recife. In: BANDEIRA, Manuel. Estrela da vida inteira. Rio de Janeiro: Nova Fronteira, 1993.

BEIGUELMAN, Paula. A formação do povo no complexo cafeeiro: aspectos políticos. São Paulo: Edusp, 2005.

BENJAMIN, Walter. Magia e técnica, arte e política: ensaios sobre literatura e história da cultura. São Paulo: Brasiliense, 1994.

BOECHAT, Cássio Arruda. Região do colonato: mobilização do trabalho e autonomização do capital na área de Olímpia (1857-1964) do Oeste Paulista. Orientador: Heinz Dieter Heidemann. 2009. Dissertação (Mestrado em Geografia Humana) - Faculdade de Filosofia, Letras e Ciências Humanas, Universidade de São Paulo, São Paulo, 2009.

BOECHAT, Cássio Arruda; TOLEDO, Carlos de Almeida. Mobilização do trabalho e o estudo da região. Boletim Campineiro de Geografia, Campinas, SP, v. 2, n. 3, p. 448-464, 2012.

BOECHAT, Cássio Arruda. O colono que virou suco: terra, trabalho, Estado e capital na modernização da citricultura paulista. Orientador: Heinz Dieter Heidemann. 2013. Tese (Doutorado em Geografia Humana) - Faculdade de Filosofia, Letras e Ciências Humanas, Universidade de São Paulo, São Paulo, 2014. 
BOLSANELLO, Maria Augusta. Darwinismo social, eugenia e racismo "científico": sua repercussão na sociedade e na educação brasileiras. Educ. rev., Curitiba, n. 12, p. 153-165, dez. 1996.

BONICENHA, Rodrigo Cardoso. Financeirização e território: uma revisão da literatura recente. In: ENANPUR, 17., 2017, São Paulo. Anais [...]. São Paulo: Enanpur, v. 17, n. 1, 2017. p. 1-16.

BOSI, Ecléa. Memória e sociedade: lembranças de velhos. São Paulo: Taq, 1979.

BOTELHO, Tarcísio Rodrigues. Demografia e família escrava em Montes Claros no século XIX. In: CARDOSO, José Maria Alves (org.). Formação social e econômica do norte de Minas. Montes Claros: Editora Unimontes, 2000.

BOXER, Charles. A idade de ouro do Brasil: dores de crescimento de uma sociedade colonial. São Paulo: Companhia Editora Nacional, 1969.

BRESSER-PEREIRA, Luiz Carlos. O conceito de desenvolvimentismo do Iseb rediscutido. Dados: Revista de Ciências Sociais, Rio de Janeiro, v. 47, n. 1, p. 49-84, 2004.

BRESSER-PEREIRA, Luiz Carlos. As três interpretações da dependência. Perspectivas, São Paulo, v. 38, p. 17-48, jul./dez. 2010.

BURTON, Richard Francis. Viagem de canoa de Sabará ao oceano Atlântico. Belo Horizonte: Itatiaia; São Paulo: Edusp, 1977.

CANÊDO, Letícia Bicalho. Caminhos da memória: parentesco e poder. Textos de História, Brasília, DF, v. 2, n. 3, p. 85-122, 1994.

CAPEL, Horácio. Historia de la ciencia y historia de las disciplinas cientificas. Objetivos y bifurcaciones de um programa de investigación sobre historia de la geografia. Geo Crítica, Barcelona, nov. 1989.

CAPEL, Horácio. A América no nascimento da geografia moderna: das crônicas medievais às crônicas sobre as Índias, passando por Plínio e pelo descobrimento das novas terras. In:

CAPEL, Horácio. O nascimento da ciência moderna e a América: o papel das comunidades científicas, dos profissionais e dos técnicos no estudo do território. Maringá: Euem, 1999.

CARDOSO, Fernando Henrique; FALETTO, Enzo. Dependência e desenvolvimento na América Latina: ensaio de interpretação sociológica. Rio de Janeiro: Zahar Editores, 1977.

CARDOSO, José Maria Alves. A Região Norte de Minas Gerais: um estudo da dinâmica de suas transformações espaciais. In: CARDOSO, José Maria Alves (org.). Formação social e econômica do norte de Minas. Montes Claros: Editora Unimontes, 2000.

CARRARA, Angelo Alves. Antes das Minas Gerais: conquista e ocupação dos sertões mineiros. Varia Historia, Belo Horizonte, v. 23, n. 38, p. 574-596, jul./dez. 2007.

CARVALHO, José Murilo de. Primeiros passos (1822-1930). In: CARVALHO, José Murilo de. Cidadania no Brasil: o longo caminho. Rio de Janeiro: Civilização Brasileira, 2003. 
CARVALHO, José Murilo de. Ouro, terra e ferro: vozes de Minas. In: GOMES, Ângela de Castro (org.). Minas e os fundamentos do Brasil moderno. Belo Horizonte: Editora da UFMG, 2005.

CARVALHO, Marcos Rogério Ribeiro de. Pratos, xícaras e tigelas; um estudo de arqueologia histórica em São Paulo, séculos XVIII e XIX: os sítios Solar da Marquesa, Beco do Pinto e Casa N. 1. Revista do Museu de Arqueologia e Etnologia, São Paulo, 13, p. 75-99, 2003.

CHAUÍ, Marilena. O que é ideologia. São Paulo: Brasiliense, 2004.

CODEVASF. Estudo de impacto ambiental: aproveitamento hidroagrícola do Jequitaí. Parte A: atualização do projeto executivo e adequação dos estudos ambientais. Brasília: Ministério da Integração Nacional, maio 2005.

COSTA, Emília Viotti da. Da monarquia à república: momentos decisivos. São Paulo: Fundação Editora da Unesp, 1999.

COSTA, João Batista de Almeida. Populações tradicionais do sertão norte mineiro e as interfaces socioambientais vividas. Revista Cerrados, Departamento de Geociências da Universidade Estadual de Montes Claros, v. 4, n. 1, p. 81-107, 2006.

COSTA, João Severiano Maciel da. Memória sobre a necessidade de abolir a introdução de africanos no Brasil: sobre o modo e condições com que esta abolição se deve fazer e sobre os meios de remediar a falta de braços que ela pode ocasionar. Coimbra: Imprensa da Universidade, 1821.

COSTA, Luciano Rodrigues. Os garimpos clandestinos de ouro em Minas Gerais e no Brasil: tradição e mudança. História \& Perspectivas, Uberlândia, v. 37-37, p. 247-279, jan./dez. 2007.

COUTO, José Vieira. Memória sobre a capitania de Minas Gerais: seu território, clima e produções metálicas. Belo Horizonte: Fundação João Pinheiro, Centro de Estudos Históricos e Culturais, 1994.

CRISTÓVÃO, Fernando. A transfiguração da realidade sertaneja e a sua passagem a mito (a Divina Comédia do Sertão). Revista USP: Dossiê Canudos, São Paulo, n. 20, p. 42-53, 1994.

CUNHA, Daniel. A natureza na "contradição em processo": contribuição para o debate da teoria da crise. Revista Sinal de Menos, ano 10, n. 13, p. 121-142, 2019. Disponível em: https://www.academia.edu/38586607/A_NATUREZA_NA_CONTRADI\%C3\%87\%C3\%83 O_EM_PROCESSO_Contribui\%C3\%A7\%C3\%A3o_para_o_debate_da_teoria_da_crise. Acesso em: 4 mar. 2020.

CUNHA, Euclides da. Os Sertões: campanha de Canudos. $3^{\text {a }}$ ed. Rio de Janeiro: Laemmert \& Cia., 1905.

D'ARAÚJO, Maria Celina; FARIAS, Ignez Cordeiro de; HIPPOLITO, Lucia (org.). IPEA: 40 anos apontando caminhos. Depoimentos ao CPDOC. IPEA, 2005. 
DAVIS, Mike. Holocaustos coloniais: clima, fome e imperialismo na formação do Terceiro Mundo. Rio de Janeiro: Record, 2002.

DAYRELL, Carlos Alberto. Geraizeiros e biodiversidade no norte de Minas: a contribuição da agroecologia e da etnoecologia nos estudos dos agroecossistemas tradicionais. Orientador: Eduardo Sevilla Guzman. 1998. Dissertação (Mestrado em Agroecologia e Desenvolvimento Rural Sustentável) - Universidade Internacional de Andalucia, La Rábida, 1998.

DIAS, Maria Odila Leite da Silva. Impasses do inorgânico. In: D'INCAO, Maria Angela (org.). História e ideal: ensaios sobre Caio Prado Júnior. São Paulo: Unesp: Brasiliense, 1989. p. 377-405.

DIAS, Maria Odila Leite da Silva. A interiorização da metrópole e outros estudos. São Paulo: Alameda, 2005.

DIAS, Renato da Silva; DIAS, Jeaneth Xavier de Araújo. Margem e cultura marginal nas Minas Setecentistas: poder, trabalho e controle social. Dimensões, v. 41, p. 301-326, jul./dez. 2018.

DULCI, Otávio Soares. João Pinheiro e as origens do desenvolvimento mineiro. In: GOMES, Ângela de Castro (org.). Minas e os fundamentos do Brasil moderno. Belo Horizonte: Editora da UFMG, 2005.

ENTREVISTA com Júlio Pimentel Pinto (DH-USP). [S. l.: s. $n$.], 5 nov. 2020. 1 vídeo (58'45”). Publicado no Instagram da Revista de História USP. Disponível em: https://www.instagram.com/p/CHOZwz6HgvS/. Acesso em: 17 jun. 2021.

ESCHWEGE, Wilhelm Ludwig von. Pluto brasiliensis. Belo Horizonte: Itatiaia, 1979. 2 v.

FÁlCON, Francisco José Calazans. A época pombalina. São Paulo: Ática, 1982.

FEDERICI, Silvia. Calibã e a bruxa: mulheres, corpo e acumulação primitiva. São Paulo: Editora Elefante, 2004.

FERNANDES, Florestan. Padrões de dominação externa na América Latina. Germinal: Marxismo e Educação em Debate, Salvador, v. 11, p. 310-324, abr. 2019.

FERREIRA, Álvaro. Caminhando em direção à metropolização do espaço. Geousp: Espaço e Tempo, São Paulo, v. 20, n. 3, p. 441-450, 2016. Disponível em:

http://www.revistas.usp.br/geousp/issue/view/6465. Acesso em: 3 jul. 2018.

FOLADORI, Guillermo. O metabolismo com a natureza. Crítica Marxista, n. 12, São Paulo: Boitempo, p. 105-117, 2001.

FONSECA, C. Damasceno. Do sertão dos cataguases às Minas Gerais: as modalidades e o léxico da ocupação. In: FONSECA, C. Damasceno. Arraiais e vilas d'el rei: espaço e poder nas Minas setecentistas. Belo Horizonte: Editora UFMG, 2011. Disponível em: https://doi.org/10.7476/9788542303070.0005. Acesso em: 11 abr. 2020. 
FOSTER, John Bellamy. A ecologia da economia política marxista. Lutas Sociais, São Paulo, n. 28, p. 87-104, 2012a.

FOSTER, John Bellamy. The four laws of ecology and the four anti-ecological laws of capitalism. Climate \& Capitalism, [s. l.], abr. 2012b. Disponível em:

https://climateandcapitalism.com/2012/04/02/four- laws/. Acesso em: jan. 2020.

FOSTER, John Bellamy. Marx, value and nature. Monthly Review, [s. l.], v. 70, n. 3, jul./ago. 2018. Disponível em: https://monthlyreview.org/2018/07/01/marx-value-and-nature/. Acesso em: fev. 2020.

FRANÇA, Jean Marcel Carvalho. A construção do Brasil na literatura de viagem dos séculos XVI, XVII e XVIII. São Paulo: Civilização Brasileira, 2012.

FRANCO, Maria Sylvia de Carvalho Franco. Homens livres na ordem escravocrata. São Paulo: Unesp, 1997.

FRANCO JÚNIOR, Hilário. Cocanha: a história de um país imaginário. São Paulo: Companhia das Letras, 1998.

FREYRE, Gilberto. Casa-grande e senzala: formação da família brasileira sob o regime da economia patriarcal. São Paulo: Global, 2006.

FREYRE, Gilberto. Sobrados e mucambos: decadência do patriarcado rural e desenvolvimento do urbano. São Paulo: Global, 2013.

FURTADO, Celso. Formação econômica do Brasil. São Paulo: Companhia das Letras, 2007.

FURTADO, Júnia Ferreira. Um cartógrafo rebelde? José Joaquim da Rocha e a cartografia de Minas Gerais. Anais do Museu Paulista: história e cultura material, São Paulo: USP, v. 17, n. 2, p. 155-187, jul./dez. 2009.

GAUDEMAR, Jean-Paul de. Mobilidade do trabalho e acumulação do capital. Lisboa: Estampa, 1977.

GEIGER, Pedro Pinchas. Regionalização. Revista Brasileira de Geografia, Rio de Janeiro, p. 5-27, mar./jun. 1969.

GEREMEK, Bronislaw. Os filhos de Caim: vagabundos e miseráveis na literatura europeia (1400-1700). São Paulo: Companhia das Letras, 1995.

GIAVAROTTI, Daniel Manzione. O Jardim Ibirapuera da imposição à crise do trabalho. Orientador: Heinz Dieter Heidemann. 2012. Dissertação (Mestrado em Geografia Humana) Faculdade de Filosofia, Letras e Ciências Humanas, Universidade de São Paulo, São Paulo, 2013.

GINZBURG, Carlo. Carlo Ginzburg. In: PALLARES-BURKE, Maria Lúcia Garcia. As muitas faces da história: nove entrevistas. São Paulo: Editora Unesp, 2000. p. 269-306. 
GINZBURG, Carlo. O queijo e os vermes: o cotidiano e as ideias de um moleiro perseguido pela Inquisição. São Paulo: Companhia das Letras, 2006.

GOMES, Ângela de Castro. Memória, política e tradição familiar: os Pinheiro das Minas Gerais. In: GOMES, Ângela de Castro (org.). Minas e os fundamentos do Brasil moderno. Belo Horizonte: Editora da UFMG, 2005. p. 79-108.

GOMES, Maria do Carmo Andrade; PILO, Luís Beethoven. As minas de salitre: a exploração econômica das cavernas em Minas Gerais nos fins do período colonial. Espeleo-Tema, São Paulo, v. 16, p. 83-93, 1992.

GONÇALVES. Múcio Tosta. A formação da economia das plantações florestais nos vales do Rio Doce e do Aço de Minas Gerais (1940-2000): notas sobre história econômica e ambiental de uma região. In: XII SEMINÁRIO SOBRE A ECONOMIA MINEIRA, 2006, Belo Horizonte. Anais [...]. Belo Horizonte: Cedeplar-UFMG, p. 1-18.

GORCEIX, Claude-Henri. Cartas de Henri Gorceix a D. Pedro II. In: LIMA, Margarida Rosa de. D. Pedro II e Gorceix: a fundação da Escola de Minas de Ouro Preto. Ouro Preto: Fundação Gorceix, 1977.

GOVERNO DO ESTADO DE MINAS GERAIS. Arquivo Público Mineiro. Inventário da coleção Nelson Coelho de Senna. [S. l.]: Secretaria de Estado de Cultura, jan. 2014. 25 p.

GUARINELLO, Norberto Luiz. Festa, trabalho e cotidiano. In: JANCSÓ, István; KANTOR, Iris (org.). Festa: cultura e sociabilidade na América Portuguesa. São Paulo: Hucitec: Edusp: Fapesp: Imprensa Oficial, 2001. v. 2, p. 969-975.

HANSEN, João Adolfo. A categoria "representação" nas festas coloniais dos séculos XVII e XVIII. In: JANCSÓ, István; KANTOR, Iris (org.). Festa: cultura e sociabilidade na América Portuguesa. São Paulo: Hucitec: Edusp: Fapesp: Imprensa Oficial, 2001. v. 2, p. 735-755.

HARVEY, David. População, recursos e a ideologia da ciência. Seleção de Textos, São Paulo: Associação dos Geógrafos Brasileiros, n. 7, p. 1-35, 1981.

HARVEY, David. A produção capitalista do espaço. São Paulo: Annablume, 2006.

HEIDEMANN, Heinz Dieter. Tá legal? Tudo em ordem? Tudo sob controle?... Travessia, São Paulo, jan./abr. 1998.

HEIDEMANN, Heinz Dieter. Os migrantes e a crise da sociedade do trabalho: humilhação secundária, resistência e emancipação. In: WITTE, D. A. (org.). Migração, discriminação e alternativas. Serviço Pastoral dos Migrantes. São Paulo: Paulinas, 2003. p. 25-40.

HEIDEMANN, Heinz Dieter. Deslocamentos populacionais e mobilidade fictícia: a razão fetichizada do migrante e do seu pesquisador. In: SILVA, Sidney Antônio da (org.). Migrantes em contextos urbanos: uma abordagem interdisciplinar. Manaus: Edua, 2010. v. 1, p. 15-33.

HOLANDA, Sérgio Buarque de. Caminhos e fronteiras. São Paulo: Companhia das Letras, 1994. 
HOLANDA, Sérgio Buarque de. Raízes do Brasil. São Paulo: Companhia das Letras, 1995.

HOLANDA, Sérgio Buarque de. Visão do paraíso: os motivos edênicos no descobrimento e colonização do Brasil. São Paulo: Brasiliense, 2007.

IEF; SEMAD. Plano de manejo do Parque Estadual da Serra do Cabral: planejamento e manual de gestão. Belo Horizonte: Governo do Estado de Minas Gerais, 2015.

INSTITUTO HISTÓRICO E GEOGRÁFICO BRASILEIRO. João Capistrano de Abreu. Perfil. Disponível em: https://ihgb.org.br/perfil/userprofile/JCAbreu.html. Acesso em: 28 dez. 2019.

IORIO, Gustavo Soares. Imagens e imaginário do sertão no Brasil sob regime militar: a revista Interior (1974-1989). Scripta Nova: Revista Electrónica de Geografía y Ciencias Sociales. Barcelona: Universidad de Barcelona, v. 16, n. 418 (70), 1 nov. 2012. Disponível em: http://www.ub.edu/geocrit/sn/sn-418/sn-418-70.htm. Acesso em: 13 out. 2020.

IRFFI, Ana Sara R. P. Cortez. Cabras, caboclos, negros e mulatos: escravidão e núcleos familiares no Cariri cearense (1850-1884). Afro-Ásia, Salvador, n. 53, p. 9-44, 2016.

JAGUARIBE, Hélio. O ISEB e a retomada do desenvolvimento nacional. In: GOMES, Ângela de Castro (org.). Minas e os fundamentos do Brasil moderno. Belo Horizonte: Editora da UFMG, 2005.

JERÔNIMO, Gabriela Guimarães; DE PAULA, Maria Helena. O vocabulário do garimpo artesanal de diamantes: das funções da escala ao bater da peneira. Moara, Belém, n. 40, p. 70-84, jul./dez. 2013.

JESUS, Alysson Freitas de. No sertão das Minas: escravidão, violência e liberdade (18301888). São Paulo: Annablume; Belo Horizonte: Fapemig, 2007.

KIDDY, Elizabeth W. O Rio São Francisco: geografia e poder na formação da identidade nacional brasileira no século XIX. RDE: Revista de Desenvolvimento Econômico, Salvador, ano 12, p. 22-29, dez. 2010.

KLUCK, Erick Gabriel Jones. Quando o planejamento vai para o brejo: a mobilidade do trabalho e o planejamento territorial na modernização do Velho Chico. São Paulo: Fapesp: Humanitas, 2019.

KRENAK, Ailton. Ideias para adiar o fim do mundo. São Paulo: Companhia das Letras, 2019.

KRISIS, Grupo. Manifesto contra o trabalho. São Paulo: Coletivo Sabotagem, 1999.

KURZ, Robert. Fetichismo sexual: notas sobre a lógica de feminilidade e masculinidade. $\mathbf{O}$ Beco, 1992a. Disponível em: www.obeco-online.org/rkurz445.htm. Acesso em: 24 jul. 2020.

KURZ, Robert. O colapso da modernização: da derrocada do socialismo de caserna à crise da economia mundial. Rio de Janeiro: Paz e Terra, 1992b. 
KURZ, Robert. A falta de autonomia do Estado e os limites da política: quatro teses sobre a crise da regulação política. O Beco, ago. 1994. Disponível em: http://www.obecoonline.org/rkurz66.htm?fbclid=IwAR2xYAVWnOXjBuRMnyAfoq4EYueZF47RpgB3DWA 03y_AkdGyEWFsAHOSKOg. Acesso em: 8 ago. 2017.

KURZ, Robert. A vitória da economia sobre a vida: como o mundo está a ser destruído pela eficiência da economia empresarial. O Beco, jun. 1996. Disponível em: http://www.obecoonline.org/rkurz.htm. Acesso em: 13 fev. 2020.

KURZ, Robert. Canhões e capitalismo: a revolução militar como origem da modernidade. $\mathbf{O}$ Beco, 30 mar. 1997. Disponível em: http://www.obecoonline.org/rkurz2.htm?fbclid=IwAR3PfkOLvAzcpCcF_EpexnAhptD81SstkXG50Isisv4v6R6yCSL6zrkANk. Acesso em: 5 mar. 2020.

KURZ, Robert. A substância do capital: o trabalho abstracto como metafísica real social e o limite interno absoluto da valorização. O Beco, ago. 2005. Disponível em: http://www.obecoonline.org/rkurz203.htm. Acesso em: 11 out. 2018.

KURZ, Robert. Ontologia negativa: os obscurantistas do Esclarecimento e a moderna metafísica da história. In: KURZ, Robert. Razão sangrenta: ensaios sobre a crítica emancipatória da modernidade capitalista e de seus valores ocidentais. São Paulo: Hedra, 2010.

LAMBERT, Jacques. Os dois Brasis. São Paulo: Companhia Editora Nacional, 1972.

LANGFUR, Hal. Mapeando a conquista. Revista do Arquivo Público Mineiro, [s. l.], ano 47, n. 1, p. 30-47, jan./jun. 2011.

LEAL, Victor Nunes. Coronelismo, enxada e voto: o município e o regime representativo no Brasil. São Paulo: Alfa-Ômega, 1975.

LEÃO, Igor Zanoni Constant Carneiro; OGAMA, Danilo Ferraz de Oliveira. Relendo "os Dois Brasis", de Jacques Lambert: o desenvolvimento econômico e sua apologia. Revista Paranaense de Desenvolvimento, Curitiba, v. 38, n.133, p. 245-258, jul./dez. 2017.

LEFEBVRE, Henri. De lo rural a lo urbano: antologia preparada por Mario Gaviria. Barcelona: Ediciones Península, 1978.

LEFEBVRE, Henri. A produção do espaço. Tradução: As (im)possibilidades do urbano na metrópole contemporânea. Belo Horizonte: [s. n.], 2006. Título original: La production de l'espace.

LE GOFF, Jacques. O deserto-floresta no Ocidente medieval. In: LE GOFF, Jacques. O imaginário medieval. São Paulo: Estampa, 1994. (Série Nova História).

LE GOFF, Jacques. História e memória. Campinas, SP: Editora da Unicamp, 2013.

LEITE, Ana Carolina Gonçalves. A modernização do Vale do Jequitinhonha mineiro e o processo de formação do trabalhador "bóia-fria" em suas condições regionais de 
mobilização do trabalho. Orientador: Heinz Dieter Heidemann. 2010. Dissertação (Mestrado em Geografia Humana) - Faculdade de Filosofia, Letras e Ciências Humanas, Universidade de São Paulo, São Paulo, 2010.

LEITE, Ana Carolina Gonçalves. O campesinato no Vale do Jequitinhonha: da sua formação no processo de imposição do trabalho à crise da (sua) reprodução capitalista. Orientador: Heinz Dieter Heidemann. 2015. Tese (Doutorado em Geografia Humana) Faculdade de Filosofia, Letras e Ciências Humanas, Universidade de São Paulo, São Paulo, 2015.

LEMKE, Maria. O Caminho do Sertão: notas sobre a proximidade entre Goiás e África. Politeia: História e Sociedade, Vitória da Conquista, v. 13, n. 1, p. 115-132, 2013.

LIMA, Nei Clara de. Os crespos do sertão. O Público e o Privado: Revista de Pós-Graduação em Sociologia da Universidade Estadual do Ceará, Fortaleza, n. 7, p. 151-169, jan./jun. 2006.

LIMA, Nísia Trindade. Um sertão chamado Brasil: intelectuais e representação geográfica da identidade nacional. Rio de Janeiro: Revan: Iuperj: Ucam, 1999.

LION, Thiago Ferreira; MELO, Thiago Arcanjo Calheiros de. O trabalho em Marx é ontológico, \#SQN: crítica categorial da forma limitada da atividade humana. Revista Sinal de Menos, ano 8, n. 12, v. 1, p. 158-198, 2016. Disponível em: https://www.dropbox.com/s/zu3dt4ejgawodev/SINAL_DE_MENOS_12_1.pdf. Acesso em: 9 abr. 2020.

LOBATO, Monteiro. A onda verde. São Paulo: Brasiliense, 1922.

LÖWY, Michael. A teoria do desenvolvimento desigual e combinado. Actuel Marx, 18, 1995. Tradução de Henrique Carneiro. Disponível em: http://afoiceeomartelo.com.br/posfsa/Autores/Lowy,\%20Michael/a\%20teoria\%20do\%20 desenvolvimento\%20desigual\%20e\%20combinado.pdf. Acesso em: 12 nov. 2019.

LUCE, Mathias Seibel. Brasil: nova classe média ou novas formas de superexploração da classe trabalhadora? Trabalho, Educação e Saúde, Rio de Janeiro, v. 11, n. 1, p. 169-190, jan./abr. 2013.

MACHADO, Lia Osório. Origens do pensamento geográfico no Brasil: meio tropical, espaços vazios e a idéia de ordem (1870-1930). In: CASTRO, Iná Elias de; GOMES, Paulo Cesar da Costa; CORRÊA, Roberto Lobato (org.). Geografia: conceitos e temas. Rio de Janeiro: Bertrand Brasil, 2000. p. 309-352.

MAGALHÃES, Beatriz Ricardina. O Divino e a "Festa do Martírio". In: JANCSÓ, István; KANTOR, Iris (org.). Festa: cultura e sociabilidade na América Portuguesa. São Paulo: Hucitec: Edusp: Fapesp: Imprensa Oficial, 2001. v. 2, p. 935-947.

MAGNOLI, Demétrio. O corpo da pátria. São Paulo: Moderna: Edunesp, 1997.

MARAVALL, José Antonio. A cultura do barroco: análise de uma estrutura histórica. São Paulo: Edusp, 1997. 
MARINI, Ruy Mauro. Dialética da dependência. Germinal: marxismo e educação em debate, Salvador, v. 9, n. 3, p. 325-356, dez. 2017.

MARTINS, Bruno Viveiros. Som imaginário: amizade, viagens e cidades nas canções do Clube da Esquina. Orientadora: Heloisa Maria Murgel Starling. 2007. Dissertação (Mestrado em História) - Universidade Federal de Minas Gerais, Belo Horizonte, 2007.

MARTINS, José de Souza. Não há terra para plantar neste verão: o cerco das terras indígenas e das terras de trabalho no renascimento político do campo. Petrópolis: Vozes, 1986.

MARTINS, José de Souza. O cativeiro da terra. São Paulo: Hucitec, 2004.

MARX, Karl. Contribuição à crítica da economia política. São Paulo: Expressão Popular, 2008.

MARX, Karl. O 18 de brumário de Luís Bonaparte. São Paulo: Boitempo, 2011.

MARX, Karl. O capital: crítica da economia política. São Paulo: Boitempo Editorial, 2013. 3 $\mathrm{V}$.

MATTOS, Hebe. Racialização e cidadania no Império do Brasil. In: CARVALHO, José Murilo de; NEVES, Lúcia Maria Bastos Pereira das. Repensando o Brasil do Oitocentos: cidadania, política e liberdade. Rio de Janeiro: Civilização Brasileira, 2009.

MBEMBE, Achille. Crítica da razão negra. 2. ed. Lisboa: Antígona, 2017.

MBEMBE, Achille. Necropolítica: biopoder, soberania, estado de exceção, política da morte. São Paulo: n-1 Edições, 2018.

MELLO, Zélia Cardoso de. Metamorfoses da riqueza: São Paulo, 1845-1895. Contribuição ao estudo da passagem da economia mercantil-escravista à economia exportadora-capitalista. São Paulo: Hucitec, 1985.

MENEGATTI, Jéssica C. L. Mulher sem Valor: o pensamento de Roswitha Scholz para a crítica radical do capitalismo e das relações de gênero. Orientador: Tales Afonso Muzfeldt Ab'Sáber. 2016. 104 p. Dissertação (Mestrado em Filosofia) - Escola de Filosofia, Letras e Ciências Humanas, Universidade Federal de São Paulo, São Paulo, 2016.

MINAS GERAIS. Terras públicas: Bonfim (Senhor do) (Montes Claros) 1856. In: MINAS GERAIS. Secretaria de Estado de Cultura. Inventário do fundo Repartição Especial das Terras Públicas. [S. l.]: Arquivo Público Mineiro, 2010.

MONTEIRO, Carlos Augusto Figueiredo. O espaço iluminado no tempo volteador (Grande sertão: veredas). Estud. Av., São Paulo, v. 20, n. 58, p. 47-64, dec. 2006.

MONTEIRO, Marianna F. M.; DIAS, Paulo. Os fios da trama: grandes temas da música popular tradicional brasileira. Estud. Av., São Paulo, v. 24, n. 69, p. 349-371, 2010. 
MOORE, Jason W. The Capitalocene, Part I: on the nature and origins of our ecological crisis. The Journal of Peasant Studies, [s. l.], 17 mar. 2017. Disponível em: http://dx.doi.org/10.1080/03066150.2016.1235036. Acesso em: 2 jan. 2021.

MORAES, Antonio Carlos Robert. Bases da formação territorial do Brasil: o território colonial brasileiro no "longo" século XVI. São Paulo: Hucitec, 2000.

MORAES, Antonio Carlos Robert. Território e história no Brasil. São Paulo: Hucitec, 2002.

MORAES, Antonio Carlos Robert. Sertão: um “outro" geográfico. Terra Brasilis, Rio de Janeiro, 2003. Território.

MORLEY, Helena. Minha vida de menina. São Paulo: Companhia de Bolso, 2016.

MOTTA, Márcia Maria Menendes. Caindo por terra (historiografia e questão agrária no Brasil do século XIX). In: GIRBAL-BLACHA, Noemí; VALENCIA, Marta. Agro, tierra y política: debates sobre la historia rural de Argentina y Brasil. Buenos Aires: Reun, 1998.

MOTTA, Márcia Maria Menendes. Nas fronteiras do poder: conflitos de terra e direito agrário no Brasil de meados do século XIX. Orientador: Silvia Hunold Lara. 1996. 325 f. Tese (Doutorado em História) - Instituto de Filosofia e Ciências Humanas, Unicamp, Campinas, SP, 1996.

MOTTA, Márcia Maria Menendes. A grilagem como legado. In: MOTTA, Márcia Maria Menendes; PIÑEIRO, Théo Lobarinhas (org.). Voluntariado e o universo rural. Rio de Janeiro: Vício de Leitura, 2002. v. 1.

MOURA, Clovis. Dialética radical do Brasil negro. São Paulo: Editora Anita, 1994.

MOURA, Margarida Maria. Os deserdados da terra: a lógica costumeira e judicial dos processos de expulsão e invasão da terra camponesa no sertão de Minas Gerais. Rio de Janeiro: Bertrand Brasil, 1988.

MUNDIM, Luis Gustavo Molinari. Sob o signo do moderno. Revista do Arquivo Público Mineiro, [s. l.], ano 56, n. 2, p. 60-73, jul./dez. 2010.

NEVES, Erivaldo Fagundes. Uma comunidade sertaneja: da sesmaria ao minifúndio. Salvador: Edufba; Feira de Santana: Uefs, 2008.

NOGUEIRA, Mônica Celeida Rabelo. Gerais a dentro e a fora: identidade e territorialidade entre Geraizeiros do Norte de Minas Gerais. Orientador: Paul Elliott Little. 2009. Tese (Doutorado em Antropologia Social) - Instituto de Ciências Sociais, Universidade de Brasília, Brasília, 2009.

NOVAIS, Fernando. Portugal e Brasil na crise do Antigo Sistema Colonial. São Paulo: Hucitec, 2001.

OLIVEIRA, Francisco de. Elegia para uma re(li)gião: Sudene, Nordeste. Planejamentos e conflitos de classes. Rio de Janeiro: Paz e Terra, 1988. 
OLIVEIRA, Francisco de. Crítica à razão dualista: o ornitorrinco. São Paulo: Boitempo, 2013.

OLIVEIRA, Marcos Fábio Martins de. O processo de formação e desenvolvimento de Montes Claros e da Área Mineira da Sudene. In: CARDOSO, José Maria Alves (org.). Formação social e econômica do norte de Minas. Montes Claros: Editora Unimontes, 2000a.

OLIVEIRA, Marly Job de. A política geral do regime militar para construção de suas políticas econômicas (1964-1985). Orientador: Emanuel Soares da Veiga Garcia. Tese (Doutorado em História Econômica) - Faculdade de Filosofia, Letras e Ciências Humanas, Universidade de São Paulo, São Paulo, 2007.

OLIVEIRA, Ricardo de. Ficção, ciência, história e a invenção da Brasilidade Sertaneja. Ipotesi: Revista de Estudos Literários, Juiz de Fora, v. 4, n. 1, p. 37-53, 2000 b.

O QUE É A UTZ? UTZ, c2021. Perguntas frequentes sobre a UTZ. Disponível em: https://utz.org/language-landingpage/portuguese/. Acesso em: 6 out. 2020.

OTTONI, Carlos. Impressões de viagem de Carlos Ottoni. Annuario Estatistico Illustrado de Minas Geraes: da Diamantina a São Francisco. Belo Horizonte: Imprensa Oficial de Minas Gerais, 1906. v. 11, p. 669-681.

PAIVA, Eduardo França. Bateias, carumbés, tabuleiros: mineração africana e mestiçagem no Novo Mundo. In: PAIVA, Eduardo França; ANASTASIA, Carla Maria Junho (org.). O trabalho mestiço: maneiras de pensar e formas de viver, séculos XVI a XIX. São Paulo: Annablume; Belo Horizonte: PPGH-UFMG, 2002. p. 187-207.

PARAISO, Maria Hilda Baqueiro. Os kurukas no mercado colonial. Revista do Arquivo Público Mineiro, [s. l.], ano 47, n. 1, p. 78-97, jan./jun. 2011.

PARRELA, Ivana Denise. O teatro das desordens: garimpo, contrabando e violência no sertão diamantino (1768-1800). São Paulo: Annablume; Belo Horizonte: Fapemig, 2009.

PAULA, Andrea Maria Narciso Rocha de. Travessias... destinos migratórios em comunidades rurais no sertão do norte de Minas Gerais. Orientador: Carlos Rodrigues Brandão. 2009. Tese (Doutorado em Geografia Humana) - Universidade Federal de Uberlândia, Uberlândia, 2009.

PELISSARO, Suelen Rosa. O sertão e suas metamorfoses em Sagarana e Primeiras Estórias, de João Guimarães Rosa. Orientador: Heinz Dieter Heidemann. 2011. Dissertação (Mestrado em Geografia Humana) - Faculdade de Filosofia, Letras e Ciências Humanas, Universidade de São Paulo, São Paulo, 2011.

PEREIRA, José Veríssimo da Costa. Vultos da Geografia do Brasil: Henrique Guilherme Fernando Halfeld. Revista Brasileira de Geografia, v. 6, n. 1, p. 95-96, jan./mar. 1944.

PEREIRA, Laurindo Mékie. Em nome da região, a serviço do capital: o regionalismo político norte mineiro. Orientador: Raquel Glezer. 2007. Tese (Doutorado em História 
Econômica) - Faculdade de Filosofia, Letras e Ciências Humanas, Universidade de São Paulo, São Paulo, 2007.

PEREIRA, Laurindo Mékie. Intelectuais em ação, mineiridade em xeque. Locus: Revista de História, Juiz de Fora, v. 20, n. 2, p. 103-124, 2015.

PESSOA, Fernando. Poesias. Lisboa: Ática, 1942.

PINTO, Maria Claudia. Licenciamento ambiental: parecer único silvicultura Serra do Cabral Agro Indústria S. A. Montes Claros: Governo do Estado de Minas Gerais, Secretaria de Estado de Meio Ambiente e Desenvolvimento Sustentável, 2007.

PIRES, Simeão Ribeiro. Raízes de Minas. Montes Claros: [s. n.], 1979.

PIRES, Simeão Ribeiro. Serra Geral: diamantes, garimpeiros e escravos. Belo Horizonte: Cuatiara, 2001.

PÓVOA NETO, Helion. No caminho das pedras: itinerários na formação da mobilidade garimpeira em Goiás. Orientador: Heinz Dieter Heidemann. 1998. Tese (Doutorado em Geografia Humana) - Faculdade de Filosofia, Letras e Ciências Humanas, Universidade de São Paulo, São Paulo, 1998.

PRADO JÚNIOR, Caio. Formação do Brasil contemporâneo. São Paulo: Brasiliense, 2006.

PUNTONI, Pedro. A guerra dos bárbaros: povos indígenas e a colonização do sertão Nordeste do Brasil, 1650-1720. São Paulo: Hucitec: Edusp, 2002.

QUEM SOMOS. BTG Pactual, c2021. Disponível em:

https://www.btgpactual.com/home/quem-somos/sustentabilidade/timberland. Acesso em: 5 ago. 2020.

QUEM SOMOS. Ecoagrícola, c2019a. Disponível em: https://www.ecoagricola.com.br/pt/quem-somos/. Acesso em: 10 nov. 2019.

QUEM SOMOS. Vallourec, c2019b. Disponível em: https://www.vallourec.com/pt-BR/br. Acesso em: 12 jun. 2020.

REIS, João José. De escravo a rico liberto: a trajetória do africano Manoel Joaquim Ricardo na Bahia oitocentista. Revista de História, São Paulo, n. 174, p. 15-68, jan./jun. 2016. Disponível em: http://dx.doi.org/10.11606/issn.2316-9141.rh.2016.108145. Acesso em: 24 ago. 2019.

REIS, Nestor Goulart. A urbanização e o urbanismo na região das minas. Revista de estudos sobre urbanismo, arquitetura e preservação, São Paulo, n. 30, jul./dez. 1999. (Série Urbanização e Urbanismo).

RENGER, Friedrich. A origem histórica das estradas reais nas Minas setecentistas. In: RESENDE, Maria Efigênia Lage de; VILlALTA, Luiz Carlos (org.). As Minas setecentistas. Belo Horizonte: Autêntica: Companhia do Tempo, 2007a. v. 1, p. 127-137. 
RENGER, Friedrich. Primórdios da cartografia das Minas Gerais (1585-1735): dos mitos aos fatos. In: RESENDE, Maria Efigênia Lage de; VILLALTA, Luiz Carlos (org.). As Minas setecentistas. Belo Horizonte: Autêntica: Companhia do Tempo, 2007b. v. 1, p. 103-126.

RENGER, Friedrich; GOMES, Maria do Carmo Andrade. Engenheiros alemães na cartografia de Minas Gerais do século XIX: Eschwege, Wagner, Halfeld e Henrique Gerber. Revista da Sociedade Brasileira de Cartografia, [s. l.], 2013.

RIBEIRO, Darcy. O Brasil sertanejo. In: RIBEIRO, Darcy. O povo brasileiro: a formação e o sentido do Brasil. São Paulo: Cia das Letras, 1995.

RIBEIRO, Eduardo de Carvalho. A obra de Elomar Figueira Mello: contexto e estilo além do popular e do erudito. Per Musi, Belo Horizonte, n. 29, p. 185-194, 2014.

RICÚPERO, Bernardo. Da formação à forma: ainda as “ideias fora do lugar”. Lua Nova: Revista de Cultura e Política, São Paulo, n. 73, p. 59-69, 2008.

ROCHA, José Joaquim da. Geografia histórica da Capitania de Minas Gerais: descrição geográfica, topográfica, histórica e política da Capitania de Minas Gerais. Memória histórica da Capitania de Minas Gerais. Belo Horizonte: Fundação João Pinheiro: Centro de Estudos Históricos e Culturais, 1995.

RODRIGUES, Carmem Marques. Os mapas das pedras brilhantes: a cartografia dos sertanistas, dos engenheiros militares e dos padres matemáticos sobre o Distrito Diamantino do Serro do Frio (1714-1771). Orientador: Júnia Ferreira Furtado. 2014. Dissertação (Mestrado em História Social) - Faculdade de Filosofia e Ciências Humanas, Universidade Federal de Minas Gerais, 2014.

RODRIGUES, Luciene. Formação econômica do Norte de Minas e o período recente. In: CARDOSO, José Maria Alves (org.). Formação social e econômica do norte de Minas. Montes Claros: Editora Unimontes, 2000.

ROLIM, Leonardo Cândido. Projetos de colonização para os sertões do Norte no "Roteiro do Maranhão a Goiás pela Capitania do Piauí" (c. 1770-1790). In: SIMPÓSIO NACIONAL DE HISTÓRIA, 28., 2015, Florianópolis. Anais [...]. Florianópolis: Anpuh, jul. 2015. p. 1-9.

RONCARI, Luiz. Antônio Conselheiro e Getúlio Vargas no Grande sertão: veredas? As fontes do autor e os caprichos da representação. O eixo e a roda: Revista de Literatura Brasileira, Belo Horizonte, v. 2, p. 121-147, 2006.

ROSA, João Guimarães. Grande sertão: veredas. Rio de Janeiro: Nova Fronteira, 1986.

ROSA, João Guimarães. No Urubuquaquá, no Pinhém. Rio de Janeiro: Nova Fronteira, 1994.

ROSA, João Guimarães. Sagarana. São Paulo: Nova Fronteira, 2006.

ROSTOW, Walt Whitman. Etapas do desenvolvimento econômico: um manifesto nãocomunista. Rio de Janeiro: Jorge Zahar, 1978. 
ROTEIRO do Maranhão a Goiaz pela Capitania do Piauhi. Revista Trimensal do Instituto Historico e Geographico Brazileiro, Rio de Janeiro: Imprensa Nacional, tomo LXII, p. 60161, 1900. Parte 1.

RULFO, Juan. Pedro Páramo e Chão em chamas. Rio de Janeiro: Record, 2008.

SAFATLE, Vladimir. Bem vindo ao estado suicidário. São Paulo: n-1 Edições, 2020.

SAINT-HILAIRE, Auguste de. Viagem pelas províncias do Rio de Janeiro e Minas Gerais. São Pulo: Editora Nacional, 1938.

SAINT-HILAIRE, Auguste de. Viagem pelo distrito dos diamantes e litoral do Brasil. Belo Horizonte: Itatiaia, 1938.

SANSI, Roger. Feitiço e fetiche no Atlântico moderno. Revista de Antropologia, São Paulo, v. 51, n. 1, p. 123-153, 2008.

SANTOS, Gilmar Ribeiro dos; SOUTO, Karine Gomes dos Santos. O desenvolvimento no norte de Minas na perspectiva da Sudene. Revista Desenvolvimento Social, Montes Claros, n. 12/01, 2014.

SANTOS, Joaquim Felício. Memorias do Districto Diamantino e da Comarca do Serro Frio (Provincia de Minas Geraes) pelo Dr. J. Felicio dos Santos. Rio de Janeiro:

Typographia Americana, 1868.

SANTOS, Joaquim Felício. Memórias do Distrito Diamantino. Belo Horizonte: Itatiaia, 1976.

SANTOS, Márcia Maria Duarte dos. Espaço e representação nas Minas setecentistas. Revista do Arquivo Público Mineiro, [s. l.], ano 46, n. 2, p. 44-59, jul./dez. 2010.

SCHOLZ, Roswitha. O valor é o homem. Teses sobre a socialização pelo valor e a relação entre os sexos. O Beco, 1992. Disponível em: http://www.obeco-online.org/rst1.htm. Acesso em: 2 jul. 2019.

SCHOLZ, Roswitha. O sexo do capitalismo: teorias feministas e metamorfose pós-moderna no patriarcado. O Beco, jan. 2000. Disponível em: http://www.obeco-

online.org/roswitha_scholz6.htm. Acesso em: 27 ago. 2019.

SCHOLZ, Roswitha. O ser-se supérfluo e a "angústia da classe média": o fenômeno da exclusão e a estratificação social no capitalismo. O Beco, maio 2008. Disponível em: http://www.obeco-online.org/roswitha_scholz8.htm. Acesso em: 10 mar. 2018.

SCHOLZ, Roswitha. Cristóvão Colombo forever? Para a crítica das actuais teorias da colonização no contexto do "colapso da modernização". O Beco, 2016. Disponível em: http://www.obeco-online.org/roswitha_scholz24.htm. Acesso em: 12 out. 2020.

SCHWARCZ, Lilia Moritz. O espetáculo das raças: cientistas, instituições e questão racial no Brasil - 1870-1930. São Paulo: Companhia das Letras, 1993. 
SCHWARZ, Roberto. As ideias fora do lugar. In: SCHWARZ, Roberto. Ao vencedor as batatas. São Paulo: Duas Cidades, 1992.

SCHWARZ, Roberto. Fim de século. In: SCHWARZ, Roberto. Sequências brasileiras: ensaios. São Paulo: Companhia das Letras, 1999. p. 155-162.

SCLIAR, Moacyr. Saturno nos trópicos: a melancolia europeia chega ao Brasil. São Paulo: Companhia das Letras, 2003.

SENA, Custódia Selma. A categoria sertão: um exercício de imaginação antropológica. Sociedade e Cultura, n. 1, v. 1, p. 19- 28, jan./jun. 1998.

SENNA, Nelson de. Annuario de Minas Geraes, Bello Horizonte: Imprensa Official do Estado de Minas Geraes, v. 3, parte 2, 1909.

SENNA, Nelson de. Annuario de Minas Geraes, Bello Horizonte: Imprensa Official do Estado de Minas Geraes, v. 5, nov. 1913.

SENNA, Nelson de. Annuario de Minas Geraes. Bello Horizonte: Imprensa Official do Estado de Minas Geraes, anno 6, tomos 1 e 2, 1918.

SILVA, Ana Paula Londe; VAL, Marina Costa. Celso Furtado: a teoria do subdesenvolvimento e o caso brasileiro. Revista Multiface, Belo Horizonte, v. 1, p. 16-21, 2013.

SILVA, Andrée Mansuy Diniz. Introdução e notas. In: ANTONIL, André João. Cultura e opulência do Brasil por suas drogas e minas. São Paulo: Edusp, 2007.

SILVA, Claiton Márcio da. A face infértil do Brasil: ciência, recursos hídricos e o debate sobre (in)fertilidade dos solos do cerrado brasileiro, 1892-1942. História, Ciências, Saúde: Manguinhos, Rio de Janeiro, v. 26, n. 2, p. 483-500, abr./jun. 2019.

SILVA, René Marc da Costa. O não-branco, o sertão e o pensamento social brasileiro. Prismas: Dir., Pol. Pub. e Mundial., Brasília, v. 3, n. 2, p. 427-454, jul./dez. 2006.

SLENES, Robert W. Os múltiplos de porcos e diamantes: a economia escrava de Minas Gerais no século XIX. Estudos Econômicos, São Paulo, v. 18, n. 3, p. 449-495, set./dez. 1988.

SLENES, Robert W. Na senzala uma flor: esperanças e recordações na formação da família escrava. Rio de Janeiro: Nova Fronteira, 1999.

SMITH, Adam. A riqueza das nações: investigação sobre sua natureza e suas causas. São Paulo: Abril Cultural, 1983. (Série Os Economistas, v. 1).

SOUZA, Elza Coelho de. Tipos e aspectos do Brasil: Carvoeiro. Revista Brasileira de Geografia, ano 8, n. 4, p. 151, out./dez. 1946.

SOUZA, Laura de Mello e. Desclassificados do ouro: a pobreza mineira no século XVIII. Rio de Janeiro: Graal, 2004. 
SPIX, Johann Baptist von; MARTIUS, Carl Friedrich Philipp von. Viagem pelo Brasil: 1817-1820. Belo Horizonte: Itatiaia, 1981.

STALLYBRASS, Peter. O casaco de Marx: roupas, memória, dor. Belo Horizonte: Autêntica Editora, 2008.

STARLING, Heloisa Maria Murgel. Lembranças do Brasil: teoria, política, história e ficção em Grande sertão: veredas. Rio de Janeiro: Revan, 1999.

SVAMPA, Maristela. EI dilema argentino: civilizacion o barbarie. Buenos Aires: El Cielo Por Asalto, 1994.

TATURANA. In: GRANDE Dicionário Houaiss da Língua Portuguesa. Rio de Janeiro: Editora Objetiva, 2001. p. 2678.

TAUSSIG, Michael T. The devil and commodity fetishism in South America. North Carolina: The University of North Carolina Press, 2010.

TAVARES, Heráclio Duarte; VIDEIRA, Antonio Augusto Passos. César Lattes, José Leite Lopes e o nacionalismo científico no Brasil dos anos 1940. Revista de História, São Paulo, n. 179, a12418, p. 1-33, 2020.

TOLEDO, Carlos de Almeida. A mobilização do trabalho nas lavras baianas. Orientador: Heinz Dieter Heidemann. 2001. Dissertação (Mestrado em Geografia Humana) - Faculdade de Filosofia, Letras e Ciências Humanas, Universidade de São Paulo, São Paulo, 2001.

TOLEDO, Carlos de Almeida. A região das lavras baianas. Orientador: Heinz Dieter Heidemann. 2008. Tese (Doutorado em Geografia Humana) - Faculdade de Filosofia, Letras e Ciências Humanas, Universidade de São Paulo, São Paulo, 2008.

TURNER, Frederick Jackson. Oeste americano: quatro ensaios de história dos Estados Unidos da América. Rio de Janeiro: Eduff, 2004.

VELLASCO, Ivan de Andrade. Os predicados da ordem: os usos sociais da justiça nas Minas Gerais 1780-1840. Revista Brasileira de História, São Paulo, v. 25, n. 50, p. 167-200, dez. 2005.

VENÂNCIO, Renato Pinto. Antes de Minas: fronteiras coloniais e populações indígenas. In: RESENDE, Maria Efigênia Lage de; VILLALTA, Luiz Carlos (org.). As Minas setecentistas. Belo Horizonte: Autêntica: Companhia do Tempo, 2007. v. 1, p. 87-102.

VEROSSIMILHANÇA. In: GRANDE Dicionário Houaiss da Língua Portuguesa. Rio de Janeiro: Editora Objetiva, 2001. p. 2.849.

VIANNA, Oliveira. Populações meridionais do Brasil. Brasília, DF: Edições do Senado Federal, 2005. v. 27.

VIGGIANO, Alan. Itinerário de Riobaldo Tatarana: geografia e toponímia em Grande sertão: veredas. Belo Horizonte: Crisálida, 2007. 
WISSEN, Leni. A matriz psicossocial do sujeito burguês na crise: uma leitura da psicanálise de Freud do ponto de vista da crítica da dissociação-valor. O Beco, mar. 2017. Disponível em: http://www.obeco-online.org/leni_wissen.htm. Acesso em: 30 nov. 2020.

\section{MÚSICAS}

BAIANO do boi. Intérprete: Ânima. Compositor: Anônimo. [S. l.: s. n.], século XVII. 1 CD. A música na festa. In: JANCSÓ, István; KANTOR, Iris (org). Festa: cultura e sociabilidade na América Portuguesa. São Paulo: Hucitec: Edusp: Fapesp: Imprensa Oficial, 2001.

CHULA no terreiro. Intérprete: Elomar Figueira Mello. Compositor: Elomar Figueira Mello. In: ... NA QUADRA das águas perdidas. Intérprete: Elomar Figueira Mello. [S. l.: s. n.], 1979. 1 vídeo (6'06"). Publicado pelo canal Various Artists - Topic. Disponível em: https://www.youtube.com/watch?v=k-TN04-eZaE. Acesso em: 17 jun. 2021.

MORRO velho. Intérprete: Milton Nascimento. Compositor: Milton Nascimento. In: COURAGE. Intérprete: Milton Nascimento. [S. l.]: UMG Recordings, 1969. 1 vídeo (4'25"). Publicado pelo canal Milton Nascimento. Disponível em:

https://www.youtube.com/watch?v=UhUnddaHP40. Acesso em: 17 jun. 2021.

NA ESTRADA das areias de ouro. Intérprete: Elomar Figueira Mello. Compositor: Elomar Figueira Mello. In: ... DAS BARRANCAS do rio Gavião. Intérprete: Elomar Figueira Mello. [S. l.]: Phillips, 1972. 1 vídeo (2’25”). Publicado pelo canal Elomar Figueira Mello.

Disponível em: https://www.youtube.com/watch?v=NEnOXKQyKYE. Acesso em: 17 jun. 2021.

PAISAGEM da janela. Intérprete: Lô Borges. Compositor: Lô Borges. In: CLUBE da esquina. Intérprete: Lô Borges; Milton Nascimento. [S. l.]: EMI Records Brasil Ltda., 1972. 1 vídeo (2’58”). Publicado pelo canal Lô Borges - Tema. Disponível em:

https://www.youtube.com/watch?v=d50EXVUzm_E. Acesso em: 17 jun. 2021.

SAÍDAS e bandeiras $\mathrm{n}^{\circ}$ 2. Intérprete: Milton Nascimento. Compositor: Milton Nascimento e Fernando Brant. In: CLUBE da esquina. Intérprete: Lô Borges; Milton Nascimento. [S. l.]: EMI Records Brasil Ltda., 1972. 1 vídeo (1'30”). Publicado pelo canal Milton Nascimento. Disponível em: https://www.youtube.com/watch?v=MYrAcK4P0Vo. Acesso em: 17 jun. 2021.

\section{NOTÍCIAS}

ANTONINI, Christiane. Escravos do século XXI. O norte de Minas, Montes Claros, 1 ago. 2019. Minas do Norte. Disponível em: https://onorte.net/minas-do-norte/escravos-dos\%C3\%A9culo-21-1.732467. Acesso em: 14 abr. 2020.

BRANDÃO, Paulo. Morre o eterno prefeito de Bocaiúva: Wan-Dick Dumont. O Norte de Minas, Montes Claros, 15 maio 2007. Minas do Norte. Disponível em: https://onorte.net/minas-do-norte/morre-o-eterno-prefeito-de-bocai\%C3\%BAva-wan-dyckdumont-1.523549. Acesso em: 4 jan. 2020. 
CARVOARIA mantinha 23 trabalhadores em situação degradante no Norte de Minas.

Aconteceu no vale, [s. l.], 17 nov. 2018. Norte de Minas. Disponível em:

https://aconteceunovale.com.br/portal/?p=139065. Acesso em: 10 mar. 2019.

GOUVEIA, Marcelo. O Cerrado está extinto e isso leva ao fim dos rios e dos reservatórios de água. Jornal Opção, [s. l.], 4 out. 2014, edição 2048. Entrevista. Disponível em:

https://www.jornalopcao.com.br/entrevistas/o-cerrado-esta-extinto-e-isso-leva-ao-fim-dosrios-e-dos-reservatorios-de-agua-16970/. Acesso em: 13 out. 2019.

G1 GRANDE MINAS. Resgatados em situação análoga ao trabalho escravo no Norte de MG buscam no Ministério do Trabalho acerto com empregador. G1, 28 dez. 2017. Disponível em: https://g1.globo.com/mg/grande-minas/noticia/resgatados-em-situacao-analoga-ao-trabalhoescravo-no-norte-de-mg-buscam-no-ministerio-do-trabalho-acerto-com-empregador.ghtml. Acesso em: 10 mar. 2019.

MACHADO, Ricardo. Fascismo, a política oficial do Antropoceno. Entrevista especial com Marco Antonio Valentim. Instituto Humanitas Unisinos, São Leopoldo, 31 out. 2018. Notícias. Disponível em: http://www.ihu.unisinos.br/159-noticias/entrevistas/584155fascismo-a-politica-oficial-do-antropoceno-entrevista-especial-com-marco-antonio-valentim. Acesso em: 3 mar. 2021.

"O PIOR inimigo do meio ambiente é a pobreza", diz Paulo Guedes em Davos. G1, [s. l.] 21 jan. 2020. Economia. Disponível em: https://g1.globo.com/economia/noticia/2020/01/21/opior-inimigo-do-meio-ambiente-e-a-pobreza-diz-paulo-guedes-em-davos.ghtml. Acesso em: 21 jun. 2020. 


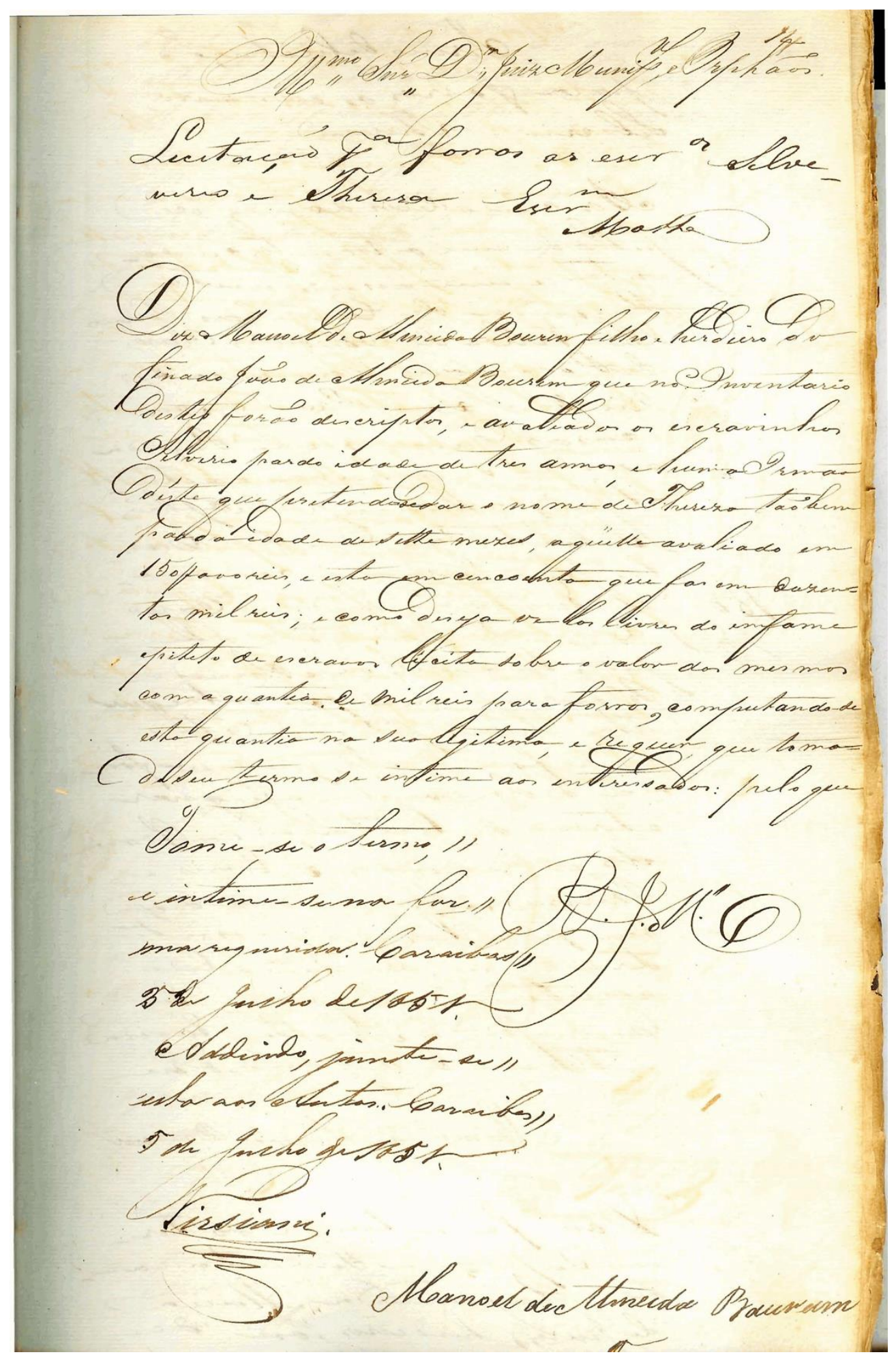

Página 27. 


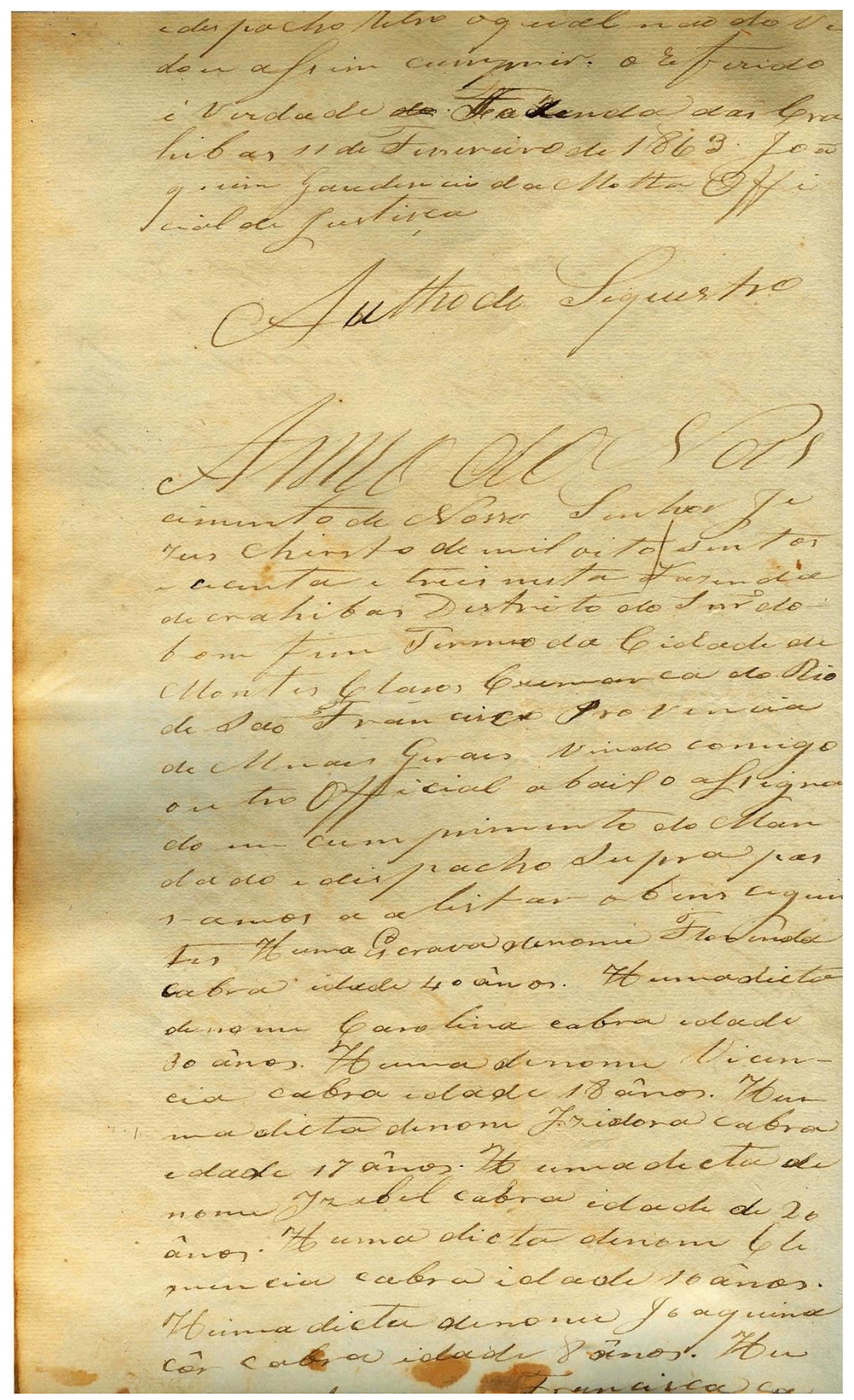

Página 35. 


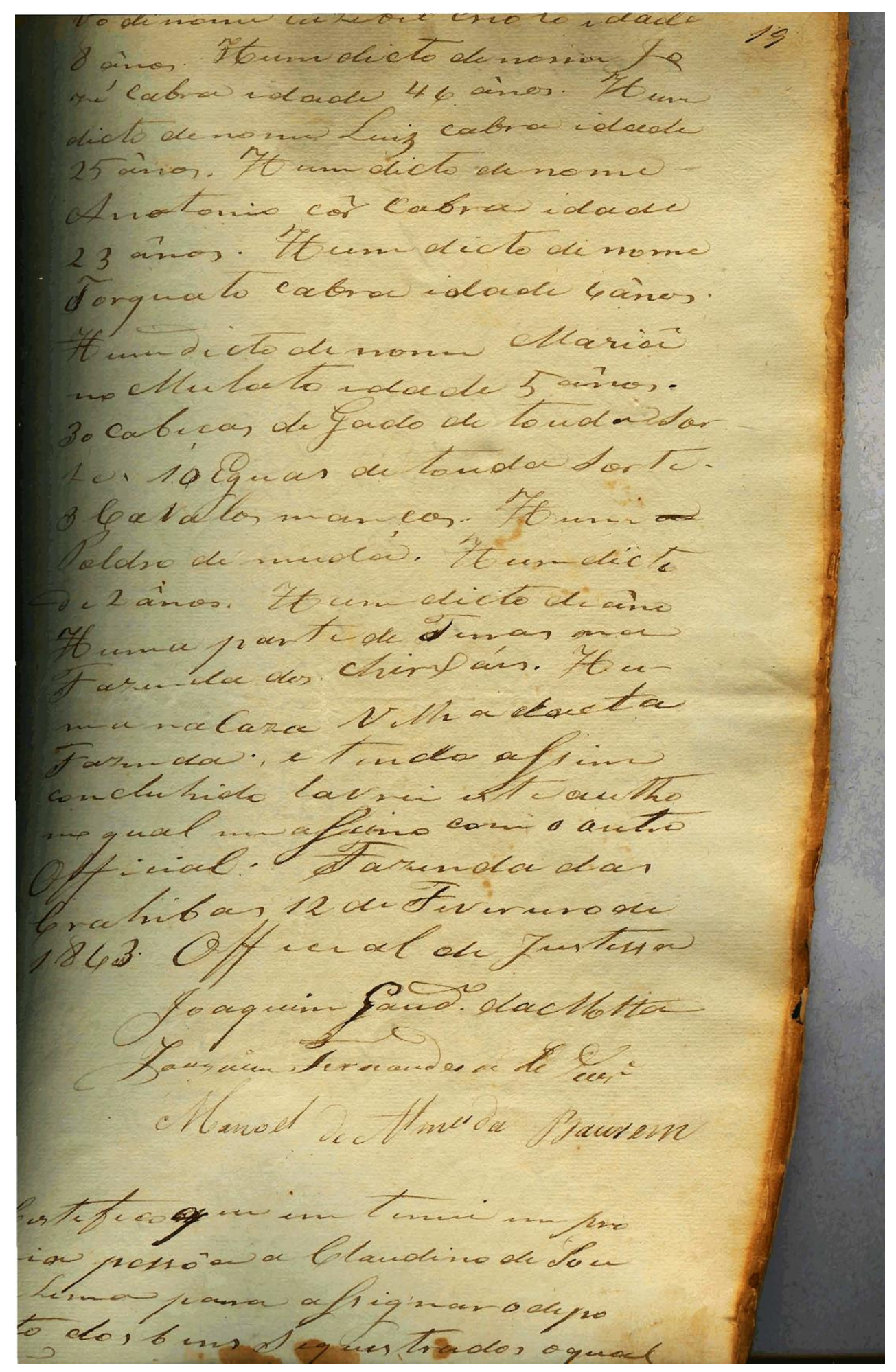

Página 36. 


\section{ANEXO B - INVENTÁRIO DE FRANCISCO DE ALMEIDA BORÉM, 1863}

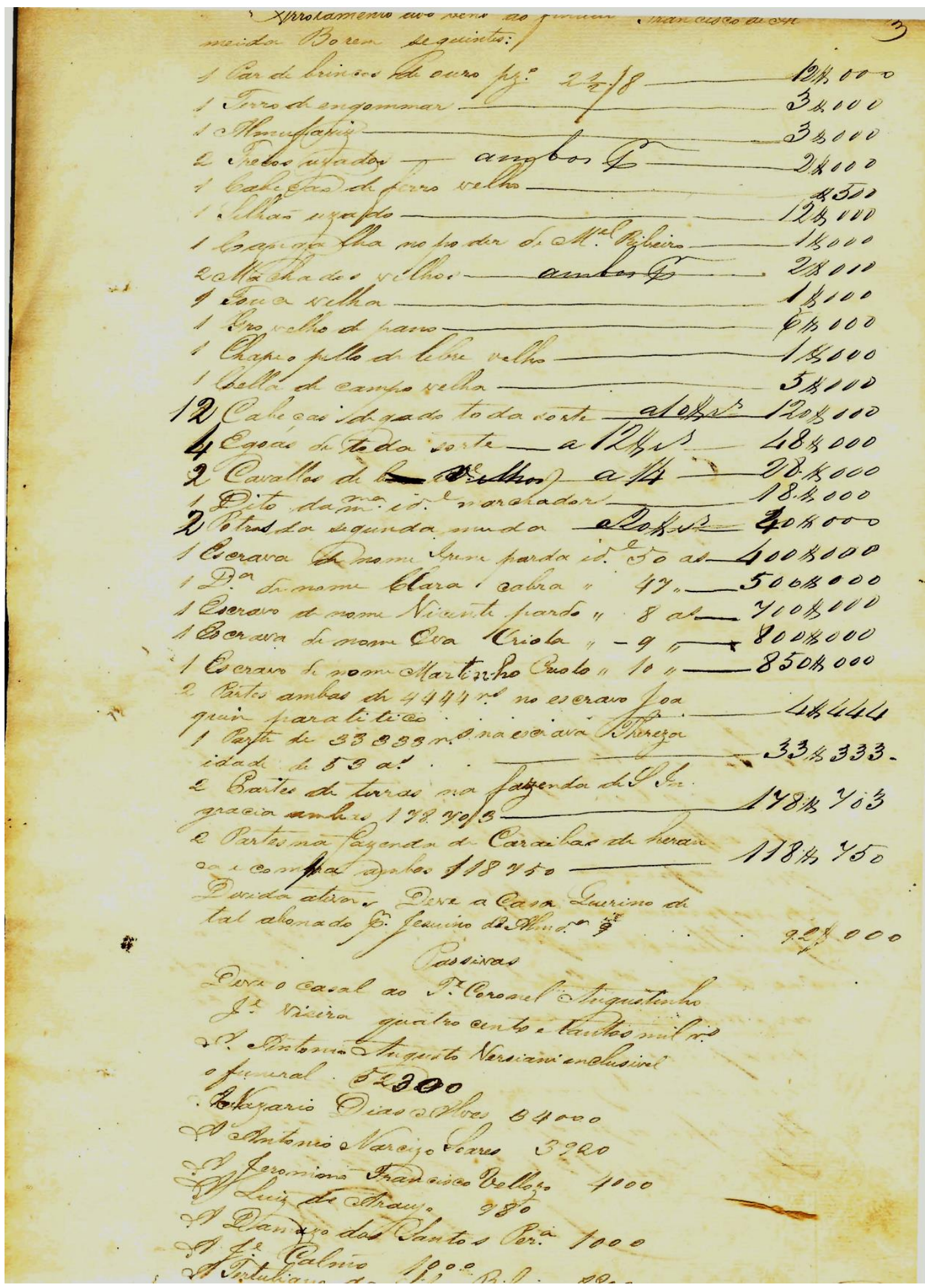

Página 5. 


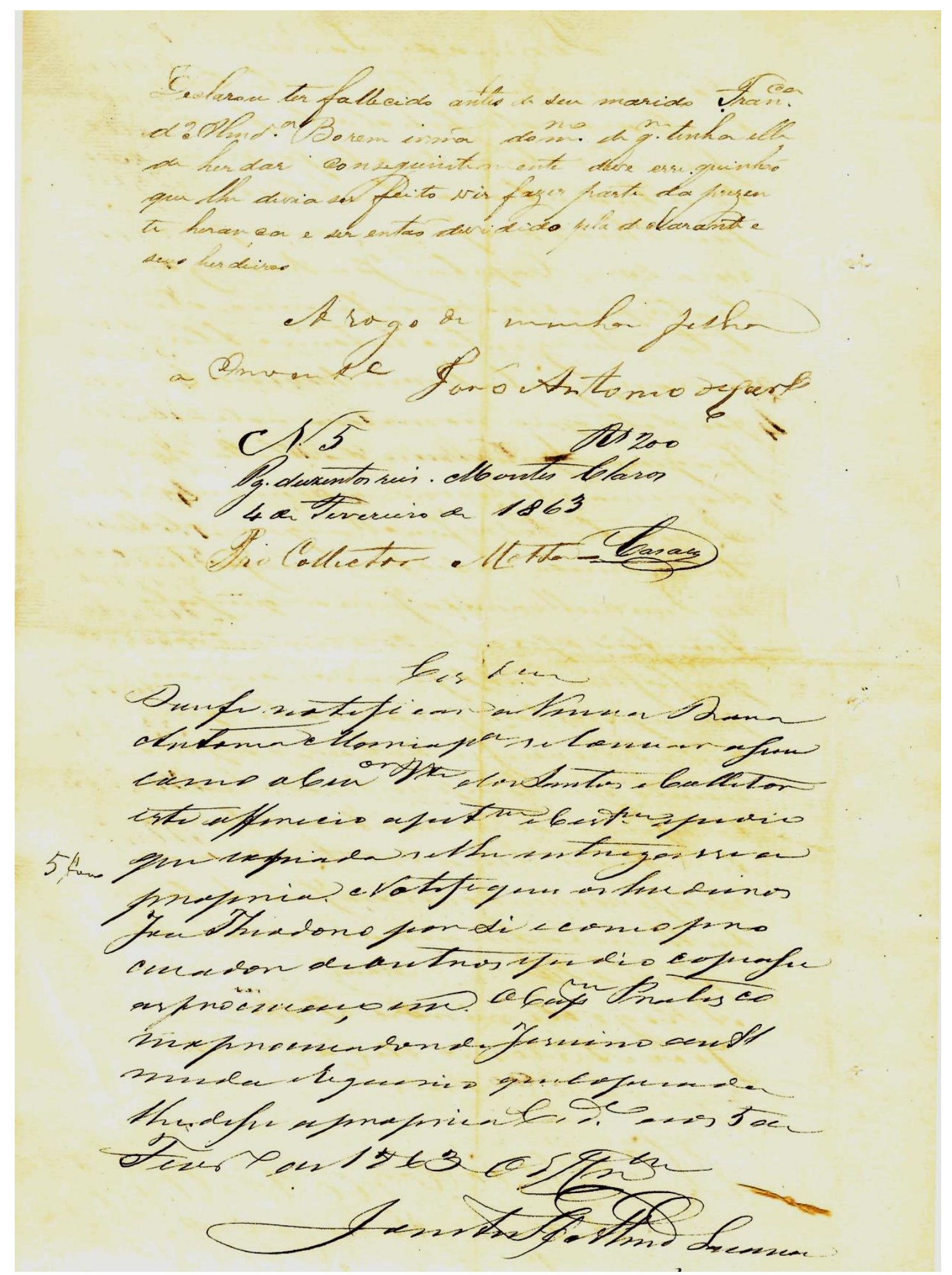

Página 6. 


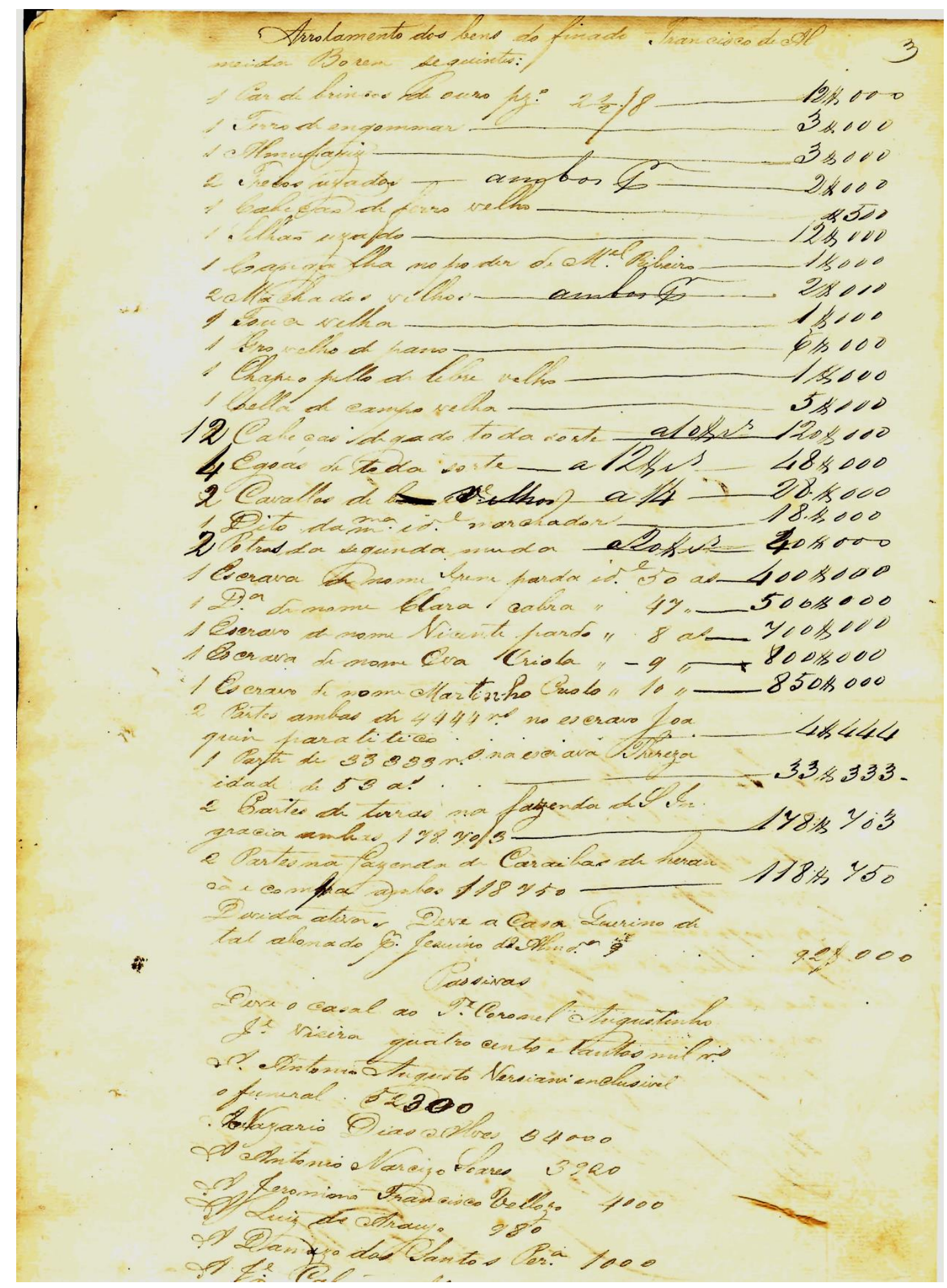

Página 7. 


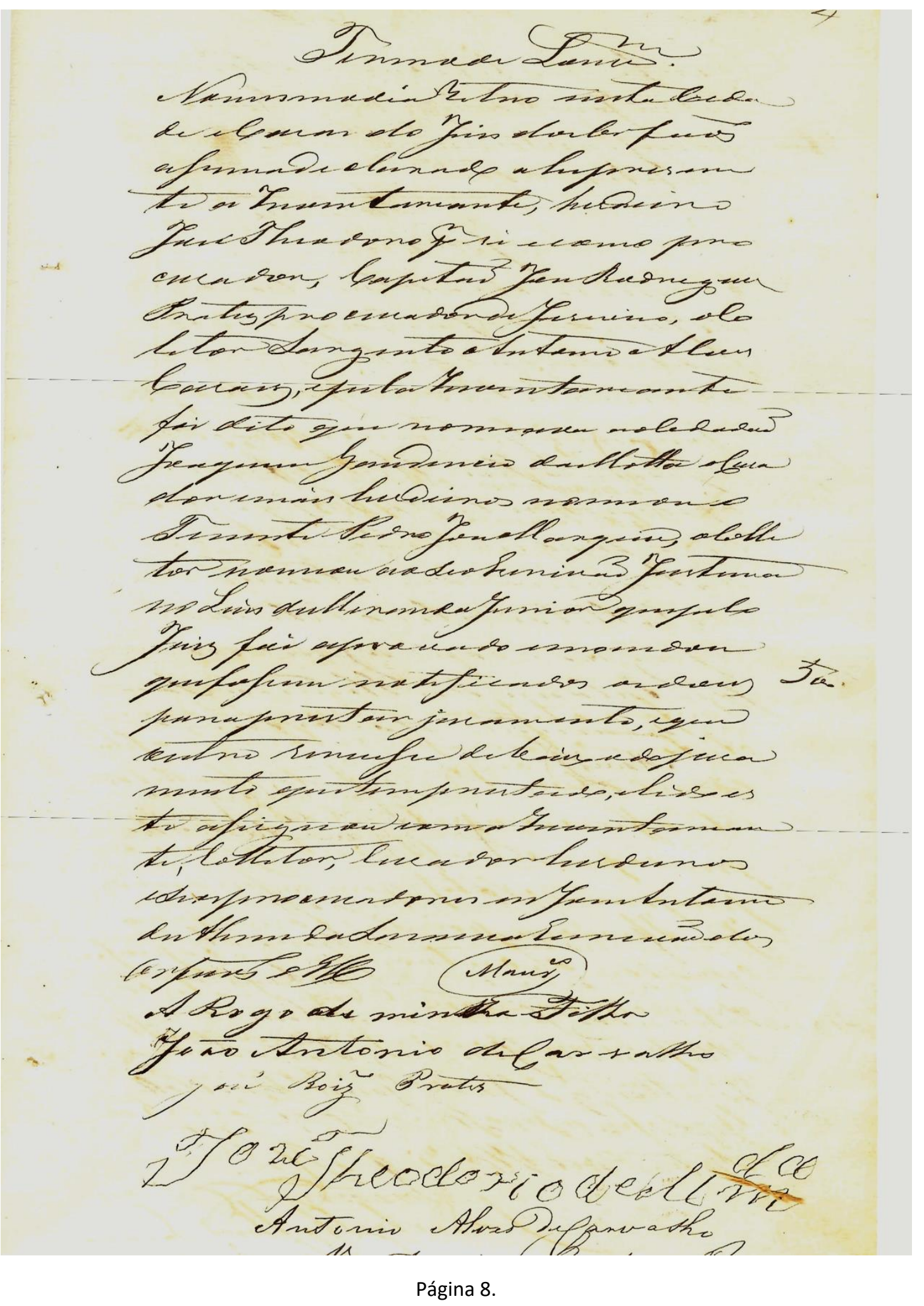

Página 8.

369 


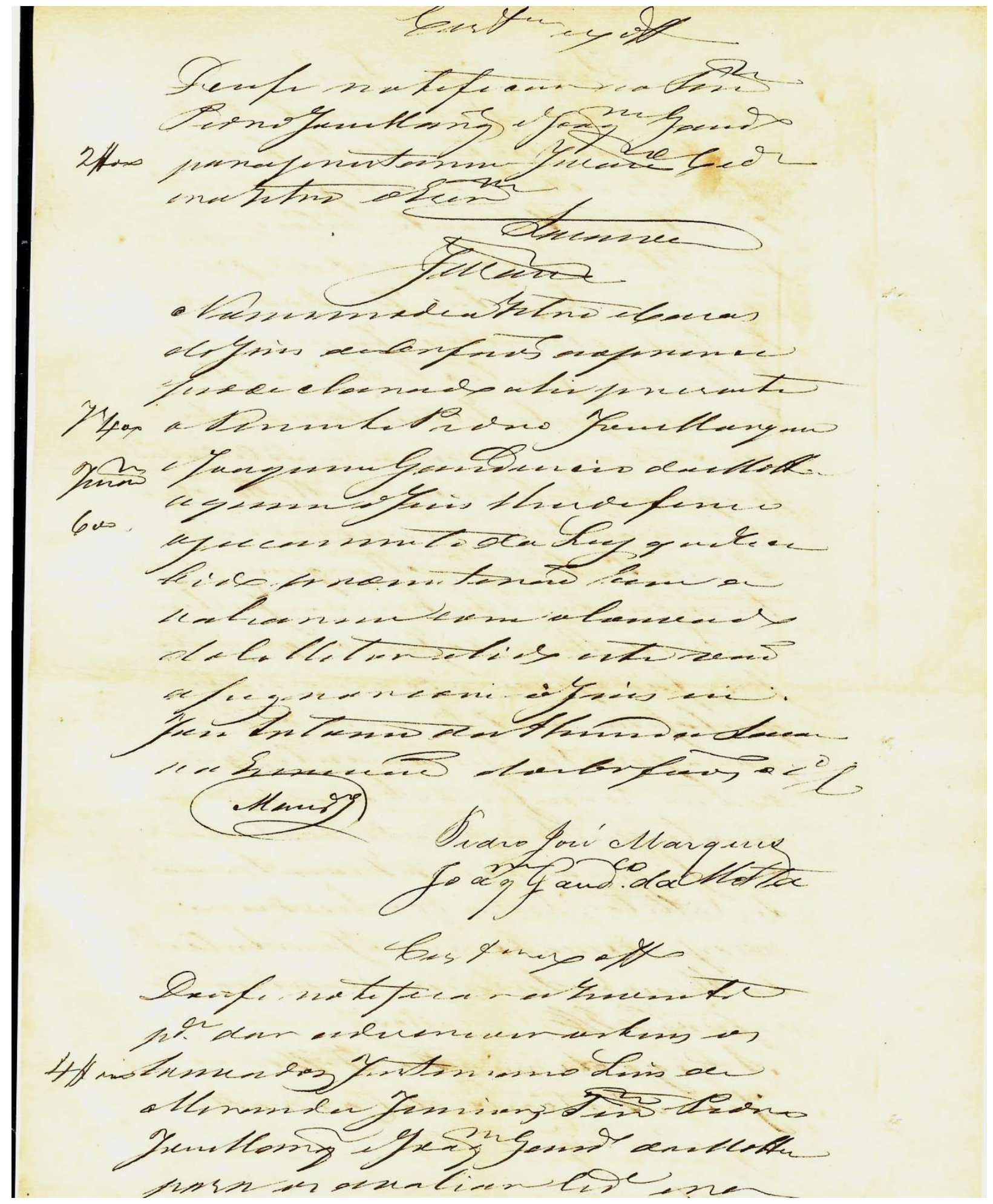

Página 9. 


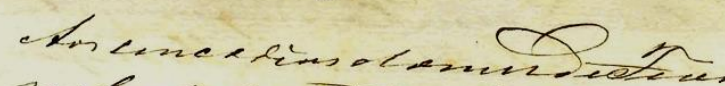

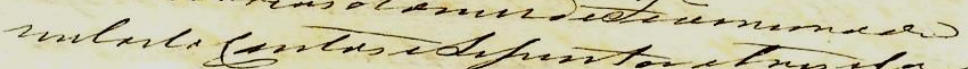

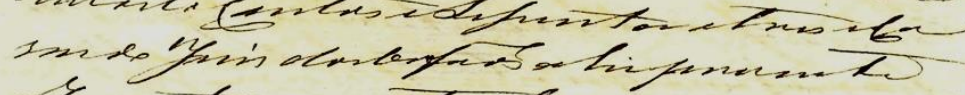

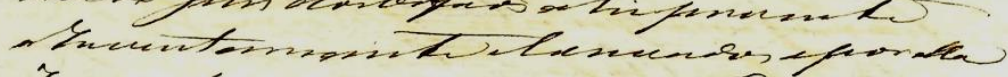

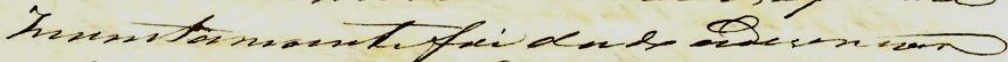

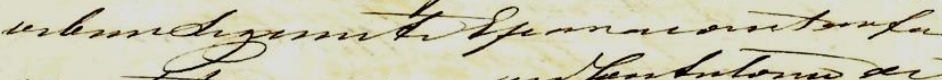

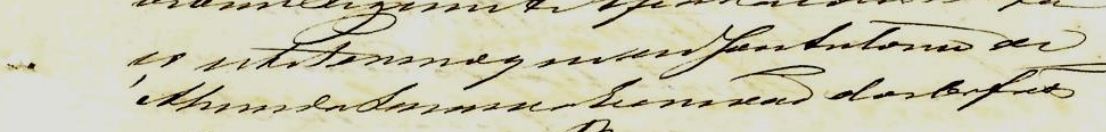
planwich Beng=

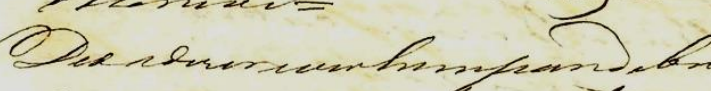

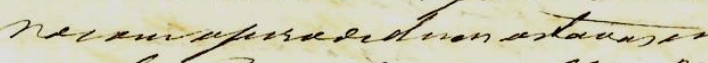
P 3 h

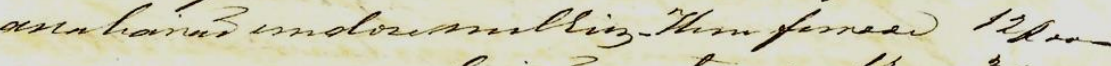

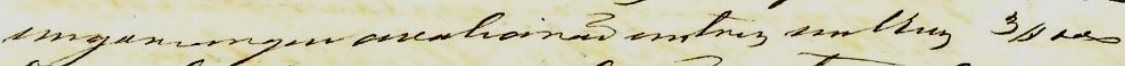

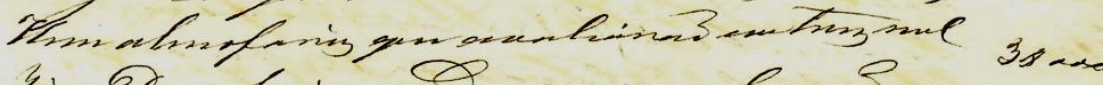

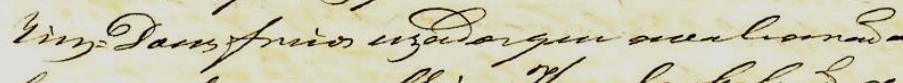

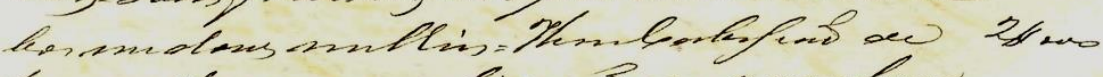

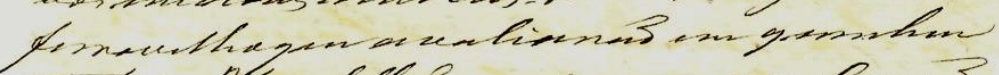

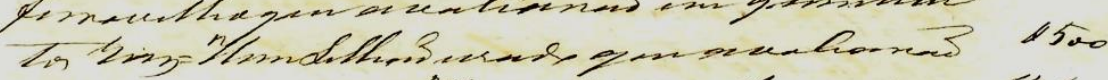

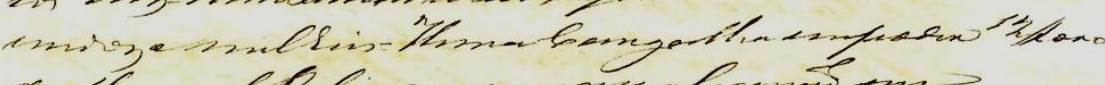

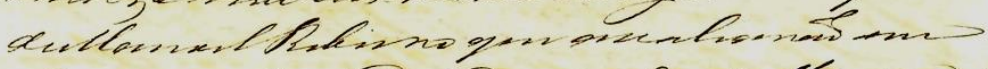

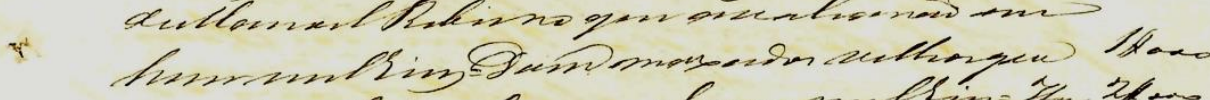

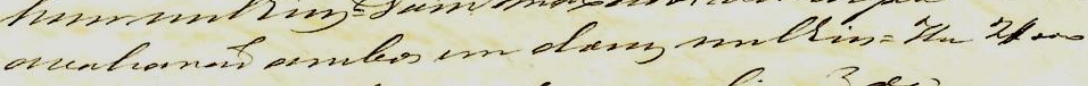

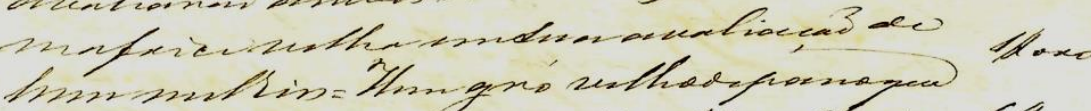

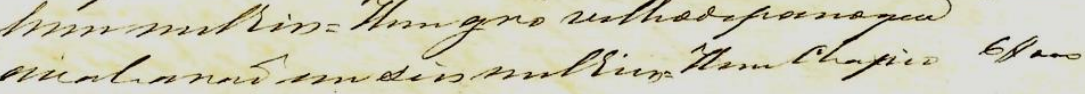

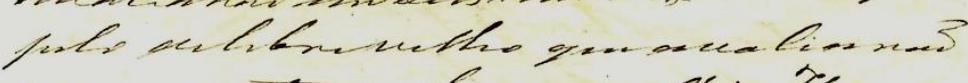

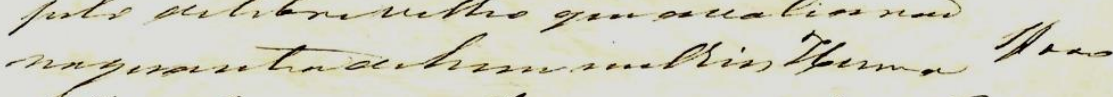

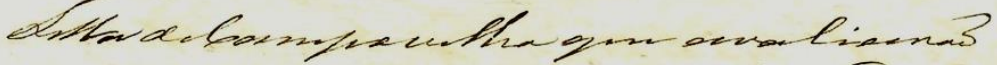

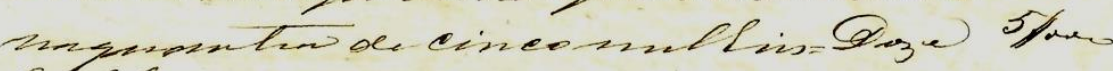

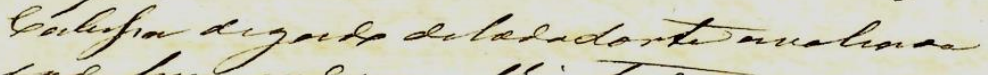

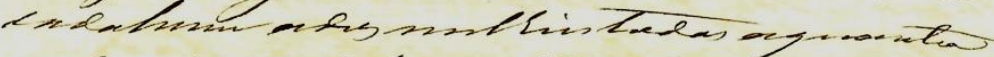

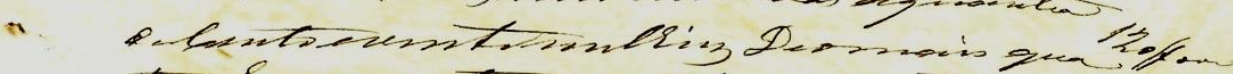

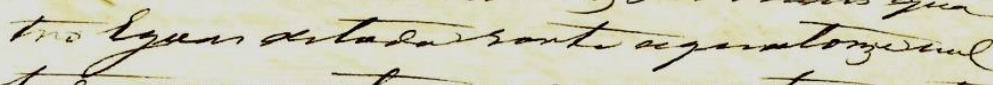

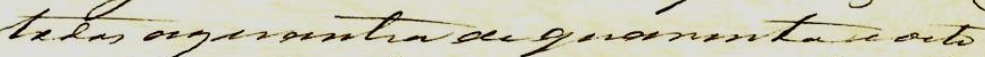

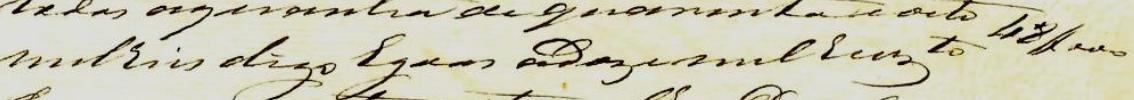

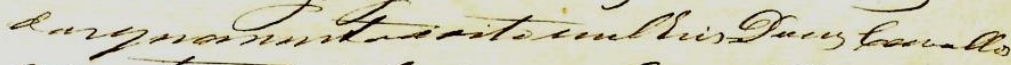

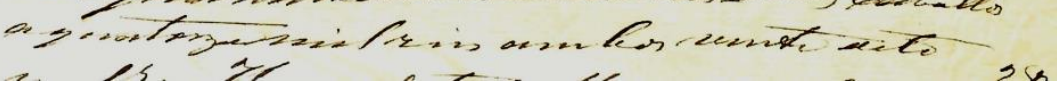

Página 10. 


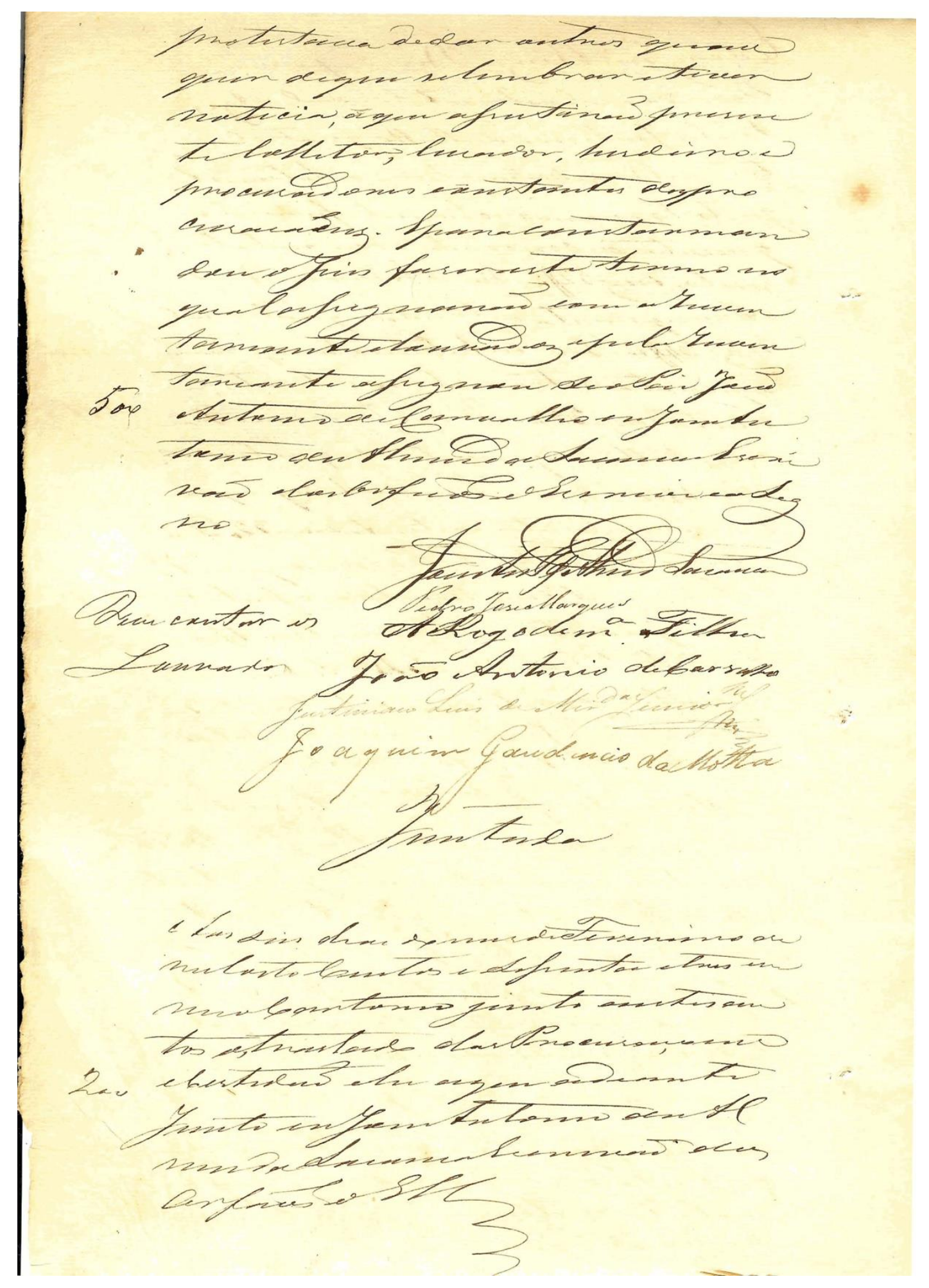

Página 11. 


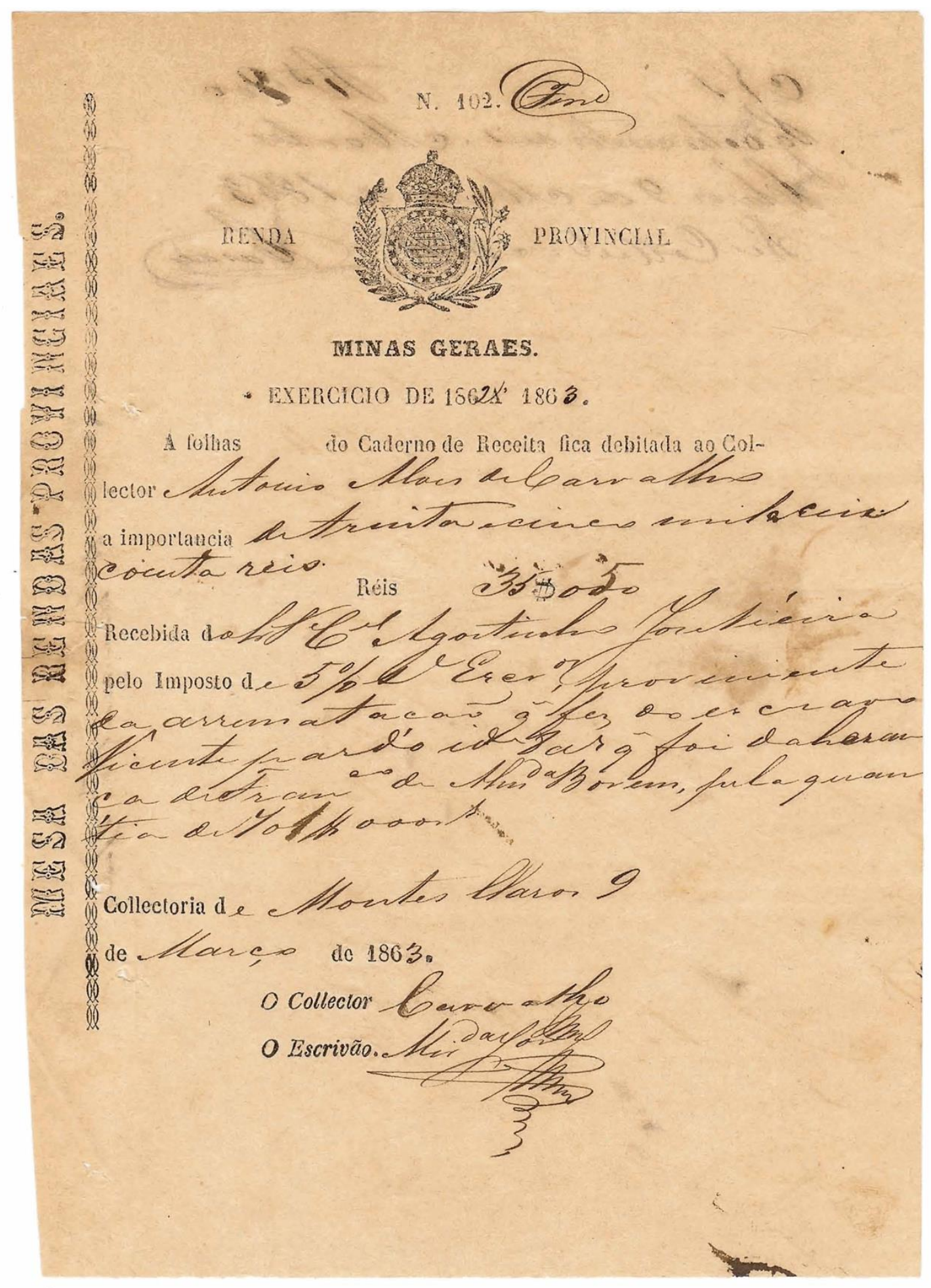

Página 104. 


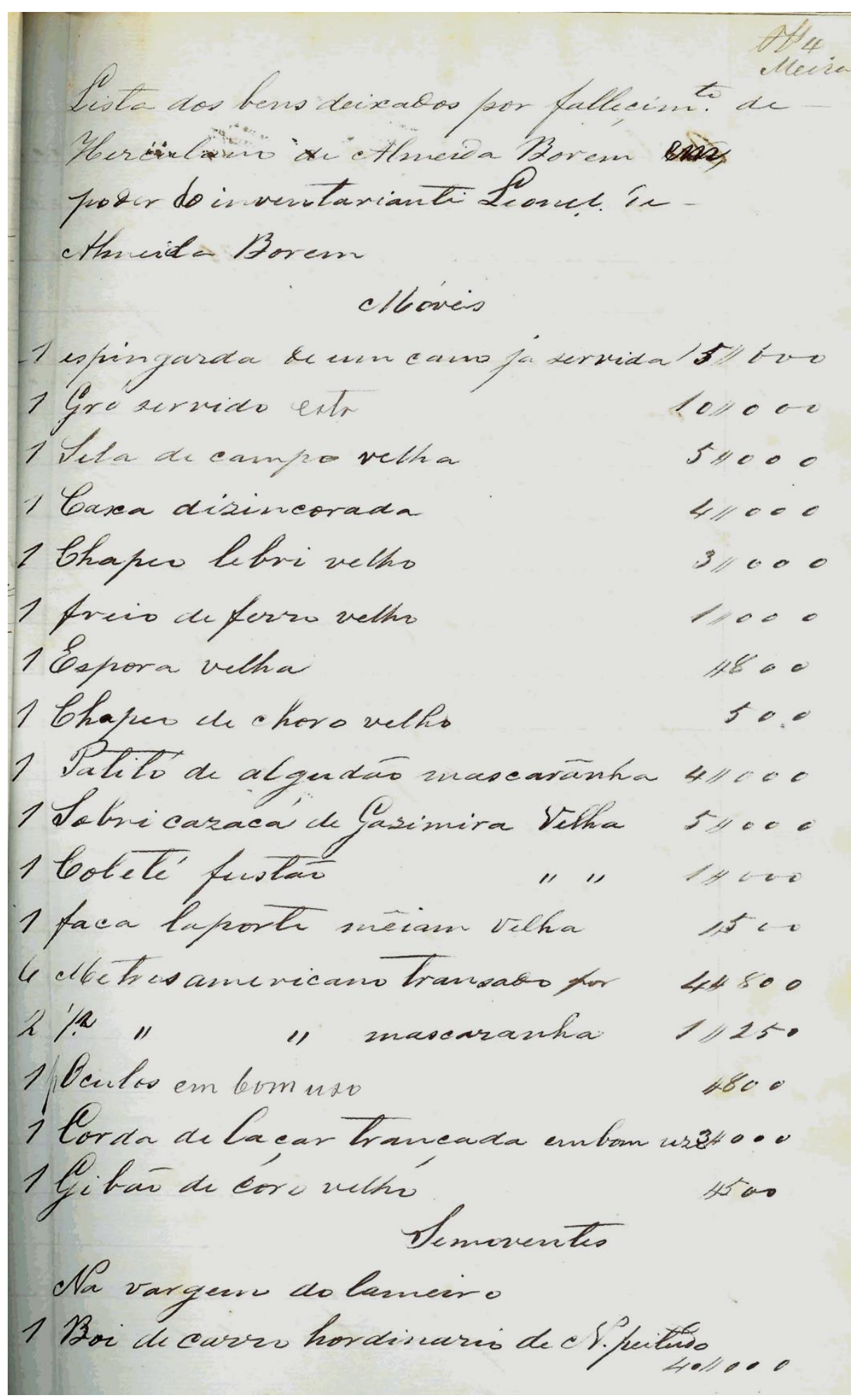

Página 6. 
1 Peitero "

4 Vacas Raridas 14 babecas an yabos

1 Poi eftgato

11 samotity

ca Rasida 3 Cabecas an gado toda dorti Navargens 1 Gava. formaa

- 254

ysllol Gavall

1 Vace Vitha linthe omovo edecolon Arrovicas

3 Vacasfraridas

3012

$$
251107
$$$$
\text { solid }
$$

11

4 Coake hecas

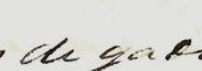

astida

Ro

1 Hoi de carro ke newee

1,

1)

11

reado

St

ir var

qe

22

$x_{c} \cot$

2 Vacas haridas joll

1 jarrate

- Na vargem da Lantra

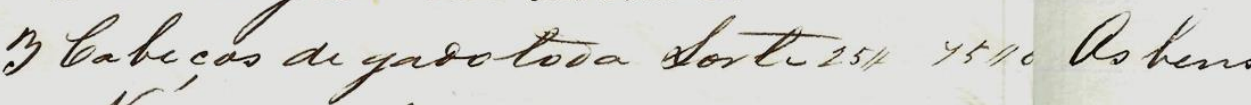
Claxeapabinka

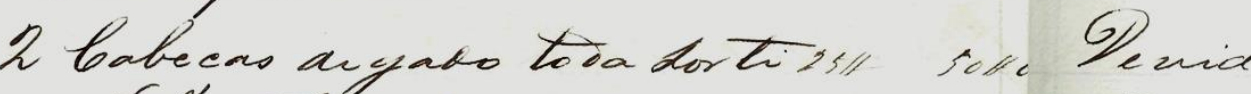
Nobunitigeinho

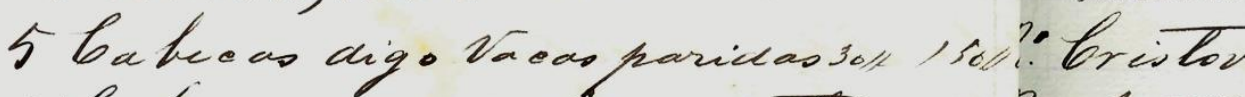
9 batreas ai guoos toda hor tirs" 22513 chnton

Página 7. 
Nofoaw Peveira

Meize

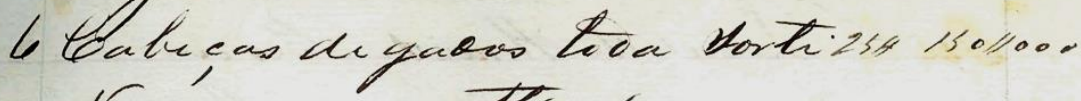
Cavargeen de téc cara

1 Vaca parida

301000 CNagaraja

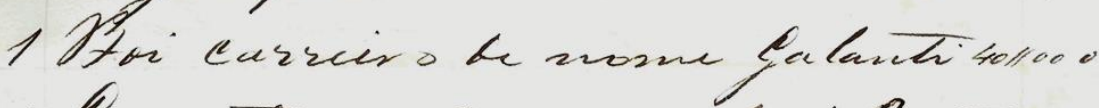

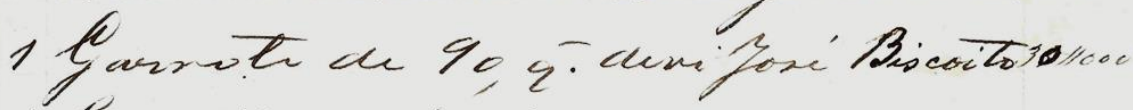
1 Gavallo cusläntos de Yy Yillew

1 Cavalk bain an 18

161000

1 clbelaro de 87

2011000

11 "'aitainas Pl 201000

1 "Carlankopampa be 8430100.

111 "baio a 853011000

111 Luinat de 75 3011000

1 "clbelab a 89 istiono

1 Egua parida 201100

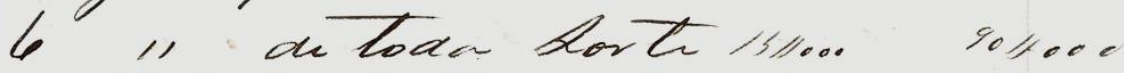

to teabecas de Carneiras 101000

Pais

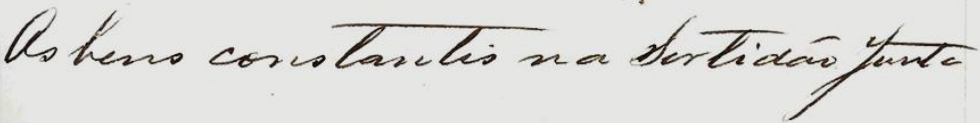

Venides Cufitineas

10 Furtaino Percira de ctnirabi:

4.000

hiloristovat cllooreira hethuciaa

Y.ooe

3 Antonio a Songa elloreira

4000

Página 8.

376 


\section{ANEXO D - ENTREVISTADOS}

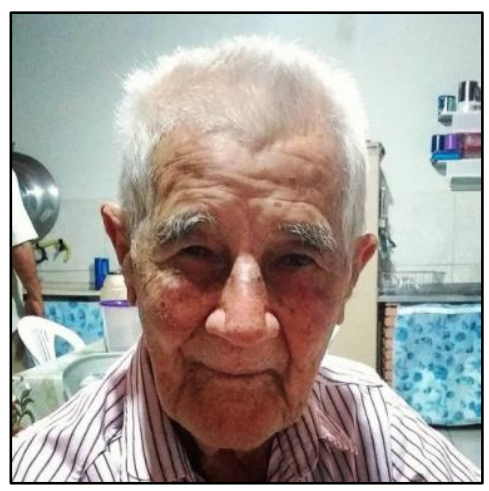

Nome: Abílio Rosa da Silva (Biloca)

Idade: 93 anos (†2019)

Cidade: Francisco Dumont

Profissão: lavrador

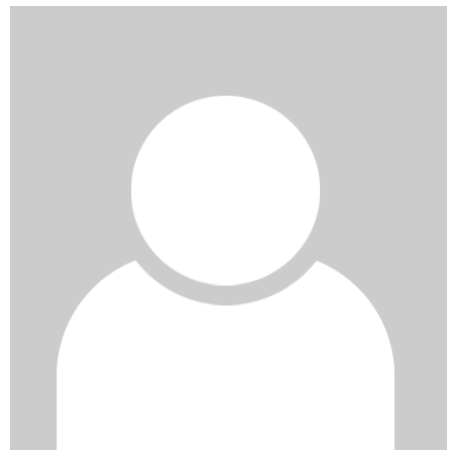

Nome: Ademar Arcanjo Cabral (Dê)

Idade: 75 anos (2016)

Cidade: Francisco Dumont

Profissão: garimpeiro

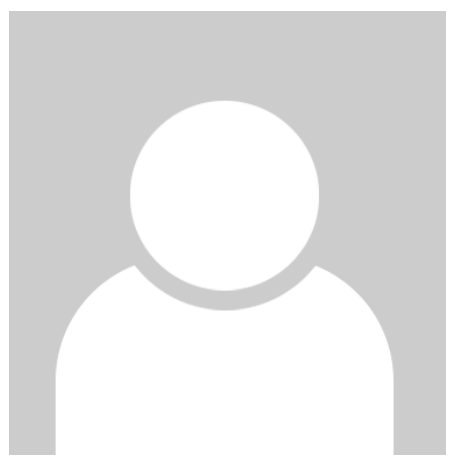

Nome: Adilson Barbosa (Neno)

Idade: 31 anos (2020)

Cidade: Francisco Dumont

Profissão: segurança de reflorestadora

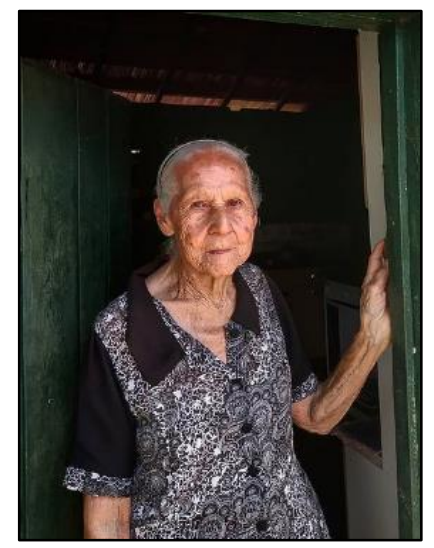

Nome: Alexandrina Medeiros (Duca)

Idade: 87 anos (2019)

Cidade: Covancas (Francisco Dumont)

Profissão: professora 

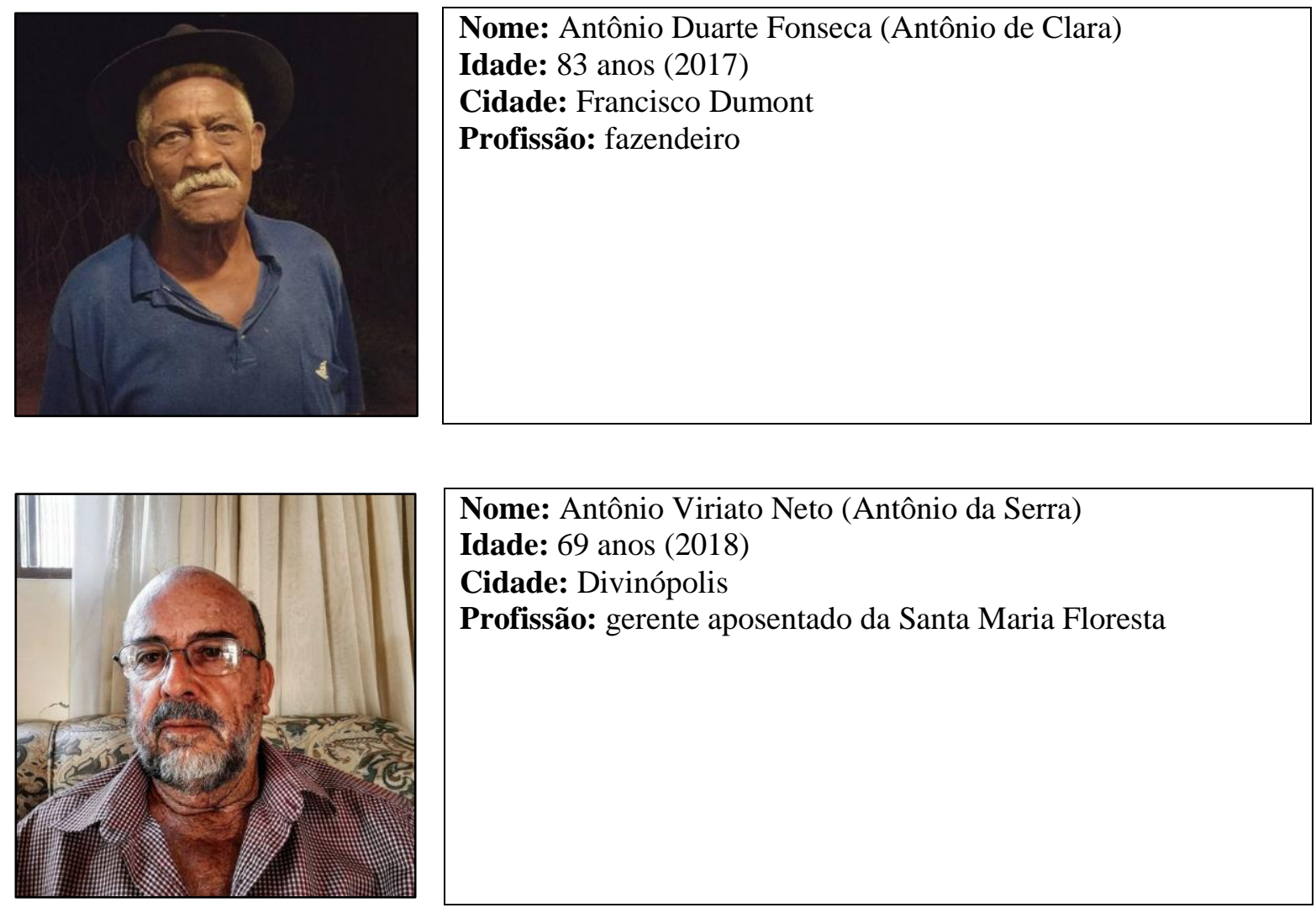

Nome: Antônio Viriato Neto (Antônio da Serra)

Idade: 69 anos (2018)

Cidade: Divinópolis

Profissão: gerente aposentado da Santa Maria Floresta

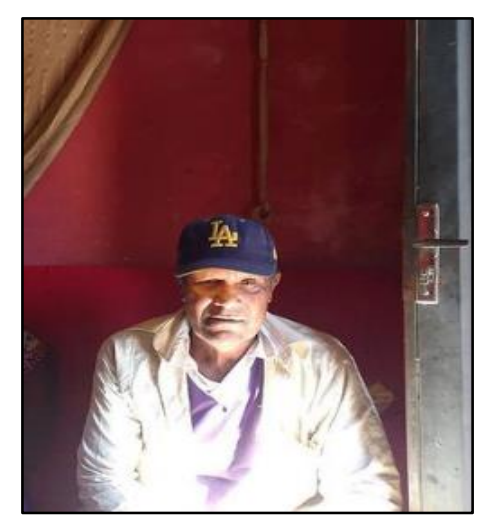

Nome: Célio Pereira de Souza

(filho de Maria de Oliveira e irmão de José Juvenal de Souza e Maria Eunice Silva Souza)

Idade: 53 anos (2017)

Cidade: Francisco Dumont

Profissão: lavrador

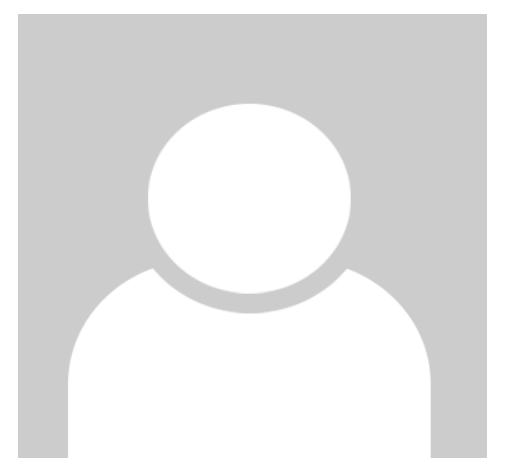

Nome: Clarice Medeiros

Idade: 36 anos (2015)

Cidade: Francisco Dumont

Profissão: faxineira e cozinheira 


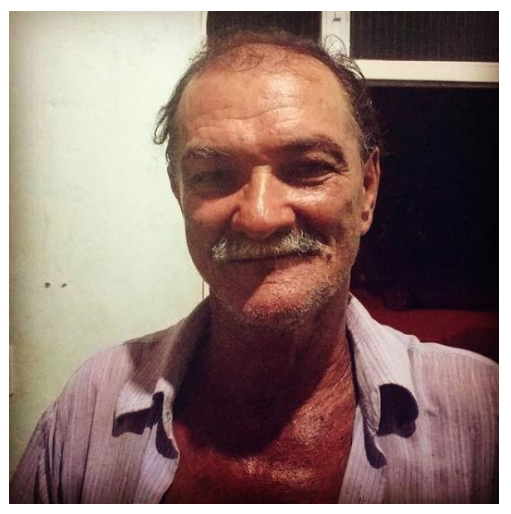

Nome: Dermeval Pereira Leite
Idade: 66 anos (2017)
Cidade: Francisco Dumont
Profissão: garimpeiro

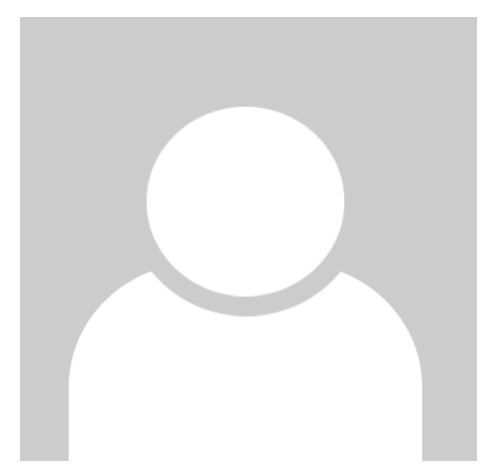

Nome: Édio Geraldo Prado (Nem de Bico)

Idade: 65 anos (2020)

Cidade: Francisco Dumont

Profissão: coletor

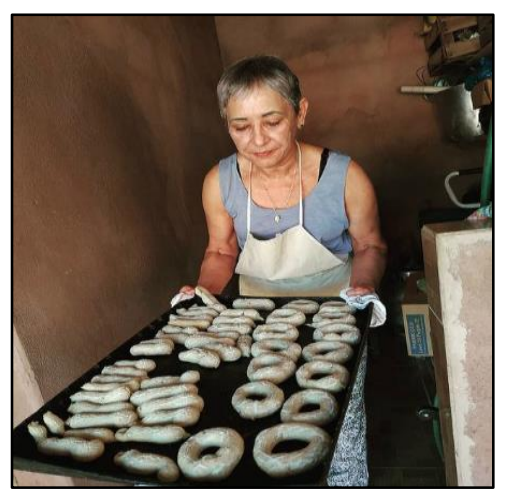

Nome: Eliane Leite Rosa

Idade: 63 anos (2021)

Cidade: Francisco Dumont

Profissão: operária aposentada

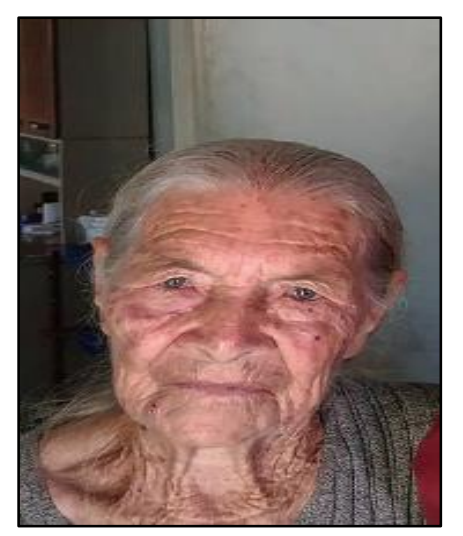

Nome: Evangelina Teles da Fonseca (Vanja) (esposa de Manoel Lopes de Azevedo)

Idade: 90 anos (†2021)

Cidade: Santo Antônio (Francisco Dumont)

Profissão: lavradora 


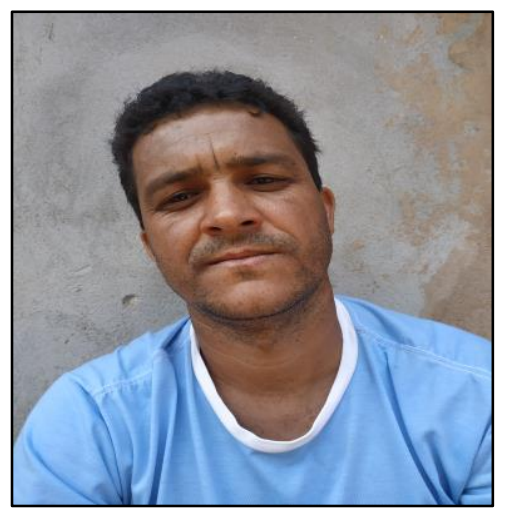

Nome: Evandro Vieira de Almeida (Dim)

Idade: 41 anos (2019)

Cidade: Francisco Dumont

Profissão: carvoeiro e lavrador

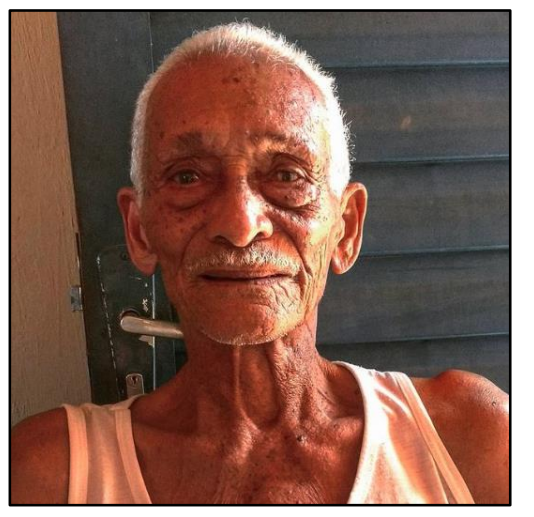

Nome: Geraldo Pereira de Jesus (Geraldinho Crente)

Idade: 96 anos (†2018)

Cidade: Jequitaí

Profissão: garimpeiro e lavrador

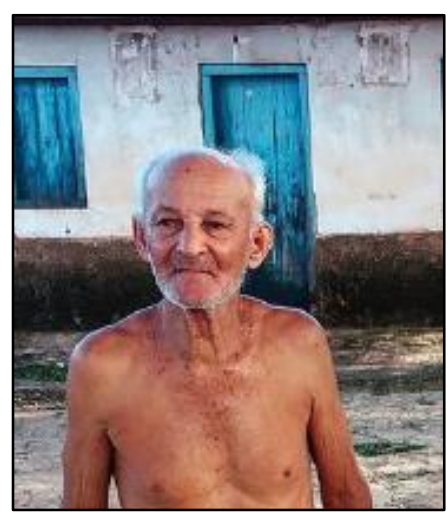

Nome: Geraldo Telheiro

(irmão de José Telheiro)

Idade: 85 anos (2017)

Cidade: Francisco Dumont

Profissão: garimpeiro

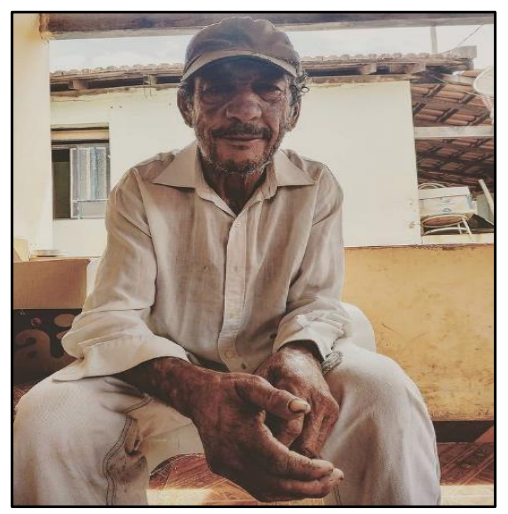

Nome: Gercino Rabelo Fonseca

Idade: 60 anos (2019)

Cidade: Carrapato (Francisco Dumont)

Profissão: lavrador 


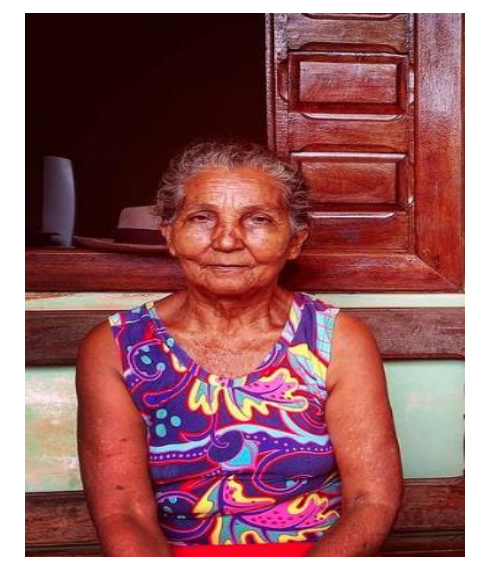

Nome: Ifigênia de Moura Silva (esposa de Salvador Elvino da Silva)

Idade: 78 anos (2018)

Cidade: Pacuí

Profissão: costureira aposentada

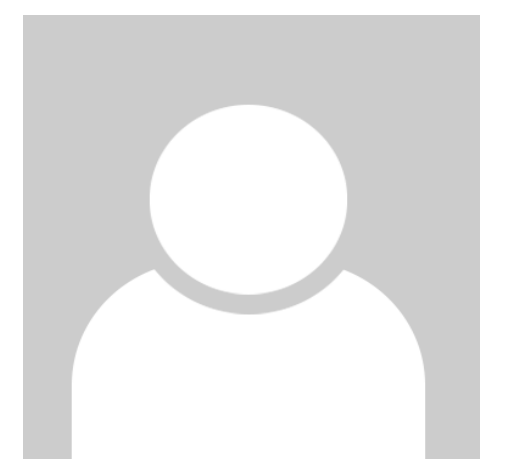

Nome: Ítalo Bernardo Costa Almeida

Idade: 28 anos (2020)

Cidade: Francisco Dumont

Profissão: engenheiro ambiental

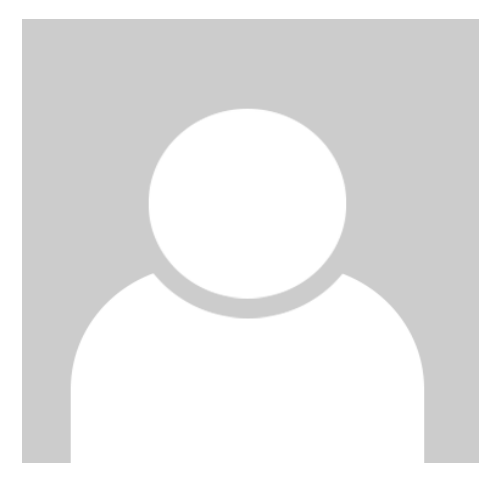

Nome: Jéssica Augusta Alves de Melo

Idade:

Cidade: ----

Profissão: advogada

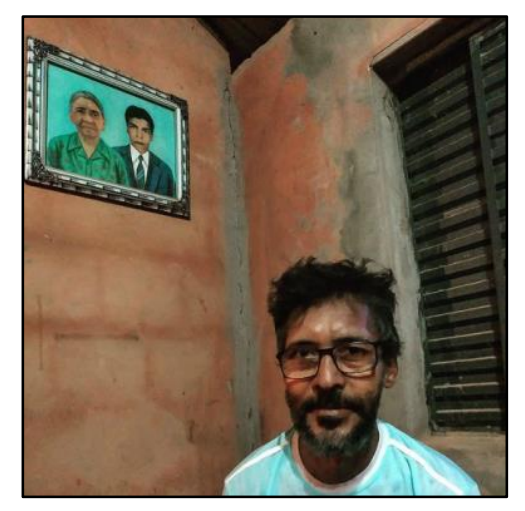

Nome: João Batista (João da Serra)

Idade: 55 anos (†2021)

Cidade: Francisco Dumont

Profissão: lavrador 

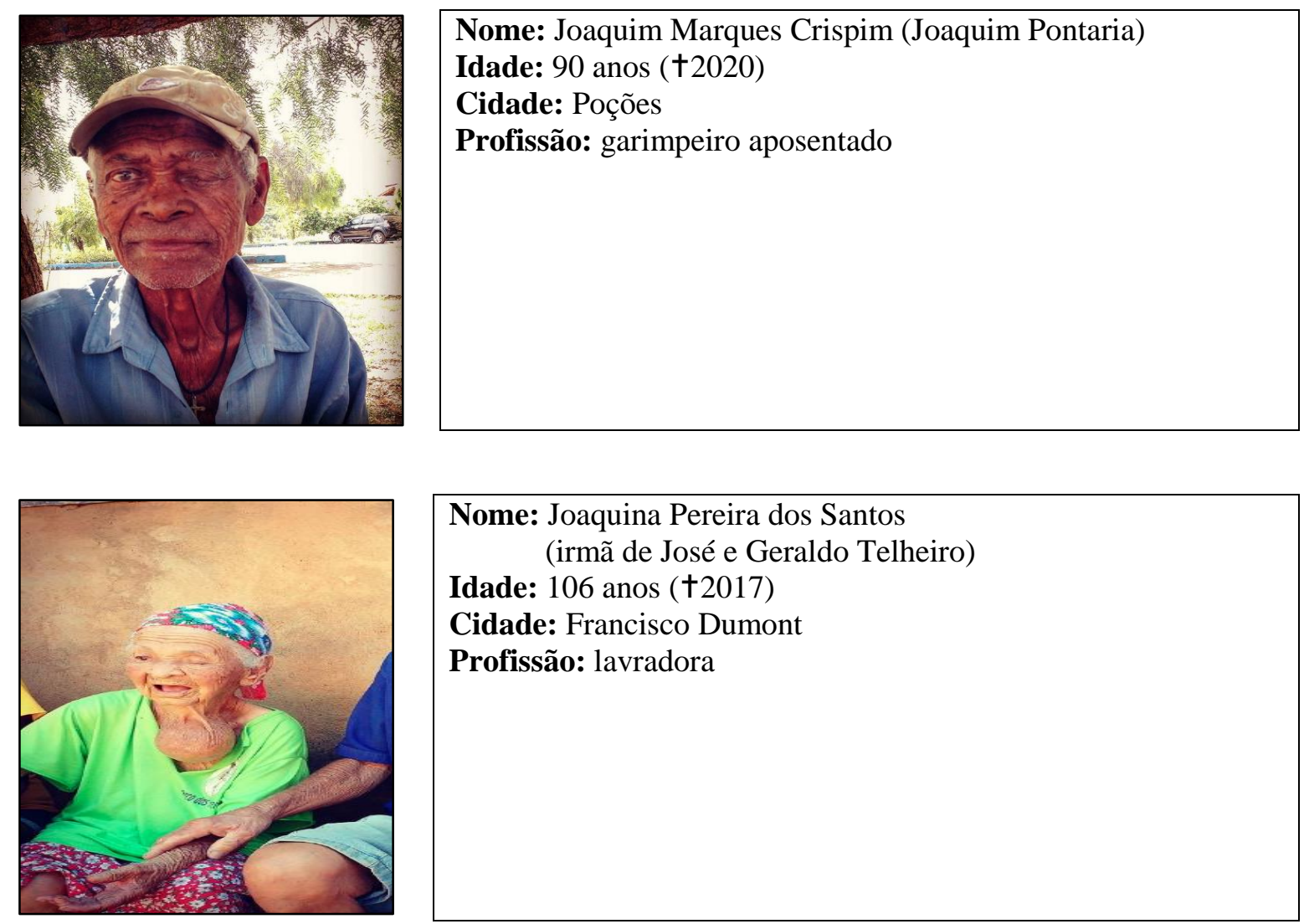

Nome: Joaquina Pereira dos Santos (irmã de José e Geraldo Telheiro)

Idade: 106 anos (†2017)

Cidade: Francisco Dumont

Profissão: lavradora

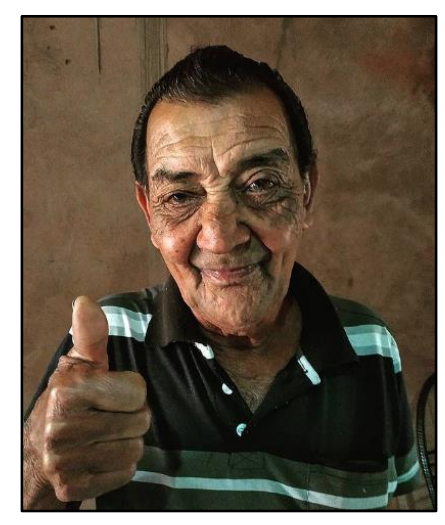

Nome: José Alves Pinto (Parceiro)

Idade: 80 anos (2017)

Cidade: Francisco Dumont

Profissão: garimpeiro

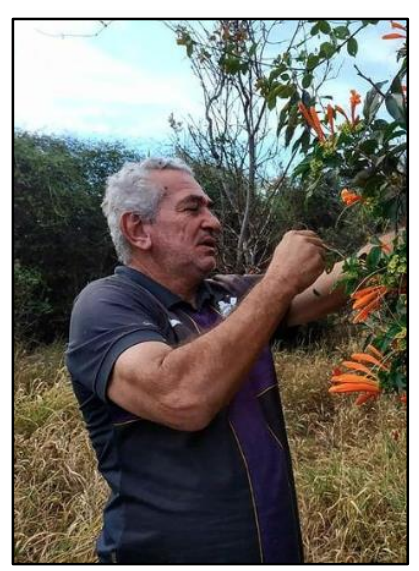

Nome: José Carlos Calixto (Boi)

Idade: ----

Cidade: Francisco Dumont

Profissão: servidor público 


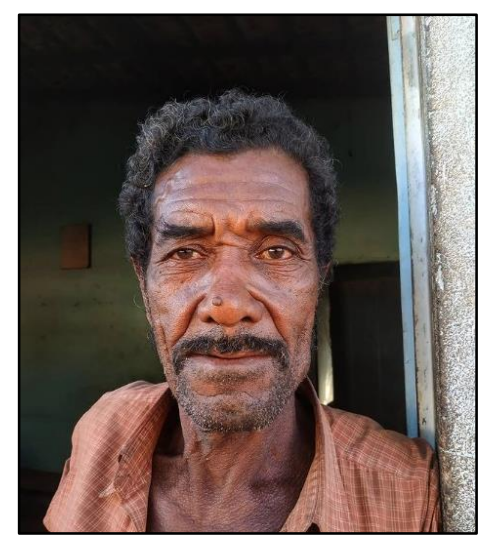

Nome: José Juvenal de Souza (Jota)

(filho de Maria de Oliveira e irmão de Célio Pereira de Souza e Maria Eunice Silva Souza)

Idade: 65 anos (2019)

Cidade: Francisco Dumont

Profissão: lavrador

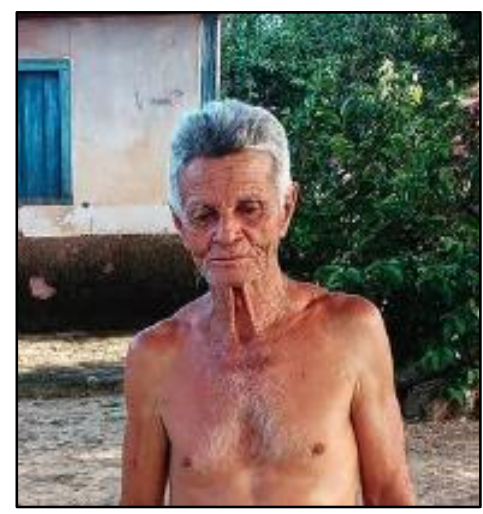

Nome: José Telheiro (irmão de Geraldo Telheiro)

Idade: 80 anos (2017)

Cidade: Francisco Dumont

Profissão: garimpeiro

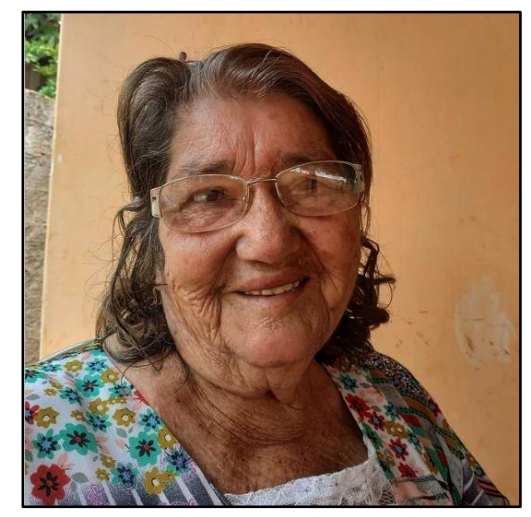

Nome: Judite Rabelo

Idade: 76 anos (2018)

Cidade: Carrapato (Francisco Dumont)

Profissão: lavradora

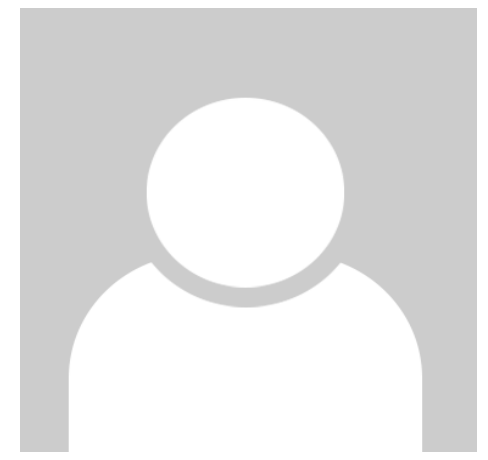

Nome: Júlio César Bruzinga Sousa (Chula)

Idade: 26 anos (2020)

Cidade: Francisco Dumont

Profissão: carvoeiro 

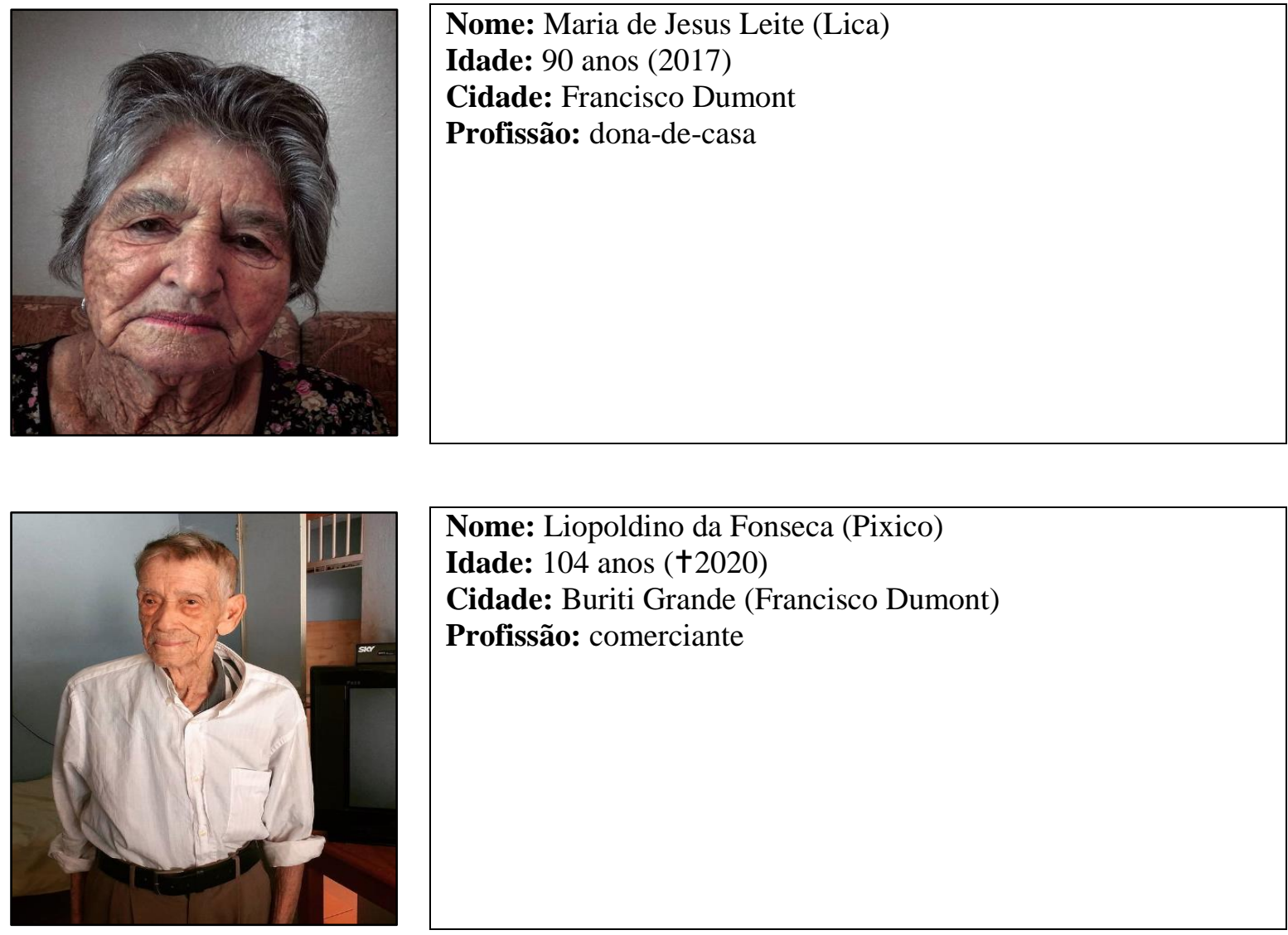

Nome: Liopoldino da Fonseca (Pixico)

Idade: 104 anos (†2020)

Cidade: Buriti Grande (Francisco Dumont)

Profissão: comerciante

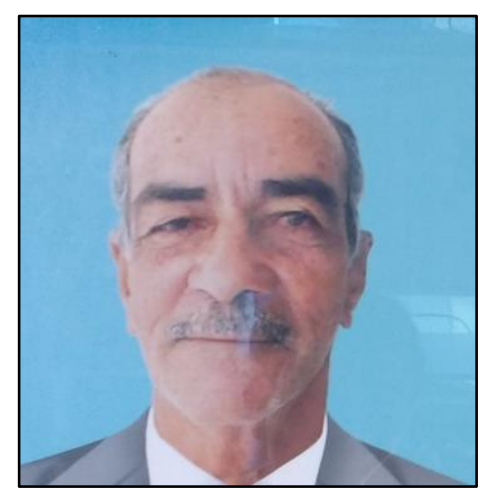

Nome: Lúcio Alves Costa

(irmão de Peargentino Alves Costa)

Idade: 81 anos (2017)

Cidade: Francisco Dumont

Profissão: garimpeiro

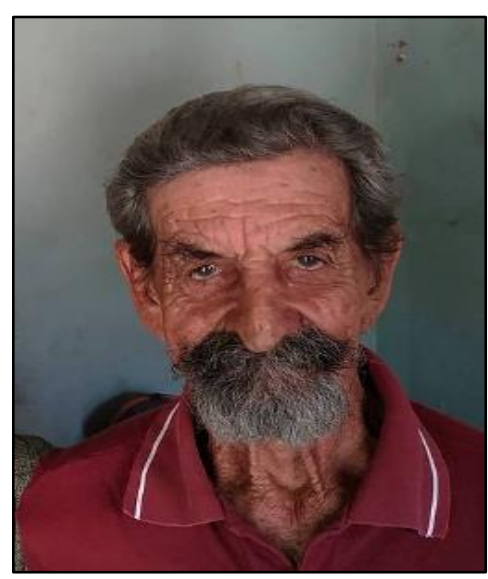

Nome: Manoel Lopes de Azevedo

(marido de Evangelina Teles da Fonseca)

Idade: 90 anos (2019)

Cidade: Francisco Dumont

Profissão: vaqueiro 


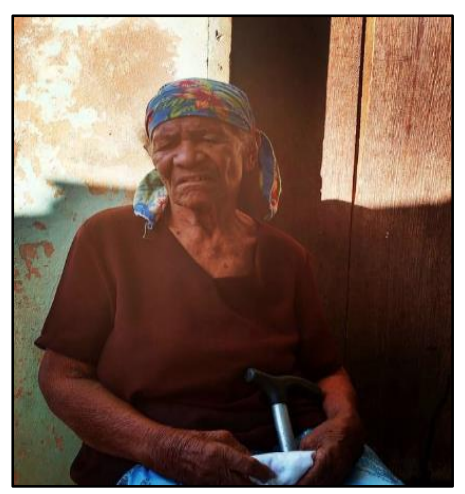

Nome: Maria de Oliveira (Maria Facão) (mãe de Célio Pereira de Souza, José Juvenal de Souza e Maria Eunice Silva Souza)

Idade: 92 anos (†2021)

Cidade: Claro dos Poções

Profissão: lavradora

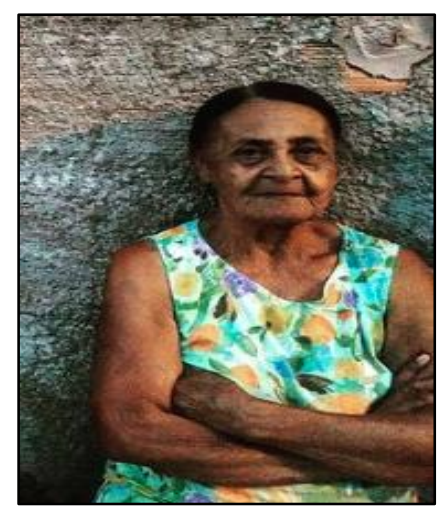

Nome: Maria do Carmo Santana

Idade: 80 anos (2021)

Cidade: Francisco Dumont

Profissão: lavradora

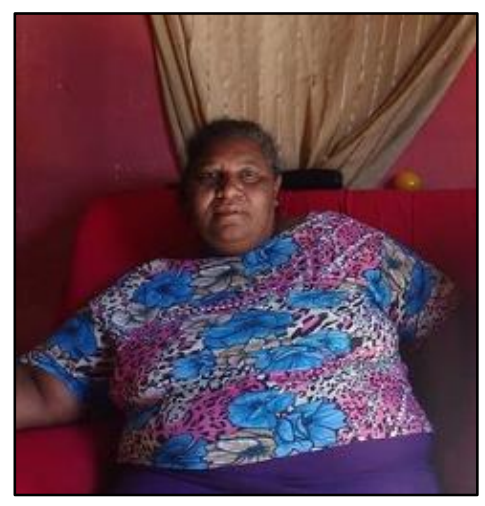

Nome: Maria Eunice Silva Souza

Idade: ---- $(† 2021)$

Cidade: Francisco Dumont

Profissão: serviços gerais

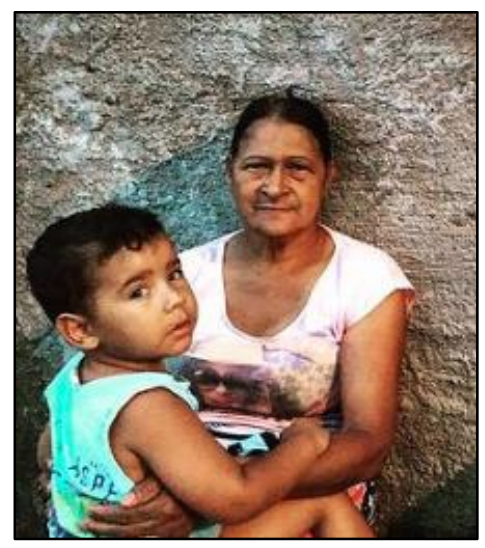

Nome: Maria Zélia Moreira dos Santos

Idade: 57 anos (2019)

Cidade: Engenheiro Dolabela

Profissão: lavradora 

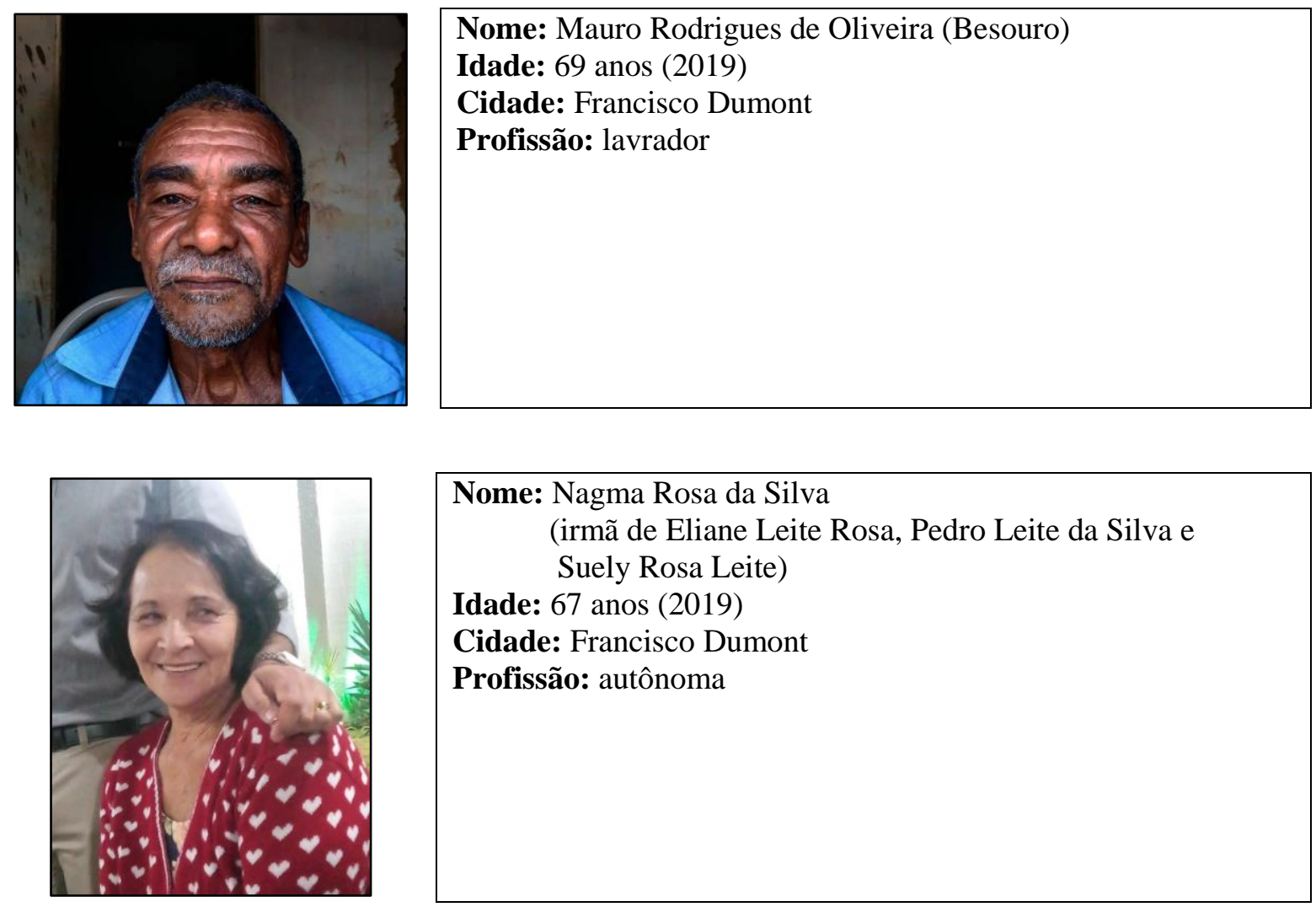
Nome: Nagma Rosa da Silva
(irmã de Eliane Leite Rosa, Pedro Leite da Silva e Suely Rosa Leite)

Idade: 67 anos (2019)

Cidade: Francisco Dumont

Profissão: autônoma

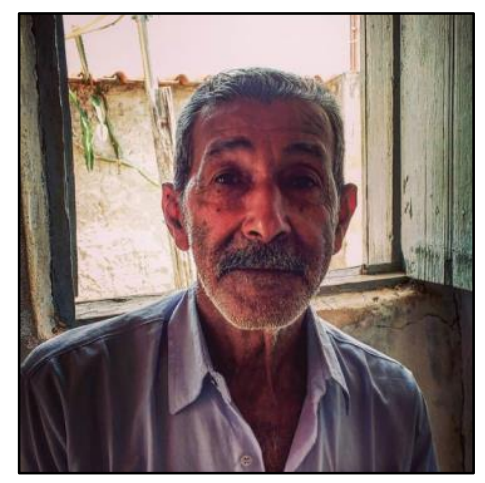

Nome: Manoel Pereira de Souza (Neco)

(marido de Maria José Alves de Souza)

Idade: 79 anos (2017)

Cidade: Francisco Dumont

Profissão: garimpeiro e lavrador

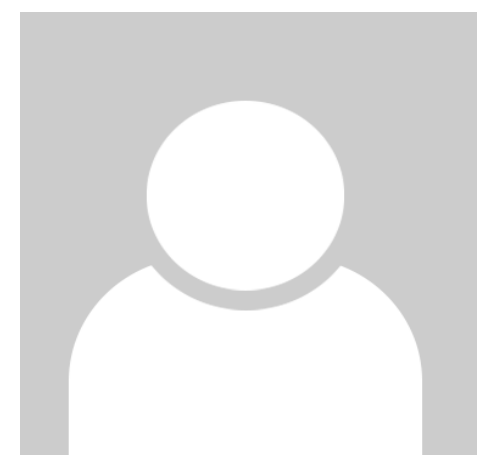

Nome: Nilo

Idade: ----

Cidade: Jequitaí

Profissão: garimpeiro 


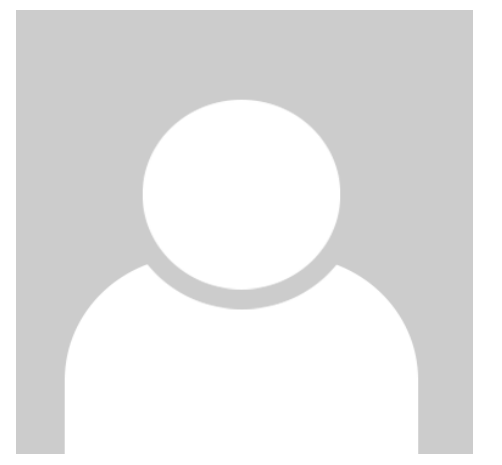

Nome: Paolo Lages Sequenzia

Idade:

Cidade: ----

Profissão: engenheiro agrônomo

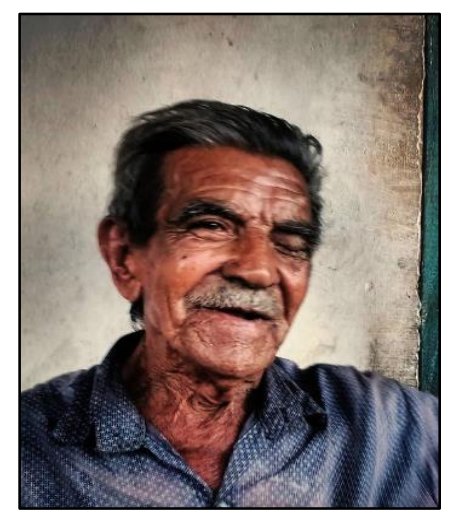

Nome: Paulo Lopes (Paulo Fura Olho)

Idade: 96 anos (†2021)

Cidade: Francisco Dumont

Profissão: garimpeiro

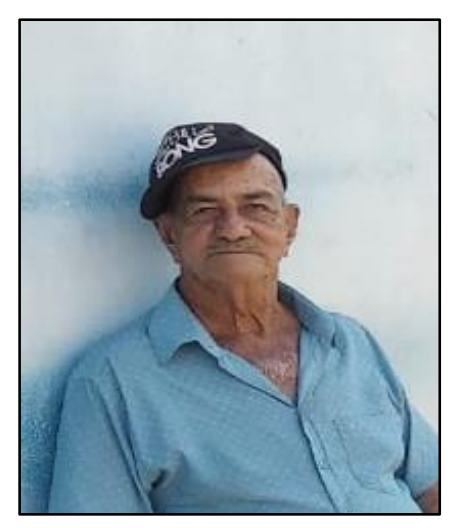

Nome: Peargentino Alves Costa

Idade: 83 anos (2017)

Cidade: Francisco Dumont

Profissão: garimpeiro

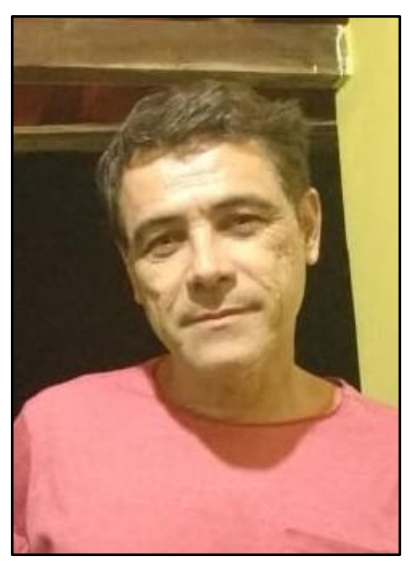

Nome: Pedro Leite da Silva

(irmão de Eliane Leite Rosa, Nagma Rosa da Silva e Suely Rosa Leite)

Idade: 51 anos (2019)

Cidade: Francisco Dumont

Profissão: autônomo 


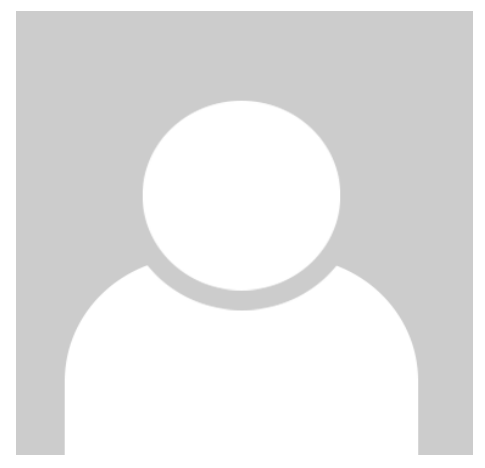

Nome: Pedroso
Idade: ----
Cidade: ----
Profissão: coordenador de assintência social

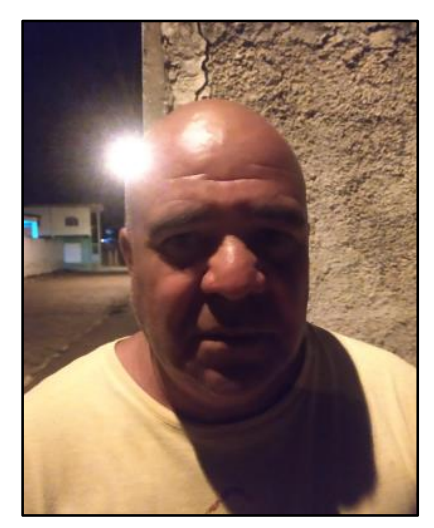

Nome: Roberto Calixto (Betão)

Idade: 56 anos (2019)

Cidade: Francisco Dumont

Profissão: servidor público

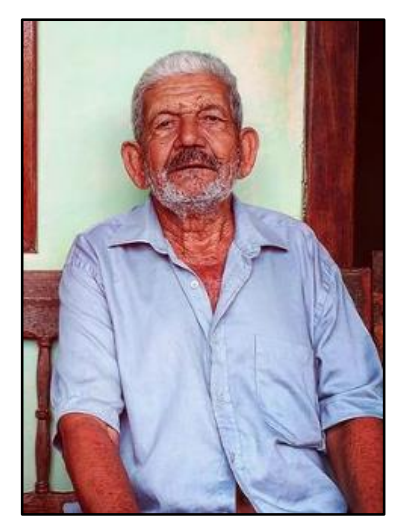

Nome: Salvador Elvino da Silva (Dodô) (marido de Ifigênia de Moura Silva)

Idade: 78 anos (2018)

Cidade: Francisco Dumont

Profissão: garimpeiro

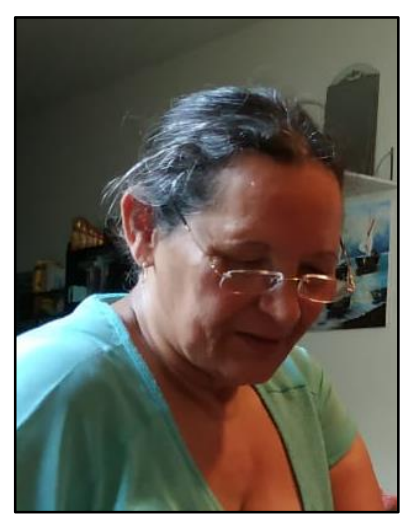

Nome: Suely Rosa Leite (irmã de Eliane Leite Rosa, Nagma Rosa da Silva e Pedro Leite da Silva)

Idade: 65 anos (2019)

Cidade: Engenheiro Navarro

Profissão: dona-de-casa 

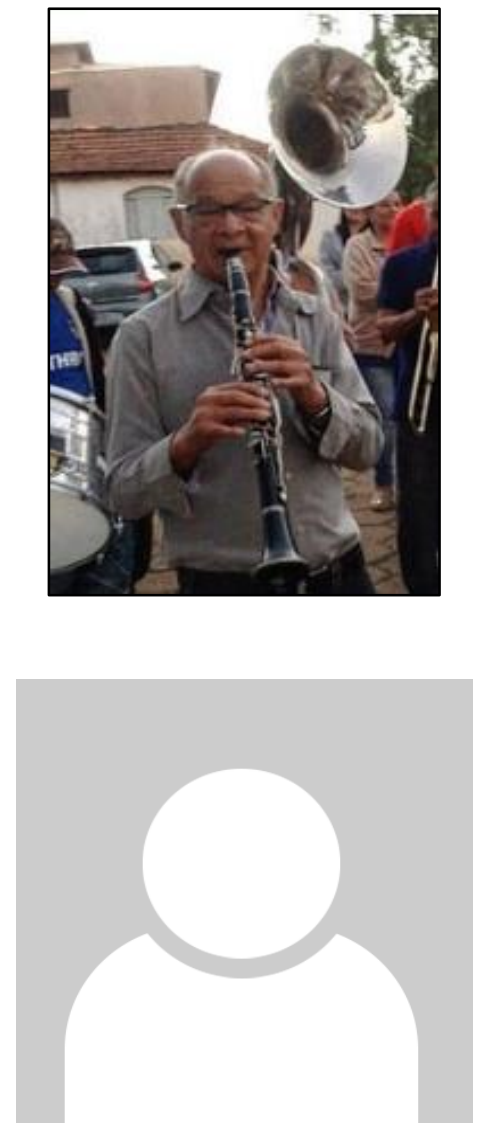

Nome: Teotônio da Silva

Idade: 92 anos (†2021)

Cidade: Buriti Grande (Francisco Dumont)

Profissão: garimpeiro

Nome: Walmir Bezerra

Idade: 56 anos (2017)

Cidade: Francisco Dumont

Profissão: garimpeiro 